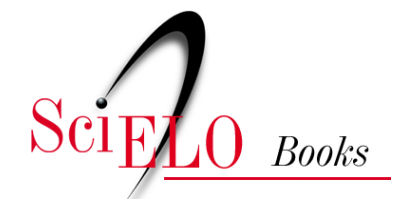

\title{
Vacinas, soros e imunizações no Brasil
}

\author{
Paulo Marchiori Buss \\ José Gomes Temporão \\ José da Rocha Carvalheiro \\ (orgs.)
}

\section{SciELO Books / SciELO Livros / SciELO Libros}

BUSS, P.M., TEMPORÃO, J.G., and CARVALHEIRO, J.R., orgs. Vacinas, soros e imunizações no Brasil [online]. Rio de Janeiro: Editora FIOCRUZ, 2005, 420 p. ISBN: 978-85-7541-606-8. Available from: doi: $10.7476 / 9788575416068$. Also available in ePUB from: http://books.scielo.org/id/wmw76/epub/buss-9788575416068.epub.

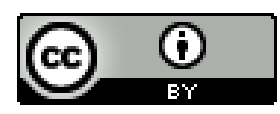

All the contents of this work, except where otherwise noted, is licensed under a Creative Commons Attribution $\underline{4.0 \text { International license. }}$

Todo o conteúdo deste trabalho, exceto quando houver ressalva, é publicado sob a licença Creative Commons Atribição 4.0. 


\section{VACINAS, SOROS IMUNIZAÇÕES}

no Brasil 
FUNDAÇÃO OSWALDO CRUZ

Presidente

Paulo Marchiori Buss

Vice-Presidente de Ensino, Informação e Comunicação

Maria do Carmo Leal

\section{EDITORAFIOCRUZ}

Coordenadora

Maria do Carmo Leal

Conselho Editorial

Carla Macedo Martins

Carlos E. A. Coimbra Jr.

Charles Pessanha

Gilberto Hochman

Jaime L. Benchimol

José da Rocha Carvalheiro

José Rodrigues Coura

Luis David Castiel

Luiz Fernando Ferreira

Maria Cecilia de Souza Minayo

Miriam Struchiner

Paulo Amarante

Paulo Gadelha

Vanize Macêdo

Coordenador Executivo

joão Carlos Canossa P. Mendes 
Paulo Marchiori Buss José Gomes Temporão José da Rocha Carvalheiro o r g a n i z a d o r e s

\section{VACINAS, SOROS \\ IMUNIZAÇÕES \\ no. Brorsil}

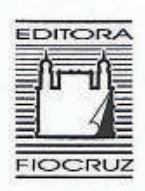


Copyright $\odot 2005$ dos autores

Todos os direitos desta edição reservados à FUNDAÇÃO OSWALDO CRUZ/EDITORA

ISBN: 85-7541-060-1

Capa, projeto gráfico e editoração eletrônica Adriana Carvalho Peixoto e Carlos Fernando Reis

Revisãoe copidesque Ana Beatriz Arena

Supervisão editorial Janaina de Souza Silva e M. Cecilia G. B. Moreira

Catalogação-na-fonte

Centro de Informação Científica e Tecnológica

Biblioteca da Escola Nacional de Saúde Pública Sergio Arouca

B981v Buss, Paulo Marchiori (org.)

Vacinas, Soros \& Imunizações no Brasil. / Organizado por Paulo Marchiori Buss, José Gomes Temporão e José da Rocha Carvalheiro. Rio de Janeiro: Editora FIOCRUZ, 2005.

420 p., tab., graf.

1.Vacinas-Brasil. 2.Soro-Brasil. 3.Imunização-Brasil. 4.Controle de doenças transmissíveis-Brasil. 5.Desenvolvimento tecnológicoBrasil. I.Temporão, José Gomes (org.). II.Carvalheiro, José da Rocha (org.). III.Título.

CDD - 20.ed. -614.470981

2005

Editora Fiocruz

Av. Brasil, $4036-1^{\circ}$ andar - sala 112 - Manguinhos

21041-361 - Rio de Janeiro - RJ

Tel.: (21) 3882-9039 e 3882-9041

Telefax: (21) 3882-9006

e-mail: editora@fiocruz.br

http://www.fiocruz.br/editora 


\section{Akira Homma}

Médico veterinário, com Pós-Doutorado em Ciências da Saúde pelo Baylor College of Medicine (EUA); Diretor do Instituto de Tecnologia em Imunobiológicos (Bio-Manguinhos) da Fundação Oswaldo Cruz.

\section{Ana Paula Brum Pizarro}

Graduada em Desenho Industrial, Doutora em Engenharia de Produção pela Universidade Federal do Rio de Janeiro (UFRJ); Assessora em Gerência de Projetos do Instituto de Tecnologia em Imunobiológicos (Bio-Manguinhos) da Fundação Oswaldo Cruz.

\section{André Luis Gemal}

Farmacêutico e Bioquímico, com Pós-Doutorado em Química Orgânica e Análise e Controle de Medicamentos pela Universidade de Grenoble (França); Diretor do Instituto Nacional de Controle de Qualidade em Saúde (INCQS) da Fundação Oswaldo Cruz.

\section{Artur Roberto Couto}

Administrador, Mestre em Economia Empresarial pela Universidade Cândido Mendes; Chefe de Gestão de Projetos do Instituto de Tecnologia em Imunobiológicos (Bio-Manguinhos) da Fundação Oswaldo Cruz.

\section{Carlos Augusto Grabois Gadelha}

Economista, Doutor em Economia da Indústria e da Tecnologia pela Universidade Federal do Rio de Janeiro (UFRJ); Secretário de Programas Regionais do Ministério da Integração Nacional e Pesquisador Adjunto da Escola Nacional de Saúde Pública Sergio Arouca (Ensp) da Fundação Oswaldo Cruz.

\section{Carlos Médicis Morel}

Médico, Doutor em Ciências Biológicas (Biofísica); Coordenador Científico do Centro de Desenvolvimento Tecnológico em Saúde (CDTS) da Fundação Oswaldo Cruz.

\section{Cláudio Maierovitch Pessanha Henriques}

Médico, Mestre em Medicina Preventiva pela Faculdade de Medicina da Universidade de São Paulo (USP); Diretor-Presidente da Agência Nacional de Vigilância Sanitária (Anvisa). 
Dario Pinto Miranda

Médico veterinário; Assessor em Produtos Biológicos đa Agência Nacional de Vigilância Sanitária (Anvisa).

Edmundo Gallo

Médico, Doutor em Planejamento Urbano e Regional pelo Instituto de Pesquisa de Planejamento Urbano e Regional (Ippur); Diretor de Investimentos e Projetos Estratégicos do Ministério da Saúde e Pesquisador Adjunto da Escola Nacional de Saúde Pública Sergio Arouca (Ensp) da Fundação Oswaldo Cruz.

\section{Eduardo de Azeredo Costa}

Médico sanitarista, Doutor em Filosofia pela Faculdade de Medicina da Universidade de Londres; Assessor de Tecnologia da Presidência e Coordenador do Centro de Desenvolvimento Tecnológico em Saúde (CDTS) da Funđação Oswaldo Cruz.

\section{Eduardo Chaves Leal}

Farmacêutico, Mestre em Biologia Molecular pela Fundação Oswaldo Cruz; Vice-diretor do Instituto Nacional de Controle de Qualidade em Saúde (INCOS) da Fundação Oswaldo Cruz.

\section{Erney Plessmann Camargo}

Médico, com Livre-Docência pela Universidade de São Paulo (USP); Presidente do Conselho Nacional de Desenvolvimento Científico e Tecnológico (CNPq).

\section{Euzenir Nunes Sarno}

Médica, com Livre-Docência pela Universidade Federal do Rio de Janeiro (UFRJ); Vice-presidente de Pesquisa e Desenvolvimento Tecnológico e Pesquisadora Titular da Fundação Oswaldo Cruz.

\section{Fernando José Caetano Lopes}

Médico veterinário, Bacharel em Direito, Mestre em Administração pela Universidade Federal Fluminense (UFF); Gerente de Projeto Tecnológico do Instituto de Tecnologia em Imunobiológicos (Bio-Manguinhos) da Fundação Oswaldo Cruz.

\section{Fernando de Oliveira Pina}

Administrador, com pós-graduação em Administração Pública pela Fundação Getulio Vargas (FGV); Chefe de Assessoria de Planejamento do Instituto de Tecnologia em Imunobiológicos (Bio-Manguinhos) da Fundação Oswaldo Cruz.

\section{Francisco Marcelo Barone}

Economista, Mestre em Administração Pública pela Fundação Getulio Vargas (FGV); Professor Adjunto da Universidade do Grande Rio (Unigranrio) e Coordenador do Curso de Pós-Graduação em Gestão de Micro e Pequenas Empresas (GMPE) da FGV.

Gina Tambini

Médica, Doutora em Saúde Pública pela School of Hygiene and Public Health da John Hopkins University (EUA); Gerente da Organização Pan-Americana da Saúde (Opas) para a Área de Saúde Familiar e Comunitária. 


\section{Hisako Gondo Higashi}

Farmacêutica e Bioquímica; Diretora da Divisão de Desenvolvimento Tecnológico e Produção do Instituto Butantan.

\section{Isaías Raw}

Médico, com Livre-Docência pela Universidade de São Paulo (USP); Diretor-presidente da Fundação Butantan.

luri da Costa Leite

Bacharel em Ciências Estatísticas, Doutor em Estatística Social; Pesquisador Associado da Escola Nacional de Saúde Pública Sergio Arouca (Ensp) da Fundação Oswaldo Cruz.

\section{Ivan Coelho}

Médico, com Especialização em Saúde Pública pela Fundação Oswaldo Cruz; Pesquisador do Núcleo de Estudos em Saúde Coletiva da Universidade Federal de Minas Gerais (Nescon/UFMG).

\section{Joaquim Gonçalves Valente}

Médico, Doutor em Epidemiologia pela Johns Hopkins University (EUA); Pesquisador Associado da Escola Nacional de Saúde Pública Sergio Arouca (Ensp) da Fundação Oswaldo Cruz.

\section{John Fitzsimmons}

Graduado em Public and International Affairs, Mestre em Planejamento Urbano e Regional; Técnico da Unidade de Imunizações na Área de Saúde Familiar e Comunitária da Organização Pan-Americana da Saúde (Opas).

\section{Jon Kim Andrus}

Médico, com especialização em Family Practice pela Universidade de Califórnia (São Francisco, EUA) e em Medicina Preventiva pelo Centers for Disease Control (Atlanta, EUA); Chefe da Unidade de Imunizaçóes na Área de Saúde Familiar e Comunitária da Organização Pan-Americana da Saúde (Opas).

\section{José Cezar Castanhar}

Engenheiro civil, Doutor em Administraçã̃o; Professor Adjunto da Escola Brasileira de Administração Pública da Fundação Getulio Vargas (FGV).

José Gomes Temporão (Organizador)

Médico sanitarista, Doutor em Saúde Coletiva pelo Instituto de Medicina Social da Universidade do Estado do Rio de Janeiro (Uerj); Diretor do Instituto Nacional do Câncer (Inca) e Pesquisador Adjunto da Escola Nacional de Saúde Pública Sergio Arouca (Ensp) da Fundação Oswaldo Cruz.

\section{José da Rocha Carvalheiro (Organizador)}

Médico, com Pós-Doutorado em Epidemiologia pela University of London (Inglaterra); Professor Titular da Universidade de São Paulo (USP), Coordenador do Projeto Inovação em Saúde (Presidência da Fundação Oswaldo Cruz) e Editor da Revista Brasileira de Epidemiologia (Abrasco). 
Jose Luis Di Fabio

Doutor em Química pela British Columbia University (Canadá); Gerente da Organização PanAmericana da Saúde (Opas) para a Área de Tecnologia e Prestação de Serviços de Saúde.

José Vítor Bomtempo

Engenheiro químico, com Pós-Doutorado em Economia Industrial pela Université de Paris XI (Paris-Dauphine, França); Professor Adjunto da Escola de Química da Universidade Federal do Rio de Janeiro (UFRJ).

Joyce Mendes de Andrade Schramm

Médica, Doutora em Saúde Coletiva pela Universidade do Estado do Rio de Janeiro (Uerj); Pesquisadora Associada da Escola Nacional de Saúde Pública Sergio Arouca (Ensp) da Fundação Oswaldo Cruz.

Julie Milstien

Química, Doutora em Bioquímica; Pesquisadora do Center for Vaccine Development da University of Maryland School of Medicine (EUA).

\section{Júlio Salomão}

Médico veterinário e Administrador, com Especialização em Sistemas de Garantia da Qualidade e em Produção de Kits para Diagnósticos pelo Centro Panamericano de Zoonosis de Buenos Aires (Argentina); Diretor administrativo do Instituto de Tecnologia do Paraná (Tecpar).

\section{Jussara Nascimento}

Médica, com Pós-Doutorado em Ciências pelo Public Health Laboratory System (Inglaterra); Pesquisadora Titular da Fundação Oswaldo Cruz e Coordenadora da Rede de Vacinas Recombinantes e de DNA do Programa de Desenvolvimento Tecnológico de Insumos para a Saúde (PDTIS/ Fiocruz).

\section{Kaizô Iwakami Beltrăo}

Engenheiro mecânico, Doutor em Estatística pela Princeton University (EUA); Professor Titular da Escola Nacional de Ciências Estatísticas (Ence) do Instituto Brasileiro de Geografia e Estatística (IBGE).

\section{Manoel Barral Netto}

Médico, com Pós-Doutorado em Patologia Humana pelo Seattle Biomedical Research Institute (EUA); Diretor de Programas Temáticos e Setoriais do Conselho Nacional de Desenvolvimento Científico e Tecnológico (CNPq).

\section{Manuel Limonta}

Médico, Doutor em Ciências Médicas; Diretor de Biotecnologia do Instituto de Hematologia e Imunologia de Havana (Cuba).

Márcia Vieira Leite Nascimento

Médica, com Especialização em Saúde Pública pela Escola Nacional de Saúde Pública Sergio Arouca (Ensp) da Fundação Oswaldo Cruz; Assessora Técnica da Coordenação Geral do Programa Nacional de Imunizações (CGPNI/Devep/SVS/MS). 


\section{Maria de Lourdes de Sousa Maia}

Médica, com Especialização em Planejamento em Saúde pela Escola Nacional de Saúde Pública Sergio Arouca (Ensp) da Fundação Oswaldo Cruz; Coordenadora Geral do Programa Nacional de Imunizações (CGPN//Devep/SVS/MS).

\section{Maria da Luz Fernandes Leal}

Farmacêutica, com Especialização em Planejamento Programação e Controle da Produção pela Fundação Getulio Vargas (FGV); Vice-diretora de Produção do Instituto de Tecnologia em Imunobiológicos (Bio-Manguinhos) da Fundação Oswaldo Cruz.

\section{Mariano de Matos Macedo}

Economista, Doutor em Economia pela Universidade Estadual de Campinas (Unicamp); Diretor Presidente do Instituto de Tecnologia do Paraná (Tecpar).

\section{Marie Paule Kieny}

Doutora em Agronomia pela École Nationale Supérieure d'Agronomie de Montpellier (França); Diretora da Initiative for Vaccine Research da Organização Mundial da Saúde (OMS).

\section{Mario Santos Moreira}

Administrador de Empresas, Mestre em Saúde Pública; Vice-diretor de Gestâo do Instituto de Tecnologia em Imunobiológicos (Bio-Manguinhos) da Fundação Oswaldo Cruz.

\section{Mirta Roses Periago}

Médica, com Especialização em Infectologia e Pós-Graduação em Saúde Pública pela Escola de Saúde Pública da Universidade de Buenos Aires; Diretora da Organização PanAmericana da Saúde (Opas) em Washington.

\section{Mônica Rodrigues Campos}

Estatística, Doutora em Saúde Coletiva pela Universidade do Estado do Rio de Janeiro (Uerj); Pesquisadora Adjunta da Escola Nacional de Saúde Pública Sergio Arouca (Ensp) da Fundação Oswaldo Cruz.

\section{Neide Fogiato Brun Binder}

Farmacêutica; Pesquisadora do Centro de Produção e Pesquisas de Imunobiológicos (CPPI).

\section{Otávio Azevedo Mercadante}

Médico, Mestre em Saúde Pública com Livre-Docência pela Faculdade de Ciências Médicas da Santa Casa de São Paulo; Diretor do Instituto Butantan.

\section{Paulo Marchiori Buss (Organizador)}

Médico, Mestre em Medicina Social pela Universidade do Estado do Rio de Janeiro (Ueri); Pesquisador Titular da Escola Nacional de Saúde Pública Sergio Arouca (Ensp) e Presidente da Fundação Oswaldo Cruz.

\section{Paulo Roberto Motta}

Bacharel em Administração pela Escola Brasileira de Administração Pública e de Empre- " sas da Fundação Getulio Vargas (Ebape/FGV), Doutor em Administração Pública pela University of North Carolina (EUA); Coordenador do Curso de Doutorado em Administração da Escola Brasileira de Administração Pública e de Empresas da FGV. 


\section{Peter Carrasco}

Graduado em Ciência Política pela Universidade de Illinois (Chicago, EUA), Mestre em Administração Pública pela Michigan State University; Gerente do Programa de Imunizações, Vacinas e Produtos Biológicos (IVB) da Sub-diretoria da Saúde da Família e da Comunidade da Organização Mundial da Saúde (OMS).

\section{Renato Rau}

Farmacêutico (bioquímico e industrial), Mestre em Engenharia da Produção pela Universidade Federal de Santa Catarina; Diretor de Produção do Instituto de Tecnologia do Paraná (Tecpar).

\section{Roberto Nascimento Rodrigues}

Economista, Doutor em Demografia pela Australian National University; Professor Titular do Centro de Desenvolvimento e Planejamento Regional (Cedeplar) da Universidade Federal de Minas Gerais (UFMG).

\section{Rosiceli Barreto Gonçalves Baetas}

Engenheira química, Doutora em Gestão e Inovação Tecnológica pela Universidade Federal do Rio de Janeiro (UFRJ); Analista de C\&T Sênior do Instituto de Tecnologia em Imunobiológicos (Bio-Manguinhos) da Fundação Oswaldo Cruz.

\section{Rubens Luiz Ferreira Gusso}

Médico veterinário, Mestre em Ciências Veterinárias pela Universidade Federal do Paraná (UFPR); Diretor do Centro de Produção e Pesquisas de Imunobiológicos (CPPI).

\section{Sandra Regina Barroso Ruiz Sella}

Farmacêutica bioquímica, com Especialização em Administração de Empresas/Qualidade e Produtividade pela Faculdade Católica de Administração e Economia (FAE); Diretora Geral do Centro de Produção e Pesquisas de Imunobiológicos (CPPI).

\section{Wim Maurits Sylvain Degrave}

Químico, Doutor em Biologia Molecular pelo Institut Pasteur (França); Pesquisador Titular do Instituto Oswaldo Cruz (IOC) da Fundação Oswaldo Cruz e Assessor do Programa de Desenvolvimento Tecnológico de Insumos para a Saúde (PDTIS/ Fiocruz). 


\section{Parte I - A MAGNITUDE DO PROBLEMADAS DOENCฺAS IMUNOPREVENIVEIS NO BRASIL}

1 Situação da Prevenção e Controle das Doenças Transmissíveis no Brasil

Secretaria de Vigilância em Saúde do Ministério da saúde

2 Projeção da Carga de Doença no Brasil (1998-2013) Iuri da Costa Leite, Kaizô Iwakami Beltrāo, Roberto Nascimento Rodrigues, Joaquim Gonçalves Valente, Mônica Rodrigues Campos e Joyce Mendes de Andrade Schramm

Parte II - COMPLEXO PRODUTIVO: POLITICAE REGULAC̦ÃO DE VACINASE SOROS NO BRASIL

3 o Complexo Industrial da Saúde: desafios para uma política de inovação e desenvolvimento Carlos Augusto Grabois Gadelha

4 Regulação Econômica e Financiamento do Complexo Produtivo da Saúde: o papel do Ministério da Saúde Edmundo Gallo e Ivan Coelho

5 Programa Nacional de Imunizações (PNI): história, avaliação e perspectivas José Gomes Temporão, Márcia Vieira Leite Nascimento e Maria de Lourdes de Sousa Maia

6 Imunobiológicos e Vigilância Sanitária 125 Dario Pinto Miranda e Cláudio Maierovitch Pessanha Henriques 
7 Controle de Qualidade dos Imunobiológicos: participação do Instituto Nacional de Controle de Qualidade em Saúde (INCQS) -Fiocruz

André Luis Gemal e Eduardo Chaves Leal

\section{Parte III - PROSPECC̣̃̃O EM VACINAS: RESULTADOS DO PROJETO INOVAÇÃO}

8 Desenvolvimento Tecnológico de Vacinas: projeções para 2015 Julie Milstien

9 Avaliação Tecnológica da Produção de Imunobiológicos no Brasil e Definição de Nichos de Atuação Manuel Limonta

10 Desenvolvimento de Vacinas no Brasil: uma análise da potencialidade da $\mathrm{P} \& \mathrm{D}$ e das estratégias de inovaçáo José Vitor Bomtempo e Rosiceli Barreto Gonçalves Baetas

11 Avaliação Gerencial dos Produtores de Vacinas no Brasil José Cezar Castanhar, Francisco Marcelo Baronee Paulo Roberto Motta

12 Programa Nacional de Competitividade em Vacinas (Inovacina) José da Rocha Carvalheiro, José Gomes Temporäo, Akira Homma e Hisako Gondo Higashi

\section{Parte IV - PESQUISA, DESENVOLVIMENTO E INOVAÇÃO EM VACINAS NO BRASIL}

13 O Fomento à Pesquisa e Desenvolvimento em Vacinas e Soros no CNPq

Manoel Barral Netto e Erney Plessmann Camargo

14 Desenvolvimento Tecnológico em Vacinas e outros Insumos para a Saúde na Fiocruz

Euzenir Nunes Sarno, Jussara Nascimento, Wim Maurits Sylvain Degrave e Paulo Marchiori Buss

15 Centro de Desenvolvimento Tecnológico em Saúde (CDTS): um instrumento da Fiocruz para avanço tecnológico do Brasil Eduardo de Azeredo Costa, Carlos Médicis Morel e Paulo Marchiori Buss

16 Pesquisa e Desenvolvimento em Vacinas e Soros no Instituto Butantan 
Parte V - COMPLEXO PRODUTIVO DA SAÚDE NO BRASIL:

A EXPERIÊNCIA DAS INSTITUIC̣ŌES

17 Desenvolvimento e Produção de Vacinas e Soros

no Instituto Butantan

Hisako Gondo Higashi, Isaias Raw e Otávio Azevedo Mercadante

18 Desenvolvimento e Produção de Vacinas no Instituto de Tecnologia em Imunobiológicos (Bio-Manguinhos) da Fiocruz

Akira Homma, Maria da Luz Fernandes Leal,

Mario Santos Moreira, Fernando de Oliveira Pina,

Rosiceli Barreto Gonçalves Baetas, Ana Paula Brum Pizarroe

Artur Roberto Couto

19 Desenvolvimento da Produção de Vacinas e Soros no Instituto de Tecnologia do Paraná (Tecpar)

Júlio Salomão, Mariano de Matos Macedo e Renato Rau

20 Desenvolvimento e Produção de Imunobiológicos no Centro de Produção e Pesquisa de Imunobiológicos (CPPI)

Rubens Luiz Ferreira Gusso, Sandra Regina Barroso Ruiz Sella e

Neide Fogiato Brun Binder

\section{Parte VI - VACINAS E IMUNIZAC̣ÕES: A EXPERIÊNCIA INTERNACIONAL}

21 Fundo Rotatório de Imunização da Opas: sustentabilidade de programas de imunização na América Latina e Caribe

Jon Kim Andrus, John Fitzsimmons, Peter Carrasco,

Jose Luis Di Fabio, Gina Tambini e Mirta Roses Periago

22 Financiamento Internacional para a Pesquisa e Desenvolvimento de Vacinas e Imunização

Marie Paule Kieny 
O Brasil, economia emergente, aproxima-se dos países desenvolvidos com características que o posicionam no segmento médio superior na classificaçăo do Banco Mundial. No campo da saúde, espera-se, para o século XXI, um acelerado avanço nos recursos diagnósticos, terapêuticos e de prevenção. Os produtos resultantes deste novo ciclo terão altos valores agregados, científico e econômico. Custarão substancialmente mais do que os produzidos com as tecnologias hoje disponíveis, prenunciando a exclusão da maioria dos países em desenvolvimento no acesso a tais produtos.

Ao lado da África do Sul, Índia, Cuba, Coréia do Sul e China, o Brasil é dos poucos países em desenvolvimento que tem potencialidades para ingressar no seleto mundo da revolução biotecnológica. Um dos elementos essenciais é a existência do Sistema Único de Saúde (SUS), um sistema público de saúde que confere ao país vantagens competitivas em comparação com os demais.

As políticas públicas de saúde e ciência \& tecnologia das últimas décadas propiciaram ao país as condições mínimas indispensáveis: acúmulo científico e tecnológico em algumas instituições; doutores, tecnólogos e técnicos experientes na área; e expressivos mercados interno (extensa população e um sistema público de saúde organizado) e externo (particularmente na América Latina e África).

Em contrapartida, a demanda do país por novos produtos, insumos e serviços especializados na área da saúde é muito grande. Este quadro exige a implementação de soluçōes urgentes, de forma a reverter a situação de dependência internacional dos insumos, visando à produção necessária ao atendimento da sociedade de maneira abrangente, garantindo a disponibilidade gratuita de vacinas, kits de diagnóstico e medicamentos.

o Projeto Inovação em Saúde, iniciativa da Fundação Oswaldo Cruz (Fiocruz), desde 2002 elabora proposta baseada num diagnóstico do setor, com ênfase no Complexo Produtivo da Saúde, que envolve a produção e o mercado de bens e serviços em saúde. Visa a fornecer subsídios para a formulação de política multissetorial que reduza a dependência externa e encoraje o desenvolvimento científico e tecnológico do país, tendo como meta principal a inclusão social, a partir da oferta dos insumos essenciais em saúde, a baixo custo, pelo SUS.

Desde o início, o Projeto foi desenvolvido em parcerias institucionais com distintas secretarias do Ministério da Saúde e com outros ministérios (Ciência e Tecnologia; Educa- 
ção; Desenvolvimento, Inđústria e Comércio Exterior; Integração Nacional), além da inđústria privada nacional, dos produtores públicos de bens e serviços em saúde, da comunidade científica e tecnológica em saúde e de organismos internacionais. Esta iniciativa precursora, de caráter intersetorial, voltada para a saúde incorpora-se em nível mais geral à criação dos fóruns de competitividade pelo Ministério de Desenvolvimento, Indústria e Comércio Exterior (MDIC). Um desses fóruns, o de Biotecnologia, reflete a orientação e estratégias governamentais em função de uma visão de futuro, buscando um planejamento de longo prazo para o desenvolvimento tecnológico e produtivo do país.

Em 2003, o Seminário Nacional sobre o Complexo Industrial da Saúde foi organizado pelo Banco Nacional de Desenvolvimento Econômico e Social (BNDES) do MDIC, com o objetivo de propiciar um processo de discussão entre os principais pesquisadores e cientistas das universidades públicas e centros de pesquisa do Brasil, centrado no desenvolvimento tecnológico (P\&D) e na produção de matérias-primas para farmoquímicos, fitofármacos, biofármacos e vacinas.

Simultaneamente, o Departamento de Ciência e Tecnologia (Decit) do Ministério da Saúde iniciou um processo consultivo com especialistas de todo o país para a elaboração de uma proposta de agenda de investigação para o setor saúde. Esse processo culminou, na sua primeira fase, numa reunião em Brasília em novembro de 2003, reunindo aproximadamente quatrocentos participantes que definiram vinte grandes tópicos e subtemas de investigação.

Em sintonia com esses acontecimentos, as "Diretrizes de Política Industrial, Tecnológica e de Comércio Exterior", estabelecidas pelo governo em novembro de 2003, contemplam como uma das quatro opções estratégicas o desenvolvimento do setor Fármacos e Medicamentos. O lançamento dessa nova política industrial foi precedido pela criação do Fórum de Competitividade da Cadeia Produtiva Farmacêutica (2003), um processo político intersetorial para a proposição de ações efetivas que integra o setor governamental (Ministério da Saúde - MS -, Ministério de Ciência e Tecnologia-MCT-e MDIC), acadêmico (universidades) e produtivo (associações de laboratórios produtores de fármacos e medicamentos).

No Congresso Nacional, foi discutida e aprovada, em 2004, a nova Lei de Inovação, de autoria do Poder Executivo, que estabelece medidas de incentivo à inovação e à pesquisa cientifica e tecnológica e ao desenvolvimento industrial do país, tendo como principal foco o incremento da interação entre as instituições científicas e tecnológicas e o setor produtivo. Prevê também ações destinadas a promover e incentivar iniciativas de empresas para desenvolver produtos e processos inovadores.

A realização da II Conferência Nacional de Ciência, Tecnologia e Inovação em Saúde, em julho de 2004, constituiu um momento fundamental para a construção de um consenso político junto às representações da sociedade civil, que orientasse as prioridades de investigação e inovação em função das reais necešsidades de saúde pública. A Conferência contemplou, entre os vinte temas prioritários da agenda nacional de pesquisa em saúde, o Complexo Produtivo da Saúde, legitimando os objetivos propostos no 
Projeto Inovação. Da mesma forma, a multiplicidade de foros de discussão acadêmico-política, liderados por instituições acadêmicas e/ou programas governamentais sobre o tema de propriedade intelectual e seu impacto nas ações de saúde pública e o acesso aos bens essenciais para a saúde, são os principais traços de um cenário extremamente efervescente e rico, que constitui o pano de fundo no desenvolvimento das açōes do Projeto Inovação.

Os aspectos de financiamento e investimento em $P \& D$ e no fortalecimento da produção também estão sendo considerados prioritários em nível de governo. Iniciativas como o Programa Profarma, criado pelo BNDES, os Fundos Setoriais do MCT e o interesse das principais agências de fomento, principalmente da Financiadora de Estudos e Projetos (Finep), em orientar os recursos para projetos que atinjam atividades de $P \& D$ ou melhoria da gestão tecnológica, são evidências concretas deste processo.

A análise dos primeiros produtos do Projeto Inovação para subsidiar a formulação de políticas nos setores envolvidos não pode se abstrair do contexto internacional. Além das importantes iniciativas governamentais mencionadas, têm ocorrido mudanças na configuração internacional sinalizadas pelos acordos multilaterais - principalmente o Trade on Right's Intellectual Properties (TRIPS) - que influenciam os movimentos do setor industrial e sua relação com a pesquisa básica e a pesquisa clínica no desenvolvimento de novos produtos, e configuram um marco inédito no Brasil.

O objetivo principal do Projeto Inovação em Saúde foi a realização de um 'processo consultivo' envolvendo os gestores públicos federais da área de vacinas, medicamentos e kits para diagnóstico e as organizações produtoras de farmoquímicos, fitofármacos, biofármacos, vacinas e kits para diagnóstico do país, visando a fornecer subsídios para a formulação de uma política multisetorial envolvendo produção, gestão e desenvolvimento tecnológico (definição de prioridades, critérios para alocação de recursos, definição de estratégias).

A metodologia proposta para alcançar esse objetivo está baseada nas práticas usuais de investigação aplicada à formulação de políticas. A diretriz básica foi estabelecer um 'processo de consultas' profissionalizado, transcendendo as avaliaçōes e estudos. Procurou-se desenvolver, no próprio trabalho, um conjunto de proposições e indicaçōes claras de açōes e decisões que devem ser tomadas pelos formuladores da política industrial e de insumos para a área da saúde no Brasil.

As etapas percorridas no desenvolvimento do Projeto relacionaram-se com cinco grandes blocos de temas:

- Estudo prospectivo do quadro demográfico-epidemiológico brasileiro, estabelecendo cenários entre 2003 e 2015;

- Avaliação das tendências tecnológicas e econômicas mundiais na área da produção e consumo de farmoquímicos, fitofármacos, biofármacos, vacinas e kits ${ }^{*}$ para diagnóstico;

- Identificação das potencialidades das instituiçôes científico-tecnológicas do Brasil em P\&D desses mesmos produtos; 
${ }^{1}$ Buss. P. M. et al. Projeto Inovaçăo em Saúde: Fiocruz/Ministério da Saúde. Revista Rio de Janeiro, 11:189-200, 2003.
- Avaliação tecnológica da produção envolvendo os produtores brasileiros com a definição de nichos de atuação;

- Avaliação gerencial dos produtores públicos no país.

Para cada um destes blocos foi produzido, por consultores, um documento específico. O estudo prospectivo do quadro demográfico-epidemiológico gerou informações para utilização pelos três objetos centrais do estudo. Para cada um dos blocos temáticos realizaram-se oficinas de trabalho em que $o$ insumo central foi o documento apresentado pela consultoria. Essas oficinas tiveram um caráter técnico-político e sua composição incluiu os principais atores envolvidos: membros da academia, produtores, financiadores, instituições de pesquisa e policy makers. O que se obteve nas oficinas foi um conjunto de conclusões, diretrizes e proposiçōes de política para cađa um dos objetos de estudo.

o documento inicial, que formalizou o Projeto Inovação em Saúde, analisou os segmentos: 1) Vacinas e Imunobiológicos no Brasil, 2) Medicamentos e Farmoquímicos no Brasil; e 3) Reativos para Diagnóstico no Brasil.

Nesta publicação transcrevemos um resumo dessa análise preliminar, exclusivamente relacionado com o Setor de Vacinas no Brasil. Uma abordagem mais abrangente encontra-se na Revista Rio de Janeiro. ${ }^{1}$

o desenvolvimento de políticas públicas de vacinação, possibilitadas pela crescente diversidade e melhoria da qualidade dos imunobiológicos, constitui uma das ações mais importantes de saúde pública em termos de seu impacto social. As transformações, que vêm ocorrendo de forma muito rápida, abrem novas possibilidades de combate às doenças infecciosas e fazem ressurgir o interesse econômico por esta área. 0 mercado passou a estruturar-se com base em dois grandes segmentos: o das vacinas tradicionais de uso difundido e baixo preço e o das vacinas modernas, de preço elevado e, portanto, de uso mais restrito.

0 crescente interesse das grandes empresas farmacêuticas por este mercado e a crescente complexidade dos processos de inovação tecnológica, com aumento de custos de $P \& D$, criou um movimento de concentração da produção em um grupo restrito de empresas. As grandes empresas líderes concentram suas estratégias na constituição de uma base tecnológica complexa e sofisticada, articulando-se com pequenas empresas de biotecnologia e instituições de P\&D. A capacidade de inovação passa a se constituir na principal base da competitividade empresarial no setor.

A indústria de vacinas vai assumindo as características da indústria farmacêutica, com uma estrutura oligopólica de competição e de concorrência. No ano de 2000, 0 volume de vendas do mercado mundial atingiu 7 bilhóes de dólares, sendo que as quatro maiores empresas, todas multinacionais do ramo farmacêutico, responderam por $80 \%$ desse valor.

Entre os países da América Latina e do Caribe, houve ąvanços na produção local apenas no Brasil, México e em Cuba. No Brasil, os produtores locais, até o final da década de 90 , restringiam sua atuação ao grupo dos produtos tradicionais ou às atividades de formulação com menor valor agregado e pouca densidade tecnológica. Nos últimos anos 
dois movimentos apontam para uma mudança estrutural: o desenvolvimento endógeno da primeira vacina moderna brasileira pelo Instituto Butantan e a celebração de acordos de transferência de tecnologia entre Bio-Manguinhos e Butantan com dois dos principais produtores mundiais (GSKe Aventis Pasteur).

A busca de novas tecnologias a partir da absorção de tecnologia desenvolvida externamente, como estratégia de queimar etapas, evidencia o grau de dificuldade encontrado por estas organizações para se aproximar da fronteira tecnológica. Ainda que esse processo de transferência atenda em curto prazo a incorporação da tecnologia requerida, existe a possibilidade de que a tecnologia em processo de transferência esteja sendo substituída por outras, nos países detentores das patentes ou do know-how específico. Portanto, é necessário que os laboratórios produtores façam forte investimento em atividades de desenvolvimento tecnológico autóctone.

A recente estruturação de uma rede de produtores independentes em nível mundial (Developing Country Vaccine Manufacturers Network-DCVMN) é sinal de mudanças no contexto internacional. Esse conjunto de fabricantes (empresas públicas e privadas localizadas majoritariamente em países em desenvolvimento), apresenta dupla estratégia: 1) a busca da certificação pela Organização Mundial da Saúde (OMS) como fornecedores para os organismos internacionais das Nações Unidas, o que implica alcançar níveis e padrōes de qualidade de produção internacionais; 2) a estruturação de parcerias com os grandes produtores internacionais, na busca do domínio de novas tecnologias de desenvolvimento e produção. A base econômica em que a maioria opera ainda é restrita, principalmente por produzirem produtos de baixo valor agregado, ainda que o volume de doses, para atender as demandas, seja expressivo (populações da China, Indonésia, Índia e Brasil, entre outras). No entanto, a participação deste bloco no conjunto de vendas no mercado mundial em 2000 não alcançou os dez por cento.

Quanto à evolução da produção nacional, toda por laboratórios públicos, houve expressivo avanço com uma reconhecida capacidade instalada de produção de vacinas e soros, além de melhoria na qualidade. Este avanço esteve calcado principalmente na produção de vacinas tradicionais ou nas atividades finais de formulação de vacinas mais modernas, a partir da importação đo princípio ativo, evidenciando a persistência de significativa dependência externa. Como decorrência, as importações continuam a responder pela maior parcela deste segmento em termos de valor. Em 2000, 80\% dos gastos com aquisiçōes de vacinas para o Programa Nacional de Imunizações (PNI) foram com importações de produtos acabados ou de granel (bulk) a ser envasado localmente.

A inclusão de algumas vacinas modernas no conjunto de produtos elaborados pela indústria brasileira ampliou seu porte econômico. A política nacional de vacinação do país é internacionalmente reconhecida pelo seu constante crescimento e pela oferta regular de uma cesta de vacinas mais sofisticada do que aquela preconizada pela OMS. Embora se possa estabelecer uma relação causal direta entre o êxito do PNI e o desenvolvimento do setor produtivo nacional, a política pública não se caracteriza pelo estabelecimento de programas com horizontes de médio e longo prazo que permitam aos produtores um adequado planejamento estratégico de suas atividades. 
A introdução de novos produtos, tecnologicamente diferenciados em relação aos tradicionais, no calendário de vacinação, vem obrigando os produtores nacionais a 'queimarem' etapas para incorporar novas tecnologias. Esses produtores respondem a este desafio a partir do estabelecimento de acordos de cooperação com as empresas líderes. $O$ nível de articulação dos produtores nacionais entre si apresenta iniciativas de projetos conjuntos para desenvolvimento e produção de alguns produtos, envolvendo acordos comerciais e de colaboração na transferência de conhecimentos.

Pode-se afirmar que o Brasil possui diversos elementos favoráveis à ampliaçăo do seu nível de competitividade no desenvolvimento e produção de vacinas, em que se destacam: a infra-estrutura em C\&T; a tradição na produção de produtos biológicos; uma base industrial considerável recém-implementada; uma boa infra-estrutura de controle de qualidade; a existência de hospitais e universidades potencialmente utilizáveis na realização de ensaios clínicos; além das dimensões do mercado interno, considerado um dos maiores do mundo. A questão se coloca, portanto, no nível da existência de uma visão estratégica da área e da decisão política para a promoção das transformações requeridas.

A obra que apresentamos é fruto das reflexôes e da produção científica elaborada nesse contexto e está composta de seis partes, que se relacionam e se articulam com o cenário nacional e internacional. A primeira parte, "A magnitude do problema das doenças imunopreveníveis no Brasil", reúne dois artigos fundamentais: um deles, que faz a fotografia dessas doenças no país, foi tomado de uma publicação da Secretaria de Vigilância em Saúde do Ministério da Saúde; 0 outro, sobre a projeção da carga de doença em dez anos, ressalta a importância que as doenças imunopreveníveis terão no futuro.

Na segunda parte, "Complexo produtivo: política e regulação de vacinas e soros no Brasil", descreve-se a dinâmica do setor produtivo de vacinas dentro do complexo da saúde; abordam-se os aspectos de regulação através da autoridade sanitária, a Agência Nacional de Vigilância Sanitária (Anvisa); discutem-se os aspectos de financiamento e regulação econômica pelo Ministério da Saúde; destaca-se o papel do Instituto Nacional de Controle de Qualidade em Saúde (INCQS) no controle de qualidade; e, fundamentalmente, dá-se um espaço para a descrição, história e evolução do Programa Nacional de Imunizações do Ministério da Saúde, mencionando seus acertos e perspectivas.

A terceira parte, "Prospecção em vacinas: resultados do Projeto Inovação" é a parte medular do livro. Apresenta o trabalho inédito do Projeto Inovação em Saúde, baseado na proposta metodológica de estabelecer um processo consultivo, de caráter técnicopolítico visando a elaborar diretrizes para a formulação de uma política mais integrada, não apenas setorial, buscando o desenvolvimento tecnológico e científico do país, em plena consonância com os interesses da saúde pública e do bem-estar comum. Os estudos feitos abordam as tendências internacionais de desenvolvimento tecnológico em vacinas; a prospecção nacional em P\&D; a avaliaçăo da capacidade tecnológica de produção e uma análise dos modelos gerenciais utilizados pelos produtores públicos de vacinas. Conclui apresentando a versão preliminar de uma proposta concreta (Inovacina) ainda em discussão no âmbito do Fórum de Competitividade de Biotecnologia (MDIC). 
A quarte parte, "Pesquisa, desenvolvimento e inovação em vacinas no Brasil", mostra os esforços das maiores instituiçóes de pesquisa na área de vacinas, a Fiocruz, o Instituto Butantan, assim como a visão do principal órgão de fomento, o Conselho Nacional de Desenvolvimento Científico e Tecnológico (CNPq).

Na quinta parte, 0 "Complexo produtivo da saúde no Brasil: a experiência das instituições", produtores públicos detalham sua experiência na área de vacinas e soros: a Fiocruz, o Instituto Butantan, o Instituto Tecnológico do Paraná (Tecpar) e o Centro de Produção e Pesquisa em Imunizações (CPPI).

Finalmente, a sexta parte, "Vacinas e imunizações: a experiência internacional", destaca o papel do Fundo Rotatório de Vacinas da Organização Pan-Americana da Saúde (Opas) na distribuição e suprimento de vacinas em nível mundial e discute as estratégias de fomento e financiamento à produção de vacinas no mundo.

A compreensão de que é necessária uma abordagem global no presente momento, com o advento dos novos paradigmas da tecnologia e da informação, tornou evidente a urgência de definições estratégicas para o país, considerando as oportunidades existentes e os nichos de desenvolvimento que podem ser explorados. O Projeto Inovação em Saúde se inseriu nessa đinâmica, e seus objetivos são consistentes com a celebração de um pacto entre as principais forças da sociedade e dos distintos setores. Seus resultados contribuem para direcionar ações e formular estratégias que visem ao desenvolvimento e garantam por sua vez a integralidade, a eqüidade e a universalidade do acesso aos bens essenciais da saúde.

Os Organizadores ${ }^{2}$

O Projeto Inovação em Saúde é dirigido por um Conselho Diretor: Paulo Buss - Presidente da Fiocruz; Akira Homma - Diretor de Bio-Manguinhos/Fiocruz; Reinaldo Guimarães - Diretor do Departamento de Ciência e Tecnologia (Decit) do Ministério da Saúde (à época) e atual Vice-presidente de Pesquisa e Desenvolvimento Tecnológico da Fiocruz; Eduardo Costa - Coordenador do Centro para o Desenvolvimento de Tecnologias em Saúde (CDTS/Fiocruz); José Gomes Temporão-Pesquisador da Fiocruz; Diretor do Instituto Nacional do Câncer (Inca) (à época) e atual Secretário de Atenção à Saúde do Ministério da Saúde (SAS/MS); Carlos Augusto Grabois Gadelha-Pesquisador da Fiocruz e Secretário de Programas Regionais do Ministério da Integração Nacional (MI); José da Rocha Carvalheiro - Pesquisador Visitante da Fiocruz - e Hayne Felipe - Pesquisador da Fiocruz e Coordenador do Programa Farmácia Popular do Brasil.

A Coordenação Executiva esteve a cargo, numa primeira fase, de José Gomes Temporão e Carlos Augusto Grabois Gadelha. A gerência do Projeto foi exercida por Flávia Neves Rocha Alves, Farmacêutica, Mestre em Saúde Pública pela Ensp/Fiocruz. Foi Assistente Administrativa Luciana Villas Boas Ferreira, Zootecnista. Na segunda fase do Projeto, a coordenação executiva é exercída por José da Rocha Carvalheiro, e a gerência do Projeto, por Carmen Nila Phang Romero Casas, Farmacêutica, Mestre em Saúde Pública e Doutoranda da Ensp/Fiocruz.

${ }^{2}$ Esta apresentaçāo contou ainda com a colaboração de Carlos Grabois Gadelha 


\section{Parte I}

A MAGNITUDE DO PROBLEMA DAS DOENCAS IMUNOPREVENIVEIS NO BRASIL 


\section{Situação da Prevenção e Controle das Doenças Transmissíveis no Brasil ${ }^{1}$}

Secretaria de Vigilância em Saúde do Ministério da Saúde

\section{SITUAÇÃO EPIDEMIOLÓGICA DAS DOENÇAS TRANSMISSÍVEIS NO BRASIL}

A situação das doenças transmissíveis no Brasil apresenta um quadro complexo, que pode ser resumido em três grandes tendências: doenças transmissíveis com tendência descendente, doenças transmissíveis com quadro de persistência e doenças transmissíveis emergentes e reemergentes.

\section{DOENÇAS TRANSMISSIIVEIS COM TENDÊNCIA DESCENDENTE}

Em um grande número de doenças transmissíveis para as quais se đispõe de instrumentos eficazes de prevenção e controle, o Brasil tem colecionado êxitos importantes. Esse grupo de doenças encontra-se em franco declínio, com reduções drásticas nos índices de incidência.

A varíola está erradicada desde 1978, a poliomielite recebeu a certificação da erradicação da transmissão autóctone em 1994, o sarampo encontra-se eliminado. Ainda nesta década será atingida a meta de erradicação da raiva humana transmitida por animais domésticos, da rubéola congênita e do tétano neonatal. Ainda dentro deste grupo de doenças transmissíveis com tendência ao declínio, estão a difteria, a rubéola, a coqueluche e o tétano acidental, que têm em comum o fato de serem imunopreveníveis, ${ }^{2}$ a doença de Chagas e a hanseníase, ambas enđêmicas há várias décadas em nosso país,
${ }^{1}$ Texto publicado originalmente em Saúde Brasil 2004: uma análise da situação de saúde (capitulo 6). Série G. Estatística e Informaçäo em Saúde. Brasilia: Departamento de Análise de Situação de Saúde. Secretaria de Vigilância em Saúde do Ministério da Saúde, 2004. (Os autores deste artigo optaram por creditar a autoria ao Ministério da Saúde).

${ }^{2}$ Doenças imunopreveníveis são aquelas preveníveis por vacinas. 
${ }^{3}$ Controle - quando se observa a redução do número de casos de determinada doença a um patamar aceitável, em conseqüência da adoção de medidas adequadas, que precisam ser continuadas para evitar a recrudescência. Erradicação - quando se elimina totalmentea circulação de um agente infeccioso causador de determinada doença, podendo até mesmo serem suspensas as medidas de prevenção e controle. Alguns autores propōem o termo 'eliminaçāo' para significar uma erradicação circunscrita a determinada regiāo (país ou continente), outros preferem usar o termo 'erradicaçäo regional'para caracterizar essa situação. e a febre tifóide, associada a condições sanitárias precárias. Por fim, estão também a oncocercose, a filariose e a peste, todas com áreas de ocorrência restritas.

As estratégias do Ministério da Saúde (MS) para esse grupo de doenças visam à manutenção da situação de controle ou mesmo à erradicação, ${ }^{3}$ quando esta é factível. Para o êxito dessas estratégias, o MS tem investido no fortalecimento da capacidade dos municípios e dos estados de detectarem rapidamente os casos suspeitos e adotarem medidas eficazes de bloqueio entre outras açōes de vigilância epidemiológica. Também tem investido no aumento da homogeneidade da cobertura vacinal de rotina para que se atinjam níveis adequados em cada um dos municípios e na adoção de estratégias específicas, como vacinações casa-a-casa, intensificações e campanhas de vacinação.

\section{Difteria}

A difteria é uma doença transmissível aguda, toxiinfecciosa, causada por bacilo toxigênico que freqüentemente se aloja nas amígdalas, na faringe, na laringe, no nariz e, ocasionalmente, em outras mucosas e na pele.

O número de casos de difteria notificado no Brasil vem decrescendo progressivamente, provavelmente em decorrência do aumento da utilização da vacina tríplice bacteriana (DTP). Em 1990, foram notificados 640 casos, com coeficiente de incidência de $0,45 / 100$ mil habitantes, número que foi progressivamente decaindo até 58 casos em 2000 (coeficiente de incidência de $0,03 / 100$ mil habitantes). Em 2003, registraram-se 40 casos (coeficiente de incidência de 0,02). A cobertura vacinal com a DTP vem se elevando neste período, passando de $66 \%$ em 1990 para mais de 90\% desde 2002.

A letalidade tem variado de $5 \%$ a $10 \%$, atingindo $20 \%$ em certas situações.

No Brasil, observaram-se variaçōes desta taxa no decorrer dos anos, sendo de $8,5 \%$ em 2002 .

A estratégia adotada para essa doença é o aprofundamento de seu controle por meio do fortalecimento da vigilância epidemiológica e da elevação e homogeneidade das coberturas vacinais com a vacina DTP, que protege contra a difteria, o tétano e a coqueluche.

\section{Coqueluche}

A morbidade da coqueluche no país também já foi elevada. No início da década de 1980, eram notificados mais de 40 mil casos anuais, e o coeficiente de incidência era superior a 30/100 mil habitantes. Este número caiu abruptamente a partir de 1983, mantendo, desde então, uma tendência decrescente. Em 1990, foram notificados 15.329 casos, resultando em um coeficiente de incidência de 10,64/100 mil habitantes, mas a partir de 1996 o número de casos anuais não excedeu 2.000 , mantendo-se com coeficiente de incidência em torno de $1 / 100$ mil habitantes.

Desde a instituição do Programa Nacional de Imunizaçōes, em 1973, quando a DTP passou a ser preconizada para crianças menores de 7 anos, observa-se um declínio na incidência da coqueluche, muito embora as coberturas vacinais iniciais não fossem elevadas. Na década de 1990, a cobertura foi-se elevando, principalmente a partir de 1998, resultando em uma modificação importante no perfil epidemiológico desta doença. 
Entretanto, nos últimos anos, surtos de coqueluche vêm sendo registrađos em populações com baixa cobertura vacinal, principalmente em populações indígenas. A estratégia para essa doença também é a manutenção de seu controle, por meio do fortalecimento da vigilância epidemiológica, reforço à detecção precoce e bloqueio imediato de qualquer surto detectado, evitando-se sua propagação, além da obtenção das coberturas vacinais adequadas ( $95 \%$ dos menores de 1 ano com a vacina tetravalente $-\mathrm{DTP}+\mathrm{Hib}$ ) em todos os municípios.

\section{Tétano}

O tétano é uma doença transmissível, não contagiosa, que apresenta duas formas de ocorrência: acidental e neonatal. A primeira forma geralmente acomete pessoas que entram em contato com o bacilo tetânico ao manusearem o solo ou por meio de ferimentos ou lesōes ocorridas por materiais contaminados, em ferimentos na pele ou na mucosa.

O tétano neonatal é causado pela contaminaçăo durante a secção do cordão umbilical pelo uso de instrumentos cortantes ou material de hemostasia inadequadamente esterilizados ou não esterilizados, pelo uso de substâncias contaminađas no coto umbilical, como teia de aranha, pó de café, fumo, esterco.

A doença reduziu-se de 2.226 casos em 1982 para menos de 600 desde 2002. Nos últimos quatro anos tem sido evidenciado que mais de $70 \%$ dos casos estão na faixa etária abaixo de 60 anos de idade e cerca de $20 \%$ a 30\% na faixa etária de 60 anos e mais. As mortes pelo tétano acidental também acompanham a tendência declinante: das 713 ocorrências anuais registradas em 1982 para menos de 300 desde 1998. No mesmo período ocorreu uma redução no número de casos de tétano neonatal, de 584 em 1982 para 15 em 2003. Considerando que esta enfermidade apresenta uma letalidade média de $70 \%$, essa redução tem um impacto importante na mortalidade infantil neonatal.

O tétano acidental pode ser evitado pelo uso da vacina DTP na infância e com a vacina dupla adulto (dT) em adultos, além dos reforços a cada dez anos para quem já tem o esquema completo. Outra medida importante é a adoção de procedimentos adequados de limpeza e desinfecção de ferimentos ou lesão suspeita para tétano nas unidades de saúde. A manutenção do esquema de vacinação preconizado atualizado é de extrema importância, porque a vacina apresenta uma eficácia de quase $100 \%$.

A conscientização da população sobre algumas medidas de prevenção contra o tétano também é um fator que tem contribuído na redução dos casos. Essa conscientização deve ser estendida ao ambiente de trabalho para algumas categorias profissionais de maior exposição a ferimentos e contato com material contaminado. O tétano neonatal pode ser evitado principalmente por meio da vacinação das gestantes durante o prénatal, iniciando com o recebimento precoce do esquema vacinal preconizado. Desde 2003, visando assegurar uma maior proteção das futuras gestantes, vem sendo adotada no país a vacinação das mulheres em idade fértil, priorizando-se os estados com maior ocorrência de casos de tétano neonatal. Segue-se a isso a importância do parto asséptico 
4 Vacinação indiscriminada é quando todas as crianças da faixa etária alvo são vacinadas, independentemente de sua situação vacinal anterior. Vacinaçẫo seletiva é quando só se vacinam os não vacinados.

${ }^{5}$ A estratégia para a eliminação do sarampo prevê as seguintes açōes: 1) atingir coberturas vacinais de rotina acima de $95 \%$ em crianças de 1 ano; 2) realizar uma campanha de vacinaçăo indiscriminada, vacinando-se todas as crianças, independentemente da situaçăo vacinal prévia; 3) repetir essa campanha a cada cinco anos, ou menos, a depender da situaçăo epidemiológica, garantindo o seguimento, impedindo 0 acúmulo de susceptiveis que vão se originando dos não vacinados $\theta$ dos vacinados que não se imunizam, a cada ano. ou limpo e o tratamento correto do coto umbilical. Esses fatores são básicos para que o tétano neonatal seja eliminado em todo o território nacional.

\section{Poliomielite}

A poliomielite (paralisia infantil), doença que pode deixar seqüelas graves e levar ao óbito, chegou a acometer 3.596 crianças no ano de 1975. A intensificação da vigilância e ações de controle, particularmente a ampliação da vacinação de rotina e a introdução das Campanhas Nacionais de Vacinação, estratégia que nosso país adotou em caráter pioneiro em 1980, levaram à diminuição do número de casos confirmados nos anos de 1987 e 1988 e culminaram, em 1989, com a notificação do último caso com isolamento do poliovírus selvagem no país. Em 1994, o país recebeu o certificado de erradicação da transmissão autóctone pela Organização Mundial da Saúde (OMS).

A persistência da poliomielite em outros continentes, com o permanente risco de importação do vírus, enquanto não for alcançada a erradicação em escala mundial, justifica a permanência da estratégia dos dias nacionais de vacinação e o fortalecimento da vigilância epidemiológica das paralisias flácidas agudas. As estratégias fundamentais para manutenção da erradicação são o alcance de coberturas vacinais adequadas de forma homogênea em todo o território nacional e o cumprimento de metas adequadas dos indicadores de vigilância epidemiológica.

\section{Sarampo}

O sarampo é uma doença transmissível e contagiosa que acometia de 2 a 3 milhões de crianças nos anos epidêmicos na década de 1970. Apresentou uma nítida tendência de redução da sua incidência no período de 1991 a 2000, e em 2001 alcançou-se a eliminação da circulação do vírus autóctone, apesar da epidemia ocorrida em 1997. O comportamento cíclico da doença, com a ocorrência de epidemias periódicas em média a cada cinco anos, ocorre pela velocidade com que se acumulam susceptíveis, caso não sejam adotadas estratégias adequadas de vacinação, com altas coberturas na vacinação de rotina (mais de $95 \%$ em crianças de 1 ano de idade), estratégias de campanhas periódicas e a investigação imediata de todos os casos suspeitos de sarampo.

No início dos anos 1990, em razão das características epidemiológicas do sarampo, da disponibilidade de uma vacina de alta eficácia e da ocorrência de um surto importante naquele momento, foi assumida a estratégia de eliminação regional dessa doença. 0 primeiro passo foi a realização de uma campanha indiscriminada ${ }^{4}$ de vacinação, o que foi cumprido em 1992, atingindo-se uma alta cobertura vacinal (96\%). Os outros passos, porém, não foram realizados a contento, e mesmo após 1992 a cobertura vacinal antisarampo de rotina continuou a não atingir os níveis adequaddos $(<95)$. A campanha de seguimento realizada em 1995 obteve cobertura menor, de $77,32 \%$, insuficiente para cumprir seu objetivo. ${ }^{5}$ 
Esses fatores, aliados à fragilidade do sistema de vigilância epidemiológica, possibilitaram a eclosão de um surto, iniciado no final de 1996 pelo estado de Santa Catarina e que se estendeu para outros 18 estados em 1997, registrando um total de 53.664 casos confirmados. A realização de uma campanha nacional de vacinação em junho de 1997 , que atingiu a cobertura adequada acima de $95 \%$, juntamente com o reforço das ações de vigilância epidemiológica para detectar e bloquear rapidamente os casos suspeitos, possibilitou o controle dessa epidemia. A continuidade dessas açōes possibilitou a interrupção da transmissão em 2000 , quando foram registrados os últimos casos autóctones de sarampo em todo o território nacional.

O número de óbitos por sarampo também demonstra o benefício conquistado com o controle da doença. Em 1980, essa doença provocou 3.236 mortes, número provavelmente ainda subestimado porque não inclui as mortes indiretas causadas por complicações, como as pneumonias, que se sucediam com freqüência ao sarampo. No ano de 1999 , ocorreram os últimos dois óbitos por sarampo no país, o que não vem mais ocorrendo, com a interrupção da transmissão do vírus. Para consolidar essa conquista e avançar rumo à errađicação, desde o ano de 1999 o MS implantou o Plano de Erradicação do Sarampo.

Dentre as estratégias deste plano, destaca-se a manutenção de um Grupo Tarefa, que está atuando em todas as 27 unidades da Federação, simultaneamente, para intensificar as ações de vigilância epidemiológica realizadas pelos técnicos dos municípios com o objetivo de detectar e investigar de forma oportuna todos os casos suspeitos de sarampo e rubéola, realizar de forma oportuna o bloqueio vacinal diante de todos os casos suspeitos e garantir que todos os municípios atinjam a cobertura vacinal adequada na rotina - de $95 \%$ nas crianças de 1 ano de idade.

Em 2000, foi realizada uma campanha vacinal de seguimento, quando foram vacinadas cerca de 15 milhões de crianças menores de cinco anos em todo o país. Năo há registro de casos autóctones no país desde outubro de 2000. Em 2001 e 2002, apenas um caso de sarampo foi confirmado em cada ano, importado do Japão. Em 2003, mais dois casos importados foram confirmados, sendo o caso índice procedente da Alemanha. Ressalte-se que as ações de investigação epidemiológica e as medidas de controle foram tomadas prontamente pelas SES/SP e SES/SC e seus respectivos municípios, evitando-se a ocorrência de casos secundários. Esse quadro reforça a expectativa de garantir a execução do objetivo de erradicar essa doença em nosso país.

\section{Rubéola}

A rubéola foi introduzida na lista de doenças de notificação compulsória no Brasil somente na segunda metade da década de 1990. Em 1997, ano em que o país enfrentou a última epidemia de sarampo, foram notificados cerca de 30 mil casos de rubéola, com ocorrência de surtos desta doença em vários estados do Brasil no período 1999/2001. Nesse mesmo período, observou-se um aumento progressivo no número de casos de Síndrome da Rubéola Congênita (SRC) (đe 200 para 600), o que reflete tanto o aumento 
da circulação do vírus (a taxa de incidência de rubéola na população feminina em 2001 chegou a 5/100 mil mulheres na faixa etária de 15 a 19 anos e de 6,3/100 mil mulheres na faixa etária de 20 a 29 anos) como o incremento de estratégias de vigilância para a detecção de casos.

A implementação do Plano de Erradicação do Sarampo no país, a partir de 1999, impulsionou a vigilância e o controle da rubéola. Em 2002, ocorreram 443 casos de rubéola no Brasil, o que corresponde a um decréscimo superior a $90 \%$, quando comparado à incidência de 1997. Destaca-se a realização de uma campanha de vacinação em massa dirigida às mulheres em idade fértil em todo o país nos anos de 1998 a 2002 , quando foram vacinadas 29 milhōes de mulheres, com alcance de cobertura média de $95,68 \%$. Também foi completada a introdução da vacina dupla ou tríplice viral no calendário básico de imunização, processo iniciado em 1992.

o fortalecimento da vigilância do sarampo e da rubéola no país revelou a necessidade de controle e prevenção da SRC. Os esforços atuais estão dirigidos à implementação de uma vigilância ativa em todos os estados, com a realização oportuna de exames laboratoriais e complementares que possam não só definir o diagnóstico, mas também oferecer um acompanhamento clínico adequado às crianças com SRC.

A vacinação de mulheres em idade fértil tem possibilitado uma importante redução dos casos de SRC, alcançando a ocorrência de 13 casos registrados em todo o país, o que indica a possibilidade de interrupção na sua transmissão.

\section{Raiva humana}

A raiva é uma doença infecciosa aguda, de etiologia viral, transmitida por mamíferos, que apresenta dois ciclos principais de transmissão: urbano e silvestre. É uma zoonose de grande importância na saúde pública por apresentar letalidade de $100 \%$. É uma doença passível de ser eliminada no ciclo urbano pela existência e pela disponibilidade de medidas eficientes de prevenção tanto em relação ao homem quanto à fonte de infecção. As principais fontes de infecção no ciclo urbano são cão e gato. No Brasil, o morcego hematófago é o principal responsável pela manutenção da cadeia silvestre. Nas duas últimas décadas, houve uma ređução significativa no número de casos humanos registrados por ano, caindo de 173 em 1980 para 17 casos em 2003, tendo o cão como o principal transmissor da doença. Atualmente, esses casos estão concentrados principalmente nas regiōes Norte e Nordeste. Desde 2003, todas as unidades da Federação disponibilizam, na rede de serviços de saúde, vacina de alta qualidade para a profilaxia da raiva humana, a vacina de cultivo celular.

A raiva humana transmitida pelo cão está controlada na região Sul e em alguns estados da regiāo Sudeste, havendo a perspectiva de sua eliminação nesta década. Para cumprir esse objetivo, foram reforçados o monitoramento da circulação viral e a intensificação da vacinação anti-rábica canina nos municípios de maior risco, com a realização de duas campanhas anuais. Foram vacinados, no ano de 2003, aproximadamente 24.274.049 animais, entre cães e gatos. 
Nos últimos dez anos, o aumento de detecção de casos de raiva em outros mamíferos, como morcegos, raposas e sagüis, e a identificação de novas variantes virais vêm apontando para uma mudança no perfil epidemiológico da raiva no país, com a caracterização dos ciclos aéreo e silvestre terrestre, além dos ciclos urbano e rural. Diante desse fato, o MS vem promovendo discussões no sentido de estabelecer novas estratégias para o controle da raiva, de acordo com as diferentes realidades epidemiológicas encontradas no país. No presente ano, a ocorrência de surtos de raiva humana transmitida por morcegos na Amazônia destaca a importância desse ciclo de transmissão, que requer estratégias diferenciadas para seu controle.

\section{Doença de Chagas}

A doença de Chagas é uma doença transmitida principalmente por triatomíneos (insetos hematófagos), ${ }^{6}$ conhecidos como barbeiros, e apresentava uma elevada incidência em nosso país, estimada, no final da década de 1970 , em cerca de 100 mil casos novos por ano.

Hoje, com a estratégia de monitoramento entomológico para identificar a presença do vetor e desencadear as ações de combate utilizando inseticidas específicos, assim como as melhorias habitacionais realizadas nas áreas endêmicas, essa doença encontrase sob controle. Esse fato pode ser constatado a partir do consolidado dos inquéritos sorológicos para a doença de Chagas realizados sistematicamente entre escolares (7-14 anos de idade) de todos os estados endêmicos no período de 1989 a 1999. Nesse consolidado, de 244.770 amostras colhidas, apenas 329 foram positivas, resultando em uma prevalência média geral de $0,13 \%$.

Com esses resultados e a redução da área onde é encontrado o Triatoma infestans, a Comissão Internacional de Especialistas, constituída pela Opas e pelos países do Cone Sul, com a finalidade de avaliar a situação epidemiológica de cada país, conferiu o certificado de interrupção da transmissão vetorial pelo T. infestans a dez estados brasileiros: São Paulo, Rio de Janeiro, Paraíba, Mato Grosso, Mato Grosso do Sul, Goiás, Minas Gerais, Pernambuco, Tocantins e Piauí. Os estados do Paraná e do Rio Grande do Sul, onde os estudos estão sendo concluídos, serão certificados brevemente. No estado da Bahia, onde ainda existem municípios com infestação pelo T. infestans, vêm sendo intensificados esforços visando à eliminação desse vetor para os próximos anos. Os estados da região Amazônica não estão incluídos no Plano de Eliminaçăo do T. infestans, por esta região ser considerada área indene. Nos estados do Maranhão, do Ceará, do Rio Grande do Norte, de Alagoas, de Sergipe, do Espírito Santo e de Santa Catarina, apesar de pertencerem à área endêmica, não existe a espécie T. infestans.

Dentre outras medidas importantes desenvolvidas no país, destacam-se o controle da transmissão transfusional e de vetores de outras espécies transmissoras, além da realização de melhorias habitacionais, o que representa uma soluçāo mais definitiva para uma futura interrupção da transmissão vetorial. Visando avaliar o impacto das ações de 
prevenção e controle da doença de Chagas, vem sendo desenvolvido em todo o país novo inquérito sorológico, que tem indicado uma importante redução na prevalência de infecção na população menor de 5 anos.

\section{Hanseníase}

A hanseníase, outra doença endêmica, tem apresentado uma redução significativa de sua prevalência, de 16,4/10 mil habitantes em 1985 para 4,52/10 mil habitantes em 2003, aproximando-se da meta proposta pela OMS de eliminar essa doença como problema de saúde pública, com a redução de sua prevalência para 1,0/10 mil habitantes no ano de 2005 .

Esse resultado vem sendo obtido inclusive pelo aumento da deteç̧ão de novos casos, que alcançou a taxa de 2,77 casos por 10 mil habitantes em 2003. Tal aumento numa doença contagiosa como a hanseníase tem sido fator importante para reduzir a possibilidade de que casos não diagnosticados e tratados continuem alimentando a cadeia de transmissão da doença. A estratégia para alcançar a prevalência de $1 / 10$ mil habitantes está concentrada na integração com a atenção básica, tornando mais acessível o diagnóstico e o tratamento, impedindo assim a manutenção da cadeia de transmissão de pessoa a pessoa.

\section{Febre tifóide}

A febre tifóide é uma doença transmissível associada às precátias condiçōes sanitárias, de higiene pessoal e ambiental, sendo freqüente sua ocorrência sob a forma de surtos relacionados com água e/ou alimentos contaminados. A imunidade adquirida após a infecção ou a vacinação não é definitiva, e a vacina não apresenta efetividade para o controle de surtos.

A doença persiste de forma endêmica no Brasil, com superposição de epidemias, especialmente nas regiōes Norte e Nordeste. Desde a década de 1980, e especificamente na década de 1990, observa-se um declínio no coeficiente de incidência, de 1,4/100 mil habitantes em 1990 para 0,5/100 mil habitantes em 2000, como também na letalidade, de $2,4 \%$ em 1990 para $1,3 \%$ em 2000 . Nos anos de 2002 e 2003, tem sido registrado um total de casos inferior a 500 em todo o país.

A estratégia de controle da febre tifóide está dirigida, no setor saúde, para o fortalecimento das vigilâncias epidemiológica, sanitária e ambiental visando à detecção de casos precoces e à adoção de medidas que impeçam sua propagação. Nesse sentido, o MS vem implantando, em todas as unidades federadas, a vigilância epidemiológica de doenças de transmissão hídrica e alimentar. Com isso, têm sido trabalhadas de forma integrada com outras doenças diarréicas as capacitações de profissionais de saúde, com utilização do Manual Integrado de Febre Tifóide.

Destacam-se ainda a ampliação da capacidade laboratorial para o diagnóstico específico e a adoção de informações sobre a ocorrência de casos de febre tifóide como um dos critérios de priorização de municípios para a aplicação de recursos em saneamento básico. 


\section{Oncocercose}

A oncocercose é uma doença causada por um verme nematódeo transmitido de uma pessoa infectada a outra por meio da picada de mosquitos vetores do gênero Simulium. Um aspecto extremamente importante dessa doença é que pode causar cegueira. A oncocercose é comum na África e na região das Américas, principalmente no México, na Guatemala e na Venezuela. É também conhecida como cegueira dos rios, pela sua maior incidência em margens de rios e riachos, onde se desenvolve o vetor.

No Brasil, a oncocercose é restrita à área Yanomami, no estado de Roraima, onde inquérito epidemiológico realizado pelo MS no período de 1993 a 1997, em 28 pólosbase, encontrou 1.247 infectados (29,12\%) entre os 4.283 indígenas examinados.

Em 1995, com a disponibilização de drogas mais eficazes contra a oncocercose, foram iniciadas atividades de controle, com distribuição de medicamentos, que atingiram $100 \%$ da área endêmica no Distrito Sanitário Yanomami em 2001. Desde então, essas atividades vêm sendo executadas regularmente com altos níveis de cobertura, o que possibilitará a eliminação da doença.

\section{Filariose}

A filariose é uma doença causada por um nematódeo, a Wucheceria quinquefasciatus. É uma doença comum na África. Em nosso país já foi muito prevalente, mas atualmente está localizada apenas em focos endêmicos na região metropolitana do Recife e, em menor escala, em Maceió, cidades onde as condições ambientais e de drenagem favorecem a permanência de alto índice de população vetorial. Em Belém, onde a eliminação se encontra próxima, a infecção ocorre de forma residual.

Nos últimos anos, o combate à filariose está apoiado no tratamento da população que vive em área de foco com Dietilcarbamazina. No Brasil, a primeira experiência com essa forma de abordagem foi realizada no Recife em novembro de 2003. Faz-se também o controle do vetor, visando reduzir a densidade populacional do mosquito transmissor, além đe atividades de educação em saúde, para que as pessoas residentes nas áreas de foco aprendam a manejar os potenciais criadouros visando à sua eliminação. A prevalência da doença é aferida mediante exames hemoscópicos e a detecção de microfilárias em residentes das áreas de foco. Nas últimas duas décadas, houve uma variação nas atividades operacionais do programa de filariose, o que pode ter se refletido na detecção dos filariêmicos. Entretanto, há uma clara redução no Índice de Lâminas Positivas (ILP), que não pode ser atribuída somente a questões operacionais. Em Belém, não se detectaram filariêmicos a partir de 2002, mesmo tendo sido examinados um total de 171.702 residentes em área de foco. Em Maceió, o ILP de 2003 foi de 0,08.

Atualmente, a filariose encontra-se em fase de eliminação. Entretanto, a descoberta recente de drogas mais potentes contra a $W$. bancrofti, assegurando maior efetividade nas ações de tratamento dos portadores, e experiências positivas em ações de controle do vetor permitem colocar a filariose como uma doença candidata à eliminação no futuro próximo. 


\section{Peste}

A peste, doença transmitida por roedores silvestres, atualmente está restrita a algumas áreas serranas ou de planalto, principalmente na regiāo Nordeste, sendo geralmente associada com o cultivo e a armazenagem de grãos.

Nessa região, os últimos casos foram registrados no ano 2000, restritos ao estado da Bahia. As atividades permanentes de vigilância sobre os roedores, com captura e exames de laboratório para detectar a infecção, têm possibilitado a manutenção e o aprofundamento da situação de controle, sendo sua ocorrência restrita à forma bubônica. A mortalidade por essa doença praticamente inexiste atualmente no país, com apenas um óbito registrado em toda a década de 1990.

\section{DOENÇAS TRANSMISSIVEIS COM QUADRO DE PERSISTÊNCIA}

Algumas doenças transmissíveis apresentam um quadro de persistência ou de redução em período ainda recente, configurando nossa agenda inconclusa nessa área. Para essas doenças, é necessário o fortalecimento de novas estratégias, recentemente adotadas, que propõem uma maior integração entre as áreas de prevenção e controle e a rede assistencial, já que o principal foco da ação nesse conjunto de doenças está voltado para o diagnóstico e o tratamento das pessoas doentes, visando à interrupção da cadeia de transmissão.

É importante também enfatizar a necessidade de açōes multissetoriais para a prevenção e o controle desse grupo de doenças, já que grande parte das razões para a endemicidade reside em processos externos ao setor saúde - urbanização acelerada sem adequada infra-estrutura urbana, alterações do meio ambiente, desmatamento, ampliação de fronteiras agrícolas, processos migratórios, grandes obras de infra-estrutura (rodovias e hidroelétricas).

\section{Malária}

A malária acometia cerca de 6 milhões de brasileiros por ano na década de 1940 em todas as regiōes. As mudanças sociais ocorridas e o intenso trabalho de controle desenvolvido por meio da Campanha de Erradicação da Malária possibilitaram o relativo controle da doença, que passou a apresentar uma ocorrência de menos de $100 \mathrm{mil}$ casos anuais, restringindo-se espacialmente às áreas de proximidade da floresta na Amazônia Legal.

A partir da década de 1970 , os projetos de desenvolvimento da Amazônia, com abertura de estradas, construções de hidroelétricas, expansão de áreas de garimpo, entre outros, promoveram uma grande migração interna no país, com alterações ambientais importantes e exposição de grande contingente populacional à área malarígena. Essa situação provocou a dispersão da malária pelas regiōes Norte e Centro-Oeste, com um aumento significativo do número de casos, passando-se a alcançar níveis de 450 a 500 mil casos anuais. 
Atualmente, a malária concentra-se na região da Amazônia Legal, que responde por mais de $99 \%$ dos casos registrados no país. Nos estados das demais regiōes, os casos registrados são quase totalmente importados da região Amazônica ou de outros países onde ocorre transmissão. Aspectos socioeconômicos, como a valorização de produtos originários de atividades extrativistas e um intenso processo de assentamento rural, que provocam deslocamentos de grandes grupos populacionais para o interior das florestas, intenso processo migratório para áreas periurbanas das grandes cidades na busca de emprego, e fatores ambientais, como a variação de índices pluviométricos, foram responsáveis por um incremento de casos até 1999, com mais de 637 mil casos, com um crescimento de 34\% em relação a 1998.

Essa situação levou o MS a elaborar o Plano de Intensificação das Ações de Controle da Malária (PIACM), desencadeando uma série de açôes na região Amazônica. Essas ações, executadas em parceria com estados e municípios, colaboraram na inversão da tendência de crescimento desta endemia.

Com o PIACM, que vigorou no período de 2000 a 2002, houve uma redução de $50,2 \%$ na incidência da malária na região da Amazônia Legal ao final do ano de 2002 (15,9 casos de malária por mil habitantes), comparando-se com 1999 (31,9 casos de malária por mil habitantes). Em números absolutos, passou-se de 637 mil casos em 1999 para 349 mil casos em 2002. Nesse mesmo período, o número de municípios de alto risco passou de 160 para 72 . As internações reduziram-se em $69,2 \%$, e o número de óbitos por malária diminui em $54,7 \%$. Além da melhoria desses indicadores, cabe ressaltar outros avanços obtidos, como a capacitação de profissionais de saúde, a inserção das atividades de controle da malária nos sistemas locais de saúde, principalmente na atenção básica, a expansão da rede de diagnóstico e tratamento, para propiciar um diagnóstico rápido e tratamento oportuno, composição de equipes de vigilância epidemiológica em alguns municípios e o controle seletivo de vetores.

Entretanto, após essa importante redução na transmissão, a malária voltou a apresentar aumento na incidência nas áreas endêmicas dos estados da Amazônia. Entre 2002 e 2003, foi observado um aumento na incidência de $17,9 \%$, chegando a um total de 410.475 casos no ano passado. Com o objetivo de manter os avanços alcançados no controle da malária até o ano de 2002, assegurando sustentabilidade ao processo de descentralização das ações de epidemiologia e controle da doença para estados e municípios, o MS vem assegurando uma política permanente para prevenção e controle da endemia, por intermédio do Programa Nacional de Controle da Malária (PNCM).

\section{Tuberculose}

Com a introdução de novos esquemas terapêuticos de curta duração, na década de 1980, a tuberculose vem apresentando uma média anual de 85 mil casos novos nos últimos anos. $O$ modelo adotado no seu controle, de excessiva centralização da assistência, o longo tempo exigido para os tratamentos atualmente disponíveis (mínimo de seis meses), o adensamento populacional nas periferias das grandes cidades sem adequada 
${ }^{7}$ Meninges são membranas que envolvem as estruturas anatômicas componentes do sistema nervoso central.

${ }^{8}$ A doença meningocócica manifesta-se, geralmente, sob a forma de meningite ou como infecção generalizada. condição sanitária, entre outros fatores, influíram para essa situação. Sobre a tuberculose, registre-se ainda que a associação com a Aids tem impulsionado seu crescimento em todo o mundo. No Brasil, cerca de $25,5 \%$ dos casos de Aids apresentam a tuberculose como doença associada.

A tuberculose tem sido objeto de ações e investimentos recentes do MS e demais instâncias do Sistema Único de Saúde (SUS), visando descentralizar o atendimento e adotar novas formas de garantir a continuidade do tratamento, para ampliar a capacidade de detecção de novos casos e aumentar o percentual de cura. Essa estratégia tem envolvido, inclusive, o repasse de recursos financeiros para ampliar a detecção de casos, elevar a taxa de cura e reduzir a taxa de abandono, visando produzir um impacto positivo já nos próximos anos.

\section{Meningites}

O termo meningites designa um quadro caracterizado por processos inflamatórios das meninges, ${ }^{7}$ que podem estar relacionados com uma grande variedade de agentes, infecciosos (vírus, bactérias, fungos e protozoários) ou não. Para a saúde pública, são relevantes as meningites infecciosas, causadas por agentes etiológicos transmissíveis. 0 quadro clínico da doença pode variar de acordo com a etiologia, mas em geral a doença é grave e pode evoluir para óbito.

A meningite constitui um problema complexo e multifacetado, por ser uma doença com diferentes etiologias, distintos impactos sobre a saúde pública e estratégias de prevenção e controle diversas.

As meningites bacterianas e virais são as mais importantes, na perspectiva da saúde pública, pela magnitude de sua ocorrência, potencial de transmissão, patogenicidade e relevância social. Dentre as primeiras, merecem destaque as meningites meningocócicas, as meningites por pneumococo, meningites por Haemophilus influenzae tipo b e a meningite tuberculosa.

A doença meningocócica ${ }^{8}$ tem ocorrência em praticamente todo o mundo, apresentando-se em forma hiperendêmica na regiảo do sub-Saara africano com alguns países, chegando a apresentar uma incidência anual de 150 casos por 100 mil habitantes. $O$ Brasil registrou uma grande epidemia de doença meningocócica na década de 1970, que teve seu epicentro em São Paulo, mas se alastrou por todo o país. Na época, foi realizada uma grande campanha nacional de vacinação de toda a população com a vacina antimeningocócica AC. Possivelmente pelo efeito combinado de dois fatores, a utilização da vacina e o esgotamento de susceptíveis, a epidemia foi controlada.

A partir da década de 1980 , houve uma mudança importante no comportamento epidemiológico da doença meningocócica no país, com o desaparecimento do sorogrupo A e o predomínio do sorogrupo $B$.

Durante a primeira metade da década de 1990, observou-se um aumento no número de casos notificados de doença meningocócica, atingindo o pico em 1996, com o registro de 
7.321 casos. Esse aumento decorreu, em grande parte, de surtos localizados em municípios com grande contingente populacional, como São Paulo, Rio de Janeiro e Rio Grande do Sul.

A partir de 1996, há uma tendência de redução constante no número de casos, de 7.321 casos, neste ano, para 2.923 casos em 2003. Alguns fatores podem ter colaborado com essa redução, dentre eles destaca-se a adoção oportuna das medidas de controle (quimioprofilaxia e vacinação de bloqueio), decorrente da ampliação da assistência à saúde da população.

Dentre as medidas adotadas pelo MS e demais esferas gestoras do SUS para a vigilância e o controle das meningites, destacam-se o aprimoramento do diagnóstico laboratorial, da assistência médica; a adoção de medidas de controle, tais como a quimioprofilaxia, quando indicada; a utilização das vacinas antimeningocócicas AC e C em situações de surto; as altas coberturas vacinais de BCG e a implantação (em 1999) da vacina contra Haemophilus influenzae tipo b (Hib) no esquema básico de imunizaçōes para todas as crianças menores de 5 anos de idade do país. ${ }^{9}$

Destaca-se que antes da introdução da vacina contra Hib este agente ocupava o segundo lugar dentre as meningites bacterianas especificadas, e hoje os dados disponíveis apontam para um impacto altamente positivo dessa vacina, com uma redução de $95 \%$ na incidência de meningites por Haemophilus influenzae em menores de 5 anos, quando comparados os anos de 1998 e 2003.

\section{Leishmaniose visceral}

A leishmaniose visceral (também conhecida por calazar) era uma doença praticamente silvestre com características de ambientes rurais que tem tido uma mudança de comportamento, fundamentalmente por modificaçōes socioambientais, como o desmatamento - que reduziu a disponibilidade de animais para servir de fonte de alimentação para o mosquito transmissor, colocando-lhe o cão e o homem como alternativas mais acessíveis - e o processo migratório, que trouxe para a periferia das cidades populaçōes humana e canina originárias de áreas rurais onde a doença era endêmica.

Além disso, para essa doença ainda não se dispõe de formas de prevenção completamente efetivas, como uma vacina.

O comportamento epidemiológico da leishmaniose visceral é cíclico, com elevação dos casos em períodos médios a cada cinco anos, além de uma tendência crescente, se considerarmos o período de 1980 a 2003. Na década de 1990 , aproximadamente $90 \%$ dos casos de LV ocorreram na região Nordeste, e atualmente essa região representa $74 \%$ do total de casos do país.

O aumento do número de casos registrados, nos anos recentes e em outras regiōes, pode ser explicado pela modificação do padrão de ocorrência geográfica, com o registro de casos em centros urbanos, como Belo Horizonte, Natal, São Luís, Teresina, Fortaleza, Montes Claros, Araçatuba, Imperatriz, Timon, Caxias e, mais recentemente, Palmas e Campo Grande, caracterizando uma expansão da área tradicional de ocorrência dessa
${ }^{9}$ No primeiro ano da implantaçẫo, a faixa etária foi para menores de 2 anos. 
doença, em decorrência do intenso processo migratório da população rural para a periferia das cidades de médio e grande portes. Além disso, o processo de organização da rede assistencial, associado ao melhor preparo para diagnóstico e tratamento, proporcionou uma maior đeteç̧ão de casos.

A partir de 2003, as normas técnicas de vigilância e controle foram revisadas, e as recomendações de vigilância e controle passaram a ser específicas para cada situação epidemiológica e adequadas a cada área a ser trabalhada. Os municípios de transmissão foram classificados de acordo com a média de casos nos últimos cinco anos. O novo enfoque é o de incorporar os estados e os municípios silenciosos para a doença, visando evitar ou minimizar os problemas referentes a este agravo em novas áreas.

\section{Leishmaniose tegumentar americana}

A Leishmaniose tegumentar americana (LTA) apresenta-se em fase de expansão geográfica. Nas últimas décadas, as análises de estudos epidemiológicos de LTA têm sugerido mudanças no comportamento epidemiológico da doença. Inicialmente considerada zoonose de animais silvestres que acometia ocasionalmente pessoas em contato com florestas, a LTA começa a ocorrer em zonas rurais já praticamente desmatadas e em regiōes periurbanas. Observa-se a coexistência de um duplo perfil epidemiológico expresso pela manutenção de casos oriundos dos focos antigos ou de áreas próximas a eles e pelo aparecimento de surtos epidêmicos associados a fatores decorrentes do surgimento de atividades econômicas, como garimpos, expansão de fronteiras agrícolas e extrativismo, em condições ambientais altamente favoráveis à transmissão da doença.

No período de 1980 a 2003, a LTA no Brasil vem apresentando coeficientes de detecção que oscilam entre 3,83 a 22,94 por 100 mil habitantes. Ao longo desse período, observou-se uma tendência ao crescimento, registrando os coeficientes mais elevados nos anos de 1994/1995, quando atingiram níveis de 22,83 e 22,94 por 100 mil habitantes, respectivamente. Vale ressaltar que o ano de 1998 apresentou uma queda significativa neste coeficiente ( $13,47 / 100$ mil habitantes), fato este que pode estar relacionado a problemas operacionais naquele ano. Ao analisar a evolução da LTA no Brasil, observase uma expansão geográfica - no início da década de 1980 foram registrados casos em vinte unidades federadas, e nos últimos anos todas as unidades federadas registraram casos autóctones da doença. No ano de 1994, houve um registro de casos autóctones em 1.861 municípios, o que representa $36,9 \%$ dos municípios do país; em 2002, houve uma expansão da doença para 2.302 municípios $(41,1 \%)$. As regiōes Nordeste e Norte vêm contribuindo com o maior número de casos registrados no período (cerca de $36,9 \%$ e $36,2 \%$ respectivamente), e a região Norte, com os coeficientes mais elevados (99,85/100 mil habitantes), seguida das regiões Centro-Oeste (41,85/100 mil habitantes) e Nordeste (26,50/100 mil habitantes).

Por ser uma doença que apresenta grande diversidade e constantes mudanças nos padrões epidemiológicos de transmissão, em virtude das diferentes espécies de vetores, 
reservatórios e agentes etiológicos, associados à ação do homem sobre o meio ambiente, a LTA apresenta dificuldades de controle. As estratégias para o controle da LTA devem ser específicas, conforme a situação epidemiológica de cada local e região, destacando-se que é fundamental o conhecimento do maior número de casos suspeitos; o diagnóstico e o tratamento precoce dos casos confirmados; a identificação do agente etiológico circulante na área; o conhecimento das áreas de transmissão e a redução do contato homem vetor por meio de medidas específicas.

Para a implementação e o fortalecimento das açōes de controle da LTA no Brasil, a Secretaria de Vigilância em Saúde, em parceria com o Departamento de Endemias Samuel Pessoa (Ensp/Fiocruz), desenvolveu um modelo de vigilância e monitoramento da LTA para identificação de áreas prioritárias para ação de prevenção e controle.

Procedeu-se a uma análise da distribuição espaço-temporal da endemia, utilizandose, além do número de casos e do coeficiente de detecção, a densidade de casos por área. Também foram analisados dados ambientais, sociais e demográficos das áreas de relevância epidemiológica para este agravo. A partir dessas análises, foram identificados os principais circuitos e pólos de produção de LTA no Brasil.

Somado a essa proposta, tem-se investido na capacitação de recursos humanos; na organização dos serviços para o atendimento primário, secundário e terciário; na aquisição e na distribuição de medicamentos para o tratamento dos doentes e de inseticidas para o controle vetorial, além do aprimoramento dos sistemas de vigilância epidemiológica e entomológica.

\section{Febre amarela silvestre}

A febre amarela apresenta duas formas de expressão, a urbana e a silvestre.

A febre amarela urbana encontra-se erradicada de nosso país desde 1942. Não é possível erradicar a febre amarela silvestre, porque a doença tem um importante ciclo natural de circulação entre os primatas não humanos das florestas tropicais.

No Brasil, com o desaparecimento da modalidade urbana da doença e a manutenção de epizootias e casos humanos silvestres, estudos anteriores à década de 1970 tornaram possível definir três áreas epidemiologicamente distintas, com risco de transmissão da doença, que foram sendo modificadas a partir de 1997: 'endêmica' ou 'enzoótica' (região Norte e Centro-Oeste e estado do Maranhão); 'epizoótica' ou 'de transição' (faixa que vai da região centro-sul do Piauí, oeste da Bahia, noroeste de Minas Gerais, São Paulo, Paraná, Santa Catarina e Rio Grande do Sul); e 'área indene' (área onde não há circulação comprovada do vírus amarílico e que abrange os estados da região Nordeste, Sudeste e Sul). Em função da última epidemia ocorrida em Minas Gerais no ano de 2003, foi definida uma 'área indene de risco potencial' para circulação viral contígua à área de transição, que apresenta ecossistemas semelhantes, considerando critérios históricos, hidrográficos e de vegetação, compreendendo os municípios do sul de Minas Gerais e da Bahia e a região centro-norte do Espírito Santo. 
Em função da epidemia de Minas Gerais, o MS e as secretarias estaduais de Saúde, em conjunto com órgãos de turismo e transporte, realizaram uma campanha de divulgação para alertar os viajantes que se dirigem às regiōes endêmicas da necessidade de vacinação prévia, sendo ampliado o acesso à vacina para toda a rede de saúde.

As açōes de vigilância epidemiológica também foram fortalecidas, buscando detectar o número real de casos de febre amarela que ocorrem durante os surtos e a adoção oportuna de medidas de bloqueio. O surto verificado no Parque Nacional da Chapada dos Veadeiros, em Alto Paraíso, Goiás, local que atraiu cerca de 3 mil turistas nas festas do final do ano de 1999, e os surtos ocorridos em 2001 e 2003 em Minas Gerais reforçaram a necessidade de se garantir a proteção para um novo grupo de risco - os praticantes do turismo ecológico ou rural - e de se redefinir as áreas de transmissão para febre amarela no Brasil, o que foi feito em 2003.

Foram adotadas novas ações de intensificação da vigilância epidemiológica, com especial atenção para a vigilância de epizootias entre primatas não humanos nas florestas brasileiras, considerando sua importância como evento sentinela para identificar a circulação do vírus amarílico e assim prevenir a ocorrência de casos humanos. Aliado a isso, tem sido recomendada a implantação da vigilância sindrômica das doenças febris que cursam com icterícia e hemorragia, com a finalidade de melhorar a sensibilidade da detecção de casos de febre amarela, bem como das doenças que entram no leque do diagnóstico diferencial. Em 2003, foram registrados 64 casos da doença, com 23 óbitos. O surto de Minas Gerais foi responsável por 58 desse total de casos e por $75 \%$ de todos os óbitos do período (21 óbitos). Os demais casos de febre amarela foram registrados em Mato Grosso $(\mathrm{n}=5)$ e Pará $(\mathrm{n}=1)$.

A vacina antiamarílica é o único meio eficaz para prevenir e controlar a doença, já que interrompe o ciclo de transmissão e tem por objetivos: conferir proteção individual e coletiva à população, bloquear a propagação geográfica da doença, criando uma barreira de imunidade, e prevenir epidemias. A partir de 1998, visando evitar a ocorrência de surtos de grande magnitude, o MS iniciou uma ampla campanha de intensificação da vacinação contra a febre amarela na área de risco, totalizando, até 2001, 58 milhões de doses de vacina aplicadas. Nos 1.341 municípios da área de transição, até o ano de 2002 foram aplicadas 21,4 milhões de doses de vacina numa população de 26,3 milhões de habitantes (81,2\% de doses aplicadas). No país como um todo, no período de 1993 a 2003 foram aplicadas 176.626 .490 de doses de vacina no Brasil. Somente em 2003 foram vacinados contra febre amarela 5.224 .672 habitantes. Na área indene, a estratégia de vacinação visa assegurar que todas as pessoas que se dirijam às áreas endêmicas ou de transição sejam vacinadas com antecedência de dez dias. Com a intensificação das ações de vacinação e após a ocorrência dos primeiros eventos adversos graves associados temporalmente à vacina contra febre amarela, foi implantado um protocolo para esses eventos, tendo sido detectados cinco casos graves com quatro óbitos no período de 1999 a 2003 no país. 
As ações de prevenção e controle da febre amarela têm como meta atingir a cobertura vacinal de $100 \%$ em todos os municípios, com estratégias diferenciadas de vacinaçâo: nas salas de vacinas, vacinação casa-a-casa na zona rural, nas escolas, em campanhas e ação conjunta com Pacs e PSF.

Outras estratégias incluem: monitoramento rápido da cobertura local; avaliação sistemática dos eventos adversos; estímulo ao porte de cartão; atividades de sensibilização para adesão da vacinação do adulto; vacinação de grupos de maior vulnerabilidade e específicos, tais como bóias-frias, assentamentos, acampamentos de sem-terra, caminhoneiros e áreas indígenas; articulaçăo e parcerias de ações conjuntas com outras instituições governamentais e não governamentais.

\section{Hepatites virais}

As hepatites virais apresentam distribuição universal e magnitude variável de acordo com a região do país. As hepatites A e E apresentam alta prevalência nos países em desenvolvimento, onde as conđiçōes sanitárias e socioeconômicas são precárias. A prevalência de hepatite $B$ tem sido reduzida em países onde a vacinação foi implementada, porém permanece alta em populaçōes de risco acrescido e em países onde a transmissão vertical e horizontal intradomiciliar não é controlada. A OMS estima que cerca de 2 bilhões de pessoas já tiveram contato com o vírus da hepatite B, com 325 milhões tornando-se portadores crônicos. A prevalência de hepatite $\mathrm{C}$, com base em dados de prédoadores de sangue, pode variar entre índices menores que $1 \%$ em países como Reino Unido, Escandinávia, Nova Zelândia e algumas áreas đo Japão, ou chegar a altas taxas, como $14 \%$ no Egito e $26 \%$ no Cairo. Em geral, a infecção pelo vírus da hepatite D ocorre em áreas com prevalência moderada a alta de hepatite $\mathrm{B}$ crônica, visto que o vírus delta depende do vírus $B$ para ser infectante. As maiores prevalências de hepatite delta ocorrem no sul da Itália e em algumas áreas da ex-URSS e África, além da região da Bacia Amazônica.

Para o Brasil, a Organização Pan-Americana da Saúde (Opas) possui estimativa de infecção pelo HAV de aproximadamente 130 casos novos por 100 mil habitantes ao ano e de que mais de $90 \%$ da população maior de 20 anos tenha tido exposição ao vírus. Entretanto, com as melhorias nas conđiçōes de saneamento, alguns estudos têm demonstrado um acúmulo de susceptíveis em adultos jovens acima desta idade.

Alguns estudos do final da década de 1980 e início da de 1990 sugeriram uma tendência crescente do VHB em direção às regiōes Sul e Norte. Assim, considerava-se que ocorriam três padrôes de đistribuição da hepatite B: 'alta endemicidade', com prevalência superior a $7 \%$, presente na região Amazônica, alguns locais do Espírito Santo e oeste de Santa Catarina; 'endemicidade intermediária', com prevalência entre $2 \%$ e $7 \%$, nas regiōes Nordeste, Centro-Oeste e Sudeste; e 'baixa endemicidade', com prevalência abaixo de $2 \%$ na regiāo Sul do país.

No entanto, esta infecção é muito dinâmica e variável. Com a implementação de campanhas de vacinação contra a hepatite B em algumas regiōes do estado do Amazo- 
nas, desde 1989, e a implantação da vacina em menores de 1 ano e em menores de 15 anos, nos anos de 1991 e 1996, respectivamente, esse padrão vem se modificando na região, como atestam estudos mais recentes. Na região de Lábrea, estado do Amazonas, a taxa de portadores do VHB passou de 15,3\% em 1988 para 3,7\% em 1998. Na região de Ipixuna, essa queda foi de $18 \%$ para $7 \%$.

No ano de 1992, implantou-se a vacinação no estado do Acre para as mesmas faixas etárias, e em 1993, para o restante da Amazônia Legal. Essa ação também teve impacto naquele estado, que em estudo de base populacional em 12 de seus 24 municípios apresentou a taxa de HbsAg de 3,4\%. Outros trabalhos também classificam a regiăo Norte como de baixa ou moderada endemicidade, permanecendo com alta endemicidade a regiāo sudeste do Pará.

Em 1993, foi implantada a vacinação para menores de 4 anos nos estados de Santa Catarina, Espírito Santo, Paraná, redefinida em 1996 para menores de 15 anos e no mesmo ano para o restante do país para menores de 1 ano.

Na região Sul, categorizada como de baixa endemicidade, permanecem com prevalência moderada a região oeste de Santa Catarina e alta endemicidade o oeste do Paraná, região que teve a faixa etária para a vacinação estendida para menores đe 15 anos em 1998.

A região Sudeste como um todo apresenta baixa endemicidade, com exceção do sul do Espírito Santo e do nordeste do estado de Minas Gerais, onde ainda são encontradas altas prevalências. A região Centro-Oeste é de baixa endemicidade, com exceção do norte do Mato Grosso, com prevalência moderada. O Nordeste como um todo está em situação de baixa endemicidade.

Com o objetivo de encurtar coortes de susceptíveis para a infecção pelo VHB, a imunizaçăo contra a hepatite $\mathrm{B}$ foi estendida em todo o território para a idade de até 19 anos.

Quanto à hepatite $\mathrm{C}$, ainda não existem estudos capazes de estabelecer sua real prevalência no país. Com base em dados da rede de hemocentros de pré-doadores de sangue, em 2002, a distribuição variou entre as regiōes brasileiras: $0,62 \%$ no Norte; $0,55 \%$ no Nordeste; $0,28 \%$ no Centro-Oeste; $0,43 \%$ no Sudeste e $0,46 \%$ no Sul. Um dos poucos estudos de base populacional realizado em nosso meio revelou $1,42 \%$ de portadores de anti-HCV na cidade de São Paulo. Resultado semelhante foi obtido em um estudo de soroprevalência realizado na cidade de Salvador, com 1,5\% de portadores de anti-HCV. Atualmente, a transmissão da hepatite $\mathrm{C}$ via transfusão sangüínea e hemoderivados é rara; porém, essa forma de contágio teve grande importância nos anos precedentes a 1993, quando foi instituída a testagem em bancos de sangue após a disponibilização de kits comerciais.

Em 2004 e 2005, inquérito soroepidemiológico de base populacional será realizado nas capitais brasileiras, levantando prevalência das hepatites A, B e Ce fatores associados nas macrorregiōes brasileiras.

A hepatite delta concentra-se na região Amazônica Ocidental, que apresenta uma das maiores incidências do mundo deste agente. $O$ vírus da hepatite delta é responsável 
por surtos epidêmicos ictero-hemorrágicos e também pela alta prevalência de hepatopatias crônicas e hepatocarcinoma entre portadores. Acredita-se que a Amazônia ofereça condições ambientais, sociais, culturais e aspectos genéticos da população que contribuem para a circulação viral do VHD. Em estudo recente no estado do Acre, a prevalência encontrada de antidelta foi de 1,3\%. Nas regióes Sudeste, Nordeste e na Amazônia Oriental a infecçăo está ausente.

O VHE é importante causador de surtos e desenvolve quadros graves, principalmente em gestantes. No Brasil, apesar de apresentar condições sanitárias deficientes em muitas regiōes, ainda não foi descrita nenhuma epidemia pelo VHE. Alguns casos isolados têm sido notificados, demonstrando que há circulação deste vírus no país.

A vigilância epidemiológica das hepatites virais no Brasil utiliza o sistema universal e passivo, baseado na notificação de casos suspeitos. O número de notificações não reflete a real incidência da infecçâo, pois a grande maioria dos acometidos apresenta formas assintomáticas ou oligossintomáticas, sendo dificilmente captados. Estados e municípios estão em điferentes estágios de implantação, refletindo diferentes níveis de sensibilidade e de capacitação das equipes das vigilâncias epidemiológicas.

\section{Esquistossomose}

A esquistossomose mansônica tem ampla distribuição geográfica no Brasil, com maior intensidade de transmissão na região Nordeste do país e no norte de Minas Gerais. Entretanto, 18 estados e mais o Distrito Federal apresentam áreas de transmissão, ainda que alguns deles sejam constituidos de áreas focais.

Desde o início da década de 1950 até o presente ano tem sido observada redução nas prevalências de infecção, detectadas mediante inquéritos coproscópicos populacionais. Entretanto, tem ocorrido uma maior distribuição espacial com o processo de urbanização e migração. Também os indicadores de morbidade hospitalar e mortalidade têm evidenciado redução em análises realizadas nos sistemas de informações existentes.

Nos últimos vinte anos, o percentual de positividade detectado em inquéritos coproscópicos realizados inicialmente pelo MS e mais recentemente pelas secretarias estaduais e municipais de Saúde tem-se situado entre 5,5\% e 11,6\% da população examinada. Observam-se variações anuais na positividade em função da heterogeneidade das áreas submetidas aos inquéritos em cada estado. Dentre os estados destacam-se Alagoas, Pernambuco, Bahia, Sergipe, Paraíba e Minas Gerais, com os maiores percentuais. Nos estados de maior percentual de positividade, também têm sido registrados os maiores coeficientes de mortalidade e proporção de internações por esquistossomose. A tendência histórica para esses indicadores aponta para uma redução na morbidade e na mortalidade por formas graves da doença para o país como um todo. Entretanto, nas áreas endêmicas da região Nordeste do Brasil, a ocorrência da forma hepatoesplênica, que pode levar ao óbito por hemorragia đigestiva, ainda representa um importante problema de saúde. A ampliação da oferta de abastecimento e esgotamento sanitário tem contribuído para a melhoria dos indicadores da esquistossomose. A utilização de critérios epidemio- 
lógicos para seleção de municípios elegíveis para aplicação de recursos para saneamento pela Funasa contribui para a redução na transmissão da esquistossomose. Por outro lado, a maior disponibilidade de assistência médica e a adoção de tratamento específico têm contribuído para a redução dos indicadores de morbidade e mortalidade.

Desde meados da década de 1970, tem sido desenvolvido um programa de controle da esquistossomose no país, baseado na realização de inquéritos coproscópicos e no tratamento de portadores e, em menor escala, nas ações de saneamento, no tratamento de criadouros e na educação em saúde. Nos municípios onde o programa tem alcançado uma boa cobertura e regularidade, tem sido observado impacto na redução dos indicadores. Desde 1993, vem sendo implementada a descentralização das ações de controle da esquistossomose, intensificando-se a partir de 1999 e 2000, quando as secretarias municipais passaram a assumir gradativamente o controle desta endemia em seu território.

\section{Leptospirose}

A leptospirose é uma zoonose de caráter endêmico, podendo apresentar-se na forma de surto ou epidemia sob determinadas condições climáticas, ambientais, de infra-estrutura sanitária e alta infestação de roedores.

Os roedores sinantrópicos (ratazanas, ratos de telhado e camundongos) são os principais reservatórios da doença. São afetados também e podem atuar como portadores cães, bovinos, suínos, ovinos, caprinos e eqüinos.

No período de 1994 a 2003, foi registrada uma média anual de 3.324 casos e 334 óbitos, correspondendo a uma letalidade média de $10 \%$. Os principais grupos etários afetados são os de 20 aos 49 anos. No Brasil, a maior parte dos casos está ligada às condições de vida e à infra-estrutura sanitária, principalmente em nível domiciliar. Ocorre em áreas urbanas e rurais, mas a maioria dos casos notificados provém das capitais e das regiões metropolitanas. Enchentes e chuvas fortes contribuem para o contato do homem com água e lama contaminadas pela urina de roedores, favorecendo a infecção. Apesar de não ser tipicamente ocupacional em nosso país, algumas profissões facilitam o contato com as leptospiras, como trabalhadores em limpeza e desentupimento de esgotos, agricultores, veterinários, tratadores de animais, pescadores, magarefes, laboratoristas e bombeiros, dentre outras.

O MS investe no fortalecimento da vigilância epidemiológica e ambiental realizada por estados e municípios por meio de elaboração de normas, apoio e assessorias técnicas, fornecimento de kits diagnósticos para a Rede Nacional de Laboratórios de Saúde Pública, realização de treinamentos em clínica e tratamento de casos, dentre outros.

É de fundamental importância que os níveis periféricos de atenção visem a um aumento na suspeita clínica, à atenção adequada e oportuna ao paciente e à conseqüente diminuição da letalidade, juntamente com o aprimoramento das etapas da investigação epidemiológica e ambiental e do controle de roedores. O desafio maior para a vigilância da leptospirose reside atualmente na promoção da sensibilidade do sistema para detectar casos leves e moderados da doença e sua notificação ao Sistema de Informação 
de Agravos de Notificação (Sinan), além do aprimoramento das etapas da investigação epidemiológica, a determinação de áreas de risco e a adequação e continuidade de medidas direcionadas ao controle de roedores. Todas essas medidas devem estar integradas com outras atividades intersetoriais que possam levar às mudanças ambientais e sociais necessárias para que ocorra um declínio sustentável no aparecimento dos casos da doença.

\section{Acidentes por animais peçonhentos}

Os acidentes por animais peçonhentos não constituem doença transmissível, porém têm sido abordados juntamente com as zoonoses, uma vez que se trata de agravo, a exemplo da raiva, na qual ocorre a agressão por um animal e o quadro clínico é conseqüente à ação de toxinas inoculadas pelas picadas. As serpentes, os escorpiões e as aranhas são os principais agentes causadores de envenenamentos. Mais recentemente, acidentes com lagartas do gênero Lonomia e envenenamentos causados por enxames de abelhas têm merecido atenção em razão da gravidade e da alta letalidade.

A đistribuição dos acidentes ofídicos no país indica incidências mais elevadas nas regiōes Centro-Oeste e Norte, apesar de o número absoluto de casos ser maior no Sudeste. Da mesma forma, a ocorrência dos acidentes ao longo do ano apresenta marcada sazonalidade, com predomínio dos casos nos meses quentes e chuvosos. Os acidentes botrópicos (causados por serpentes do gênero Bothrops, conhecidas popularmente por jararacas) representam $88 \%$ dos casos, enquanto os acidentes crotálicos (Crotalus, cascavéis), laquéticos (Lachesis, surucucu-pico-de-jaca) e elapídicos (Micrurus, corais verdadeiras) correspondem a, respectivamente, $9 \%, 2,5 \%$ e $0,5 \%$ do total das notificações. $O$ conhecimento das características epidemiológicas dos acidentes tem orientado a distribuição e a utilização dos soros antipeçonhentos de acordo com as necessidades regionais, ao mesmo tempo em que as ações de vigilância e controle da fauna peçonhenta determinam abordagens específicas, segundo os ecossistemas em que os animais são encontrados.

A interferência humana sobre o meio ambiente está provavelmente muito associada ao incremento dos casos de escorpionismo, araneísmo (particularmente aranhas do gênero Loxosceles). Por outro lado, em que pese ao processo crescente de urbanização, não se verifica diminuição dos acidentes ofídicos, sugerindo uma possível aproximação e adaptação das serpentes às periferias das cidades, onde as precárias condições de saneamento básico propiciam a proliferação de roedores, que servem de alimento para esses animais.

Paralelamente às ações de prevenção e controle dos animais peçonhentos, tem-se buscado o fortalecimento das atividades de capacitação dos profissionais de saúde no diagnóstico e no tratamento, com ênfase na correta administração dos soros específicos, visando à redução da freqüência de seqüelas e da letalidade dos acidentes. 


\section{DOENÇAS TRANSMISSIIVEIS EMERGENTES E REEMERGENTES}

Um terceiro grupo de doenças expressa, em nosso país, o fenômeno mundial de emergência e reemergência de doenças transmissíveis. Para o propósito do presente documento, serão consideradas algumas doenças transmissíveis que foram introduzidas ou ressurgiram no país nas últimas duas décadas, que é o período de análise que está sendo considerado para as doenças transmissíveis. Destacam-se o surgimento da Aids no início da década de 1980; a reintrodução da cólera, a partir do Peru, em 1991; e a epidemia de dengue, que passou a constituir-se, no final da década de 1990, em uma das maiores prioridades de saúde pública no continente e no país.

Aids

A Aids foi identificada no Brasil, pela primeira vez, em 1980 e apresentou um crescimento na incidência até 1998 , quando foram registrados 25.732 casos novos, com um coeficiente de incidência de 15,9 casos por 100 mil habitantes. A partir de então, observou-se uma desaceleração nas taxas de incidência de Aids no conjunto do país, a despeito da manutenção das principais tendências da epidemia: heterossexualizaçăo, feminização, envelhecimento e pauperização do paciente, aproximando-o cada vez mais do perfil socioeconômico do brasileiro médio. Desde o início da década de 1980 até setembro de 2003, o MS notificou 277.154 casos de Aids no Brasil. Desse total, 197.340 foram verificados em homens e 79.814 em mulheres.

No ano de 2003, foram notificados 5.762 novos casos da epidemia, e, desses, 3.693 foram verificados em homens e $2.069 \mathrm{em}$ mulheres, mostrando que, atualmente, a epidemia cresce mais entre as mulheres.

Outro dado não menos preocupante é a crescente incidência da Aids em relação à faixa etária de 13 a 19 anos em adolescentes do sexo feminino. Tal fato é explicado pelo início precoce da atividade sexual em relação aos adolescentes do sexo masculino, normalmente com homens com maior experiência sexual e mais expostos aos riscos de contaminação por DST e pela Aids.

Quanto às principais categorias de transmissão entre os homens, as relaçōes sexuais respondem por $58 \%$ dos casos de Aids, com maior prevalência nas relações heterossexuais, que é de $24 \%$. Entre as mulheres, a transmissão do HIV também se dá, predominantemente, pela via sexual $-86,7 \%$. As demais formas de transmissão, em ambos os sexos, de menor peso na epidemia, são: transfusão, transmissão materno-infantil ou ignoradas pelos pacientes.

\section{Cólera}

Dentro do elenco de doenças reemergentes inclui-se a cólera, que alcançou o continente americano e o território brasileiro em 1991, trinta anos após o início dessa que é a sétima pandemia a acometer a humanidade e a primeira a ser causada pelo vibrio 
cholerae El Tor. Esta patologia, apesar de todo o conhecimento acumulado, continua impondo desafios não somente em função das características do agente, mas principalmente pela vulnerabilidade de grande parcela da população munđial, que sobrevive em condições de pobreza extrema.

A sétima pandemia chegou ao Brasil em 1991 e até 2001 atingiu todas as regiōes do país, produzindo um total de 168.598 casos e 2.035 óbitos, com registro de grandes epidemias na região Nordeste. O coeficiente de incidência de cólera em 1993, ano em que ocorreu o maior número de casos, foi de $39,81 / 100$ mil habitantes, com 670 óbitos e letalidade de $1,11 \%$.

A magnitude da doença no território brasileiro esteve relacionada às condições altamente favoráveis à sua disseminação, principalmente as condições de vida da população, tendo encontrado nas regiôes Norte e Nordeste condições altamente favoráveis à sua implantação e disseminação.

Porém, a vulnerabilidade à doença também pode ser constatada em áreas mais desenvolvidas do país, principalmente nos bolsões de pobreza existentes nas periferias dos centros urbanos.

Apesar da intensidade com que a doença atingiu principalmente a região Nordeste entre os anos de 1992 e 1994, os esforços do sistema de saúde conseguiram reduzir drasticamente esses valores a partir de 1995, com o registro em 2001 de somente sete casos confirmados (quatro casos no Ceará e um caso em Pernambuco, Alagoas e Sergipe). Em 2002 e 2003, não foram detectados casos confirmados de cólera no Brasil. Contudo, o risco de sua reintrodução em áreas já atingidas ou ainda indenes continua presente, tendo em vista que persistem as baixas coberturas de saneamento.

Em abril de 2004, foram registrados três casos no agreste de Pernambuco, cuja investigação epidemiológica se encontra em andamento para determinar as possíveis fontes de infecção e interromper a transmissão.

Nesta fase atual, em que a cólera se encontra sob controle no país, é importante que sejam intensificados estudos que permitam detectar precocemente a presença do Vibrio cholerae 01 toxigênico e avaliar as características genéticas das cepas eventualmente encontradas. Para alcançar esse objetivo, é importante realizar o mapeamento e a pesquisa de ambientes reconhecidamente favoráveis à sobrevivência do agente, além do aprofundamento de estudos acerca do comportamento do agente diante de alterações ambientais.

As equipes técnicas de vigilância epidemiológica e ambiental dos três níveis de governo têm desenvolvido atividades de prevenção, com a realização de investigação de casos suspeitos, envolvendo a coleta de amostras clínicas e de amostras de água e de meio ambiente, principalmente nos mananciais que abastecem os sistemas de captação da água para consumo humano.

A Monitorização das Doenças Diarréicas Agudas (MDDA), atualmente implantada em 4.227 municípios do país, representa a mais importante estratégia para a detecção 
precoce de casos de cólera. A manutenção desse sistema de vigilância epidemiológica integrado e o fortalecimento do sistema de vigilância de controle da qualidade da água para consumo humano são as principais ações que garantirão que essa doença se mantenha sob controle no país.

\section{Dengue}

A dengue tem sido objeto de uma das maiores campanhas de saúde pública realizadas no país. O mosquito transmissor da doença, o Aedes aegypti, que havia sido erradicado de vários países do continente americano nas décadas de 1950 e 1960, retorna na década de 1970 por falhas na vigilância epidemiológica e pelas mudanças sociais e ambientais propiciadas pela urbanização acelerada dessa época.

Atualmente, o mosquito transmissor é encontrado numa larga faixa do continente americano, que se estende desde o Uruguai até o sul dos Estados Unidos, com registro de surtos importantes de dengue em vários países, como Venezuela, Cuba, Brasil e Paraguai.

As dificuldades de erradicar um mosquito domiciliado têm exigido um esforço substancial do setor saúde, com um gasto estimado de quase $\mathrm{R} \$ 1$ bilhão por ano, quando computados todos os custos dos dez componentes do Programa Nacional de Controle da Dengue. Essas dificuldades são decorrentes do fato de o mosquito se multiplicar nos vários recipientes que podem armazenar água, particularmente aqueles encontrados nos lixos das cidades, como garrafas, latas e pneus, ou no interior dos domicílios, como vasos de plantas. As atividades de prevenção da dengue perpassam o setor saúde e necessitam ser articuladas com outras políticas públicas, como a limpeza urbana, além de uma maior conscientização e mobilização social sobre a necessidade de as comunidades manterem seu ambiente livre do mosquito.

Entre 1999 e 2002, foi registrado um aumento na incidência de dengue, alcançando 794.219 casos notificados em 2002. Já em 2003, observou-se uma redução de $56,6 \%$ no total de casos notificados em relação a 2002, refletindo, em parte, a intensificação das açōes para controlar a doença.

Dentre outros fatores que pressionam a incidência da dengue, destaca-se a introdução recente de um novo sorotipo, o DEN 3, para o qual uma grande parcela da população ainda permanece susceptível. Por esse motivo, o MS, por meio da Secretaria de Vigilância em Saúde e em conjunto com as secretarias estaduais e municipais de saúde, vem executando um conjunto de ações, em que se destacam: 1) a intensificação das ações de combate ao vetor, focalizando-se os municípios com maior participação na geração dos casos; 2) o fortalecimento das ações de vigilância epidemiológica e entomológica para ampliar a oportunidade da resposta ao risco de surtos; 3) a integração das ações de vigilância e de educação sanitária com o Programa de Saúde da Família e de Agentes Comunitários de Saúde; 4) uma forte campanha de mobilizaçã̃o social e de informação para garantir a efetiva participação da população. Tem sido priorizada também a melhoria na capacidade de deteç̧ão de casos de dengue hemorrágica, com vistas a reduzir a letalidade por esta forma da doença. 


\section{Hantaviroses}

As hantaviroses constituem uma doença emergente com duas formas clínicas principais, a renal e a cardiopulmonar. A forma renal é mais freqüente na Europa e na Ásia, enquanto a forma cardiopulmonar ocorre somente no continente americano. A doença faz-se presente em quase todos os países da América do Norte e da América do Sul. Nestes, Argentina e Estados Unidos apresentam o maior registro de casos. Na América Central, somente têm sido registrados casos no Panamá. A infecção humana ocorre, mais freqüentemente, pela inalação de aerossóis formados a partir de secreções e excreções dos reservatórios, que são roedores silvestres.

Os primeiros casos no Brasil foram detectados em 1993 em São Paulo, e a doença tem sido detectada principalmente na região Sul, além dos estados de São Paulo, Minas Gerais e Mato Grosso. Desde o início da deteç̧ão de casos no país já foram registrados 338 casos em onze estados até 2003 , com uma letalidade média de 44,5\%. As medidas adotadas pelo MS possibilitaram a implantação da vigilância epidemiológica dessa doença, o desenvolvimento da capacidade laboratorial para realizar diagnóstico, a divulgação das medidas adequadas de tratamento para reduzir a letalidade e o conhecimento da situação de circulação de alguns hantavírus nos roedores silvestres brasileiros, objeto de ações de vigilância ecoepidemiológica.

Essas ações aumentaram a capacidade de deteç̧ão, possibilitando um quadro mais apropriado da realidade epidemiológica das hantaviroses em nosso país, assim como a adoção de medidas adequadas de prevenção e controle. 


\section{Projeção da Carga de Doença no Brasil (1998-2013)}

luri da Costa Leite

Kaizô Iwakami Beltrão

Roberto Nascimento Rodrigues

Joaquim Gonçalves Valente

Mônica Rodrigues Campos

Joyce Mendes de A. Schramm

\section{INTRODUC̣̃̃O}

Estudos epidemiológicos sobre condiçōes de saúde da população devem levar em consideração as características da dinâmica populacional, especialmente quando se quer aduzir a eles uma visão prospectiva. Essa matéria reveste-se de importância ainda maior quando as transformações demográficas não ocorrem em sintonia com melhoria nas conđições gerais de vida e de saúde da população. Nessa perspectiva, a estrutura etária da populaçăo exerce influência crescente sobre os desafios impostos ao sistema de saúde, uma vez que a emergência de questões específicas da saúde da população idosa se soma aos problemas, não totalmente resolvidos, relacionados à saúde das crianças, notadamente aquelas com menos de um ano de idade. Em meio a condições de escassez de recursos, as conseqüências econômicas para os sistemas de saúde são preocupantes.

Desde os anos 70, o Brasil depara com um declínio rápido e acentuado da fecundidade, o que, combinado com reduções da mortalidade, tem acarretado um processo de envelhecimento da população e de aumento da longevidade desta, de maneira sem precedentes na sua história. Em 1991, a proporção de pessoas de 60 anos e mais correspondia a 7,3\% da população total do país, percentual que se elevou para $8,6 \%$ em 2000 . 0 ritmo de crescimento da população idosa foi de $3,4 \%$ a.a. nos anos 90 , em contraste com um crescimento de apenas $1,6 \%$ a.a. da população total no mesmo período. 
De acordo com Carvalho e Garcia (2003), mesmo que não haja continuidade do processo de declínio da fecundidade no Brasil, a partir do ano 2000, o envelhecimento da população continuará até que $\mathrm{o}$ efeito direto e indireto da alta fecundidade do passado desapareça totalmente de sua configuração etária. A expectativa, hoje, é que, em 2020, a população de idosos brasileira atingirá o montante de 26,2 milhões, representando quase $12,4 \%$ da população total (UFMG/Cedeplar, 1999).

o progressivo e acentuado aumento da proporção dessa população tem implicações importantes que envolvem a vida do próprio idoso, de sua família, da comunidade em que vive e, principalmente, dos órgãos responsáveis pela assistência social e de saúde. $O$ aumento do número de idosos em uma população se traduz em um maior número de problemas de longa duração, que com freqüência dependem de intervenções de custos elevados, envolvendo tecnologia complexa para um cuidado apropriado. Assim, o aumento relativo de idosos, associado à maior longevidade da população brasileira, pode representar um grave problema para a sociedade se os anos de vida adicionados não forem vividos em condições de saúde adequadas (Chaimowicz, 1997).

Apesar de o processo de envelhecimento não estar, necessariamente, relacionado a enfermidades e incapacidades, as doenças crônico-degenerativas são freqüentemente encontradas entre os idosos. À medida que um maior número de pessoas atinge idades mais avançadas, há uma tendência de alteração no padrão da morbidade e causąs de morte, modificando o perfil de saúde da população e criando demandas específicas, tais como programas de prevenção de doenças crônicas, especialmente neoplasmas, modificaçōes no estilo de vida e hábitos alimentares, além de aumento de leitos hospitalares para ocupação com a população idosa. Portanto, a tendência atual é termos um número crescente de indivíduos idosos que, apesar de viverem mais, encontram-se funcionalmente incapacitados e com saúde precária (Alves, 2004).

Nesse cenário, a mensuração das condiçōes de saúde da população passa a guardar uma relação ainda mais forte com a necessidade de incorporar aos indicadores clássicos, como taxas de mortalidade e esperança de vida, a incidência e prevalência de morbidade. Com isso, é possível obter medidas que espelhem de maneira mais próxima a qualidade de vida da população, que poderia ser expressa em termos de anos vividos sem restrições de atividade, ou sem incapacidade.

Um passo importante nessa direção foi dado com o Projeto Carga de Doença no Brasil (Gadelha et al., 2002), o qual, pela primeira vez no país, estabeleceu parâmetros clínicoepidemiológicos para cerca de quinhentos agravos e seqüelas como subsídio para a estimativa de anos de vida ajustados por incapacidade. Esse estudo adaptou a metodologia proposta por Murray e Lopez (1994) ao contexto brasileiro, tendo como objetivo medir o impacto da mortalidade e dos problemas de saúde sobre a qualidade de vida dos indivíduos.

Dessa forma, estende-se o conceito de anos potenciais de vida perdidos por morte prematura, por meio da incorporação de anos equivalentes de vida saudável perdidos por causa de problemas de saúdè ou incapacidade (Murray, 1994). Para uma determinada doença ou condição de saúde, a estimativa de anos de vida perdidos ajustados por incapacidade (Disability Adjusted Life Years -DALY) é dada pela soma dos anos de vida 
perdidos em virtude de morte prematura (mortalidade) e anos de vida perdidos causados por incapacitação (morbidade).

Para o delineamento e implementação de políticas públicas visando à melhoria da qualidade de vida e saúde da população, é fundamental que se levem em consideração cenários futuros. Daí o interesse crescente em projeçōes de saúde, a exemplo dos estudos desenvolvidos por Bezold, Garrett e Taket, citados por Murray e Lopez (1996a). O Brasil, no entanto, ressente-se da falta desses estudos, o que justifica os esforços empreendidos ao longo desta pesquisa para minimizar tal carência, a despeito da escassez de informações adequadas e de boa qualidade nas quais seja possível basear-se.

O objetivo deste estudo é projetar a carga global de doença, ou seja, os anos de vida perdidos ajustados por incapacidade, de forma a avaliar os impactos futuros de doenças e agravos que possam incidir sobre a população brasileira. Trata-se de propiciar um resultado importante, capaz de subsidiar ações específicas de saúde, a fim de melhorar a qualidade de vida, de modo que se elevem os anos vividos sem incapacitação de maneira mais efetiva do que o permite a utilização de medidas convencionais ou usuais de saúde até então disponíveis no país.

A discussão do método de projeção da carga global de doença adotado é precedida pela apresentação da metodologia de estimativa de DALY. Os resultados da aplicação desse método são cotejados à luz da contextualização do panorama de saúde da população brasileira, delineado com base em informações retrospectivas e atuais e nos resultados apresentados no Estudo da Carga de Doença, realizado no Brasil em 1998.

\section{METODOLOGIA DA CARGA GLOBAL DE DOENÇA}

O indicador de saúde utilizado para medir a carga de doença de uma população éo DALY, que procura estimar, simultaneamente, o impacto da mortalidade e dos problemas de saúde que afetam a qualidade de vida dos indivíduos. Os anos de vida perdidos ajustados por incapacidade são calculados adicionando-se os anos de vida perdidos por morte prematura (Years of Life Lost-YLL) aos anos vividos com incapacidade (Years Lived with Disability-YLD):

$$
D A L Y=Y L L+Y L D
$$

Os anos de vida são calculados em relação a uma esperança de vida ideal, e o padrão utilizado foi o do Japão, país com maior esperança de vida ao nascer do mundo (80 anos para homens e 82,5 anos para mulheres). Para que os dois componentes possam ser estimados, é preciso criar uma escala associando pesos à mortalidade e às doenças e seqüelas. Para isso, o DALY está ancorado em uma escala de saúde que varia entre zero e um, em que zero significa o estado de plena saúde, ao passo que um, o pior estado de saúde possível: a morte. Sendo assim, o cálculo do número de anos vividos com incapacidade é feito multiplicando-se o peso atribuído à doença ou seqüela pela duração desta.

A metodologia da carga de doença incorpora no cálculo dos componentes do DALY dois elementos. O primeiro é a função de ponderação de idade, que atribui pesos menores aos anos perdidos no início e fim do ciclo da vida - crianças e idosos. O segundo é 
a taxa de desconto, que é aplicada aos anos de vida perdidos no futuro (Murray \& Lopez, 1996b; 1996d).

A pertinência das críticas que têm sido feitas ao uso da ponderação de idade, principalmente em relação à equanimidade do método (Arnand \& Hanson, 1997; Bobadilla, 1996), resultou na não-adoção dessa função no Estudo da Carga de Doença. Todavia, optou-se por utilizar uma taxa de desconto de 3\%, recomendada por um painel de especialistas em custo-efetividade em saúde (Weinstein et al., 1996).

Os estudos da carga global de doença dividem as causas de perdas de anos de vida por morte prematura ou incapacidade em três grandes grupos: grupo 1 (doenças infecciosas e parasitárias, causas maternas, causas perinatais e deficiências nutricionais); grupo 2 (doenças crônico-degenerativas); grupo 3 (causas externas). Esses três grandes grupos são subdivididos em 21 subgrupos, que, por sua vez, são desagregados num terceiro nível, de 109 doenças e agravos específicos (Gadelha et al., 2002).

\section{PROJEÇÃO DE CARGA DE DOENÇA}

Em geral, as projeçōes de mortalidade partem do pressuposto de que as alternativas futuras se resumem à elaboração de hipóteses relacionadas à velocidade de elevação da esperança de vida ao nascer, em decorrência de redução nos níveis de mortalidade ou melhorias nas condições de saúde da população. Situam-se nesse caso as projeções elaboradas pelas Nações Unidas e pelo Banco Mundial, que se inserem na alternativa de projetar, conjuntamente, a mortalidade por todas as causas de morte, geralmente sem desagregaçōes subseqüentes em causas específicas ou grupos de causas de morte. Nessa vertente, assume-se que elevaçōes na esperança de vida ocorram independentemente das políticas de saúde, de desenvolvimento social ou de crescimento econômico de determinado país ou região.

Mais recentemente, em virtude dos efeitos da incidência e espraiamento da epidemia de Aids, o ritmo de crescimento da esperança de vida em alguns países tem sido desacelerado, de tal forma a refletir o impacto do aumento da mortalidade por essa causa específica.

Ao relacionarem-se causas específicas de mortalidade com mortalidade para todas as causas, para um determinado grupo de idade e sexo, com base em modelos lineares, admite-se que a estrutura de causas da mortalidade é estreitamente ligada ao nível geral de mortalidade. De acordo com Murray e Lopez (1996a), essa abordagem apresenta como principal limitação o fato de assumir que as tendências futuras da mortalidade por todas as causas podem ser derivadas, sem alteração, de tendências passadas, as quais, na verdade, refletem a conseqüência combinada de diferentes tendências de causas específicas.

Uma alternativa para esse tipo de projeção por todas as causas de mortalidade é, obviamente, projetar causas individuais ou grupos de causas, obtendo mortalidade por todas as causas como o agregado das projeções de causas individuais. Nesse caso, a projeção da taxa de mortalidade por determinada doença ou agravo pode ser feita com base na extrapolação de tendências passadas, por meio de ajustes de curvas, tais como 
as distribuiçōes gama para incidência de Aids (Chin et al., 1992), ou com base em modelos de idade-período-coorte (Caselli, 1996).

Em que pese a maior plausibilidade das projeçōes específicas por idade e causa, em relação às projeções por todas as causas, não se deve esquecer que os pressupostos básicos que as norteiam podem não se verificar na realidade. O primeiro pressuposto é que tendências nos determinantes reais de saúde irão continuar no futuro. O segundo é que a relação entre esses determinantes e a taxa de mortalidade por doenças específicas será aproximadamente a mesma. Se esses pressupostos, de fato, tornarem-se falsos, as projeçôes ficam comprometidas (Lopez \& Hakama, 1986).

Murray e Lopez (1996a) advogam o emprego de modelos multivariados, nos quais as taxas de mortalidade são associadas com variáveis socioeconômicas e fatores de risco. Esses modelos, no entanto, não podem ser utilizados para projetar o impacto de políticas de saúde específicas, porque a ligação da cadeia causal desses fatores para a saúde não é especificada.

A fim de estimar as taxas de mortalidade com base em cenários sobre os fatores de risco e variáveis socioeconômicas, Murray e Lopez (1996d) desenvolveram vários modelos para grupos de causas, segundo sexo e faixa etária. Contudo, o coeficiente de determinaçấo encontrado foi muito baixo em muitos desses modelos; por isso, para causas em que o coeficiente de determinação foi menor do que $10 \%$, os autores decidiram pressupor que as taxas manter-se-iam constantes durante o período avaliado, ou seja, entre 1990 e 2020. Para as mulheres com idade entre 45 e 59 anos, a taxa das causas externas não intencionais também foi mantida constante, ainda que o coeficiente de determinação observado fosse maior do que $30 \%$. Isto se deveu ao fato de que as estimativas realizadas mostravam aumentos nas taxas desse grupo que foram considerados implausíveis. As taxas estimadas para os grandes grupos foram utilizadas no processo de estimativas das causas específicas.

Com base nas projeções das taxas de mortalidade, Murray e Lopez (1996d) estimaram os anos perdidos por morte prematura. Em virtude da escassez de informações sobre morbidade, os anos vividos com incapacidade foram estimados de uma forma menos elaborada. As causas de morte e incapacidade foram divididas em três grupos:

1) Formado por causas para as quais a relação entre os YLD e os YLL foi menor do que dez, em todas as regiōes, no ano base de 1990. Nesses casos, os YLD foram projetados utilizando-se esta mesma relação nos grupos de idade, sexo e região.

2) Constituído por causas em que há uma carga considerável de incapacidade e baixa mortalidade, como as doenças sexualmente transmissíveis. Nesses casos, foi projetado um declínio nas taxas específicas conforme aumentos em renda e educação. Os autores presumiram que as taxas das doenças tropicais e tracoma declinariam na mesma velocidade que as taxas do grupo 1 , e que as taxas de catarata apresentariam queda semelhan- " te àquela observada no grupo 2 .

3) Formado por doenças para as quais há pouca informação sobre a variação temporal (transtorno bipolar, depressão unipolar maior, dependência de álcool, esquizofrenia, doen- 
ça de Parkinson, esclerose múltipla, casos de estresse pós-traumático, síndrome do pâni$\mathrm{co}$, transtorno depressivo recorrente, artrite reumatóide, osteoartrose, hipertrofia benigna da próstata, cárie, doença peridontal, edentulismo e glaucoma). Nesses casos, as taxas foram mantidas constantes no período 1990-2020.

o DALY estimado para o ano de 2020 , considerando cada doença ou seqüela, foi calculado somando-se as projeções de YLL e YLD realizadas também para esse ano.

\section{Metodologia}

A base para projeção da carga de doença é a mortalidade e, nesse caso, suas taxas por grupos de causas, sexo e faixa etária precisam ser projetadas. Necessita-se, ainda, de informações sobre YLL e YLD, pelo menos para um ano específico. Essa informação está disponível para 1998, ano para o qual a carga de doença foi calculada (Gadelha et al., 2002).

o método de projeção baseou-se na descrição da tendência das taxas de mortalidade e sua extrapolação. $O$ problema é que os dados do Sistema de Informações de Mortalidade (SIM) não podem ser utilizados sem antes corrigir-se o sub-registro de óbitos. É preciso, também, redistribuir as causas maldefinidas e os códigos-lixo, ou seja, códigos inespecíficos que não caracterizam precisamente a causa do óbito (Gadelha et al., 2002). Entretanto, a lista de códigos-lixo elaborada para o Projeto Carga de Doença no Brasil tomou como base a CID-10, e essa codificação só foi introduzida no SIM a partir de 1996. Por isso, para que se pudesse avaliar a tendência para os grupos de causas, fez-se necessário estimar pelo menos mais um ponto e repetir todos os procedimentos realizados nas informações utilizadas em 1998. No que se refere ao sub-registro de óbitos, as informaçōes que serviram como ponto de partida foram os corretores para o ano de 1991, postos à đisposição por Luiz Armando de Medeiros Frias,' para o Projeto Carga de Doença, assim como aqueles calculados para o ano de 1998. Esses fatores foram estimados por unidades da federação (UF), sexo e faixa etária (menores de um ano e com um ano de vida ou mais). Corretores do IBGE para o ano de 2000 foram recalculados para esses dois grupos etários e incluídos na análise.

Presumiu-se que o nível de cobertura $\left(1 / k_{\text {tsgu }}\right)$, para um dado ano t, UF $(u), \operatorname{sexo}(s)$ e grupo etário (g) seria dado pela fórmula:

$$
\ln \left(\frac{1 / k_{\text {tggut }}}{1-1 / k_{\text {tggut }}}\right)=\alpha_{t}+\beta_{s}+\gamma_{g t}+\lambda_{u},
$$

em que: $\alpha_{t}$ é o logito da cobertura para o conjunto do Brasil, $\beta_{s}$ é o efeito sexo para um dado ano t, $\gamma_{s t}$ é o efeito do grupo etário para o ano te $\lambda_{n}$ é o efeito UF.

Com base nesse modelo, fatores de correção para cada UF, sexo e grupo de idade foram estimados para o ano de 1996, sendo comparados com os obtidos para 0 ano de 1998. Observou-se que, para algumas regiōes, os valores de 1996 estavam bem abaixo

' Comunicação pessoal do demógrafo Luiz Armando de Medeiros Frias. dos obtidos para o ano de 1998, e foram corrigidos. O fator de correção foi aplicado à base de dados de 1996, e os códigos-lixo, assim como as causas maldefinidas, foram redis- 
tribuídos, seguindo o mesmo padrão para 1998. Os dados de 1996 foram, então, classificados segundo a estrutura definida no estudo da carga de doença.

Valendo-se das taxas de mortalidade estimadas para os anos de 1998 e 1996 para os grupos etários do estudo e grandes grupos de causas (1,2 e 3), foram projetadas as taxas correspondentes para cada quinto ano dentro do horizonte da projeção (2013). Para isso, foi utilizado um modelo logital no tempo. A taxa central de mortalidade total (todas as causas) foi comparada com as projetadas pelo IBGE para os mesmos anos e, como a diferença encontrada foi pequena, os resultados foram mantidos.

Num segundo passo, calculou-se a participação de cada causa dentro do grande grupo de causas. Novamente, um modelo logito foi utilizado. Para garantir que a soma das participações de cada grupo de causas nos grandes grupos totalizasse exatamente $100 \%$, uma padronização foi efetuada em cada ano da projeção. Para diminuir a variância do estimador da taxa de variação para cada sexo e grupo etário, utilizou-se uma média ponderada das taxas de variação observadas entre 1996 e 1998 dos grupos vizinhos e do mesmo grupo etário do outro sexo. A diferença encontrada entre a soma das partes projetadas individualmente e a soma dos grandes grupos foi pequena. Posteriormente, séries de óbitos para o período de 1996 a 2001 foram construídas e suavizadas por meio de média móvel para descrever a tendência. No caso das causas externas, cujo grau de cobertura pressuposto foi de 100\%, utilizaram-se séries para o período 1991-2001 a fim de descrever o comportamento dos grupos.

$\mathrm{Na}$ determinação das taxas de mortalidade por causas específicas, admitiu-se uma hipótese de homogeneidade, na qual a distribuiçăo dentro de cada grupo de causas reproduziria aquela encontrada em 1998. Este padrão não foi aplicado a doenças como HIV/Aïds tuberculose e hepatite, pois elas não apresentavam o mesmo comportamento do grupo ao qual pertenciam. As taxas de mortalidade atribuídas ao HIV/Aids apresentavam uma forte queda entre 1996 e 1998, mas a série histórica mostrava uma desaceleraçāo nesse processo; dessa forma, a queda nas taxas por HIV/Aids passou a ser mais lenta do que a do seu grupo. Por outro lado, tuberculose e hepatite aumentavam, em contraposição à diminuição verificada no grupo de doenças em que essas enfermidades estão inseridas. Ajustes também foram feitos em relação às causas externas não intencionais, cuja velocidade de declínio observada na série histórica era bem menos brusca do que a projetada.

Com as taxas estimadas, os valores de YLL foram calculados para cada grande grupo e para os grupos de causas específicas. A relação YLD/YLL observada em 1998 foi utilizada para projeção dos anos vividos com incapacidade. Nos casos onde a carga de YLL era elevada e a de YLD muito reduzida, empregou-se a mesma proporção, por sexo e faixa etária, observada em 1998.

\section{Resultados}

Os resultados da projeção apontam para um aumento de $12 \%$ no número total de óbitos (de 1.129.427 para 1.263.363) entre 1998 e 2013. Durante esse período, espera-se 
que haja redução no diferencial de óbitos por sexo, uma vez que o aumento projetadoé de $11 \%$ entre os homens e $13 \%$ entre as mulheres.

A Tabela 1 apresenta os números absolutos e taxas, por mil habitantes, de YLL, YLD e de DALY, desagregados por sexo, para 1998 e 2013. A análise desses resultados, no tempo e entre sexos, deve ser feita com cautela, uma vez que se trata de medidas-síntese que, por não terem sido padronizadas, são influenciadas pela estrutura etária da população. Deve-se observar, por exemplo, que, mesmo incorporando a taxa de desconto, as estimativas de YLL conferem perda maior às ocorrências em idades jovens. Como a estrutura etária da população brasileira está sofrendo alterações significativas em razão do processo de envelhecimento populacional, a comparação de medidas globais deve levar em consideração tais transformações.

De qualquer forma, os dados mostram que, para ambos os sexos, mantidas as condições de saúde vigentes, é de se esperar que aumente o número absoluto dos três inđicadores entre 1998 e 2013. No total, o aumento esperado é de $3,1 \%$ na taxa de YLL ( 565,6 mil), $10,7 \%$ na de YLD ( 2,1 milhões) e $7,1 \%$ na de DALY ( 2,7 milhões). Para os três indicadores, o aumento esperado é mais expressivo entre os homens do que entre as mulheres. Por exemplo, vislumbra-se um aumento na taxa de DALY de 8,7\% entre os representantes do sexo masculino e de $5,1 \%$ entre as do sexo feminino.

Tabela 1 - Números absolutos e taxas de YLL, YLD e DALY, por mil habitantes, segundo o sexo. Brasil - 1998 e 2013

\begin{tabular}{|c|c|c|c|c|c|c|c|c|c|}
\hline \multirow{3}{*}{ Ano } & \multicolumn{9}{|c|}{ Números absolutos } \\
\hline & \multicolumn{3}{|c|}{ YLL } & \multicolumn{3}{|c|}{ YLD } & \multicolumn{3}{|c|}{ DALY } \\
\hline & Homens & Mulheres & TOTAL & Homens & Mulheres & TOTAL & Homens & Mulheres & TOTAL \\
\hline 1998 & 10.996 .759 & 7.034 .511 & 18.031 .271 & 9.224 .311 & 10.262 .656 & 19.486 .968 & 20.221 .071 & 17.297 .168 & 37.518 .239 \\
\hline 2013 & 11.417 .205 & 7.179 .620 & 18.596 .825 & 10.573 .014 & 11.003 .561 & 21.576 .576 & 21.990 .220 & 18.183 .181 & 40.173 .401 \\
\hline \multicolumn{10}{|c|}{ Taxas por mil habitantes* } \\
\hline 1998 & 134 & 84 & 109 & 113 & 122 & 118 & 247 & 206 & 226 \\
\hline 2013 & 118 & 71 & 94 & 109 & 109 & 109 & 227 & 180 & 203 \\
\hline
\end{tabular}

* As taxas referentes a 1998 estão um pouco diferentes das apresentadas no relatório do Projeto Carga de Doença (Gadelha et al., 2002), pois a populaçăo daquele ano foi atualizada pelo IBGE. Fonte dos dados básicos: Gadelha et al. (2002).

O segundo painel da Tabela 1 apresenta as taxas de YLL, YLD e DALY, por mil habitantes. Projeta-se, então, uma redução nos três indicadores, entre 1998 e 2013, e esperase que a taxa de YLL sofra redução de $11,9 \%$ entre os homens e de $15,5 \%$ entre as mulheres, perfazendo uma redução total de $13,8 \%$ na estimativa global. Igualmente, projeta-se uma redução na taxa de YLD, que atingiria a magnitude de $3,5 \%$ entre os homens, $10,7 \%$ entre as mulheres e $7,6 \%$ em termos globais. No caso da taxa de DALY, a perspectiva é de redução de $8,1 \%$ entre os homens, $12,6 \%$ entre as mulheres e de $10,2 \%$ no conjunto da população.

Embora se deva ter cautela na comparação entre os sexos, uma vez que as taxas não foram padronizadas por idade, é importante ressaltar o fato de que, em 1998, a taxa de 
YLD era maior entre as mulheres (122 por mil) do que entre os homens ( 113 por mil). Trata-se, na verdade, de um resultado esperado, uma vez que, por apresentarem maior longevidade do que os homens, não é contraditório supor que as mulheres apresentem um número maior de anos vividos com incapacidade. Na medida em que a população masculina passa também a sobreviver um número maior de anos, a despeito de permanecerem vivendo, em média, menos do que a população feminina, é de se esperar que se reduza o diferencial entre a taxa de anos vividos com incapacidade entre homens e mulheres. A situação projetada para 2013 é que essas taxas sejam similares.

A composição de cada um dos três indicadores, por sexo, segundo os três grandes grupos de causas (infecciosas e parasitárias, crônico-degenerativas e causas externas) é apresentada na Tabela 2. Conforme esperado, observa-se um decréscimo significativo na proporção de anos de vida perdidos por morte prematura ou incapacidade durante 0 período considerado.

Tabela 2 - Proporção de YLL, YLD e DALY, por sexo. Brasil - 1998 e 2013

\begin{tabular}{|c|c|c|c|c|c|c|c|c|c|}
\hline \multirow{3}{*}{ Ano } & \multicolumn{9}{|c|}{ YLL } \\
\hline & \multicolumn{3}{|c|}{ Homens } & \multicolumn{3}{|c|}{ Mulheres } & \multicolumn{3}{|c|}{ TOTAL } \\
\hline & Grupo 1 & Grupo 2 & Grupo 3 & Grupo 1 & Grupo 2 & Grupo 3 & Grupo 1 & Grupo 2 & Grupo 3 \\
\hline 1998 & 25,85 & 52,72 & 21,43 & 29,83 & 64,17 & 6,01 & 27,40 & 57,19 & 15,42 \\
\hline 2013 & 17,84 & 62,45 & 19,71 & 21,08 & 73,64 & 5,28 & 19,09 & 66,77 & 14,14 \\
\hline \multicolumn{10}{|c|}{ YLD } \\
\hline 1998 & 16,48 & 75,86 & 7,67 & 22,65 & 73,65 & 3,49 & 19,83 & 74,70 & 5,47 \\
\hline 2013 & 12,22 & 82,06 & 5,72 & 18,45 & 78,81 & 2,74 & 15,40 & 80,40 & 4,20 \\
\hline \multicolumn{10}{|c|}{ DALY } \\
\hline 1998 & 21,57 & 63,27 & 15,15 & 25,69 & 69,80 & 4,52 & 23,47 & 66,28 & 10,25 \\
\hline 2013 & 15,14 & 71,88 & 12,99 & 19,49 & 76,77 & 3,75 & 17,11 & 74,09 & 8,80 \\
\hline
\end{tabular}

Fonte dos dados básicos: Gadelha et al. (2002).

A expectativa projetada é que a proporção de anos de vida perdidos por morte prematura decorrente de doenças do grupo 1 (infecciosas e parasitárias) sofra uma redução de $30 \%$ no conjunto da população ( $31 \%$ entre os homens e $29,3 \%$ entre as mulheres). Situação inversa ocorre no caso da participação das doenças do grupo 2 (crônico-degenerativas), em que se espera que, no total, a proporção de YLL aumente em $17 \%$ (18\% entre os homens e $15 \%$ entre as mulheres). Já o resultado esperado para o comportamento do percentual de YLL para o grupo 3 (causas externas) é de redução de $8 \%$ na população total ( $8 \%$ entre os homens e $12 \%$ entre as mulheres). $O$ ritmo esperado de redução nos percentuais de YLL é maior entre as doenças infecciosas e parasitárias do que entre as causas externas. Adicionalmente, verifica-se a previsão de que a proporção de redução de * YLL por causas externas seja 50\% maior entre as mulheres do que entre os homens.

A tendência projetada para as proporçōes de YLD, por grupos de causas, segue a mesma direção verificada para YLL, obviamente que com diferenças em relação à magni- 
tude. No que diz respeito à população total, a expectativa é de redução de $22 \%$ na participação de YLD por doenças do grupo 1, aumento de $8 \%$ na participação de YLD por doenças do grupo 2 e redução de $23 \%$ na participação de YLD por doenças do grupo 3.

Considerando-se o DALY, tem-se a expectativa de que, entre os homens, a proporção atribuída a doenças do grupo 1 diminua em aproximadamente $30 \%$, valor bem acima do esperado para o percentual do grupo 3 (14\%). Espera-se um aumento de $14 \%$ na proporção de DALY atribuída a doenças do grupo 2 entre os homens. Entre as mulheres, a expectativa é de declínio de $24 \%$ e $17 \%$ na proporção de DALY atribuída, respectivamente, aos grupos 1 e 3 . Vislumbra-se um aumento de aproximadamente $10 \%$ na proporção de DALY atribuída a doenças do grupo 2.

As projeções feitas por Murray e Lopez (1996a) para a América Latina, correspondentes ao período compreendido entre 1990 e 2010, indicam que a participação prevista de doenças dos grupos 1 e 2 no DALY apresenta tendências na mesma direção daquelas esperadas para o Brasil entre 1998 e 2013. Com relação à proporção de DALY atribuído ao grupo 3, as projeções para América Latina mostram que haverá um aumento médio de $7,6 \%$ (4,4\% para os homens e $15 \%$ para as mulheres), ao contrário da tendência projetada para o Brasil, que prevê redução total de $14 \%$ ( $14 \%$ entre os homens e $17 \%$ entre as mulheres).

Os resultados das projeções para grupos de causas (Quadro 1) somente são apresentados com relação aos anos de vida perdidos ajustados por incapacidade, que incorpora os efeitos de anos de vida perdidos por morte prematura e anos vividos com incapacidade. $O$ quadro projetado para 2013 apresenta relativamente pouca modificação em comparação com a situação vigente em 1998. Os dois primeiros grupos de causas, doenças neuropsiquiátricas e doenças cardiovasculares, nessa ordem, respondem, nos dois anos considerados, pelas maiores proporções de DALY, muito embora a previsão seja de aumento de $14,0 \%$ na participação das doenças neuropsiquiátricas e redução de $3,8 \%$ na participação das doenças cardiovasculares.

Em que pese a similaridade entre o ordenamento da contribuição de cada grupo específico de causas para os anos de vida perdidos ajustados por incapacidade entre 1998 e 2013, pelo menos quatro modificações podem ser destacadas. A previsão é que as causas externas não intencionais, que em 1998 ocupavam a quinta posição entre os grupos de causas mais importantes, passem a ocupar a oitava, com redução projetada em $22 \%$ na sua participação. Prevê-se também queda de $22 \%$ na participação das anomalias congênitas, que perdem três posiçōes no ordenamento, passando do $15^{\circ}$ para o $18^{\circ}$ lugar. Tendência contrária foi projetada para os grupos de câncer, que deverá aumentar a participação em $27 \%$ e subir três posições no ordenamento (da sétima para a quarta posição), e de diabetes mellitus, que deverá ter sua participação acrescida em $22 \%$ e subir da nona para a sexta posição.

No Quadro 2, está representado o ordenamento das trinta causas específicas com maior participação no DALY, para ambos os sexos, entre 1998 e 2013. Note que não houve alteração no ordenamento das quatro principais doenças em 1998 (diabetes mellitus, doença isquêmica do coração, doenças cérebrovasculares e transtornos depressivos 
recorrentes). A causa específica mais expressiva do grupo de doenças neuropsiquiátricas (que ocupa a primeira posição em 1998, com expectativa de mantê-la em 2013) é o transtorno depressivo, que ocupava a quarta posição em 1998, com perspectiva de manter essa posição em 2013.

Quadro 1 - Distribuição proporcional e ordenamento da carga de doença, segundo grupos de causa. Brasil - 1998 e 2013

\begin{tabular}{|c|c|c|c|c|c|}
\hline \multicolumn{3}{|c|}{1998} & \multicolumn{3}{|r|}{2013} \\
\hline Grupos de causas & (\%) & Posto & Posto & (\%) & Grupos de causas \\
\hline Doenças neuropsiquiátricas & 18,6 & 1 & 1 & 21,2 & Doenças neuropsiquiátricas \\
\hline Doenças cardiovasculares & 13,3 & 2 & 2 & 12,8 & Doenças cardiovasculares \\
\hline Infecciosas e parasitárias & 9,2 & 3 & 3 & 9,7 & Doenças respiratórias crônicas \\
\hline Doenças respiratórias crônicas & 8,1 & 4 & 4 & 8,0 & Câncer \\
\hline Causas externas não intencionais & 6,4 & 5 & 5 & 7,4 & Infecciosas e parasitárias \\
\hline Condições do período perinatal & 6,4 & 6 & 6 & 6,2 & Diabetes mellitus \\
\hline Câncer & 6,3 & 7 & 7 & 6,0 & Doenças musculoesqueléticas \\
\hline Doenças musculoesqueléticas & 5,5 & 8 & 8 & 5,0 & Causas externas não intencionais \\
\hline Diabetes mellitus & 5,1 & 9 & 9 & 3,9 & Causas externas intencionais \\
\hline Causas externas intencionais & 3,9 & 10 & 10 & 2,9 & Condiçōes do período perinatal \\
\hline Infeç̧ões respiratórias & 3,5 & 11 & 11 & 2,9 & Doenças do aparelho digestivo \\
\hline Doenças do aparelho digestivo & 2,7 & 12 & 12 & 2,9 & Infecçōes respiratórias \\
\hline Condições maternas & 2,4 & 13 & 13 & 2,1 & Deficiências nutricionais \\
\hline Deficiências nutricionais & 2,1 & 14 & 14 & 1,8 & Condiçōes maternas \\
\hline Anomalias congênitas & 1,8 & 15 & 15 & 1,8 & Doenças endócrinas e metabólicas \\
\hline Doenças endócrinas e metabólicas & 1,5 & 16 & 16 & 1,7 & Desordens de órgãos do sentido \\
\hline Condições orais & 1,2 & 17 & 17 & 1,5 & Condiçōes orais \\
\hline Desordens de órgãos do sentido & 1,1 & 18 & 18 & 1,4 & Anomalias congênitas \\
\hline Doenças geniturinárias & 0,8 & 19 & 19 & 0,7 & Doenças geniturinárias \\
\hline Doença de pele & 0,1 & 20 & 20 & 0,2 & Doença de pele \\
\hline Neoplasias benignas & 0,1 & 21 & 21 & 0,0 & Neoplasias benignas \\
\hline
\end{tabular}

$\longrightarrow$ Sobem 3 ou + posiçōes no ordenamento

$\longrightarrow$ Descem 3 ou + posiçöes no ordenamento

Fonte dos dados básicos: Gadelha et al. (2002).

No que diz respeito à evolução prevista para a participação das outras causas específicas, deve-se destacar a perspectiva de redução bastante acentuada da posição ocupada por asfixia e traumatismo ao nascer (do $5^{\circ}$ lugar em 1998 para o $14^{\circ} \mathrm{em} 2013$ ), baixo peso ao nascer (que deverá perder 21 posições, caindo do $25^{\circ}$ para $046^{\circ}$ lugar) e doenças tropicais (da $24^{\mathrm{a}}$ para a $31^{\mathrm{a}}$ posição). Dentre as enfermidades que passarão a ter maior influência no DALY, destacam-se os transtornos mentais e comportamentais devido ao uso de álcool (com previsão de elevação da $11^{\text {a }}$ para a $7^{\text {a }}$ posiçăo), asma (que deverá subir do $14^{\circ}$ para o $10^{\circ}$ lugar), epilepsia (da $23^{\text {a }}$ para a $19^{\text {a }}$ posição) e neoplasia maligna do estômago (que deverá passar da 35ª posição em 1998 para a 29a em 2013). 
VACINAS, SOROS E IMUNIZAÇÕES NO BRASIL

Quadro 2 - Evolução do ordenamento das trinta primeiras causas de DALY, para ambos os sexos. Brasil - 1998 e 2013

\begin{tabular}{|c|c|c|c|}
\hline \multicolumn{2}{|l|}{1998} & \multicolumn{2}{|r|}{2013} \\
\hline DALY Causas & Posto & Posto & DALY Causas \\
\hline Diabetes mellitus & 1 & 1 & Diabetes mellitus \\
\hline Doenças isquêmicas do coração & 2 & 2 & Doenças isquêmicas do coração \\
\hline Doenças cerebrovasculares (infarto cerebral, AVC) & 3 & 3 & Doenças cerebrovasculares (infarto cerebral, AVC) \\
\hline Transtorno depressivo recorrente/Episódio depressivo & 4 & 4 & Transtorno depressivo recorrente/Episódio depressivo \\
\hline Asfixia e traumatismo ao nascer & 5 & 5 & Casos sintomáticos - D. pulmonar obstrutiva crônica \\
\hline Casos sintomáticos - D. pulmonar obstrutiva crônica & 6 & 6 & Violências (agressões, negligência/abandono) \\
\hline Violências (agressöes, negligência/abandono) & 7 & 7 & Transtornos mentais e comportamentais - uso de álcool \\
\hline Episódios - Infecções de vias aéreas inferiores & 8 & 8 & Demência/Alzheimer/D. degenerativas do SNC \\
\hline Acidente de trânsito (traumatismo em colisão) & 9 & 9 & Episódios - Infecções de vias aéreas inferiores \\
\hline Demência/Alzheimer/D. degenerativas do SNC & 10 & 10 & Casos-Asma \\
\hline Transtornos mentais e comportamentais - uso de álcool & 11 & 11 & Esquizofrenia/Psicose \\
\hline Episódios - Diarréia e infecçōes intestinais & 12 & 12 & Acidente de trânsito (traumatismo em colisão) \\
\hline Esquizofrenia/Psicose & 13 & 13 & Doenças endócrinas/metabólicas \\
\hline Casos-Asma & 14 & 14 & Asfixia e traumatismo ao nascer \\
\hline Outras externas não intencionais & 15 & 15 & Casos-Cirrose hepática \\
\hline Doenças endócrinas/metabólicas & 16 & 16 & Episódios - Diarréia e infecçōes intestinais \\
\hline Casos-Cirrose hepática & 17 & 17 & Anemia por deficiência de ferro \\
\hline Anemia por deficiência de ferro & 18 & 18 & HIV (Doenças resultantes) \\
\hline Episódios - Aborto & 19 & 19 & Casos-Epilepsia \\
\hline HIV (Doenças resultantes) & 20 & 20 & Outras externas não intencionais \\
\hline Quedas (de mesmo nível ou de um para outro) & 21 & 21 & Doenças inflamatórias do coração \\
\hline Doenças inflamatórias do coração & 22 & 22 & Osteoartroses \\
\hline Casos - Epilepsia & 23 & 23 & Episódios - Aborto \\
\hline Doenças tropicais & 24 & 24 & Transtornos mentais e comportamentais - uso de drogas \\
\hline Baixo peso ao nascer & 25 & 25 & Casos - Neop. maligna da traquéia/brônquios/pulmões \\
\hline Osteoartroses & 26 & 26 & Tuberculose \\
\hline Transtornos mentais e comportamentais - uso de drogas & 27 & 27 & Quedas (de mesmo nivel ou de um para outro) \\
\hline Tuberculose & 28 & 28 & Catarata \\
\hline Casos - D. congênita do coração (do ap. circ./SVP) & 29 & 29 & Casos - Neoplasia maligna do estômago \\
\hline Casos - Neop. maligna da traquéia/brônquios/pulmỗes & 30 & 30 & Desnutriçāo protéico-calórica \\
\hline Catarata & 31 & 31 & Doenças tropicais \\
\hline Desnutrição protéico-calórica & 33 & 38 & Casos - D. congênita do coraçäo (do ap. circ.//SVP) \\
\hline Casos - Neoplasia maligna do estômago & 35 & 46 & Baixo peso ao nascer \\
\hline
\end{tabular}

Sobem 4 ou + posiçős no ordenamento

$\longrightarrow$ Descem 4 ou + posições no ordenamento

Fonte dos dados básicos: Gadelha et al. (2002). 


\section{CONSIDERAÇÕES FINAIS}

Neste estudo, a carga de doença foi projetada para cada quinto ano no período 19982013. Os resultados mostram aumento nos valores absolutos e diminuição nas taxas do número de anos de vida perdidos ajustados por incapacidade. Esse declínio resulta de mudanças reais nas taxas das doenças ou agravos, mas também de mudanças na estrutura etária da população. As taxas dos componentes da mortalidade e morbidade do DALY, YLL e YLD também declinaram durante o período.

Com relação às morbidades que afetam o DALY, espera-se um forte declínio, de aproximadamente $27 \%$, para o grupo 1 (doenças infecciosas e parasitárias, causas maternas, causas perinatais e deficiências nutricionais). Essa queda é superior à redução de $14 \%$ esperada para o grupo 3 (causas externas). Já para o grupo 2 (doenças crônicodegenerativas), a expectativa é que haja um crescimento de aproximadamente $12 \%$.

No que diz respeito aos grupos de causas, ainda que as variações no seu ordenamento não tenham sido tão significativas em relação aos anos de vida perdidos ajustados por incapacidade entre 1998 e 2013, pelo menos quatro modificações podem ser destacadas. A previsão é que as causas externas não intencionais, que em 1998 ocupavam a quinta posição entre os grupos de causas mais importantes, passem a ocupar a oitava posição, com redução projetada em $22 \%$ na sua participação. Prevê-se também queda de $22 \%$ na participação das anomalias congênitas, que perdem três posições no ordenamento, passando do $15^{\circ}$ para o $18^{\circ}$ lugar. Tendência contrária foi projetada para os grupos de câncer, que deverão aumentar a participação em $27 \%$ e subir três posições no ordenamento (da sétima para a quarta posição), e de diabetes mellitus, que deverá ter sua participação acrescida em $22 \%$ e subir da nona para a sexta posição.

Em relação às causas específicas, o diabetes mellitus, a doença isquêmica do coração, as doenças cerebrovasculares e o transtorno depressivo recorrente continuarão sendo as principais causas de carga de doença em 2013. Em geral, as doenças do grupo 1 perderão posição no ordenamento, segundo o número de DALY. Asfixia e traumatismo ao nascer passam da $5^{\mathrm{a}}$ para $14^{\mathrm{a}}$ posição. As diarréias e infecções intestinais perđem quatro posições, passando para a $16^{a}$ posição em 2013. Por outro lado, várias doenças do grupo das neuropsiquiátricas e cânceres tornam-se mais importantes em relação ao número de anos de vida perdidos ajustados por incapacidade.

Deve-se considerar, contudo, que este estudo ainda está em estágio incipiente, e vários procedimentos estão sendo implementados para sua melhoria. Uma lista de códigos-lixo já foi elaborada para CID-9, a fim de possibilitar a incorporação das informaçōes de anos anteriores a 1996. O modelo de regressão está sendo aperfeiçoado de modo que se possam ter fatores de correção para vários anos. Dessa forma, será possível implementar modelos de regressão mais apropriados para projetar a carga de doença por causas. De qualquer forma, vale registrar que o Sistema de Informações de Mortalidade deve ser melhorado com o objetivo de eliminar o sub-registro e codificar melhor as causas de óbito, fazendo com que se reduza a proporção de causas maldefinidas. 
Finalmente, é importante ressaltar que a reflexão sobre os resultados sintéticos das projeçōes de morbidade requer que se considere o alcance e limitações dos resultados, à luz dos procedimentos metodológicos adotados no exercício de projeção. Por exemplo, a estimativa dos anos de vida perdidos ajustados por incapacidade para 1998, que serviu de base para as projeçōes subseqüentes, foi elaborada com base em um conjunto de pressupostos e métodos que oferecem apenas uma abordagem, em meio a um conjunto virtualmente infinito de possibilidades. De acordo com Murray e Lopez (1996d), os resultados dessas projeçōes, por mais plausíveis que possam parecer ou por mais corretos (ou incorretos) que possam ser, refletem nada mais do que as conseqüências numéricas dos pressupostos e métodos utilizados.

Por outro lado, a despeito dessas ressalvas, que devem estar implícitas na análise dos resultados, os dados apresentados aqui constituem o mais abrangente conjunto de projeções do estado de saúde já produzido no Brasil, em nível nacional, e é de se esperar que o cenário prospectivo descrito possa inspirar políticas voltadas para garantir que ele seja, de fato, melhor do que se vislumbra atualmente.

\section{REFERÊNCIAS BIBLIOGRÁFICAS}

ALVES, L. C. Determinantes da autopercepção de saúde dos idosos no município de São Paulo, 1999/2000. 2004. Dissertação de Mestrado em Demografia, Belo Horizonte: Centro de Desenvolvimento e Planejamento Regional, Universidade Federal de Minas Gerais.

ARNAND, S. \& HANSON, K. Disability-adjusted life of years: a critical review. Journal of Health Economics, 16: 685-702, 1997.

BOBADILLA, J. L. Priority setting and cost effectiveness. In: JANOVSKY, K. (Ed.) Health Policy Systems Development: an agenda for research. Genebra: World Health Organization, 1996.

CARVALHO, J. A. M. \& GARCIA, R. A. O envelhecimento da população brasileira: um enfoque demográfico. Cadernos de Saúde Pública, 19(3): 109-118, 2003.

CASELLI, G. Future longevity among the elderly. In: CASELLI, G. \& LOPEZ, A. D. (Eds.) Health and Mortality among Elderly Populations. Oxford: Clarendon Press, 1996.

CHAIMOWICZ, F. A saúde dos idosos brasileiros às vésperas do século XXI: problemas, projeçōes e alternativas. Revista de Saúde Pública, 31(2): 184-200, 1997.

CHIN, J. et al. The global epidemiology of the HIV/Aids pandemic and its projected demographic impact in Africa. World Health Statistics Quarterly, 45(2-3): 220-227, 1992.

GADELHA, A. M. J. et al. Projeto carga de doença. Relatório Técnico. Ensp/Fiocruz/ Fiotec, 2002.

LOPEZ, A. D. \& HAKAMA, M. Approaches to the projection of health status. In: WORLD HEALTH ORGANIZATION (WHO). Health Projections in Europe: methods and applications. Copenhagen: World Health Organization, 1986. 
MURRAY, C. J. L. Quantifying the burden of disease: the technical basis for DALYs. Bulletin of the World Health Organization, 72(3): 429-445, 1994.

MURRAY, C. J. L. \& LOPEZ, A. D. (Eds.) Global Comparative Assessments in the Health Sector. Geneva: World Health Organization, 1994.

MURRAY, C. J. \& LOPEZ, A. A. (Eds.) The Global Burden of Disease: a comprehensive assessment of mortality and disability from diseases, injuries and risk factors in 1990 and projected to 2020. Harvard: Harvard School of Public Health, 1996a.

MURRAY, C. J. \& LOPEZ, A. A. Estimating causes of death: new methods and global and regional application for 1990. In: MURRAY, C. J. \& LOPEZ, A. A. (Eds.) The Global Burden of Disease: a comprehensive assessment of mortality and disability from diseases, injuries and risk factors in 1990 and projected to 2020. Harvard: Harvard School of Public Health, 1996b.

MURRAY, C. J. \& LOPEZ, A. A. The global burden of disease in 1990: final results and their sensitivity to alternative epidemiologic perspectives, discount rates, age-weightsand disability weights. In: MURRAY, C. J. \& LOPEZ, A. A. (Eds.) The Global Burden of Disease: a comprehensive assessment of mortality and disability from diseases, injuries and risk factors in 1990 and projected to 2020. Harvard: Harvard School of Public Health, 1996c.

MURRAY, C. J. \& LOPEZ, A. A. Alternative visions of the future: projecting mortality and disability, 1990-2020. In: MURRAY, C. J. \& LOPEZ, A. A. (Eds.) The Global Burden of Disease: a comprehensive assessment of mortality and disability from diseases, injuries and risk factors in 1990 and projected to 2020. Harvard: Harvard School of Public Health, 1996d.

UFMG/CEDEPLAR. Projeção populacional das unidades da federação, Brasil, por sexoe grupos qüinqüenais de idades: 1990-2020. Trabalho realizado no âmbito do Projeto "Dinâmica Demográfica, Desenvolvimento Regional e Políticas Públicas". Belo Horizonte: Cedeplar/UFMG, 1999. (Mimeo.).

WEINSTEIN, M. C. et al. Recommendations of the panel on cost effectiveness in Health and Medicine. Journal of the American Medical Association, 276:1253-1258, 1996. 


\section{Parte II}

BOMPLEXO PRODUIIV: POLIIICA E REGULACÁO DE VACINAS E SOROS NO BRASIL 


\section{Complexo Industrial da Saúde: desafios para uma política de inovação e desenvolvimento ${ }^{1}$}

\section{CARACTERIZAC̣ÃO DO COMPLEXO INDUSTRIAL DA SAÚDE}

O desenvolvimento tecnológico (DT) em saúde está inserido em um ambiente setorial e institucional mais amplo que configura o complexo industrial da saúde. Este corte delimita os setores e segmentos produtivos atuantes na área da saúde, os quais, crescentemente, seguem a lógica industrial capitalista (Cordeiro, 1980; Braga \& Silva, 2001), envolvendo a produçâo e o mercado de bens e serviços em saúde, cuja dinâmica competitiva condiciona a evolução dos paradigmas e trajetórias tecnológicas estratégicas para as inovaçōes em saúde, como é o caso da biotecnologia, da química fina, da eletrônica e dos novos materiais.

Apesar de sua dispersão em termos tecnológicos, a produção industrial em saúde conflui para mercados fortemente articulados que caracterizam a prestação de serviços de saúde (hospitalares, ambulatoriais e de saúde pública), condicionando a dinâmica competitiva e tecnológica que permeia as inđústrias da área. Há, de fato, um ambiente econômico e político em saúde que permite caracterizar mercados fortemente interligados e interdependentes, os quais configuram um complexo industrial marcado por relações intersetoriais de natureza comercial, tecnológica e institucional (Erber, 1992). Em contrapartida, é possível pensar políticas industriais, tecnológicas e sociais que apresentem um grande potencial de articulação, permitindo a concepção de intervençōes, sistêmicas e de alta relevância, no ritmo e no direcionamento das inovações do país e na competitividade empresarial nos setores da saúde.

\begin{abstract}
'Este artigo foi extraído, com modificaçōes, do trabalho "Complexo da Saúde", desenvolvido pelo autor para o projeto Estudo de Competitividade por Cadeias Integradas no Brasil, coordenado por Luciano G. Coutinho (NEIT-IE-Unicamp), Mariano F. Laplane (NEIT-IE-Unicamp), David Kupfer (IE-UFRJ) e Elizabeth Farina (FEA-USP); contou, ainda, com 0 apoio de Flávia Neves Rocha Alves como auxiliar de pesquisa. Este projeto foi efetuado no âmbito do convênio entre 0 Núcleo de Economia Industrial e da Tecnologia do Instituto de Economia da Universidade Estadual de Campinas e o Ministério do Desenvolvimento, da Indústria e do Comércio Exterior (MDIC), em parceria com o Ministério da Ciência e Tecnologia (MCT) e a Financiadora de Estudos e Projetos (Finep). 0 conjunto do trabalho está sendo editado para publicação, já aprovada, em um livro sobre o complexo industrial da saúde, do autor em parceria com José Gomes Temporão.
\end{abstract}


Do ponto de vista da política tecnológica e industrial, a saúde e as indústrias que fazem parte dessa área compartilham o fato de possuírem um elevado grau de inovação e de intensidade de conhecimentos científicos e tecnológicos, os quais conferem um alto dinamismo em termos de taxa de crescimento e de competitividade (Gelijns \& Rosemberg, 1995). Expressando essa característica, os setores da saúde, invariavelmente, estão entre os que recebem maior estímulo governamental, como se depreende do fato de que os recursos estatais destinados às atividades de pesquisa e desenvolvimento (P\&D) neste campo sempre aparecem como os mais significativos, juntamente com os do setor militar (Rosemberg \& Nelson, 1994). No Brasil, esse padrão se mantém, e a área da saúde tem a liderança nos esforços nacionais apoiados pelas agências federais de fomento à ciência e tecnologia (C\&T) (Brasil, 2001).

Do ponto de vista da política social, é possível afirmar que, a despeito dos esforços generalizados, em termos internacionais, para a contenção do gasto público a partir dos anos 80 , a saúde continuou elevando sua participação nas despesas nacionais financiadas pelo Estado e pelo setor privado, conformando um horizonte dinâmico de longo prazo para os agentes e setores de atividade da área. Ou seja, os requerimentos de saúde por parte da população constituem uma demanda social em permanente processo de expansão (fruto das mudanças demográficas e das características inerentes dos bens e serviços em saúde), que confere uma perspectiva bastante ativa de evoluçâo dos mercados, seja a curto, médio ou longo prazo.

Em síntese, a área da saúde e o complexo industrial que congrega os setores de atividade que dela fazem parte aliam alto dinamismo industrial, elevado grau de inovação e interesse social marcante. Ambos constituem um campo central para a concepção de políticas de ciência, tecnologia e inovação, permitindo um vínculo bastante promissor com a política social.

A Figura 1 procura delimitar os principais setores de atividade que fazem parte desse complexo, caracterizando sua morfologia básica.

É possível identificar um primeiro grande grupo de produtos de origem química ou biotecnológica, havendo uma tendência de predomínio e difusão do padrão de competição farmacêutico para os demais setores, consubstanciado em estratégias empresariais fortemente interligadas. No caso das vacinas, essa tendência já pode ser nitidamente verificada, como se depreende do trabalho desenvolvido por Gadelha e Temporão (1999), que levanta a hipótese de esse segmento se configurar como mais um entre os diversos segmentos competitivos do setor, tendo o interesse da indústria ressurgido no bojo da difusão da trajetória da biotecnologia. No caso dos hemoderivados, estes constituem, efetivamente, um segmento análogo a outras classes terapêuticas típicas da indústria farmacêutica, destacando-se, sobretudo, em virtude das questōes políticas e institucionais particulares relacionadas à comercialização do sangue e seus derivados.

Um segundo grupo de indústrias relaciona-se à produção de equipamentos e materiais médicos e odontológicos extremamente diversificados, envolvendo aparelhos não eletroeletrônicos, eletroeletrônicos, próteses e órteses, além de uma gama ampla de materiais de consumo (Furtado \& Souza, 2001). No caso específico dos reagentes para 
diagnóstico, há indefinição da localização e proximidade entre a indústria farmacêutica e a de equipamentos e materiais médicos e odontológicos, verificando-se movimentos competitivos e estratégias que 'transbordam' de ambas as indústrias.

Figura 1 - Complexo industrial da saúde: morfologia

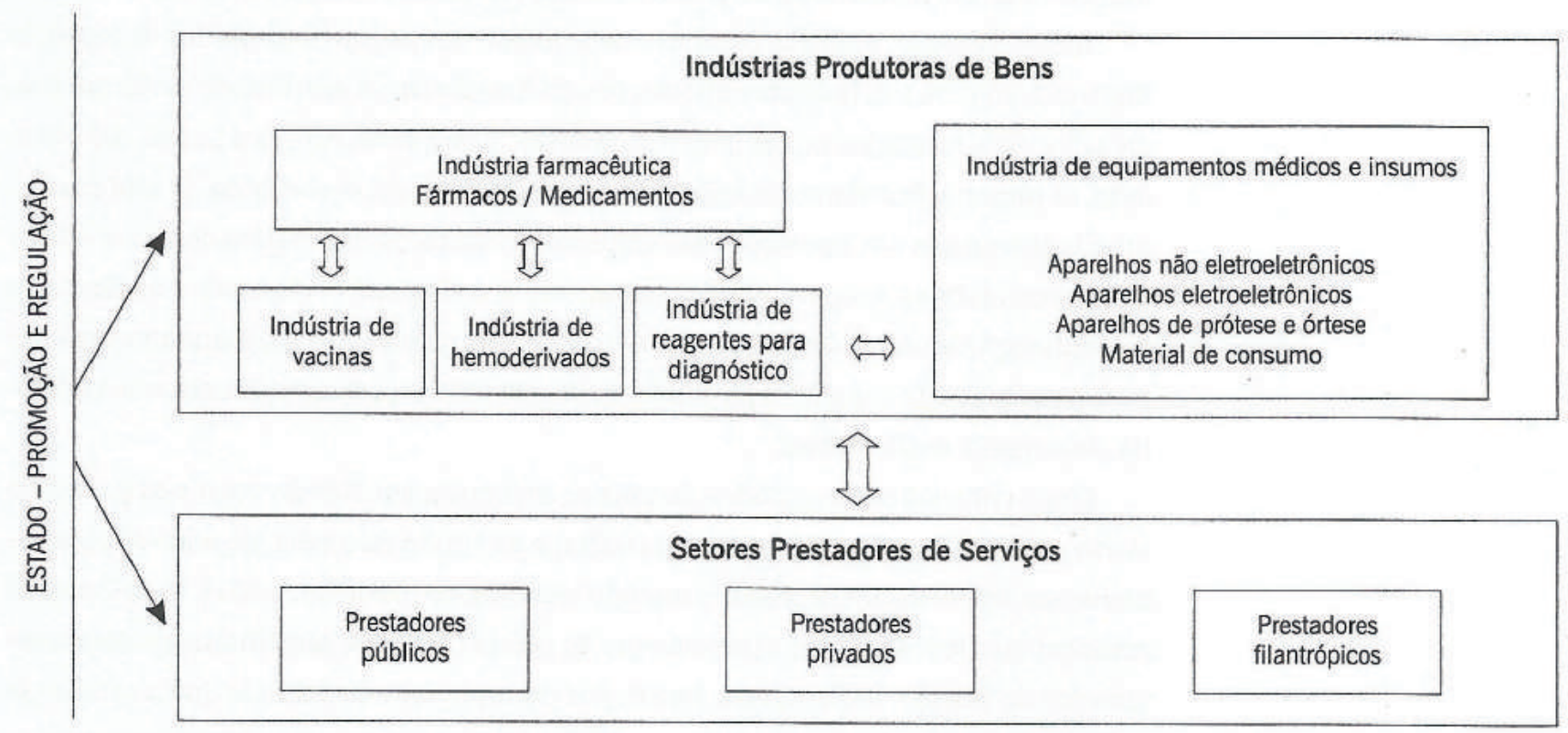

Fonte: Gadelha (2002)

A indústria prestadora de serviços de saúde de natureza hospitalar e ambulatorial constitui um terceiro grupo de atividades, envolvendo agentes públicos, privados e públicos não estatais (hospitais filantrópicos, organizações sociais etc.). Observe-se que esse segmento conforma, do ponto de vista das relações intersetoriais, a demanda para os demais setores, estruturando e delimitando, do ponto de vista econômico, o complexo industrial da saúde.

Ainda na Figura 1, pode-se situar o Estado como um ator central na dinâmica industrial dos setores de atividade, mediante suas ações, explícitas ou implícitas, de promoção e de regulação que, na área da saúde, adquirem uma abrangência dificilmente encontrada em outro grupo ou cadeia produtiva.

A dinâmica recente dos segmentos produtivos do complexo da saúde, a despeito da diversidade de indústrias e setores, evidencia a presença de regularidades marcantes. Todas as indústrias que fazem parte do complexo da saúde perderam competitividade internacional ao longo da década, sem qualquer exceção! O déficit acumulado sai de 750 milhões de dólares no final dos anos 80 para o expressivo patamar de, aproximadamen- . te, 3,5 bilhões de dólares (Tabelas 1 e 2; Gráfico 1).

A natureza desse déficit é claramente estrutural, ou seja, não depende apenas da sinalização dos preços relativos, considerando-se que a forte desvalorização ocorrida em 1999, a 
despeito de ter um pequeno efeito em sua redução, não mudou o patamar, que se manteve praticamente constante no período analisado, inclusive elevando-se de modo importante no ano 2001. Nesse quadro, as exportações têm apresentado um baixo dinamismo e é de se supor que as importaçóes somente tenham ficado estáveis, se bem que num patamar elevado, em decorrência do pouco crescimento da economia e da renda per capita.

Nesse contexto, a globalização tem acarretado um padrão assimétrico de inserção internacional. De um lado, as exportações do Brasil vêm se destinando de forma progressiva para mercados muito pouco dinâmicos, como os da América Latina. De outro lado, as importações vêm crescendo de forma explosiva, em decorrência da alta competitividade baseada nas inovações das empresas localizadas nas regiões desenvolvidas e de suas estratégias de configuração global. Isto é, a abertura comercial e a ausência de mecanismos indutores de política industrial têm se mostrado extremamente danosas para a evolução do complexo da saúde, cuja competitividade apresentou uma trajetória claramente desfavorável.

Como conseqüência, o déficit do país se concentra em $70 \%$ do valor nos países do North America Free Trade Agreement (Nafta) e da União Européia, de onde são provenientes as importações de maior conteúdo tecnológico (Gadelha, 2002). Todavia, cabe ressaltar que $30 \%$ do déficit é proveniente de países com grau semelhante de desenvolvimento do Brasil - Índia, China, Israel, por exemplo -, evidenciando que a estratégia passiva de desenvolvimento dos anos 90 foi desastrosa para a indústria, mesmo se comparada com este bloco de países.

As considerações anteriores indicam que o hiato tecnológico existente está em processo de ampliação. Em praticamente todos os setores (talvez com exceção da área de vacinas), está havendo um processo de reestruturação produtiva que está direcionando o complexo da saúde para a realização de atividades de menor densidade tecnológica, mesmo no interior de cada segmento. Esse processo de reespecialização e de downgrade tecnológico da indústria local certamente constitui o fator explicativo central para a explosão do déficit nos anos 90.

Tabela 1 - Complexo da saúde: evolução do comércio exterior - 1997-2001

\begin{tabular}{l|l|l|c}
\hline Ano & Exportação & Importação & Saldo comercial \\
\hline 1997 & 520.767 .971 & 3.288 .615 .899 & -2.767 .847 .928 \\
1998 & 600.496 .048 & 3.861 .922 .183 & -3.261 .426 .135 \\
1999 & 590.777 .695 & 3.883 .018 .245 & -3.292 .240 .550 \\
2000 & 549.261 .375 & 3.679 .415 .420 & -3.130 .154 .045 \\
2001 & 552.954 .779 & 4.016 .332 .759 & -3.463 .328 .752 \\
\hline
\end{tabular}

Fonte: Gadelha (2002). Elaboração própria, com base em levantamento efetuado pelo NEIT-IE-Unicamp junto à Sedex. 


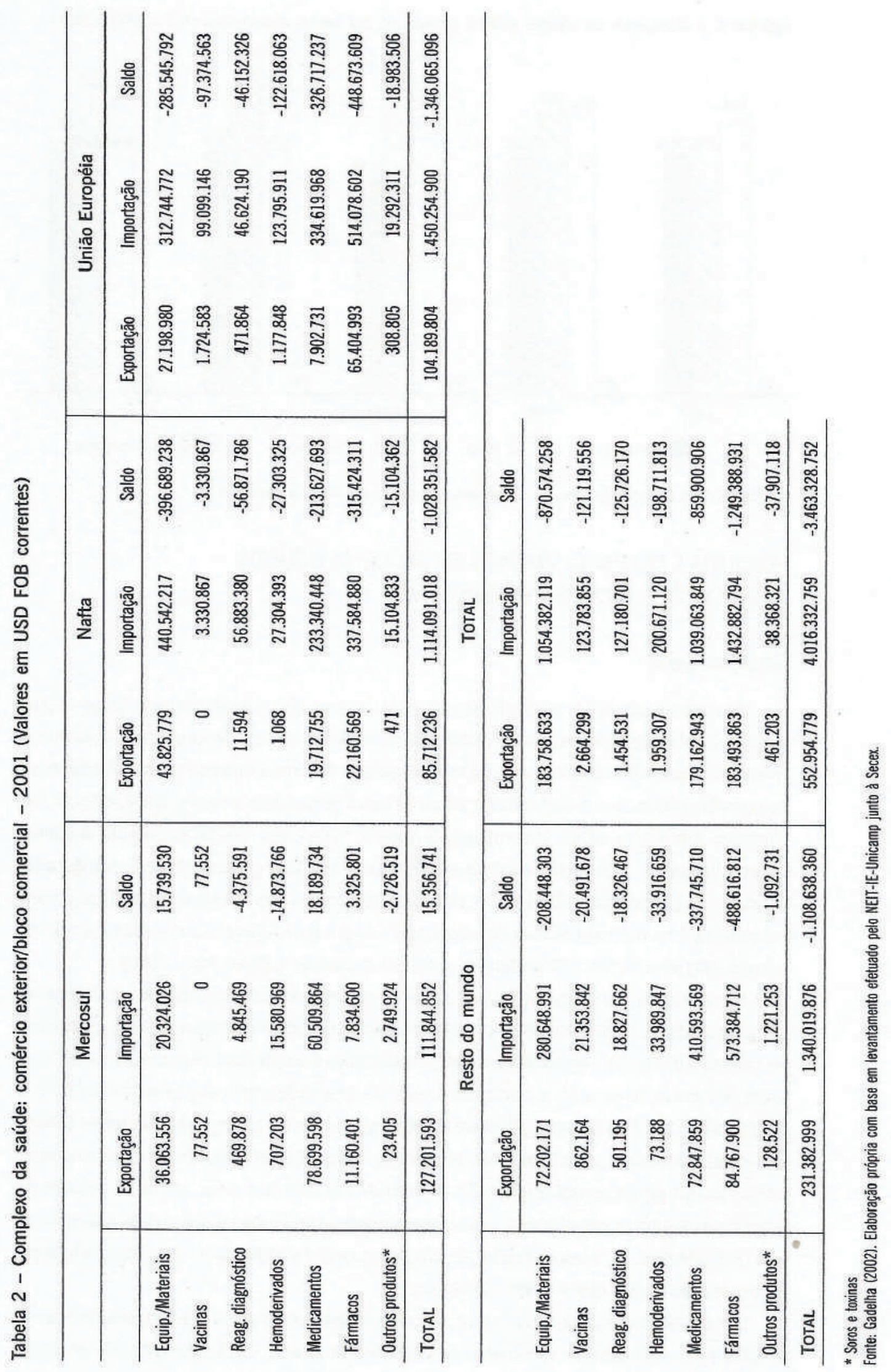


Gráfico 1 - Complexo da saúde: déficit comercial por bloco econômico (\%) - 1997-2001

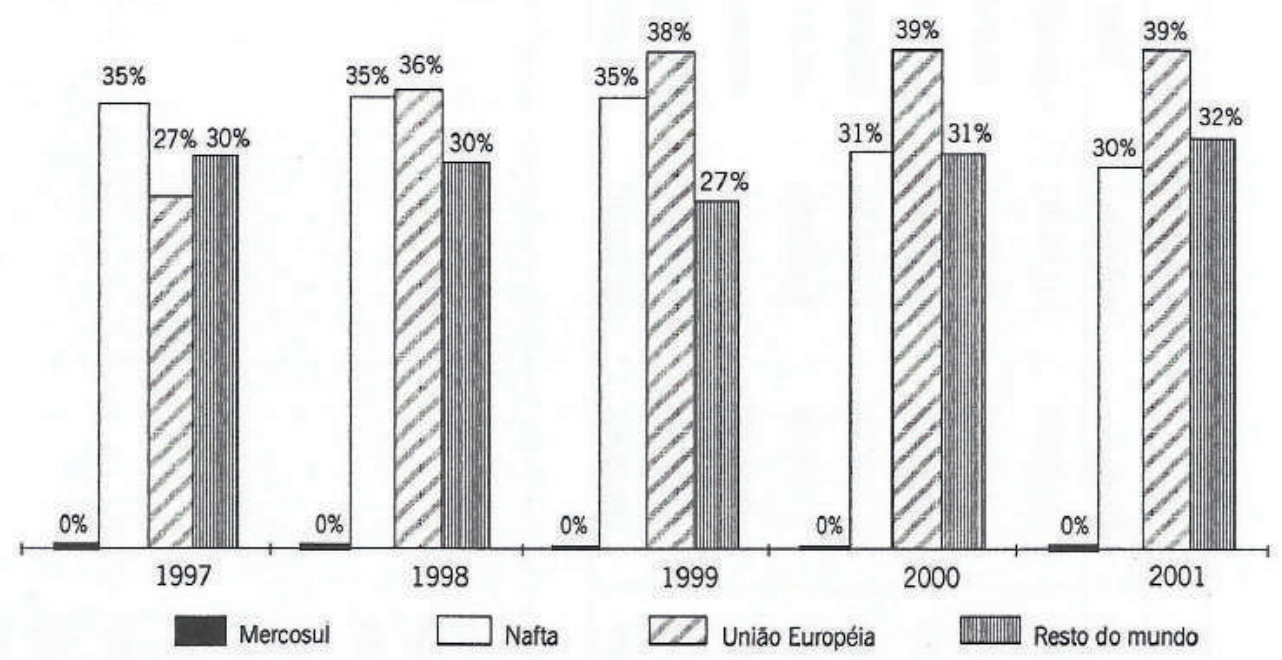

Fonte: Gadelha (2002). Elaboração própria, com base em levantamento efetuado pelo NEIT-IE-Unicamp junto à Sedex.

PESQUISA E DESENVOLVIMENTO EM SAÚDE: BLOQUEIOS ÀS INOVAC̣ÕES, NICHOS E PERSPECTIVAS

\section{Situação geral}

No contexto geral apresentado, o potencial de inovação constitui o fator decisivo para a dinâmica da produção em saúde numa perspectiva estrutural e de longo prazo. No que se refere aos países desenvolvidos, a área de pesquisa e desenvolvimento em saúde está entre as que vêm obtendo o maior esforço público para a geração de novos conhecimentos, em conjunto com a área militar (Rosemberg \& Nelson, 1994). Em relação à pesquisa acadêmica, sua liderança se mostra de forma ainda mais clara. Dos gastos públicos dos Estados Unidos com pesquisa acadêmica, $27,4 \%$ foram destinados para as ciências médicas, representando a área individualizada de maior gasto do governo federal e das instâncias subnacionais (National Science Foundation, apud Albuquerque $\&$ Cassiolato, 2000).

Assim sendo, no grupo de países avançados foram criadas condições sistêmicas de competitividade, relacionadas à convergência dos seguintes elementos: infra-estrutrura de ciência e tecnologia avançada, setores industriais e empresas fortemente inovadoras, além de uma ação estatal que articula o sistema de saúde com o sistema de inovação, a despeito das tensōes e trade-off's entre a lógica econômica e a sanitária (Gadelha, 2003). Esses fatores foram, ao mesmo tempo, causa e conseqüência do forte impacto que os novos paradigmas tecnológicos vêm causando em, literalmente, todos os setores do complexo da saúde, envolvendo estratégias empresariais fortemente articuladas com as instituiçôes de C\&T, a especialização em processos e produtos de alta tecnologia e a incorporação destes aos serviços de saúde.

Dentre os novos paradigmas que, de certa forma, estão preservando, senão mesmo ampliando, o dinamismo histórico dos setores da saúde, destacam-se a eletrônica e 
novos materiais nas áreas de equipamentos e artefatos de uso médico, bem como a biotecnologia nas áreas dos produtos químicos e biológicos. Esses paradigmas e as trajetórias tecnológicas em gestação constituem forças (inclusive interdependentes) que estão alargando aceleradamente a fronteira científica e tecnológica em saúde. Círculos virtuosos e excludentes entre geração de conhecimento, inovação e competitividade estão sendo claramente gerados em âmbito internacional, fortalecendo as estratégias e vantagens empresariais e nacionais por parte das firmas e países desenvolvidos.

A Figura 2 ilustra, de forma simplificada e estilizada, a existência de uma convergência entre as ações de saúde e a dinâmica de inovações e desenvolvimento industrial nos países desenvolvidos. Obviamente, sem deixar de reconhecer a diversidade e exclusão ainda presentes em muitos desses sistemas (a exemplo dos Estados Unidos), é essencial destacar a existência de movimentos convergentes entre a lógica sanitária e a lógica econômica e das inovaçôes. Sistemas nos quais o acesso quantitativo e qualitativo aos serviços de saúde é amplo e universal - como o francês, o inglês ou dos países nórdicos - são também caracterizados por uma base tecnológica e industrial avançada e competitiva em termos internacionais.

Figura 2 - Sistema de ciência, tecnologia e inovação e sistema de saúde

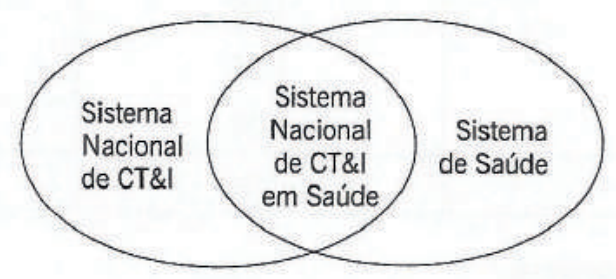

Fonte: Fiocruz (2001).

No Brasil, esse cenário se apresenta de forma dicotômica. Por uma vertente, o país vem seguindo o padrão internacional de suporte à atividade científica em saúde. Conforme as estimativas do governo federal, mencionadas anteriormente (Brasil, 2001), as agências federais de fomento destinam um quarto de seu orçamento para a área da saúde, estando dentro do padrão verificado internacionalmente. Contribuindo para esses esforços, criou-se, em 2001, o fundo setorial da saúde, o que mostra a prioridade dessa área em praticamente todas as esferas de atuação do Estado para o desenvolvimento científico e tecnológico. Quanto aos resultados da política científica, existe uma série de indicadores de avanço significativo, tendo o Brasil evoluído favoravelmente não só nas publicaçōes científicas (a área biomédica tem sido apontada como um destaque em termos internacionais) mas também na qualidade dos trabalhos desenvolvidos, a exemplo dos relacionados ao projeto genoma na área da saúde.

A Tabela 3 mostra o peso da saúde em termos tanto das linhas de pesquisa, quanto do número de pesquisadores, segundo dados do CNPq referentes ao diretório dos grupos de pesquisa.

Por outra vertente, os resultados da política nacional em termos tecnológicos têm sido bastante limitados, observando-se, de fato, um aumento do descompasso dessa 
área em relação aos países desenvolvidos. Para ilustrar esse atraso tecnológico, dados apresentados por Zanow, Diniz e Fernandes (2000) evidenciam que, com a liberalização do patenteamento em saúde, há um forte predomínio das patentes de não residentes depositadas no INPI, em comparação com as dos residentes no Brasil. Ainda que seja esperada uma diferença significativa em favor dos não residentes, sua magnitude mostra-se bastante sugestiva: as patentes depositadas pelos residentes, incluindo as empresas estrangeiras que atuam no território nacional, somente representam $3 \%$ das depositadas pelos não residentes.

Tabela 3 - Linhas de pesquisa e pesquisadores segundo grandes áreas do conhecimento. Brasil - 2002

\begin{tabular}{l|c|c}
\hline Grandes áreas do conhecimento & Linhas de pesquisa & Pesquisadores* \\
\hline Engenharia e ciência da computação & 7.202 & 9.378 \\
Ciências exatas e da terra & 6.733 & 8.616 \\
Ciências biológicas & 6.551 & 8.576 \\
Ciências da saúde & 6.272 & 9.385 \\
Ciências agrárias & 5.983 & 7.639 \\
Ciências humanas & 4.843 & 9.980 \\
Ciências sociais aplicadas & 2.756 & 5.245 \\
Lingüistica, letras e artes & 1.199 & 2.468 \\
\hline ToTAL & 41.539 & 61.287 \\
\hline
\end{tabular}

${ }^{*}$ Há dupla contagem no número de pesquisadores.

Fonte: $\mathrm{CNPq}$ (Diretório de grupos de pesquisa: http://www.cnpq.br).

Por outra vertente, os resultados da política nacional em termos tecnológicos têm sido bastante limitados, observando-se, de fato, um aumento do descompasso dessa área em relação aos países desenvolvidos. Para ilustrar esse atraso tecnológico, dados apresentados por Zanow, Diniz e Fernandes (2000) evidenciam que, com a liberalização do patenteamento em saúde, há um forte predomínio das patentes de não residentes depositadas no Instituto Nacional da Propriedade Industrial (INPI), em comparação com as dos residentes no Brasil. Ainda que seja esperada uma diferença significativa em favor dos nāo residentes, sua magnitude mostra-se bastante sugestiva: as patentes depositadas pelos residentes, incluindo as empresas estrangeiras que atuam no território nacional, somente representam $3 \%$ das depositadas pelos não residentes.

Esse dado global é confirmado quando se estuda a competitividade dos setores vinculados à saúde. Comparando-se a situação atual com a do início da década passada, essa competitividade, como mostrado, e com raríssimas exceções, parece estar se deslocando para produtos de menor conteúdo tecnológico. Ao se indagar sobre o porquê dessa dicotomia entre capacitação científica e inovação na saúde, chega-se a uma das teses centrais defendidas neste trabalho: o potencial nacional de geração de conhecimentos no campo da saúde não se desdobra em inovaçōes que suportam estratégias empresariais e nacionais de 
competitividade por causa da fragilidade do complexo industrial da saúde. Este se constitui no principal bloqueio à entrada do país nos novos paradigmas tecnológicos em saúde.

o padrão de política para a área da saúde, em poucas palavras, tem sido errado do ponto de vista prático e, sobretudo, conceitual. De um lado, no que tange à política de $C \& T$, confunde-se a geração de conhecimento com a geração de inovações. A política tecnológica para o estímulo às inovações requer uma seletividade muito grande em termos dos projetos apoiados. As empresas ou instituições, para terem sucesso em seu empenho de gerar produtos ou processos utilizados em larga escala, devem concentrar esforços em apostas muito seletivas, o que significa excluir de seu horizonte uma enorme magnitude de projetos em favor de poucos e, muitas vezes, até mesmo, de uma única iniciativa com capacidade para alavancar conhecimentos e potenciais produtivos estratégicos. A aposta de Cuba na vacina contra hepatite B ou no interferon reflete bem o grau de seletividade requerido. Do lado da prestação de serviços, a interação desta com a indústria tem sido marcada por um elevado grau de desconfiança e baixa interatividade, cuja raiz é uma oferta assistencial precária que se baseia em produtos com baixo requerimento de qualidade e avaliação tecnológica.

\section{Nichos, redes e âncoras}

A despeito desses bloqueios de natureza estrutural, as condições específicas do sistema nacional de inovação em saúde permitem indicar diversos nichos que apresentam um potencial elevado de sucesso na hipótese da concepção de políticas ativas que promovam a articulação entre política industrial, tecnológica e de saúde. Sem pretender esgotar o tema, a seguir são sugeridos alguns desses nichos, ou janelas de oportunidade, para a política brasileira na área da saúde, à luz da análise efetuada anteriormente.

\section{Biotecnologia}

Desde os anos 80, verifica-se uma ação importante para o estímulo às atividades científicas e tecnológicas no campo da biotecnologia no Brasil, havendo iniciativas como o Programa Nacional de Biotecnologia (Pronab), o Programa para o Apoio ao Desenvolvimento Científico e Tecnológico (PADCT) e algumas outras açōes para o fortalecimento de áreas relacionadas, como genética e biologia molecular. Mais recentemente, o Ministério da Ciência e Tecnologia formulou o Programa de Biotecnologia e Recursos Genéticos (Brasil, 2002), e está em andamento uma série de iniciativas de apoio à área biotecnológica, seja por intermédio de agências federais de fomento e de alguns estados, seja, especialmente, mediante a ação das fundaçōes de amparo à pesquisa.

A Tabela 4 mostra como, hoje, o Brasil já dispõe de uma massa crítica importante no campo científico, havendo 1.718 grupos de pesquisa em biotecnologia, 3.844 linhas de investigação e 6.738 pesquisadores, além de 16.174 estagiários.

Todavia, mesmo quando selecionam alguns produtos prioritários, o foco desses programas acaba sendo genérico, enfatizando as linhas de apoio à área, a exemplo das mostradas no Quadro 1. A despeito de sua importância, essas ações de apoio horizontal têm-se mostrado insuficientes para basear iniciativas de maior fôlego na inovação industrial. Sua 
contribuição se volta, principalmente, para a capacitação de recursos humanos e para a pesquisa científica, mesmo quando, na formulação dos programas e iniciativas, priorizam-se produtos ou processos de alto impacto potencial no sistema produtivo.

Todavia, mesmo quando selecionam alguns produtos prioritários, o foco desses programas acaba sendo genérico, enfatizando as linhas de apoio à área, a exemplo das mostradas no Quadro 1. A despeito de sua importância, essas ações de apoio horizontal têm-se mostrado insuficientes para basear iniciativas de maior fôlego na inovação industrial. Sua contribuição se volta, principalmente, para a capacitação de recursos humanos e para a pesquisa científica, mesmo quando, na formulação dos programas e iniciativas, priorizam-se produtos ou processos de alto impacto potencial no sistema produtivo.

Quadro 1 - Linhas de apoio ao desenvolvimento da biotecnologia

\begin{tabular}{|c|c|c|}
\hline Linhas de apoio & Atividades & Setores beneficiados \\
\hline $\begin{array}{l}\text { Coleções de culturas de serviços e } \\
\text { de referência, de microorganismos e } \\
\text { de células e tecidos. }\end{array}$ & $\begin{array}{l}\text { Conservação, caracterização, } \\
\text { manutenção ex situ de microorganismos } \\
\text { e células/tecidos de interesse para } \\
\text { pesquisa cientifica e industrial, com } \\
\text { aplicaçāo em diversos setores. }\end{array}$ & \multirow[t]{2}{*}{$\begin{array}{l}\text { Saúde, agropecuária, meio ambiente, } \\
\text { setor industrial, a exemplo da indústria } \\
\text { de alimentos e farmacêutica, instituiçōes } \\
\text { de ensino e pesquisa. }\end{array}$} \\
\hline $\begin{array}{l}\text { Bancos de germoplasma e } \\
\text { conservação on farm de plantas e } \\
\text { núcleos de criação de animais - } \\
\text { raças crioulas. }\end{array}$ & $\begin{array}{l}\text { Conservação, caracterização e } \\
\text { manutenção ex situ de material genético. } \\
\text { Apoio a estudos de mapeamento da } \\
\text { ocorrência de parentes silvestres das } \\
\text { principais espécies agronômicas e } \\
\text { medicinais de uso atual e potencial com } \\
\text { ênfase para aquelas que tenham o Brasil } \\
\text { como centro de origem ou de } \\
\text { diversificação. }\end{array}$ & \\
\hline Laboratórios nacionais & $\begin{array}{l}\text { Fortalecimento da infra-estrutura } \\
\text { nacional de pesquisa e serviços, com o } \\
\text { apoio à criação e fortalecimento de } \\
\text { centros de excelência em bioinformática } \\
\text { e de um laboratório nacional de biologia } \\
\text { molecular estrutural. }\end{array}$ & $\begin{array}{l}\text { Instituiçōes de ensino e pesquisa, } \\
\text { incubadoras de empresa, bioindústrias, } \\
\text { dentre outros. }\end{array}$ \\
\hline Bioinformática & $\begin{array}{l}\text { Organizaçāo de redes interativas de } \\
\text { pesquisa e inovaçāo biotecnológica e de } \\
\text { diretórios contendo dados sobre banco } \\
\text { de genes de espécies seqüenciadas, } \\
\text { desenvolvimento de serviços e } \\
\text { softwares. }\end{array}$ & $\begin{array}{l}\text { Instituiçōes de ensino e pesquisa, } \\
\text { incubadoras de empresa, bioindústrias, } \\
\text { dentre outros. }\end{array}$ \\
\hline Biossegurança & $\begin{array}{l}\text { Apoio à capacitação de recursos } \\
\text { humanos. Apoio à certificação e } \\
\text { credenciamento de laboratórios } \\
\text { nacionais para realizaçăo de testes de } \\
\text { segurança alimentar de OGMs, incluindo } \\
\text { a implantação de boas práticas } \\
\text { laboratoriais. Realização de estudos } \\
\text { específicos em biossegurança. Apoio ao } \\
\text { funcionamento e às atividades da } \\
\text { Comissão Técnica Nacional de } \\
\text { Biossegurança (CTNBio). }\end{array}$ & $\begin{array}{l}\text { Profissionais, pesquisadores, } \\
\text { instituiçōes de ensino e pesquisa, e } \\
\text { sociedade em geral. }\end{array}$ \\
\hline
\end{tabular}

Fonte: Brasil (2002) - Programa de Biotecnologia e Recursos Genéticos. 
Tabela 4 - Distribuição dos grupos de pesquisa em biotecnologia no Brasil, por região geográfica, número de linhas de pesquisa, pesquisadores, estudantes e estagiários

\begin{tabular}{l|c|c|c|c}
\hline $\begin{array}{l}\text { Setor de atividade } \\
\text { por regiäo } \\
\text { geográfica }\end{array}$ & $\begin{array}{c}\text { Grupos } \\
\text { de pesquisa } \\
\text { (G) }\end{array}$ & $\begin{array}{c}\text { Linhas de } \\
\text { pesquisa (L) }\end{array}$ & $\begin{array}{c}\text { Pesquisadores } \\
(\mathrm{P})\end{array}$ & $\begin{array}{c}\text { Estudantes } \\
\text { e estagiários }\end{array}$ \\
\hline Centro-0este & 99 & 213 & 470 & 334 \\
Nordeste & 242 & 500 & 958 & 1.336 \\
Norte & 59 & 117 & 233 & 312 \\
Sudeste & 991 & 2.279 & 3.832 & 11.204 \\
Sul & 327 & 735 & 1.245 & 2.988 \\
TOTAL & 1.718 & 3.844 & 6.738 & 16.174 \\
\hline
\end{tabular}

Fonte: CNPq (Diretório de grupos de pesquisa: http://www.cnpq.br).

\section{Vacinas}

No caso específico da biotecnologia na área da saúde, pode-se mostrar em outros trabalhos (Gadelha, 2000; Gadelha \& Azevedo Brito, 2003), centrados na biotecnologia aplicada à área de vacinas - certamente o setor no qual o Brasil apresenta um dos maiores potenciais de entrada nas novas biotecnologias em saúde -, que a esfera científica, industrial e da política de saúde estão isoladas, não mantendo vínculos estreitos e orgânicos. Temporão (2002) faz uma excelente e detalhada análise do setor.

No campo científico, observa-se uma tendência de que os projetos sejam orientados pela curiosidade, buscando-se formas de legitimação intrínsecas à comunidade científica, conforme expresso nas publicações dessa área. Ou seja, mesmo num setor de alto impacto social como o de vacinas, a pesquisa é orientada pela lógica interna da geração de conhecimentos, tendo como indicador de produtividade a publicação em revistas especializadas, como foi mostrado, nos trabalhos citados, para o PADCT.

No campo da política de saúde, a desarticulação entre pesquisa e produção também é evidente. Inicialmente, nota-se uma surpreendente ausência de prioridades, estratégias e recursos para o desenvolvimento de vacinas no âmbito do Ministério da Saúde, desde a criação do Programa Nacional de Imunização (PNI) em 1973 até o final đo século passado. A força da política de saúde vinculada à imunização jamais se desdobrou em termos de estímulo à pesquisa e ao desenvolvimento de novas ou melhores vacinas, não havendo nenhuma fonte de financiamento à pesquisa básica e aplicada na área, a despeito dos vultosos recursos envolvidos nos programas de vacinação.

Mais surpreendente ainda é o fato de que mesmo o apoio dado especificamente à área de produção pelo Programa de Auto-Suficiência Nacional em Imunobiológicos (Pasni), com investimentos da ordem de 150 milhōes de dólares, não envolveu a canalização de recursos para o desenvolvimento de vacinas, à exceção da vacina contra a hepatite $\mathrm{B}$. Na realidade, o Programa confundia, em termos conceituais, o desenvolvimento tecnológi-" $\mathrm{co}$, que necessariamente deve estar assentado numa base de pesquisa ampla e complexa, com a obtenção de tecnologia operacional de produção. Como desdobramento dessa filosofia, o investimento realizado concentrou-se em obras e equipamentos, relegando 
para segundo plano o investimento em atividades de pesquisa e desenvolvimento e na formação de recursos humanos com alta qualificação. Certamente é esta visão que explica o fato de que a auto-suficiência jamais foi atingida, sequer proximamente, uma vez que a pesquisa desenvolvida internacionalmente coloca, a cada momento, novas possibilidades em termos de produtos e processos que os agentes nacionais não conseguem acompanhar. Observe-se que a meta estipulada pelo Pasni previa a auto-suficiência para o ano de 1990, quando, de fato, o país ainda importava mais de $50 \%$ do valor das compras de vacinas (Gadelha, 1990).

Os dois únicos casos analisados que representavam um avanço nacional em biotecnologia na área da saúde - o desenvolvimento e produção da vacina contra a hepatite $B$ pelo Butantan e da vacina contra Haemophillus influenzae tipo b por Bio-Manguinhos/ Fiocruz - mostraram uma interação dinâmica entre a montagem de uma base interna de $P \& D$, a existência de uma base industrial e de desenvolvimento tecnológico e a presença de uma demanda estatal estável. Reforça-se, portanto, a idéia defendida de que somente com a superação da fragilidade industrial e de mercado verificada no complexo da saúde é possível avançar nos novos paradigmas que possuem um potencial destacado na área, como é o caso da biotecnologia.

Com base nessas experiências, que refletem ações mais ou menos bem-sucedidas, pode-se afirmar que $\mathrm{o}$ apoio horizontal à formação de redes científicas e tecnológicas deve estar assentado em 'âncoras' que tenham a função de desenvolver tecnologias, ligando o mundo da pesquisa com o mundo da produção industrial. No caso das vacinas, Bio-Manguinhos/Fiocruz e o Butantan têm exercido esse papel, colocando o setor como um nicho promissor das potencialidades do país em biotecnologia. A seguir são indicados, de forma mais sucinta, alguns outros nichos e âncoras que podem servir como base para o avanço tecnológico no complexo da saúde, pensando a possibilidade de uma articulação virtuosa com a política de saúde.

\section{Reagentes para diagnóstico}

O desenvolvimento e a produção de reagentes biológicos utilizados no controle das transfusões sangüíneas constitui uma área que alia potencial científico destacado, havendo vários exemplos de reagentes desenvolvidos no Brasil, com a utilização do recurso da engenharia genética, com a capacidade institucional nas universidades e institutos de pesquisa, com a possibilidade de empreendimentos de menor porte e demanda potencial estável e crescente por parte do Estado, exigindo-se alta qualidade e tecnologia. Nesse caso, alguns institutos de pesquisa em saúde pública, como Bio-Manguinhos/ Fiocruz - cuja capacitação na área já é significativa -, poderiam formar a âncora tecnológica para alavancar e transformar o potencial científico disponível em produtos utilizados pelos programas de saúde.

\section{Fitomedicamentos}

A biodiversidade brasileira torna a área de fitomedicamentos, envolvendo fitofármacos e fitoterápicos, natural para o fortalecimento da capacitação local de ino- 
vação em saúde. Segundo levantamento efetuado por meio de entrevistas na FarManguinhos e ao gerente do programa Fitoterapia e Saúde Pública, do Plano Plurianual 2000/2003 (PPA), foi possível identificar que as iniciativas ainda se encontram em um estágio incipiente, havendo poucas inserções empresariais. Em todo caso, está havendo um processo de construção de uma rede de instituições com capacitação tecnológica na área.

No estágio atual, a prioridade está sendo a montagem de um 'projeto plataforma', a fim de fornecer as bases para a interação entre os agentes, definindo as capacitações institucionais, a padronização dos processos, os direitos de propriedade e as bases contratuais para normatizar as parcerias (Quadro 2). Espera-se que, como resultado desse esforço normativo, a rede possa operar sustentada em um terreno sólido e confiável.

Quadro 2 - Projeto plataforma: objetivos específicos

\begin{tabular}{|l|l|l|l|}
\hline Objetivo específico & \multicolumn{1}{|c|}{ Meta } & \multicolumn{1}{|c|}{ Atividades } & \multicolumn{1}{c|}{ Ator } \\
\hline $\begin{array}{l}\text { Identificar e qualificar as instituições } \\
\text { prestadoras de serviços tecnológicos }\end{array}$ & $\begin{array}{l}\text { Cadastro nacional de instituições } \\
\text { envolvidas ou a se envolver com DT em } \\
\text { fitomedicamentos }\end{array}$ & $\begin{array}{l}\text { - Levantamento (bases de dados, } \\
\text { formulários) } \\
\text { - Classificação (critérios) } \\
\text { - Auditoria (posterior) }\end{array}$ & Grupos técnicos, CNPq, Finep \\
\hline $\begin{array}{l}\text { Estabelecer POPs* e protocolos } \\
\text { padronizados para os processos das } \\
\text { áreas técnicas envolvidas no DT de } \\
\text { fitomedicamentos }\end{array}$ & $\begin{array}{l}\text { Organização e elaboração das diretrizes } \\
\text { válidas para as áreas técnicas envolvidas } \\
\text { no DT de fitomedicamentos }\end{array}$ & $\begin{array}{l}\text { - Seleção, análise e desenvolvimento de } \\
\text { POPs* para as áreas específicas }\end{array}$ & Grupos técnicos de trabalho \\
\hline $\begin{array}{l}\text { Definir os direitos de propriedade } \\
\text { intelectual e industrial entre os } \\
\text { parceiros do DT de fitomedicamentos }\end{array}$ & $\begin{array}{l}\text { Critério universal para a partilha de } \\
\text { dividendos dos produtos desenvolvidos }\end{array}$ & $\begin{array}{l}\text { - Desenvolvimento e análise de } \\
\text { ferramentas para respaldo jurídico às } \\
\text { divisões de direitos }\end{array}$ & $\begin{array}{l}\text { Grupos técnicos, consultoria } \\
\text { especializada de suporte }\end{array}$ \\
\hline $\begin{array}{l}\text { Estabelecer base contratual nas } \\
\text { parcerias do DT de fitomedicamentos }\end{array}$ & $\begin{array}{l}\text { Contratos 'uniformizados' quanto ao } \\
\text { suporte jurídico para as relações de } \\
\text { parceria }\end{array}$ & $\begin{array}{l}\text { - Análise dos tipos de contratos existentes } \\
\text { - Propostas de novos modelos }\end{array}$ & $\begin{array}{l}\text { Grupos técnicos, consultoria } \\
\text { especializada de suporte }\end{array}$ \\
\hline
\end{tabular}

* POPs: Procedimentos Operacionais Padronizados.

Fonte: Diretoria de Produtos Naturais/Núcleo de Planejamento e Gestão de Projetos - Far-Manguinhos/Fiocruz - Programa de Fitoterápicos e Saúde Pública - Plano Plurianual (2000-2003).

O Quadro 3 mostra o impacto esperado da implantação dessa plataforma nos diferentes tipos de agentes. Nesse caso, é possível pensar na constituição de uma rede que se baseie em um núcleo de instituições, como Far-Manguinhos/Fiocruz e empresas que estão entrando na área, para estruturar a busca e o desenvolvimento de novos produtos. 
VACINAS, SOROS E IMUNIZAÇŌES NO BRASIL

Quadro 3 - Impactos da implantação da plataforma para o desenvolvimento de fitomedicamentos

\begin{tabular}{|l|l|l|}
\hline Ator & \multicolumn{1}{|c|}{ Impacto } & \multicolumn{1}{c|}{ Meio } \\
\hline Instituições & $\begin{array}{l}\text { - Fortalecimento institucional em torno de eixo de excelência } \\
\text { - Aumento da capacidade de competição por projetos e financiamentos } \\
\text { (nacional e internacionalmente) }\end{array}$ & $\begin{array}{l}\text { - Cumprimento mais efetivo das metas técnicas } \\
\text { - Maior capacidade de validação da pesquisa } \\
\text { - Maior agilidade e segurança na efetuação de parcerias }\end{array}$ \\
\hline Empresas & $\begin{array}{l}\text {-Melhor relação de custo-benefício na fase de planejamento de projetos } \\
\text { - Maior visibilidade de suas potencialidades como parceiros em P\&D }\end{array}$ & $\begin{array}{l}\text { - Maior facilidade e agilidade para efetuar parcerias } \\
\text { - Maior agilidade e segurança na contratação de serviços especializados } \\
\text { - Postura mais clara com o potencial parceiro ou contratante de serviços }\end{array}$ \\
\hline $\begin{array}{l}\text { Agências de } \\
\text { fomento }\end{array}$ & $\begin{array}{l}\text { - Maior clareza e agilidade para o direcionamento dos fomentos } \\
\text { - Posse de requisitos mais seguros na captação e canalizaçăo de } \\
\text { recursos internacionais } \\
\text { - Maior capacidade de gerenciamento de programas da área }\end{array}$ & $\begin{array}{l}\text { - Melhor visibilidade dos parâmetros de qualidade nas instituições de } \\
\text { P\&D } \\
\text { - Disponibilidade de ferramenta referencial para gerenciarmento de } \\
\text { programas e projetos na área (redes) }\end{array}$ \\
\hline $\begin{array}{l}\text { Agências de } \\
\text { regulação }\end{array}$ & $\begin{array}{l}\text {-Maior agilidade e segurança nos processos de avaliação das } \\
\text { solicitaçōes de registro }\end{array}$ & \\
\hline
\end{tabular}

Fonte: Diretoria de Produtos Naturais/Núcleo de Planejamento e Gestão de Projetos - Far-Manguinhos/Fiocruz - Programa de Fitoterápicos e Saúde Pública - Plano Plurianual (2000-2003).

\section{Fármacos e medicamentos}

Neste segmento, há um claro espaço para o avanço e mesmo a retomada da produção nacional de produtos de maior valor agregado e intensidade de conhecimento. A maior parte do déficit comercial é proveniente de produtos fora de proteção patentária, o que reflete a viabilidade de estratégias de engenharia reversa e de aumento do porte dos produtores nacionais para que, a médio e longo prazos, possam se constituir numa base de inovação em alguns nichos específicos.

Dentre os produtos que poderiam ter seu desenvolvimento competitivo favorecido pela articulação da política de saúde com a política tecnológica, cabe destacar os seguintes grupos, a título de ilustração, que serviriam como base para se pensar em estratégias seletivas e de focalização dos esforços tecnológicos: drogas para doenças negligenciadas, hemoderivados, produtos da Relação Nacional de Medicamentos Essenciais (Rename), genéricos, biofármacos e antibióticos.

Observe-se que esse potencial de articulação da política de saúde com a política tecnológica e industrial já está ocorrendo na experiência de Far-Manguinhos/Fiocruz, que constitui o caso mais bem-sucedido no passado recente de $P \& D$ em fármacos e medicamentos de origem sintética e natural. Esse produtor público tem sido um dos alicerces essenciais da política de suprimento e regulação (preço e qualidade) dos medicamentos por parte do Ministério da Saúde, fornecendo, paralelamente, um importante suporte para as empresas privadas nacionais, desenvolvendo tecnologias em conjunto e estabelecendo acordos comerciais para atender ao mercado público de saúde. Conta com cerca de duzentos pesquisadores em atividades de $P \& D$, os quais atuam, inclusive, na busca de novas moléculas, fato inédito na experiência do setor. 
Tabela 5 - Evolução das vendas. Far-Manguinhos - 1994-2001

\begin{tabular}{c|c|c|c}
\hline \multirow{2}{*}{ Ano } & \multicolumn{3}{|c}{ Fontes de arrecadação (R\$) } \\
\cline { 2 - 4 } & $\begin{array}{c}\text { Vendas } \\
\text { Ministério da Saúde }\end{array}$ & Vendas diretas & TotAL \\
\hline 1997 & 9.194 .328 & 710.895 & 9.905 .223 \\
1998 & 46.818 .390 & 455.913 & 47.274 .303 \\
1999 & 76.515 .643 & 3.581 .457 & 80.097 .100 \\
2000 & 109.743 .911 & 9.252 .756 & 118.996 .667 \\
2001 & 194.504 .659 & 14.235 .992 & 208.740 .651 \\
\hline
\end{tabular}

Fonte: Dados proporcionados por Far-Manguinhos/Fiocruz.

Quadro 4 - Negociaçōes e parcerias em andamento. Far-Manguinhos/Fiocruz - 2002

\begin{tabular}{|c|c|c|}
\hline Princípio ativo/Medicamento & Empresa & Tipo de contrato \\
\hline Ciclosporina (microemulsão em cápsula gelatinosa mole) & RPG LS (Índia) & $\mathrm{TT} / \mathrm{SMP}$ \\
\hline Ritonavir (microemulsão em cápsula mole) & Cristália & $T S / \pi$ \\
\hline Saquinavir (microemulsão em cápsula mole) & Cristália & $\mathrm{TS} / \mathrm{TT}$ \\
\hline Ritonavir + Saquinavir (associação, microemulsão) & Cristália & AS/CT \\
\hline Antimoniato de meglumina injetável & Aventis & Não definido \\
\hline Novos inibidores de protease & Cristália & $\mathrm{TS} / \mathrm{CT}$ \\
\hline Benzonidazol & Roche & FT \\
\hline Organofluorados (antiinflamatório) & Torrent (Índia) & TS/LP/CT \\
\hline Mesilato de imatinib (Glivec) & Hetero & $\mathrm{AS} / \mathrm{CT}$ \\
\hline Lopinavir + Ritonavir (associação) & Hetero & $\mathrm{AS} / \mathrm{CT}$ \\
\hline Indinavir + Ritonavir (associaçāo) & Hetero & $\mathrm{AS} / \mathrm{CT}$ \\
\hline Abacavir, Amprenavir, Fosamprenavir & Glaxo SmithKline & $A S / L P$ \\
\hline Anti-retrovirais/Medicamentos para doenças negligenciadas & Médicos sem Fronteira - MSF & $\mathrm{ME} / \mathrm{FM}$ \\
\hline Objetos diversos (deverão ser estabelecidos, posteriormente, vários contratos específicos) & Merck Sharp \& Dohme - MSD & AS/CE \\
\hline Megazol & OMS/MSF/FAR & AS/AM \\
\hline Medicamentos à base de proteínas recombinantes & Chron Epigen Ltda. & AS/FT \\
\hline Anti-retrovirais & Brasil/Ucrânia (MSF) & AS/TT \\
\hline
\end{tabular}

AM - acordo de cooperação mútua

AS - acordo de sigilo

CE - contrato especifico

CT - acordo de cooperaçāo técnico-cientifica

FM - contrato de fornecimento de medicamentos para Aids

FT - contrato de fornecimento de tecnologia

LP - contrato de licença para exploração das patentes

ME - memorando de entendimentos

SMP - contrato de suprimento de matérias-primas e produto

TS - termo de sigilo

$\pi$ - contrato de transferência de tecnologia industrial

Fonte: Assessoria de Propriedade Industrial, Far-Manguinhos/Fiocruz. 
A Tabela 5, analisada em conjunto com $\circ$ Quadro 4, mostra a evolução exponencial das vendas de Far-Manguinhos ao Ministério da Saúde e a simultânea construção de relações fortes de parceria com empresas do setor e instituições acadêmicas, constituindo uma âncora necessária para o avanço na área e para o estabelecimento de redes de desenvolvimento de fármacos e medicamentos no país.

\section{Equipamentos e materiais médicos}

Neste segmento, a despeito de haver um conjunto de produtos fora do horizonte imediato das empresas locais (equipamentos por imagem de maior porte e complexidade tecnológica, por exemplo), é possível identificar uma série de nichos que podem ser explorados.

Uma das ações de maior impacto na área é a prestação de serviços tecnológicos, como o programa que as empresas do setor possuem com o Instituto de Pesquisas Tecnológicas (IPT), o Programa de Apoio Tecnológico à Exportação (Progex), tendo um impacto essencial na superação das barreiras técnicas e sanitárias. Do lado da política de saúde, os investimentos públicos nos serviços de saúde - estatais e filantrópicos - têm um alto potencial de alavancagem do setor, infelizmente muito pouco aproveitado. Dos produtos relacionados no levantamento de campo que poderiam ser priorizados pela política industrial e tecnológica, podem ser mencionados os seguintes: cateteres especiais, câmaras de vacinas e sangue, telemedicina, equipamentos para video-cirurgias, de imagem (segmentos), para radiologia, terapia intensiva e esterilização, órteses e próteses, mobiliário cirúrgico e ortopédico, entre outros que possuem alto valor agregado e potencial de competitividade internacional.

Figura 3 - Conhecimento, complexo industrial e inovações em saúde

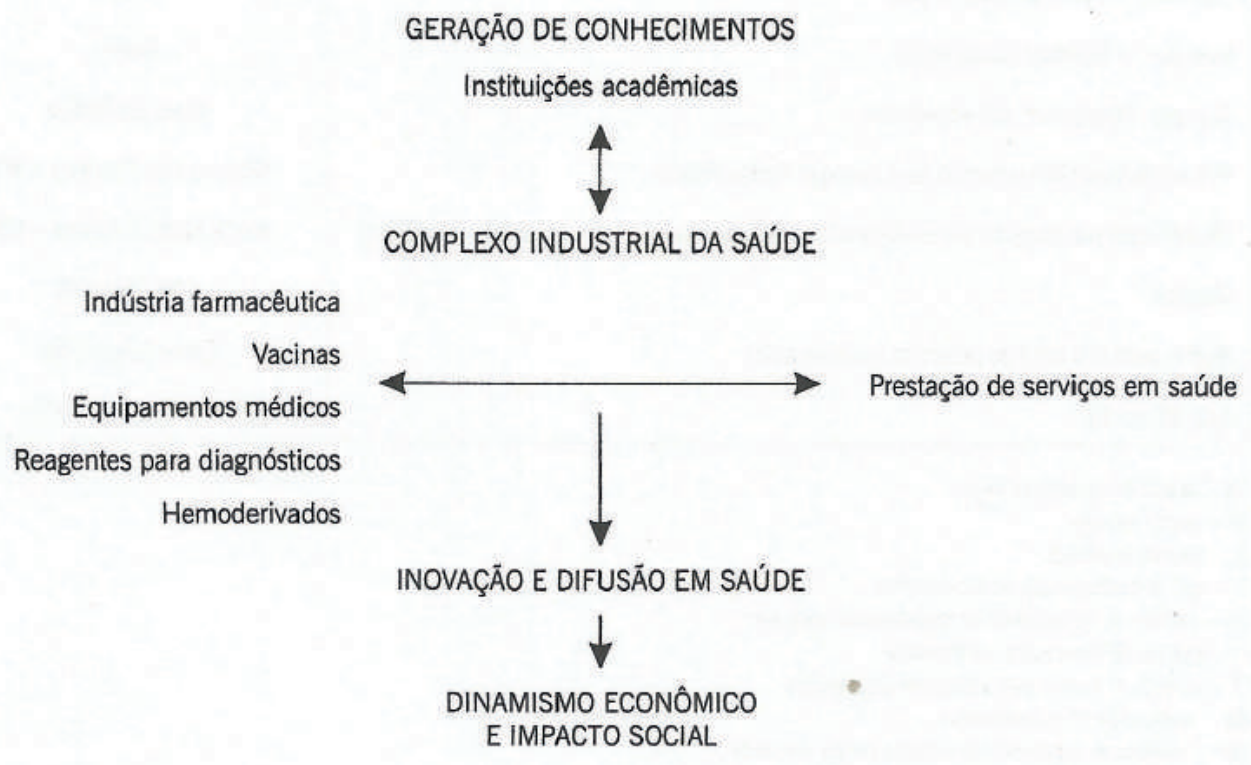


Pode-se afirmar, portanto, que, em virtude da fragilidade das indústrias do complexo da saúde, existe uma situação estrutural de difícil superação para o avanço das inovaçōes nessa área. Não obstante, a capacidade científica já adquirida pelo país e a abrangência das ações do Estado na área da saúde permitem pensar em nichos tecnológicos que se baseiem, simultaneamente, na formação de 'redes' cooperativas de P\&D e no fortalecimento de 'âncoras' produtivas e tecnológicas, públicas ou privadas, que permitam transformar o potencial de pesquisa em produtos e processos competitivos no mercado mundial.

A Figura 3 evidencia que os gargalos centrais para a transformação do potencial científico existente em uma base concreta de inovações estão associados à fragilidade do complexo industrial da saúde. Tal fragilidade somente pode ser atenuada mediante o estabelecimento de vínculos orgânicos com a política de saúde e um esforço seletivo não trivial para o padrão brasileiro de política de ciência e tecnologia.

\section{CONCLUSÕES E DESDOBRAMENTOS PARA A POLITICA DE INOVAC̄̃̃O EM SAÚDE}

A política de abertura econômica em conjunto com a passividade da política industrial e tecnológica para a área da saúde se mostraram extremamente danosas para o país, engendrando um movimento de reespecialização produtiva e tecnológica das indústrias dessa área. Como conseqüência, houve um claro processo de deterioração comercial e de dessubstituição de importações nos segmentos de maior densidade tecnológica e, portanto, de maior valor agregado. Em termos prospectivos, como o setor da saúde é dos mais impactados pelos novos paradigmas tecnológicos, a expectativa para os próximos dez anos é de continuidade na tendência de perda de competitividade e de ampliação do déficit existente, a menos que haja uma alteração profunda no contexto local em que o complexo está inserido.

Isto posto, a situação atual e prospectiva se mostra crítica para a política tecnológica e de inovaçăo, bem como para a política de saúde do Brasil, considerando a importância do complexo da saúde tanto para a evolução de indústrias e segmentos tecnológicos de alto dinamismo quanto para a viabilização de ações de promoção, prevenção e assistência à saúde, num contexto em que o sistema de saúde brasileiro está em pleno processo de expansão e reestruturação.

A justificativa para uma ação pública decidida para o desenvolvimento do complexo da saúde pode ser calcada em três fatores essenciais:

Primeiro, esse complexo possui alta relevância econômica e potencial de inovações, sendo um veículo importante de entrada do país nos novos paradigmas tecnológicoscom destaque para a biotecnologia, a química fina e a microeletrônica-, determinantes, em última instância, da competitividade nacional a longo prazo.

Segundo, o Estado possui uma atuação abrangente e crescente na área da saúde, constituindo um campo privilegiado para o estabelecimento de estratégias de desenvolvimento industrial. Os casos recentes de sucesso (ainda reduzidos), como a política para os medicamentos genéricos, para algumas vacinas que incorporam as novas biotecnologias e para segmentos da indústria de equipamentos e materiais que se beneficiaram da política de aumento da capacidade da prestação de serviços de saúde, evidenciam esta 
potencialidade. Como desdobramento, pode-se afirmar que, nas negociações internacionais, o uso do 'poder de compra do Estado' vinculado à política de inovação ativa $e$ fortemente seletiva constituem os 'principais instrumentos' para o desenvolvimento do complexo, devendo haver flexibilidade para o estímulo à produção nacional.

Terceiro, a forte e crescente dependência de importaçōes no complexo da saúde leva a uma situação de vulnerabilidade da política social que pode ser extremamente danosa para o bem-estar da população. Os programas sociais de assistência farmacêutica, de vacinação, de assistência médica, de testes para diagnóstico das transfusões sangüíneas, entre outros, não podem ficar com uma dependência tão expressiva de divisas, sujeitas a oscilações do mercado financeiro internacional. Por isso, sugere-se, à semelhança da argumentação a favor da relativização dos direitos de propriedade intelectual na área da saúde nas recentes negociações no âmbito da Organização Mundial do Comércio (OMC), que a idéia de 'vulnerabilidade da política social' brasileira seja uma justificativa legítima para o estabelecimento de políticas para o desenvolvimento do complexo da saúde.

Em face dessas justificativas, propõe-se colocar o complexo da saúde como uma das prioridades da política industrial e de inovaçã̃o do país. Todavia, é importante enfatizar que a história das indústrias que fazem parte do complexo mostra uma reduzida eficácia das políticas meramente protecionistas, que não foram suficientes para o salto qualitativo na competitividade dos diferentes setores. A disseminação de mecanismos de proteção desvinculados de resultados e de estratégias tecnológicas de maior fôlego tendem a apresentar resultados muito restritos.

Assim sendo, os incentivos concedidos pelo Estado - ainda claramente insuficientesdevem ser 'condicionados a resultados' (obtenção de saldos comerciais ou redução progressiva dos déficits comerciais das empresas ou segmentos, por exemplo) e 'focalizados' no desenvolvimento do potencial empresarial de inovaçăo em nichos específicos com alto conteúdo estratégico - produção de genéricos, de fármacos e medicamentos da Rename, de vacinas dos programas nacionais de imunização, fitoterápicos, hemoderivados, certos grupos de equipamentos e materiais, biofármacos, drogas negligenciadas e reagentes para diagnóstico, por exemplo-, conformando uma estratégia de ganhos efetivos de competitividade a longo prazo. Igualmente, as 'inovações organizacionais' aparecem como centrais para as indústrias do complexo, devendo-se induzir a superação das estruturas patrimoniais fragmentadas e de base familiar, predominantes em muitos dos segmentos do complexo, e a modernização do modelo gerencial das organizações públicas produtoras de bens e serviços em saúde.

No campo particular da 'política tecnológica', as experiências de sucesso observadas indicam que, para a transformação de conhecimentos em inovações, é necessária a concentração de esforços em produtos específicos de forma articulada com o setor industrial. 0 descolamento entre a geração de conhecimentos e estruturas empresariais de desenvolvimento tecnológico está na raiz do atraso do sistema de inovação em saúde. Todos os casos de sucesso apresentaram, como característica comum, a confluênçia de açōes para a geração de conhecimentos e para a obtenção de produtos em bases industriais, para o que a demanda do Estado vinculada ao setor de serviços de saúde invariavelmente representou um fator decisivo, inclusive para o sucesso dos processos de transferência de tecnologia (o caso do acesso às novas biotecnologias para a produção de vacinas é exemplar a esse respeito). 
Ou seja, a ação estruturante do Estado se mostra decisiva para o avanço tecnológico do complexo da saúde, não sendo suficiente a existência de medidas horizontais e fragmentadas concentradas apenas na infra-estrutura de C\&T. Às iniciativas para o estímulo à formação de redes devem ser acopladas iniciativas para a constituição de 'âncoras tecnológicas e industriais' que permitam orientar os resultados das atividades cooperativas para a inovação nos setores industriais e de serviços.

O Quadro 5 detalha os fatores de competitividade relacionados aos distintos segmentos do complexo da saúde, sugerindo suas fontes, alguns nichos prioritários e as principais políticas públicas capazes de exercer impactos expressivos no dinamismo das diferentes indústrias e na reversão do quadro de perda de competitividade verificado na década de 1990.

Quadro 5 - Complexo industrial da saúde: fatores e políticas de competitividade

\begin{tabular}{|c|c|c|c|c|}
\hline Segmentos & $\begin{array}{l}\text { Fatores críticos de } \\
\text { competitividade }\end{array}$ & $\begin{array}{l}\text { Fontes de vantagens } \\
\text { competitivas no Brasil }\end{array}$ & $\begin{array}{l}\text { Nichos tecnológicos } \\
\text { e de mercado }\end{array}$ & $\begin{array}{l}\text { Principais políticas de } \\
\text { competitividade }\end{array}$ \\
\hline $\begin{array}{l}\text { Equipamentos e } \\
\text { materiais }\end{array}$ & $\begin{array}{l}\text { - Potencial de inovação e de } \\
\text { melhorias incrementais em } \\
\text { materiais e microeletrônica } \\
\text { - Relaçöes com os prestadores } \\
\text { de serviços } \\
\text { - Porte ou especialização em } \\
\text { nichos }\end{array}$ & $\begin{array}{l}\text { - Expansão do sisterna de saúde (rede } \\
\text { hospitalar e ambulatorial) } \\
\text { - Capacidade industrial relevante em } \\
\text { diversos segmentos }\end{array}$ & $\begin{array}{l}\text { - Cateteres especiais } \\
\text { - Câmaras de vacinas e sangue } \\
\text { - Telemedicina } \\
\text { - Equipamentos para videocirurgias, de } \\
\text { imagem (segmentos), para radiologia, } \\
\text { terapia intensiva } \theta \text { esterilização } \\
\text { - Órteses e próteses } \\
\text { - Mobiliário cirúrgico e ortopédico }\end{array}$ & $\begin{array}{l}\text { - Articulaçāo da indústria com política } \\
\text { de investimento na rede hospitalar } \\
\text { - Financiamento do BNDES, inclusive } \\
\text { para hospitais públicos } \\
\text { - Financiamento da Finep para } \\
\text { empresas de tecnologia } \\
\text { - Incentivo tributário equivalente ao } \\
\text { dado às importaçôes } \\
\text { - Incentivo à profissionalização da } \\
\text { gestão } \\
\text { - Consolidação expansāo da } \\
\text { estrutura de serviços tecnológicos e } \\
\text { certificação } \\
\text { - Política comercial ativa para atenuar } \\
\text { as barreiras técnicas e sanitárias e } \\
\text { para a promoçāo das exportaçōes }\end{array}$ \\
\hline Vacinas & $\begin{array}{l}\text { - Potencial de inovação em } \\
\text { biotecnologia } \\
\text { - Porte tecnológico } \\
\text { - Entrada nos produtos de maior } \\
\text { valor agregado }\end{array}$ & $\begin{array}{l}\text { - Dimensāo do mercado nacional e } \\
\text { consolidação do PNI } \\
\text { - Capacidade produtiva e potencial } \\
\text { tecnológico dos principais produtores } \\
\text { - Infra-estrutura de controle de } \\
\text { qualidade } \\
\text { - Base científica nacional }\end{array}$ & $\begin{array}{l}\text { - Novas vacinas utilizadas no PNI: } \\
\text { hepatite B, Hib, tríplice viral } \\
\text { - Novas vacinas combinadas: quíntupla } \\
\text { (ex. DTP + Hib + hep. B) } \\
\text { - Desenvolvimento de novas vacinas com } \\
\text { base na prospecção do quadro } \\
\text { epidemiológico nacional }\end{array}$ & $\begin{array}{l}\text { - Soldagem das compras do PNI com } \\
\text { o desenvolvimento da capacidade de } \\
\text { inovação dos produtores } \\
\text { - Reativação do Pasni } \\
\text { - Financiamento do BNDES e Finep } \\
\text { para produtores públicos } \\
\text { - Flexibilização e modernização do } \\
\text { modelo de gestão dos produtores } \\
\text { públicos } \\
\text { - Consolidação das estruturas de P\&D } \\
\text { da Fiocruz e do Butantan (ponte com } \\
\text { o potencial científico) } \\
\text { - Eliminação dás restriçōes legais } \\
\text { para as exportaçōes dos produtores } \\
\text { públicos }\end{array}$ \\
\hline
\end{tabular}


Quadro 5 - Complexo industrial da saúde: fatores e políticas de competitividade (continuaçăo)

\begin{tabular}{|c|c|c|c|c|}
\hline Segmentos & $\begin{array}{l}\text { Fatores críticos de } \\
\text { competitividade }\end{array}$ & $\begin{array}{l}\text { Fontes de vantagens } \\
\text { competitivas no Brasil }\end{array}$ & $\begin{array}{l}\text { Nichos tecnológicos e de } \\
\text { mercado }\end{array}$ & $\begin{array}{l}\text { Principais políticas de } \\
\text { competitividade }\end{array}$ \\
\hline $\begin{array}{l}\text { Reagentes para } \\
\text { diagnóstico }\end{array}$ & $\begin{array}{l}\text { - Potencial de inovação em } \\
\text { biotecnologia e química } \\
\text { - Articulação entre empresas de } \\
\text { tecnologia e instituiçōes } \\
\text { acadêmicas } \\
\text { - Entrada nos produtos de maior } \\
\text { valor agregado } \\
\text { - Estratégias de mercado junto } \\
\text { aos laboratórios de análise }\end{array}$ & $\begin{array}{l}\text { - Dimensão do mercado nacional } \\
\text { - Atuação do Estado no controle do } \\
\text { sangue, transfusōes e atividades dos } \\
\text { laboratórios de saúde pública } \\
\text { - Base científica e tecnológica nacional }\end{array}$ & $\begin{array}{l}\text { - Reagentes para diagnóstico químicos e } \\
\text { biológicos utilizados nos programas } \\
\text { públicos } \\
\text { - Novos reagentes para diagnóstico que } \\
\text { utilizam biotecnologias modernas } \\
\text { (monoclonais, sondas de DNA, clonagem } \\
\text { e expressão etc.) }\end{array}$ & $\begin{array}{l}\text { - Articulação das compras nacionais } \\
\text { para o sistema público com o } \\
\text { desenvolvimento tecnológico dos } \\
\text { produtores } \\
\text { - Financiamento do BNDES e Finep, } \\
\text { enfatizando os produtores públicos e } \\
\text { empresas de base tecnológica } \\
\text { - Articulação das instituições } \\
\text { acadêmicas e tecnológicas com o } \\
\text { setor empresarial via parcerias, } \\
\text { parques tecnológicos e acordos de } \\
\text { cooperação }\end{array}$ \\
\hline $\begin{array}{l}\text { Fármacos e } \\
\text { medicamentos } \\
\text { (hemoderivados } \\
\text { inclusive) }\end{array}$ & $\begin{array}{l}\text { - Potencial de inovaçăo em } \\
\text { biotecnologia e química fina } \\
\text { - Porte tecnológico e de mercado } \\
\text { - Desenvolvimento e lançamento } \\
\text { permanente de novos produtos } \\
\text { no mercado }\end{array}$ & $\begin{array}{l}\text { - Dimensão do mercado nacional } \\
\text { - Presença marcante do Estado nas } \\
\text { compras em diversos programas } \\
\text { específicos } \\
\text { - Capacidade instalada em } \\
\text { medicamentos, incluindo grandes } \\
\text { empresas líderes mundiais } \\
\text { - Potencial de crescimento da } \\
\text { capacidade produtiva em fármacos } \\
\text { - Biodiversidade brasileira } \\
\text { - Base científica nacional }\end{array}$ & $\begin{array}{l}\text { - Drogas para doenças negligenciadas } \\
\text { - Fitomedicamentos } \\
\text { - Hemoderivados } \\
\text { - Biofármacos } \\
\text { - Produtos da Rename } \\
\text { - Genéricos }\end{array}$ & 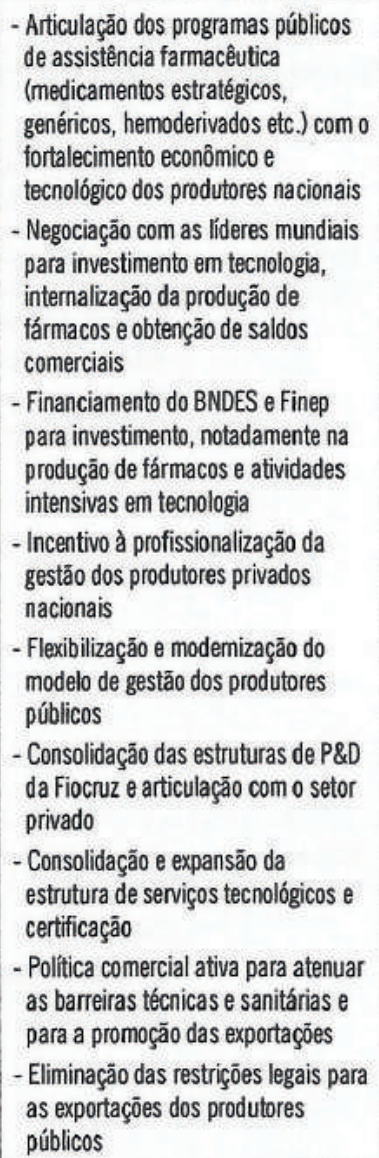 \\
\hline
\end{tabular}

Em síntese, torna-se necessário um novo padrão de intervenção e uma aproximação entre o universo da ciência, da tecnologia e da inovação e o universo da política social. Para tanto, é necessário pensar o complexo industrial da saúde de forma integrada, articulando a prestação de serviços de saúde à população e a competitividade das indústrias fornecedoras de produtos e de inovações. O vínculo da política industrial e tecnológica com a política social em saúde se apresenta, assim, como uma oportunidade para o desenvolvimento do 
país em paradigmas de elevado dinamismo, favorecendo a redução da vulnerabilidade tanto externa quanto da política social, uma vez que esta se mostra fortemente dependente das condições de oferta dos produtos das indústrias da saúde. Mesmo considerando as tensôes inerentes entre os objetivos da política social de saúde e da política industrial e tecnológica, acredita-se que há um espaço único para a promoção da articulação entre ambas, com a ação social do Estado convertendo-se, simultaneamente, numa alavanca de competitividade e de bem-estar.

\section{REFERÊNCIAS BIBLIOGRÁFICAS}

ALBUQUERQUE, E. \& CASSIOLATO, J. As Especificidades do Sistema de Inovação do Setor Saúde: uma resenh a da literatura como introdução a uma discussão sobre o caso brasileiro. Estudos Fesbe 1. São Paulo: USP, 2000.

BRAGA, J. C. S. \& SILVA, P. L B. S. A mercantilização admissível e as políticas públicas inadiáveis: estrutura e dinâmica do setor saúde no Brasil. In: NEGRI, B. \& GIOVANNI, G. (Orgs.) Brasil: radiografia da saúde. Campinas: Instituto de Economia/Unicamp, 2001.

BRASIL. Ministério da Ciência e Tecnologia (MCT). Livro Verde. Documento-base da Conferência de Ciência, Tecnologia e Inovação. Brasília, setembro 2001.

BRASIL. Ministério da Ciência e Tecnologia (MCT). Programa de Biotecnologia e Recursos Genéticos. Brasília, 2002.

CORDEIRO, H. A Indústria de Saúde no Brasil. Rio de Janeiro: Graal, 1980.

ERBER. F. S. Desenvolvimento industrial e tecnológico na década de 90: uma nova política para um novo padrão de desenvolvimento. Ensaios FEE, 13(1): 9-42, 1992.

FIOCRUZ. Conferência Nacional de Ciência, Tecnologia e Inovação: proposiçōes da Fiocruz para a área da saúde. Elaboração de C. A. G. Gadelha e coordenação de E. Sarno e N. R. Costa. Rio de Janeiro, 2001. (Mimeo.)

FURTADO, A. T. \& SOUZA, J. H. J. Evolução do setor de insumos e equipamentos médicohospitalares, laboratoriais e odontológicos no Brasil: a década de 1990. In: NEGRI, B. \& GIOVANNI, G. (Orgs.) Brasil: radiografia da saúde. Campinas: Instituto de Economia/Unicamp, 2001.

GADELHA, C. A. G. Biotecnologia em saúde: um estudo da mudança tecnológica na indústria farmacêutica e das perspectivas de seu desenvolvimento no Brasil, 1990. Dissertação de Mestrado, Campinas: Instituto de Economia, Universidade Estadual de Campinas.

GADELHA, C. A. G. Vaccine research, development and production in Brazil. COHRED: Lessons in Research to Action and Policy. Document 10. Genebra: COHRED, 2000.

GADELHA, C. A. G. Complexo da Saúde. Relatório de Pesquisa desenvolvido para o projeto Estudo de Competitividade por Cadeias Integradas, sob a coordenação de 
L. G. Coutinho, M. F. Laplane, D. Kupfer, D. e E. Farina. Núcleo de Economia Industrial e da Tecnologia do Instituto de Economia, convênio Fecamp/MDIC/MCT/Finep, 2002.

GADELHA, C. A. G. O complexo industrial da saúde e a necessidade de um enfoque dinâmico na economia da saúde. Ciência e Saúde Coletiva, 2(8): 521-535, 2003.

GADELHA, C. A. G. \& AZEVEDO BRITO, N. Inovação em vacinas no Brasil: experiência recente e constrangimentos estruturais. História, Ciência e Saúde, 2(10): 697, 2003.

GADELHA, C. A. G. \& TEMPORÃO, J. G. A Indústria de Vacinas no Brasil: desafiose perspectivas. Rio de Janeiro: BNDES, 1999.

GELIJNS, A. C. \& ROSEMBERG, N. The changing nature of medical technology development. In: ROSEMBERG, N.; GELIJNS, A. C \& DAWKINS, H. (Eds.) Sources of Medical Technology: universities and industry. Washington, DC: National Academy Press, 1995.

ROSEMBERG, N. \& NELSON, R. R. American university and technical advance in industry. Research Policy, 23: 323-348, 1994.

TEMPORÃO, J. G. Complexo Industrial da Saúde: público e privado na produção e consumo de vacinas no Brasil, 2002. Tese de Doutorado, Rio de Janeiro: Instituto de Medicina Social (IMS)/Uerj.

ZANOW, A.; DINIZ, A. \& FERNANDES, R. Introdução à análise de patentes brasileiras na área da saúde. In: ALBUQUERQUE, E. M. \& CASSIOLATO, J. E. (Orgs.) As Especificidades do Sistema de Inovação no Setor Saúde: uma resenha da literatura como introdução a uma discussão sobre o caso brasileiro. Estudos Fesbe 1. Belo Horizonte: Fesbe, 2000. 


\section{Regulação Econômica e Financiamento do Complexo Produtivo da Saúde:}

\section{o papel do Ministério da Saúde}

Edmundo Gallo

Ivan Coelho

\section{INTRODUÇÄO}

$\mathrm{Na}$ formulação de políticas de saúde, deve-se ressaltar a importância de modificar o enfoque tradicional sobre os investimentos na área. Estes têm sido vistos como gastos improdutivos, justificados exclusivamente por seu caráter redistributivo, de justiça social.

Tal abordagem é limitada por, pelo menos, dois motivos. Primeiro, focaliza-se estrito senso a dimensão da atenção - especialmente assistencial -, espaço em que se realizam os valores produzidos em cadeias produtivas de insumos, as quais deixam de ser consideradas como objeto da política de investimentos setorial. Segundo, desconsidera-se a capacidade de geração de emprego, renda e produção em um setor extremamente dinâmico do ponto de vista econômico.

Como resultante, as políticas têm-se voltado, majoritariamente, para o investimento na assistência, mediante a construção de unidades, aquisição de equipamentos e expansão da oferta de serviços, sem buscar a articulação destas açōes com o fortalecimento das cadeias produtivas de insumos. Em decorrência, as políticas de ciência e tecnologia, industrial, comercial, de formação e regulação da força de trabalho deixam de ser objeto de políticas articuladas, gerando ineficiência na alocação de recursos governamentais e baixa capacidade indutora do Estado (Gadelha, Quental \& Fialho, 2003).

Além disso, a caracterização desses recursos como investimentos 'não produtivos', em contexto de restrições orçamentárias, sujeita-os às contingências necessárias ao 


\footnotetext{
' Nosso sistema de saúde é extremamente complexo. Dos 5.560 municípios, $73 \%$ têm menos de 20 mil habitantes e um Índice de Desenvolvimento Humano Municipal (IDHM) que varia de 0,467 (Manari-PE) a 0,919 (São Caetano do Sul-SP), refletindo uma diferenciação regional imensa e reforçando a necessidade de priorizaçăo da eqüidade. Grosso modo, podemos afirmar que cerca de 600 municipios encontram-se em Gestăo Plena do Sistemae 5 mil, em Gestāo Plena da Atenç̧ăo Básica. Além disso, 22 estados estão habilitados em gestão plena, intensificando a heterogeneidade e a complexidade dos problemas, que precisam ser enfrentados para a construçāo de uma politica de investimentos.
}

ajuste fiscal. Em contrapartida, essa desarticulação das ações ocasiona sérios impactos na gestão da política de saúde, pelo comprometimento da sustentabilidade dos investimentos, da capacidade de operação e manutenção de equipamentos, da insuficiência de tetos financeiros para sua utilização e, não raro, da dissociação das necessidades de saúde locais (Brasil, 2005b).

A conseqüência prática dessa ótica tem sido, até o presente, a utilização de recursos públicos em níveis substanciais - apenas o Projeto de Reforço à Reorganização do Sistema Único de Saúde (Reforsus) investiu cerca de US $\$ 650$ milhōes, nos últimos sete anos. Porém, isso não foi capaz de produzir desenvolvimento local, configurando uma herança organizacional de baixa sustentabilidade.

O Ministério da Saúde (MS) tem como perspectiva qualificar e humanizar a atenção, priorizando ações que consolidem os princípios da universalidade, eqüidade e integralidade (Brasil, 2002c). Diante da complexidade tanto do quadro contextual de demandas ${ }^{1}$ quanto dos grandes desafios assumidos, essa tarefa exige uma capacidade de produção de políticas concertadas, integradas e com elevado grau de eficiência e eficácia (Brasil, 2002b).

Nesse sentido, uma questão central é pensar a saúde não apenas numa dimensão restrita, que considere somente a assistência, a atenção ou as necessidades de saúde. Deve-se, sim, abordá-la em toda sua complexidade, em uma dimensão muito mais ampla, que abrange um conjunto de setores da economia e das políticas institucionais, que têm impactos na prođução da saúde.

Desse modo, quando se fala da importância de uma política de regulação econômica, é necessário relevar o papel que desempenham os investimentos e as compras governamentais, uma vez que ambos são fatores fundamentais para as políticas que propiciem a inclusão social e o desenvolvimento humano e de setores econômicos estratégicos. É o que passaremos a tratar a seguir.

\section{INVESTIMENTOS COMO POLITIICA DE REGULAC̣ÃO}

O sucesso e a sustentabilidade de uma política de qualificação da atenção à saúde só serão plenamente alcançados se estiverem embasados no desenvolvimento integrado do complexo produtivo da saúde, que é composto por cinco grandes componentes: de ciência e tecnologia (C\&T), industrial, de força de trabalho, de serviços e comercial. Esses segmentos estabelecem um conjunto de relaçōes entre si, algumas mais ou menos marcantes, mas todas interdependentes, conforme mostra a Figura 1.

O componente de serviços, por meio da assistência, constitui-se no locus de realização dos valores de troca produzidos nas outras esferas, que se mostram, portanto, dependentes dos investimentos nele realizados.

Por outro lado, embora algumas ações nos segmentos responsáveis pelos insumos não apresentem grande visibilidade, por se tratarem de ações-meio, elas se constituem efetivamente em elementos indutores de impacto nas ações finalísticas (Gráfico 1). Em outros termos, mudanças no enfoque da política de investimentos, mesmo que eventualmente sem grande visibilidade, poderão impactar diretamente o processo de qualificação do sistema de saúde e de melhoria da qualidade đa atenção ao usuário. 
Figura 1 - Fluxo do complexo produtivo da saúde

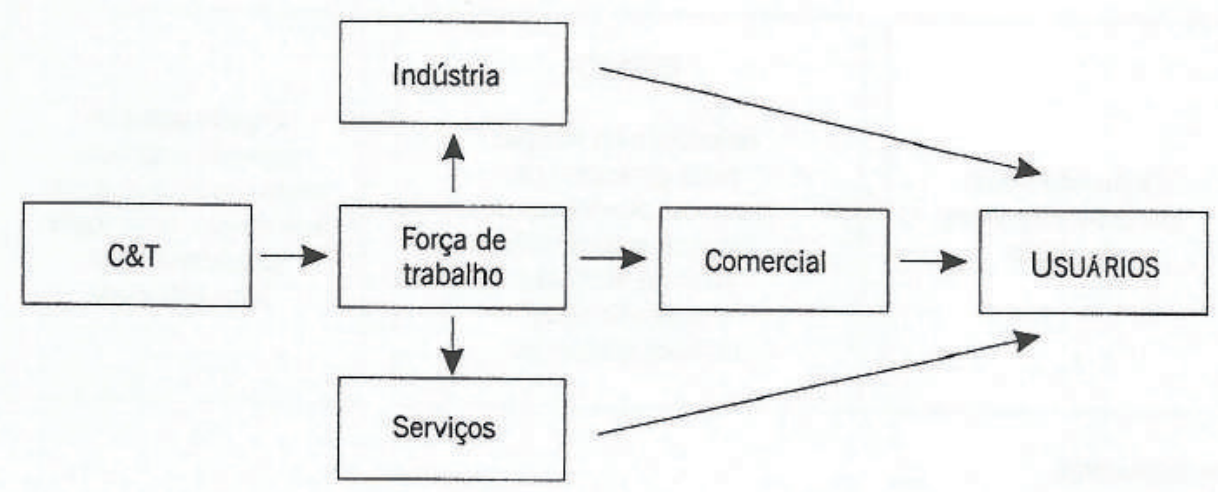

Fonte: Gadelha (2003).

Gráfico 1 - Comércio exterior de produtos farmacêuticos - 1997-2002

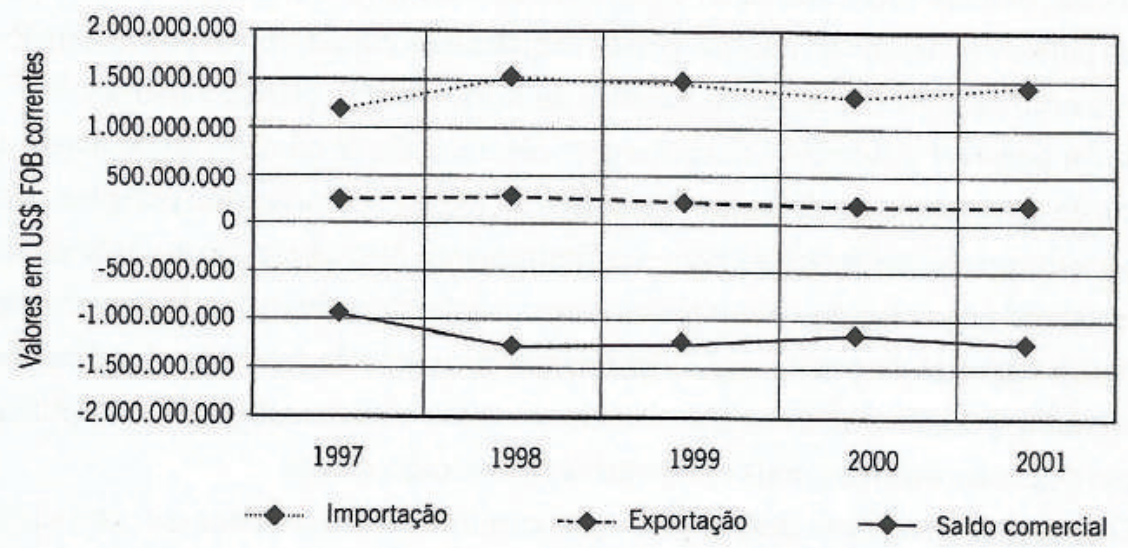

Fonte: Gadelha (2002).

Além disso, o investimento em outros segmentos - seja diretamente, como na modernização de plantas para certificação de vacinas, seja indiretamente, na articulação com outras políticas governamentais, como a de integração regional (desenvolvimento de arranjos produtivos locais e de áreas degradadas e de fronteiras) e a de desenvolvimento da indústria e comércio (implantação de plantas industriais, ampliação de capacidade produtiva) - contribui para a retomada da competitividade do segmento industrial nacional. Amplia-se, assim, a capacidade de inovação e reposiciona-se positivamente o segmento nos mercados interno e externo, com conseqüências desejáveis, inclusive quanto à redução da dependência tecnológica.

É papel do Estado atuar, também, na redução dos desequilíbrios entre a oferta e a demanda dos insumos e recursos, estimulando a interlocução entre os diversos segmentos do complexo produtivo e aproximando as dimensões da formação, da força de trabatho, da pesquisa e desenvolvimento (Figura 2). Dessa forma, contribui decisivamente para a integração e racionalização dos investimentos no setor, explorando toda sua potencialidade social e econômica para geração de bem-estar e redução do hiato tecnológico que nos separa dos países desenvolvidos. 
Figura 2 - Função regulatória do Estado

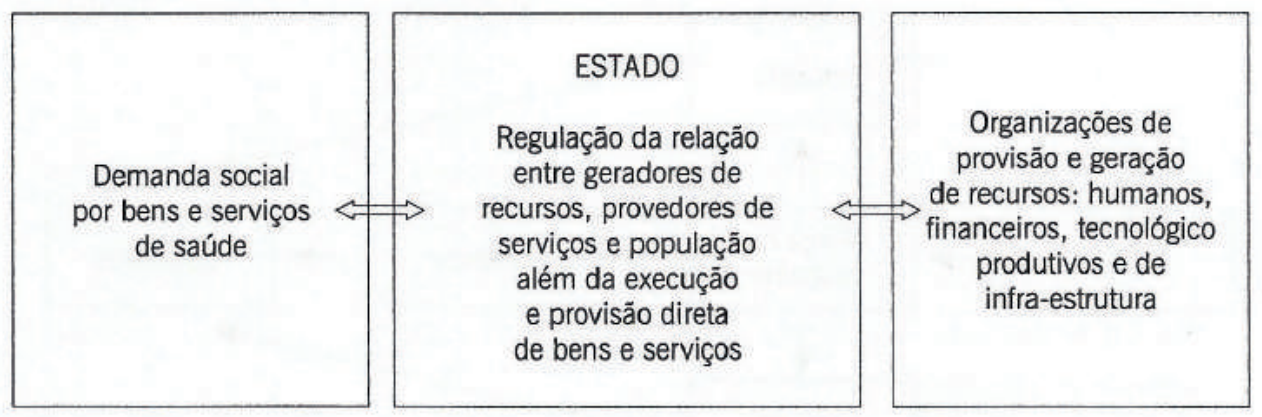

Fonte: Gadelha (2003).

Ampliando o escopo dessa intervenção, não podemos pensar em investimento exclusivamente na ótica interna do país. É preciso pensá-lo no contex to de integração com o Mercosul, demais nações da América do Sul e de interação com outros atores, como os demais países em desenvolvimento, países centrais e os blocos comerciais (União Européia e Acordo de Livre Comércio da América do Norte - Nafta, principalmente).

Se for possível vislumbrar uma imagem-objetivo, ela se dá na perspectiva de uma integração dos complexos de saúde dos países da região, identificando complementaridades e vantagens comparativas para o enfrentamento da questão da provisão de serviços, assistência e promoção, atuando como mecanismo de estímulo ao desenvolvimento econômico regional. Se por um lado isso implica abrir mão de determinadas dimensôes da soberania, por outro se constitui em elemento para a sustentabilidade da política de atenção e de uma inserção mais competitiva no mercado global.

Essas ações ajudarão a definir para onde caminharemos com nossas potencialidades e vocações, complementadas pela identificação de parceiros na região, como os países do Mercosul. Do ponto de vista global, serão traçadas estratégias para a construção de parcerias com países e/ou blocos que têm vocação para determinados segmentos nos quais não há necessidade ou justificativa, a médio e longo prazos, para o investimento nacional (Opas, 2004).

Localismos na alocação dos recursos para investimentos fixos

Outra questão fundamental a ser abordada está na permanência de critérios localistas, fragmentados, de distribuição dos recursos para a realização de investimentos fixos.

As emendas parlamentares representam a grande massa de recursos governamentais investidos na saúde, mecanismo pelo qual, não raro, a barganha política é mais relevante que a racionalidade dos critérios técnicos. A sua desarticulação como política de investimentos para o SUS apresenta um impacto extremamente significativo: em 2003 alcançaram $\mathrm{R} \$ 900$ milhões, enquanto os demais subprojetos totalizaram apenas R\$ 100 milhões.

O Executivo ainda não teve capacidade de discutir com o parlamento a necessária articulaçăo desses investimentos às políticas de saúde. Em 2003, por exemplo, foi apre- 
sentada quase uma centena de emendas para a aquisição de unidades móveis, que poderiam, em tese, ser apresentadas pelos mesmos parlamentares, porém focalizadas no plano de reorientação da urgência e emergência pré-hospitalar.

Sendo assim, a expectativa é avançar no sentido de fazer com que as emendas parlamentares estejam alinhadas às necessidades e prioridades dos municípios e estados, consubstanciadas nos planos de desenvolvimento regional (PDRs), planos diretores de investimento (PDIs) e prioridades das políticas nacionais de saúde (Brasil, 2002b; 2002c). Entretanto, isso não deve deixar de atender às expectativas dos parlamentares e dos segmentos populacionais que representam.

É necessário, portanto, desenvolver um conjunto de parâmetros importantes, visando a favorecer a adequação e sustentabilidade desses investimentos, evitando-se a repetição de ocorrências freqüentemente observadas, como a desconsideração da capacidade técnico-financeira dos beneficiários, que resulta em ociosidade da capacidade instalada e/ou incapacidade de custeio por ausência de teto financeiro nos estados e municípios, baixa capacidade de manutenção e operação dos equipamentos (Brasil, 2005a; Viacava \& Bahia, 2002).

\section{COMPRAS GOVERNAMENTAIS COMO MECANISMO DE REGULAC̣ÃO}

O debate deste tema no Brasil é, até o presente, bastante deficiente, apesar de sua importância crescente como fator de alavancagem do desenvolvimento local ou regional nos contextos nacional e internacional. É igualmente importante pela necessidade de se definirem, entre as nações, as práticas, normas e procedimentos comuns, essenciais à formação e consolidação dos consensos comerciais.

Tradicionalmente, o principal objetivo das políticas de compras governamentais está voltado à melhoria das condições de aquisiçăo de bens e serviços necessários ao funcionamento dos órgãos dos Estados. Ao longo dos anos, contudo, a utilização do poder de compra destes vem sendo parcialmente redirecionada com a finalidade de servir também de instrumento para o desenvolvimento de setores considerados estratégicos da economia ou de segmentos, em geral com relevância social.

Embora variem significativamente entre os países, pode-se afirmar que os valores envolvidos giram em torno de $12 \%$ do Produto Interno Bruto, o que, por si mesmo, já é motivo suficiente para definir sua inclusão na agenđa estratégica dos governos, especialmente quando se trata da formação de blocos econômicos.

O governo americano, por exemplo, dispōe de mecanismos legais para utilizar seu poder de compra, como o Buy American Act, o Balance of Payments Program e o Small Business Act, que se coadunam para alcançar amplos objetivos de políticas que envolvem aspectos militares, sociais, de desenvolvimento local, entre outros. Estes mecanismos determinam, essencialmente, que o setor público - órgãos e empresas - dê preferência à produção doméstica em suas compras.

Por sua vez, os países da União Européia, embora utilizem diretivas que, em tese, permitirão maior abertura para a participação internacional nas compras governamen- 
${ }^{2}$ Mesmo no âmbito da OMC, que confere tratamento especial à questão, existe abertura para situaçōes especiais que permitiriam uma politica de compras governamentais que fomentasse o setor saúde nacional. tais, na prática, apresentam um nível baixo de demanda atendida por fornecedores estrangeiros. Nesses países, mesmo que os acordos internacionais de comércio patrocinados pela Organização Mundial do Comércio (OMC) apontem, regra geral, no sentido de não se privilegiar a nacionalidade das empresas como fator de diferenciação nos processos de compra, ${ }^{2}$ a utilização desse poder como mecanismo indutor de políticas vem sendo pouco abalada. Acredita-se que esse fato pode estar associado a dispositivos licitatórios, dificuldades de acesso às informações e qualificação para a participação dos concorrentes externos, configurando um quadro de posicionamentos pragmáticos em defesa dos interesses locais.

Ao mesmo tempo, outros organismos internacionais, como o Banco Mundial (Bird) e o Banco Interamericano de Desenvolvimento (BID), reconhecem a legitimidade do uso do poder de compra do Estado para a atribuição de preferência nas compras governamentais à produção doméstica, especialmente quando se refira a parques produtivos recentemente implantados (World Bank, 2001).

O Brasil tem se utilizado muito pouco desse poder. A normatização que regula os processos de compra objetiva apenas atingir as melhores condições para a aquisição de bens e serviços, atendendo aos princípios constitucionais da economicidade, da impessoalidade e da publicidade, porém desconsiderando outras finalidades típicas da ação do Estado.

Como nossa legislação foi concebida em um momento de consolidação da democracia no país, objetivava, principalmente, maior transparência no processo de contratação e o resgate da credibilidade, inclusive junto ao mercado fornecedor. Todavia, freqüentemente sua aplicação tem se constituído, para o gestor público, em entrave à agilidade demandada pela sociedade ao funcionamento do aparelho estatal. A Lei de Licitações não apenas restringe efetivamente a capacidade de gestão, como impede qualquer poder discricionário ao gestor, até mesmo quanto à definição de critérios que restrinjam a competição ou estabeleçam preferências conforme a origem dos bens ou a nacionalidade, sede ou domicílio dos potenciais fornecedores.

A propósito, cabe salientar que a decisão política de utilizar o poder de compra do Estado como parte de uma política de desenvolvimento, estimulando a produção de determinados bens ou serviços, envolve, geralmente, a concordância com o pagamento de algum sobrepreço em favor do desenvolvimento da produção nacional, especialmente quando se trata de mercados nos quais a presença de monopólio ou oligopólios é dominante (Rondinelli, James \& Ronald, 1989).

A nossa legislação pressupõe um mercado de concorrência perfeita, em que se obtém, ao final de um certame, a proposta mais vantajosa para a administração. $\mathrm{Na}$ realidade, não é isto que se observa. A concorrência perfeita é um parâmetro normativo: as falhas de mercado são elementos concretos que conţam na sua constituição. Na saúde, especificamente, essas falhas são de grande magnitude, tendo em vista que o peso representado pelas atividades de pesquisa e inovação cria barreiras de entrada, gerando assimetrias de informação, baixa elasticidade preço-demanda e oligopólios. 
Voltar-se exclusivamente às melhores condições de aquisição pode, portanto, significar antagonismo às políticas de desenvolvimento industrial e tecnológico, que seriam fortalecidas com a compra de determinados insumos ou equipamentos, envolvendo inovações tecnológicas ou metodológicas (Sen, 1999).

Na saúde, em particular, o governo depara com uma dificuldade adicional. Se por um lado o Sistema Único de Saúde (SUS), ao constituir-se de forma descentralizada, permitiu enormes avanços, por outro promoveu uma redistribuição dos recursos para a aquisição de insumos, bens e serviços entre os níveis subnacionais, dificultando a implementação de uma política de compras governamentais que influencie a formação de preços em um setor econômico fortemente oligopolizado (Gráfico 2). Apesar disso, o SUS é um sistema que tem uma capacidade de indução gigantesca, ocupando posição 'semimonopsônica' em alguns nichos, e um poder de introdução de novas tecnologias pela rede assistencial-própria, conveniada e contratada - expressivo.

Gráfico 2 - Participação do SUS em serviços, profissionais e equipamentos - 2000

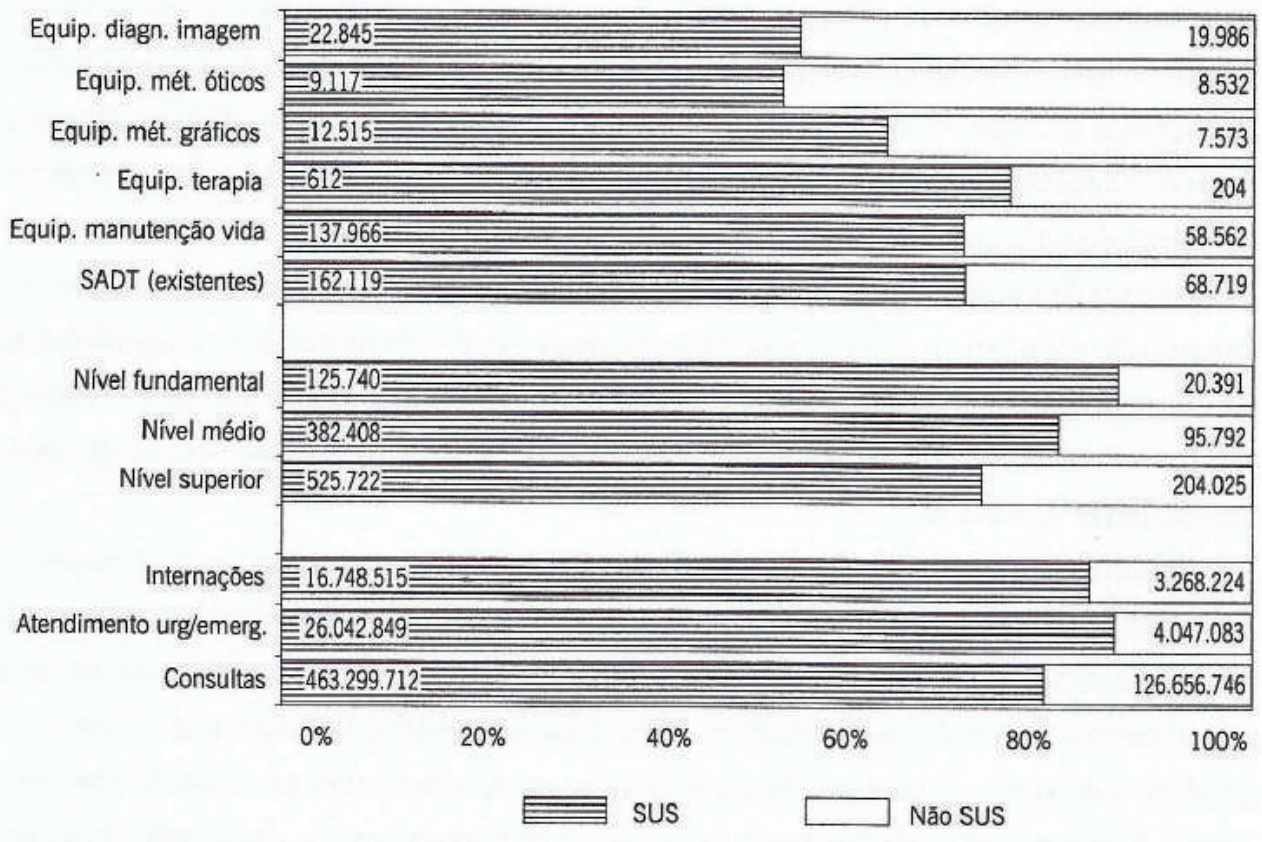

Fonte: Brasil (2002b).

As compras governamentais de medicamentos, por exemplo, alcançam a cifra de $\mathrm{R} \$ 6$ bilhões de reais/ano, em um mercado protegido por patentes e marcadamente conformado pela presença de oligopólios (Brasil, 2002a). A sinalização de políticas de longo prazo apontaria para cenários mais estáveis, contribuindo para a redução das incertezas desse mercado e incentivando o investimento em parques produtivos que demandam valores elevados e de perspectivas de retorno a longo prazo.

A definição de uma política nacional de compras governamentais que contribua para o fortalecimento do complexo produtivo, desenvolvendo equipamentos e insumos 
de qualidade e reduzindo a dependência externa do país, passa pela revisão da Lei de Licitações e pela proteção de indústrias estratégicas nascentes (equipamentos, fármacos, imunobiológicos e hemoderivados) e de pequeno e médio portes.

Torna-se necessária, também, a formação de conglomerados de compradores, integrando os procedimentos de compra entre as três esferas do governo e entidades a elas ligadas, reduzindo os efeitos indesejados da descentralização. Operando de forma agregada, obter-se-ia grande influência nas decisões empresariais de formação de preços, conseqüência do porte do conglomerado e da redução de incertezas decorrente da estabilidade de compras para alguns segmentos estratégicos (Afonso \& Lobo, 1996).

\section{CONCLUSÕES}

Independentemente das motivações centrais de realização dos princípios do SUS (universalidade, eqüidade, integralidade e controle social), para a promoção de uma saúde mais justa dentro do quadro mais geral das políticas sociais (Brasil, 2003), é fundamental que nosso olhar se amplie para outras dimensões. Se incorporarmos à lógica do investimento em saúde o desenvolvimento integrado do complexo produtivo, poderemos produzir, a médio e longo prazo, uma política que efetivamente estimule e induza o desenvolvimento socioeconômico sustentável, contribuindo para o reposicionamento do país no cenário internacional.

Apesar de todos os problemas, o SUS não encontra paralelo no mundo, seja por sua magnitude econômica, seja por sua complexidade e êxito em responder às necessidades de saúde da população e promover inclusão social. Acrescente-se aí o fato de o Brasil ser um país em desenvolvimento, de dimensões continentais, em contexto político de redução do papel do Estado.

o Ministério da Saúde tem se voltado tradicionalmente ao segmento de serviços e à ação dos órgãos públicos. Entretanto, fica cada vez mais clara a possibilidade e necessidade de direcionar a ação governamental para ações regulatórias mais eficientes, que extrapolem a dimensão estrita do SUS, visando ao desenvolvimento de todo o complexo produtivo da saúde. Pretendemos incorporar no escopo das políticas de saúde o investimento no setor produtivo, por meio de parcerias público-privadas, compondo uma carteira global que supere a dimensão segmentada dos investimentos. Nesse sentido, 0 portfolio de investimentos no setor deve refletir os investimentos diretos e a ação integrada das diversas agências de financiamento, em sua relação com os diversos tipos đe beneficiários, objetivando potencializar os recursos disponíveis.

Nosso país necessita redefinir marcos político-legais que refletem o papel regulador do Estado, como as compras governamentais e a política de investimentos públicos no setor, de modo a induzir o desenvolvimento da capacidade produtiva do país, contribuin-

${ }^{3}$ Agradecemos a colaboração de Adailton Amaral, assessor da DIPE/SE/MS. do decisivamente para a sustentabilidade econômica e o bem-estar da população - e tem amplas condições para isso. ${ }^{3}$ 


\section{REFERÊNCIAS BIBLIOGRÁFICAS}

AFONSO, J. R. R. \& LOBO, T. Descentralização fiscal e participação em experiências democráticas retardatárias. Planejamento e Políticas Públicas, 14:3-32, 1996.

BRASIL. Ministério da Saúde. A Saúde no Brasil: estatísticas essenciais 1990-2000. 2. ed. revista e atualizada. Brasília: Ministério da Saúde, 2002a. (Série G. Estatística e Informação para Saúde).

BRASIL. Ministério da Saúde. Regionalização da Assistência à Saúde: aprofundando a descentralizaçāo com equidade no acesso: Norma Operacional da Assistência d̀ Saúde-Noas-SUS 01/02. Portaria MS/GM 373, de 27 de fevereiro de 2002, e regulamentação complementar. Brasília: Ministério da Saúde, 2002b. (Série A. Normas e Manuais Técnicos).

BRASIL. Ministério da Saúde. Reduzindo as Desigualdades e Ampliando o Acesso à Assistência à Saúde no Brasil. Brasília: Ministério da Saúde, 2002c. (Série G. Estatística e Informação para Saúde).

BRASIL. Ministério da Saúde. Departamento de Informação e Informática do Sistema Único de Saúde-Datasus. Pesquisa Assistência Médico-Sanitária (AMS). Disponível em: http://tabnet.datasus.gov.br/cgi/ams/amsopcao.htm, 2002d.

BRASIL. Presidência da República. Mensagem ao Congresso Nacional. Disponível em: http://www.presidencia.gov.br/publi_04/mens2003.htm, 2003.

BRASIL. Ministério da Saúde. Critérios para Análise de Investimentos em Saúde. Brasília: Ministério da Saúde, 2005a. (Série B. Textos Básicos de Saúde).

BRASIL. Ministério da Saúde. Diretrizes para Investimentos em Saúde. Brasília: Ministério da Saúde, 2005b. (Série B. Textos Básicos de Saúde).

GADELHA, C. A. G. Estudo de Competitividade por Cadeias Integradas no Brasil: impactos das zonas de livre comércio. Cadeia: complexo da saúde. Nota Técnica Final. Disponível em: <http://www.desenvolvimento.gov.br/arquivo/sdp/proAcao/forCompetitividade/impZonLivComercio/52saudeCompleto.pdf $>, 2002$.

GADELHA, C. A. G. O complexo industrial da saúde e a necessidade de um enfoque dinâmico na economia da saúde. Ciência \& Saúde Coletiva, 8(2):52 1-535, 2003.

GADELHA, C. A. G.; QUENTAL, C. \& FIALHO, B. C. Saúde e inovação: uma abordagem sistêmica das indústrias da saúde. Cadernos de Saúde Pública, 19(1):47-59, 2003.

OPAS (ORGANIZAÇĀO PAN-AMERICANA DA SAÚDE). Sistema Integrado de Saúde do Mercosul: SIS-Mercosul: uma agenda para integração. Brasília: Opas, 2004. (Série Técnica Projeto de Desenvolvimento de Sistemas e Serviços de Saúde).

RONDINELLI, D. A.; JAMES, S. M. \& RONALD, W. J. Analysing decentralization policies in . developing countries: a political-economy framework. Development and Change, 20(1):57-87, 1989.

SEN, A. Development as Freedom. Nova York: Alfred A. Knopf, 1999. 
VACINAS, SOROS E IMUNIZAÇÕES NO BRASIL

VIACAVA, F. \& BAHIA, L. Oferta de Serviços de Saúde: uma análise da pesquisa Assistência Médico-Sanitária de 1999. Brasília: Ipea, 2002. (Texto para Discussão, 915, p.1-48).

WORLD BANK. Decentralization and governance: does decentralization improve public service delivery? PREM Notes, 55, June, 2001. 


\section{Programa Nacional de Imunizações (PNI):}

\section{história, avaliação e perspectivas}

José Gomes Temporāo

Márcia Vieira Leite Nascimento

Maria de Lourdes de Sousa Maia

\section{BRASIL: ALGUMAS CONSIDERAÇÕES}

O desenvolvimento do Programa Nacional de Imunizações do Brasil (PNI) ao longo da história acresce-se de méritos quando entendidas as diversidades geográficas, políticas, demográficas e culturais do país, palco que conquistou e onde se estabeleceu, favorecendo a prevenção de doenças infecto-contagiosas graves.

Localizado na parte oriental da América do Sul, o Brasil possui uma vasta área de 8,5 milhões de $\mathrm{Km}^{2}$; limita-se ao leste com o oceano Atlântico, numa extensão costeira de 7,3 mil Km, e ao norte, oeste e sul com 10 países em 15,7 mil Km de divisas, a exceção do Chile e do Equador. Com a mais rica e extensa rede hidrográfica do globo, disposta em sete grandes bacias, e a maior biodiversidade vegetal do planeta, o país possui lagos, lagunas e rios caudalosos, matas, florestas, savanas, caatinga, campanha, pantanal, restingas e manguezais. É cortado pela Linha do Equador e pelo Trópico de Capricórnio, apresentando ampla variedade pluviométrica e climática em toda sua extensão, zonas de clima equatorial, tropical, subtropical, semi-árido e temperado, $20^{\circ} \mathrm{C}$ de temperatura média e baixa amplitude térmica. Conforme a localização, a temperatura pode variar de alguns graus negativos, durante o inverno, ao calor de $40^{\circ} \mathrm{C}$ no verão. Trata-se de uma República Federativa composta de 26 estados (com 5.561 municípios) e um Distrito Federal, distribuídos em cinco macrorregiōes: Norte, Nordeste, Sudeste, Sul e Centro-oeste. A Uniāo e os governos estaduais têm competências próprias em todas as matérias. 
A rede viária apresenta áreas com boa infra-estrutura, acesso facilitado e rápido em qualquer estação do ano e outras de acesso bastante restrito, a exemplo de alguns municípios interioranos, principalmente nas regiões Norte, Nordeste e Centro-oeste. Também as épocas de cheias e de secas influenciam na opção pelo meio de transporte. Há estradas vicinais, mal conservadas, acidentadas ou inexistentes; estradas que só estão acessíveis apenas uma época do ano; localidades cujo acesso se dá pelo ar - em aeronave de pequeno porte; pelo mar (rios e igarapés), por navegação; a pé, animal ou bicicleta.

Com uma população de 180 milhões de habitantes (IBGE, 2003), pouco mais de 17 milhốes são crianças na faixa etária de 0 a 4 anos; cerca de 15 milhões são idosos com 60 anos ou mais, grupos que demandam maiores cuidados e investimentos no campo da saúde pública. Esta população se distribui de maneira bastante heterogênea, numa densidade populacional média de $18,4 \mathrm{hab} / \mathrm{Km}^{2}$ ( $75 \%$ são residentes urbanos). A população foi composta, ao longo de cinco séculos, por indígenas nativos, brancos colonizadores portugueses e negros escravos, aos quais somaram-se, pelo fluxo imigratório principalmente, italianos, espanhóis, alemães, eslavos e japoneses. Miscigenaram-se em suas culturas, tradições, hábitos e crenças, constituindo famílias e descendentes.

Com base nos dados já apresentados, pode-se depreender que as condições sanitárias do país variam de um estado para outro. As capitais e as maiores cidades apresentam melhor infra-estrutura, enquanto que as cidades do interior ainda mostram muitas deficiências no que se refere à assistência à saúde, algumas inclusive ainda convivendo com a rotina de deslocamento de seus municípios para atendimento na rede pública. A atual Constituição, promulgada em 1988, define a responsabilidade do Estado nos cuidados com a saúde. O Sistema Único de Saúde (SUS) coordena a rede pública sanitária e normatiza as atividades privadas estabelecidas.

Setecentos e três milhōes de turistas internacionais chegaram em 2002 nos diversos países do mundo, dos quais 13 milhōes na América do Sul (WTO, 2004). O Brasil registrou aproximadamente 3,8 milhões de chegadas, principalmente nas cidades de São Paulo, Rio de Janeiro, Rio Grande do Sul e Paraná, e 3,5 milhões de saídas, com destinos diversos. Com relação ao movimento interno nacional, foram registados nos principais aeroportos 31,5 milhões de embarques aéreos e 32,6 milhões de desembarques (Embratur, 2003). A globalização intensificou os movimentos migratórios, e o Brasil oferece atrativos em vários setores.

Cálculos da WTO estimam para o mundo um bilhão de chegadas internacionais em 2010. Este fluxo contínuo entre as mais diversas regiōes do globo se constitui em um meio facilitador da disseminação de agentes infecciosos, exigindo das autoridades de saúde pública nacionais e internacionais a definição de ações efetivas de vigilância epidemiológica e medidas oportunas de prevenção e/ou controle de enfermidades, além de uma política de parcerias multinacionais, de modo a garantir a manutenção da saúde e bem-estar de todos os povos. 


\section{INICIATIVAS QUE ANTECEDEM A CRIACุÃO DO PROGRAMA DE IMUNIZAC̣ÕES DO BRASIL}

Durante os primeiros anos do século XIX, quando ainda colônia de Portugal, o Brasil realizou as primeiras tentativas de imunizar sua população. Em 1804, a vacina contra a varíola foi trazida da Europa pelo Marquês de Barbacena, em braços de negros escravos, e espalhada pela nação. Naqueles anos, a vacinação consistia na coleta de material da pústula (linfa) de um indivíduo, inoculando-se em seguida em outro. A população do país correspondia a aproximadamente 3,5 milhões de habitantes e havia um intenso fluxo migratório, principalmente de chegadas, que contribuía para a disseminação de doenças tropicais e de outros males trazidos do velho mundo (Bassanezi \& Bacellar, 2002). As enfermidades infecto-contagiosas grassavam em todos os povos. Na Europa, desde 1839, surtos de cólera dizimavam milhares de vidas. A pólio teve nas duas últimas décadas desse século os seus primeiros registros.

Os primeiros esforços que se conhece para a criação de uma ação de controle de saúde pública internacional ocorreram antes de 1851, como parte da luta contra a disseminação de doenças infecciosas. Na época, os conhecimentos eram muito incipientes, e os primeiros trabalhos não obtiveram sucesso. Em 1902, foi criada a Oficina Sanitária Internacional com sede em Washington, uma organização cujo objetivo principal era promover ações capazes de elevar a qualidade de vida dos povos das Américas. Esta oficina foi precursora da Organização Pan-Americana da Saúde (Opas).

No início do século XX, muitas vidas já haviam sido ceifadas em decorrência de epidemias incessantes em várias nações. No Brasil, a febre amarela, a peste bubônica e a varíola se constituíam nos problemas mais sérios de saúde pública, com altos índices de mortalidade e muito sofrimento. As epidemias na capital, Rio de Janeiro, motivaram uma campanha de saneamento coordenada por Oswaldo Cruz, com apoio do Instituto de Manguinhos, e o estabelecimento, por decreto federal, da obrigatoriedade da vacina contra a varíola, que fora imediatamente suspenso em vista de uma séria reação popular, a conhecida "Revolta da Vacina" (1904). Mas, temerosa com o quadro crítico que assolava o país, a população não tardou em procurar os postos de vacinação. Era o princípio da aceitabilidade pública ao produto vacinal.

Naquele início de século, a especificidade dos soros antipeçonhentos estava sendo mundialmente reconhecida, graças aos esforços de Vital Brazil, e a saúde pública brasileira contava com a garra de grandes parceiros que se estruturavam e se faziam decisivos para o êxito das ações nacionais de imunizações: o Instituto Soroterápico de Manguinhos/RJ (mais tarde Instituto Oswaldo Cruz); o Laboratório de Produção de Soro Antipestoso (mais tarde Instituto Serumtherápico e depois Instituto Butantan/SP); o Laboratório Farmacêutico do Estado do Rio de Janeiro (mais tarde Instituto Vital Brazil/RJ); a Fundação Ataulpho de Paiva/RJ; o Instituto Experimental do Norte (mais tarde Instituto Evandro Chagas/PA) e o Instituto de Tecnologia do Paraná (Tecpar).

No decorrer do século XX, novas vacinas foram sendo desenvolvidas, tendo por base os primeiros conhecimentos obtidos pelos estudos do Dr. Edward Jenner com a varíola e 
as descobertas de Pasteur. Durante os anos 20, as vacinas contra difteria, tétano e coqueluche e a BCG foram gradualmente sendo introduzidas no país e ao final dos anos 30 , a vacina contra a febre amarela.

Na primeira metade do século $\mathrm{XX}$, o Brasil já produzia a a $\mathrm{BCG}$, a vacina contra a varíola, contra febre amarela e soros heterólogos; acompanhava e contribuía com os avanços da ciência, enquanto proporcionava à sua população desfrutar dos novos produtos que surgiam no mercado mundial, muito embora suas baixíssimas coberturas permitissem que os surtos continuassem a devastar comunidades ainda durante décadas.

Os primeiros surtos de poliomielite que se tem notícia no país foram relatados nas duas primeiras décadas desse século, no Rio de Janeiro e em São Paulo. Nas décadas seguintes, outros surtos de pólio ocorreram, mas em 1953 uma grande epidemia causou pânico na população carioca pelo caráter paralisante da enfermidade. Naqueles anos, a ciência conquistava os primeiros conhecimentos que levariam ao desenvolvimento de uma vacina (Campos, Nascimento \& Maranhão, 2003). Com a febre amarela, o melhor entendimento da forma silvestre da doença como a mais comum possibilitou a definição de novas estratégias de imunizaçōes e vigilância epidemiológica e entomológica, que proporcionaram em 1942 a extinção da forma urbana e o controle da forma silvestre.

O acontecimento da II Grande Guerra Mundial (1939-1945) trouxe uma explosão no desenvolvimento tecnológico e agilizou a evolução histórica das vacinaçōes. A partir de 1948, a saúde pública mundial passa a contar com uma grande parceira, estava criada a Organização Mundial da Saúde (OMS), com a missão institucional de levar a todos os povos o mais alto nível de saúde e coordenar a luta internacional de combate a doenças passíveis de disseminação. No ano seguinte, a Organização Sanitária Pan-Americana passou a ser considerada oficina regional da OMS; anos mais tarde (1958), recebeu a denominação de Organização Pan-Americana da Saúde (Opas). Com o surgimento da OMS, a varíola logo ganhou um enfoque especial, em virtude dos conhecimentos técnico-científicos conquistados até então e do reconhecimento mundial da sua importância.

Em meio às primeiras tentativas de utilização global da vacina antivariólica, já na segunda metade dos anos 50, experiências na África e Ásia mostravam a importância da conservação adequada do produto vacinal, mediante a possibilidade de perda de potência. Iniciavam as primeiras preocupações com a manipulação e o estoque de vacinas, para a garantia da obtenção dos resultados epidemiológicos almejados.

Em 1955, um grande ensaio clínico conclui sobre a segurança e eficácia da primeira vacina contra poliomielite, a Salk, composta por vírus inativados. Havia uma grande expectativa mundial por esta descoberta. No mesmo ano em que estava sendo disponibilizada mundialmente a vacina, o Brasil introduzia o seu uso na clínica privada, por indicação de alguns pediatras, e em vacinações de pequenas áreas, promovidas por secretarias estaduais e municipais de saúde, mais especialmente no Rio de Janeiro e em São Paulo. As primeiras tentativas de intensificação da vacina ocorreram em 1960, motivadas por um considerável aumento do número de casos da enfermidade. 
Surgia a vacina Sabin e com ela vários fóruns no Brasil e no mundo para a eleição do produto contra a enfermidade. A Academia Médica Americana defendeu a Sabin como produto capaz de erradicar a doença. A partir de 1961, o Brasil decidiu adotar a Sabin. Com entusiasmo, realizou experiências-piloto em São Paulo e no Rio de Janeiro de vacinação em massa na população infantil e, pouco a pouco, outras campanhas antipólio foram sendo realizadas em capitais brasileiras, também com uso do produto, distribuído pelo Ministério da Saúde (MS); no entanto, problemas logísticos dificultavam os resultados (Campos, Nascimento \& Maranhão, 2003).

O Brasil aprimorava a produção de imunobiológicos, preocupava-se com aspectos de conservação e potência, iniciava-se a fabricação nacional da vacina liofilizada contra a varíola e da fórmula intradérmica da BCG, também em liófilos. O Instituto Oswaldo Cruz passou a realizar a diluição e o envase das primeiras vacinas antipólio que chegavam ao país. Com apoio da Opas, este Instituto também introduziu o diagnóstico laboratorial do poliovírus, por isolamento em amostras fecais.

A luta contra a varíola crescia. A partir de 1962, com base nas experiências já acumuladas, o país instituiu a campanha nacional de vacinação contra a enfermidade, e diversas unidades federadas mobilizaram-se com recursos locais. Eram iniciativas isoladas, de caráter setorizado e mais presentes nas zonas urbanas. Pouco depois, em 1966, com a definição da meta de erradicação nacional da doença, novas estratégias (vigilância epidemiológica intensiva, confinamento dos casos e vacinação de possíveis contatos em um determinado raio) conduziram o país a resultados animadores. De 1966 a 1971, durante a fase de ataque à enfermidade, 135 milhões de doses foram aplicadas $e$ $84 \%$ da população brasileira foi vacinada. Em áreas de difícil acesso, na região ocidental do país, as ações de vacinação contaram com a colaboração das equipes de combate à malária, que as desenvolveram numa operação coincidente. A doença, que entre $1967 \mathrm{e}$ 1969 totalizou 16,2 mil casos confirmados, já em 1970 chegou a 1,7 mil, com uma taxa de morbidade de 1,9/100 mil hab. Em 1971, o Brasil registrava os seus últimos casos, no Rio de Janeiro (Brasil, 1973), e as vacinaçōes se mantiveram até 1973, quando a erradicação nacional da doença foi certificada pela OMS, após estudos realizados por uma comissão médica internacional da Cruz Vermelha. ${ }^{1}$

O bloqueio da transmissão vírus responsável pela varíola, em território brasileiro, e o somatório de experiências acumuladas no decorrer dos anos passados no setor de vigilância epidemiológica e imunizaçōes se fizeram marco na história das políticas públicas de saúde no país. O Brasil, com toda a sua extensão e diversidades, crescia no campo da prevenção em saúde pública e conquistava o reconhecimento internacional no setor. Os resultados com a varíola motivaram o traçado de novas metas e investimentos. Muito havia que ser feito no país para a redução da morbimortalidade por doenças imunopreveníveis, em especial a ampliação do uso de imunizantes. Esta necessidade se consolidou com o compromisso assumido pelos ministros da Saúde das Américas, em reunião no Chile em 1972, quando da elaboração do Plano Decenal para a Saúde. A meta foi também assumida pela OMS em 1974, levando à criação do Programa Ampliado de
' 0 último caso registrado no mundo ocorreu na Somália, e a certificação da erradicação foi declarada em 1980 
Imunizações/OMS (PAI), a partir de quando começam a surgir os programas nacionais de imunizaçōes (PNIs). Segue abaixo um demonstrativo da ocorrência de doenças imunopreviníveis - fins dos anos 60 e início dos anos 70 - às vésperas da criação do PNI no Brasil segundo a Divisão Nacional de Epidemiologia e Estatística do Ministério da Saúde (Brasil, 1973).

- Sarampo-126 mil casos confirmados em 1967. A doença grassava endêmica nas grandes coletividades, com picos epidêmicos a cada dois ou três anos, pela concentração de suscetíveis. A letalidade apresentava-se mais elevada quando os períodos epidêmicos se espaçavam. Os coeficientes de mortalidade na maioria das capitais eram muito elevados, apenas ultrapassados pela tuberculose e pela pneumonia. Na zona rural, os surtos faziam-se mais espaçados. As primeiras campanhas massivas de vacinação não alcançaram resultados satisfatórios.

- Tuberculose - 78,7 mil casos em 1967. A doença apresentava altos índices de morbimortalidade, atingindo principalmente as classes menos favorecidas. Os menores de cinco anos pagavam maiores tributos. Estimava-se haver entre trinta e quarenta milhões de indivíduos infectados e quinhentos mil casos de tuberculose ativa. Calculava-se que $50 \%$ da população aos vinte anos já estava infectada e que ocorria cerca de cem mil novos casos/ano. A enfermidade acometia também a população indígena.

- Difteria-22 mil casos em 1967. Alta incidência em menores de cinco anos, com uma mortalidade bastante significativa (14,7 óbitos/100 mil hab. - Natal, RN, 1970).

- Tétano-Elevados índices de mortalidade, principalmente em sua forma neonatal, bem demonstrado por estudos em São Paulo, onde em 1969 corresponderam a 70\% do total de óbitos por tétano. A cada ano, mais de mil crianças morriam naquele estado. Em Salvador/BA, 1971, foram registrados 14,6 6́bitos por 100 mil habitantes.

- Coqueluche-Mais de 100 mil casos/ano registrados, vitimando principalmente os menores de um ano, pela maior gravidade da doença nessa faixa etária. Os menores de quatro anos eram mais suscetíveis.

- Poliomielite - 11,5 mil casos em 1970. A doença encontrava-se em expansão no país, com repetidos surtos urbanos e rurais.

- Varíola-1,7 mil casos em 1970 e 19 casos em 1971 (último ano com registro de casos).

\section{ANOS 70: A CRIAÇÃO DO PROGRAMA DE IMUNIZAÇÕES DO BRASIL}

As políticas públicas dos anos 70 foram marcadas pela modernização dos aparelhos estatais, pelo planejamento, racionalização, formação de recursos humanos e ampliação da capacidade gerencial e pela busca da universalidade do âtendimento. Também, estava-se estruturando a inđústria de insumos materiais voltada para o setor saúde (Temporão, 2003). O país vivenciava o 'movimento sanitário', e os serviços de saúde pública pouco a pouco ganhavam novo perfil. 
O início da década foi marcado pelo surgimento de programas prioritários no MS, desenvolvidos com novas bases estruturais técnicas e administrativas, elaborados por competentes equipes intersetoriais e multidisciplinares, com rigorosa apreciação de comissões integradas por especialistas, secretários de saúde, universidades, institutos de pesquisa, Associação Médica Brasileira e Opas. Tais programas contavam com planejamento, recursos orçamentários da União e o apoio do Programa das Nações Unidas para o Desenvolvimento (PNUD). O Programa Nacional de Imunizações (PNI) foi um desses programas prioritários.

Uma reforma ministerial em 1970 criou a Divisão Nacional de Epidemiologia e Estatística de Saúde (DNEES), integrando o novo Departamento Nacional de Profilaxia e Controle de Doenças. Utilizando-se das experiências acumuladas, coube a DNEES estudar estratégias que proporcionassem maior abrangência do uso de imunizantes no país, visando ao controle de doenças imunopreveníveis. As atividades de vacinaçāo estavam dispersas, parte operacionalizadas pelo MS, como no caso da varíola, febre amarela e tuberculose, e parte executadas por meio das secretarias estaduais de saúde, como o sarampo e a tríplice bacteriana.

Na ocasião, ainda em 1971, foi criada também a Central de Medicamentos (Ceme), cujo objetivo era produzir e adquirir medicamentos direcionados às camadas menos favorecidas da população brasileira, apoiar o desenvolvimento tecnológico de fármacos e medicamentos e buscar autonomia em relação aos produtos essenciais na assistência à saúde da população. Seu surgimento fez-se fundamental para as mudanças nacionais no setor das imunizações, em especial no aspecto gerencial, com planejamento e garantia de suprimento e qualidade de produtos distribuídos. A Ceme incorporou no seu orçamento a aquisição de imunobiológicos. Eram os primeiros passos para a organização de um programa que cuidaria de um amplo plano nacional de imunização.

Entre 1971 e 1973, a DNEES desenvolveu tecnologia e metodologia necessárias à implementação de vacinação em massa, promoveu estudos de impacto epidemiológico com a vacina oral antipólio (a falta de dados prévios dificultaram suas análises), criou o Plano Nacional de Controle da Poliomielite e promoveu projetos locais com aplicação simultânea de vacina.

Numa ação conjunta, DNEES e Ceme elaboraram o PNI e com ele as diversas práticas no campo das imunizaçōes ganharam uma coordenação nacional, indispensável à conquista de melhores resultados e, sobretudo, à otimização dos grandes investimentos federais. O PNI foi criado em 1973, na gestão do ministro Mário Machado de Lemos (1972 - 1974), vinculado a DNEES. Sua coordenação fora composta por representantes do MS, da Ceme, da Opas e da Fundação Serviços de Saúde Pública (FSESP), sob a presidência desta e a quem cabia o seu controle e avaliação.

Com base nos censos IBGE 1960 e 1970, calculou-se o quantitativo de doses que * seriam utilizadas no período de sete anos (1973 a 1979), um total de 325 milhões, estimadas a um custo de 160 milhões de cruzeiros, moeda corrente na época. À Ceme, coube a aquisição de produtos que atendiam aos padrões recomendados pela OMS, usan- 
do, para isso, o mercado interno ou externo, o estoque e a distribuição às unidades federadas. As vacinas antipólio e anti-sarampo eram provenientes de importação, o que era realizado com apoio da Opas. A BCG oral, BCG intradérmica, a vacina antivariólica, a DTP e o toxóide tetânico eram adquiridos em laboratórios nacionais com ela conveniados. Para sua distribuição às unidades federadas, os imunobiológicos permaneciam nas próprias embalagens de papelão, ao que se acrescentava apenas gelo e/ou bobinas (gelo reciclável).

O programa priorizava as populaçōes urbanas e áreas rurais viáveis de cobertura imediata. As multivacinaçōes eram restritas a áreas onde se contava com recursos humanos capacitados. Garantiam o respeito ao perfil cultural de cada comunidade e trabalhavam grupos populacionais de possível mobilização (Brasil, 1973).

O objetivo prioritário do PNI era contribuir para o controle da poliomielite, do sarampo, da tuberculose, da difteria, do tétano e da coqueluche, e para a manutenção da situação de erradicação da varíola.

Em 1974, o PNI ainda se estruturava, quando uma epidemia de meningite meningocócica assustou o Brasil. Com foco principalmente em São Paulo, onde se registrava casos desde 1972, a situação exigiu do governo uma operação imediata, eficaz e de grandes proporções. Numa campanha massiva, em 1975, o país foi rapidamente vacinado com um novo produto. Esse fato reforçou as teorias sobre a necessidade de ações mais agressivas para a conquista dos resultados epidemiológicos almejados. Naquele ano da campanha, os índices de coberturas vacinais do PNI em rotina alcançaram uma média de $20 \%$, e os surtos de poliomielite e sarampo insistiam em ocorrer.

Em 1975, implementava-se a informatização na vigilância epidemiológica, nos laboratórios de saúde pública, nos estoques, no controle de qualidade de medicamentos, nas pesquisas e nas imunizações (iniciava-se a implantação do Sistema de Registro de Doses Aplicadas, que favoreceu a partir de então informações padronizadas sobre a produtividade no setor, uma base de dados para análise e tomada de decisões). A amplitude dessas mudanças extrapolou fronteiras, prestando significativa colaboração à saúde pública latino-americana.

As normas técnicas referentes ao funcionamento do PNI e à notificação de doenças foram estabelecidas em 1975, com a promulgação da Lei Federal n. 6.259 que instituiu o Sistema Nacional de Vigilância Epidemiológica e Imunizações, regulamentado no ano seguinte. Estavam definidas as vacinas básicas obrigatórias para o primeiro ano de vida e o seu não atendimento ocasionava a suspensão do pagamento do salário-família. Com o caráter de obrigatoriedade das vacinas infantis e a necessidade de mobilizar a população para o seu atendimento, a mídia surgia com campanhas para a vacinação que convocavam as famílias aos centros de saúde, utilizando-se de um personagem, o Doutor Prevenildo.

No final dos anos 70, iniciaram-se os cuidados específicos com a manipulação, conservação, estoque e distribuição dos produtos imunobiológicos. Concomitantemente, foram realizadas capacitaçōes das equipes e as primeiras publicações de normas do programa. 
As coberturas vacinais em rotina teriam chegado a uma média aproximada de $50 \%$. o PNI reconhecia as dificuldades para ampliar o seu alcance, assistia a surtos que apavoravam o país e preocupava-se com a aceleração desse percentual, o que se tornou ainda mais veemente após a Conferência Internacional de Alma-Ata, que ocorreu em 1978, na antiga URSS, e que apontou a necessidade da soma de esforços para a garantia de cuidados primários de saúde em todas as nações.

Dados da OMS indicavam que entre 1976 e 1978 o Brasil ocupou o segundo lugar em registro de casos de poliomielite, vindo logo depois da Índia. Em dezembro de 1979, uma epidemia na fronteira entre o Paraná e Santa Catarina causou pânico social, conduzindo o MS ao estabelecimento do Dia Nacional de Vacinação, decisão que teve como base todas as experiências até então acumuladas com o uso da vacina antipólio oral, com campanhas de vacinação e em vigilância epidemiológica. As campanhas de vacinação passaram a ser vistas como única opção capaz de antecipar o impacto epidemiológico almejado. Naquele momento, fazia-se necessária uma adequação na logística utilizada até entăo, na estrutura dos serviços de saúde e na rede de frio, que, à época, era insuficiente para o grande quantitativo de vacinas que se propunha utilizar.

\section{ANOS 80: OS DIAS NACIONAIS DE VACINAÇÃO E A EMERGÊNCIA DA FIOCRUZ NO CENÁRIO BRASILEIRO}

Os Dias Nacionais de Vacinação contra a Poliomielite (DNV) foram implantados no país em 1980 e se propunham a vacinar todas as crianças menores de cinco anos de idade com uma dose da vacina oral trivalente (poliovírus I, II e III), em duas ocasiões a cada ano, independente da situação vacinal anterior. Contando com um produto de simples administração, 92 mil postos de vacinação e aproximadamente 320 mil pessoas, entre profissionais da rede pública de saúde, parceiros e voluntários, o PNI proporcionou o acesso da população infantil à vacina em grandiosa mobilização social.

O modelo de campanhas massivas também teve opositores, que entendiam que os esforços do governo deveriam estar voltados para implementação da infra-estrutura e para os serviços na rede básica, por recearem que a estratégia viesse acomodar a população ao hábito, reduzindo a procura pelos postos na rotina. O fato é que a sociedade já demonstrava grande aceitabilidade às campanhas e, nesse primeiro ano, mais de 18 milhões de crianças receberam a dose vacinal em cada etapa, correspondendo a uma cobertura de $100 \%$ da população-alvo em ambas as ocasiōes.

Os DNVs trouxeram resultados animadores, proporcionando uma redução de casos da enfermidade - de 1.290 (em 1980) a 125 (no ano seguinte). Em 1983, observou-se o menor número de casos já registrados até então (45 casos confirmados). Os índices de coberturas vacinais foram superiores a $95 \%$, havendo uma queda nos anos seguintes.

Alguns estados passaram a utilizar os DNVs, aproveitando as altas coberturas e a infra-estrutura disponível, na tentativa de ampliar o acesso a todas as vacinas. Isto, no entanto, durou pouco tempo, a estratégia foi acusada de trazer prejuízos aos resultados da vacinação antipólio. 
Os números grandiosos de doses vacinais necessárias para atender ao PNI com uma cobertura adequada no país e a crise nacional pela falta de soro antiofídico nos primeiros anos desta década preocupavam o governo brasileiro, que resolveu estabelecer uma política de apoio à produção nacional de imunobiológicos, visando à auto-suficiência nacional dos produtos considerados indispensáveis á saúde pública. Eram dados os primeiros passos em direção ao desenvolvimento do mercado de vacinas no país.

Em paralelo, estava clara a necessidade da criação de um órgão đe referência técnica para os laboratórios produtores nacionais, surgindo, em 1981, o Instituto Nacional de Controle de Qualidade em Saúde (INCQS) da Fiocruz/MS, que dois anos mais tarde passou a analisar amostras dos imunobiológicos adquiridos pelo PNI, lote a lote, antes de sua distribuição, garantindo qualidade e segurança para consumo. Esse controle acresceu aos produtos oferecidos pela rede pública um grande diferencial.

As ações logísticas de aquisição, estoque, distribuição e controle dos imunobiológicos foram se adequando ao crescimento rápido do PNI. Em 1982, a Fiocruz assumiu a responsabilidade para com estas ações, em substituição da Ceme, mediante convênio com a Secretaria Nacional de Açōes Básicas de Saúde (SNABS) e contando com recursos do Programa. A Fiocruz já possuía uma infra-estrutura de produção de vacina contra febre amarela. Em Bio-Manguinhos/Fiocruz, foi então criada a Central Nacional de Distribuição e Estocagem (Cenade), e a distribuição dos produtos aos estados se dava mediante a autorização do PNI.

Os gestores estaduais passaram a receber informaçōes sobre o monitoramento do envio de produtos para o seu estoque. Algumas adaptações foram pouco a pouco sendo necessárias a fim de se evitar perdas e desperdícios de recursos. Organizou-se uma padronização de envio por companhias aéreas, com embalagens de isopor, gelo, termômetros e rótulos. Mas a demanda em crescimento exigia maiores e breves investimentos para uma infra-estrutura adequada e moderna.

Em 1985, o estoque médio da Cenade já atingia 350 milhões de doses (CGPNI, 2003). Nesse ano, o MS criou o Programa de Auto-Suficiência Nacional de Imunobiológicos (Pasni), a fim de fortalecer o parque produtor nacional. o Pasni era então prioritário para o governo federal.

Em 1985, a campanha antipólio apresentou as mais baixas coberturas $(80,17 \% \mathrm{e}$ $85,02 \%)$. Este fato, associado à baixa imunidade da população para o poliovírus tipo III, apresentada por deficiência na composição da vacina oral em uso na época, levou à ocorrência da última epidemia da enfermidade no país, que atingiu seu pico em 1986 , com expressão máxima na região Nordeste. Estudos epidemiológicos e investigações laboratoriais realizadas pela Fiocruz, através do seu Centro Internacional de Referência em Enterovírus, identificaram o surto e proporcionaram o desenvolvimento de nova formulação vacinal com aumento da concentração daquele subtipo, típico das Américas e outras regiões tropicais. A nova formulação vacinal passou a ser adotada em 1988 pela Opas para o Continente.

A situação epidemiológica da poliomielite então vigente, somada ao compromisso assumido pelos ministros da Saúde das Américas de erradicação da transmissão autóctone 
do poliovírus selvagem no Continente (1985), exigiu do PNI a retomada de altas coberturas e a realização de mais um DNV anual, na região Nordeste. ${ }^{2}$ A mudança na formulação vacinal e a ampliação de coberturas findam por zerar o número de casos registrados no país. A poliomielite foi registrada pela última vez, no Brasil, em março de 1989.

As campanhas de vacinação em massa foram ganhando adeptos e reconhecimento em proporções internacionais. Contribuíram para o maior acesso da população às vacinas do PNI, para o desenvolvimento da informação e da comunicação em saúde. Em meio a luta contra a pólio, foi criado o símbolo da campanha, o Zé Gotinha, um personagem-herói que vence todas as enfermidades que cativou crianças e adultos, estabelecendo-se, pouco depois, como marca das imunizações no Brasil.

Durante as décadas de 80 e 90 , surgiram as primeiras vacinas desenvolvidas com base em tecnologia de DNA e em genética molecular, a exemplo da vacina contra hepatite B, disponibilizada no mercado em 1986 , que chegava para substituir o produto em uso na época, derivado de sangue humano. Em 1989, o Brasil a introduzia em áreas de alta endemicidade da doença, ampliando gradativamente sua oferta.

\section{ANOS 90: DESCENTRALIZACฺÃO}

A década de 90 traz mais desafios para as imunizações. 0 ritmo acelerado da ciência em suas descobertas e a necessidade de se avançar mediante a ocorrência ainda persistente de enfermidades imunopreveníveis exigiam mudanças no PNI. Nas Américas, sob a coordenação da Opas, o tétano neonatal e o sarampo ganharam prioridade dos governos das nações. Há muito se vacinava e, no entanto, tais enfermidades insistiam em fazer vítimas.

O Brasil elaborou o seu plano de eliminação do tétano neonatal em 1991 e, no ano seguinte, um outro plano foi traçado, para eliminação do sarampo. Este, logo mais (1994) foi ampliado, visando a uma meta mais ousada: erradicar a enfermidade. Naquele mesmo ano, a erradicação da transmissão autóctone do poliovírus selvagem no Brasil e no continente americano foi certificada pela OMS. Com isto, assumia-se a responsabilidade do aprimoramento dos serviços de vigilância epidemiológica das paralisias flácidas agudas e de manutenção de coberturas vacinais ótimas e homogêneas com a terceira dose da antipólio oral na faixa etária de zero a quatro anos.

Áreas geográficas com persistentes baixas coberturas são capazes de favorecer uma reintrodução da doença no país. Algumas regiōes do globo mantêm o poliovírus selvagem circulante, e o Brasil, como receptor de viajantes internacionais em fluxo intenso e contínuo, estava exposto ao risco de reintrodução da doença, por importação.

Já nos finais da década, um surto em Angola, na África, advertiu e motivou providências específicas de vacinação e vigilância que garantiram a manutenção da situação epidemiológica vigente. Em 2000/2001, um outro surto apontou a importância da homogeneidade de altas coberturas, desta vez no continente americano (República Dominicana e Haiti), motivado pela manutenção de áreas com baixas coberturas por longo * período, o que favoreceu a persistência da circulação do poliovírus vacinal entre imunodeprimidos por alguns anos, levando a mutações genéticas e, conseqüentemente proporcionando a virulência e a ocorrência de novos casos da doença.
${ }^{2}$ Os Dias Nordestinos de Vacinaçăo acontecem de 1986 a 1993 , quando voltam a ser realizadas apenas duas etapas anuais em todo o território nacional (MS, 1994). 
As campanhas nacionais de vacinação contra a poliomielite prosseguem e acolhem mais uma vez outras vacinas. É retomada a metodologia de multivacinação, que fora abandonada por alguns anos, e a estratégia se consolida com bons resultados para todos os produtos e favorece o melhor aproveitamento dos investimentos destinados para a pólio em benefício de outras doenças.

O PNI passou a perseguir a homogeneidade de coberturas vacinais adequadas, buscando o cumprimento de metas por todos os municípios brasileiros e para todos os produtos preconizados, iniciando, a partir do final dos anos 90 , um importante processo de descentralização de suas ações.

O processo envolveu investimentos em capacitação técnico-administrativa de suas equipes em todos os âmbitos; em educação continuada; em um novo perfil de supervisão e busca de parcerias. A participação do PNI em fóruns sobre temas do seu interesse foi intensificada, e surgia, por meio de portaria ministerial, o Comitê Técnico Assessor em Imunizações (CTAI), composto por experts em áreas afins, incluindo o coordenador nacional do PNI, o diretor do Centro Nacional de Epidemiologia, representantes de associações médicas, do INCOS/Fiocruz e das cinco macrorregiões do país. Estabeleceram-se o Sistema de Vigilância de Eventos Adversos Pós-vacinais (SI-EAPV) e o Sistema de Informação e Avaliação do PNI (SI-API), ambos informatizados; foi regulamentada a parceria com clínicas privadas de vacinação, por meio de portaria do MS; investiu-se e incentivouse a pesquisa e a aquisição de novas tecnologias pelos laboratórios produtores oficiais.

O país muda a política de investimentos na produção nacional de imunobiológicos, mas a grande demanda do PNI e o seu apoio ao desenvolvimento científico e tecnológico mantiveram aquecido o parque produtor nacional. Pelo quantitativo necessário ao atendimento de suas metas em imunizações, o Brasil também se mantém no alvo do mercado internacional de imunobiológicos. A aquisição e o controle dos produtos imunobiológicos passam para a responsabilidade da coordenação nacional do PNI. Foram adquiridos equipamentos para a adequação das centrais estaduais de frio, e a Cenade, sem mais condições de permanecer em Bio-Manguinhos, passou a utilizar temporariamente apenas câmaras frias alugadas da Cibrazem.

Entre 1993 e 1996, foi construída uma sede própria da central nacional, que passou a ser Central Nacional de Armazenamento e Distribuição de Imunobiológicos (Cenadi). A nova sede localiza-se em área cedida por regime de comodato pelo Ministério do Exército (em Benfica, $14^{\circ}$ Batalhão de Suprimento/Rio de Janeiro), contando com a sua custódia durante todos os dias do ano. A planta da nova central contava com $2,3 \mathrm{mil} \mathrm{m}^{2}$ de área frigorífica (mais tarde ampliada para pouco mais de $3 \mathrm{mil} \mathrm{m}^{2}$ ); foi concebida dentro dos mais modernos padrões técnicos, possuindo um sistema de monitoramento eletrônico de temperaturas e funcionamento garantido independente do abastecimento elétrico da cidade.

Começavam a surgir as vacinas conjugadas e as combinadas no mercado mundial. o Brasil vivenciava o dinâmico processo de atualização e implementação do calendário básico de vacinação, garantindo a oferta dos mais modernos produtos disponíveis no mercado, a exemplo da vacina contra Haemophilus influenzae b (Hib), a vacina quádru- 
pla (DTP+Hib, contra difteria, tétano, coqueluche e Haemophilus influenzae tipo b), a tríplice viral (SRC, contra sarampo, rubéola e caxumba) e a vacina contra influenza.

Em 1999, a decisão de vacinar a população idosa se constituiu em mais uma ousada meta do PNI. O programa, então, propunha-se a contribuir para o controle da morbimortalidade pelo vírus influenza e outras causas imunopreveníveis de importância para a faixa etária, mobilizada pela primeira vez para comparecer aos postos de vacinação.

Neste primeiro ano, o programa disponibilizou à população a partir dos 65 anos as vacinas contra o vírus influenza, a dupla bacteriana tipo adulto (contra difteria e tétano) e a antipneumocócica, numa grande campanha nacional que contou com a importante parceria da classe médica, de lideranças comunitárias e da sociedade civil. A campanha alcançou a cobertura de $87,3 \%$, resultado de parâmetros internacionais, ultrapassando a meta prevista $(70 \%)$. Foram vacinados 7,5 milhões de pessoas naquela ocasião.

O PNI preocupou-se, também, com portadores de imunodeficiência congênita e adquirida e de doenças crônicas degenerativas, implantando os primeiros Centros de Referência para Imunobiológicos Especiais (Cries). Os Cries disponibilizam na rede pública produtos especiais para indivíduos portadores de condições clínicas específicas, com indicações estabelecidas em normas. Cabe inclusive aos Cries o atendimento aos indivíduos com história de eventos adversos pós-vacinais graves. Há um total de 33 Cries, com pelo menos um centro em cada unidade federada.

No Quadro 1, apresenta-se a evolução das coberturas vacinais em ações de rotina e em campanhas, no decorrer da década.

Quadro 1 - Evolução das coberturas vacinais em ações de rotina e em campanhas - década de 90

\begin{tabular}{|c|c|c|}
\hline Início da década & Metade da década & Final da década \\
\hline $\begin{array}{l}\text { As coberturas vacinais em rotina para a } \\
\text { faixa etária de menores de um ano } \\
\text { atingiram índices abaixo de } 80 \% \text {, com a } \\
\text { vacina BCG-id, antipólio oral, trílice } \\
\text { bacteriana DTP e anti-sarampo } \\
\text { (Gráfico 1). }\end{array}$ & & $\begin{array}{l}\text { Ao final da década de } 90 \text { e início do } \\
\text { novo milênio, as vacinas de rotina para } \\
\text { menores de um ano de idade chegaram } \\
\text { a uma média de cobertura de } 95 \% \text {, } \\
\text { agora com seis produtos - acrescidas } \\
\text { as vacinas contra hepatite B e contra } \\
\text { Haemophilus influenzae b (Gráfico } 1 \text { ). }\end{array}$ \\
\hline $\begin{array}{l}\text { Homogeneidade de coberturas } \\
\text { adequadas }\end{array}$ & $\begin{array}{l}\text { Homogeneidade de coberturas } \\
\text { adequadas }\end{array}$ & $\begin{array}{c}\text { Homogeneidade de coberturas } \\
\text { adequadas }\end{array}$ \\
\hline \multirow[t]{3}{*}{$\begin{array}{l}\text { Nas campanhas de vacinação contra a } \\
\text { pólio, pouco mais de } 50 \% \text { dos } \\
\text { municípios brasileiros alcançaram a } \\
\text { meta de cobertura então proposta pelo } \\
\text { MS ( } 90 \% \text { da população de zero a cinco } \\
\text { anos de idade), durante as duas etapas } \\
\text { da campanha nacional (Gráfico 2). }\end{array}$} & $\begin{array}{l}\text { Nas campanhas de vacinação contra a } \\
\text { pólio, aproximadamente } 60 \% \text { dos } \\
\text { municípios brasileiros alcançaram meta } \\
\text { ( } 90 \% \text { da população de zero a cinco } \\
\text { anos de idade), durante as duas etapas } \\
\text { da campanha nacional (Gráfico 2). }\end{array}$ & $\begin{array}{l}\text { Nas duas etapas da campanha } \\
\text { antipólio, cerca de } 80 \% \text { dos municípios } \\
\text { alcançaram meta; na ocasião, 95\% dos } \\
\text { menores de cinco anos (Gráfico 2). }\end{array}$ \\
\hline & Em rotina & Em rotina \\
\hline & $\begin{array}{l}\text { Menos de } 50 \% \text { dos municípios } \\
\text { obtiveram resultados satisfatórios na } \\
\text { vacinação de rotina (Gráfico } 3 \text { ). }\end{array}$ & $\begin{array}{l}\text { Durante a década, a evolução na } \\
\text { homogeneidade de coberturas vacinais } \\
\text { por municípios brasileiros das vacinas } \\
\text { de rotina ganhou relevância (Gráfico } 3 \text { ). }\end{array}$ \\
\hline
\end{tabular}

Obs: A populą̧ão brasileira ao iníic da década era de 145 milhőes de habitantes. Em 2000, aproximadamente 170 milhŏes de habitantes (IBGE, 2003). 
Gráfico 1 - Cobertura vacinal nas ações de rotina para menores de um ano de idade. Brasil - 1980-2004

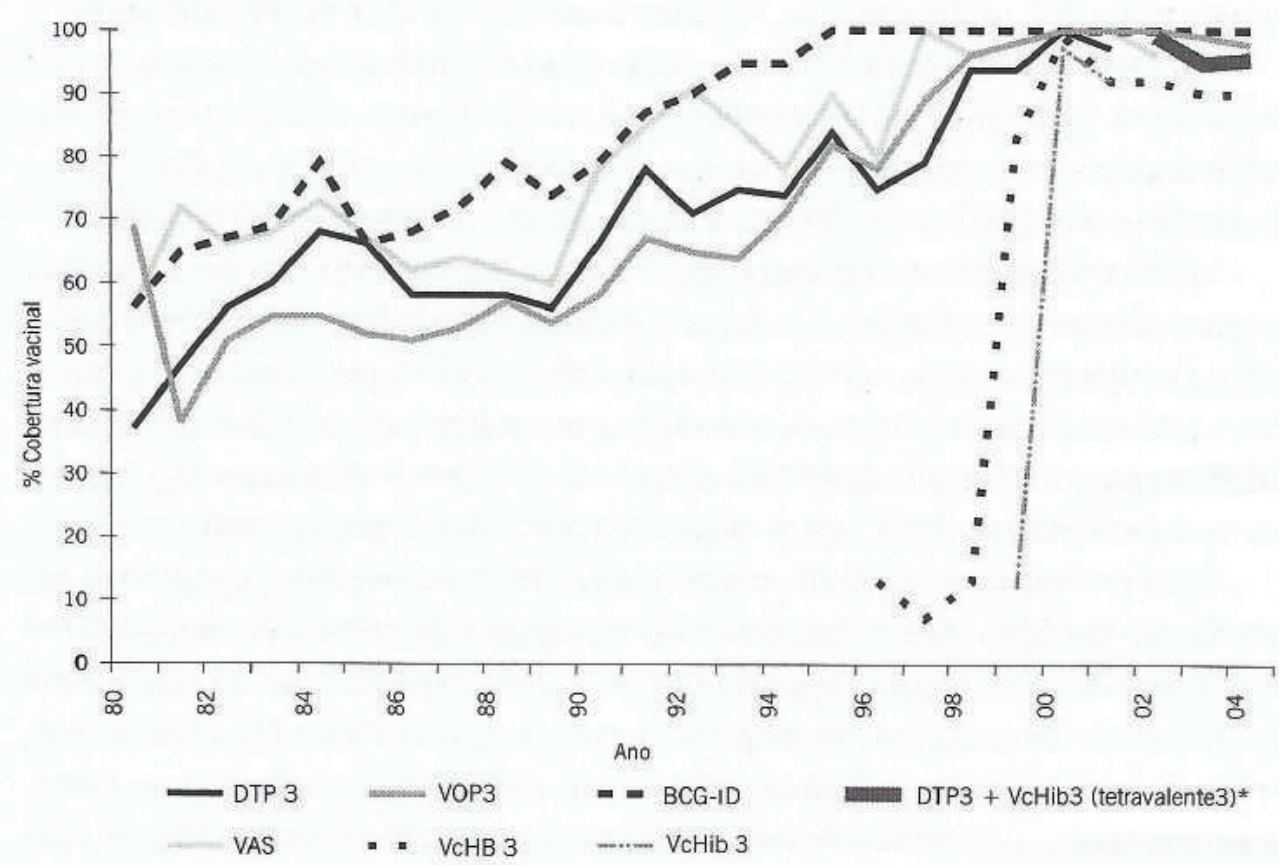

*A vacina combinada tetravalente DTP + Hib foi implantada em 2002, para menores de um ano em início de esquema.

Gráfico 2 - Municípios brasileiros que alcançaram as metas preconizadas para a vacinação de menores de cinco anos de idade com a antipólio oral, das duas etapas anuais de campanha nacional de vacinação.* Brasil - 1992-2004

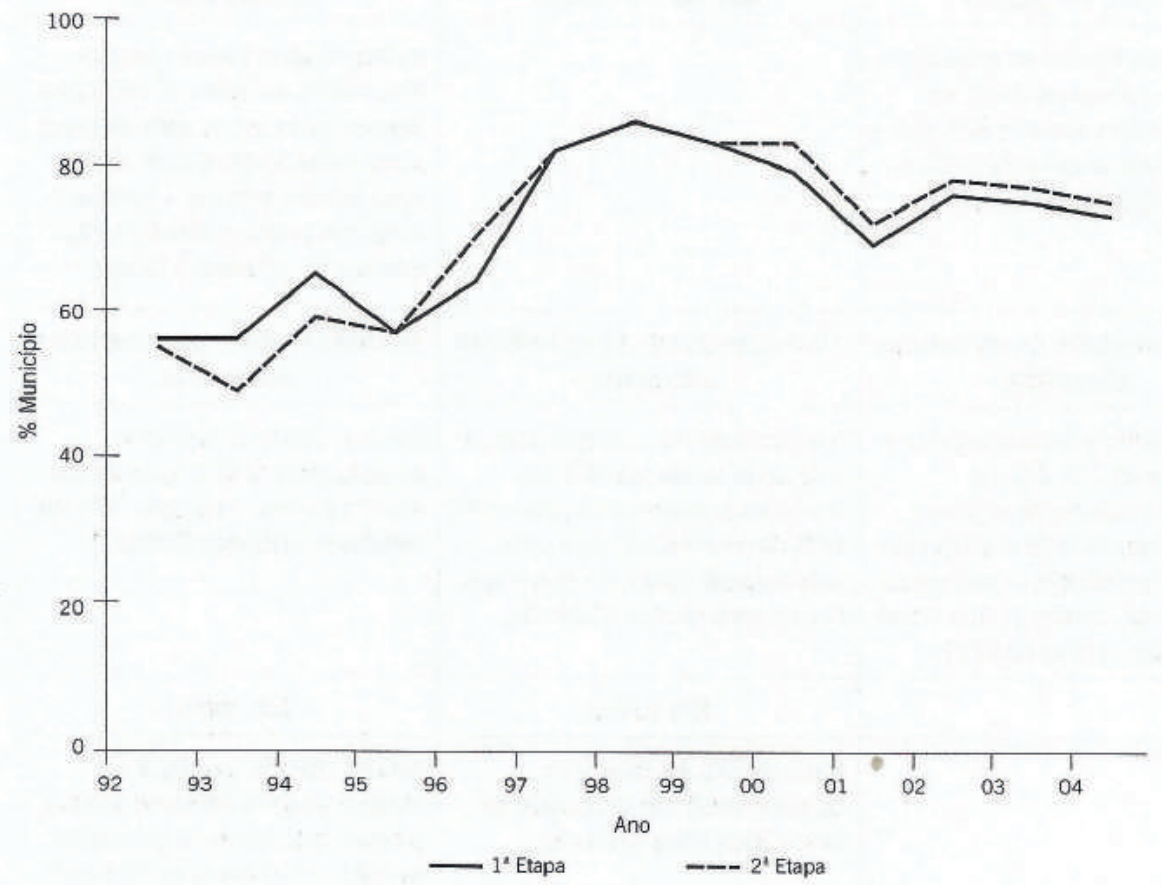

*Entre 1992 e 2000, meta $90 \%$, e a partir de 2001, 95\%. 
Gráfico 3 - Municípios brasileiros que alcançaram as metas preconizadas para as vacinas de rotina de menores de um ano de idade e para a vacina tríplice viral de menores de dois anos de idade.* Brasil - 1996-2004

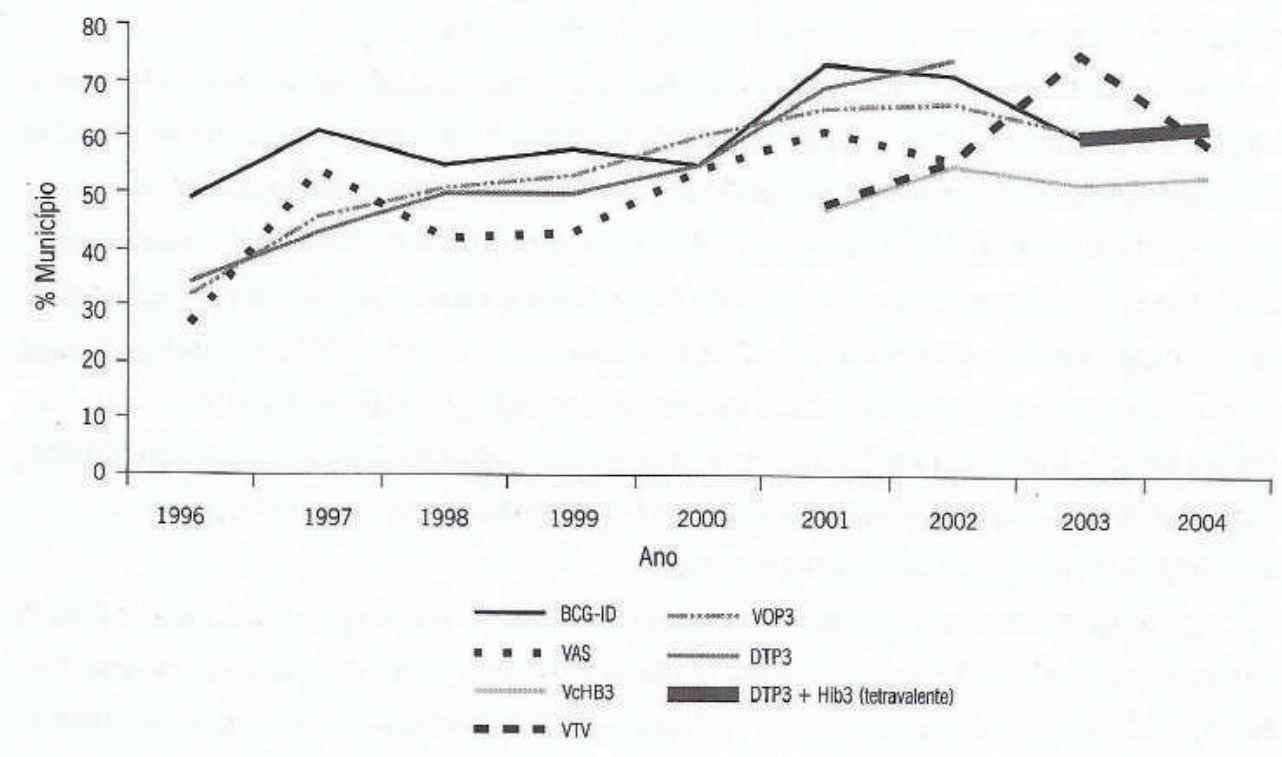

*A vacina combinada tetravalente DTP + Hib foi implantada em 2002, para menores de um ano em início de esquema.

\section{PROGRAMA NACIONAL DE IMUNIZAÇÕES: NOVO MILÊNIO}

Em 2000, o PNI recebe a denominação de Coordenação Geral do Programa Nacional de Imunizações (CGPNI), integrada pela Coordenação de Normatização e pela Coordenação de Imunobiológicos, ainda compondo o Cenepi/Funasa. Mais tarde, o Cenepi ganha o status de uma nova Secretaria do MS, a Secretaria de Vigilância em Saúde, e a CGPNI passa a compor o seu Departamento de Epidemiologia.

A poliomielite está fora do território nacional há pouco mais de dez anos, mas a circulação viral ainda é realidade em algumas áreas do globo. Todos os países do mundo, sob a coordenação da OMS, șomam esforços pela erradicação global da enfermidade. As nações já livres ao mesmo tempo em que perseguem os indicadores epidemiológicos estabelecidos atuam na contenção do poliovírus em laboratórios. No Brasil, a Fiocruz/MS coordena esses trabalhos.

As imunizações no país avançaram, na sombra das grandes mobilizações motivadas pela poliomielite. As campanhas massivas de vacinação antipólio, que ocorrem desde 1980, favoreceram o acesso da população a todas as vacinas que compõem o calendário básico nacional, contribuindo, desse modo, para o crescimento do PNI e de seus resultados (Gráficos 1 e 3). Atualmente, em cada etapa anual de campanha de vacinação contra a poliomielite, aproximadamente 14 milhões de crianças de zero a quatro anos são vacinadas; a meta estabelecida pelo PNI é de $80 \%$ dos municípios brasileiros com êxito nas coberturas (95\%) em cada etapa (Gráfico 2). A praticidade na administração da vacina oral antipólio, o seu baixo custo e a boa aceitabilidade por parte da população pelo receio da doença paralisante concorreram como motivos para o sucesso alcançado. 
Essas campanhas se fizeram ainda mais proveitosas porque puderam contribuir com outras açōes em saúde pública, como as campanhas nacionais com uso de vacinas injetáveis ou a incorporação de faixas etárias mais ausentes dos postos de vacinação, visando a antecipar resultados epidemiológicos almejados.

As campanhas de seguimento realizadas pela erradicação do sarampo e as intensificações pela eliminação do tétano neonatal também foram exitosas. Seus resultados satisfatórios somados à sensibilidade do sistema nacional de vigilância epidemiológica $\mathrm{e}$ à eficiência da rede de laboratórios de referência garantiram o bloqueio da transmissão autóctone do sarampo desde 2000 , tendo havido desde então apenas alguns registros de casos importados de outras nações. O vírus do sarampo ainda circula em muitos países do mundo e muito ainda falta para que se alcance igual êxito em âmbito global. Isto requer do país intensa atenção aos seus indicadores epidemiológicos e de imunizações. Para o tétano neonatal, novas estratégias visam agora a zerar a ocorrência de casos, o que exige ampliação de coberturas vacinais.

As campanhas massivas para a população idosa se repetiram a cada ano e foram ampliadas a partir de 2000 para a faixa etária de 60 anos e mais. $O$ êxito foi crescente. Em 2003, 12,3 milhôes de idosos foram vacinados no Brasil contra a influenza, correspondendo a uma cobertura de $82,3 \%$ e, naquela ocasiāo, $93 \%$ dos municípios brasileiros cumpriram a meta estabelecida pelo PNI. O programa também ampliou a faixa etária para a vacinação contra hepatite B em todo o país, abrangendo adolescentes e adultos. Em paralelo, vacinou a população feminina em idade reprodutiva, visando a contribuir para o controle da rubéola e para a prevenção da síndrome da rubéola congênita, numa proposta pioneira. Outra vez obteve sucesso, alcançando mais de 30 milhões de mulheres, 95,6\% de cobertura vacinal (Gráficos 4 e 5).

Atualmente, são objetivos prioritários do PNI contribuir para a manutenção da situação de erradicação da febre amarela urbana, da poliomielite e do sarampo; zerar os casos de tétano neonatal; manter o controle da tuberculose em suas formas graves, da difteria, do tétano acidental, da coqueluche, da febre amarela silvestre e da raiva humana; alcançar e manter o controle da influenza das infecções pneumocócicas e suas complicações das infeç̧ões por Haemophilus influenzae tipo b, da rubéola e da síndrome da rubéola congênita, da hepatite $B$ e da caxumba na populaçăo idosa; contribuir para o controle de doenças imuno-preveníveis e suas complicações na parcela populacional portadora de condições clínicas específicas objeto dos Cries e para o controle de surtos ocasionais de doenças imunopreveníveis e de acidentes por animais peçonhentos.

Em 2002, 95,5 mil pessoas foram atendidas com soros ou imunoglobulinas e 163,5 milhōes de doses de vacinas foram aplicadas. Dentre todos os produtos imunobiológicos utilizados no país anualmente, são adquiridos cerca de 250 milhões de doses, das quais $65 \%$ têm origem nacional (Gráfico 6). São 44 produtos oferecidos: 14 tipos de vacina e dois tipos de soro heterólogo, em postos de vacinação; 13 tipos de vacina e quatro tipos de imunoglobulina, nos Cries; 14 tipos de soro heterólogo, em unidades hospitalares e pronto-atendimentos. 
Gráfico 4 - Casos suspeitos e confirmados de síndrome da rubéola congênita. Brasil 1997-2002*

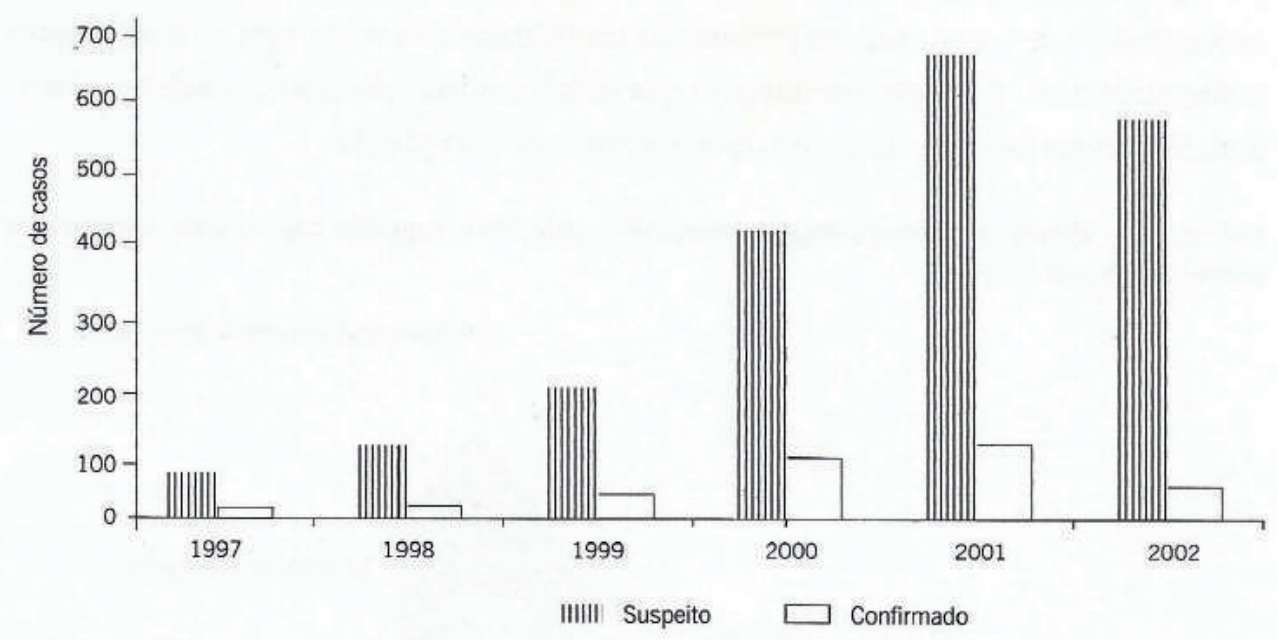

*Dados sujjeitos a alteração.

Gráfico 5 - Casos confirmados de rubéola por semana epidemiológica. Brasil - 2000-2003*

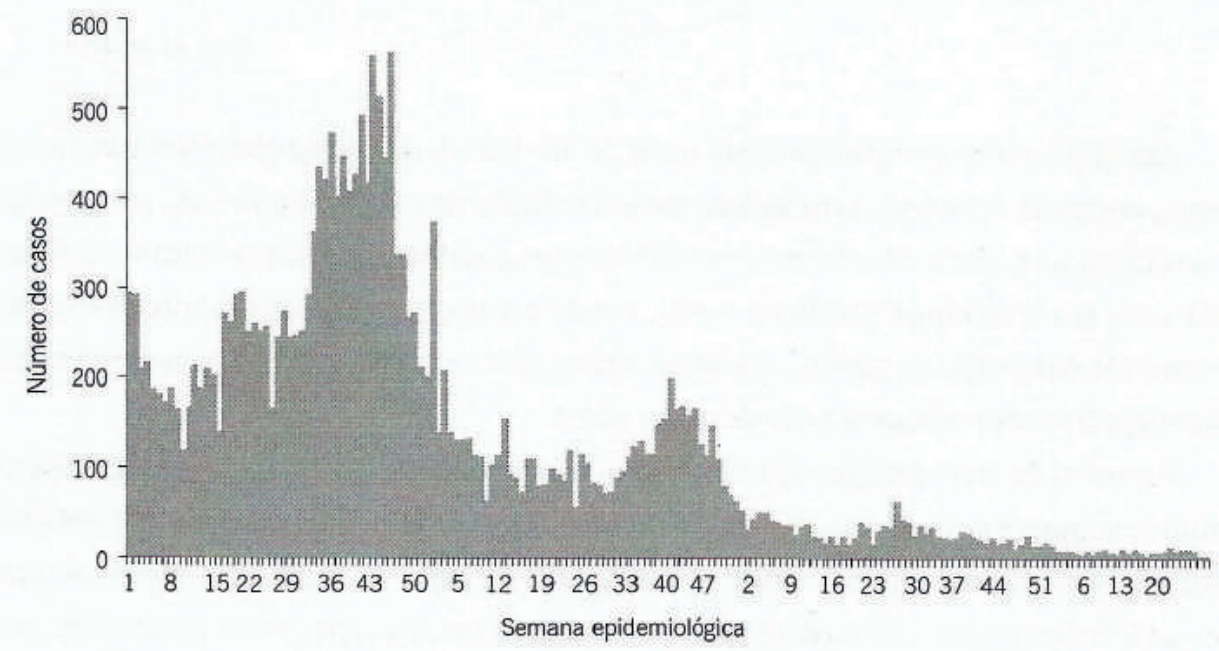

*Dados preliminares até a semana 26/2003.

Gráfico 6 - Aquisição nacional de produtos imunobiológicos, quanto à sua origem e ao quantitativo de doses. Brasil - 2002

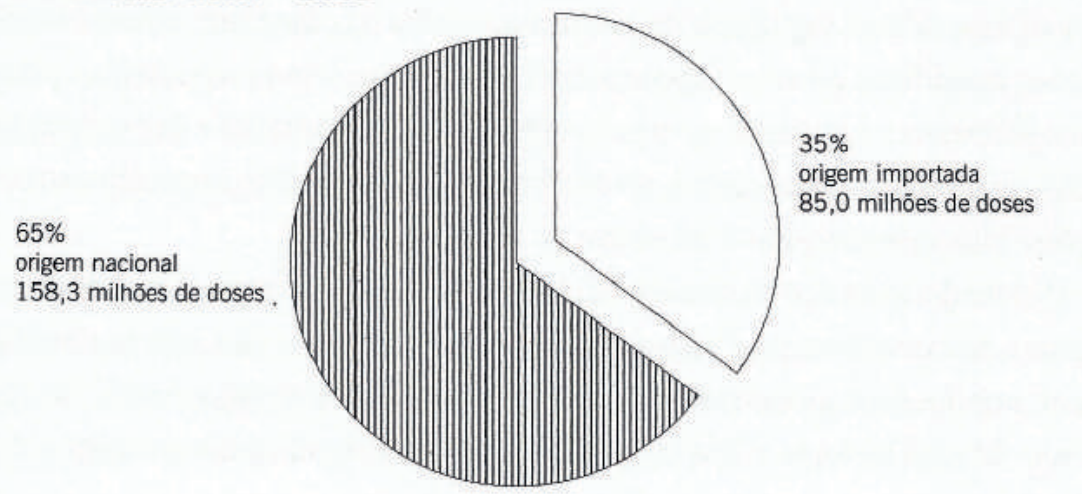


O PNI ainda garante um estoque estratégico de produtos imunobiológicos de uso em condiçōes epidemiológicas específicas. Dos 44 tipos de produtos, 27 têm auto-suficiência assegurada, 5 se encontram em processo de transferência de tecnologia e 12 são importados (Gráfico 7). É importante destacar que os laboratórios produtores nacionais atendem às normas da OMS, referentes às Boas Práticas de Produção.

Gráfico 7 - Produtos imunobiológicos adquiridos pelo PNI, segundo capacidade nacional de produção. Brasil - 2003

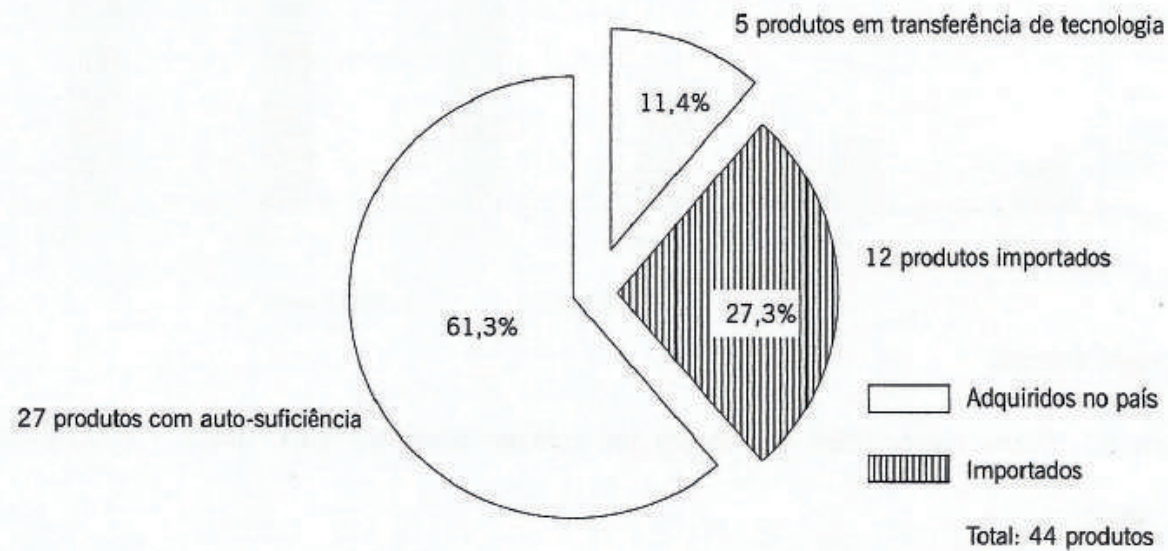

Em 2003, o PNI completou trinta anos de atividades de vacinações sistemáticas em escala nacional, concreta contribuição para a redução da morbimortalidade por doenças infecciosas no país, inclusive enfermidades cujas medidas de controle foram iniciadas nos anos mais recentes (Gráficos 5 e 8). Desde a sua criação, o PNI mantém-se como prioridade das políticas governamentais. Entre 1995 e 2002, usufruiu um crescimento orçamentário equivalente a mais de cinco vezes.

Por meio de procedimentos simples, mas numa evolução de grande complexidade, 0 programa garante capacitação e atualização dos gestores e suas equipes, em todos os níveis; dedicação das equipes e humanização dos serviços de vacinaçāo; modernização de sua infra-estrutura, de suas técnicas e procedimentos; suprimento nacional de imunobiológicos, segurança e eficácia dos produtos que preconiza; sustentabilidade; economia nacional e atendimento efetivo da população brasileira; atualização dinâmica đo seu leque de ofertas, do calendário básico e dos produtos especiais dirigidos a casos clínicos específicos; vigilância de eventos adversos pós-vacinais; apoio e incentivo aos estudos científicos do setor; apoio à aquisição de modernas tecnologias pelos laboratórios produtores nacionais, ao crescimento do mercado interno e de exportação; participação em fóruns de temas afins; intercâmbio técnico-científico-operacional com outras nações; busca de parcerias e incentivo ao controle social.

O calendário básico nacional é implementado de acordó com a realidade nosológica do país e do exterior e com a disponibilidade de produtos no mercado nacional e internacional, nos imensos quantitativos necessários ao alcance de suas metas. Para a garantia do êxito de seus projetos, o PNI lança mão das mais diversificadas estratégias de comuni- 
cação, mobilização, vacinação, supervisão e avaliação, adequando-as a cada canto do extenso território nacional e usufruindo de uma rede de frio e de um sistema de informações (SI-PNI) em contínua atualização.

\section{CONSIDERAÇÕES FINAIS}

Globalmente, a varíola está erradicada há mais de vinte anos e a poliomielite foi confinada a pequenas áreas, onde missões internacionais coordenadas pela OMS desenvolvem medidas destinadas ao bloqueio da circulação do poliovírus selvagem, a fim de que o mundo esteja definitivamente livre de um ressurgimento da enfermidade. A OMS recomenda a todos os países do mundo a atenção aos indicadores de vigilância e imunizações, até que se concretize a erradicação mundial do agente infeccioso e que estudos (em andamento) definam sobre o momento seguro para a suspensão das vacinaçōes. A febre amarela também conta com medidas de controle internacionais, claramente definidas pelo Regulamento Sanitário Internacional/OMS. O sarampo e o tétano neonatal se mantêm em foco nas Américas, enquanto novas doenças vão ganhando a atenção das ações públicas de imunizações e vigilância epidemiológica, mediante metas internacionais assumidas por seus governos, sob a coordenação da Opas.

A luta contra as doenças imuno-preveníveis corresponde a uma ação de dimensões internacionais. Cada nação é responsável pelo seu território e pela saúde de sua população, em benefício individual e coletivo, nacional e internacional. As açōes desenvolvidas para o bloqueio da circulação do poliovírus selvagem, de modo especial, envolveram medidas multinacionais conjuntas com vistas a um mesmo resultado, cessar fogo em áreas de conflito e promover uma cultura preventiva em saúde. Essa luta ganhou proporções e contribuiu intensamente para o desenvolvimento dos programas nacionais de imunizações. No Brasil, há quase meio século, as ações vêm proporcionando a ampliação da rede pública de saúde, o aperfeiçoamento de sua infra-estrutura, a modernização de insumos materiais, equipamentos e procedimentos, a capacitação das equipes, 0 aprimoramento da metodologia de trabalho interdisciplinar, a visão de novos conceitos de atendimento ao público e a busca da universalidade, da equidade e da integralidade.

O desenvolvimento do PNI contribuiu de forma decisiva para a construção da história da saúde pública do país. A sociedade, fundamental para o seu êxito, dele usufrui e o apóia. As imunizações, que nos primeiros anos enfrentaram bravas resistências, com método e competência conquistaram aceitabilidade como bem público e hoje com responsabilidade e credibilidade promovem a participação e o controle social.

Poderíamos listar algumas outras grandes contribuições do PNI para a nação ao longo dos seus trinta anos: o planejamento em saúde pública, a metodologia de operacionalizaçấo de vultosas mobilizaçōes, a criteriosa metodologia de capacitação dos profissionais de saúde que atuam no setor público, avanços na ciência e tecnologia,'a valorização do cartão de vacinas e da história individual de saúde, a promoção da qualidade de vida e da longevidade, o olhar diferenciado para os grupos de maior vulnerabilidade, a garantia da cidadania, o processo contínuo e crescente de inclusão social. 
O PNI contribuiu ainda para o crescimento dos setores de informação e comunicação em saúde. O marketing para as campanhas, que nos primeiros anos reforçavam o temor e o preconceito e chocou a população, evoluiu. Com o passar do tempo, evocou heróis nacionais, explorou a diversidade ética, convocou a responsabilidade e o compromisso de vacinar, até chegar a um linguajar simples, diretamente voltado ao públicoalvo de cada vacinação proposta (Porto \& Ponte, 2003).

Com base nas experiências acumuladas no campo das imunizações, desenvolvidas num extenso e diversificado território e conquistadas pelo enfrentamento de críticas situaçōes epidemiológicas a cada época que culminou no controle das enfermidadesalvo (Gráficos 4, 5, 8 a 13), o Brasil garante sua contribuição em missões de cooperação técnica internacional, disponibiliza modelos de ações bem-sucedidas no setor e realiza doações de produtos imunobiológicos com a intermediação da Opas.

É desse modo que o PNI garantirá para o próximo decênio o apoio e a prioridade política, atendendo efetivamente às necessidades do povo brasileiro e contribuindo como medida pronta, eficaz e segura de promoção da saúde, proteção individual e, acima de tudo, coletiva, nacional e internacional. A saúde e o bem-estar públicos, no entanto, certamente que também terão o progresso como aliado. o desenvolvimento das cidades, o saneamento básico, o acesso à água potável e à cultura em saúde favorecerão, além das imunizações, a qualidade de vida.

Gráfico 8 - Incidência de difteria, coqueluche e tétano acidental. Brasil - 1990-2002*

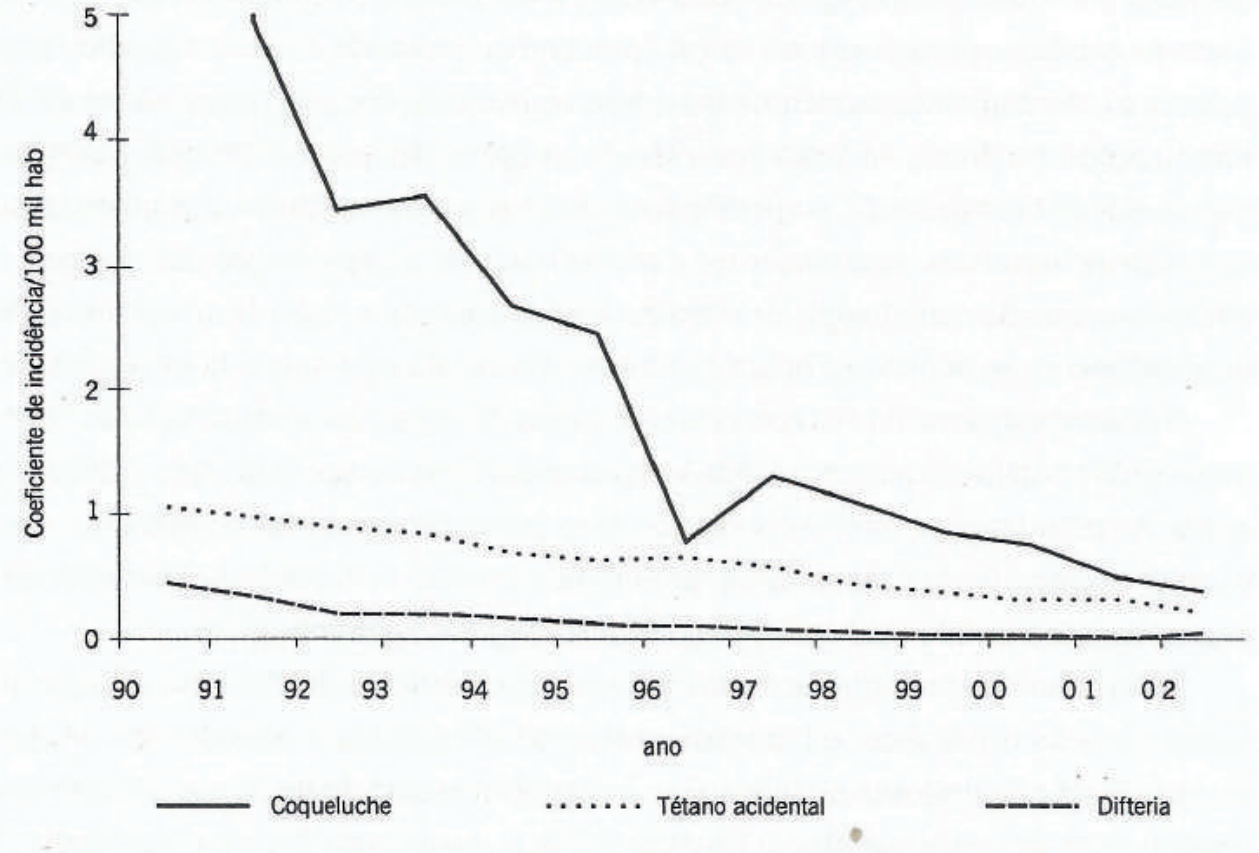

*Dados de morbidade sujeitos a alteraçâo 
Gráfico 9 - Incidência de sarampo e cobertura vacinal anti-sarampo em menores de um ano. Brasil - 1990-2002*

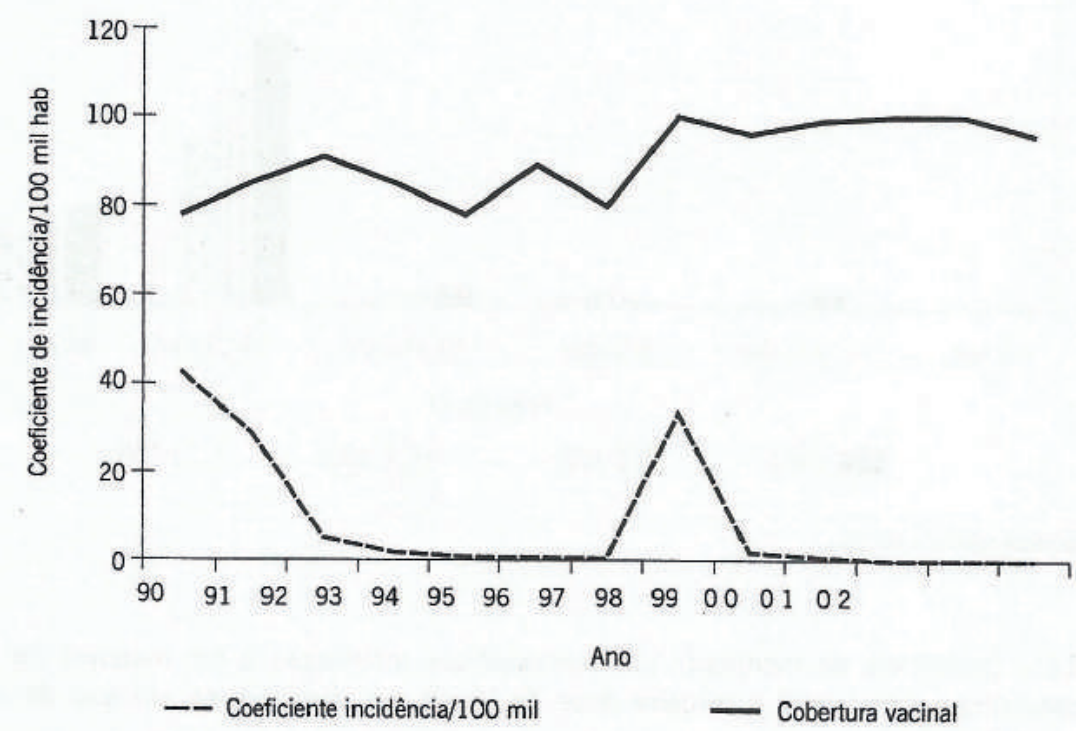

*Dados de morbidade sujeitos a alteração

Gráfico 10 - Incidência de meningite tuberculosa e cobertura vacinal com a BCG-ID em menores de um ano de idade. Brasil - 1990-2004*

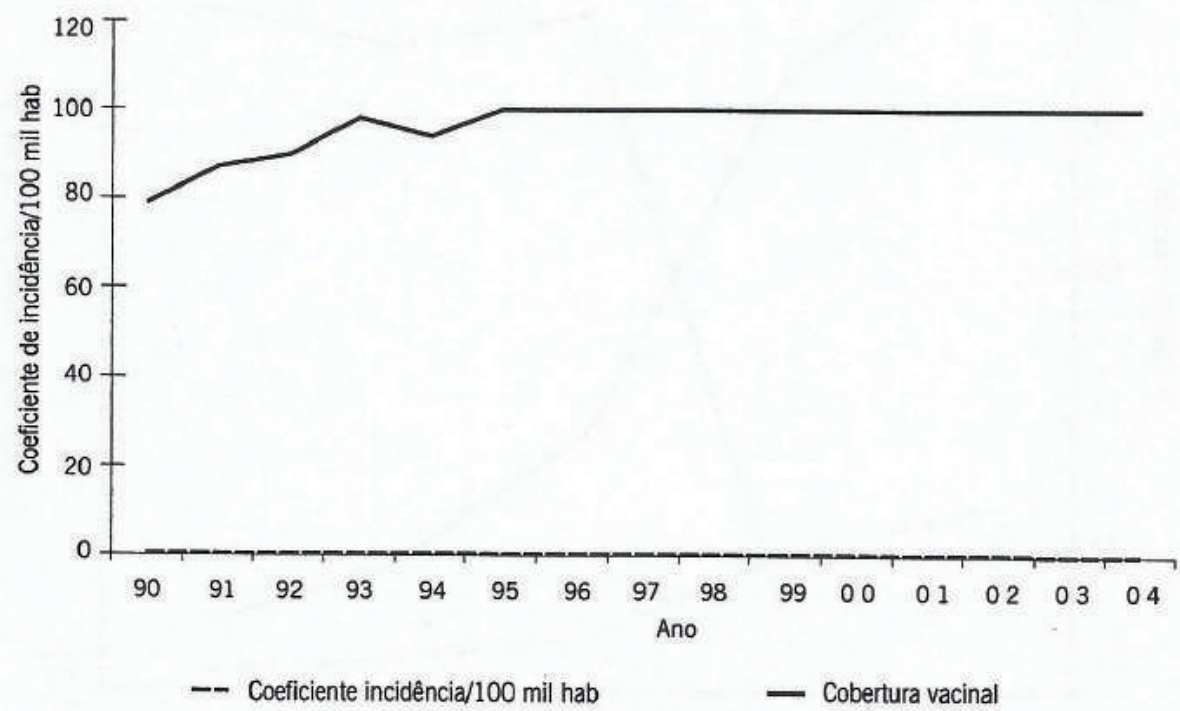

*Dados de morbidade sujeitos a alteração 
Gráfico 11 - Casos confirmados de tétano acidental por faixa etária. Brasil - 1998-2002*

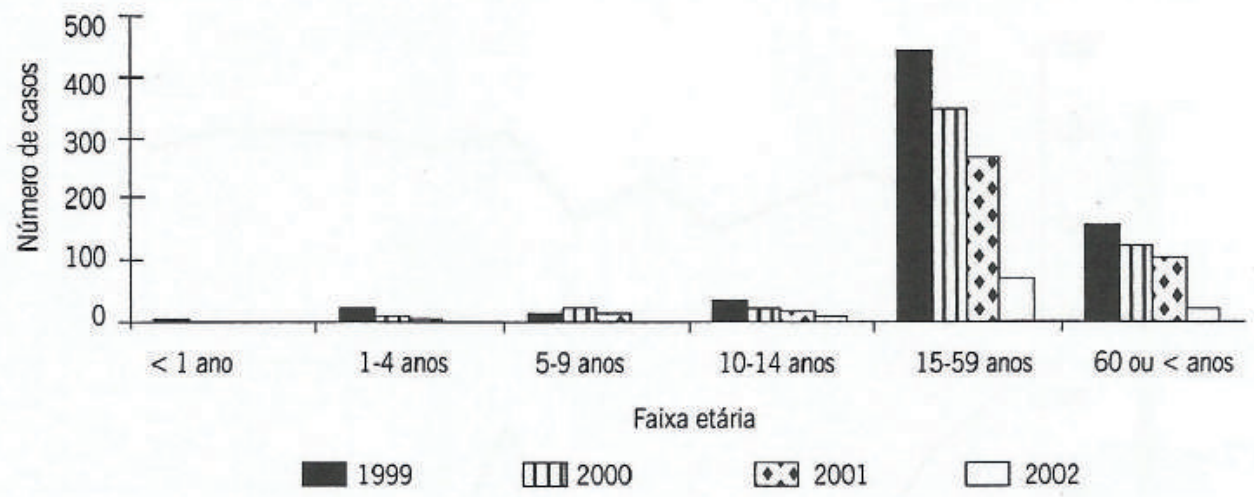

*Dados de morbidade sujeitos a alteraçāo.

Gráfico 12 - Incidência de meningite por Haemophilus influenzae b em menores de cinco anos e cobertura vacinal com a terceira dose da VcHib em menores de um ano de idade. Brasil - 1998-2002*

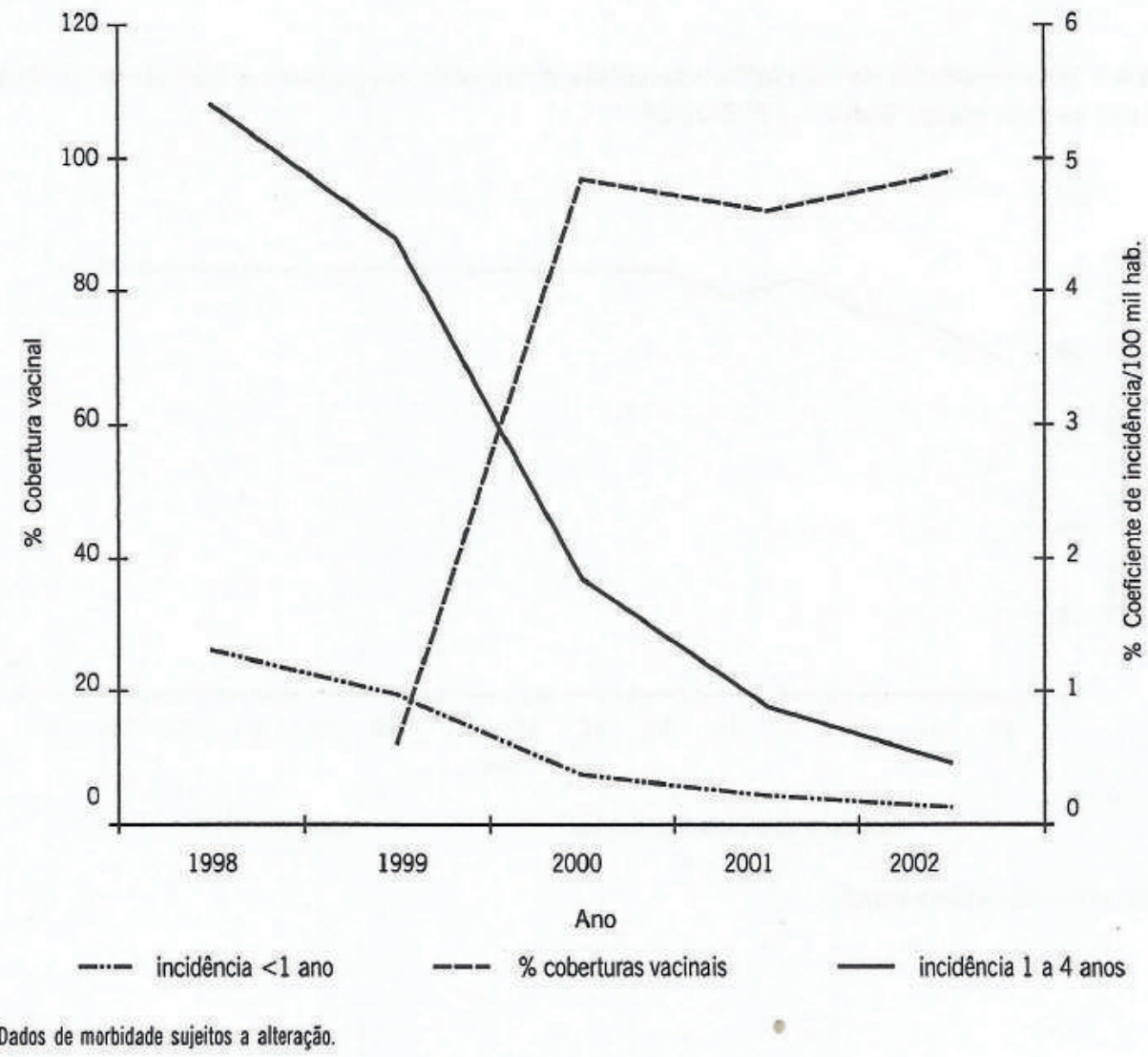


Gráfico 13 - Casos confirmados de tétano neonatal. Brasil - 1982-2003*

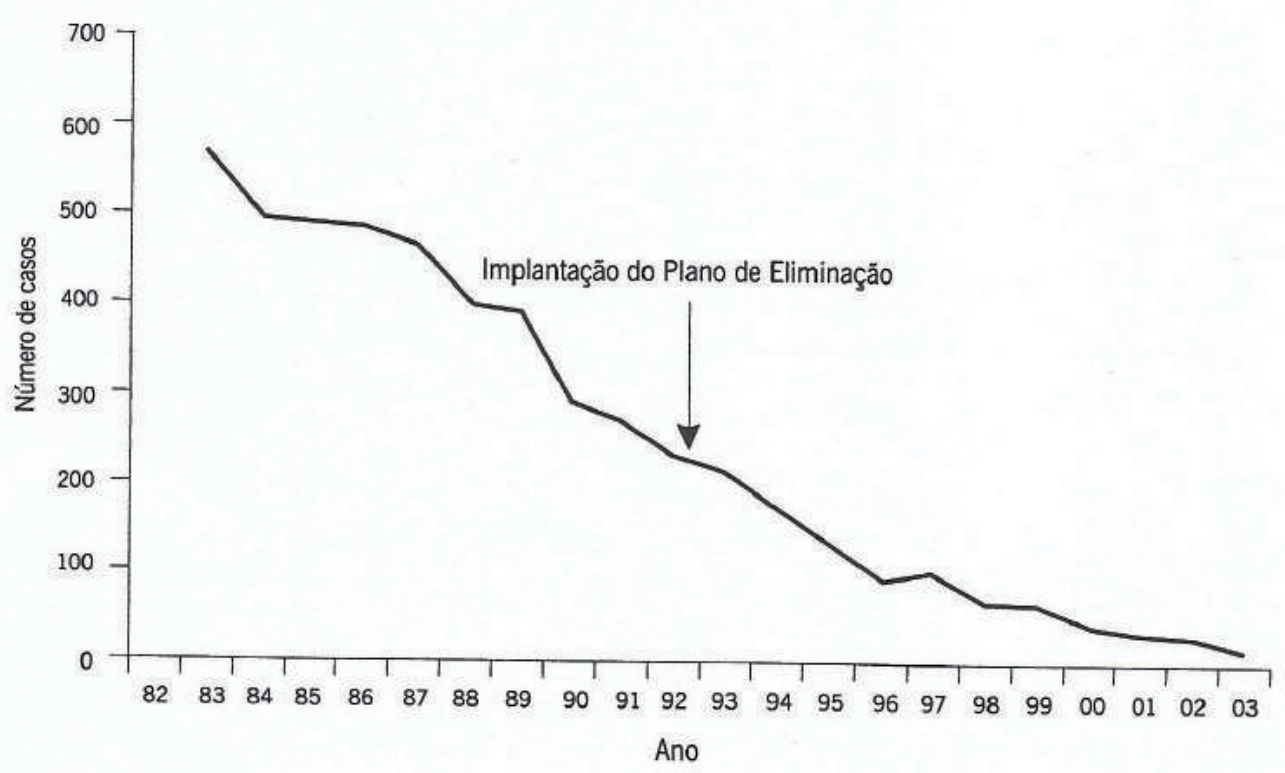

*Dados de morbidade sujeitos a alteração.

\section{REFERÊNCIAS BIBLIOGRÁFICAS}

BASSANEZI, M. S. C. B. \& BACELLAR, C. de P. Levantamento de população publicados da Província de São Paulo no século XIX, 2002. Disponível em: $<$ www.abep.nepo.unicamp.br/docs/anais/pdf/2002/GT_His_MR1_Bassanezi_texto.pdf > . Acesso em: jun. 2003.

BRASIL. Ministério da Saúde. Programa Nacional de Imunizaçōes. Brasília: MS, 1973.

BRASIL. Ministério da Saúde. Programa Nacional de Imunizaçōes 30 anos. Brasília: MS, 2003.

CAMPOS, A. L. V. de; NASCIMENTO, D. R. do \& MARANHÃO, E. A história da poliomielite no Brasil e seu controle por imunização. História, Ciências e Saúde-Manguinhos, 10 (supl. 2), 2003.

EMPRESA BRASILEIRA DE TURISMO (Embratur). Estatísticas do Turismo. Disponível em: <www.embratur.gov.br>. Acesso em: abr. 2005.

INSTITUTO BRASILEIRO DE GEOGRAFIA E ESTATÍSTICA (IBGE). Dados Censitários. Disponível em: <www.ibge.gov.br>. Acesso em: 24 de junho de 2003.

PORTO, A. \& PONTE, C. F. Vacinas e Campanhas: as imagens de uma história a ser contada. História, Ciências e Saúde-Manguinhos, 10 (supl.2), 2003.

TEMPORÃO, J. G. O Programa Nacional de Imunizaçōes (PNI): origens e desenvolvimento. História, Ciências e Saúde-Manguinhos, 10 (supl. 2): 601-617, 2003.

WTO: Datos Esenciales. Disponível em: <www.world_tourism.org>. Acesso em: 2004. 


\section{6}

\section{Imunobiológicos e Vigilância Sanitária}

Dario Pinto Miranda

Cláudio Maierovitch P. Henriques

As autoridades sanitárias nacionais têm a obrigação de assegurar que os imunobiológicos disponíveis no Brasil, importados ou de produção nacional, sejam seguros, de qualidade e eficácia comprovadas. Essas características são particularmente difíceis de comprovar, já que a segurança, a qualidade e a eficácia não podem ser determinadas exclusivamente por testes laboratoriais. Assim, é preciso que as autoridades sanitárias adotem uma série de medidas técnico-administrativas e laboratoriais que garantam que o fabricante de imunobiológicos cumpra com as normas nacionais ou internacionais para esses produtos, e que cada lote produzido esteja de acordo com os requerimentos estabelecidos no processo de registro aprovado.

Os imunobiológicos têm a particularidade de poderem ser aplicados em grupos de pessoas sadias, em especial em lactentes ou crianças menores. Ações de Vigilância Sanitária que permitam estabelecer os parâmetros de segurança, qualidade e eficácia dos imunobiológicos utilizados são atividades prioritárias para as autoridades sanitárias do país.

O programa de vacinação no Brasil, nos últimos vinte anos, tem logrado grande êxito em reduzir drasticamente os efeitos das doenças infecto-contagiosas no que se refere à mortalidade e à morbidade. Os êxitos alcançados são o resultado do Programa Nacional de Imunizações (PNI), bem estabelecido e gerenciado, e das medidas de Vigilância Sanitária que permitiram ao Programa contar com imunobiológicos seguros, de qualidade e eficazes. 
O Ministério da Saúde (MS), para cumprir seu papel de garantir à sociedade a utilização de medicamentos seguros, de qualidade e de eficácia comprovadas, estabeleceu, com a Lei 6.360, de 23 de setembro de 1976, regulamentada pelo Decreto 79.094, de 5 de janeiro de 1977, que todos os medicamentos - entre eles os imunobiológicos-, para serem comercializados e utilizados no país, deveriam ser registrados na, então existente, Secretaria Nacional de Vigilância Sanitária (SNVS/MS).

No final da década de 70 e início da década seguinte, três fatos importantes, relacionados à segurança, qualidade e atividade dos imunobiológicos utilizados no Brasil, causaram impacto no iniciante programa de imunizações do Ministério de Saúde. Lembrarmonos deles é interessante para entender todo o desenvolvimento das atividades de Vigilância Sanitária na área dos imunobiológicos, que se iniciaram no princípio da década de 80 .

1) Desvio na atividade (potência)

O PNI iniciou uma campanha de vacinação maciça contra as doenças controláveis pela vacina tríplice bacteriana DTP (difteria, tétano e coqueluche), utilizando aquelas fabricadas pelos produtores nacionais. Todavia, embora a cobertura vacinal aumentasse ano a ano, a incidência da coqueluche se mantinha elevada. Os pesquisadores da área propuseram, então, a hipótese de que as cepas que produziam a doença no Brasil eram totalmente diferentes, em suas características sorológicas, das cepas internacionais recomendadas para se preparar o componente coqueluche (pertussis) da vacina DTP. Portanto, não existia a possibilidade de proteção das crianças com a vacina obtida dessas cepas.

Assim, iniciou-se uma série de pesquisas para isolar a nova cepa de coqueluche que afetava as crianças brasileiras. Não se logrou, no entanto, isolar alguma que tivesse sorologia diferente das internacionalmente descritas, o que explicaria a possibilidade de que as vacinas preparadas no Brasil com as cepas recomendadas pela OMS năo davam proteçăo às crianças vacinadas.

Naquele momento, a Secretaria Nacional de Açōes Básicas de Saúde (SNABS) enviou ao exterior lotes da vacina DTP para controlar sua qualidade. Os resultados enviados pelo laboratório externo demonstraram que a atividade do antígeno coqueluche era inferior aos requerimentos mínimos estabelecidos pela OMS. Em conseqüência desse fato, o Ministério da Saúde teve de importar vacina DTP para cumprir as metas de vacinação do Programa de Imunizaçōes. Após dois anos de utilização do produto importado, a curva de incidência da doença decresceu até o mesmo patamar encontrado em países com programas nacionais de vacinação.

Este fato demonstrou que não só não existia uma cepa de coqueluche diferente no país, mas também que a vacina produzida pelos laboratórios nacionais não dava a proteção mínima às crianças.

2) Desvio na qualidade (esterilidade)

Para cumprir as metas de um dia de vacinação contra pólio, o Ministério da Saúde importou vacina pólio oral đe um laboratório da Europa Oriental. No dia da vacinação, que mobilizara dezenas de milhares de profissionais, apenas iniciada a atividade, a 
coordenação de vacinação da SNABS começou a receber ligaçōes telefônicas dos postos de vacinação do país informando que a vacina apresentava uma cor roxa intensa. O fato se devia à mudança de cor do indicador de $\mathrm{pH}$ agregado no momento de formular a vacina, utilizado como indicador de contaminação. O Ministério de Saúde teve que suspender aquele dia de vacinação.

O teste de esterilidade realizado pelo fabricante não detectou a contaminação do produto, e não existia no Brasil um laboratório que pudesse confirmar a esterilidade do imunobiológico adquirido.

3) Desvio na segurança (vírus residual)

Como consequiência de fracassos da vacinação contra a raiva, observados no tratamento de algumas pessoas mordidas por cães raivosos, o Ministério da Saúde determinou que todos os lotes dessa vacina produzidos no país deveriam ser submetidos a controle de qualidade lote a lote antes de serem utilizados. Foi a primeira vacina a ser controlada dessa forma, e a atividade foi iniciada no Centro de Referência em Raiva, que existia dentro de Bio-Manguinhos/Fiocruz. A investigação de alguns lotes de vacina com histórico de fracasso de vacinaçăo constatou a presença de vírus rábico residual (não inativado), que não fora detectado no teste realizado pelo produtor. Ou seja, a vacina, potencialmente, podia contaminar o usuário e causar raiva.

Esse episódio dramático tornou evidente que não existia um procedimento eficaz, por parte do produtor, para detectar a presença de vírus rábico residual. 0 desvio de qualidade relacionado à segurança dessa vacina demonstrou que um imunobiológico pode trazer danos graves, ao invés de benefícios para o usuário.

Como conseqüência de tais fatos, no início da década de 80, o Ministério da Saúde, através da SNABS, responsável pelo PNI, estabeleceu o Programa de Qualidade em Imunobiológicos, sob a responsabilidade de um grupo de trabalho (GT), que iniciou algumas atividades de vigilância sanitária sobre os imunobiológicos que vinham sendo utilizados nos programas oficiais de vacinação. As atividades incluíam: controle de qualidade lote a lote, inspeções nos produtores nacionais, solicitação de consultorias internacionais de especialistas e controle de qualidade externo dos imunobiológicos produzidos no país.

Na mesma época, requisitou-se ao Instituto Nacional de Controle de Qualidade em Saúde (INCQS), inaugurado em fins da década de 70 , que adequasse uma das áreas construídas para implantar o Programa de Controle de Qualidade, lote a lote, dos imunobiológicos utilizados nos programas oficiais de imunização do Ministério da Saúde. O Programa foi implantado progressivamente e, no final do ano de 1984, estava totalmente estabelecido, ligado operativamente ao PNI da SNABS/MS. Posteriormente, com a extinção desta Secretaria, foi criada a Fundação Nacional de Saúde (Funasa/MS), que assumiu as atividades desenvolvidas pelo PNI.

As atividades de vigilância sanitária sobre os produtos imunobiológicos foram desenvolvidas pelo PNI em conjunto com o INCQS durante a década do 80 , estendendo-se até o final da década de 90. Com a elaboração das Normas Nacionais de Produção e Controle de Qualidade de Imunobiológicos produzidos no país e com a realização de 
inspeções nos produtores nacionais para verificar o cumprimento dos requerimentos estabelecidos nas Boas Práticas de Fabricação (BPF), essas atividades de vigilância sanitária ampliaram-se.

Em meados da década do 90, a Secretaria de Vigilância Sanitária do Ministério da Saúde (SVS/MS), mediante uma portaria, transferiu para o INCQS a análise técnica da documentação de solicitação de registro de alterações pós-registro dos produtos imunobiológicos, a qual deveria ser feita previamente à publicação pela SVS. Essa atividade foi desenvolvida pelo INCQS até a publicação da RDC 80 , de março de 2000, pela Agência Nacional de Vigilância Sanitária (Anvisa), que retomou as atividades regulatórias referentes ao registro dos imunobiológicos.

O INCQS continua sendo o Laboratório Nacional de Controle de Qualidade das Autoridades Sanitárias, dando suporte técnico à Anvisa na análise dos procedimentos de controle de qualidade que fazem parte do processo de registro dos imunobiológicos. Ele é, também, o responsável pelo Programa de Controle de Qualidade lote a lote dos imunobiológicos utilizados oficialmente e participa de todas as atividades regulatórias relacionadas a esse controle.

Com o estabelecimento de um programa de produtos biológicos (entre eles os imunobiológicos), a Agência foi assumindo todas as atividades que uma autoridade regulatória tem que realizar para assegurar qualidade, eficácia e segurança dos imunobiológicos produzidos ou importados pelo país, de acordo com a documentação de orientação publicada pela OMS.

As principais atividades que a autoridade nacional regulatória, no caso a Anvisa, deve cumprir para assegurar a qualidade dos imunobiológicos no país são:

- Autorização de funcionamento

De acordo com a legislação vigente, todas as empresas que pretendam produzir ou importar imunobiológicos devem, primeiramente, solicitar às autoridades locais a licença municipal ou estadual; em seguida, devem requerer autorização prévia à autoridade sanitária federal. Segundo o regulamento interno da Anvisa, a Gerência de Inspeção de Medicamentos da Gerência Geral de Inspeção de Medicamentos e Produtos é a área responsável por conceder a autorização de funcionamento.

- Registro dos imunobiológicos

As empresas com autorização de funcionamento e com licença válidas para comercializar um produto por elas produzido ou importado devem solicitar autorização prévia para registro dos imunobiológicos à autoridade sanitária federal. De acordo com o regulamento interno da Anvisa, a Unidade de Produtos Biológicos e Hemoterápicos da Gerência Geral de Medicamentos é a área responsável por conceder o registro solicitado e autorizar as alterações pós-registro. A legislação vigente de produtos biológicos, onde estão incluídos os imunobiológicos, estabelece que não existe produto similar, todos eles são considerados novos e devem apresentar a documentação estabelecida na legislação em vigor, para análise da Anvisa. 
Um pré-requisito para conceder ou revalidar o registro de um produto imunobiológico é que a empresa solicitante do registro (detentora) e a empresa produtora do imunobiológico, nacional ou estrangeira, possuam o certificado de cumprimento das BPF. Isso garante que suas instalaçôes e procedimentos estão de acordo com as normas nacionais ou internacionais.

\section{- Inspeçāo}

De acordo com a legislação vigente, as empresas com autorização de funcionamento e com licença válidas para comercializar um produto imunobiológico registrado devem cumprir os requerimentos estabelecidos nas BPF de medicamentos. $O$ regulamento interno da Anvisa estabelece que a Gerência de Inspeção de Medicamentos da Gerência Geral de Inspeção de Medicamentos e Produtos é a área responsável pela verificação do cumprimento desses requerimentos e pela emissão do certificado de BPF.

Existe um programa na Anvisa, sob a responsabilidade da Gerência de Inspeção de Medicamentos, que fiscaliza todos os produtores nacionais e estrangeiros de imunobiológicos que têm produtos registrados no Brasil. Quanto às empresas importadoras de imunobiológicos, são as vigilâncias sanitárias locais que fazem a verificação do cumprimento das BPF no que diz respeito à recepção, ao armazenamento e à distribuição dos imunobiológicos importados.

- Vigilância pós-registro (farmacovigilância)

As atividades relacionadas à vigilância pós-registro dos imunobiológicos utilizados no país (desvios de qualidade, reações adversas e confirmação da atividade) são, conforme a legislação vigente, de competência da Unidade de Farmacovigilância da Gerência Geral de Medicamentos, que realiza tal trabalho, articulada à coordenação do PNI, da SVS/MS.

- Autorização dos estudos clínicos

De acordo com a legislação em vigor, os estudos clínicos com produtos imunobiológicos no Brasil requerem a autorizaçáo prévia do comitê de ética e pesquisa local; além disso, conforme a instituição patrocinadora da pesquisa, é necessária a aprovação prévia do comitê nacional de ética e pesquisa. As atividades relacionadas à vigilância sanitária de pesquisas clínicas são de responsabilidade da Gerência de Medicamentos Novos e Estudos Clínicos da Gerência Geral de Medicamentos.

- Controle da propaganda e promoção dos imunobiológicos

De acordo com o regulamento interno da Anvisa, a Gerência de Controle e Fiscalização de Medicamentos e Produtos da Gerência Geral de Inspeção de Medicamentos e Produtos é a área responsável pelo controle das atividades de propaganda e promoção dos imunobiológicos. .

- Controle de qualidade lote a lote dos imunobiológicos

A atividade de controle de qualidade lote a lote dos imunobiológicos a serem utilizados no país e a emissão dos laudos analíticos indicando se o lote analisado está de 
acordo com as especificações estabelecidas no registro do produto sâo de responsabilidade do INCQS.

Esse tipo de controle de qualidade pode ter duas modalidades: 1) controle de qualidade analítico, em que o INCQS realiza todos ou quase todos os testes preconizados pelas normas nacionais e internacionais e, de acordo com os resultados obtidos, emite laudo analítico; 2) controle de qualidade documental, em que o INCQS analisa a documentação de controle de qualidade do lote e emite parecer técnico sobre a conformidade dos testes realizados pelo controle interno do produtor.

- Liberação dos lotes de imunobiológicos para uso

A atividade de liberar para uso os lotes de produtos imunobiológicos registrados, com a documentação conforme e/ou com laudo do INCQS satisfatório, é realizada pela autoridade sanitária, o que permite garantir que os imunobiológicos utilizados no país são seguros, de qualidade e eficácia comprovadas.

Dessa forma, pode-se dizer que, ao lado de um dos programas de imunizações mais abrangentes do mundo, o PNI, o Brasil conta com um sistema de controle sanitário de vacinas capaz de verificar os diversos pontos da cadeia, desde as condições de produção até a notificação de eventos adversos. A integração entre os sistemas de Vigilância Sanitária e Vigilância Epidemiológica confere à população brasileira um elevado grau de confiabilidade na segurança e na eficácia dos produtos em questão.

Finalmente, não podemos nos esquecer da imensa tarefa que tem o Sistema Nacional de Vigilância Sanitária de Imunobiológicos, com as novas tecnologias de preparação de vacinas, que estão sendo desenvolvidas no mundo, em busca de antígenos de maior atividade e com menos reaçōes adversas; novas vacinas que, em um futuro mais próximo do que imaginamos, estarão disponíveis no mercado internacional para prevenir uma série de doenças que afetam a humanidade. Esse é nosso grande desafio: estarmos prontos para poder dar uma resposta tecnicamente satisfatória à demanda desses novos produtos. Devemos lembrar sempre que nossa tarefa maior está entrelaçada diretamente com a expectativa dos pesquisadores da área de produção de vacinas: produzir uma vacina em dose única, oral, de múltiplos antígenos, aplicável nos primeiros dias de vida e de proteção para toda a vida. Temos de nos preparar para tão importante e interessante desafio que pode bater à nossa porta mais cedo do que pensamos. 


\section{Controle de Qualidade dos Imunobiológicos:}

\section{participação do Instituto Nacional de Controle de Qualidade em Saúde (INCQS) - Fiocruz}

André Luis Gemal

Eduardo Chaves Leal

\section{O INSTITUTO NACIONAL DE CONTROLE DE QUALIDADE EM SAÚDE}

Em 16 de fevereiro de 1954, o Presidente da República, Getúlio Vargas, sancionou a Lei 2.187 (Brasil, 1954), criando o Laboratório Central de Controle de Drogas e Medicamentos (LCCDM), que, logo em seguida, foi transformado em LCCDMA por se tornar responsável também pelo controle dos alimentos.

Pode-se considerar que, no âmbito do Ministério da Saúde (MS), tem início a moderna história do controle sanitário no Brasil e dos trabalhos técnico-científicos sobre os chamados produtos que afetam a saúde. São especificamente mencionados no artigo segundo da Lei 2.187: drogas, plantas medicinais, especialidades farmacêuticas, antisépticos, desinfetantes, produtos biológicos e químicos e quaisquer outras substâncias que interessem à saúde pública (Brasil, 1954).

O LCCDMA deveria trabalhar apoiando tecnicamente o já existente Serviço Nacional de Fiscalização da Medicina nas chamadas licenças, autorizaçōes de funcionamento, inspeções e outros atos afetos ao que atualmente é chamado de Vigilância Sanitária. Vale ressaltar que a lei de 1954 criava diversas taxas que deveriam servir para auxiliar na manutenção das atividades laboratoriais especificas, incluindo as referentes à análise prévia e fornecimento de padrões.

O Decreto 82.201, de 30/8/1978 (Brasil, 1978), publicado 24 anos depois, transfere o LCCDMA para a Fundação Oswaldo Cruz (Fiocruz) e, logo em seguida, em 1981, o Ato da 
Presidência da Fiocruz 044/81-PR (Brasil, 1981) altera seu nome para Instituto Nacional de Controle de Qualidade em Saúde (INCQS), que mantém até hoje. Suas novas instalações foram inauguradas em setembro do mesmo ano, contando com a presença do Presidente da República à época, General João Baptista de Oliveira Figueiredo. Com uma área de $12.000 \mathrm{~m}^{2}$, o INCQS passou a ser uma das estruturas laboratoriais mais modernas da América Latina. Contando com apoio político e financeiro necessários para contratação e treinamento dos recursos humanos, o Instituto assumiu a sua missão, relacionada ao controle de qualidade dos produtos vinculados à Vigilância Sanitária e, principalmente naquele momento, dos produtos imunobiológicos.

Esse quadro permaneceu inalterado até o final de 1998, com a edição da Medida Provisória 1.791/1998, que, votada, foi transformada na Lei 9.782/99, criando a Agência Nacional de Vigilância Sanitária (Anvisa). A partir de entăo, o INCQS, com a edição de uma nova Medida Provisória, 2.000-17/2000, passa a manter um 'vínculo administrativo' com a Fiocruz e um 'vínculo técnico' com a recém-criada Anvisa. Essa situação peculiar, no entanto, não foi ainda regulamentada.

\section{O CONTROLE DE QUALIDADE OFICIAL DOS IMUNOBIOLÓGICOS NO BRASIL}

A história do controle de qualidade oficial dos imunobiológicos utilizados no Brasil se inicia com a criação do Programa Nacional de Imunização (PNI) em 1973 (Brasil, 1998b), o qual tinha como objetivo a promoção do controle das principais doenças infecto-contagiosas da época: sarampo, poliomielite, tuberculose, tétano, difteria e coqueluche. Elaborado por profissionais da Divisão Nacional de Epidemiologia e Estatística de Saúde (DNEES), do Departamento Nacional de Profilaxia e Controle de Doenças do Ministério de Saúde (DNPCD) e da Central de Medicamentos (Ceme), o PNI incorporava, no seu documento de criação, a necessidade de aferição da qualidade dos antígenos para uso humano (Da Ponte, 2003). Reconhecia-se, assim, a importância, para o país, de contar com uma infra-estrutura laboratorial capaz de avaliar os requisitos de qualidade das vacinas a serem aplicadas na população.

Embora o otimismo quanto à diminuição das incidências das doenças evitáveis pelo uso de vacinas fosse grande, a cobertura vacinal crescia de forma lenta ao longo dos anos. Dessa forma, em 1979, com intuito de analisar os problemas enfrentados pelo PNI, o governo criou uma comissão interministerial formada por um representante da Organização Pan-Americana da Saúde (Opas), por técnicos do MS e do Ministério da Previdência e Assistência Social. 0 relatório da comissão teceu forte crítica, principalmente quanto à forma como o programa vinha sendo conduzido e à precariedade do sistema nacional de saúde, que deveria dar suporte ao Programa. Além disso, o relatório também apontava que deveria ser dada atenção especial às questōes relacionadas à produção e ao controle de qualidade dos produtos. Recomendava-se apoio ao desenvolvimento de vacinas nacionais, por meio de investimentos nos produtores nacionais, bem como a criação de mecanismos de análise, por laboratórios externos, até que o país pudesse contar com uma estrutura laboratorial em condições de assumir as atividades de avaliação da qualidade e da conformidade - principalmente as relacionadas à esterilidade e potência das vacinas ofertadas à população. 
A partir de 1980, a dinamização das estratégias de imunização em massa levou a um aumento considerável do número de doses de imunobiológicos compradas pelo governo e distribuídas à população. Novamente, demonstrou-se imprescindível que o país contasse com uma estrutura laboratorial capaz de avaliar a qualidade dos produtos adquiridos - de forma independente dos produtores - e mantivesse um trabalho contínuo e integrado ao PNI, mas garantindo autonomia, conforme os preceitos da Organização Mundial da Saúde (OMS).

Outro fato que reforçou a importância da avaliação oficial prévia da qualidade desses biológicos para a liberação de seu uso foi a deteç̧ão de contaminação microbiológica da vacina oral contra a poliomielite, produzida pelo Laboratório Torlak, da Iugoslávia, que seria usada nas campanhas de vacinação infantil de 1981.

A suspeita ocorreu durante os preparativos da campanha, quando foram observadas alterações em alguns frascos do produto e na coloração, como também presença de corpos estranhos em suspensão. As análises laboratoriais foram realizadas na Fiocruz, que identificou a presença do fungo Penicillium $\mathrm{sp}$. Com isso, adiaram-se as campanhas, previstas para ocorrer em junho e agosto do mesmo ano, já que o Laboratório Torlak não tinha condições de repor os lotes contaminados em tempo hábil.

Esse episódio levou o MS a discutir a implementação de um Sistema Nacional de Controle de Qualidade, procurando identificar laboratórios em condições de realizar as análises, principalmente a verificação da potência da vacina contra poliomielite, que passou, então, a ser realizada pelo Departamento de Virologia do Instituto Oswaldo cruz. Posteriormente, em virtude de colaborações de repasse de tecnologia da produção dessas vacinas, essa verificação passou a ser realizada pelo Instituto de Tecnologia em Imunobiológicos - Bio-Manguinhos, cujos técnicos eram treinados em instituições japonesas. No início de 1983, o INCQS assume a responsabilidade pelo controle oficial de todos os produtos e lotes dos imunobiológicos a serem utilizados pelo PNI.

\section{Análise laboratorial e liberação de lotes}

A responsabilidade do INCQS pelo controle de qualidade dos imunobiológicos tem início com a implementação dos ensaios biológicos, microbiológicos, químicos e físicoquímicos nos soros e vacinas. Ao final de 1985 , já eram realizadas análises laboratoriais de todas as vacinas virais (pólio, sarampo, febre amarela, raiva), das vacinas bacterianas (BCG, DTP, DT, dT) e dos soros hiperimunes (antitóxicos, antipeçonhentos e antirábico), adquiridos pelos programas oficiais de imunização. No processo contínuo de oferta de novas vacinas à população brasileira, outros produtos foram introduzidos. Ainda na década de 80 , a vacina contra meningite meningocócica teve o seu controle oficial implementado. Em seguida, muitas outras passaram a fazer parte do PNI e são avaliadas pelo Instituto, como, por exemplo, as vacinas contra gripe e, mais recentemente, hepatite A (Quadro 1) (Brasil, 2001).

Após 1994, conforme critérios da OMS, os produtos - tanto os de produção nacional quanto os importados - passaram a ser liberados para consumo após análise laboratorial e análise do protocolo resumido de produção e controle de qualidade emitido pelo 
fabricante. Para tanto, foram realizadas reuniões com os produtores nacionais e padronizaram-se os protocolos resumidos de todos os produtos, de acordo com as normas de produção e controle publicadas nas séries de informes técnicos da OMS.

Quadro 1 - Vacinas introduzidas no PNI após 1990

\begin{tabular}{|c|c|}
\hline Ano & Imunobiológico \\
\hline 1990 & Vacina contra hepatite B \\
\hline 1992 & Vacina contra caxumba, sarampo e rubéola \\
\hline 1993 & Vacina contra Haemophilus tipo b e pneumocócica 23 \\
\hline 1998 & $\begin{array}{l}\text { Vacina conjugada contra Haemophilus tipo b } \\
\text { Vacina contra gripe }\end{array}$ \\
\hline 1999 & $\begin{array}{l}\text { Vacina contra raiva, produzida em cultura de célula } \\
\text { Vacina contra varicela }\end{array}$ \\
\hline 2001 & $\begin{array}{l}\text { Vacina tetravalente (DTP }+ \text { Hib) } \\
\text { Vacina contra hepatite } \mathrm{A} \\
\text { Vacina conjugada contra meningite meningocócica sorotipo } \mathrm{C}\end{array}$ \\
\hline 2002 & $\begin{array}{l}\text { Vacina pentavalente (DTP + Hib + HBV) } \\
\text { Vacina conjugada antipneumocócica heptavalente }\end{array}$ \\
\hline
\end{tabular}

Assim, nos vinte anos (1983 a 2003) em que o INCQS vem assumindo a responsabilidade pelo controle de qualidade oficial dos produtos imunobiológicos adquiridos pelos programas oficiais de imunização do Estado brasileiro, foram analisados mais de 25.000 lotes de produtos (Tabelas 1 a 4) (Brasil, 2001). Essas avaliações laboratoriais vêm sendo fundamentais a fim de garantir que somente produtos que demonstrem requisitos mínimos de qualidade e conformidade sejam aplicados na população.

Como conseqüência desse trabalho, foram detectados desvios de qualidade e conformidade em vários lotes de vacinas, como também em lotes de soros hiperimunes, emitindo-se laudos de reprovação, principalmente em ensaios de toxicidades (específica e inespecífica), potência, esterilidade, e pirogêneo. O controle permanente de todos os lotes dos diferentes imunobiológicos levou a uma diminuição contínua do percentual de reprovação dos soros e vacinas a serem utilizados na população (Tabela 5).

A qualidade e a importância do trabalho realizado levam o INCQS a ter uma crescente inserção internacional. Já a partir de 1993, por exemplo, participou do estudo colaborativo para estabelecimento de padrões de referência e harmonização de metodologias de controle de vacinas contra sarampo, febre amarela, raiva, pólio oral, BCG e DPT na Rede Regional Nacional de Laboratórios de Controle de Qualidade de Vacinas (RRNLCQV), apoiado pelo Sistema Regional de Vacinas (Sireva/Opas). Essa rede contava com a presença dos principais laboratórios oficiais de controle de qualidade da América do Sul: Instituto Dr. Carlos Malbran, da Argentina; Instituto Nacional de Vigilancia de Medicamentos y Alimentos - Invima, da Colômbia; Instituto Nácional de Salud Pública, do Chile; Instituto Leopoldo Perez Izquieta, do Equador; e Instituto Rafael Rangel, da Venezuela. Contava, ainda, com o Centro Estatal de Control de Medicamentos, de Cuba e o Laboratorio Nacional de Salud Pública, do México. Neste contexto, o INCQS participou de 
todos os estudos colaborativos para estabelecimento de padrões e harmonização de métodos de potência de referência e coordenou três desses estudos: vacina contra raiva, vacina contra febre amarela e vacina oral contra pólio.

Tabela 1 - Número de lotes de produtos imunobiológicos analisados - 1986 a 1991

\begin{tabular}{l|r|r|r|r|r|r|r}
\hline Ano/Produto & 86 & 87 & 88 & 89 & 90 & 91 & TOTAL \\
\hline Diluente & 72 & 130 & 122 & 133 & 142 & 280 & 879 \\
Soros & 30 & 31 & 121 & 131 & 67 & 96 & 476 \\
Vacinas & 526 & 723 & 837 & 877 & 1.209 & 769 & 4.941 \\
TOTAL & 628 & 884 & 1.080 & 1.141 & 1.418 & 1.145 & 6.296 \\
\hline
\end{tabular}

Tabela 2 - Número de lotes de produtos imunobiológicos analisados - 1992 a 1997

\begin{tabular}{l|r|r|r|r|r|r|r}
\hline Ano/Produto & 92 & 93 & 94 & 95 & 96 & 97 & TOTAL \\
\hline Diluente & 218 & 120 & 197 & 176 & 220 & 291 & 1222 \\
Soros & 81 & 113 & 94 & 78 & 127 & 149 & 642 \\
Vacinas & 670 & 620 & 914 & 548 & 1.101 & 1.602 & 5.455 \\
TOTAL & 969 & 853 & 1.205 & 802 & 1.448 & 2.042 & 7.319 \\
\hline
\end{tabular}

Tabela 3 - Número de lotes de produtos imunobiológicos analisados - 1998 a 2003

\begin{tabular}{l|r|r|r|r|r|r|r}
\hline Ano/Produto & 98 & 99 & 00 & 01 & 02 & 03 & TOTAL \\
\hline Diluente & 272 & 424 & 371 & 283 & 241 & 262 & 1.853 \\
Soros & 112 & 106 & 124 & 144 & 100 & 113 & 699 \\
Vacinas & 1.385 & 1.881 & 1.515 & 1.083 & 1.172 & 904 & 7.940 \\
TOTAL & 1.769 & 2.411 & 2.010 & 1.510 & 1.513 & 1.279 & 10.492 \\
\hline
\end{tabular}

Tabela 4 - Número de lotes de produtos imunobiológicos analisados - 1986 a 2003

\begin{tabular}{l|c|c|c|c}
\hline Período/Produto & 86 a 91 & 92 a 97 & 98 a 03 & TOTAL \\
\hline Diluente & 272 & 424 & 371 & 1.853 \\
Soros & 112 & 106 & 124 & 699 \\
Vacinas & 1.385 & 1.881 & 1.515 & 7.940 \\
TOTAL & 1.769 & 2.411 & 2.010 & 10.492 \\
\hline
\end{tabular}

Tabela 5 - Percentual de resultados insatisfatórios - 1986 a 2002

\begin{tabular}{l|c|c|c}
\hline & 86 a 89 & 90 a 94 & 00 a 02 \\
\hline Total analisado & 3.733 & 5.590 & 5.033 \\
Total reprovado & 420 & 239 & 73 \\
Percentual de reprovaçäo & $11,25 \%$ & $4,27 \%$ & $1,45 \%$ \\
\hline
\end{tabular}


Com a experiência de sete anos em controle de qualidade de vacinas, em 1989, o Instituto passa a ser um dos laboratórios colaboradores da rede credenciada pela OMS para realizar análises de potência e termoestabilidade na vacina oral contra pólio, adquirida por intermédio do Fundo Rotatório da Opas. Alguns anos depois, em 1987, é solicitado a ampliar esta colaboração internacional, realizando ensaios de potência na vacina contra febre amarela e posteriormente, em 2003, avaliando as vacinas contra raiva.

Como conseqüência de um acordo firmado com a Anvisa e a Funasa, em reunião realizada em junho de 2002 em Brasília, o INCQS passa, a partir do início de 2003, a não mais realizar análise laboratorial em todos os lotes de algumas vacinas. A liberação do laudo analítico desses insumos se dá após a verificação das informações descritas nos protocolos de produção e controle de qualidade do produto e, no caso de importados, também com base no certificado de liberação emitido pela autoridade regulatória do país de origem. Essa decisão levou em consideração três critérios básicos: histórico de consistência de resultados analíticos satisfatórios ao longo dos anos; autorização de comercialização expedida pela Anvisa (registro) e ausência de eventos adversos. Tal procedimento é sugerido como forma efetiva de controle de qualidade pela OMS e já vem sendo realizado pelos principais laboratórios oficiais dos países de tecnologia de ponta.

\section{Normas técnicas sobre produção e controle de qualidade}

No momento em que o INCQS assumiu a responsabilidade pela avaliação da qualidade dos imunobiológicos utilizados nos programas oficiais de imunização, havia um conjunto de atos legais que incluía, em seu escopo, o tema produção e controle de qualidade.

Dentre esses atos, a Portaria 35, de 9 de setembro de 1974 (Brasil, 1974), do Serviço Nacional de Fiscalização de Medicina e Farmácia - organismo responsável pelas instruções a serem observadas no licenciamento e revalidação de licenças de determinados produtos biológicos -, apresentava 19 anexos em forma de monografias. Nestes, constavam informações sobre a composição do produto, normas gerais de produção, controle de qualidade nos processos de produção, lote final, prazo de validade, condições de conservação e administração de produtos específicos, tais como: soros antitóxicos e soros antipeçonhentos, toxóide tetânico, além de vacinas de vírus e de bactérias, inativados ou atenuados.

Por sua vez, o Decreto 79.094, de 5 de janeiro de 1977 (Brasil, 1977) - que regulamenta a Lei 6.360, de 23 de setembro de 1976 (Brasil, 1976), a qual submete os medicamentos, insumos farmacêuticos, drogas e outros produtos ao sistema de vigilância sanitária - incluía, entre os artigos 130 a 142, título XII, as medidas a serem adotadas para o controle de qualidade e da inspeção da produção.

Outro ato, a Resolução Normativa 10, de dezembro de 1978 (Brasil, 1979), da Câmara Técnica de Medicamentos do Conselho Nacional de Saúde, estabelecia as normas técnicas básicas relacionadas com a prescrição, produção e emprego dos medicamentos. Em seu escopo, constavam normas complementares - subordinadas às disposiçōes da Lei 6.360 
(Brasil, 1976) e seu regulamento, o Decreto 79.094 (Brasil, 1977) - sobre os produtos biológicos destinados à prevenção e tratamento de doenças infecciosas. Essa Resolução definia que a eficácia dos produtos biológicos devia ser comprovada mediante exames de laboratórios e ensaios clínicos, mencionando, ainda, os tipos de testes a serem aplicados.

Por outro lado, a Farmacopéia Brasileira publicava em 1977, na sua terceira edição, monografias das principais vacinas e soros disponíveis para uso.

Contudo, apesar da existência desses atos legais, eles não eram capazes de sustentar de maneira adequada as ações técnicas de vigilância sanitária dos produtos imunobiológicos. Careciam de informações mais específicas sobre controle de qualidade, com particular referência às normas técnicas de produção e controle. Mesmo as monografias publicadas na terceira edição da Farmacopéia Brasileira não continham informaçōes completas sobre os requisitos mínimos de qualidade do produto ou dos principais métodos analíticos a que deveriam ser submetidos e, portanto, também não serviam de parâmetro para as ações legais.

Dessa forma, para resolver esse impasse, documentos internacionais, como farmacopéias de outros países e, principalmente, as normas técnicas sobre produção e controle de qualidade, publicadas nas séries de informes técnicos da OMS, passaram a ser utilizados. Com o fortalecimento do PNI e a elaboração de uma nova proposta de política nacional de imunobiológicos - a partir da institucionalização do Programa Nacional de Auto-Suficiência em Imunobiológicos (Pasni) em 1986 (Brasil, 1998b) -, fez-se necessário elaborar documentos oficiais nacionais, nos quais seriam definidos os procedimentos de produção e do controle de qualidade das diversas etapas de produção, lote final e das matérias-primas, dos soros e das vacinas utilizadas pela população. Para tal, vários grupos de especialistas se reuniram para atender à necessidade de elaboração dessas normas técnicas específicas, que deveriam englobar os seguintes produtos: soros antipeçonhentos, soros antitóxicos, soro anti-rábico, toxóide tetânico, vacinas contra sarampo, vacina oral contra poliomielite, vacina contra febre amarela, vacina contra raiva para uso humano, vacina BCG, vacina dupla DT e dT e vacina tríplice DPT.

Participavam do grupo de especialistas representantes dos diversos laboratórios nacionais produtores de imunobiológicos, como o Instituto Butantan, o Instituto de Tecnologia em Imunobiológicos - Bio-Manguinhos, o Instituto Vital Brazil (IVB), a Fundação Ataulpho de Paiva (FAP), a Fundação Ezequiel Dias (Funed) e o Instituto de Tecnologia do Paraná (Tecpar); representantes do INCQS; da Opas e do Programa Nacional de Imunização da Divisão Nacional de Epidemiologia da então Secretaria Nacional de Ações Básicas de Saúde (SNABS).

Para a elaboração das normas, foram necessárias várias reuniōes dos diferentes grupos envolvidos em cada um dos produtos específicos, tornando-a, assim, um proces so lento e de custo elevado. Por isso, somente em 1997, foram publicadas as Portarias SVS/MS 174/96 (normas técnicas de produção e controle de qualidade dos soros antiofídicos, antitóxicos e do anti-rábico) (Brasil, 1996a); SVS/MS 175/96 (normas técnicas de 
produção e controle de qualidade das vacinas tríplice bacteriana, toxóide tetânico, dupla adulto e dupla infantil) (Brasil, 1996b) e SVS/MS 176/96 (normas técnicas de produçãoe controle de qualidade da vacina contra raiva para uso humano (CCL) - FuenzalidaPalacios) (Brasil, 1996c). Duas outras Portarias, 661 (Brasil, 1997) e 551 (Brasil, 1998a), relativas a normas da vacina tríplice DPT, também foram publicadas nos anos de $1997 \mathrm{e}$ 1998, respectivamente.

O trabalho de elaboração das normas técnicas nacionais dos outros produtos não foi concluído por esses grupos, pois o Ministério passou a implementar essa ação por meio do incentivo às atividades da Farmacopéia Brasileira.

Destaca-se que, como o modelo brasileiro de Vigilância Sanitária adota a separação entre o Laboratório Nacional e a Farmacopéia, somente em 1994 o INCQS passa a ter um representante na Comissão Permanente de Revisão da Farmacopéia Brasileira (CPRFB), responsável pela atualização, revisão e elaboração de monografias dos produtos farmacêuticos. Em 1988, a Farmacopéia Brasileira publica sua quarta edição, porém composta apenas pela parte 1 , na qual se encontram os métodos analíticos gerais biológicos, químicos e físico-químicos, pouco avançando nas necessidades técnicas do setor.

Com objetivo de efetuar a revisão e atualização das monografias editadas na terceira edição e de elaborar novas monografias a serem incluídas na quarta edição, publicandose novos fascículos, foram criadas diversas subcomissões específicas para o trabalho. A subcomissão responsável pela revisão e elaboração das monografias dos imunobiológicos foi oficializada no Diário oficial da União em 1997, sendo o grupo composto por representantes dos principais laboratórios nacionais produtores de imunobiológicos, por um doutor em microbiologia de uma universidade pública e por um representante do INCQS, coordenador da subcomissão.

A subcomissão de imunobiológicos priorizou, em um primeiro momento, a elaboração das monografias dos principais produtos utilizados pelos programas oficiais de imunização. O trabalho foi realizado de acordo com o guia para elaboração de monografias da CPRFB, tomando como base as normas técnicas sobre produçăo e controle de qualidade, publicadas nas séries de informes técnicos da OMS, monografias de farmacopéias internacionais e os relatórios técnicos para fins de registro dos produtos comercializados.

A primeira publicação dessas monografias ocorreu no segundo fascículo da quarta edição. Em 2000, foram publicadas outras 28, sendo 12 de soros hiperimunes (antipeçonhentos, antitóxicos e anti-rábico), além de 16 sobre vacinas. Essa quantidade de monografias foi capaz de abranger a necessidade de praticamente $90 \%$ dos produtos utilizados pelos programas nacionais de imunização.

Algumas monografias publicadas no segundo fascículo receberam revisões e foram republicadas no terceiro fascículo em 2002. No quinto e no sexto fascículos, com publicação prevista para o ano de 2004, estarão presentes monografias de novos imunobiológicos, além daquelas que foram revisadas dos fascículos anteriores, em um movimento contínuo de atualização, necessário para acompanhar a incorporação de novos produtos ao mercado e de novas tecnologias aos produtos tradicionais. 


\section{Autorização de comercialização e Boas Práticas de Fabricação (BPF)}

A partir de 1993, em Portaria da Secretaria Nacional de Vigilância Sanitária (Portaria 109, de 4 de novembro de 1993) (Brasil, 1993), o então Secretário Ronan Tanus delega ao INCQS a responsabilidade pela análise e emissão de pareceres técnicos nos processos de solicitação de registro e, também, pelas visitas de inspeção à indústria produtora de imunobiológicos para aferição do cumprimento das Boas Práticas de Fabricação (BPF). Fundamentou-se na capacidade científica e técnica existente no Instituto e no fato de este ser o laboratório nacional que realiza as análises de controle de qualidade nos imunobiológicos.

Com essa atribuição, o INCQS passou, segundo os critérios estabelecidos pela OMS, a ter maior participação nas seis funçōes (avaliação dos requisitos mínimos de qualidade por meio de análise laboratorial; liberação de lotes; registro; inspeção das BPF; farmacovigilância; e autorização para estudos de clínicos) de uma autoridade de vigilância sanitária consideradas essenciais para garantir a qualidade dos produtos imunobiológicos a serem utilizados pela população. Assumiram-se quatro dessas atividades fundamentais: avaliação dos requisitos mínimos de qualidade por meio de análise laboratorial; liberação de lotes; registro; e inspeção das BPF.

Nos anos de 1994 e 1995, o Instituto realizou, juntamente com um representante da Opas no Brasil e técnicos do Programa Nacional de Imunização, as visitas de avaliação do cumprimento das BPF em todo o parque nacional produtor e fornecedor de soros $\mathrm{e}$ vacinas para o programa oficial de imunização do MS. Foram visitados o Instituto Butantan (SP), o Instituto de Tecnologia de Imunobiológicos - Bio-Manguinhos (RJ), a Fundação Ataulpho de Paiva (RJ), o Instituto Vital Brazil (RI), a Funed (MG) e o Tecpar (PR). O relatório dessas inspeções tornou-se documento fundamental para a continuidade dos programas de implementação das BPF nos laboratórios nacionais.

O INCQS criou, então, uma comissão interna de especialistas (Comissão de Avaliação de Registro de Imunobiológicos - Capre), que tinha como objetivo principal emitir parecer técnico quanto à concessão de registro de produtos no país, a ser encaminhado à Secretaria de Vigilância Sanitária do Ministério da Saúde (SVS/MS).

A primeira atribuição dessa comissão foi elaborar um Manual de Qualidade a fim de assegurar a coerência e a uniformidade com relação à análise dos processos de solicitação de registro, para que estes estivessem em conformidade com a legislação, orientar os avaliadores dos processos e subsidiar a SVS/MS quanto à concessão ou não de registro dos produtos no país. Esse manual é adotado como norma oficial para análise de processo de registro de imunobiológicos, obedecendo à Portaria SVS/MS n 107, de 20 de setembro de 1994 (Brasil, 1994).

Até o final de 2003, o Instituto tinha emitido cerca de trezentos pareceres técnicos para concessão ou alteração de registro.

Com a criação da Anvisa, pouco a pouco, a situação vai sendo alterada e, em março de 2002, mediante uma Resolução da Diretoria Colegiada (RDC 80/2002) (Brasil, 2002), a agência retira do INCQS as atribuições definidas anteriormente pelo MS, assumindo responsabilidade sobre os processos de solicitaçăo de registro e inspeção para avaliação 
da BPF. Essa resolução trata do registro de produtos biológicos e, portanto, amplia o escopo para outros produtos - hemoderivados, biomedicamentos e alergênios-, além dos imunobiológicos.

Após a publicação dessa resolução, o INCQS passa a participar, quando solicitado pela Anvisa, de uma parte da avaliação dos processos de registro, não tendo mais a responsabilidade pelo parecer técnico de todo relatório de autorização de fabricação e comercialização. A agência, por sua vez, estabelece todo um setor específico para lidar com o tema, tendo que contratar e formar os novos recursos humanos necessários para efetuar a recente tarefa que assumiu diretamente. Essas mudanças afetaram fundamentalmente o processo de registro e alterações dos imunobiológicos, tornando-o mais próximo daquele dos medicamentos.

\section{Recursos humanos}

Para cumprir sua missão, o INCQS conta com um total de 346 funcionários. Destes, 224 são servidores públicos, sendo os demais contratados como prestadores de serviço vinculados a empresas de manutenção e apoio. A maior parte desse corpo funcional $(60 \%)$ está diretamente envolvida em atividades de laboratório e em atividades-meio, de apoio às ações de vigilância sanitária; em torno de $25 \%$ estâo envolvidos diretamente com as atividades relacionadas aos imunobiológicos; o restante, em atividades de planejamento, gestão, administração, apoio, manutenção, informatização e sistema da qualidade. Dentre os 207 funcionários com curso superior, 16 têm o título de doutor, 44 o de mestre e os demais apresentam-se com especializações diversas.

A capacitação e o desenvolvimento de seus profissionais têm sido um dos pontos altos do Instituto, e podemos mencionar que esse investimento vem ocorrendo desde a sua inauguração, graças, principalmente, às visitas de especialistas, aos estágios e treinamentos em instituições de reconhecimento internacional e a cursos específicos. As principais fontes de investimento financeiro para o apoio ao desenvolvimento profissional foram provenientes da Opas, Conselho Nacional de Desenvolvimento Científico e Tecnológico. (CNPq), Programa GTZ de Cooperação Brasil/Alemanha e, sobretudo, do MS. Recentemente, a criação de um curso de Pós-Graduação (lato e stricto sensu) específico para atender a demanda da Vigilância Sanitária nos seus aspectos laboratoriais dá uma nova dimensão à participação do INCQS na formação de profissionais para o setor.

No período de 1983 a 1989, o INCQS recebeu consultores procedentes do Instituto Nacional de Virología, do México, do Centro Panamericano de Zoonosis (Cepanzo), da Argentina, e do Instituto Nacional de Salud Pública, do Chile, para apoiar e colaborar no fortalecimento e implementação dos métodos de controle de qualidade de vacinas virais (vacina oral contra poliomielite, vacina contra o sarampo e vacina contra raiva), BCG e vacina tríplice DTP, respectivamente. Paralelamente, foram efetuados estágios no Cepanzo, em controle de qualidade da BCG e da vacina contra raiva, além de estágios no Instituto Nacional de Virología, no México, para o controle das vacinas contra sarampo e da vacina oral contra poliomielite. Ao final dos anos 80 , também ocorreram treinamen- 
tos no Paul Ehrlich Institut e no Max Von Pettnkofer Institut, ambos na Alemanha, e no National Institute of Biological Standartization for Control (NIBSC), na Inglaterra, para treinamento em controle de vacina contra hepatite $B$.

Após a década de 80 , a fim de dar continuidade ao desenvolvimento da força de trabalho do INCQS, foram realizados estágios e treinamentos no Center for Biological Evaluation and Research (CBER), do Food and Drug Administration (FDA/Estados Unidos), no NIBSC, no Instituto Pasteur Merrieux e na então denominada Agência Francesa de Medicamentos, principalmente para conhecimento dos novos produtos que vinham sendo introduzidos no PNI, tais como: vacina inativada contra poliomielite, vacina tríplice viral (vacina combinada contra a caxumba, rubéola e sarampo), vacina contra hepatite $\mathrm{B} A D N r$, vacinas conjugadas com polissacarídeos e vacina contra raiva, produzida em cultura de células. Também ocorreu estágio no American Type Culture Collection (ATCC), nos EUA, para assuntos relacionados a materiais de referência biológica e banco de cultura de células, nos anos de 1993 e 1994 , respectivamente.

Outra forma de investimento no desenvolvimento e atualização dos profissionais foi o apoio à participação em cursos de temas relevantes para as atividades do Instituto. Como conseqüência, vários funcionários participaram do curso de produção e controle de qualidade de vacina contra o sarampo, realizado em Bio-Manguinhos e organizado em parceria com a Japan International Cooperation Agency (JICA), do Japão, nos anos 90. Igualmente importantes foram os cursos sobre métodos alternativos in vitro para os componentes tetânico e diftérico da vacina tríplice DTP, que ocorreu no National Institute of Public Health and the Evironment (RIVEM, sigla original em holandês), e sobre BPF de vacinas, na Universidade de Massachusets, Boston, USA. Ambos fizeram parte do Global Training Network da Opas/OMS e foram realizados em 1999. Nos anos 2001 a 2003, o Instituto continuou apoiando a participação de seus profissionais em cursos importantes, dos quais podemos mencionar Controle de Qualidade de Vacinas Virais, no Biken Institute, no Japão; Ensaios Clínicos para Registro de Vacinas, patrocinado em parte pela Opas/OMS, curso de estabilidade de imunobiológicos - com consultores cubanos, no INCQS/Fiocruz - e Animais Peçonhentos: Clínica, Produção e Controle de Soros Hiperimunes, realizado no Instituto Butantan e patrocinado pela JICA.

Na mesma linha de conduta - a valorização da formação técnica específica -, foi đada uma grande importância aos acordos de cooperação técnico-científicos com organismos similares em outros países, que também se afirmaram como importante forma de crescimento profissional dos funcionários do INCQS. Essas cooperações tinham como objetivo o intercâmbio de experiências e não ocorreram somente nas questões analíticolaboratoriais; deram-se, também, em outros assuntos relacionados à autorização de comercialização, BPF e estabilidade de produtos. Destacamos, nesse campo de atuação, dois dos principais intercâmbios que vêm sendo realizados desde 1995 . O primeiro com a Agence Française de Sécurité Sanitaire des Produits de Santé (AFSSAPS) e o segundo com as instituições cubanas. $O$ intercâmbio com a agência francesa tem sido financiado com recursos dela, do INCQS e com o apoio de um convênio (já encerrado) Anvisa-CNPq. Já a 
permuta com institutos cubanos, principalmente com o Centro Estatal para Controle de Medicamentos (Cecmed), vem se dando por intermédio do Technical Cientific Cooperation (TCC) da Opas e pela utilização de recursos próprios.

Além da formação específica lato sensu, a pós-graduação stricto sensu também foi incentivada, e diversos profissionais realizaram cursos de mestrado e doutorado, tanto em instituições nacionais (biologia molecular e celular na Fiocruz; microbiologia na Universidade Federal do Rio de Janeiro - UFRJ), quanto em instituições fora do país (George Washington University, Estados Unidos, e Lioughborough University of Technology, Inglaterra). Além disso, com o início do programa de pós-graduação em Vigilância Sanitária do próprio INCQS em junho de 2001, ampliou-se a possibilidade de formação de mestres e doutores em temas mais diretamente relacionados com a missão do Instituto.

Após dois anos e meio da implantação desse programa, entre as primeiras dissertações e teses apresentadas, tem-se uma de mestrado sobre controle de vacina pertussis e estão em andamento diversos outros projetos na área de imunobiológicos, sendo dois de mestrado e quatro de doutorado.

\section{PERSPECTIVAS DO CONTROLE OFICIAL EM FACE DO PROJETO INOVAC̣ÃO}

Nos últimos vinte anos, no âmbito da Vigilância Sanitária de Imunobiológicos, principalmente no que diz respeito às vacinas, o Brasil adotou um programa - o Pasnique tinha como base o Laboratório Nacional e sua relação com o próprio PNI, gerenciado pela Funasa.

Na década de 80, quando ocorreram os maciços investimentos no setor estatal para dar suporte ao Pasni, o Laboratório Nacional foi, também, agraciado, sendo considerado como parte integrante do Programa. Na década de 90 - em menor ritmo -, continuaram os investimentos no setor produtivo, mas pode-se afirmar que praticamente nenhum recurso orçamentário específico e dirigido foi operacionalizado para o controle de qualidade oficial, embora, como demonstra o Quadro 1 , inúmeras novas vacinas tenham sido introduzidas para o PNI.

Implantado no Brasil ao longo dos últimos vinte anos, esse modelo deu certo, quer pelo resultado obtido do ponto de vista sanitário, quer pela confiabilidade que a sociedade brasileira deposita nas vacinas do setor público. Todavia, ele está mudando. É importante que se tenha clareza das razões da mudança e o que está sendo construído em substituição ao modelo anterior, de forma que se possa garantir, no futuro, que será mantida a posição de destaque que o Brasil ocupa nesse tema e que lhe permitiu a obtenção de índices tão significativos no controle das doenças imunocontroladas.

$\mathrm{Na}$ atual década, com a criação da Anvisa e principalmente após a publicação da RDC 80/2002 (Brasil, 2002), uma forte alteração começou ą ocorrer no sistema de controle sanitário dos produtos imunobiológicos. 0 processo de autorização para comercialização (registro) não mais passa integralmente pelo INCQS, assim como as inspeções das plantas produtoras não contam mais com a participação permanente do Laboratório Nacional. $O$ financiamento específico para a modernização e acompanhamento tecno- 
lógico dos novos produtos desapareceu e, mais importante, temos nitidamente delineado um movimento de separar as questões referentes à produção nacional, os aspectos regulatórios e a questão do controle de qualidade oficial.

Com a publicação da Portaria 11/2003 da Secretaria de Vigilância em Saúde (SVS/MS), delineia-se claramente esta nova posição do Estado brasileiro, pois o Laboratório Nacional deixa de ter representação no Comitê Técnico Assessor em Imunobiológicos (CTAI).

Esses movimentos do setor público mostram que futuramente, quando do ingresso de novas vacinas no mercado consumidor - resultante, por exemplo, do Projeto Inovação em Saúde -, o modelo de controle lote a lote e as alternativas atuais de consistência de produção não serão seguidos ou, mais importante, não poderão, do ponto de vista operacional, ser seguidos.

Assim, a escolha do modelo futuro e de sua eficiência dependerá das decisões políticas e ações que forem delineadas agora, pressupondo que tecnologia e produto não se implementam no mesmo momento da tomada de decisão. Necessitam de tempo e amadurecimento, bastando para isso olhar a própria história do INCQS, em que o tempo entre a deliberação política de efetuar o controle de qualidade oficial e a sua real implementação foi de alguns anos, necessitando de um significativo aporte de recursos financeiros, humanos e de continuidade na gestão e no planejamento estratégico.

\section{REFERÊNCIAS BIBLIOGRÁFICAS}

BRASIL. Lei 2.187, de 16 de fevereiro de 1954. Cria o Laboratório Central de Controle de Drogas e Medicamentos, e dá outras providências. Diário Oficial, Brasília, 17/2/1954, Seção 1, p. 002387, 1954.

BRASIL. Portaria SNFMF n. 35, de 9 de setembro de 1974. Dispōe sobre normas técnicas referentes à produção, controle, importação, exportação e ao comércio de produtos destinados à prevenção e ao tratamento das doenças infecciosas. Diário Oficial, Brasília, 3/3/1975, Seção 1, p. 2.603, 1975.

BRASIL. Lei 6.360, de 23 de setembro de 1976. Dispõe sobre a vigilância sanitária a que ficam sujeitos os produtos. Diário Oficial, Brasília, 24/9/1976, Seção 1, p. 12.647, 1976.

BRASIL. Decreto 79.094, de 5 de janeiro de 1977. Regulamenta a Lei 6.360/76. Diário Oficial, Brasília, 7/1/1977, Seção 1, p.11, 1977.

BRASIL. Decreto 82.201, de 30 de agosto de 1978. Dispõe sobre a transferência do Laboratório Central de Controle de Drogas, Medicamentos e Alimentos da estrutura da administração direta do Ministério da Saúde para a Fundação Oswaldo Cruz, e dá outras providências. Diário Oficial, Brasília, 31/8/1978, Seção 1, p. 14.089, 1978.

BRASIL. Resolução Normativa CTM/CNS 10, de 6 de dezembro de 1978. Estabelece normas básicas relacionadas com prescrição, produção e emprego dos medicamentos. Diário Oficial, Brasília, 15/2/1979, Seção 1, p. 2375, 1979. 
BRASIL. Ato da Presidência da Funđação Oswaldo Cruz n. 044/1981-PR, de 27 de julho de 1981. Alterar a denominação do Laboratório Central de Controle de Drogas, Medicamentos e Alimentos - LCCDMA - para Instituto Nacional de Controle de Qualidade em Saúde-INCQS.

BRASIL. Portaria SVS n. 109, de 4 de novembro de 1993. Delega ao INCQS a responsabilidade sobre emissão de parecer técnico sobre solicitação de registro e de programar as inspeçôes sobre Boas Práticas de Fabricação. Diário Oficial, Brasília, 8/1 1/1993, p. $16.723,1993$.

BRASIL. Portaria SVS n. 107, de 20 de setembro de 1994. Sobre normas para análise de processo de registro de imunobiológicos. Diário Oficial, Brasília, 30/9/1994, Seção 1, p. $14.885,1994$.

BRASIL. Portaria 174, de 11 de novembro de 1996. Aprova as normas técnicas de produção e controle de qualidade dos soros antiofídicos antitóxicos e anti-rábico. Diário Oficial, Brasília, 12/11/1996, Seção 1, p. 23.491, 1996 a.

BRASIL. Portaria 175, de 26 de janeiro de 1996. Fica aprovado o Fascículo 1 da Parte II da quarta edição da Farmacopéia Brasileira - Monografias, elaborado pela Comissão Permanente de Revisão da Farmacopéia Brasileira. Diário Oficial, Brasília, 19/6/1996, Seção 1, p. 10.828, 1996b.

BRASIL. Portaria 176, de 11 de novembro de 1996. Aprova as normas técnicas de fabricação e controle de qualidade da vacina contra a raiva para uso Humano (CCL) Fuenzalida-Palacios modificada, na conformidade do anexo desta Portaria. Diário oficial, Brasília, 12/11/1996, Seção 1.p. 23.549, 1996c.

BRASIL. Portaria 661, de 22 de dezembro de 1997. Aprova as normas de produção e controle de qualidade da vacina tríplice (VTP), constantes do anexo da Portaria. Diário Oficial, Brasília, 24/12/1997, Seção 1, p.1, 1997.

BRASIL. Portaria 551, de 13 de julho de 1998. Aprova as normas de produção e controle de qualidade da vacina tríplice (DTP) e os procedimentos de controle. Diário Oficial, Brasília, 14/07/1998, Seção 1, p. 6, 1998a.

BRASIL. Ministério da Saúde. Programa Nacional de Imunizações. PNI 25 anos. Brasília: Fundação Nacional de Saúde/MS, 1998b.

BRASIL. Ministério da Saúde. Atividades Institucionais no INCQS período 1999 a 2001. Rio de Janeiro: Instituto Nacional de Controle de Qualidade em Saúde, Fiocruz/MS, 2001.

BRASIL. Resolução RDC Anvisa n. 80, de 18 de março de 2002. Aprova o regulamento técnico de registro, alteraçōes e inclusão pós-registro e revalidação dos produtos biológicos, conforme documento anexo a esta Resolução. Diário oficial, Brasília, 19/3/2002, Seção 1, p. 43, 2002.

DA PONTE, F. C. Vacinação, controle de qualidade e produção de vacinas no Brasil a partir de 1960. História, Ciências e Saúde, 10(2): 619-653, 2003. 


\section{Parte III}

PROSPECGAO EM VACINAS: RESULTADOS DO PROJETO InOVAĢ̃̃o 


\section{Desenvolvimento Tecnológico de Vacinas: projeções para $2015^{1}$}

Julie Milstien

\section{INTRODUC̣ÃO}

Um estudo sobre as tendências do desenvolvimento de vacinas no tocante ao caso brasileiro foi realizado, com foco especial na projeção de tendências do mercado mundial, incluindo o papel das organizações internacionais e dos fabricantes independentes. Essa projeção foi então aplicada ao caso brasileiro, sendo revistos os pontos fortes e fracos do país em termos de desenvolvimento de vacinas. Os pontos fortes incluem o grande apoio governamental, as amplas potencialidades de seu mercado, a força dos programas de vacinação e đe vigilância epidemiológica, a grande base de funcionários treinados e um sistema nacional de regulação que se desenvolve intensamente. Já as fraquezas consistem na relativa escassez de investimentos em Pesquisa e Desenvolvimento (P\&D) e na natureza da produção de vacinas no setor público, que podem vir a ameaçar a formação de parcerias e a posição de seus produtos no mercado.

O estudo levou em conta as tendências da indústria de vacinas, da carga das doenças e dos portfolios dos vários fabricantes e criadores de vacinas. Por fim, projetou o comportamento do mercado desse produto para o intervalo entre o momento presente e o ano de 2015. É com base nessas projeções que devem ser consideradas as recomendações de encaminhamento. A seguir, os principais prognósticos para os próximos 10 ou 15 anos:

- Dois nichos de populações-alvo de vacinas, de meia idade e idosa, crescerão. Isso indica a necessidade do desenvolvimento de novas vacinas e estratégias de administração.

${ }^{1}$ Tradução do original em inglês: Cristiano Botafogo. 
- Haverá redução gradual da incidência da Síndrome da Imunodeficiência Adquirida (Aids), da malária e da tuberculose, com aumento da disponibilidade do tratamento e do avanço das iniciativas de prevenção. Ocorrerá um relativo crescimento da importância de doenças infecciosas endêmicas, baseado em uma melhoria da vigilância epidemiológica.

- Em razáo do enfoque da tecnologia de desenvolvimento, vacinas altamente purificadas e muito bem caracterizadas surgirão e, por causa disso, serão mais caras. A existência de novas vacinas para substituir as já existentes apresentará um desafio para o campo de estratégias de introdução do uso de vacinas.

- O bioterrorismo continuará a ser um assunto secundário, mas as lições que se terão aprendido com uma futura pandemia global de influenza irão apontar para a necessidade de maior flexibilidade no desenvolvimento e na regulação de vacinas.

- Os fabricantes de vacinas sem acesso ao mercado global e/ou algum tipo de vantagem tecnológica terão um papel menos importante no processo. Os grandes fornecedores regionais da Índia, do Brasil e da China preencherão essa lacuna.

- Autoridades reguladoras terão um papel ainda mais decisivo no desenvolvimento de vacinas, influenciando o curso seguido por este. Por outro lado, terão que demonstrar a existência de uma forte base científica em suas decisões.

Tendo essas projeções como base e levando-se em conta as análises de risco versus potencial de mercado, vários caminhos parecem ser apropriados para a indústria brasileira de vacinas:

- Quanto às vacinas já existentes, assegurar a disponibilidade e a boa qualidade dos componentes da DTP (toxóides diftéricos e tetânicos e vacina contra a coqueluche); aumentar a capacidade de produção da vacina contra o sarampo e a rubéola (MR); dar continuidade às atividades dedicadas ao desenvolvimento de uma vacina contra febre amarela produzida em cultura de células - contanto que a lucratividade não esteja comprometida, visto que o mercado global para essa vacina pode ser relativamente pequeno ( 25 milhões de doses).

- No que concerne às vacinas novas e às aperfeiçoadas produzidas para o mercado global, fazer uso de parcerias para obter acesso à tecnologia de produção de vacinas contra rotavírus e considerar colaboração para o desenvolvimento de vacinas mais modernas contra a raiva e/ou a gripe.

- Desenvolver vacinas importantes regionalmente, como a vacina contra a leishmaniose e contra a dengue.

- Manter-se atualizado quanto aos avanços da pesquisa e quanto às possibilidades de colaboração, especialmente para o desenvolvimento de vacinas contra o HIV.

- Para todos os produtos, considerar novas estratégias de distribuição e a necessidade de criar novas plataformas de administração exequî́veis. 


\section{CONTEXTO}

\section{O Brasil em 2003}

\section{População e economia}

O Brasil, um país ligeiramente menor do que os Estados Unidos em termos de área (com 8,5 milhões de quilômetros quadrados), tem sido a principal potência econômica da América do Sul desde os anos 70. A populaçăo é de 176 milhões (CIA, 2002), com 3,374 milhões de nascimentos por ano (OPS, 2002). Em termos de distribuição por faixa de idade, $28 \%$ da população está entre 0 e 14 anos de idade, $66,4 \%$ entre 15 e 64 e $5,6 \%$ está acima dos 65 . Pelas tendências atuais, pode-se prever que se trata de uma população que se torna cada vez mais idosa. Em 2002, no Brasil, a taxa de mortalidade por doenças infecciosas foi menor-90,6/100 mil - do que por câncer e por doenças circulatórias, 109,1 e 209,8, respectivamente (OPS, 2002). Todavia, o HIV/Aids causará impacto nesses números de alguma forma: há 540.000 pessoas vivendo com HIV/Aids - a taxa de prevalência é de $0,57 \%$ nos adultos - e já houve 18.000 mortes até agora (números de 1999).

A economia do Brasil é a mais importante dos países sul-americanos, com um Produto Interno Bruto (PIB) de 134 trilhōes de dólares e uma taxa real de crescimento de 1,9\% (CLA, 2002). O PIB per capita é de US $\$ 7.400$, inscrevendo-o na categoria dos países de renda média, com $22 \%$ da população abaixo da linha de pobreza. Comparando-se o Brasil com os Estados Unidos com base nos dados de 1990 , o PIB percapita brasileiro foi de US $\$ 4.719$, ao passo que o dos EUA foi de US \$21.449. No mesmo ano em questão, o gasto anual com medicamentos percapita dos dois países foi de US \$ 14 contra US \$ 191, respectivamente (Balance, Pogany \& Forstmer, 1992), mostrando um nível baixíssimo e desproporcional de gastos por parte do Brasil, padrão que se repete na maioria dos países de renda baixa e média (Gráfico 1).

Gráfico 1 - PIB/Capita versus total per capita de gastos com medicamentos - 1990

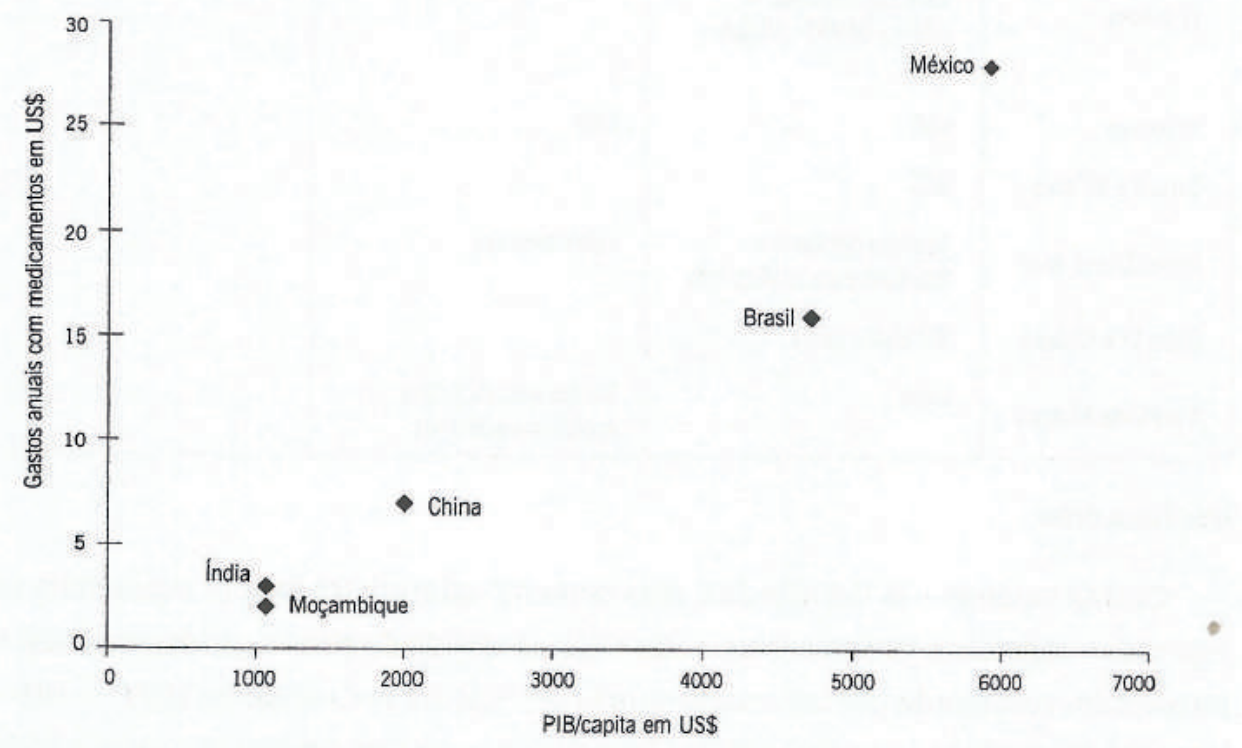

Fonte: Balance et al., 1992. 
Em 1997, os Estados Unidos representavam 34,5\% da produção farmacêutica mundial, enquanto os países latino-americanos foram responsáveis por 7,7\% (www.imshealth.com, 1999).

\section{Sistema de imunização}

A cobertura da vacinação no Brasil vem crescendo constantemente e, atualmente, abrange cerca de $90 \%$ de todos os antígenos (WHO/Unicef, 2000). O Programa de Imunização Nacional (PNI), que completou 30 anos em 2000, é administrado pela Funasa, a Fundação Nacional de Saúde. Existem 26.000 pontos de vacinação não somente para crianças como também para mulheres em idade reprodutiva e pessoas acima de sessenta anos de idade. A vacina contra hepatite B está sendo acrescentada sistematicamente ao calendário de vacinas desde 1992 , e a vacina contra o Haemophilus influenzae tipo b (Hib) foi introduzida em 1999 (na combinação DTP-Hib, em 2002). A responsável pelas vacinas é a Funasa, vindas da produção local ou adquiridas de outras fontes. O calendário de vacinação pode ser visto no Quadro 1.

Quadro 1 - Calendário de vacinação no Brasil

\begin{tabular}{|c|c|c|c|}
\hline Idade & \multicolumn{3}{|c|}{ Vacina } \\
\hline Ao nascer & $\begin{array}{l}\text { Bacilo Calmette-Guérin } \\
\text { (BCG) }\end{array}$ & Hepatite B & \\
\hline 1 mês & Hepatite B & & \\
\hline 2 meses & $\begin{array}{l}\text { Vacina oral contra pólio } \\
\text { (VOP) }\end{array}$ & $\begin{array}{l}\text { Vacina tetravalente (DTP + } \\
\text { Hib) }\end{array}$ & \\
\hline 4 meses & VOP & DTP + Hib & \\
\hline 6 meses & VOP & DTP + Hib & Hepatite B \\
\hline 9 meses & Febre amarela (YF) & & \\
\hline 12 meses & $\begin{array}{l}\text { Sarampo, caxumba e } \\
\text { rubéola (MMR)- tríplice } \\
\text { viral) }\end{array}$ & & \\
\hline 15 meses & VOP & DTP & \\
\hline Entre 6 e 10 anos & $\mathrm{BCG}$ & & \\
\hline Entre 10 e 11 anos & $\begin{array}{l}\text { Toxóides diftéricos e } \\
\text { tetânicos para adultos (dT) }\end{array}$ & Febre amarela & \\
\hline Entre 12 e 49 anos & MR (dupla viral) & & \\
\hline A partir de 60 anos & Gripe & $\begin{array}{l}\text { Vacina polissacarídea } \\
\text { contra pneumococos }\end{array}$ & \\
\hline
\end{tabular}

Fonte: Funasa (2003a).

Outras vacinas - já licenciadas, mas somente administradas em circunstâncias especiais - incluem a vacina contra a febre tifóide, obtida do polissacarídeo capsular VI purificado, conjugado contra o meningococo $\mathrm{C}$; vacina pentavalente $(\mathrm{DTP}+\mathrm{Hib}+$ Hepatite B); conjugado pneumocócico heptavalente; vacina inativada contra a pólio; vacina contra a raiva produzida em cultura de células; vacina contra a catapora, toxói- 
des tetânicos e diftéricos (dT); a vacina DtaP-composta de toxóides tetânicos e diftéricos e da vacina acelular contra a coqueluche - e imunoglobulinas contra hepatite B, raiva, tétano e contra o vírus varicella zoster.

No período compreendido entre 1995 e 2000, a Funasa intermediou a aplicação de 1,6 bilhão de doses de vacinas, sendo 214 milhōes em 1995, chegando ao número de 329 milhões de doses em 2000 , das quais $75 \%$ foram feitas no próprio país (Funasa, 2003a).

\section{Ciência e tecnologia}

Comparado com países de nível similar de desenvolvimento em termos de suporte básico para a ciência e a tecnologia, o Brasil está em grande desvantagem. Em 1993, havia 15.000 cientistas e pesquisadores em exercício no país, bem como cerca de mil estudantes de pós-graduação atuando em praticamente todas as áreas do conhecimento (Schwartzman et al., 1993). Além disso, não houve muita inovação. Por exemplo, entre 1990 e 1995 , somente 2.572 patentes foram registradas, $85 \%$ destas por não residentes. Entre 1991 e 1993, o Escritório Europeu de Patentes (EPO) recebeu somente 127 pedidos de patentes por parte do Brasil (Gabinete Científico-Tecnológico, 1997). Contudo, já foi observado que a lei de propriedade intelectual brasileira é 'TRIPS Plus' (Trade-related Aspects of Intellectual Property Rights) no que concerne à proteção contra inovadores estrangeiros (Barbosa, 1999). O texto dessa lei está disponível na Internet (Brasil, 2003).

Por outro lado, em um estudo sobre P\&D em saúde global (Global Forum for Health Research, 2001), foi estimado que, em 1996, a verba total destinada à $P \& D$ na área de saúde no Brasil foi de 715,6 milhões de dólares, o que significa 0,1\% do PIB. De acordo com um estudo da RICYT (2002), o país gastou 850 milhōes de dólares em P\&D na área de saúde, e quase $2 \%$ do total gasto em saúde foi destinado à $P \& D$ (Global Forum for Health Research, 2003), estando, assim, de acordo com uma recomendação feita pela commission for Health Research and Development, em 1990, para países de renda baixa ou média. Somente Cuba atingiu níveis similares de gastos com $P \& D$.

\section{Regulação}

A Agência Nacional de Vigilância Sanitária (Anvisa) e o Instituto Nacional de Controle de Qualidade em Saúde (INCQS), respectivamente, a agência nacional reguladora e o laboratório nacional, participaram recentemente do processo de reorganização do sistema de regulação de vacinas. A Organização Mundial da Saúde (OMS), em Relatório Técnico ad hoc (2001), avaliou o funcionamento da Anvisa e chegou às seguintes conclusões:

O sistema - visto que foi instituído por meio de vários decretos, portarias e resoluções - é sólido e capaz de tornar a Anvisa uma autoridade reguladora nacional de primeira linha. O envolvimento do INCQS - o laboratório nacional responsável pela regulação-em todas as etapas do processo foi crucial. Contudo, a oferta mundial de vacinas está atravessando uma brutal revolução. 0 resultado disso será o aumento da produção de novos produtos destinados ao mercado de países em desenvolvi- 
mento, como o Brasil. Isso significa que é imperativo que a Anvisa faça planos para esse futuro, empenhando-se no desenvolvimento das qualidades necessárias para atuar como principal agência reguladora de novos produtos - qualidades essas que ainda não foram totalmente desenvolvidas dentro de sua estrutura. (Relatório Técnico ad hoc, 2001)

A junta de avaliadores concluiu que o sistema regulador como um todo e as seis funçôes reguladoras básicas estavam adequadamente encaminhados e sendo implementados de acordo com as orientações da OMS. Entretanto, a base legal para algumas dessas atividades -e em especial a do sistema de aprovação de lotes - ainda não havia sido estabelecida. Além disso, ao passo que, em um ano, o país conseguiu atingir as normas de Boas Práticas de Fabricação (BPF) em suas instalaçôes de produção, os recursos humanos disponíveis para assegurar o número de inspeções necessárias ficaram comprometidos. Por fim, apesar de existirem duas estruturas bem equipadas para monitorar e investigar a ocorrência de eventos adversos após as imunizações no Brasil, havia a necessidade de uma boa conexão entre elas para garantir a troca de informaçōes em prol đe uma ação reguladora mais eficiente e do feedback sobre o funcionamento das vacinas para o sistema de vacinação.

\section{A indústria de produção de vacinas}

No Brasil há uma série de fabricantes, pertencentes ao setor público, que já estiveram na posição de fornecer ao país uma grande porção de suas vacinas. Dois deles, Bio-Manguinhos e Butantan, são membros da Developing Country Vaccine Manufacturers' Network e forneceram a essa rede as seguintes informações recentes sobre seus produtos e prospectos.

Bio-Manguinhos produz uma vacina contra a febre amarela obtida da cepa 17D, cultivada em ovos livres de agentes patogênicos (Specific Pathogen Free - SPF), tanto para uso dentro do Brasil quanto para exportação. Essa vacina obteve pré-qualificação da OMS para ser vendida para as agências das Nações Unidas. Além disso, as vacinas contra sarampo e meningite tipos A e C estão sendo produzidas em sua capacidade máxima - apesar de não necessariamente atenderem as normas de BPF. A formulação e o envasamento das seguintes vacinas estão em processo de desenvolvimento: oral contra a pólio (da GlaxoSmithKline); contra o Hib (da GlaxoSmithKline) - para serem vendidas somente para o Brasil e para os países do Mercosul; tetravalente (cujo DTP vem do Butantan); contra a rubéola (da Biken) - para venda mundial, exceto no Japão e na Coréia; a MR (sendo a vacina contra a rubéola produzida pela Biken). Estão em fase de desenvolvimento as vacinas contra a meningite tipo B (em conjunto com o Butantan), um conjugado contra meningite tipos $\mathrm{A}$ e $\mathrm{C}$, uma vacina contra o Streptococus Pneumoniae (com o Instituto Adolfo Lutz e o Butantan) e um novo processo de produção de vacinas contra a febre amarela usando cultura de células. Os projetos de mais longo prazo estão sendo encaminhados e utilizam 1) o desenvolvimento das vacinas recombinantes com vetores de BCG e febre amarela para a expressão de antígenos de dengue e malária; 2) antígenos recombinantes no Escherichia coli; 3) uma vacina recombinante contra a leishmaniose e 4) anticorpos monoclonais da dengue para diagnóstico. Bio- 
Manguinhos também produz kits para diagnóstico da doença de Chagas, da leishmaniose, da leptospirose, da hanseníase, das hepatites A e B, do HIV, do vírus T-linfotrópico humano (HTLV), de diarréias virais (rotavírus e adenovírus), de sarampo e de rubéola. Um kit para o diagnóstico de dengue está sendo desenvolvido.

- O Butantan produz, com seus próprios recursos, a DTP, o dT e o toxóide tetânico; a $B C G$ e a vacina contra hepatite B. O Instituto está fazendo o envasamento da vacina contra a gripe (sendo o bulk da Aventis) e está colaborando com Bio-Manguinhos e a GlaxoSmithKline para a produção da vacina tetravalente (DTP-Hib). Outros produtos estão sendo desenvolvidos através de vários acordos, como éo caso da vacina MMR, através do Memorandum of Agreement com o Institute of Immunology Zagreb para o envasamento do seu bulk; da vacina pentavalente, em parceria com uma grande companhia farmacêutica não revelada; da vacina contra o Hib, com o RIVM, o instituto público de saúde holandês; da vacina contra a raiva produzida em cultura de células Vero, em fase I de desenvolvimento; DTP-hepatite B e BCG-hepatite B, ambas desenvolvidas no Butantan. Outras pesquisas estão investigando vetores de BCG, a esquistossomose (com Bio-Manguinhos), uma vacina contra pneumococos e conjugados contra meningite meningocócica tipos B e C.

O Instituto de Tecnologia do Paraná (Tecpar) possui um acordo com a Chiron para a produção da MMR. Ambos constituem um dos maiores produtores de vacinas contra raiva para uso em cães, mas ainda usam a tecnologia Fuenzalida-Palacios em sua produção. A Fundação Ataulpho de Paiva tem produzido alguns lotes da BCG. Uma equipe do Children's Vaccine Initiative (CVI) chegou à conclusão, há dez anos, que as instalações necessitavam de renovação, mas a construção destas não foi concluída.

A indústria brasileira de vacinas se caracteriza pelo forte apoio governamental, pelo grande mercado interno - além do Mercosul-, pela larga base de pessoal treinado e por um sistema regulador nacional em franco desenvolvimento. Tomando como referência o caso dos medicamentos contra o HIV/Aids, o governo tem um compromisso real com o acesso a produtos relevantes para a saúde pública, mesmo que o acesso à tecnologia dependa de licenciamento compulsório (Galvão, 2002).

Por outro lado, entre suas fraquezas, inclui-se a natureza pública da indústria de produção de vacinas do Brasil. O governo brasileiro tem preferência sobre todas as vacinas, o que faz o produto destinado à exportação - necessária para se poder produzir na maior escala possível - não ser digno de confiança. Levantar fundos pode ser difícil, especialmente para manutenção, atualização e inovação da produção, podendo também sofrer influência política. Além disso, as indústrias públicas de fabricação de vacinas são, freqüentemente - mas não sempre -, caracterizadas como tendo baixo compromisso com as normas de BPF, nos casos em que a autoridade reguladora não tenha poder adequado para intervir. Finalmente, algumas empresas internacionais receiam fazer acordos de repasse de tecnologia com a indústria de vacinas do governo brasileiro, temendo o vazamento das informações e a exploração econômica de sua propriedade intelectual. Embora este caso não aconteça sempre nas instalações do setor público, já ocorreu; portanto, deve-se frisar que esse tipo de atitude é factível. 


\section{TENDÊNCIAS NA INDÚSTRIA DE VACINAS}

\section{A questão da eficiência na produção de vacinas}

Desde o início de sua implantação, a indústria de vacinas brasileira se desenvolveu, em maior parte, por intermédio do setor público, fabricando produtos que usam tecnologias simples, mas de difícil padronização. Por isso, esse tipo de indústria foi formado de maneira muito diversa da indústria farmacêutica e era comum a crença de que as vacinas não eram capazes de competir com os grandes sucessos de venda dos produtos farmacêuticos, uma vez que os governos fornecem as vacinas à população gratuitamente ou a baixos custos, exigindo-se que tenham preços demasiadamente baixos, se levados em conta os custos de produção e de controle de qualidade. A dificuldade de padronização dos produtos causava uma grande dependência na eficiência dos testes feitos no produto final e significava que a tecnologia envolvida no processo era difícil de transferir. Essas dificuldades, somadas ao fato de que a maioria das vacinas tem por volta de cinqüenta anos de idade - situação que se agrava com o baixo investimento em inovação -, traduziam-se em pequena margem de lucro para a indústria de vacinas. Recentemente, alguns fabricantes de vacinas do mundo industrializado foram adquiridos por grandes companhias farmacêuticas e, nos últimos anos, em virtude do aumento dos investimentos em inovação, a indústria de produção de vacinas tem obtido números similares aos das drogas mais vendidas. Ainda assim, vendendo 8 bilhöes de dólares por ano, a indústria de vacinas representa somente uma pequena fração do tamanho da indústria farmacêutica, que está bem acima dos 300 bilhões de dólares por ano (Shot, 2003b - Gráfico 2).

A inovação na indústria de vacinas tem sido limitada, se comparada com a ocorrida na indústria química de medicamentos. Em termos de investimentos em P\&D, para o biênio 1999 e 2000, os gastos anuais são bastante ilustrativos: 26 bilhões de dólares em fármacos, 9,9 bilhões em biotecnologia e 1,5 bilhão em vacinas (Global Forum for Health Research, 2001).

Um estudo recente a respeito da indústria de vacinas, comissionado pelo Fundo de Vacinas (Vaccine Fund) e pelo Banco Mundial, revelou o seguinte (WHO, 2002a):

- Tendências de demanda: manutenção da previsão de taxa de crescimento anual em $10 \%$, o qual decorre, principalmente, do aumento da demanda de vacinas mais caras por países de renda alta, responsáveis por $82 \%$ da receita, mas por somente $12 \%$ do volume total produzido; divergência cada vez maior entre os calendários de vacinação dos países de renda alta e dos países em desenvolvimento (Quadro 2-Recommended, 2002a; WHO, 2002b), o que poderia colocar em risco a política de preços diferenciados-um mecanismo que permitiu que países pobres pudessem ter acesso a vacinas a preços baixos, por causa das vantagens de se produzir em larga escala.

- Economia da produção de vacinas: é altamente influenciada pelo volume produzido, sendo a escala de produção a que mais influencia no preço. Para minimizar os custos de produção, as decisões a respeito da capacidade instalada devem ser feitas precocemente no início do ciclo de vida do produto, exatamente no ponto mais difícil de se fazer essa previsão de capacidade. As fontes dos componentes e o número de antígenos por combinação afetarão os custos de produção significativamente. 
Gráfico 2 - Tendências na indústria de vacinas

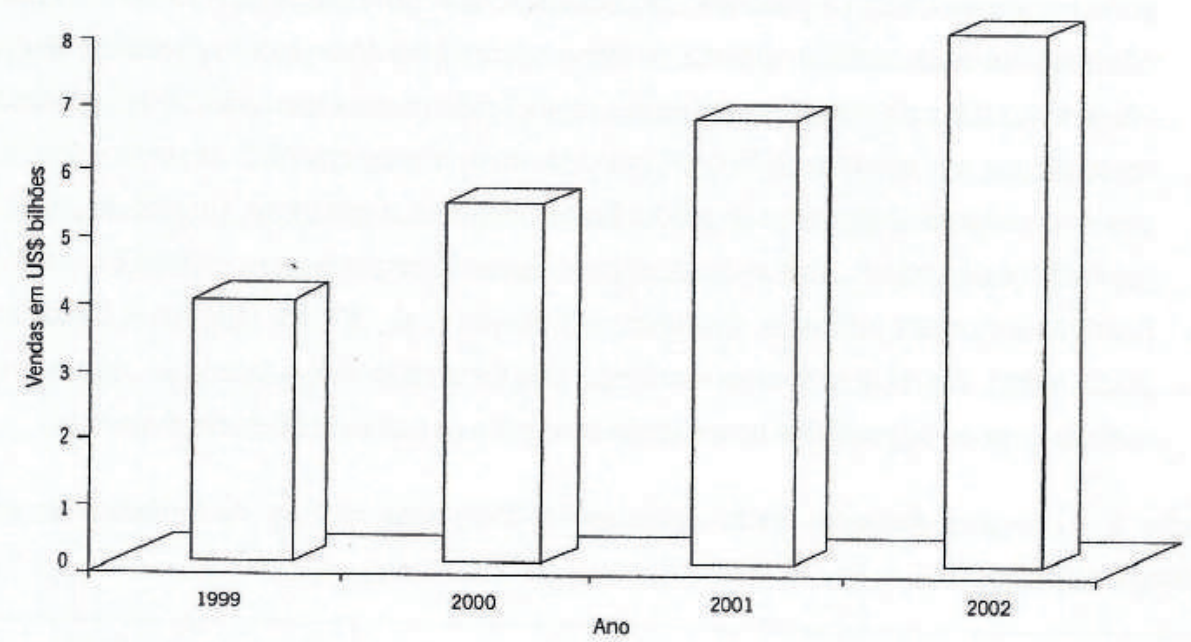

Fonte: Datamonitor apud Shot (2003b).

Quadro 2 - Calendário recomendado de imunização infantil - 2002

\begin{tabular}{|c|c|c|}
\hline Vacina & Estados Unidos* & Países em desenvolvimento** \\
\hline BCG & - & Uma dose \\
\hline Hepatite B & 3 doses, também para adolescentes. & 3 doses \\
\hline DTP & DTaP, 5 doses & DTwP, 3 doses \\
\hline Tétano & Td, entre 11 e 12 anos de idade & $\begin{array}{l}\text { Toxóide tetânico (TT) ou Td para mulheres em idade } \\
\text { reprodutiva }\end{array}$ \\
\hline Hib & 4 doses & 3 doses quando a carga da doença justificar \\
\hline Pólio & Vacina inativada contra pólio (elPV), 4 doses & $\begin{array}{l}\text { VOP, } 4 \text { doses, mais as administradas em } \\
\text { campanhas em países endêmicos }\end{array}$ \\
\hline Sarampo & MMR, 2 doses & $\begin{array}{l}\text { Sarampo, uma dose mais, em uma segunda } \\
\text { oportunidade, sarampo, MR ou MMR }\end{array}$ \\
\hline Catapora & 2 doses & - \\
\hline Conjugado contra pneumococos & 4 doses, heptavalente & * \\
\hline Hepatite A & 2 doses em grupos de alto risco & - \\
\hline Gripe & Anual a partir dos seis anos de idade & - \\
\hline Febre amarela & - & $\begin{array}{l}\text { Uma dose em áreas endêmicas em caso de } \\
\text { epidemia }\end{array}$ \\
\hline Meningite & $\begin{array}{l}\text { Conjugado contra a meningite tipo } \mathrm{C} \text { para grupos de } \\
\text { alto risco }\end{array}$ & $\begin{array}{l}\text { Vacina polissacarídea, pelo menos trivalente (contra } \\
\text { os tipos A, C e W135) em caso de epidemia }\end{array}$ \\
\hline
\end{tabular}

*Fonte: Recommended (2003a).

** Fonte: Shot (2003b). 
- Tendências no fornecimento: a lucratividade aumentou significativamente para as empresas multinacionais de produção de vacinas, tendo como conseqüência um aumento nos investimentos em $P \& D$; todavia, os fornecedores de vacinas para os países em desenvolvimento são cada vez mais produtores estabelecidos nesses mercados. Esses produtores tendem a ter custos mais baixos, mas investem menos em $P \& D$, em inovação e no desenvolvimento do processo de produção. Isso limita sua produção, em grande parte, a produtos mais antigos. Apesar disso, alguns desses fabricantes conseguem lucros significativos com esses produtos. O Quadro 3 (Milstien et al., 2001b; Milstien \& Candries, 2002; WHO, 2003) ilustra essa tendência dos fornecedores emergentes - que ocorre mesmo quando os produtos novos estão indo para os países em desenvolvimento.

Quadro 3 - Compras efetuadas pelas agências da ONU: uma mistura de fornecedores em mudança constante

\begin{tabular}{|c|c|c|c|}
\hline Ano & Número de vacinas & Número de fornecedores & $\begin{array}{l}\text { Percentual localizado } \\
\text { em países em } \\
\text { desenvolvimento e } \\
\text { economias emergentes }\end{array}$ \\
\hline 1986 & 4 & 7 & 0 \\
1996 & 5 & 14 & 50 \\
2001 & 6 & 12 & 58 \\
2003 & 10 & 16 & 56 \\
\hline
\end{tabular}

Obs: A BCG não foi incluída.

Tecnologias: o crescimento da biotecnologia

Um fator de influência na indústria de produção de vacinas que ainda não foi totalmente levado em conta é o crescimento da indústria de biotecnologia. O total de investimentos das empresas de biotecnologia, tanto públicas quanto particulares, está na ordem de 10 bilhôes de dólares por ano, incluindo o fato de que são feitos trezentos novos acordos entre empresas farmacêuticas e de biotecnologia por ano (Bioworld, 2002). Os fármacos e vacinas resultantes do emprego da biotecnologia resultaram em aproximadamente 25 milhōes de dólares em rendimentos em 2002, o que reflete o crescimento progressivo dessa tendência. As vacinas representam o maior volume de produtos presentes na linha de produção do setor de biotecnologia - sem levar em conta os medicamentos contra o câncer (McGarry \& Rigg, 2002).

Uma das funçōes mais importantes da indústria de biotecnologia nos Estados Unidos tem sido o desenvolvimento de vacinas contra doenças deflagráveis pelo bioterrorismo, como a varíola, o antraz, a peste causada poryersinia pestis, o botulismo, a tularemia e as febres hemorrágicas - todas presentes na lista do $\mathrm{CDC}$ de doenças mais nocivas para a saúde humana. Alguns contratos foram assinados com várias empresas de biotecnologia, entre elas a Acambis e a VaxGen, em prol do desenvolvimento de vacinas biotecnológicas contra alguns desses agentes (Clem, 2002). Mas ainda não se sabe com 
certeza se as companhias de países em desenvolvimento estarão imunes a essa tendência - que poderia redirecionar para outras prioridades os investimentos em produtos destinados ao serviço de saúde.

\section{Tendências na regulação}

Na década de 90 , a regulação do processo de fabricação de vacinas era caracterizada pelas exigências cada vez mais rígidas de padronização e validação-dedicando-se em maioria à manutenção da regularidade da produção - e pelo processo de substituição da dependência anterior nos testes realizados no produto final pela realização de testes durante todo o desenvolvimento da vacina, para confirmar a base contínua da produção (Dellepiane, Griffiths \& Milstien, 2000). Hoje, o compromisso com as normas de BPF é essencial, e está sendo cada vez mais exigido, embora ter esse tipo de atitude custe caro, tanto para o fabricante quanto para a agência reguladora. As agências estão atuando mais acentuadamente em todo o processo de desenvolvimento e fabricação, na intenção de desenvolver linhas gerais de procedimento e sugerir aspectos a serem considerados - o que acontece freqüentemente -, em vez de impor regras rigorosas e normas inflexíveis (Baylor \& McVittie, 2002).

Nesses primeiros momentos do século XXI percebemos um inegável crescimento do controle governamental, pois a supervisão das atividades assume um posto de maior importância para a garantia de certos níveis de segurança e eficácia. Podemos apontar duas das várias possibilidades para o desenrolar desse processo (Milstien \& Candries, 2002): 1) aumento das atividades dedicadas a assegurar a harmonização das exigências, como as elaboradas pela International Conference on Harmonization - união de colaboradores da indústria e das agências reguladoras dos Estados Unidos, da Europa e do Japão-, e a padronização de testes e reagentes; 2) aumento da atenção dedicada à adequação dos testes clínicos realizados para estabelecer a segurança e a eficácia dos produtos.

Como consequiência do aumento atenção dedicada à adequação dos testes clínicos, houve um crescimento enorme das atividades das Contract Research Organizations, a fim de assegurar que os testes clínicos estão de acordo com as exigências dos órgãos reguladores. Em relação à eficácia, será importante, quando possível, fazer tais demonstrações em testes laboratoriais, e, quando não for possível, garantir que meios pelos quais se possa demonstrar a eficácia do produto possam ser descobertos-inclusive nos casos onde não se pode fazer testes em humanos (Goodman, 2002). À luz da experiência que se teve nos Estados Unidos com alguns casos de infecção por rotavírus logo após a administração da vacinas, pode ser necessário o aumento dos testes de segurança na fase III, ao passo que já se espera uma melhora da comunicação de efeitos colaterais na fase IV, após a colocação do produto no mercado (Foulkes \& Ellenberg, 2002). Isso significa que os fabricantes devem estar cada vez mais atentos às normas de BPF e de Boas Práticas Clínicas (BPC), devendo agir para que seus testes clínicos sejam adequados e de duração apropriada. Um fabricante responsável verá com bons olhos a oportunidade de ter encontros freqüentes com as autoridades reguladoras para que possa ser direcionado no desenvolvimento de seus produtos. 
Por fim, e colocando ênfase no desenvolvimento de produtos que podem ter somente alguns mercados específicos como destino (como as vacinas contra o HIV, a malária e a leishmaniose, por exemplo), ou, se voltados ao mundo industrializado, ser utilizados somente por viajantes e pelas forças armadas, devem ser aumentados os esforços em prol de maior participação das agências reguladoras dos países em desenvolvimento e dos especialistas em epidemiologia da doença do mercado-alvo nas decisões. Isso vai requerer a existência de atividades destinadas ao enriquecimento do conhecimento a respeito desses países e, provavelmente, vai aumentar a possibilidade de mudança na avaliação da quantificação de risco quanto a certas decisōes (Milstien et al., 2001a).

\section{A evolução dos preços}

A previsão de preços para os próximos anos revela que, por mais incrível que pareça, os preços de vacinas tradicionais estão aumentando - apesar da considerável diferença de valores entre as grandes agências de aquisição de material e o setor privado dos Estados Unidos-, ao passo que os preços das vacinas de fabricantes particulares (protegidas por patentes) estão caindo. 0 Quadro 4 apresenta dados de 2003 a respeito das vacinas adquiridas pelo setor público e privado dos Estados Unidos, pelo Fundo Rotatório da Opas (PAHO RF) e pela Unicef (Centers for Disease Control and Prevention, 2003: Unicef, 2003; PAHO RF, 2003).

O Fundo Rotatório da Opas está, cada vez mais, comprando vacinas em frascos de uma dose e vacinas cuja dose custa alguns dólares (como as contra a raiva, a MMR e contra o Hib). As diferenças entre os produtos e suas configurações podem ser vistas claramente no Quadro 4. Dentre as vacinas combinadas usadas nos Estados Unidos, estão aquelas contra hepatite A-hepatite B, hepatite B-Hib, DTaP-Hib, e DtaP-hepatite B-eIPV. No mundo em desenvolvimento, dentre as vacinas combinadas, estão as vacinas contra DTwP-hepatite B, DTwP-Hib, e DTwP-hepatite B-Hib. Neste momento, ainda não é possível prever se certos países emergentes passarão a utilizar a acelular contra coqueluche e a eIPV em suas vacinas de base DTP - apesar de haver alguns países da Europa Oriental onde essa mudança está sendo realizada. A Financing Task Force, da GAVI, está comissionando um estudo que tem como objetivo compreender melhor as possibilidades de desenvolvimento de novas vacinas combinadas, quais fornecedores teriam mais propensão a produzi-la e a capacidade global de produção (http:// www.vaccinealliance.org/home/General_Information/Immunization_informa/ Economic_Impact/vacc_cost.php, 2003). 
Quadro 4 - Preço dos principais produtos

\begin{tabular}{|c|c|c|c|c|}
\hline Vacina & Setor privado dos EUA & Setor público dos EUA & $\begin{array}{l}\text { Fundo Rotatório da } \\
\text { Opas }\end{array}$ & Unicef SD \\
\hline DTP/DTaP & DTaP US $\$ 19,65$ & DTaP US $\$ 11,75$ & DTWP US $\$ 0,095 *$ & DTwP US $\$ 0,08 *$ \\
\hline Sarampo/MR/MMR & MMR US $\$ 34,73$ & MMR US $\$ 15,99$ & $\begin{array}{l}\text { Sarampo US } \$ 0,80 \text {; US } \$ \\
0,12^{*} ; \text { MR US } \$ 0,48^{*} ; \text { MMR } \\
\text { US } \$ 1,49\end{array}$ & $\begin{array}{l}\text { Sarampo US } \$ 0,82 \text {, US } \$ \\
0,12^{*} ; \text { MR US } \$ 1,55 \text { MMR } \\
\text { US } \$ 1,55\end{array}$ \\
\hline VOP/elPV & elPV US $\$ 21,80$ & elPV US $\$ 9,96$ & VOP US $\$ 0,143^{*}$ & VOP US $\$ 0,097$ * \\
\hline Hepatite B & US $\$ 21,37$ & US $\$ 9,00$ & US $\$ 0.52$, US $\$ 0,29$ * & US $\$ 0,58$, US $\$ 0,32^{*}$ \\
\hline Hib & US $\$ 21,52$ & US $\$ 7,49$ & US $\$ 2,95$ & DTwP-Hib US $\$ 2.35^{*}$ \\
\hline Febre amarela & - & - & US $\$ 0.53+$ & US $\$ 0.45+$ \\
\hline $\begin{array}{l}\text { Conjugado contra } \\
\text { pneumococo }\end{array}$ & US $\$ 61,65$ & US $\$ 48,25$ & - & - \\
\hline $\begin{array}{l}\text { Raiva (em cultura de } \\
\text { células Vero) }\end{array}$ & - & - & US $\$ 8,50$ & - \\
\hline Gripe & US $\$ 8,50$ & US $\$ 6,60$ & - & - \\
\hline Meningite A e C & . & - & - & US\$0.30@ \\
\hline
\end{tabular}

Obs.: Os preços apresentados são os mais baixos possíveis para a configuração do produto. Todos vêm em frascos de uma dose, exceto quando indicado: +com 5 doses; *com 10 doses; @com 50 doses. As vacinas combinadas não foram incluidas para preservar a clareza do quadro.

Os produtos e seus ciclos de vida: incluindo questões sobre a distribuição de vacinas

\section{Ciclo de desenvolvimento do produto}

Para vacinas, o ciclo é longo, durando de 10 a 15 anos. Além disso, há um processo significativo de seleção: das 25 candidatas iniciais, cinco atingem a fase III de desenvolvimento clínico e apenas uma chega ao mercado. À parte o longo tempo demandado para o retorno do investimento e a alta taxa de insucessos na fase de desenvolvimento, os investidores ainda têm que lidar com o fato de que o tempo de vida das vacinas pediátricas está ficando cada vez mais curto. 0 Quadro 5 mostra o caso dos Estados Unidos.

Sendo assim, talvez as empresas e instituições que desenvolvem vacinas não tenham a possibilidade de decidir sabiamente que produtos desenvolver. Tudo $o$ que podem fazer é monitorar o mercado e a linha de prođução para poder gerenciar melhor o ciclo de vida dos produtos nas fases de seu lançamento e penetraçăo no mercado, bem como de sua maturidade. 0 ciclo será de grande influência na fixação do preço do produto e de sua margem de lucro, assim como está ilustrado no Quadro 6 (Whitehead,1999). 
Quadro 5 - Redução do tempo de vida das vacinas pediátricas dos Estados Unidos

\begin{tabular}{|l|c|c|l|}
\hline Vacina & $\begin{array}{c}\text { Ano em que foi } \\
\text { introduzida }\end{array}$ & $\begin{array}{c}\text { Anos até a 1a } \\
\text { substituição }\end{array}$ & Vacina substituta \\
\hline DTP & 1948 & 48 & DtaP \\
eIPV & 1954 & 9 & VOP \\
VOP & 1963 & 36 & elPV \\
Hib (polissacarídeo) & 1985 & 2 & Hib (conjugado) \\
Hepatite B-feita a partir & 1981 & 5 & $\begin{array}{l}\text { Hepatite B } \\
\text { (recombinante) } \\
\text { de plasma }\end{array}$ DTP-Hib \\
Hib (Conjugado) & 1987 & 6 & $\begin{array}{l}\text { Substituída pelas vacinas } \\
\text { combinadas com DTP }\end{array}$ \\
DTP-Hib & 1993 & 7 & \\
\hline
\end{tabular}

Fonte: Adaptado do discurso feito por Kevin Reilley (Wyeth), no World Vaccine Congress, realizado em Montreal em 2002.

Quadro 6 - Gerenciando o ciclo de vida dos produtos

\begin{tabular}{|c|c|c|c|}
\hline $\begin{array}{l}\text { Fase no ciclo de } \\
\text { vida }\end{array}$ & $\begin{array}{l}\text { Lançamento de } \\
\text { novo produto }\end{array}$ & $\begin{array}{l}\text { Penetração no } \\
\text { mercado }\end{array}$ & $\begin{array}{l}\text { Maturidade do } \\
\text { produto }\end{array}$ \\
\hline Número de fabricantes & 1 & $\begin{array}{l}\text { Diversos, países } \\
\text { industrializados }\end{array}$ & $\begin{array}{l}\text { Alto, países } \\
\text { industrializados e em } \\
\text { desenvolvimento }\end{array}$ \\
\hline Capacidade disponivel & Baixa & Alta & Possível excedente \\
\hline Demanda de mercado & Baixa & $\begin{array}{l}\text { Alta, países } \\
\text { industrializados e setor } \\
\text { privado }\end{array}$ & Alta, todos os mercados \\
\hline Custo & Alto & Médio & Baixo \\
\hline Preço & Alto e uniforme & $\begin{array}{l}\text { Diferenciado dentro e } \\
\text { através dos mercados, } \\
\text { média de preço alta }\end{array}$ & $\begin{array}{l}\text { Diferenciado dentroe e } \\
\text { através dos mercados, } \\
\text { média de preço baixa }\end{array}$ \\
\hline
\end{tabular}

\section{Acesso aos produtos: o impacto do TRIPS}

Hoje em dia, o acesso à propriedade intelectual é um dos fatores decisivos no ciclo de desenvolvimento do produto. Todavia, a maioria dos países em desenvolvimento terá de levar em conta o impacto das leis de propriedade intelectual se decidir ingressar na Organização Mundial do Comércio (OMC), concordando com os termos do acordo TRIPS, que estabelece um padrão mínimo global para a propriedade intelectual. A partir do momento em que esses países já se recusaram a reconhecer as leis de propriedade intelectual no passado - quando o acesso aos produtos ficou ameaçado -, pode-se esperar algum impacto dessas leis. Um estudo publicado no país sobre o acesso a drogas antiretrovirais é bastante ilustrativo (Galvão, 2002).

o Brasil adota uma política de distribuição gratuita de medicamentos para o tratamento de portadores do HIV; essa distribuição é feita através do sistema de saúde pública 
em todo o território nacional e é obrigatória por lei desde 1996 (Brasil, 2002). Em 2001, os custos desses medicamentos chegaram a 232 milhões de dólares, mas, em prol da redução de custos, o país passou a favorecer a produção doméstica dessas drogas importando o componente ativo e, assim, honrando a proteção das patentes. Dessa forma, em 2001, $63 \%$ dos anti-retrovirais usado no país eram produzidos por empresas brasileiras, sendo o restante ( $57 \%$ dos gastos) comprado no mercado internacional. No entanto, o Brasil ameaçou a quebra de patentes, usando a possibilidade prevista pelo TRIPS de licença compulsória, caso não houvesse redução de preços por parte dos fabricantes. 0 efeito disso foi a redução dos preços pela Merck e pela Roche.

As discussões para se definir em que termos funcionará a licença compulsória aceitáveis para países tanto como o Brasil quanto como os Estados Unidos - estão em andamento. O estudo de Galvão (2002) conclui que a resposta brasileira para a questão do acesso poderia servir de modelo para outros países e aconselha estudo mais aprofundado do assunto.

No caso das vacinas, a barreira do know-how pode ser mais importante do que a das leis de proteção intelectual. Até hoje, a única vacina que teve o seu acesso restrito por patentes foi a contra a hepatite B. Quando a vacina passou a ser produzida fora dos Estados Unidos e da Europa, sendo oferecida no mercado mundial, seu preço finalmente caiu. Os fabricantes atuais de novas vacinas têm se mostrado mais dispostos a, primeiro, permitir o acesso a elas a preços diferenciados e, segundo, formar parcerias com fabricantes de países em desenvolvimento para fornecer o know-how e, com isso, permitir o acesso. A indústria brasileira de desenvolvimento de vacinas deveria, entretanto, estar ciente de seus direitos e responsabilidades sob o TRIPS, especialmente no que concerne às inovações produzidas no próprio país.

\section{Novas tecnologias de administração de vacinas}

É normal que mudanças na tecnologia de administração de vacinas sejam somente interpretadas como alterações na dosagem, nas vias de administração e no calendário e estratégia de vacinação. Contudo, novas tecnologias estão sendo investigadas visando ao desenvolvimento de novas plataformas de distribuição, que podem ser divididas em pelo menos três áreas gerais:

- Plataformas mecânicas - Podem abarcar dispositivos como pistolas de vacinação, seringas autodescartáveis após o uso (autodisable - $A D$ ) e novos métodos de administração, caracterizados pelo uso do aerossol na aplicação, podendo ser nasal ou oralmente, para vacinas líquidas ou em pó. Essas plataformas estão sendo desenvolvidas (em especial para o sarampo) e têm o potencial de se tornar uma fonte importante de inovações.

- Plataformas epidemiológicas - Dentro desse grupo, estaria incluída a aplicação em grupos-alvo diferentes - como mulheres grávidas a fim de imunizar os recémnascidos, ou adolescentes para a prevenção de doenças sexualmente transmissíveis - e outras estratégias de administração que não dependessem dos programas 
de imunização tradicionais, por exemplo, ou paralelas a aconselhamentos e outras intervenções. Essas plataformas serão importantes na investigação de vacinas contra o HIV/Aids.

- Plataformas moleculares - Nesse grupo, inclui-se o uso de adjuvantes mais modernos, de tecnologia de recombinação genética (como nas vacinas de DNA) e de novos alvos - utilizados para melhorar a resposta imunológica de maneira geral, $\mathrm{e}$ não específica. É bom reiterar que, em termos de inovação, o potencial de impacto das descobertas citadas anteriormente não pode ser desprezado.

Parcerias: o que está acontecendo no mundo e como isso vai influenciar a indústria de vacinas

No estudo realizado pela Mercer a respeito da indústria de produção vacinas (Whitehead \& Pasternak, 2002), esta é dividida em cinco diferentes segmentos: multinacionais dos Estados Unidos (como a Merck e a Wyeth); multinacionais européias (como a GlaxoSmithKline, a Aventis-Pasteur e a Chiron); empresas locais, membros da Organização para Cooperação Econômica e Desenvolvimento (OECD) (Como o Statens Serum Institute, a CSL); fornecedores emergentes (como o Serum Institute of India, a Biofarma, a Green Cross; encaixam-se nesse grupo Bio-Manguinhos e Butantan) e companhias locais de países em desenvolvimento (como os fabricantes do governo da China, do Egito e do Vietnã, que não exportam). A análise aqui apresentada inclui uma sexta categoria, as empresas de biotecnologia (como a Acambis e a VaxGen), que, no futuro, terão grande força na produção de vacinas.

Cada um desses grupos procura parcerias de maneira diferente. Para o propósito desse estudo, analisa-se a tendência de crescimento do número de parcerias, pois vai afetar a disponibilidade de vacinas produzidas em mercados emergentes para quatro grupos-chave de stakeholders: os fabricantes dos países industrializados, a indústria de biotecnologia, o setor público e fornecedores emergentes.

\section{A questão vista pelo lado dos fabricantes de países industrializados}

Os fabricantes de países industrializados formam parcerias para obter acesso a uma tecnologia nova (como por exemplo, o acordo entre a Merck e a Crucell sobre um sistema de replicação específico) ou a um certo mercado (como os acordos entre a GlaxoSmithKline e os produtores do Brasil, do Egito e de Cuba); além disso, investem de forma significativa em pesquisa. Noticiou-se que a Merck, por exemplo, investiu 1.821 bilhāo de dólares em P\&D em 1998, 12\% do total de vendas no setor farmacêutico (Global Forum for Health Research, 2001). Por isso, foi previsto que parcerias específicas de acesso a tecnologia ocorrerão mediante acordos limitados. Apesar da existência de alguns acordos entre companhias como a GlaxoSmithKline e a Aventis-Pasteur e fornecedores emergentes para o compartilhamento de tecnologia (como o feito entre o Instituto Finlay Cuba e 
a GlaxoSmithKline para a vacina contra o meningococo B, por exemplo), a maioria dos pactos se refere ao acesso a mercados e não à tecnologia. Os fornecedores emergentes devem estar atentos a esse tipo de motivação quando estiverem se decidindo por esse tipo de acordo.

\section{A questão vista pelo lado da indústria de biotecnologia}

A indústria de biotecnologia é composta por empresas que desenvolveram uma ou duas tecnologias aplicáveis a diferentes plataformas e querem fazer acordos de financiamento. Há uma grande gama de tecnologias de plataformas de produção de certos produtos, como linhagens celulares, moléculas que estimulam o sistema imunológico, diferentes tecnologias de produção de vacinas e mudanças na totalidade da produção. A essência das empresas de biotecnologia é pesquisa e desenvolvimento e seu investimento nessa área pode chegar a $50 \%$ ou mais do seu total de vendas (Global Forum for Health Research, 2001). Geralmente, dentre os objetivos das empresas, está, pelo menos, uma ou mais parcerias para conseguir o dinheiro necessário ao prosseguimento de seus projetos. Todavia, as melhores companhias de biotecnologia se caracterizam pelo excelente know-how, pelo ótimo quadro de funcionários, pela experiência na produção (como, por exemplo, a Berna Biotech, a VaxGen e a Acambis, que fizeram acordos para a produção de vacinas contra doenças deflagráveis pelo bioterrorismo) e pela habilidade de fazer grande parte do trabalho de desenvolvimento clínico necessário à chegada do produ to ao mercado. Se as partes estiverem de acordo quanto aos objetivos da parceria, a indústria de biotecnologia pode ser uma boa parceira para os fornecedores emergentes.

\section{A questão vista pelo lado do setor público}

O interesse do setor público é o acesso a vacinas novas produzidas pelo mercado em desenvolvimento a preços que possa pagar. O setor público só apóia parcerias que permitem que isso aconteça. Entretanto, duas tendências potencialmente negativas podem ser abrandadas pela formação de parcerias - tendências essas que já se concretizaram nos últimos anos: de redução progressiva de fabricantes multinacionais no mercado de vacinas dos países em desenvolvimento e de aumento da diferença entre os produtos dos países industrializados e dos países emergentes. Ambas as tenđências ameaçam o acesso a vacinas desenvolvidas no futuro. É por esse motivo que o setor público irá promover parcerias voltadas para resolver essas questões.

\section{A questão vista pelo lado dos fornecedores emergentes}

Há uma tendência entre os fornecedores emergentes de limitar-se a parcerias que permitam o fornecimento de vacinas para a população de seus países a preços convenientes. Muitas das parcerias firmadas sob essas condições limitam-se a acordos sobre o envasamento do bulk - como as entre a Aventis-Pasteur e a GPO (da Tailândia); a GlaxoSmithKline e a Vacsera (do Egito); a Aventis-Pasteur e o Butantan; a GlaxoSmithKline e BioManguinhos e entre a Chiron e a Panacea Biotec (da Índia). Algum movimento já foi 
iniciado nessa direção com as joint ventures e acordos de transferência de tecnologia entre fornecedores emergentes - como entre o CIGB, de Cuba, o Instituto Pasteur no Irã e a Panacea Biotech da Índia, ou ainda acordos entre os fabricantes brasileiros, apesar de esse caminho ainda não ter sido totalmente explorado. Até hoje, poucos fornecedores emergentes fizeram uso de parcerias como meio de acesso a tecnologias verdadeiramente inovadoras. As parcerias com produtores multinacionais, ao invés disso, foram firmadas para o acesso a vacinas já em estágios avançados de produção. o desafio apresentado aos fornecedores emergentes será o de encontrar uma maneira de acessar esses novos produtos por intermédio de parcerias, especialmente se os investimentos em pesquisa e desenvolvimentos forem baixos.

\section{QUESTÕES A RESPEITO DA CARGA DAS DOENÇAS}

\section{A relação custo-benefício da imunização}

Uma grande quantidade de estudos demonstrou a boa relação custo-benefício da vacinação, se comparada a outras tecnologias empregadas na saúde pública. Um sumário do trabalho que já foi feito pode ser encontrado nas páginas de Internet da GAVI (GAVI, 2003).

\section{Desenvolvimento futuro do campo das vacinas}

Foi previsto por diversos grupos que o desenvolvimento de vacinas e sua utilização aumentariam no período entre os próximos dez ou vinte anos, fazendo uso tanto da informaçăo disponível a respeito do custo-benefício quanto de outros fatores decisivos.

O Institute of Medicine (IOM) comissionou um estudo para examinar alguns parâmetros específicos da relação de custo-benefício, na forma de QALYs (Quality-Adjusted Life Years) (Stratton, Durch \& Lawrence, 2000). Nesse estudo em particular, levou-se em consideração somente o mercado doméstico dos Estados Unidos; vacinas contra o HIV foram consideradas fora do espectro de investigação do estudo, que foi limitado a vacinas que pudessem ser licenciadas e estar disponíveis nas próximas duas décadas. Já as vacinas terapêuticas foram omitidas aqui, apesar de aparecerem no estudo. Os resultados foram divididos em categorias, dependendo do quão favorável é a relação custobenefício. São consideradas mais favoráveis: vacina contra o citomegalovírus, administrada em crianças de 12 anos de idade; vacina contra a gripe para toda a população; vacina contra estreptococo grupo $\mathrm{B}$, administrada rotineiramente na prevenção da doença em recém-nascidos e em indivíduos em alto risco; vacina contra Streptococcus pneumoniae para crianças e idosos. São favoráveis: vacina contra clamídia para crianças de 12 anos de idade; vacina infantil contra Helicobacter pylori; vacina infantil contra o

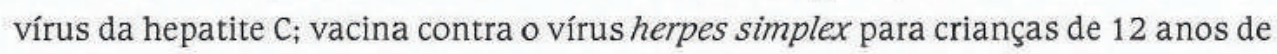
idade; vacina contra o vírus do papiloma humano para crianças de 12 anos de idade; vacina contra o Mycobacterium tuberculosis para populações de alto risco; vacina contra 
Neisseria gonorrhea para crianças de 12 anos de idade; vacina contra o vírus respiratório sincicial (VRS) para crianças e para meninas de 12 anos de idade. E no grupo das menos favoráveis estão: vacina contra o vírus da parainfluenza para crianças e na primeira gravidez; vacina infantil contra rotavírus; vacina infantil contra estreptococos grupo A; vacina contra estreptococos grupo B para adultos de alto risco e meninas de 12 anos de idade.

Apesar de aqui se ter considerado a seleção anterior, outros grupos fizeram previsões diferentes quanto à utilização de vacinas no futuro. Stanley Plotkin (Plotkin, 2002) fez previsōes de vacinas que estarâo disponíveis e poderão ser recomendadas para o uso em populaçōes específicas em 2012: HIV, vacinas orais contra $E$. coli enterotoxigênico (Etec) e Shigella, vacinas contra papiloma, citomegalovírus, herpes simples tipo 2 e vacina pertussis acelular para adolescentes.

O IOM, em um de seus volumes de 2000 , produziu uma lista de vacinas que provavelmente serão recomendadas para uso universal em 2020 (Committee on Immunization Finance, 2000). Segundo o autor, esta lista parece ser a projeção mais completa conforme a situação se mostrava em 2000:

- Gripe para adultos e crianças

- DtaP incluindo componentes para adultos

- MMR e catapora

- Hib

- Hepatite A

- Hepatite B

- Hepatite C

- Conjugado pediátrico (polissacarídeo pneumocócico)

- Conjugado (polissacarídeo meningocócico contra os tipos A, B, C, Y e W135)

- Helicobacter pylori

- Vírus do papiloma humamo

- Parainfluenza

- Vírus respiratório sincicial

- Rotavírus

- Estreptococo grupo A

Seria útil reavaliar essa lista de vacinas - cuja tecnologia de produção já está disponível e provavelmente será indicada para o uso universal, pelo menos nos Estados Unidos - com base nas informaçōes já obtidas a respeito da carga das doenças.

Informações específicas sobre a carga de doenças em nivel mundial

Dependendo dos métodos utilizados e da confiabilidade dos dados, pode ser difícil quantificar informaçōes a respeito da carga das doenças. No Quadro 7, adaptado de um artigo de Roy Widdus (Widdus, 2000), é possível ter uma base de comparação. 
Quadro 7 - Número de mortes em decorrência de doenças infecciosas

\begin{tabular}{|c|c|c|}
\hline Doença & Mortes (000) & Comentários \\
\hline \multicolumn{3}{|c|}{ Vacinas ainda não satisfatórias } \\
\hline Aids & 3.100 & $\begin{array}{l}\text { A prevalência ( } 42 \text { milhões) e o número de novos casos por ano estāo crescendo rapidamente; forte } \\
\text { impacto na expectativa de vida na Árrica }\end{array}$ \\
\hline Tuberculose & 2.000 & Mais de oito milhöes de casos por ano \\
\hline Malária & 1.110 & Entre 300 e 500 casos por ano \\
\hline Pneumococo & 1.100 & Prevalência de sorotipo varia bastante \\
\hline Shigelose & 1.100 & Responsável por $10 \%$ dos casos de doenças diarréicas entre crianças abaixo dos 5 anos de idade \\
\hline Rotavírus & 660 & \\
\hline E. coli enterotoxigênico & 380 & 216 milhōes de casos por ano \\
\hline VRS & 160 & 64 milhöes de casos \\
\hline Esquistossomose & 150 & 600 milhões sob risco de contrair a doença, prevalência de 200 milhōes \\
\hline Leishmaniose & 42 & Prevalência de 350 milhões de pessoas em 89 países \\
\hline Tripanossomíase & 40 & \\
\hline Doença de Chagas & 17 & \\
\hline Dengue & 15 & 2,5 bilhōes de pessoas sob risco de contrair a doença \\
\hline Lepra & 2 & \\
\hline Vírus do papiloma humano & & 510.000 novos casos por ano, 630 milhões de pessoas infectadas \\
\hline Herpes simplex tipo 2 & & De $20 \%$ a $40 \%$ dos adultos estäo contaminados \\
\hline \multicolumn{3}{|c|}{ Vacinas satisfatórias disponíveis } \\
\hline Hepatite B & 1.000 & \\
\hline Sarampo & 888 & \\
\hline Febre tifóide & 600 & \\
\hline Haemophilus influenziae tipo b & 500 & \\
\hline Tétano & 410 & \\
\hline Coqueluche & 346 & \\
\hline Cólera & 120 & \\
\hline Raiva & $40-70$ & Por ano, 10 milhōes de pessoas recebem a vacina contra a raiva após terem sido mordidas \\
\hline Gripe & $20-40$ & $\begin{array}{l}\text { Número para os Estados Unidos, a Europa e o Japão: } 120 \text { milhōes de casos. Mortes podem chegar } \\
\text { a alguns milhōes em todo o mundo }\end{array}$ \\
\hline Febre amarela & 30 & Estimativa de 200.000 casos por ano em certas regiōes da África e na América do Sul \\
\hline Difteria & 5 & \\
\hline Encefalite japonesa & 3 & 2,4 bilhöes de pessoas sob o risco de contaminação \\
\hline
\end{tabular}

Fonte: Dados de 1999, em maioria, de Widdus (2000). 
Assim, em escala global, entre as doenças que ainda não possuem uma vacina satisfatória, a Aids, a tuberculose, a malária, as causadas por pneumococos, a shingelose e as provocadas por rotavírus estão no topo da lista. Todavia, pensando-se em toda a população-alvo possível, há vacinas adicionais que seriam de grande utilidade se fossem desenvolvidas. O principal problema em relação às vacinas já existentes, para a maioria das pessoas, é o acesso. Possivelmente, haverá um grande mercado (e em expansão) para as vacinas contra a raiva, gripe a encefalite japonesa tipo B.

\section{Informações específicas sobre a carga das doenças no Brasil}

Um quadro semelhante também foi montado para se observar a epidemiologia das doenças no Brasil (Quadro 8) (Funasa, 2003b).

Quadro 8 - Mortes e casos de doenças infecciosas - Brasil - 2001

\begin{tabular}{|c|c|c|}
\hline Doença & Mortes & Comentários \\
\hline \multicolumn{3}{|c|}{ Não há vacinas desenvolvidas } \\
\hline Tuberculose & 5.528 & 94.360 casos \\
\hline Aids & 4.036 & 17.504 casos \\
\hline Malária & 98 & 389.737 casos \\
\hline Leishmaniose visceral & 93 & 2.754 casos \\
\hline Dengue & 28 & 428.117 casos (note que, em 2002, houve 96 mortes causadas por dengue hemorrágica) \\
\hline Rotavírus & $?$ & $\begin{array}{l}21 \% \text { das } 685 \text { amostras coletadas de crianças com diarréia obtiveram resultado positivo no teste de } \\
\text { identificação do rotavírus* }\end{array}$ \\
\hline \multicolumn{3}{|c|}{ Há vacinas disponiveis } \\
\hline Tétano & 86 & 366 casos, dos quais 34 de tétano neonatal, com 27 mortes \\
\hline Febre amarela & 22 & 41 casos, em áreas florestais \\
\hline Raiva & 21 & Todos os 21 casos foram fatais \\
\hline Coqueluche & 13 & 1.464 casos \\
\hline Febre tifóide & 9 & 584 casos \\
\hline Difteria & 2 & 19 casos \\
\hline Rubéola & - & 16 casos \\
\hline Cólera & 0 & 7 casos \\
\hline Sarampo & 0 & 1 caso importado do Japão \\
\hline
\end{tabular}

^Fonte: Santos et al. (1999). 
Note-se que 2.867 casos de meningite - dos quais 555 foram fatais -, não separados por tipo, foram registrados em 2001. Além disso, todos os três tipos de hepatite (A, B e C) têm alta prevalência em certas regiōes do Brasil, chegando a duzentos casos por cem mil habitantes, dependendo do local.

Concluir-se-á, com base na informação contida no Quadro 8 , que as vacinas contra todas as doenças que ainda não dispõem de imunizante, como aquelas contra meningite e hepatite, teriam uma utilidade concreta para o Brasil. Além disso, entre doenças contra as quais existem vacinas, o tétano, a febre amarela, a raiva e a coqueluche continuam sendo perigosas para o Brasil.

\section{Previsão de demanda: qual é a 'cara' do mercado?}

\section{Prevendo os cenários possíveis}

A previsão de demanda pode ser dividida em várias categorias, cada uma com sua metodologia, para situações rotineiras ou epidêmicas. Essas situações estão definidas na Quadro 9.

Quadro 9 - Previsão de possíveis cenários para a demanda de vacinas

\begin{tabular}{|c|c|c|}
\hline $\begin{array}{l}\text { Disponibilidade das } \\
\text { vacinas }\end{array}$ & A) Rotina, possivel de antever & B) Em resposta a epidemias \\
\hline $\begin{array}{l}\text { 1) Disponivel, amplo } \\
\text { fornecimento }\end{array}$ & Baseado em usos anteriores & $\begin{array}{l}\text { Necessidades do projeto baseadas } \\
\text { em suposiçōes. Uso dos estoques de } \\
\text { matéria-prima }\end{array}$ \\
\hline $\begin{array}{l}\text { 2) Disponivel, fornecimento } \\
\text { restrito }\end{array}$ & \multicolumn{2}{|c|}{0 mesmo que o número 1 , mas alocada segundo critérios de necessidade e de preço } \\
\hline $\begin{array}{l}\text { 3) Vacina nova, amplo } \\
\text { fornecimento }\end{array}$ & $\begin{array}{l}\text { Desenvolver modelo de referência para a } \\
\text { dosagem }\end{array}$ & $\begin{array}{l}\text { O mesmo que o número } 1 \mathrm{~B} \text {, } \\
\text { somando-se um fator de capacidade } \\
\text { de absorçäo, o que complicará a } \\
\text { dosagem }\end{array}$ \\
\hline $\begin{array}{l}\text { 4) Vacina nova, fornecimento } \\
\text { restrito }\end{array}$ & \multicolumn{2}{|c|}{$\begin{array}{l}0 \text { mesmo que o número } 3 \text {, sendo as decisōes relativas à alocação dos recursos } \\
\text { tomadas com base na necessidade e no preço }\end{array}$} \\
\hline $\begin{array}{l}\text { 5) Vacina ainda não } \\
\text { desenvolvida, características } \\
\text { conhecidas }\end{array}$ & $\begin{array}{l}\text { Desenvolver demanda baseando-se na } \\
\text { necessidade e nas capacidades financeiras, } \\
\text { supondo a disponibilidade e a aceitabilidade } \\
\text { das características das vacinas }\end{array}$ & 0 mesmo que o número $3 \mathrm{~B}$ \\
\hline $\begin{array}{l}\text { 6) Vacina ainda não } \\
\text { desenvolvida, características } \\
\text { desconhecidas }\end{array}$ & $\begin{array}{l}\text { Desenvolver uma família de cenários de } \\
\text { demanda com variaçōes de características e } \\
\text { de disponibilidade }\end{array}$ & $\begin{array}{l}0 \text { mesmo que o número } 3 \mathrm{~B} \text {, sendo as } \\
\text { decisōes relativas à alocação dos } \\
\text { recursos tomadas com base na } \\
\text { necessidade e no preço }\end{array}$ \\
\hline
\end{tabular}

É claro que é mais fácil fazer previsões de demanda para situações de uso rotineiro e supondo disponibilidade total do produto (1A). Nos últimos anos, o Unicef - no caso da GAVI e das vacinas combinadas de base DTP - está na situação 4A. Assim, a previsão de demanda para um novo produto foi dificultada pela escassez de fabricantes. Questōes de 
sincronia tornaram-se de suma importância: se um país atrasasse a introdução da vacina, mesmo que só por um mês, as estratégias de fornecimento desordenavam-se. 0 Vaccine Provision Project (VPP), que será descrito adiante, foi montado para suportar esse tipo de cenário.

O Unicef e a OMS, no caso de epidemias de febre amarela e de meningite, está em situação 2B (ou 4B, no caso das vacinas contra a cepa W135). Esse tipo de situação está sendo revertido, usando um estoque controlado por uma aliança, a Interagency Coordinating Group (ICG).

No que se refere ao uso de uma nova vacina, como o conjugado contra pneumococo, em um mercado limitado, cuja planificação pode ser realizada com um alto grau de certeza tomando-se como referência um cenário de uso de rotina, o que estaria acontecendo seria a situação 3A. Quanto a uma vacina desconhecida como a contra o HIV, cujas previsões de demanda já começaram a ser feitas, a situação é ainda mais complexa, assim como foi definido na situação $6 \mathrm{~A}$. De todos, o cenário mais complicado é o das vacinas para situações emergenciais, como a contra a varíola - no caso de bioterrorismo -, ou contra a gripe, no caso de uma pandemia global (que se encaixam nas situaçōes 5 e 6B).

\section{O Vaccine Provision Project (VPP)}

Esse projeto da GAVI (Whitehead \& Pasternak, 2002), com a participação ativa da OMS, do Unicef e do Fundo de Vacinas, fez um prognóstico a respeito da necessidade de vacinas que contenham antígenos contra o Hib e a hepatite $\mathrm{B}$ nos países-membros do Fundo de Vacinas para 2004-2006. O prognóstico foi feito com base em uma categorização dos países em termos de quais vacinas estão usando ou quais já foram aprovadas e de quais fontes elas estão sendo compradas. Por exemplo, alguns dos países-membros americanos do Fundo de Vacinas estão comprando através do fundo rotatório da Opas, não sendo, por isso, incluídos no prognóstico.

Esse processo, necessário seja pelo fato de que esses países estão introduzindo novos produtos, seja porque podem vir a sofrer certas pressões ou constrangimento cionais e financeiros para adquiri-los, seja por causa do cenário de fornecimento limitado, cuja conseqüência é amplamente desconhecida e imprevisível para o período entre 2004 e 2006, é feito em três etapas. A primeira consta em prever uma demanda nacional 'pura', baseada na população-alvo, na área-alvo e na previsão de aproveitamento do produto da maneira aprovada. Essa demanda não considera possíveis mudanças para produtos novos (por exemplo, vacinas contendo eIPV, vacinas conjugadas contra meningite tipos A e C ou vacina acelular contra coqueluche) e presume que o uso de vacinas contra o Hib na Ásia e na Europa Oriental será nulo ou limitado. O segundo passo será desenvolver um prognóstico ajustado à oferta, comparando-se o prognóstico 'puro' com as ofertas reais. Isso será feito usando a Vaccine Allocation Policy, que será revista por uma junta da GAVI, constituindo o terceiro passo. 
Dentre os aspectos que diferem dos prognósticos anteriores estăo:

- Mais países já se inscreveram e foram aprovados, tornando o prognóstico mais robusto.

- O VPP relaciona o prognóstico à gestão e ao acompanhamento de programas de introdução de novas vacinas sob a liderança da OMS.

- A análise dos riscos e os efeitos dos processos (como a sustentabilidade financeira e a dinâmica do mercado de vacinas) estão mais confiáveis.

- Os riscos foram avaliados e estratégias de atenuação foram implementadas. Um exemplo disso é um cenário onde não há aumento da disponibilidade de vacinas combinadas com DTwP: esse risco será quantificado e precauções já serão tomadas contra ele.

Espera-se que o novo modo de administração de projetos do VPP nos dê um modelo que facilite a previsão de demanda em situações de introdução de novas vacinas cujo fornecimento pode ser uma questão bastante complexa (situações 3 e 4A).

Quanto aos planos futuros de compra da GAVI, a decisão será tomada por sua Direção (board). Um ponto-chave será a compra de vacinas contra o Hib, pois seu preço relativamente alto demandará um volumoso capital de giro para que se possa assegurar a sustentabilidade. Para adicionar novas vacinas, ainda será necessário levar o preço e a oferta em consideração, sendo, portanto, muito difícil que a vacina inativada contra a pólio e a acelular contra coqueluche sejam incluídas. Porém, a Financing Task Force da GAVI está comissionando um estudo para tentar determinar que vacinas estarão incluídas nas combinações a serem usadas no futuro e qual será o papel dos fornecedores emergentes em sua oferta. Além disso, se for necessário escolher entre o fornecimento de vacinas contra rotavírus e o đe conjugados contra pneumococos, é mais provável que a vacina contra rotavírus seja escolhida, tendo por base a projeção de seus custos de fornecimento. É provável também que a vacina contra sarampo e rubéola (MR) seja comprada, tendo em vista as metas da GAVI para a redução da incidência do sarampo. Levando em conta as metas do Unicef, pode-se prever que, no futuro, ele tenderia a apoiar o fornecimento de vacinas contra a malária em detrimento de vacinas contra o HIV/Aids, apesar de essa decisão ainda não ter sido tomada. O Fundo, provavelmente, não iria apoiar nem a compra de vacinas contra gripe em caso de pandemia global nem a estocagem de vacinas contra ataques de bioterrorismo - embora esses produtos pudessem ser comprados pelo Unicef em prol de alguns de seus doadores.

\section{Situação peculiar da vacina contra a febre amarela}

A vacina contra a febre amarela, que também está sendo adquirida pelo Unicef para o Fundo de Vacinas da GAVI, está em uma situação particular. Como ela não está no calendário de vacinação infantil de países onde a doença ocorre, a maioria na África subsaariana, foi colocada na lista do Fundo de Vacinas. No entanto, o fato de a demanda ser esporádica fez com que sua oferta não tivesse sido suficiente nos últimos anos. Assim, a natureza imprevisível das epidemias fez com que o estoque de vacinas para uso 
de rotina se esgotasse. Ademais, estudos demonstraram que adicionar simplesmente a vacina contra febre amarela no sistema de rotina - dando-se uma dose à criança aos nove meses de idade - faria com que demorasse quarenta anos até que a maioria da população em situação de risco estivesse imunizada. Por isso, a imunização de rotina deve ser combinada com uma campanha de imunização preventiva que alcance toda a população em situação de risco. Isso exige uma quantidade de vacinas muito maior do que normalmente está disponível, sem contar com aquelas para uso de rotina e as destinadas à formação de um estoque em caso de epidemia.

Em novembro de 2002, a mesa de diretores da GAVI recomendou que, além do apoio dado à vacinação de rotina contra a febre amarela, o Fundo de Vacinas apoiasse também a formação de um estoque de vacinas para a prevenção e o controle de epidemias, permitindo que essa estratégia fosse implementada em sua totalidade (GAVI, 2003). Um estoque de vacinas contra a febre amarela será constituído, no pior dos casos, para o uso no controle de epidemias, e as vacinas que sobrarem, no fim do ano, poderão ser usadas para complementar as usadas nas campanhas de imunização preventiva já existentes em áreas de grande risco. Sendo assim, a Direção da GAVI pediu ao Fundo de Vacinas que destinasse 9 milhões de dólares -3 milhões por ano durante três anos - como apoio à formação de um estoque de seis milhões de vacinas. Estimou-se que um estoque dessa natureza teria de ser mantido por um período entre 10 e 15 anos. Além das vacinas contra febre amarela que podem ser fornecidas pelo Fundo Rotatório da Opas (incluindo - Brasil), esta será a maior compra mundial de vacinas contra a febre amarela: em frascos de 50 doses, melhores para o uso em epidemias e em campanhas de vacinação indiscriminada, e de 20 doses, para o uso de rotina. Todavia, um fator importante no que concerne à compra eventual de vacinas contra a febre amarela pelo Unicef é a fonte das vacinas a serem utilizadas na Nigéria, um dos maiores usuários em potencial. Esse estoque é um exemplo do grau de simplificação da previsão de demanda que se pode alcançar trocando uma estratégia de utilização de vacinas baseada somente em epidemias imprevisíveis por uma de rotina, previsível - como na situação $1 \mathrm{~A}$.

\section{0 papel das agências internacionais na construção da demanda}

Os exemplos dados até agora dão uma visão geral dos esforços empreendidos pelo setor de saúde pública para calcular a demanda, mas, até hoje, pouca atenção foi dada aos esforços feitos com o intuito de construir uma demanda proativamente. No caso das vacinas usadas no setor privado, isso é feito pelos próprios membros da indústria de vacinas, porém, excluindo-se a defesa do valor das vacinas, esse grupo pouco se empenhou no caso do uso das vacinas pelo setor público. Tal responsabilidade cabe, tradicionalmente, à OMS e a outras agências, co-patrocinando testes clínicos e projetos-piloto em países emergentes. Dois exemplos serão discutidos aqui: as atividades do Fundo Rotatório da Opas e os Accelerated Development and Introduction Projects (ADIP).

O Fundo Rotatório da Opas atuou, no passado, como meio de estímulo à demanda por novos produtos a serem incluídos nos programas de vacinação de rotina, utilizando 
três mecanismos: 1) efetuando estimativas da carga das doenças com base em estudos realizados em laboratórios e hospitais - por exemplo, um estudo sobre a prevalência de sorogrupo do streptococcus pneumoniae, realizado nos últimos anos;2) desenvolvendo o consenso regional sobre quais vacinas introduzir no programa de imunização de rotina, incluindo apoio programático - como a recomendação da administração de MMR ou da vacina contra o Hib em países da região; 3) negociando a compra de grandes volumes dessas vacinas pelos países da região a preços favoráveis, a fim de promover seu uso - é o caso do Uruguai, que costumava comprar a vacina contra o Hib por US $\$ 9$ a dose, e, na época, o Fundo Rotatório da Opas conseguiu um preço de US $\$ 3,50$ a dose. Para 2003, o valor é de US $\$ 2,95$ (unidose, liofilizada), e US $\$ 2,50$ a dose para a DTP-Hib (líquida, em frascos com 10 doses).

Os ADIP são uma nova estratégia da GAVI para colocar em uso as vacinas conjugadas contra rotavírus e streptococcus pneumoniae. Funcionarăo utilizando equipes dentro do Program for Advanced Technology in Health (lidando com o rotavírus) e da Johns Hopkins University Bloomberg School of Public Health (lidando com o pneumococo), com recursos do Fundo de Vacinas, além disso coordenarão atividades nas áreas de desenvolvimento de vacinas, regulação, quantificação de mercado, e, eventualmente, aquisição de material e financiamento. Espera-se que um projeto seguro de gestão faça, em nível global, o que o Fundo Rotatório da Opas fez pela promoção do uso de vacinas em nível regional - sem deixar de levar em conta o que ainda está por ocorrer com esses produtos, visto que ainda estão em fase de desenvolvimento.

Construindo uma previsão de demanda: a situação da Aids

Nos anos de 2000 e 2001, a OMS-Unaids, a Iniciativa Internacional para Vacinas contra a Aids (Iavi) e muitos representantes de governos de países nos quais há alta incidência de HIV se encontraram para uma série de reuniōes. Os encontros visavam a estimar o número necessário de vacinas contra a Aids e quantas provavelmente seriam administradas efetivamente, fundamentando-se na projeção de cenários de características da vacina e de sua aceitação (Esparza et al., 2003). Consultas regionais, realizadas em Florianópolis (Brasil), Entebbe (Uganda), Seul (Coréia) e na Genebra (Suíça), consideraram duas previsōes de eficácia (entre $30 \%$ e $50 \%$ e entre $80 \%$ e $90 \%$ ) e estimaram o consumo provável baseando-se na capacidade de distribuição da vacina e na aceitação desses produtos em seus países. Os resultados foram mais baixos do que o esperado: $38 \%$ da estimativa inicial de 690 milhôes de tratamentos para a vacina de alta eficácia e 19\% da estimativa inicial de 260 milhões de tratamentos para a vacina de eficácia entre baixa e moderada. Um aspecto-chave para se compreenderem esses resultados é a projeção de uso de vacinas de eficácia entre baixa e moderada somente em população de alto risco. Quanto mais se souber sobre as estratégias de distribuição e aplicação e as características das vacinas, mais as estimativas serão precisas. Todavia, isso serve de exemplo para as atividades de construção de cenários que devem necessariamente acompanhar as projeções de demanda para vacinas na situação $6 \mathrm{~A}$. 
Em que aspectos o Brasil tem vantagens competitivas?

Um fabricante de vacinas no Brasil tem vantagem competitiva quando há uma necessidade explícita no mercado global ou regional por um produto que ele tem a capacidade de produzir. Isso inclui o uso de tecnologias já desenvolvidas, de seu patrimônio (em termos de equipamentos e know-how), de sua excelência na capacidade de realizar os testes, de suas virtudes em termos de regulação, da vigilância epidemiológica e do acesso ao mercado. Dentre as necessidades principais, que também coincidem com as necessidades do país e da região, estão as vacinas que ainda não foram desenvolvidas contra HIV/Aids; tuberculose; malária; dengue; leishmaniose e rotavírus--, bem como as que já foram desenvolvidas - conjugadas de polissacarídeos; contra raiva (produzida em cultura de células); contra febre amarela; componentes da DTP e MR.

Cada uma delas será analisada pormenorizadamente a seguir. Quando for relevante, serão consideradas, para cada vacina, a história dos esforços em termos de P\&D no Brasil, a vigilância epidemiológica da doença que previne, as possibilidades de sua produção e questōes a respeito de sua regulação, incluindo os testes clínicos. ${ }^{2}$

\section{Vacina contra o HIV/Aids}

Apesar de desconhecer qualquer atividade de P\&D da vacina contra o HIV/Aids, em específico, sendo realizada no Brasil, o país tem vantagem competitiva por ser sítio de pesquisas clínicas para esse imunizante. Ainda estão abertas as inscriçōes para a realização de testes clínicos multicentro (ou seja, feito em parceria com outros centros) de fase II para o desenvolvimento de uma vacina de subunidades contra o subtipo B do HIV-1, utilizando a glicoproteína 120 , presente no capsídeo do vírus, e de fase II do ALCVACvCP1452 (varíola aviária, da Aventis), também com a glicoproteína 120 do subtipo B do HIV-1, patrocinado pelo USAID e pelo NIH. Em ađição, testes com plasmídeos contendo o gene gag do subtipo $\mathrm{B}$ do HIV e com vetores de adenovírus do tipo 5 contendo genes gag, pol e nef do subtipo B do HIV (Merck) também estão com inscrições abertas. Uma experiência desse tipo daria alguma vantagem ao Brasil quanto ao licenciamento de uma vacina contra o HIV/Aids, pois o país já analisou as questões relativas à autorização desses testes clínicos. Atualmente, há, no mundo inteiro, três vacinas contra o HIV em fase I, oito em fase II e duas em fase III (Jordan Report, 2002a).

\section{Vacina contra a malária}

Um levantamento de testes em vacinas contra a malária não encontrou nenhum estudo ou pesquisa sobre a enfermidade no Brasil. Atualmente, em nível global, existem oito vacinas contra malária em fase I, quatro em fase II e uma em fase III (Jordan Report, 2002b).

\section{Vacina contra a tuberculose}

Exceto pelo trabalho realizado com a BCG no Butantan, não se sabe de qualquer pesquisa em vacinas contra a tuberculose em andamento no Brasil. Atualmente, no mundo, há duas vacinas contra tuberculose em fase de testes: um em fase I e outro em fase II (Jordan Report, 2002b).

\footnotetext{
${ }^{2}$ Há um grande número de vacinas que năo considerei, como as contra a hepatite $A \in$ a catapora. Isso não significa que acredito que - Brasil nāo as possa produzir, mas sim que não creio que 0 país tenha uma vantagem comparativa quanto a elas.
} 


\section{Vacina contra dengue}

A Aventis, o Walter Reed Army Institute of Research e a Acambis têm vacinas contra a dengue em fase de testes clínicos. A Aventis está desenvolvendo em parceria com a Acambis a tecnologia de produção de vacinas quimeras, ou seja, vacinas feitas de dois ou mais organismos, baseadas na cepa 17D do vírus da febre amarela. Bio-Manguinhos está desenvolvendo um kit de diagnóstico da dengue de anticorpos monoclonais que deve ajudar nas atividades de introdução de uma vacina contra a dengue. A possibilidade de se firmar um acordo com a Aventis para investimento no know-how que Bio-Manguinhos tem na produção da vacina contra a febre amarela é algo a ser considerado. Atualmente, no mundo todo, há três vacinas contra a dengue em fase I de testes e uma em fase II (Jordan Report, 2002b).

\section{Vacina contra a leishmaniose}

O Brasil tem licença para usar uma vacina feita com a tecnologia antiga. Atualmente, Bio-Manguinhos está desenvolvendo uma nova vacina contra a leishmaniose usando tecnologia recombinante. Esse produto tem um amplo mercado em potencial e a promessa de assistência do programa de Pesquisa em Doenças Tropicais (co-patrocinado pela OMS) e de outras organizações. A experiência adquirida pela Anvisa na revisão de registros de vacinas será um artigo de grande valor. Além do mais, Bio-Manguinhos já desenvolveu kits de diagnóstico de leishmaniose. Uma nova vacina recombinante está entrando, nesse momento, em fase I de testes, produzida pela Corixa.

\section{Vacina contra o rotavírus}

Parte da estratégia da GlaxoSmithKline no desenvolvimento de vacinas contra o rotavírus é, primeiramente, produzi-la para uso na América Latina. A empresa está analisando possibilidades de transferência de tecnologia, com a idéia de licenciar o produto para ser usado em mercados em desenvolvimento num país da América Latina, onde seria envasado. O Brasil é uma opção atraente por causa do acordo já feito com BioManguinhos para o envasamento de produtos, pela importância do país na região e pela experiência da Anvisa. Se a vacina atravessar todas as fases de testes, esse parece ser um negócio de baixo risco e, possivelmente, de grande lucratividade. Atualmente, em todo o mundo, há três vacinas contra rotavírus em fase I de testes, uma em fase II e uma em fase III (Jordan Report, 2002b).

Vacinas conjugadas de polissacarídeos (meningococos, pneumococos e Hib)

No Brasil, como já foi mencionado, a carga da doença causada por esses agentes é grande. Bio-Manguinhos tem alguma experiência na produção de vacinas polissacarídeas contra meningite, e o Butantan, por sua vez, está desenvolvendo uma vacina conjugada contra o Hib. Levando em consideração as prioridades no que concerne à competição e o fato de que outros fabricantes podem já ter vacinas em nível de de- 
senvolvimento mais avançado, a experiência de Bio-Manguinhos pode não ser suficiente para dar-lhe uma clara vantagem - a não ser que uma parceria interessante de acesso à tecnologia seja proposta.

Vacina contra a raiva produzida em cultura de células

O Butantan já está desenvolvendo essa tecnologia. Contudo, se for criada uma vacina contra a raiva produzida em cultura de células, se tiver boa qualidade e preço razoável, haverá um grande mercado para ela, pois os países estão abandonando o uso de produtos feitos a partir de tecido nervoso. Há vacinas desse tipo em fases I, II e III de testes em diferentes lugares do mundo (Jordan Report, 2002b).

\section{Vacina contra a febre amarela}

Devido ao bom histórico de Bio-Manguinhos na produção de vacinas contra a febre amarela, a sua grande capacidade de produção, ao fato de essa vacina já estar préqualificada e ao prognóstico de aplicação da tecnologia de produção de vacinas em cultura de células pelo projeto, esse produto parece ter seu lugar garantido no portfolio. A projeçāo de demanda anual para essa vacina é da ordem de 25 milhões de doses. Há vacinas de vetores recombinantes contra a febre amarela em fases I, II e III de testes em diferentes lugares do mundo (Jordan Report, 2002b).

\section{Os componentes da DTP}

Em nível global, năo há muita oferta para esses produtos, mas estão senđo produzidos pelo Butantan. Sabendo-se que haverá um aumento de demanda pela vacina celular contra a coqueluche (causado pelo fato de que a maioria dos produtores dos países industrializados passou a produzir a vacina acelular) e que foi projetada uma demanda crescente por toxóides diftéricos e/ou tetânicos para a produção de vacinas conjugadas, pode-se prever um aumento da demanda por componentes da DTP, já que, cada vez mais, as companhias estão deixando esse nicho. Observando o caso da vacina tetravalente, que foi licenciada pela Anvisa e está atualmente em uso no calendário de vacinação brasileiro, Bio-Manguinhos deveria tomar providências para assegurar a disponibilidade dos componentes da DTP produzidos pelo Butantan (apesar de não se esperar que o produto atinja um mercado adicional muito grande no resto do mundo, salvo se a oferta da vacina quadrivalente continuar restrita).

\section{A vacina contra sarampo e rubéola (MR)}

A tecnologia de produção dessa vacina está sendo importada do Japão por BioManguinhos, e uma vacina contra a rubéola está sendo licenciada pela Anvisa. A partir do momento em que a GAVI está apoiando estratégias de redução do sarampo e recomenda o uso da vacina contra rubéola na maioria dos países, há, provavelmente, um grande mercado para a MR. Pode ser uma boa aposta para um aumento na capacidade de produção no futuro. 


\section{Quais são as ameaças a essas projeções?}

Existem vários tipos de cenários que poderiam vir a ameaçar as informaçōes nas quais essas projeçōes se baseiam e, assim, modificar o resultado previsto. Alguns desses cenários são: fracasso da ciência das vacinas; mudança nas prioridades, passando a outros produtos, especificamente contra o bioterrorismo; falta de financiamento; imprecisão das previsões de demanda; incapacidade de atender a demanda, como, por exemplo, com o fracasso da produção e com o uso de estoques inadequados; fracasso por parte de um dos lados das parcerias no cumprimento de suas obrigações.

Para evitar esses riscos, a solução é prever os riscos principais; quantificar sua probabilidade de acontecer e o impacto que causariam se acontecessem; controlá-los antes que se concretizem.

\section{Critérios para a priorização de P\&D}

A utilidade de se estabelecerem critérios para a priorização dos projetos de pesquisa e desenvolvimento é poder selecionar os que têm maiores chances de obter sucesso, tanto em termos de retorno de investimento quanto em termos de impacto na saúde pública. Recomenda-se que os fatores a seguir sejam considerados no processo de priorização:

- Mercado provável (população-alvo X número de doses X preço): vai depender da carga da doença, da capacidade de construção da demanda, da capacidade potencial de produção e da possibilidade de o produto ter um preço razoável (pelo menos um que o mercado possa tolerar).

- Margem de lucro: vai depender dos custos de desenvolvimento de tecnologia e dos custos de produção por dose.

- Ciclo de vida do produto.

- Possibilidade de acesso à tecnologia para a reprodução de fórmulas já existentes.

- Ausência de barreiras na regulação, ligada a fatores como o grau de resposta imunitária (correlatos de imunidade), a metodologia empregada nos testes, o potencial de padronização destes e questões de segurança.

\section{PORTFOLIOS}

O Quadro 10 mostra, de forma resumida, os principais produtos presentes na linha de pesquisa das empresas mais conhecidas, separando-os nas seguintes categorias: 1) grandes companhias farmacêuticas, 2) fabricantes de países em desenvolvimento, 3) companhias de biotecnologia e 4) empresas de desenvolvimento de plataformas de administração. Após o quadro, foram incluídas informaçōes mais detalhadas sobre as empresas e sobre seus prospectos. 
Quadro 10 - Resumo das informações disponíveis a respeito da linha de pesquisa dos fabricantes

\begin{tabular}{|c|c|c|c|c|}
\hline \multicolumn{5}{|c|}{ Grandes companhias farmacêuticas (big pharma) } \\
\hline Fabricante & Principais vacinas & P\&D & Parcerias & Comentários \\
\hline Merck & $\begin{array}{l}\text { MMR, catapora, polissacarídeo } \\
\text { contra pneumococos, hepatite A, } \\
\text { hepatite B, Hib, Hib-hepatite }\end{array}$ & $\begin{array}{l}\text { Vírus do papiloma humano - fase } \\
\text { III; Rotavírus bovino -fase III; HIV } \\
\text { - uma em fase de pesquisa } \\
\text { básica e outra em fase I }\end{array}$ & $\begin{array}{l}\text { Com a Aventis, para o mercado } \\
\text { europeu; Crucell; CSL }\end{array}$ & $\begin{array}{l}\text { A OMS pré-qualificou sua vacina } \\
\text { contra a hepatite B, Hib }\end{array}$ \\
\hline Wyeth & $\begin{array}{l}\text { Conjugado pneumocócico } 7 \\
\text { valente; Hib; vacina nasal contra } \\
\text { a gripe (FluMist) }\end{array}$ & $\begin{array}{l}\text { Conjugado pneumocócico } 9 \text { e } 11 \\
\text { valente - fases II e III }\end{array}$ & Aviron & $\begin{array}{l}\text { Vacina contra rotavírus aprovada } \\
\text { mas retirada do mercado; } \\
\text { interrompeu a produçāo da } \\
\text { vacina inativada contra a gripe, } \\
\text { de polissacarídeo pneumocócico } \\
\text { e da DTP; OMS pré-qualificou Hib }\end{array}$ \\
\hline Aventis-Pasteur & $\begin{array}{l}\text { Hepatite B, hepatite A, Hib, gripe, } \\
\text { encefalite japonesa, sarampo, } \\
\text { meningite, caxumba, } \\
\text { polissacarídeo pneumocócico, } \\
\text { pólio (tanto oral quanto } \\
\text { inativada), raiva, rubéola, febre } \\
\text { tif́ide, BCG, DTwP, DTaP, febre } \\
\text { amarela, vacinas combinadas } \\
\text { com coqueluche acelular }\end{array}$ & $\begin{array}{l}\text { Combinaçāo contra hepatite B e } \\
\text { febre tifóide para adolescentes; } \\
\text { HIV/Aids e varíla aviária - fase } \\
\text { II; H. pylori e vírus respiratório } \\
\text { sincicial - fase I/ll; dengue - } \\
\text { fase II }\end{array}$ & $\begin{array}{l}\text { NIH; Instituto Pasteur; Walter } \\
\text { Reed Army Institute of Research; } \\
\text { Eurovac; Merck }\end{array}$ & $\begin{array}{l}\text { DTaP-eIPV-hepatite B-Hib } \\
\text { totalmente líquidas, para o } \\
\text { mercado Europeu junto com a } \\
\text { Merck; OMS pré-qualificou dT, } \\
\Pi T, \text { DTP, DTP-Hib, sarampo, } \\
\text { MMR, VOP, polissacarídeos } \\
\text { contra meningite A e C e febre } \\
\text { amarela }\end{array}$ \\
\hline Chiron/PowderJect & $\begin{array}{l}\text { Conjugado contra meningite C, } \\
\text { encefalite transmitida por } \\
\text { carrapatos, acelular contra } \\
\text { coqueluche, DTaP, Hib, hepatite } \\
\text { A, sarampo, MMR, MR, meningite } \\
\mathrm{AeC}, \mathrm{VOP}, \mathrm{dT} \text {, TI, Td, raiva, } \\
\text { mais a vacina PowderJect contra } \\
\text { gripe, febre amarela, BCG, cólera } \\
\text { (com E. coli enterotoxigênico), } \\
\text { inativada contra a pólio }\end{array}$ & $\begin{array}{l}\text { H. pylori - fase I; conjugado } \\
\text { contra meningite tipos A, C, Ye } \\
\text { W135 (ACYW) - fase I; meningite } \\
\text { tipo B - fase I; vacina contra a } \\
\text { gripe produzida em cultura de } \\
\text { células - fase I; DTP-Hib - fase } \\
\text { II; nova fórmula contra encefalite } \\
\text { transmitida por carrapatos - fase } \\
\text { pré-clinica. Quanto à PowderJect: } \\
\text { varíola - fase pré-clínica; gripe e } \\
\text { vacina de DNA contra o HIV - } \\
\text { fase pré-clínica; vacina de DNA } \\
\text { contra hepatite tipo B - fase I; } \\
\text { febre amarela EUA - fase III }\end{array}$ & $\begin{array}{l}\text { A Powderject tem parceria com a } \\
\text { CSL e a Acambis para a febre } \\
\text { amarela e com a GlaxoSmithKline } \\
\text { para a hepatite B e o HIV }\end{array}$ & $\begin{array}{l}\text { A OMS pré-qualificou DTP, } \\
\text { sarampo, MR, MMR, VOP, raiva, } \\
\text { Hib, DTP-Hib. Quanto à } \\
\text { Powderject, a OMS pré-qualificou } \\
\text { a sua vacina da Evans contra } \\
\text { febre amarela e sua vacina } \\
\text { Dukoral contra a cólera. A } \\
\text { PowderJect adquiriu a Dukoral } \\
\text { (da Suécia), empresa que fabrica } \\
\text { as vacinas contra cólera e E. coli } \\
\text { enterotoxigênico e a vacina } \\
\text { inativada contra a pólio }\end{array}$ \\
\hline GlaxoSmithKline & $\begin{array}{l}\text { DTaP-hepatite B-elPV acabou de } \\
\text { ser licenciada nos EUA; VOP, } \\
\text { MMR, MR, DTP-hepatite B, DTP- } \\
\text { hepatite B-Hib, vacina de } \\
\text { polissacarídeo contra meningite } \\
\text { tipos A, C, } Y \in \text { W135 }\end{array}$ & $\begin{array}{l}\text { Malária, tuberculose, HIV/Aids, } \\
\text { gripe intranasal - ainda no } \\
\text { começo do processo de } \\
\text { desenvolvimento; conjugados } \\
\text { contra meningite, rotavírus - fase } \\
\text { III }\end{array}$ & $\begin{array}{l}\text { Malaria Vaccine Initiative (MVI) } \\
\text { para a vacina contra a malária; } \\
\text { Biochem Pharma para a vacina } \\
\text { contra a gripe }\end{array}$ & $\begin{array}{l}\text { A OMS pré-qualificou VOP, } \\
\text { sarampo, MMR, DTP-hepatite B, } \\
\text { DTP-hepatite B-Hib, vacina } \\
\text { polissacarídea contra meningite } \\
\text { tipos A e C }\end{array}$ \\
\hline
\end{tabular}


Quadro 10 - Resumo das informações disponíveis a respeito da linha de pesquisa dos fabricantes (continuação)

\begin{tabular}{|c|c|c|c|c|}
\hline \multicolumn{5}{|c|}{ Fabricantes de países em desenvolvimento } \\
\hline Fabricante & Principais vacinas & P\&D & Parcerias & Comentários \\
\hline GPO (Tailândia) & $\begin{array}{l}\text { Raiva, encefalite japonesa e } \\
\text { DTwP }\end{array}$ & & $\begin{array}{l}\text { Joint venture com a Aventis; } \\
\text { alianças anteriores com a Chiron } \\
\text { para a vacina contra a raiva; com } \\
\text { a Biken para a vacina contra a } \\
\text { encefalite japonesa; com a } \\
\text { GlaxoSmithKline para a vacina } \\
\text { contra hepatite B }\end{array}$ & $\begin{array}{l}\text { Apenas o envasamento, em } \\
\text { maioria }\end{array}$ \\
\hline Lanzhou (China) & $\begin{array}{l}\text { Vacina contra a febre tifóide } \\
\text { usando o antígeno VI, DTwP, } \\
\text { hepatite B, vacina de rotavírus do } \\
\text { carneiro }\end{array}$ & & & $\begin{array}{l}\text { Inovadora, mas ainda não está } \\
\text { presente no mercado } \\
\text { internacional }\end{array}$ \\
\hline Biological E (Índia) & חT, DTwP & DTP-hepatite B & $\begin{array}{l}\text { Acordos com a Bharat para } \\
\text { comercializar a vacina contra a } \\
\text { hepatite B e com a Aventis para } \\
\text { comercializar a vacina contra o } \\
\text { Hib, a MMR e a vacina contra a } \\
\text { pólio; está trabalhando com a } \\
\text { RIVM no desenvolvimento de } \\
\text { novos produtos }\end{array}$ & Possivelmente de interesse \\
\hline Biofarma (Indonésia) & $\begin{array}{l}\text { VOP, sarampo, DTP, } \Pi, \Pi \\
\text { (Uniject), hepatite B, hepatite B } \\
\text { (Uniject), BCG, raiva }\end{array}$ & $\begin{array}{l}\text { DTP-hepatite B, DTP-hepatite B- } \\
\text { Hib }\end{array}$ & RIVM & $\begin{array}{l}\text { A OMS pré-qualificou TT, dT, } \\
\text { DTwP, VOP, sarampo e } \Pi \text { em } \\
\text { Uniject }\end{array}$ \\
\hline Birmex (México) & DTP (toxóide tetânico importado) & $\begin{array}{l}\text { Hib, DTP-hepatite B-Hib, VOP, } \\
\text { vacina contra raiva produzida em } \\
\text { cultura de células }\end{array}$ & & $\begin{array}{l}\text { GlaxoSmithKline adquiriu parte } \\
\text { das instalaçōes para o } \\
\text { desenvolvimento de um novo } \\
\text { produto }\end{array}$ \\
\hline CIGB (Cuba) & Hepatite B & $\begin{array}{l}\text { Hib, Hib-hepatite B, DTP-hepatite } \\
\text { B e hepatite de aplicação nasal }\end{array}$ & $\begin{array}{l}\text { Finlay, Instituto Pasteur do Irã, } \\
\text { Panacea Biotec }\end{array}$ & A OMS pré-qualificou hepatite B \\
\hline Finlay (Cuba) & $\begin{array}{l}\text { Meningite B e C, ח, DTwP, dT, } \\
\text { Vacina polissacarídea contra a } \\
\text { febre tif́́ide usando } 0 \text { antígeno VI, } \\
\text { leptospirose }\end{array}$ & $\begin{array}{l}\text { Meningite B para a Europa, } \\
\text { vacina contra meningite tipos A e } \\
\text { C e vacina contra meningite tipo } \\
\text { A, C, Y e W135, cólera, uma nova } \\
\text { DTwP, hepatite A, dengue }\end{array}$ & GlaxoSmithKline, CIGB & \\
\hline $\begin{array}{l}\text { Panacea Biotec } \\
\text { (Índia) }\end{array}$ & $\begin{array}{l}\text { Hepatite B, DIwP-hepatite B, } \\
\text { VOP, até hoje somente } 0 \\
\text { envasamento }\end{array}$ & $\begin{array}{l}\text { Produção da vacina contra } \\
\text { hepatite B }\end{array}$ & Chiron, CIGB, BioFarma & $\begin{array}{l}\text { A OMS pré-qualificou a VOP, que } \\
\text { envasa com os bulks da Chiron e } \\
\text { da Biofarma }\end{array}$ \\
\hline $\begin{array}{l}\text { Serum Institute of } \\
\text { India (Índia) }\end{array}$ & $\begin{array}{l}\text { Sarampo, caxumba, rubéola, MR, } \\
\text { MMR, } T \text {, dT, DTwP, hepatite B, } \\
\text { BCG }\end{array}$ & & & $\begin{array}{l}\text { A OMS pré-qualificou TT, dT, Td, } \\
\text { DTwP, sarampo e MR, MMR } \theta \\
\text { BCG }\end{array}$ \\
\hline
\end{tabular}


Quadro 10 - Resumo das informações disponíveis a respeito da linha de pesquisa dos fabricantes (continuação)

\begin{tabular}{|c|c|c|c|c|}
\hline \multicolumn{5}{|c|}{ Empresas de biotecnologia } \\
\hline Fabricante & Principais vacinas & P\&D & Parcerias & Comentários \\
\hline Acambis & & $\begin{array}{l}\text { Varíola - em fase pré-clínica; } \\
\text { encefalite japonesa usando } \\
\text { tecnologia Chimerivax - fase II; } \\
\text { dengue - fase I; vírus do oeste do } \\
\text { Nilo - fase I }\end{array}$ & $\begin{array}{l}\text { Baxter; Aventis-Pasteur (para } \\
\text { uma vacina contra a dengue); } \\
\text { Berna Biotech (para uma vacina } \\
\text { contra febre tifóide) }\end{array}$ & \\
\hline Bavarian Nordic & & Varíola & $\begin{array}{l}\text { PowderJect (para uma vacina } \\
\text { contra a varíola) }\end{array}$ & $\begin{array}{l}\text { Contratos feitos com os governos } \\
\text { no Reino Unido e da Grécia para } \\
\text { a vacina contra a varíola }\end{array}$ \\
\hline Berna Biotech & $\begin{array}{l}\text { Gripe (virossomo), hepatite B, } \\
\text { hepatite A, oral contra a cólera, e } \\
\text { oral contra a febre tifóide }\end{array}$ & $\begin{array}{l}\text { Sistema de leveduras Hanensula; } \\
\text { virossomos; varíola; febre } \\
\text { amarela - fase III; vacina nasal } \\
\text { contra a gripe - fase I; malária - } \\
\text { em fase pré-clinica; vacinas } \\
\text { combinadas de base DTwP - em } \\
\text { fase pré-clínica }\end{array}$ & $\begin{array}{l}\text { Assim como a Green Cross, a } \\
\text { Rhein Biotech agora faz parte da } \\
\text { Berna Biotech }\end{array}$ & $\begin{array}{l}\text { Assinou um contrato de produção } \\
\text { da vacina contra varíla com um } \\
\text { país do oriente ainda nāo } \\
\text { revelado; divulgou recentemente } \\
\text { um acordo feito com o Vietnã } \\
\text { para construir duas fábricas } \\
\text { (seguindo as BPF) e transferir a } \\
\text { tecnologia do sistema Hanensula } \\
\text { utilizado na produção da vacina } \\
\text { contra hepatite B. A Berna } \\
\text { Biotech, através da Green Cross, } \\
\text { é um dos fabricantes pré- } \\
\text { qualificados pela OMS para a } \\
\text { produção da vacina contra } \\
\text { hepatite B; aliança estratégica } \\
\text { com a Shire }\end{array}$ \\
\hline Avant & & $\begin{array}{l}\text { Vacina viva e atenuada contra a } \\
\text { cólera - fase II; vacina viva e } \\
\text { atenuada contra a febre tifóide - } \\
\text { fase I/II; E. coli enterotoxigênico, } \\
\text { Shigella, Camphylobacter jejuni- } \\
\text { ainda no começo de seu } \\
\text { desenvolvimento; antraz - em } \\
\text { fase pré-clínica; rotavírus - fase } \\
\text { ॥I }\end{array}$ & $\begin{array}{l}\text { GlaxoSmithKline (para a vacina } \\
\text { contra rotavírus); Departamento } \\
\text { de Defesa dos EUA (para a } \\
\text { vacina contra } 0 \text { antraz); NIH; } \\
\text { Walter Reed Army Institute of } \\
\text { Research; Instituto Internacional } \\
\text { de Vacinas (com a produçāo feita } \\
\text { pela BioSidus, da Argentina) para } \\
\text { as outras }\end{array}$ & . \\
\hline Baxter & $\begin{array}{l}\text { Gripe; conjugado contra } \\
\text { meningite tipo C }\end{array}$ & $\begin{array}{l}\text { Novas tecnologias no que } \\
\text { concerne à vacina contra a gripe }\end{array}$ & $\begin{array}{l}\text { Acambis (para a vacina contra a } \\
\text { varíola) }\end{array}$ & $\begin{array}{l}\text { Pode ser uma parceria } \\
\text { interessante }\end{array}$ \\
\hline VaxGen & & $\begin{array}{l}\text { AIDSVAX gp } 120 \text { - fase III; antraz } \\
\text { - fase I; varíola - em fase pré- } \\
\text { clínica }\end{array}$ & $\begin{array}{l}\text { Com a Kekutsuken, do Japāo, } \\
\text { contra varíola }\end{array}$ & $\begin{array}{l}\text { Contrato para a vacina contra } 0 \\
\text { antraz com o governo dos EUA }\end{array}$ \\
\hline Corixa & & $\begin{array}{l}\text { Tecnologia de vacinas } \\
\text { recombinantes contra a }\end{array}$ & & \\
\hline Shire & Gripe e meningite tipo $C$ & $\begin{array}{l}\text { Contra pneumococos (antígeno } \\
\text { protéico) e meningite } \\
\text { meningocócica - em fase de } \\
\text { desenvolvimento }\end{array}$ & Acordo com a Berna Biotech & $\begin{array}{l}\text { Novo centro de pesquisas de } 18 \\
\text { milhōes de dólares }\end{array}$ \\
\hline
\end{tabular}


Quadro 10 - Resumo das informações disponíveis a respeito da linha de pesquisa dos fabricantes (continuação)

\begin{tabular}{|c|c|c|c|c|}
\hline \multicolumn{5}{|c|}{ Tecnologias de distribuição e aplicação } \\
\hline Fabricante & Principais vacinas & P\&D & Parcerias & Comentários \\
\hline Biofarma & TT e hepatite B em Uniject & & & $\begin{array}{l}\Pi \pi \text { em Uniject foi pré-qualificado } \\
\text { pela OMS }\end{array}$ \\
\hline Chiron/Powderject & & $\begin{array}{l}\text { Vacina contra o vírus da gripe } \\
\text { usando a tecnologia de } \\
\text { biobalística - sem agulhas; } \\
\text { método de injeção de vacinas de } \\
\text { DNA sem agulhas }\end{array}$ & & \\
\hline Crucell & & $\begin{array}{l}\text { Células PerC6; sistema de } \\
\text { replicação para vacinas de vírus } \\
\text { incompetentes (HIV e gripe) }\end{array}$ & Merck & \\
\hline Bavarian Nordic & & $\begin{array}{l}\text { Tecnologia MVA (Modified } \\
\text { Vaccinia Ankara) de vetores para } \\
\text { vacinas contra o vírus orthopox e } \\
\text { contra a dengue }\end{array}$ & & . \\
\hline Berna Biotech & Virossomos & $\begin{array}{l}\text { Tecnologia de partículas, } \\
\text { adjuvantes para mucosa }\end{array}$ & Aventis, Acambis, Chiron, Shire & $\begin{array}{l}\text { Vacina nasal contra a gripe é um } \\
\text { exemplo da tecnologia que } \\
\text { possuem }\end{array}$ \\
\hline
\end{tabular}

\section{Grandes companhias farmacêuticas (big pharma)}

Entre os 15 primeiros da lista de líderes de mercado em P\&D (em relação a todos os produtos) estão a SmithKlineBeecham (hoje GlaxoSmithKline), a RhonePoulenc (subsidiária da Aventis-Pasteur) e a American Home Products (hoje Wyeth) (Global Forum for Health Research, 2001). Após a aquisição da Powderject, a Chiron se torna um elemento muito mais importante no jogo do mercado de vacinas.

\section{Merck}

As vendas de vacinas da empresa somaram mais de 1 bilhão de dólares (Merck \& Co. Inc., 2001) do total de vendas de 47,7 bilhōes de dólares em 2001. Nesse mesmo ano, no portfolio da Merck, de forma geral, constavam vacinas virais destinadas ao mercado dos Estados Unidos. A Merck está em umajoint venture com a Aventis para a comercialização de vacinas na Europa. Em termos de vacinas presentes em suas linhas de pesquisa destinadas ao uso nos países em desenvolvimento, há um verdadeiro interesse por aquela contra o rotavírus e contra o vírus do papiloma humano. Também firmaram um acordo de pesquisa com a Aventis-Pasteur para o desenvolvimento de uma vacina contra a Aids usando a varíola aviária da Aventis junto com o adenovírus da Merck.

\section{Wyeth}

Wyeth é o novo nome da American Home Products. Nos últimos anos, a Wyeth vem sistematicamente parando de produzir vacinas por causa de potencial responsabilidade quanto a efeitos adversos de seus produtos ou por estratégias de produçăo. Foi o que 
aconteceu com a vacina Rotashield - associada a relatos de intussuscepção intestinal (obstrução com prolapso para segmento distal); com a vacina inativada contra a gripe, descontinuada para se concentrar em FluMist; com os produtos que continham toxóides bacterianos, por causa das dificuldades de seguir as BPF e por achar que investimentos futuros na área não compensariam, e com a vacina polissacarídea contra pneumococo, em razão do sucesso da Prevnar, a vacina conjugada heptavalente. A Wyeth está tendendo a se concentrar em mercados nos quais possui algum produto que seja sucesso de vendas, como o Prevnar. A FluMist, uma vacina contra a gripe em aerossol, foi licenciada recentemente pelo FDA nos Estados Unidos e já se prevê que terá grande sucesso nas vendas.

\section{Aventis-Pasteur}

A Aventis é um das poucas grandes empresas farmacêuticas que tem mantido sua linha de vacinas de utilidade global. Além disso, a empresa tem, em P\&D, várias outras vacinas de interesse para os mercados em desenvolvimento (como a vacina contra a dengue, por exemplo). A Aventis não nega a possibilidade de efetuar parcerias com governos e instituições do mundo em desenvolvimento e tem vários projetos na área de produção de vacinas em países como o Brasil, a Argentina, a Tailândia e a China, dentre outros. Além disso, para se precaver dessas apostas, continuam desenvolvendo produtos para o mundo industrializado, principalmente vacinas combinadas baseadas na acelular contra coqueluche e na eIPV.

\section{Chiron}

A Chiron é a quinta maior empresa do mercado de vacinas no mundo inteiro e tem mais de trinta produtos sendo comercializados. A receita total da empresa em 2001 foi de 1,25 bilhão de dólares, dos quais um terço vem da venda de vacinas, de acordo com a página da empresa na internet (Chiron, 2002). A sua conjugada contra meningite tipo C foi sucesso de vendas, pois foi a primeira do gênero no mercado. Em virtude da fusão com a Powderject, a Chiron passa a ter uma linha de pesquisa estimulante. Ademais, estima-se que as duas empresas juntas sejam o segundo maior fornecedor no mercado de vacinas contra a gripe, estimando-se a receita em 1 bilhão de dólares (Shot in the arm, 2003b).

\section{GlaxoSmithKline}

A GlaxoSmithKlein (GSK) tem um grande número de produtos de interesse para o mundo em desenvolvimento e algumas parcerias já formadas. Nos últimos anos, a empresa parou de fornecer alguns dos produtos menos lucrativos que produzia e abriu o campo para os fornecedores emergentes (a vacina contra sarampo é um exemplo). É a única grande companhia farmacêutica que tem planos de desenvolver novos produtos destinados primeiramente para os mercados dos países em desenvolvimento (como a vacina contra o rotavírus e a polissacarídea contra meningite tipos A, C e W135), bem como projetos de desenvolvimento de vacinas contra a malária e o HIV. A GSK tem, provavelmente, entre todas as grandes companhias farmacêuticas, o maior número de parcerias ejoint ventures com fornecedores emergentes (Bio-Manguinhos, Finlay, Birmex, Vacsera, GPO, ejoint ventures na China e na Rússia). 


\section{Fabricantes de países em desenvolvimento}

Os fabricantes de países em desenvolvimento encontram-se tanto no setor público, quanto no privado. Porém, até mesmo o setor privado parece ser mais influenciado por questōes dos mercados em desenvolvimento do que pelas ações das grandes empresas farmacêuticas. Os fabricantes desse setor estão, em maioria, na Índia, e, quanto a isso, conhecer as atividades do Serum Institute of India e da Panacea, acessando suas páginas na internet, pode ser bastante instrutivo (Serum Institute of India, 2003; Panacea Biotec, 2003). Somente os fabricantes do setor privado-mesmo assim, nem todos-colocam informações sobre suas vendas e seus investidores em suas páginas na internet, tornando difícil ter uma visão abrangente dos demais fabricantes. Portanto, índices de viabilidade desses fabricantes devem ser colhidos de outras fontes.

A pré-qualificação de um dos produtos do fabricante pela OMS é a primeira indicação de viabilidade do produtor. A segunđa é a filiação à Developing Countries Vaccine Manufacturers Network (DCVMN), o que exclui alguns fabricantes promissores, como a Wockhardt, da Índia. Desses fabricantes, o Serum Institute of Índia e a Biofarma têm as maiores linhas de produção de vacinas tradicionais, ao passo que o conjunto de fabricantes de Cuba e o do Brasil também possuem grandes portfolios. Os fabricantes chineses têm o maior número de produtos no mercado, estando algumas de suas próprias inovações incluídas entre estes, mas esses produtos ainda não estão no mercado internacional. A GPO, assim como os fabricantes brasileiros, tem sido uma das mais inovadoras na tentativa de trazer vacinas úteis para o país, mesmo que suas atividades estejam limitadas ao envasamento. Em termos de linha de pesquisa, a Serum Institute of Índia se destaca, assim como os fabricantes brasileiros e cubanos.

\section{Empresas de biotecnologia}

O Quadro 10 apresenta somente uma fração das empresas de biotecnologia existentes atualmente e somente um pequeno número daquelas apresentadas em um encontro recente da indústria para discussão do desenvolvimento de vacinas. Dentre as empresas cujos nomes são mais recorrentes, a Acambis, a Powderject, a Berna Biotech e a Bavarian Nordic são as mais mencionadas no que concerne à possibilidade de sucesso futuro, graças a suas atividades no desenvolvimento de vacinas a serem usadas em caso de bioterrorismo.

A Berna Biotech - que tem uma inovadora linha de pesquisa, possui experiência na produção de vacinas, fez uma série de aquisiçōes e está determinada a ser uma das maiores empresas no mercado -é proprietária de um certo número de tecnologias de administração de vacinas bastante interessantes. Em adição, formou algumas parcerias com fornecedores emergentes e está entrando de maneirą agressiva na esfera de produção dos países em desenvolvimento. Uma das suas parcerias é para desenvolver a primeira vacina a obter o status na Europa de orphan drug - medicamentos de uso restrito-, contra fibrose cística, e está tentando licenciar a vacina do Instituto Robert Koch contra febre amarela em toda a Europa (Berna Biotech, 2003). 
Dignas de nota também são a Avant e a VaxGen, por sua disposição de fazer uso de suas tecnologia para o desenvolvimento de produtos para o mercado dos países em desenvolvimento. Além disso, a VaxGen está desenvolvendo uma vacina contra o antraz. A Corixa é, igualmente, muito importante, pois está desenvolvendo uma vacina contra a leishmaniose em colaboração com o setor público internacional e tem interesse em fazer parcerias com os países onde ocorre a endemia.

\section{Plataformas de administração de vacinas}

Somente algumas plataformas de administração foram incluídas, no intuito de apresentar uma idéia geral de quão dinâmica é a área. É o caso do trabalho da Serum Institute of Índia com a OMS e seus colaboradores no desenvolvimento de uma vacina contra o sarampo em aerossol - um exemplo do rumo que o setor está tomando. Os problemas da transmissão de doenças infecciosas através de agulhas e seringas, as dificuldades em se obter estatísticas sobre o assunto e as questões de estocagem e transporte indicam que haverá um crescimento enorme da área no futuro.

\section{O QUE TUDO ISSO SIGNIFICA PARA A INDÚSTRIA DE VACINAS DO BRASIL?}

Com base nos dados supracitados, um cenário de como será o mundo das vacinas daqui a 12 ou 15 anos foi montado.

\section{Tendências quanto à população e quanto à carga da doença}

Aparentemente, a população brasileira irá ficar cada vez mais velha. Sendo assim, novas vacinas terão de ser fabricadas para esse mercado e novas estratégias de imunização terão de ser desenvolvidas para atingir essas populações. Em vez de pensar em novas estratégias de administração, deve-se pensar em novas tecnologias de administração, que serão importantes para esse grupo, como, por exemplo, uma via đe administração nẫo injetável para a vacina contra a gripe. Já foi previsto que, no futuro, a incidência de Aids, malária e tuberculose vai começar a diminuir. No relatório de 2002 sobre a Aids, "Improving access to care in developing countries", disponível na página da Unaids na internet, são apresentados exemplos de queda na incidência da doença com metodologias de mudança comportamental que presentemente estão em uso. Além disso, a disponibilidade de drogas anti-retrovirais prolongou a expectativa de vida e praticamente erradicou a transmissão vertical (de mãe para filho) onde foi utilizada (Unaids, 2002). Outras doenças infecciosas novas, especialmente aquelas regionalmente significativas, vão aparecer. Isso seria parciale mente amplificado pelo desenvolvimento das tecnologias de vigilância epidemiológica, permitindo uma melhor quantificação dos casos. Apesar de estar fora do escopo desse estudo, a expansão da vacinação terapêutica será um grande fator de influência na indústria de vacinas. 


\section{Futuros fabricantes e futuras tecnologias}

A tecnologia de recombinação genética será importante, ou melhor, pode-se dizer que todas as vacinas farão uso de algum aspecto novo da biotecnologia em sua produção. As 'antigas', como a BCG, ou aquelas feitas tradicionalmente, por exemplo, usando-se embriões de galinha, serão eliminadas para dar lugar a imunizantesde mais rápida padronização. A tendência será em favor da produção de vacinas que podem ser produzidas consistentemente, com as características da farmacêutica molecular. Sendo assim, elas ficarão mais caras e provavelmente haverá mais preocupações quanto a questões de propriedade intelectual. As vacinas contra Aids, malária e tuberculose terão sido desenvolvidas, mas precisarão ser refinadas. Isso quer dizer que os programas de vacinação nacionais e as autoridades responsáveis pela regulação terão que descobrir como lidar com produtos ainda imperfeitos e como introduzir seus substitutos quando forem desenvolvidos.

o bioterrorismo será um assunto secundário para todos, mas a ameaça de uma pandemia global (de gripe, por exemplo) terá entrado em seu lugar. A necessidade de flexibilidade no desenvolvimento de novas vacinas e em sua regulação ficará latente em decorrência dessa pandemia.

Vacinas de uso regional, como contra a dengue, a encefalite japonesa tipo B e a leishmaniose, serão importantes em certas áreas do mundo.

Os fabricantes de vacinas terão mudado. A Merck será basicamente um fornecedor de produtos para os EUA com uma boa linha de P\&D. A GlaxoSmithKline será uma fornecedora global - assim como a Berna Biotech, que terá grande parte do mercado dos países em desenvolvimento. Os fornecedores regionais da Índia, do Brasil e da China serão muito poderosos e terão papéis principais no mercado global.

\section{Parcerias}

As parcerias serão o modus operandi de todos os fabricantes de vacinas bemsucedidos, para obter acesso a tecnologias, mercados, novas metodologias de produção, novas maneiras de conduzir os testes clínicos e de monitorar o uso das vacinas. As companhias não se limitarão somente a algumas parcerias (binding partnerships), mas assinarão contratos rapidamente com alguns parceiros mesmo que seja apenas para o fornecimento de um dos componentes de um produto. Ao analisar a possível compra de um novo produto para o portfolio - causando, assim, o aumento do número de novas parcerias -, os fabricantes terão que colocar de um lado da balança os riscos e, do outro, o potencial de mercado. o objetivo é maximizar o potencial do mercado minimizando o risco. o Gráfico 3 demonstra esse conceito de forma esquemática. 
Gráfico 3 - Quantificando o risco e o potencial de mercado dos novos produtos

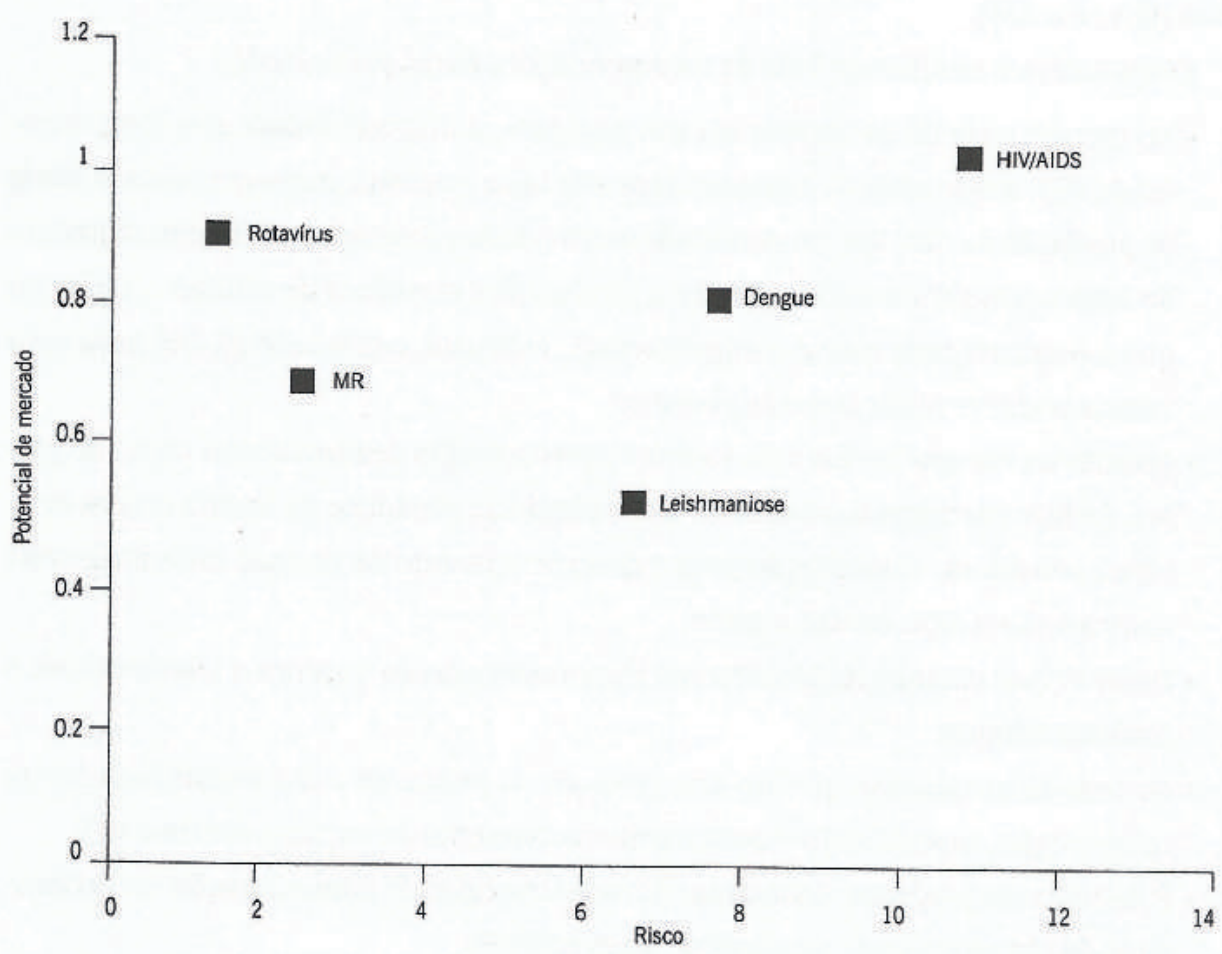

\section{Regulação}

Haverá mais ênfase em uma regulação mais atenta e na implementação de testes clínicos maiores e melhores. Os fabricantes terão de fazer mais estudos de pós-marketing (após o produto ter entrado no mercado), prestar mais atenção às normas de BPF e executar protocolos bastante padronizados para testes. Isso significa que as autoridades reguladoras nacionais deverão ser mais inovadoras, científicas, flexíveis e comunicativas.

\section{CONCLUSÃO}

De acordo com o Ministro da Saúde do governo brasileiro, a prioridade será para produtos que vão ao encontro das necessidades epidemiológicas nacionais, como as vacinas contra a febre amarela, vacinas que possam ter sua disponibilidade limitada (como a contra a gripe) e vacinas com alto valor técnico agregado, como a contra a hepatite B. Vacinas novas serão desenvolvidas conforme os seguintes critérios: a) melhorar a segurança e a eficácia das vacinas já existentes - febre amarela (mudar para um produto desenvolvido a partir de cultura de células), coqueluche (mudar para a vacina acelular), pólio (mudar para a vacina inativada), cachumba (mudar para uma cepa menos agressiva - menos reatogênica); b) desenvolver novas combinações, como as baseadas na DTP; c) desenvolver vacinas que, apesar de já estarem no mercado, sâo demasiadamente caras ou são essenciais para as novas estratégias de imunização, como as vacinas conjugadas contra pneumococos e meningite tipo $C$; d) desenvolver vacinas 
novas para doenças de grande relevância, como a malária, a dengue, a leishmaniose, a tuberculose e a Aids.

Esses critérios se ajustam bem às recomendações feitas pelo estudo:

- No que diz respeito às vacinas atuais, assegurar a disponibilidade dos componentes da DTP, sendo estes de boa qualidade e de base contínua; aumentar a capacidade de produção da MR; dar continuidade às atividades dedicadas ao desenvolvimento de uma vacina contra febre amarela produzida em cultura de células - a não ser que a lucratividade esteja comprometida, visto que o mercado global para essa vacina pode ser relativamente pequeno.

- Quanto às vacinas novas e às vacinas aperfeiçoadas destinadas ao mercado global, formar parcerias para acessar a tecnologia de produção da vacina contra rotavírus; considerar colaboração para o desenvolvimento de vacinas mais modernas contra a raiva e/ou contra a gripe.

- Desenvolver vacinas regionalmente importantes como a contra a leishmaniose e contra a dengue.

- Manter-se atualizado quanto aos avanços da pesquisa e das possibilidades de colaboração, especialmente para o desenvolvimento de vacinas contra o HIV.

- Para todos os produtos, considerar novas estratégias de administração e a necessidade de plataformas de administração exeqüíveis.

\section{REFERÊNCIAS BIBLIOGRÁFICAS}

BALANCE, R.; POGANY, F. \& FORSTMER, H. The World's Pharmaceutical Industries: an international perspective on innovation, competition, and policy. Aldershot: Edward Elgar Publishing, 1992.

BARBOSA, A. Sobre a Propriedade do Trabalho Intelectual: uma perspectiva crítica. Rio de Janeiro: Editora UFRJ, 1999.

BAYLOR, N. W. \& McVITTIE, L. D. Changes in the regulations for vaccine research and development. Jordan Report. Accelerated Development of Vaccines 2002. US Department of Health and Human Services, 2002. p. 55-59.

BERNA BIOTECH. Disponível em: <http://www.bernabiotech.com> Acesso em: nov. 2003.

BIOWORLD. NASDAQ. As reported in Bionews, Dec. 2002-Jan. 2003, p.5. Disponível em: $<$ www,bionews.org.uk>.

BRASIL. Ministério da Saúde. National aids drug policy. Brasília: Coordenação Nacional de DST e Aids, 2002.

BRASIL. Lei da Propriedade Industrial. Disponível em: <http://www.inpi.gov.br $>$. Acesso em: nov. 2003.

CHIRON. 2002. Disponivel em: <http://www.chiron.com>. Acesso em: nov. 2003.

CIA. World Factbook, 2002, Brazil. Disponível em: <www.cia.gov>. 
CLEM, F. Biotechnology takes the lead in biodefence vaccine development. Bionews, Dec. 2002-Jan. 2003. Disponível em: <www,bionews.org.uk>.

COMMITTEE ON IMMUNIZATION FINANCE. Policies and Practice; calling the shots. Institute of Medicine. Washington, DC: National Academy Press, 2000. p. 58.

DELLEPIANE, N.; GRIFFITHS, E. \& MILSTIEN, J. B. New challenges in assuring vaccine quality. Bulletin of the World Health Organization, 78:155-162, 2000.

ESPARZA, J. et al. Estimation of "needs" and "probable uptake" for HIV/Aids preventive vaccines based on possible policy and likely acceptance (a WHO-UNAIDS-IAVI study). Vaccine, 21:2.041-2.050, 2003.

FOULKES, M. A. \& ELLENBERG, S. Vaccine efficacy and safety evaluation. Jordan Report. Accelerated Development of Vaccines. US Department of Health and Human Services, p. 63-68, 2002.

FUNASA. 2003a. Disponível em: < http://www.funasa.gov.br/imu/imu01.htm>. Acesso em: nov. 2003.

FUNASA. 2003b. Disponível em: <http://www.funasa.gov.br/epi/pdfs/ situacao_doencas.pdf>. Acesso em: nov. 2003.

GABINETE CIENTÍFICO-TECNOLÓGICO. Plan Nacional de Cienciay Tecnología 1998-2000. Buenos Aires: Presidencia de la Nación, 1997.

GALVÃO, J. Access to anti-retroviral drugs in Brazil. Lancet, 360:1.862-1.865, 2002.

GLOBAL FORUM FOR HEALTH RESEXCDDARCH,. Monitoring of financial flows for health research. Genebra, p. 14-20, 2001

GLOBAL FORUM FOR HEALTH RESEARCH, The 10/90 Report on Health Research 2001 2002. Genebra, p.112, 2003.

GOODMAN, J.Presentation to American Enterprise Institute. 27 June 2002. Disponível em: < http://www.fda.gov/cber/summaries/aei062702jg.htm>. Acesso em: nov. 2003

JORDAN REPORT. Accelerated Development of Vaccines 2002. US Department of Health and Human Services, 2002a. Appendix E.

JORDAN REPORT. Accelerated Development of Vaccines 2002. US Department of Health and Human Services, 2002b. Appendix C.

MCGARRY, S. \& RIGG, L. G. S. Biotech Research. Presented at Phacilitate Meeting. Paris, 2002.

MERCK \& CO., INC. Annual Report, 2001.

MILSTIEN, J. \& CANDRIES, B. Economics of vaccine development and implementation: changes over the past 20 years. Jordan Report. Accelerated Development of Vaccines 2002. US Department of Health and Human Services, p. 87-93, 2002.

MILSTIEN, J. B. et al. Vaccine quality - can a single standard be defined? Vaccine, 2.956:1-4,2001a. 
MILSTIEN, J. B. et al. Divergence of vaccine product lines in industrialized and developing countries. Trabalho apresentado para Strategic Advisory Group of Experts of the World Health Organization's Department of Vaccines and Biologicals. 2001b. (Mimeo.)

OPS (ORGANIZACIÓN PANAMERICANA DE LA SALUD). Programa especial de análisis de salud 2002: situación de salud en las Américas, indicadores básicos. Washington: OPS, 2002.

PAHO RF. Comunicação pessoal, 2003.

PANACEA-BIOTEC. Disponível em: < http://www.panacea-biotec.com> Acesso em: nov. 2003.

PLOTKIN, S.A. The ten most important discoveries in vaccinology during the last two decades. Jordan Report. Accelerated Development of Vaccines, 2002. US Department of Health and Human Services, p. 25.

RECOMMENDED childhood and adolescent immunization schedule. Mortality and Morbidity Weekly Report, 52: Q1-Q4, 2003a.

RICYT (RED IBEROAMERICANA DE CIENCIA Y TECNOLOGÍA). El estado de la ciencia: principales indicadores de ciencia y tecnología Iberoamericanos/Interamericanos. 2002. Disponível em: < http://www.ricyt.org/>. Acesso em: nov. 2003.

SANTOS, N. et al. Deteç̧ão de rotavírus atípicos em crianças com diarréia no Rio de Janeiro. Newslab, 32: 431, 1999.

SCHWARTZMAN, S. et al. Science and technology in Brazil: a new policy for a global world, study carried out by São Paulo School of Business Administration. Rio de Janeiro: Fundação Getúlio Vargas, 1993.

SERUM INSTITUTE OF INDIA. Disponível em: < http://www.seruminstitute.com > Acesso em: nov. 2003.

SHOT in the arm. Economist, 24 May, p. 62, 2003b.

STRATTON, K. R.; DURCH, J. S. \& LAWRENCE, R. S. (Eds.) Vaccines for the $21^{\text {st }}$ century: a tool for decision making. Washington, DC: National Academy Press, 2000.

UNAIDS. Improving access to care in developing countries. 2002. Disponível em: <http:/ /www.unaids.org > . Acesso em: nov. 2003.

UNICEF. 2003. Disponível em: <http://www.unicef.org/supply/2003_vaccine_projection.pdf> . Acesso em: nov. 2003.

WHITEHEAD, P. Public sector procurement approaches. Presentation to the Board of the Global Alliance for Vaccines and Immunization. Nova York: GAVI, 1999, p. 47-49.

WHITEHEAD, P. \& PASTERNAK, A. Lessons learned: new procurement strategies for vaccines. Final Report to the GAVI Board, 28 June 2002.

WHO (WORLD HEALTH ORGANIZATION). State of the world's vaccines and immunization. Genebra: WHO, 2002a. p. 24. 
WHO (WORLD HEALTH ORGANIZATION). Core information for the development of immunization policy (V\&B/O2.26). 2002b. Disponível em: <http://www.who.int/vaccinesdocuments/DocsPDF02/www557.pdf>.

WHO (WORLD HEALTH ORGANIZATION). United Nations prequalified vaccines. Nov. 2003. Disponível em: <http://www.who.int/vaccines-access/quality/un_prequalified/ prequalvaccinesproducers.html>

WHO (WORLD HEALTH ORGANIZATION)/UNICEF. Review of national immunization coverage, 2000.

WIDDUS, R. The future of public/private partnerships to improve the health of the poor: a preliminary analysis. Paper prepared for meeting on Creating Global Markets for Orphan Drugs and Vaccines: a challenge for public/private partnerships. Califórnia, 2000.

\section{GLOSSÁRIO}

Anvisa - Agência Nacional de Vigilância Sanitária

ARV - anti-retroviral

BCG - Bacille Calmette-Guérin

BPF - Boas Práticas de Fabricação (GMP - Good Manufacturing Practice)

$\mathrm{CDC}$ - Centers for Disease Control and Prevention

CRO - Contract Research Organisations

CVI - Children's Vaccine Initiative

DCVMN - Developing Country Vaccine Manufacturers' Network

DOTS - Directly Observed Therapy, short-course (Tratamento Diretamente Observado)

dT - toxóides diftéricos e tetânicos infantil

DTaP - toxóides diftéricos e tetânicos com vacina acelular contra coqueluche

DTP - toxóides diftéricos e tetânicos e vacina contra coqueluche

DTwP - toxóides diftéricos e tetânicos e vacina celular contra coqueluche

eIPV - Vacina inativada contra a pólio

ETEC-Escherichia coli enterotoxigênico

Funasa - Fundação Nacional de Saúde

GAVI - Global Alliance for Vaccines and Immunization

gp-Glicoproteína

$\mathrm{Hib}$-Haemophilus influenziae tipo b

HIV - Vírus da Imunodeficiência Humana (Human Immunodeficiency Virus)

ICG - Interagency Coordinating Group

ICH - International Conferece on Harmonization

INCQS - Instituto Nacional de Controle de Qualidade em Saúde

IOM - Institute of Medicine

MMR - Vacina contra sarampo, rubéola e caxumba 


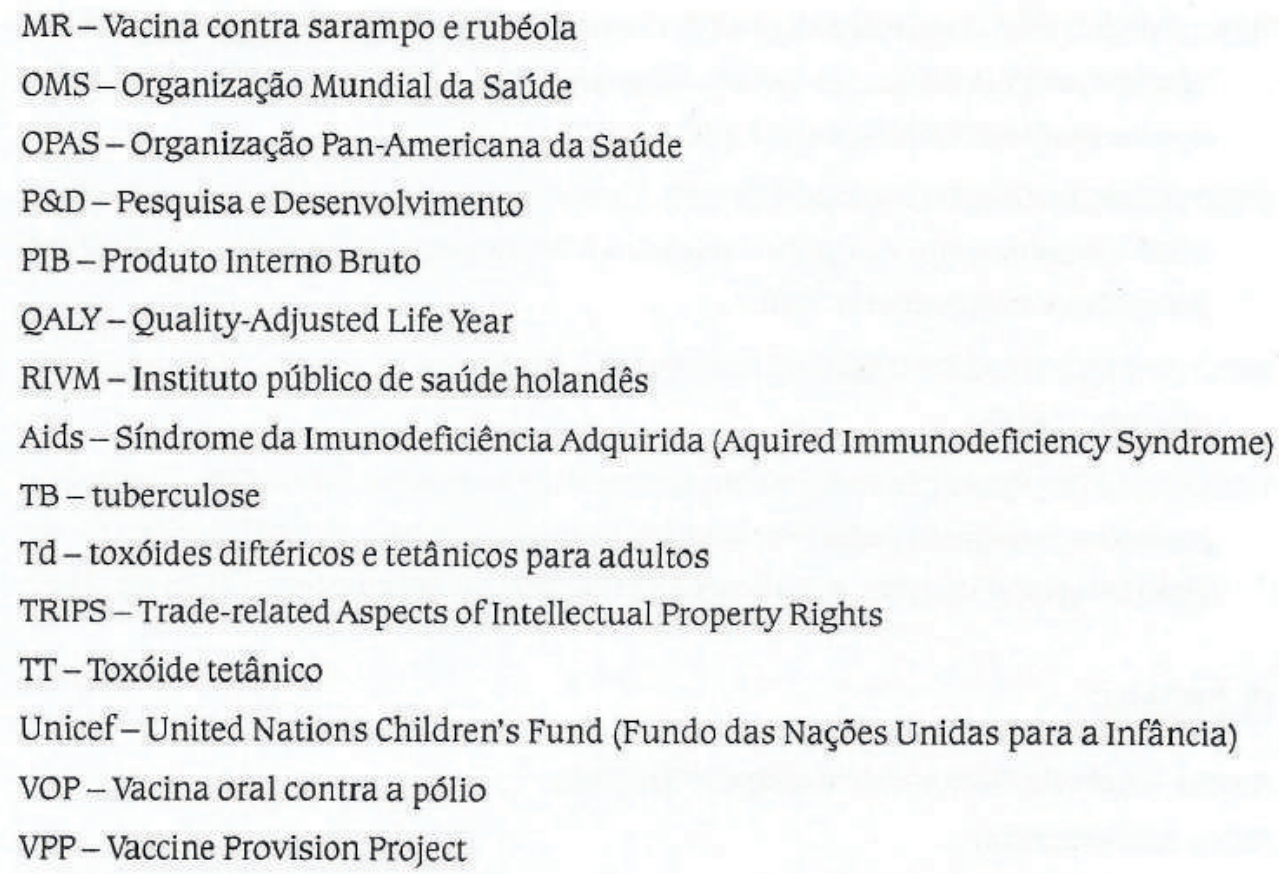




\section{Avaliação Tecnológica da Produção de Imunobiológicos no Brasil e Definição de Nichos de Atuação ${ }^{1}$}

\section{INTRODUÇÃO}

Este artigo tem como objetivo analisar a capacidade nominal e real da produção dos laboratórios produtores de imunobiológicos do Brasil, levando em consideração especialmente: perfil tecnológico dos produtores; adequação das rotas tecnológicas, instalações e processos adaptados aos parâmetros internacionais de qualidade; auto-sustentabilidade tecnológica. É propósito também desta unidade servir de apoio a propostas de prospecção de crescimento e desenvolvimento para o setor, numa perspectiva de 10 a 15 anos.

\section{TRABALHO REALIZADO E METODOLOGIA EMPREGADA}

A equipe responsável pela investigação, composta pelo autor deste artigo e dois assistentes de pesquisa, reuniu-se com a Coordenação do Projeto Inovação em Saúde/ Fiocruz para definir:

1) As instituiçōes participantes, escolhidas entre laboratórios nacionais responsá-。 veis pela produção de vacinas e soros incluídos no Programa Nacional de ImunizaÇões (PNI): Bio-Manguinhos/Fiocruz, Rio de Janeiro; Instituto Butantan, São Paulo; Fundação Ataulpho de Paiva (FAP), Rio de Janeiro; Instituto de Tecnologia do Paraná (Tecpar), Curitiba.

'Tradução do original em espanhol: Fernanda Ferreira da Silva Revisãotécnica: José da Rocha Carvalheiro e Carmen Romero. 
2) A metodologia, fundada em entrevistas com dirigentes dos diversos laboratórios, 0 cronograma das visitas e os instrumentos de coleta de dados: questionário, baseado em modelo da Anvisa, modificado; planilha com os dados do equipamento empregado em cada uma das produções das instituições; planilha com os dados de cada um dos produtos das instituiçōes.

3) Os aspectos a avaliar por observação direta, durante a visita da comissão aos institutos produtores: características da organização institucional que asseguram a produção; características do pessoal dedicado a cada uma das produções; tecnologia de produção em uso; equipamentos; instalações.

Analisando essas características em sua relação com parâmetros internacionais de qualidade, será possível definir: auto-sustentabilidade tecnológica da instituição; autosustentabilidade integral da instituição.

As descrições das visitas às diferentes instituiçöes encontram-se em anexos do relatório final do trabalho realizado. Contemplam as diversas características mencionadas anteriormente e são mantidas em poder dos dirigentes das diversas instituições, podendo ser divulgadas a seu critério. Este artigo destina-se apenas à análise final do projeto, apresentando suas conclusōes gerais. As quatro instituiçōes produtoras de vacinas que foram visitadas são analisadas de maneira conjunta, mediante um diagnóstico circunstanciado e um conjunto de sugestōes.

Ao final, em um parágrafo à parte, apresentam-se os dados consolidados das instituições produtoras de soros.

\section{CARACTERÍSTICAS DAS INSTITUIÇÕES}

\section{Bio-Manguinhos}

Em 1900, foi criado por Oswaldo Cruz o Instituto Soroterápico Federal que, com o trabalho desenvolvido ao longo dos anos, converteu-se na Fundação Oswaldo Cruz. Em 1976 criou-se Bio-Manguinhos, unidade técnico-científica da Fundação Oswaldo Cruz responsável pelo desenvolvimento tecnológico e pela produção de imunobiológicos.

o primeiro desafio para a produção de Bio-Manguinhos foi a vacina antimeningocócica C. Para este propósito, estabeleceu-se a primeira unidade-piloto de vacinas bacterianas para combater uma epidemia de meningite AC no princípio da década de 70.0 Brasil importou essa vacina da empresa Merieux por 120 milhōes de dólares e, como parte do acordo, a empresa doou uma fábrica, que foi construída em seis meses, para produzir o imunizante.

Bio-Manguinhos aproveitou a relação com a Merieux para negociar a transferência de tecnologia da vacina contra sarampo, que se deu por etapas. Primeiro adquiriu-se $o$ bulk e depois, pouco a pouco, as outras partes do processo produtivo foram introduzidas. No período de 1978-9, a Merieux interrompeu a transferência de tecnologia. 
Em 1980, fez-se um acordo com o Japão que implicava a transferência de tecnologia das vacinas contra sarampo e poliomielite. Ao longo de cinco anos, foram enviados em torno de quarenta investigadores ao Japão, e também vieram japoneses ao Brasil, na tentativa de estabelecer essas duas produções em Bio-Manguinhos.

No início dos anos 80 , criou-se o PNI no Brasil, o que gerou a necessidade de estabelecer novos enfoques no processo produtivo de imunizantes. Passaram a vigorar novas exigências de qualidade na produção de vacinas, e Bio-Manguinhos precisou instituir uma nova estrutura de controle de qualidade.

Bio-Manguinhos tem como missão contribuir para a melhoria dos padrões da saúde pública brasileira mediante a investigação tecnológica e a produção dos imunobiológicos necessários para atender a demanda gerada pelo quadro epidemiológico do país. Sua visão do futuro é construir a base tecnológica do Estado brasileiro para as políticas do setor de saúde. É reconhecido por protagonizar a oferta de novos produtos de interesse epidemiológico, biomédico e sanitário; possuir certificaçōes nacionais e internacionais de todos os produtos e suas instalações; ter uma gestão tecnológica que propicia associações e o desenvolvimento autóctone de produtos importantes para a saúde pública; possuir uma infra-estrutura científica e tecnológica capaz de responder rapidamente às demandas emergentes de novos produtos para a área de saúde, ter um pessoal permanentemente qualificado, comprometido e motivado.

Bio-Manguinhos tem 560 funcionários, além de outros 180 contratados para área de manutenção de equipamentos.

\section{Instituto Butantan}

Em fevereiro de 1901, uma parte se separou do Instituto Bacteriológico, recebendo o nome de Instituto Soroterápico de São Paulo; posteriormente passou a se chamar Instituto Soroterápico do Butantan. Em agosto do mesmo ano, foram entregues as primeiras ampolas de soro contra a peste. Com a reorganização do serviço sanitário do estado, em 1925, foi chamado de Instituto Butantan.

Ao longo de sua história, além de estudos sobre enfermidades ou agentes patógenos e a produção de soros e vacinas para o controle e prevenção de diferentes doenças, o Instituto Butantan tem mantido as investigações, utilizando o veneno de animais e produção de soros, que foi um dos principais interesses do seu fundador, Vital Brazil.

Trata-se de uma instituição pública, subordinada à Coordenação dos Institutos de Pesquisa da Secretaria de Saúde do Estado de São Paulo, e seu diretor é designado pelo Secretário de Saúde do Estado. O Instituto tem uma organização com uma área administrativa e seis divisões técnicas: desenvolvimento científico; desenvolvimento tecnológico e produção; desenvolvimento cultural; recursos humanos; engenharia e arquitetura; biotério geral. Possui certificação outorgada pela Secretaria de Vigilância Sanitária do Ministério da Saúde e registro de todos os seus produtos, concedido pelas autoridades sanitárias competentes. 
Está instalado em uma área de $70.000 \mathrm{~m}^{2}$, dos quais $18.000 \mathrm{~m}^{2}$ pertencem à área de produção central e ao biotério. Tem um total de $5.400 \mathrm{~m}^{2}$ de área construída. Conta com 1108 funcionários, dos quais 350 estão diretamente vinculados à produção.

\section{Fundação Ataulpho de Paiva (FAP)}

A Fundação Ataulpho de Paiva foi fundada em 4 de agosto de 1900 para combater a tuberculose pulmonar. Em 1930, começou a produzir a vacina BCG. A vacina BCG intradérmica produzida pela FAP já foi aplicada, até os dias de hoje, em 165 milhões de pessoas e 60 milhões foram vacinados por via oral, suprindo as necessidades do Brasil como principal produtora.

A produção de BCG pela FAP representa $5 \%$ da produção mundial. A cifra de produção anual é de 15 milhões e a capacidade instalada permite produzir até 20 milhões de doses anuais, existindo um estoque estratégico do produto. Em 1985, exportaram-se vacinas para a América do Sul e, em 2002, para Angola. Ao longo dos anos de aplicaçăo dessa vacina, não foram relatadas reações fatais ou importantes.

Atualmente estăo sendo realizados estudos para a utilização da cepa oral da vacina BCG como hospedeiro para introduzir outros antígenos vacinais, como meningococo e Escherichia coli. Além disso, está sendo negociada com a Fiocruz a possibilidade de incluir $\mathrm{o}$ antígeno do HIV recombinado com a BCG. Esta cepa oral também pode ser empregada em câncer de bexiga com concentrações altas (40mg).

Não há condições de Boas Práticas de Fabricação (BPF) integralmente na Fundação, ainda que existam áreas que cumpram os níveis de BPP e o pessoal esteja treinado. A perspectiva de melhoria se dará após a estruturação da nova instalação, que já teve a sua construção iniciada, mas não foi concluída ainda. A um custo de 10 milhões de dólares, ainda necessitará de 3 milhões para o seu término. Existem equipamentos importantes e valiosos na nova instalação que estão se depreciando por não serem utilizados.

Tem como missão institucional garantir a produção da vacina BCG com máxima qualidade para atender as necessidades do Brasil; sua visão institucional é produzir outros medicamentos de importância para o país, além da BCG, e não depender de suporte financeiro do governo.

A FAP, que conta com 140 trabalhadores, não está certificada pela Anvisa.

\section{Instituto de Tecnologia do Paraná (Tecpar)}

O Tecpar surgiu na década de 40 como uma instituição para o desenvolvimento agropecuário. Desde 1970, produz a vacina anti-rábica animal e, em 1986, começou a produzir a vacina anti-rábica humana com a técnica de Fuenzallida y Palacio.

Atualmente, o Tecpar está realizando mudanças na produção da vacina anti-rábica humana. A tropicalização do vírus já foi realizada e os lotes de células-origem já estão prontos. A instalação do equipamento adquirido e o término das instalaçōes permitirão a produção da célula Vero em escala adequada, para realizar os estudos que viabilizam a certificação e registro do produto. 
Com relação à vacina anti-rábica animal, o Instituto já desenvolveu e registrou uma tecnologia baseada no cultivo de célula do tipo BHK.

Em 2001, foi criado o Instituto de Biologia Molecular do Paraná (IBMP) em associação com a Fiocruz, constituindo um dos principais núcleos internos de investigação e desenvolvimento do Tecpar.

Em fase de estruturação final encontra-se um laboratório de química fina, com capacidade para desenvolver síntese de novas proteínas, e um de seus primeiros trabalhos será a síntese da proteína da seda.

O Tecpar é um instituto tecnológico organizado como uma empresa pública que oferece serviços tecnológicos de metodologia e ensaios laboratoriais para diferentes instituições e empresas. Ademais, é um órgão do Sistema Nacional de Emissão de Certificados de Conformidade do Sistema de Gestão Empresarial de Processos e de Produtos. Executa também programas de apoio tecnológico a pequenas e médias empresas; realiza cursos e seminários de capacitação de recursos humanos; faz inspeção veicular e responde pela estrutura tecnológica de Curitiba.

A visão da instituição é de modernização constante para responder às demandas existentes. Atualmente está se adequando às normas da ISO 9001/2000.

\section{CONCLUSÕES}

Neste momento, o Brasil se move num espaço contraditório na área de imunobiológicos, com dois aspectos principais. Por um lado, existe a necessidade de desenvolver e produzir novas vacinas, imunobiológicos e outros produtos. Por outro, a obrigatoriedade de cumprir o acordo sobre Aspectos de Direitos de Propriedade Intelectual Relacionados ao Comércio (TRIPS) do sistema internacional de patentes.

Nos relatórios encaminhados a cada uma das instituições produtoras de imunobiológicos, foram mostrados dados que nos permitiram fazer recomendações para lidar com as oportunidades de cada uma delas. Esses relatórios pertencem a essas instituições e poderão ser tornados públicos por sua iniciativa. Os interessados devem buscar um contato direto com elas.

Neste artigo apresentamos a análise conjunta dessas instituições e, para uma melhor compreensão do trabalho de avaliação realizado, foram contemplados os seguintes aspectos: perfil tecnológico dos produtores; adequação das rotas tecnológicas; perfil da mão-de-obra disponível; auto-sustentabilidade tecnológica.

1) Perfil tecnológico dos produtores

\section{Diagnóstico}

- Durante a inspeção, verificou-se que as instituições (excetuando o Tecpar, que não está produzindo neste momento), possuem produtos que, ainda que estejam registrados, não têm certificação da Anvisa (Tabelas 1 e 2). ${ }^{2}$

\section{Sugestões}

- Criação um programa nacional que defina a data de início e culminância desse processo de certificação para cada um dos produtos em cada uma das instituições. Propomos, ${ }^{2}$ As tabelas, gráficos e quadros encontram-se
ao final do texto. 
também, organizar, a partir de agora, o Programa de Certificação OMS para cada produto de cada uma das instituiçôes, em forma de projetos com definição clara de viabilidade econômica, data de início, culminância, materialização, execução e fluxo de caixa.

2) Adequação das rotas tecnológicas, instalações e processos adaptados aos parâmetros internacionais de qualidade

Diagnóstico

- o Brasil possui uma produção impressionante de vacinas humanas, que representa o maior volume da América Latina, elaboradas com as tecnologias existentes (Tabelas 1, 2 e 3). Existem duas vacinas de nova geração, a vacina recombinante contra hepatite $\mathrm{B}$ do $\mathrm{Bu}$ tantan (comercializada há mais de 15 anos em outros países) e a vacina Hib, feita com tecnologia transferida da GlaxoSmithKline, produzida por Bio-Manguinhos. Analisando as produções de vacina dos últimos cinco anos de cada uma das instituições brasileiras (Tabelas 1, 2 e 3; Gráficos 1, 2, 3 e 4) e com base tecnológica estabelecida no país, verificamos que o Brasil está em condições de dar um salto para maior modernização da sua produção de vacinas e de outros produtos.

- Uma modernização intensa da produção no Brasil resolverá o problema estratégico da auto-suficiência em vacinas. Por exemplo, das 23 vacinas ou combinações de vacinas que têm sido aplicadas nos últimos cinco anos no Brasil, existem seis que são totalmente importadas e outras três que são envasadas a partir de componentes importados (Tabela 3). Para estas vacinas já foram encaminhadas as possíveis soluções.

- A modernização também pode ser apoiada na análise das capacidades produtivas das instituições visitadas. Verificamos que existem capacidades instaladas de locais e de pessoal que podem ser utilizados para enfrentar novos desafios, aumentando a rentabilidade e reduzindo os custos fixos de produção, contribuindo para a diversificação de produtos da área de biotecnologia do Brasil (Tabela 2). Todavia, essa diversificação não será somente para produzir novas vacinas; serăo desenvolvidos também medicamentos e modernos sistemas de diagnósticos com tecnologia avançada como: recombinante, recombinantes transgênicos e síntese de peptídeos. Com a modernização, será possível enfrentar os desafios que o acordo TRIPs impõe ao Brasil.

- Durante as visitas, verificamos os equipamentos que necessitam de renovação, bem como as características e dificuldades das instalaçōes produtivas, o que foi comentado especificamente na análise de cada instituição.

Sugestões

- Elaboramos uma lista de prioridades de imunobiológicos para o Brasil, que também deve se relacionar com os dados sobre a situação de vários projetos do país e com algumas das parcerias existentes entre as instituiçōes (Quadros 1 e 2):

- Desenvolvimento com parcerias internas e eventualmente externas: vacina pneumocócica, vacina BCG recombinante e vacina contra leptospirose.

- Busca de acordos com transferência tecnológica: vacina dupla viral, vacina tríplice viral, vacina contra rotavírus e vacina contra leishmaniose. 
- Busca de oportunidades para desenvolvimento conjunto com outros países e parcerias internas: vacina contra dengue, vacina contra hepatite $\mathrm{C}$, vacina contra malária. - Outras vacinas para considerar diferentes modos de transferência tecnológica e/ou desenvolvimento conjunto com outros países: vacina contra S. pneumoniae conjugada, vacina contra HPV.

- Análise de oportunidades para futuros trabalhos conjuntos com outros países: vacina contra HIV.

- A elaboração do programa definitivo de prioridades é uma tarefa que deve ser coordenada por uma comissão nacional, como proposto a seguir (Figura 1).

Figura 1 - Proposta de estrutura organizacional para a Comissão Nacional de Biotecnologia

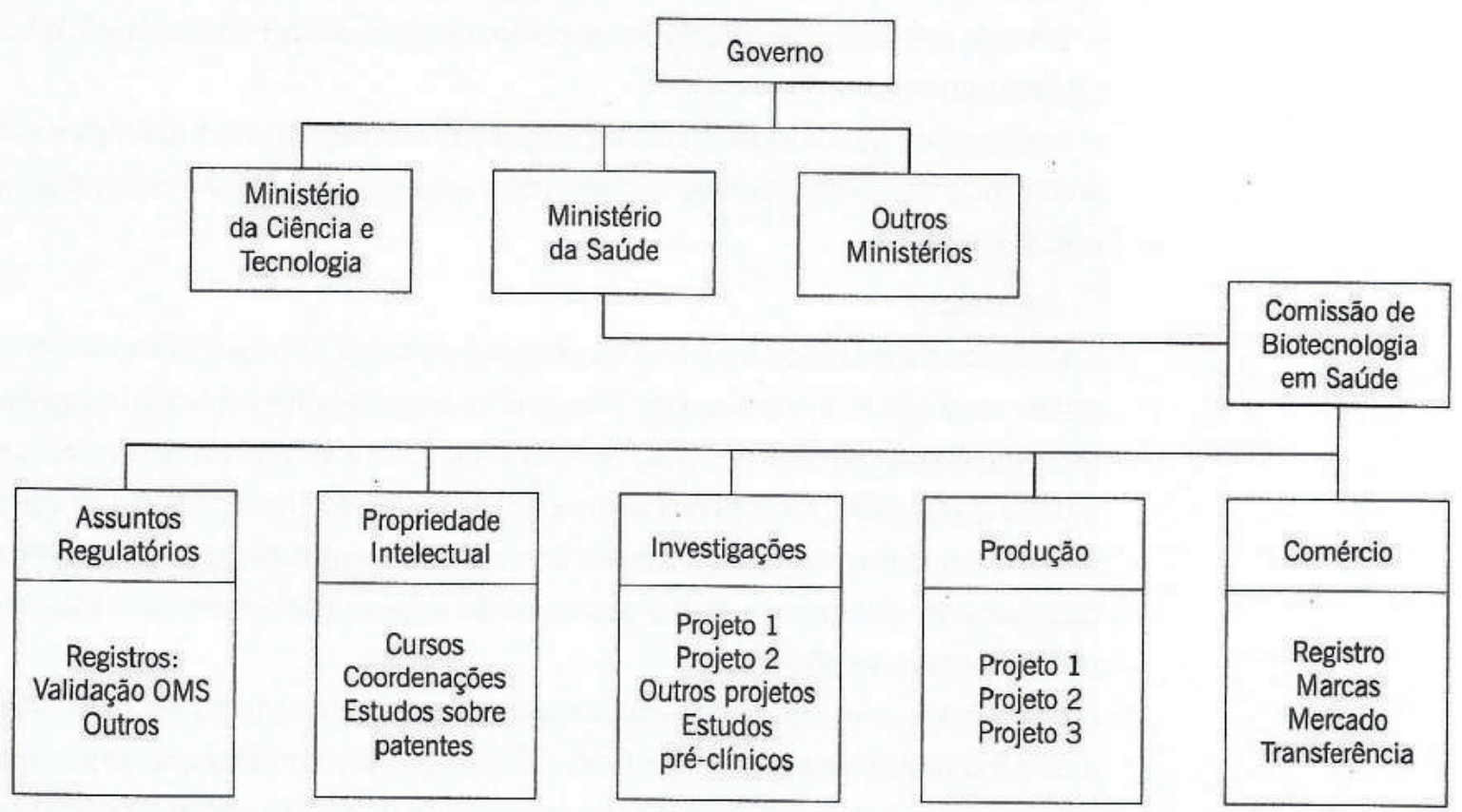

- A realidade do acordo TRIPs, com seus impactos, obriga-nos a ter em mente alternativas, como as produções de fármacos e outros produtos, além de vacinas. Portanto, é imprescindível que essa comissão que se propõe a elaborar a lista de prioridades de produtos que serão desenvolvidos analise o status que cada um dos produtos tem, do ponto de vista de propriedade intelectual. Devem-se avaliar as necessidades do Brasil em primeiro lugar (com base no quadro epidemiológico), para então definir o tempo que resta para o vencimento das patentes existentes. Esta análise nos permitirá definir os nichos de atuação para os produtores.

3) Perfil da mão-de-obra disponível

\section{Diagnóstico}

- O quadro geral da força de trabalho das quatro instituições produtoras de vacinas mostra uma situação diversa segundo cada instituição (Tabela 4). No total, há um 
contingente expressivo que atinge 1.092 trabalhadores, sendo 333 (30,5\%) de nível superior. Na distribuição por unidade operacional, apenas 140 (12,8 \%) estão lotados em funções de direção, administrativas ou comerciais. Embora a maioria esteja em funções técnicas, apenas 101 (9,2\%) pertencem ao esforço de desenvolvimento tecnológico.

- O pessoal de nível superior distribui-se por um amplo espectro de formação profissional (Tabela 5) e tem níveis de especialização $(31,3 \%)$, mestrado $(24,5 \%)$ e doutorado $(16,6 \%)$ bastante elevados em comparação com o mercado de trabalho. Considera-se, no entanto, preocupante a distribuição etária, com média de idade de 40,8 anos e apenas 57 trabalhadores $(17,1 \%$ ) abaixo de trinta anos (Tabela 6). Além disso, a idade de início no serviço é também relativamente alta, com média de 29,3 anos. O tempo de serviço dos trabalhadores atuais é de 11,5 anos em média (Tabela 7).

- Deve-se priorizar o treinamento específico de técnicas de biotecnologia aplicada às distintas atividades (Tabela 7).

- Analisando o domínio do idioma inglês por parte do pessoal das instituições visitadas. verificamos que todas precisam melhorar esse quadro, algumas com maior urgência que outras (Tabela 8).

Sugestões

- No Relatório Jordan do ano de 2002, foram reportados 351 tipos diferentes de vacinas (quase todas do Primeiro Mundo), em nível de investigações básicas, das quais 331 já estão em fase de estudos pré-clínicos. Isso demonstra a velocidade desses trabalhos no mundo e o tamanho do hia to existente entre os países do Primeiro Mundo e aqueles em desenvolvimento (incluindo o Brasil). Conhecendo o significado do acordo TRIPs e seu cumprimento obrigatório, damo-nos conta da urgência de desenvolver estratégias de trabalho eficazes e eficientes.

- É necessária uma exploração dos melhores países desenvolvidos para fazer um programa de formação de pessoal em perfis de trabalho que estejam de acordo com as prioridades que forem estabelecidas no programa nacional de desenvolvimento de vacinas e outros produtos.

- As negociaçōes para transferência de tecnologia, além da aquisição de novos produtos, também constituem as vias de superação e atualização para promover novos desenvolvimentos.

- O conhecimento de técnicas de gerenciamento de projetos é muito importante para todo o pessoal da produção, do desenvolvimento, das investigações e dos grupos de gestão comercial de cada uma das instituições. Dessa forma, será possível alcançar uma maior identificação coletiva da missão e da visão desses órgãos, assim como a definição dos papéis de cada grupo e cada pessoa neles.

- Consideramos igualmente fundamental cursos de preparação em propriedade intelectual, que permitam atualização de conhecimento do acordo TRIPs e seu impacto na tecnologia de países em desenvolvimento, como o Brasil, além de outros conhecimentos considerados importantes. 


\section{4) Auto-sustentabilidade tecnológica}

\section{Diagnóstico}

- Como conclusão desta avaliação, podemos dizer que, para os produtos biotecnológicos elaborados neste momento, o Brasil possui uma capacidade tecnológica com um estado da arte que é comparado às instituições de Primeiro Mundo. O que não chega aos padrões dos países desenvolvidos são as condições dos locais, que nem sempre cumprem as condições para a certificação de Boas Práticas de Fabricação (BPF). A organização e funcionamento do trabalho de controle e manutenção da qualidade possuem diferenças nas distintas instituiçôes. Não obstante elas terem atingido grande desenvolvimento, no sentido geral ainda não estão totalmente à altura do padrão do Primeiro Mundo.

- O modelo de desenvolvimento produtivo empregado nas instituições, tendo como referência o quadro epidemiológico do Brasil, é muito bom graças à sua projeção social. Entretanto, atualmente, para poder chegar ao grau de excelência que o Brasil está propondo, é necessário agregar, paralelamente a esse modelo, uma perspectiva comercial para a exportação, que considere a gestão comercial como uma fonte de auto-sustentabilidade tecnológica e também econômica.

- Deve-se estabelecer uma interação com o mercado privado de medicamentos no Brasil, a fim de aproveitar a experiência das empresas brasileiras distribuidoras de medicamentos estrangeiros ou produzidos no exterior com o processo produtivo finalizado no Brasil e também para ocupar esses nichos com produção local, o que pode ser facilitado por causa do tamanho do mercado brasileiro.

- É necessário fortalecer os grupos para negociações comerciais, aumentando o conhecimento pertinente da situação internacional. Assim, propostas e mecanismos de associaçōes convenientes ao Brasil poderão ser gerados, permitindo contornar o acordo TRIPS por meio de acordos de licença com companhias que sejam donas de determinadas patentes de produtos interessantes de se produzirem no país.

- o Brasil demonstra estar em um período de mudança rumo a uma maior sustentabilidade tecnológica, e devemos promover essa mudança. Cremos que a biotecnologia necessita ser colocada em um maior nível de viabilidade nacional e internacional, a fim de facilitar o incremento de parcerias com diferentes países e ganhar a confiança necessária para alcançar posicionamento no mercado.

Sugestões

- É necessário dar maior visibilidade ao trabalho da biotecnologia brasileira, por meio de diferentes ações, como as seguintes:

- Fazer uma publicação com todos os aspectos positivos encontrados na visita de avaliação e difundi-Ia em nível nacional e internacional.

- Organizar um evento internacional sobre biotecnologia (latino-americano, pelo menos), com o intuito de realizá-lo dentro de dois ou três anos, e promovê-lo o quanto antes.

- Dar ao Brasil maior importância no contexto latino-americano de biotecnologia; para isso, pode-se, por exemplo, reativar a Sociedade Latino-americana de Biotecnolo- 
gia, promover e fortalecer a Sociedade Brasileira de Biotecnologia, e então ocupar o seu verdadeiro lugar.

- A comercialização dos produtos da biotecnologia brasileira em outros países irá gerar concorrência, o que elevará a qualidade da produção. A definição de prioridades deve ser baseada, em primeiro lugar, no quadro epidemiológico do Brasil, que é um país com mercado importante. Devemos incluir, também, um estudo do mercado internacional, buscando nichos de posicionamento comercial.

- As negociações para vendas de vacinas validadas (como a vacina contra febre amarela) em outros países podem abrir o caminho de uma nova era da biotecnologia brasileira para Bio-Manguinhos. A vacina contra Hib possui um potencial maior que a vacina contra febre amarela e pode oferecer grandes benefícios. Claro que a Hib poderá atuar somente em mercados em que as negociaçōes com a GlaxoSmithKline permitam. A vacina recombinante contra hepatite B do Butantan também tem importantes possibilidades. Neste caso, devem-se buscar processos produtivos cada vez mais rentáveis e preços mais baixos do produto. Há ainda as vacinas combinadas, que, igualmente, oferecem uma oportunidade importante para o Brasil.

- Propomos um projeto nacional de desenvolvimento da biotecnologia, e consideramos a complementação de dois aspectos para a elaboração de um plano com nichos de atuação conjunta, o que o tornará totalmente auto-sustentável:

- Uma definição estratégica do governo brasileiro, aproximando mais o trabalho de biotecnologia do nível máximo de decisão do país.

- Uma organização (comissão, equipe, grupo) que tenha um enlace com a direção do país e integre o trabalho de biotecnologia das instituições, de forma paralela e coordenada com os ministérios, estados, ou por meio da estrutura de subordinação administrativa que cada centro possua.

- Essa comissão não possui uma linha de mandato administrativo, sendo uma estrutura de coordenação e integração, que retroalimenta diretamente o governo e se apóia nas estruturas às quais esses centros são subordinados.

- Serāo organizados dois grupos de assessores estrangeiros para apoiar essa comissão, um para assuntos técnicos e outro para assuntos gerenciais.

- A comissão deve dar continuidade à proposta preliminar dessa Organização Nacional de Coordenação, com seus componentes e suas funções, sendo passível de modificações em sua concepção, forma de organização e funções de acordo com as definições das autoridades brasileiras (Figura 1).

\section{CENTROS PRODUTORES DE SOROS}

Os dados encontrados nas visitas às instituições expressam, em conjunto, que esses centros e/ou áreas produtoras de soros constituem coletivos muito motivados com sua atividade e realizam um trabalho estratégico muito importante para a saúde pública. Verificamos que, com exceçâo do Instituto Butantan, todas as demais instituições possuem más condições, especialmente de edificaçōes, para o cumprimento das BPF. Tam- 
bém têm dificuldades com seus equipamentos, tendo sido elaborado um plano de aquisições a curto prazo (até dez anos), a médio (até vinte anos) e a longo prazo (mais de vinte anos) (Tabela 9). O quadro de pessoal mostra que apenas $15,4 \%$ dos 324 trabalhadores se dedicam a funções de direção e administração (Tabela 10). A distribuição do pessoal de nível superior e sua qualificação mostram que se originam de diversas áreas disciplinares e fizeram especialização ( $41,3 \%)$, mestrado $(21,3 \%)$ e doutorado $(5,3 \%)$ (Tabela 11). O quadro etário institucional é preocupante, assim como o treinamento de pessoal e o domínio de idiomas (Tabelas 12,13 e 14). Sugerimos que seja feita uma avaliação profunda das instituições em estudo, já que a nossa equipe não pôde se aprofundar por causa do tempo limitado que foi possível dedicar a elas. ${ }^{3}$

${ }^{3}$ Agradecemos a colaboração de Fernando Lopes (Bio-Manguinhos) e Hisako Gondo Higashi (Instituto Butantan). 


\begin{tabular}{|c|c|c|c|c|c|c|c|c|c|c|c|c|c|c|c|}
\hline \multicolumn{2}{|c|}{ 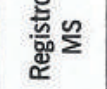 } & \multirow[t]{2}{*}{ 틈 } & \multirow{2}{*}{ 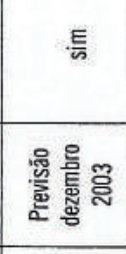 } & \multirow{2}{*}{ 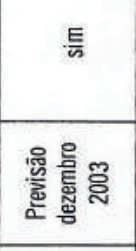 } & \multirow{2}{*}{ 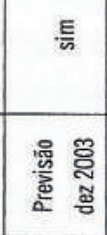 } & \multirow[t]{2}{*}{ 틈 } & \multirow[t]{2}{*}{ हE } & & \multirow{2}{*}{ 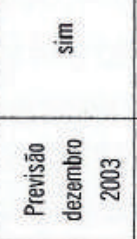 } & \multirow[t]{2}{*}{ E } & \multirow[t]{2}{*}{ 㞻 } & & \multirow[t]{2}{*}{ 㞻 } & \multirow[t]{2}{*}{ 点 } & \multirow[t]{2}{*}{ 系 } \\
\hline & oิ & & & & & & & & & & & & & & \\
\hline 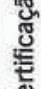 & 울 & 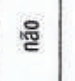 & 曼 & & 茞 & 욤 & & & \%ి & & ఊి & & & 訕 & "曷 \\
\hline & 嵩 & @ & 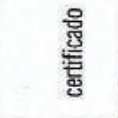 & & 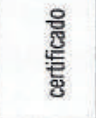 & 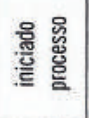 & & & 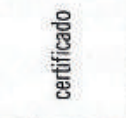 & & 음 & & & 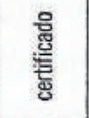 & ๓ి \\
\hline & ؛ें & & & & 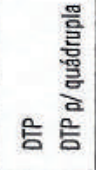 & & 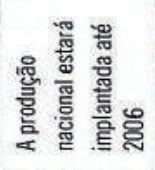 & 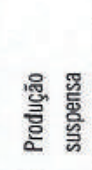 & & 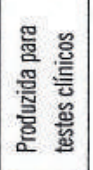 & & & & & \\
\hline & 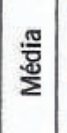 & 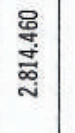 & 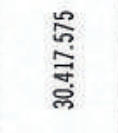 & 誉 & 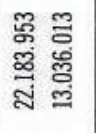 & 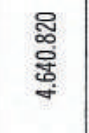 & 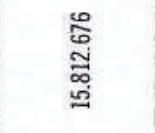 & స్ & 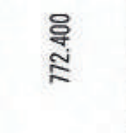 & 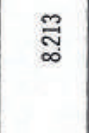 & 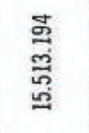 & 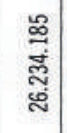 & 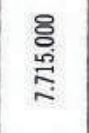 & $\begin{array}{l}\stackrel{\circ}{\circ} \\
\stackrel{0}{0} \\
\stackrel{0}{\circ} \\
\forall\end{array}$ & 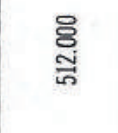 \\
\hline & ๙ั้ & 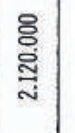 & $\underset{\substack{\text { స్ల } \\
\text { d }}}{ }$ & 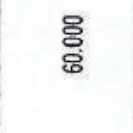 & 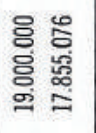 & $\begin{array}{l}\text { ठ․․ } \\
\text { ్․ }\end{array}$ & 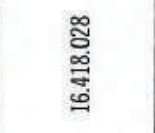 & . & . & స્さ & 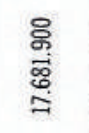 & 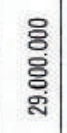 & $\begin{array}{l}\text { ठ্. } \\
\text { ळ. } \\
\text { N }\end{array}$ & $\begin{array}{l}\stackrel{8}{0} \\
\text { 怘 } \\
\text { స్ల. }\end{array}$ & $\begin{array}{l}\stackrel{8}{0} \\
\text { 品 }\end{array}$ \\
\hline 믐 & $\overrightarrow{\mathrm{o}}$ & 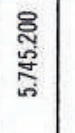 & 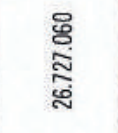 & ষ্. & 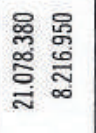 & 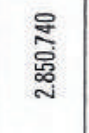 & 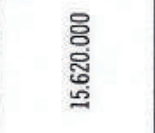 & జ్. & . & . & 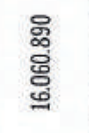 & 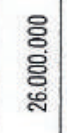 & 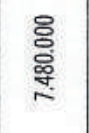 & 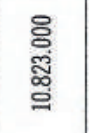 & . \\
\hline$\stackrel{2}{2}$ & ঃ & 壳 & $\begin{array}{l}\text { छ్ } \\
\infty \\
00 \\
0 \\
0\end{array}$ & 莺 & 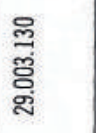 & $\begin{array}{l}\text { 芯 } \\
\text { 胥 } \\
\text {. }\end{array}$ & 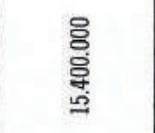 & 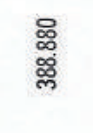 & ' & $\begin{array}{l}\widetilde{\widetilde{0}} \\
\stackrel{\Xi}{-}\end{array}$ & 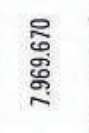 & 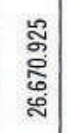 & $\begin{array}{l}\stackrel{\circ}{0} \\
\stackrel{8}{0} \\
\stackrel{\Xi}{\Xi}\end{array}$ & 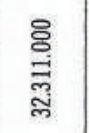 & 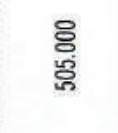 \\
\hline & Љু & 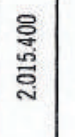 & $\begin{array}{l}\text { 过 } \\
\text { 总 } \\
\text { ô }\end{array}$ & $\begin{array}{l}\vec{z} \\
\text { ్ํㅁ }\end{array}$ & 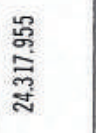 & $\begin{array}{l}\text { 으․ } \\
\text { 여․ }\end{array}$ & I & 宫 & ' & 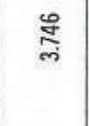 & 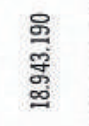 & 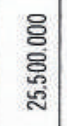 & 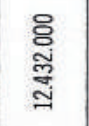 & $\begin{array}{l}\stackrel{8}{0} \\
\text { 芦 } \\
\text { g. }\end{array}$ & . \\
\hline & $\stackrel{\circ}{\stackrel{్}{్}}$ & 总 & 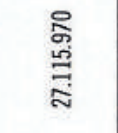 & $\begin{array}{l}\text { ष्ठ் } \\
\text { ․․ }\end{array}$ & 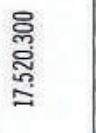 & 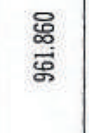 & ' & 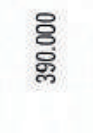 & 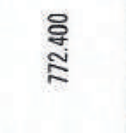 & . & 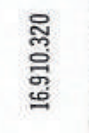 & 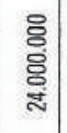 & $\begin{array}{l}\text { ठ্. } \\
\text { ठ유. }\end{array}$ & 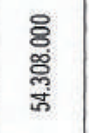 & ' \\
\hline & 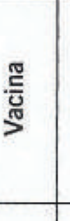 & $\mathscr{్}$ & 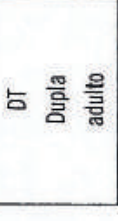 & 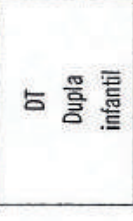 & 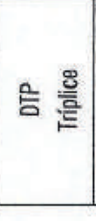 & 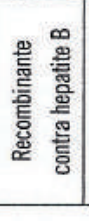 & 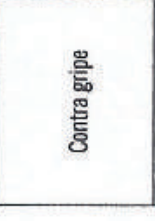 & 莺总 & 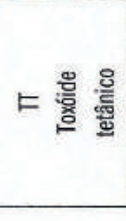 & 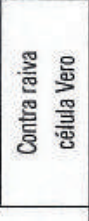 & . & 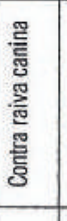 & 总 查 & 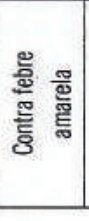 & 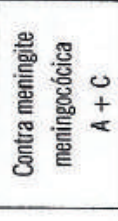 \\
\hline & 홈 & 号旁 & & & & & & & & & 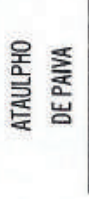 & 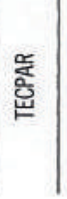 & 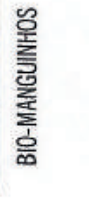 & & \\
\hline
\end{tabular}



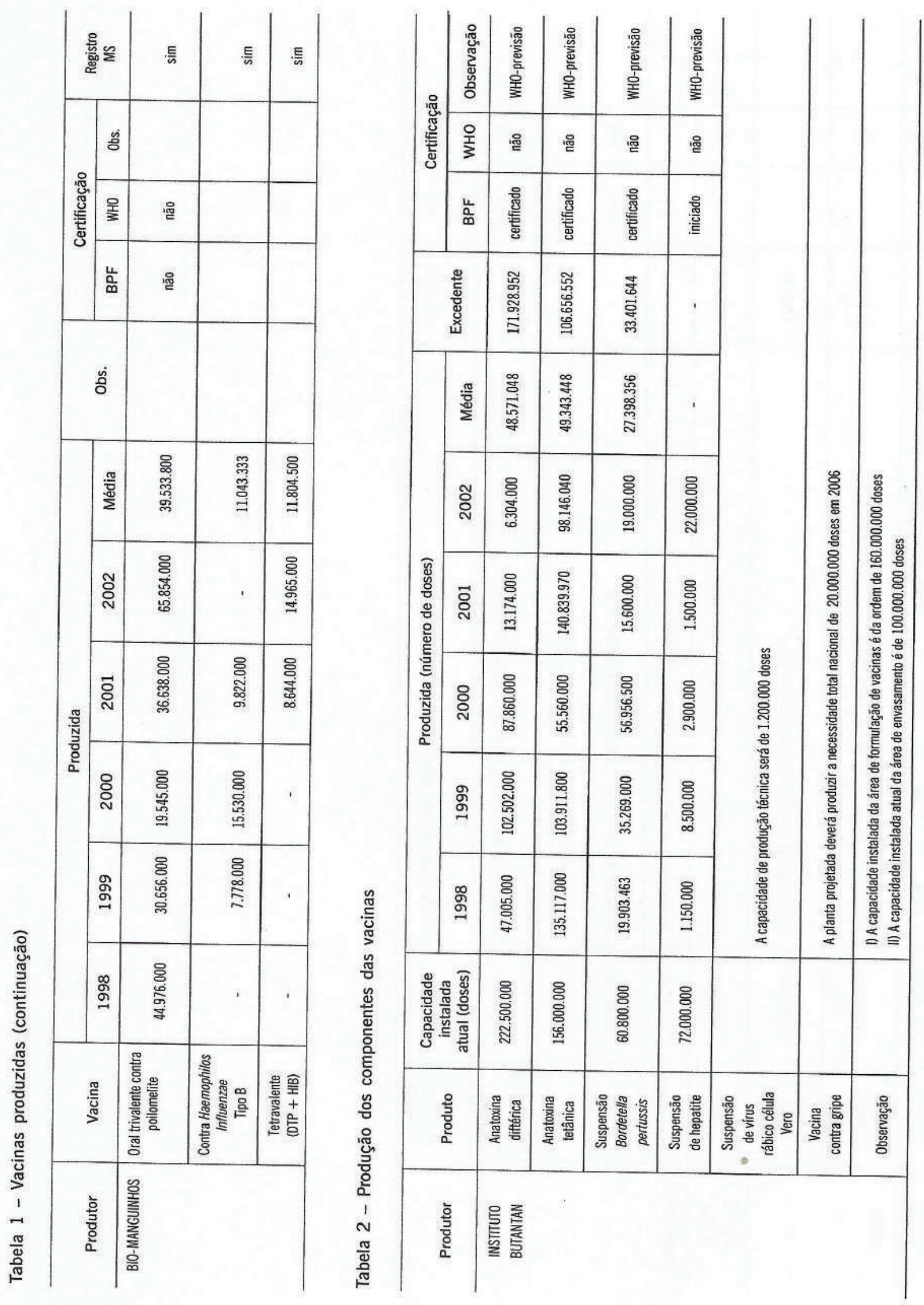
VACINAS, SOROS E IMUNIZAÇÕES NO BRASIL

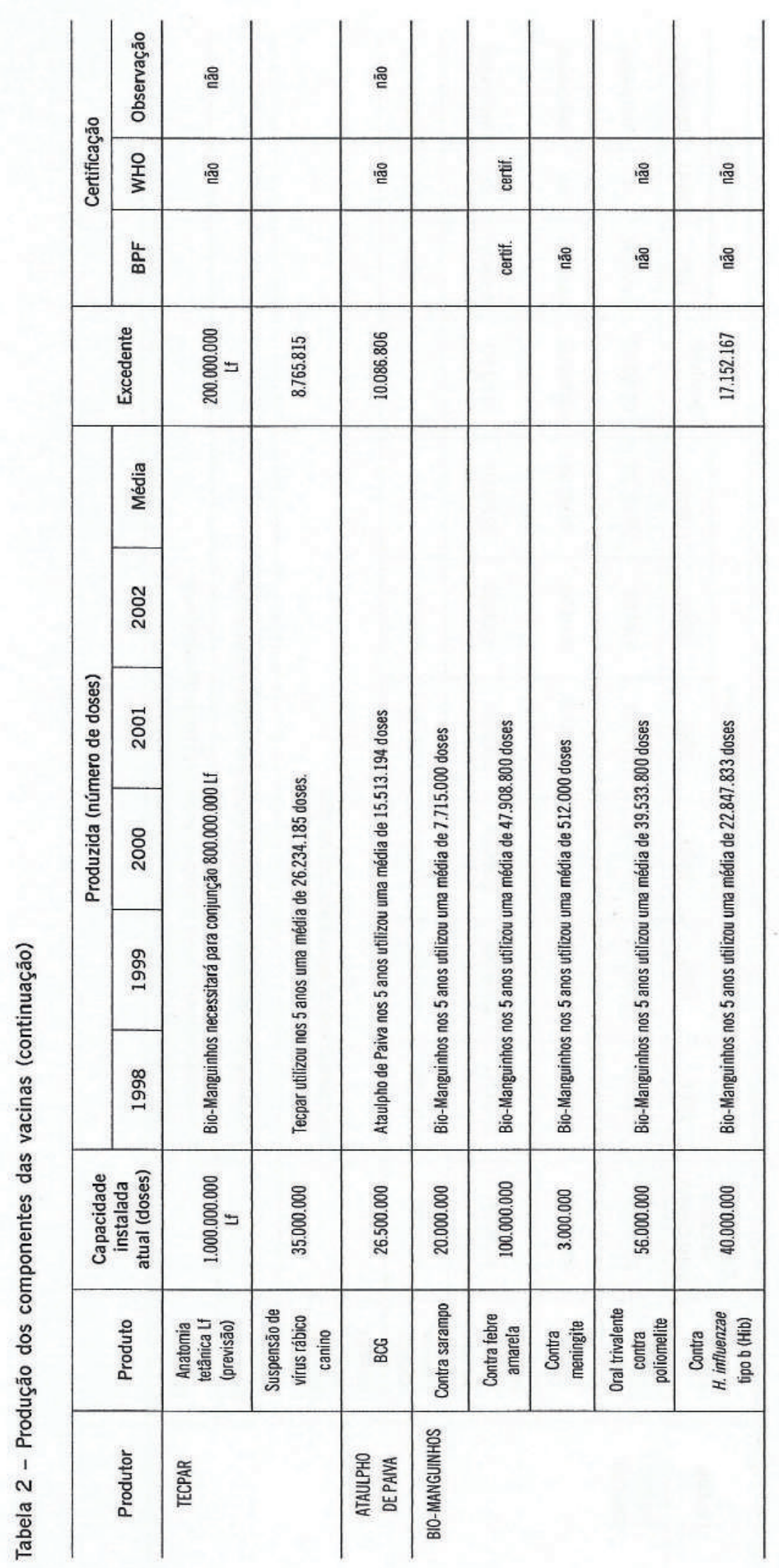


Tabela 3 - Vacinas aplicadas no Brasil - 1998 a 2002

\begin{tabular}{|c|c|c|c|c|c|}
\hline Imunobiológicos & $\begin{array}{c}\text { Necessidade } \\
\text { nacional }\end{array}$ & Produção nacional & $\begin{array}{l}\text { Envasamento } \\
\text { bulk importado }\end{array}$ & $\begin{array}{c}\text { Importação } \\
\text { produto acabado }\end{array}$ & Situação do país \\
\hline Vacina pólio oral & 352.064 .360 & - & 197.669 .000 & 157.831 .000 & - \\
\hline Vacina sarampo & 46.172 .285 & 46.290 .000 & - & - & Auto-suficiente \\
\hline Vacina BCG & 81.576 .700 & 91.608 .270 & - & - & Auto-suficiente \\
\hline Vacina tríplice & 91.833 .350 & 87.000 .000 & - & - & Auto-suficiente \\
\hline Vacina dupla adulto (DT) & 132.161 .208 & 120.196 .170 & - & - & Auto-suficiente \\
\hline Toxóide tetânico & 500.000 & 772.400 & - & - & Auto-suficiente \\
\hline Vacina dupla infantil (DT) & 1.368 .150 & 1.450 .000 & - & - & Auto-suficiente \\
\hline Vacina meningite $A / C$ & 2.988 .150 & 1.536 .000 & - & - & - \\
\hline Vacina meningite $B / C$ & 413.636 & - & - & - & - \\
\hline Vacina dupla viral & 70.840 .000 & - & - & 65.000 .000 & - \\
\hline Vacina hepatite B & 100.136 .465 & 17.324 .555 & - & 78.000 .000 & Auto-suficiente em 2003 \\
\hline Vacina tríplice viral & 72.998 .000 & - & - & 73.000 .000 & - \\
\hline Vacina febre amarela & 189.758 .485 & 239.544 .000 & - & - & Auto-suficiente \\
\hline Vacina raiva humana & 9.862 .845 & 9.740 .000 & - & - & Auto-suficiente \\
\hline Vacina raiva canina & 130.176 .040 & 130.000 .000 & - & - & Auto-suficiente \\
\hline Vacina Hib & 42.537 .606 & - & 25.700 .000 & 9.022 .680 & Auto-suficiente em 2004 \\
\hline Vacina pneumococo & 3.086 .200 & - & - & 1.000 .000 & - \\
\hline Vacina raiva (cel. dipl. humana) & 622.220 & - & 600.000 & 43.720 & - \\
\hline Vacina tríplice acelular & 64.000 & - & - & 49.000 & - \\
\hline Vacina varicela & 388.040 & - & - & 14.500 & - \\
\hline Vacina hepatite A & 54.400 & - & - & 4.000 & - \\
\hline Vacina influenzae & 52.126 .380 & - & 44.500 .000 & 7.626 .380 & Auto-suficiente em 2005 \\
\hline Vacina quádrupla (DTP/Hib) & 22.173 .948 & 23.300 .000 & 23.300 .000 & - & - \\
\hline Doses totais & 1.403 .902 .468 & 768.761 .395 & 291.769 .000 & 391.591 .280 & - \\
\hline$\%$ sobre doses totais & - & $54,76 \%$ & $20,78 \%$ & $27,89 \%$ & - \\
\hline
\end{tabular}


VACINAS, SOROS E IMUNIZAÇÕES NO BRASIL

Tabela 4 - Produtores de vacinas: quadro geral da força de trabalho

\begin{tabular}{l|c|c}
\hline Unidade operacional & Qtd. & $\%$ \\
\hline Direção/Administração/Comercial & 140 & 12,8 \\
Controle da qualidade (1) & 168 & 15,4 \\
Garantia da qualidade (2) & 24 & 2,2 \\
Produção de virais (3) & 212 & 19,4 \\
Produçāo de reativos (4) & 60 & 5,5 \\
Produção de bacterianas & 98 & 9,0 \\
Processamento final (5) & 167 & 15,3 \\
Desenvolvimento tecnológico & 101 & 9,2 \\
Metrologia/Nalidação (2) & 45 & 4,1 \\
Engenharia/ Arquitetura/Manutenção & 77 & 7,1 \\
\hline Total & 1.092 & \\
\hline
\end{tabular}
(1) Inclui $30 \%$ da força de trabalho do biotério do Tecpar
(2) Năo formalizado no Butantan
(3) Inclui $70 \%$ da força de trabalho do biotério do Tecpar
(4) Inclui pessoal de soros do Butantan
(5) Não estruturado no Tecpar

Tabela 5 - Produtores de vacinas: pessoal de nível superior segundo qualificação profissional

\begin{tabular}{lrrrrc}
\hline Formação* & Grad. & Esp. & Mestr. & Dout. & $\%$ por formaçăo \\
\hline Farmácia/Bioquímica & 48 & 19 & 9 & 12 & $14,7 \%$ \\
Biologia & 130 & 37 & 37 & 24 & $39,9 \%$ \\
Engenharia Química & 18 & 4 & 8 & 3 & $5,5 \%$ \\
Engenharia/Arquitetura & 28 & 8 & 5 & 0 & $8,6 \%$ \\
Medicina Veterinária/Zootecnia & 23 & 6 & 6 & 6 & $7,1 \%$ \\
Química & 29 & 6 & 7 & 8 & $8,9 \%$ \\
Física & 1 & 0 & 0 & 0 & $0,3 \%$ \\
Administração & 22 & 7 & 6 & 0 & $6,7 \%$ \\
Economia & 5 & 3 & 0 & 0 & $1,5 \%$ \\
Comunicação Social & 3 & 1 & 1 & 0 & $0,9 \%$ \\
Pedagogia & 3 & 3 & 0 & 0 & $0,9 \%$ \\
Desenho Industrial & 2 & 0 & 1 & 1 & $0,6 \%$ \\
Medicina & 2 & 1 & 0 & 0 & $0,6 \%$ \\
Direito & 3 & 1 & 0 & 0 & $0,9 \%$ \\
Contabilidade & 2 & 0 & 0 & 0 & $0,6 \%$ \\
Matemática & 1 & 1 & 0 & 0 & $0,3 \%$ \\
Processamento de Dados & 6 & 5 & 0 & 0 & $1,8 \%$ \\
\hline Total & 326 & 102 & 80 & 54 & \\
\hline \% sobre total & - & $31,3 \%$ & $24,5 \%$ & $16,6 \%$ & \\
\hline
\end{tabular}

* Critério de inclusăo: curso completo ou cursando 
Tabela 6 - Produtores de vacinas: pessoal de nível superior segundo distribuição etária

\begin{tabular}{l|c|c|c}
\hline Faixa etária & Quantidade & \% sobre total & Idade média \\
\hline$>61$ & 9 & 2,7 & \\
$51-60$ & 51 & 15,3 & \\
$41-50$ & 109 & 32,7 & \\
$31-40$ & 107 & 32,1 & \multirow{2}{*}{40,8} \\
$21-30$ & 57 & 17,1 & \\
$<20$ & 0 & 0,0 & \\
\hline Total & 333 & & \\
\hline
\end{tabular}

Tabela 7 - Produtores de vacinas: pessoal de nível superior segundo tempo de serviço e treinamento*

\begin{tabular}{c|c|c|c|c}
\hline Tempo de serviço & Quantidade & \% sobre total & Treinamentos realizados* & Índex T/P \\
\hline $31->35$ & 6 & 1,8 & 0 & 0,0 \\
$26-30$ & 15 & 4,5 & 6 & 0,4 \\
$21-25$ & 41 & 12,3 & 34 & 0,8 \\
$16-20$ & 54 & 16,2 & 32 & 0,6 \\
$11-15$ & 30 & 9,0 & 24 & 0,8 \\
$06-10$ & 68 & 20,4 & 53 & 0,8 \\
$00-05$ & 119 & 35,7 & 58 & 0,5 \\
\hline Total & 333 & - & 207 & 0,6 \\
\hline
\end{tabular}

* Criterio de inclusāo: mínimo de $40 \mathrm{~h}$ por treinamento (ocorrido entre 1998 \& 2003)

Tempo de serviço - Consolidado - 11,5

Idade cronológica - Consolidada - 40,8

Idade de inicio $-29,3$

Tabela 8 - Produtores de vacinas: pessoal de nível superior segundo domínio de idioma(s)*

\begin{tabular}{l|c|c}
\hline \multicolumn{2}{l|}{ Idiomas } & \% sobre total \\
\hline Inglês & 150 & 45,0 \\
Espanhol & 44 & 13,2 \\
Francês & 25 & 7,5 \\
Italiano & 12 & 3,6 \\
Japonês & 5 & 1,5 \\
Alemão & 2 & 0,6 \\
Hebraico & 1 & 0,3 \\
Chinês & 1 & 0,3 \\
Javanês & 1 & 0,3 \\
\hline
\end{tabular}

* Critério de inclusão: ler + escrever + falar

Dominio de idiomas - consolidado - 333 pessoas

Obs:. Há pessoas habilitadas em mais de um idioma (máx. 4 idiomas). 
VACINAS, SOROS E IMUNIZAÇÕES NO BRASIL

Tabela 9 - Centros produtores de soros: plano de aquisição de equipamentos

\begin{tabular}{|c|c|c|c|c|c|c|c|c|}
\hline \multirow[b]{2}{*}{ Instituto } & \multirow[b]{2}{*}{ Produção } & \multicolumn{2}{|c|}{ Até 10 anos } & \multicolumn{2}{|c|}{ De 10 a 20 anos } & \multicolumn{2}{|c|}{$>20$ anos } & \multirow[b]{2}{*}{ Observações } \\
\hline & & $\%$ & $\begin{array}{l}\text { Idade } \\
\text { média }\end{array}$ & $\%$ & $\begin{array}{l}\text { Idade } \\
\text { média }\end{array}$ & $\%$ & $\begin{array}{l}\text { Idade } \\
\text { média }\end{array}$ & \\
\hline Instituto Vital Brazil & anti-soros & 46,66 & 6,00 & 53,33 & 14,57 & 0,00 & 0,00 & $\begin{array}{l}53,33 \% \text { - aquisição a curto prazo } \\
\text { Idade média = } 14,57 \\
46,66 \% \text { - aquisição a médio prazo } \\
\text { Idade média }=6,00\end{array}$ \\
\hline $\begin{array}{l}\text { Centro de Pesquisa e } \\
\text { Produção de Imunobiológicos } \\
\text { (CPPI) }\end{array}$ & anti-soros & 53,00 & 6,25 & 47,00 & 14,33 & 0,00 & 0,00 & $\begin{array}{l}47,00 \% \text { - aquisição a médio prazo } \\
\text { Idade média }=14,33 \\
53,00 \% \text { - aquisição a longo prazo } \\
\text { Idade média }=6,25\end{array}$ \\
\hline Instituto Butantan & anti-soros & 43,33 & 6,20 & 41,66 & 14,20 & 15,00 & 23,10 & $\begin{array}{l}15,00 \% \text { - aquisiçāo a curto prazo } \\
\text { Idade média }=23,10 \\
41,66 \% \text { - aquisição a médio prazo } \\
\text { Idade média }=14,20 \\
44,33 \% \text { - aquisição a longo prazo } \\
\text { Idade média }=6,20\end{array}$ \\
\hline Fundação Ezequiel Dias & anti-soros & 59,90 & 8,00 & 38,00 & 16,30 & - & - & $\begin{array}{l}38,00 \% \text { - aquisição a médio prazo } \\
\text { Idade média }=8,00 \\
59,9 \% \text { - aquisição a longo prazo } \\
\text { Idade média }=8,00\end{array}$ \\
\hline
\end{tabular}

Tabela 10 - Centros produtores de soros: quadro geral da força de trabalho - lotação de pessoal (total)

\begin{tabular}{l|c|c}
\hline Unidade operacional & Quantidade & $\%$ \\
\hline Direção/Administraçăo/Comercial & 50 & 15,4 \\
Controle da qualidade (1) & 64 & 19,8 \\
Garantia da qualidade (2) & 14 & 4,3 \\
Produção de reativos/soros & 111 & 34,3 \\
Desenvolvimento tecnológico & 52 & 16,0 \\
Engenharia/Arquitetura/Manutenção & 33 & 10,2 \\
\hline Total & 324 & \\
\hline
\end{tabular}


Tabela 11 - Centros produtores de soros: pessoal de nível superior segundo qualificação profissional

\begin{tabular}{l|c|c|c|c|c}
\hline Formaçäo* & Grad. & Espec. & Mestr. & Dout. & $\%$ por formação \\
\hline Farmácia/Bioquímica & 28 & 16 & 6 & 1 & $37,3 \%$ \\
Biologia & 20 & 6 & 5 & 1 & $26,7 \%$ \\
Engenharia Química & 2 & 0 & 0 & 0 & $2,7 \%$ \\
Engenharia/Arquitetura & 4 & 2 & 0 & 0 & $5,3 \%$ \\
Medicina Veterinária/Zootecnia & 15 & 4 & 4 & 2 & $20,0 \%$ \\
Química & 2 & 1 & 0 & 0 & $2,7 \%$ \\
Desenho Industrial & 1 & 1 & 0 & 0 & $1,3 \%$ \\
Medicina & 1 & 0 & 1 & 0 & $1,3 \%$ \\
Contabilidade & 1 & 1 & 0 & 0 & $1,3 \%$ \\
Processamento de Dados & 1 & 0 & 0 & 0 & $1,3 \%$ \\
\hline Total & 75 & 31 & 16 & 4 & \\
\hline \% sobre total & & 41,3 & 21,3 & 5,3 & \\
\hline * Critério de inclusäo: completo ou cursando &
\end{tabular}

Tabela 12 - Centros produtores de soros: pessoal de nível superior segundo distribuição etária

\begin{tabular}{c|c|c|c}
\hline Faixa etária & Quantidade & \% sobre total & Idade média \\
\hline$>61$ & 1 & 1,5 & \\
$51-60$ & 6 & 9,2 & \\
$41-50$ & 31 & 47,7 & \\
$31-40$ & 17 & 26,2 & \multirow{2}{*}{41,4} \\
$21-30$ & 11 & 16,9 & \\
$<20$ & 0 & 0,0 & \\
\cline { 1 - 3 } Total & 72 & & \\
\hline
\end{tabular}

Tabela 13 - Centros produtores de soros: tempo de serviço e treinamento*

\begin{tabular}{c|c|c|c|c}
\hline Faixa tempo de serviço & Quantidade & \% sobre total & Treinamentos realizados & Índex T/P \\
\hline $31->35$ & 0 & 0,0 & 0 & 0,0 \\
$26-30$ & 2 & 2,7 & 1 & 0,5 \\
$21-25$ & 9 & 12,0 & 27 & 3,0 \\
$16-20$ & 19 & 25,3 & 23 & 1,2 \\
$11-15$ & 12 & 16,0 & 18 & 1,5 \\
$06-10$ & 9 & 12,0 & 39 & 4,3 \\
$00-05$ & 24 & 32,0 & 49 & 2,0 \\
\hline Total & 75 & - & 157 & 2,1 \\
\hline
\end{tabular}

* Critério de inclusão: mín. $40 \mathrm{~h}$ por treinamento ocorrido entre 1998 e 2003

Tempo de serviço consolidado - 12,1

Idade cronologica consolidada - 41,4

Idade de inicio - 29,3 
VACINAS, SOROS E IMUNIZAÇÕES NO BRASIL

Tabela 14 - Centros produtores de soros: domínio de idioma(s)*

\begin{tabular}{l|c|c}
\hline \multicolumn{2}{l|}{ Idiomas } & \% sobre total \\
\hline Inglês & 21 & 28,0 \\
Espanhol & 3 & 4,0 \\
Francês & 4 & 5,3 \\
\hline
\end{tabular}

* Critério de inclusäo: ler + escrever + falar Domínio de idiomas: 75 pessoas

Obs. Há pessoas habilitadas em mais de um idioma (máx. 4 idiomas).

\section{Gráfico 1 - Vacinas produzidas - Instituto Butantan}

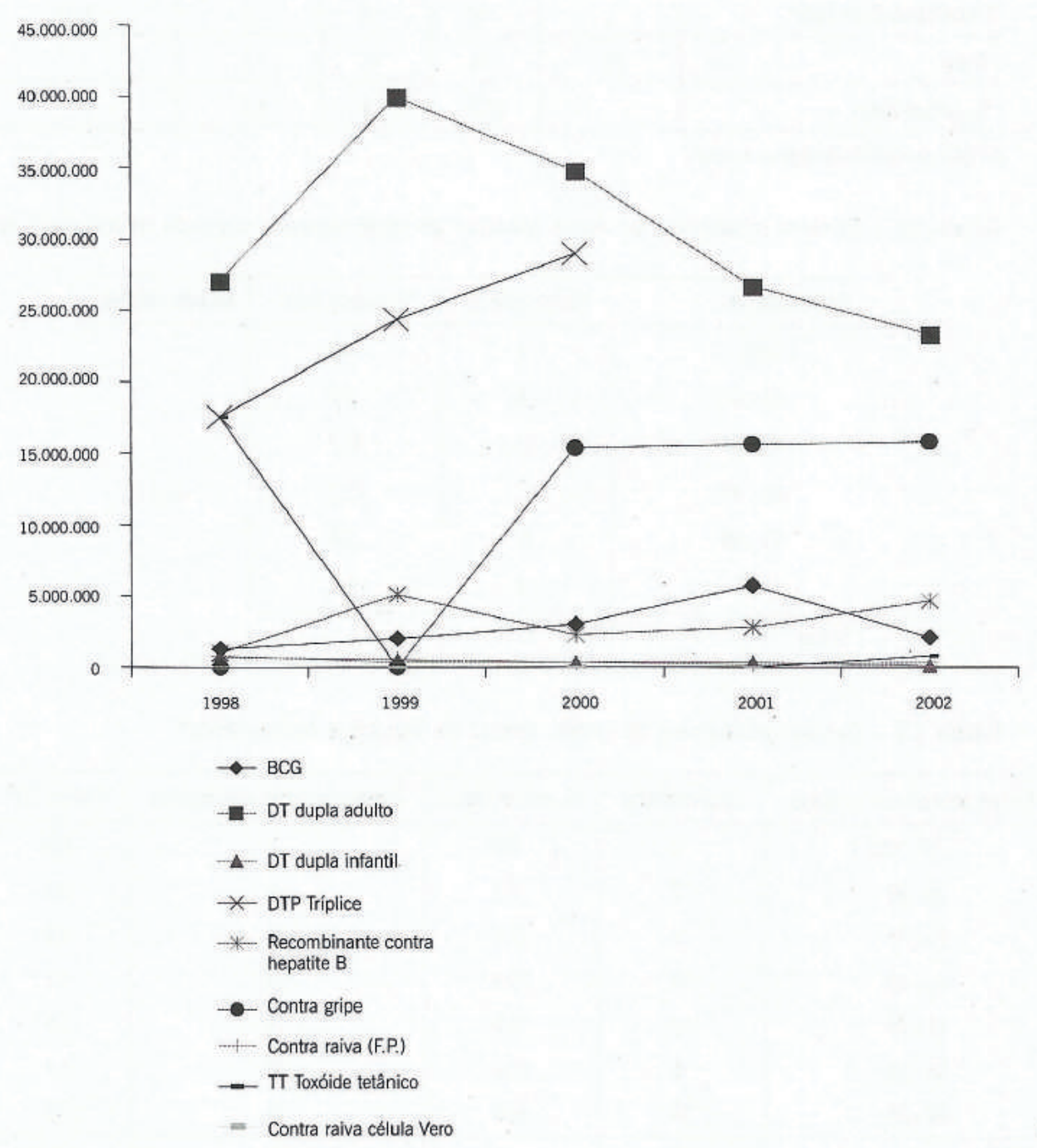


Gráfico 2 - Vacinas produzidas - Ataulpho de Paiva

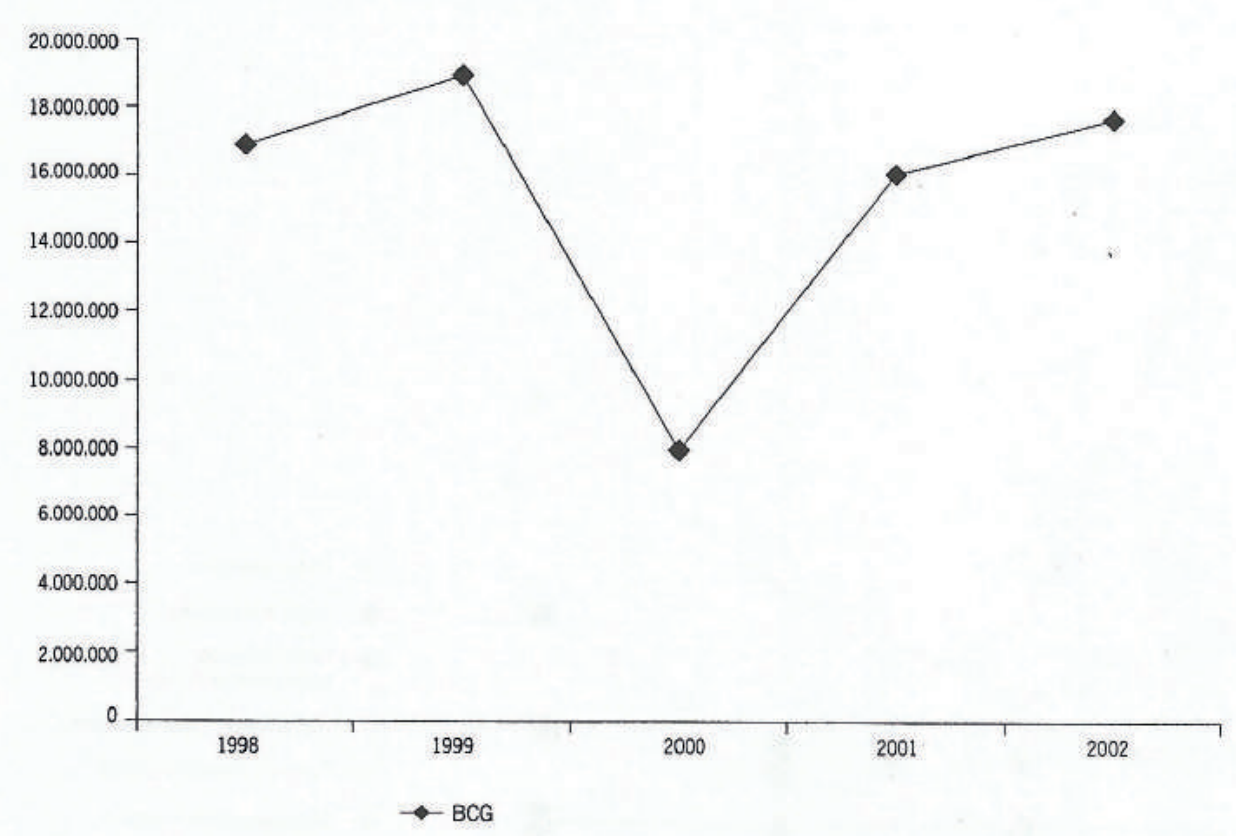

Gráfico 3 - Vacinas produzidas - Tecpar

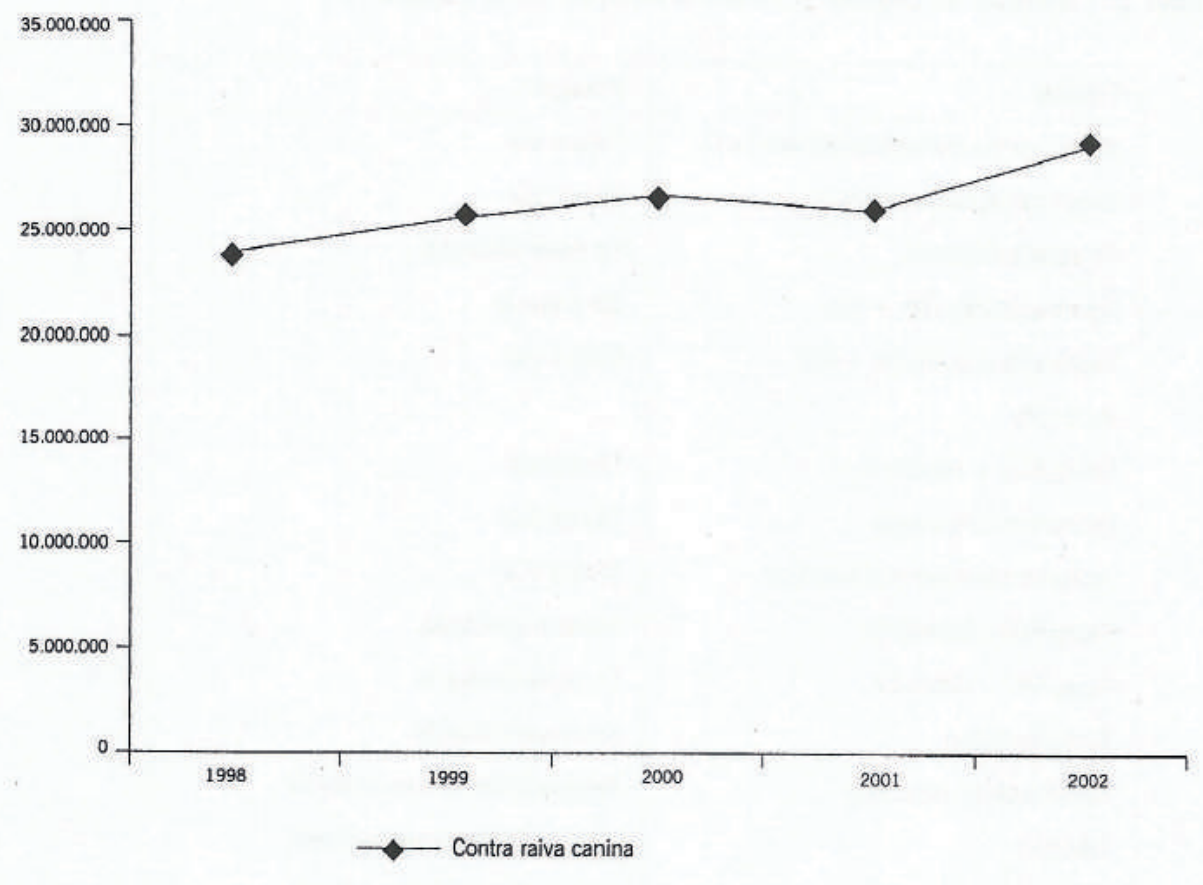


Gráfico 4 - Vacinas produzidas - Bio-Manguinhos

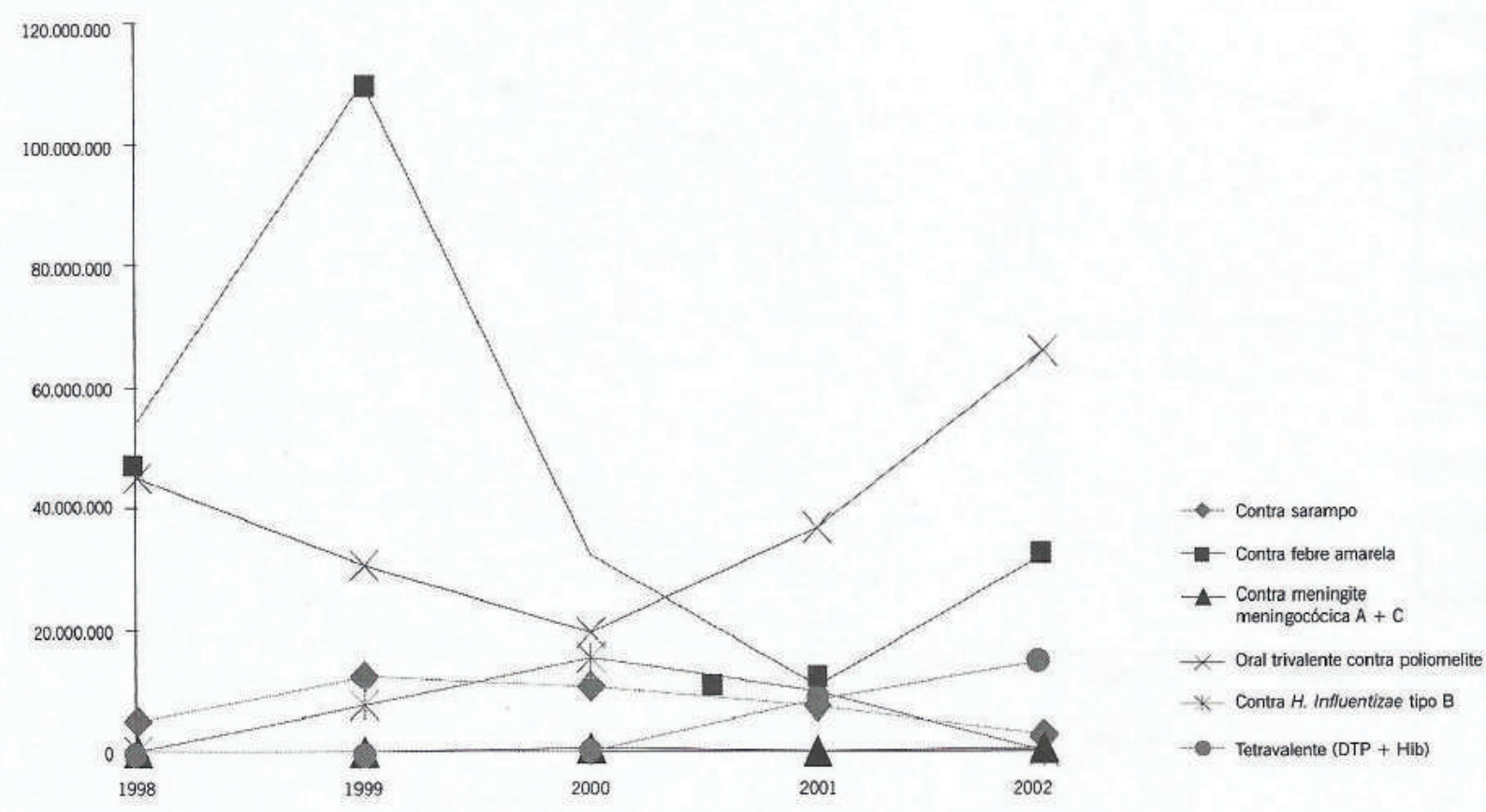

Quadro 1 - Relação de projetos e desenvolvimento e seu estágio

\begin{tabular}{|l|l|}
\hline Projeto & Estágio \\
\hline Vacinas contra meningite bacteriana (B, C) & Clinical trial \\
Vacina contra esquistossomose & Clinical trial \\
Vacina pneumocócica & Em desenvolvimento \\
Vacina quádrupla (Dtp + Hib) & Em produção \\
Vacina quíntupla (Dtp Hp + Hib) & Clinical trial \\
Vacina Hib & \\
Vacina BCG + Hepatite B & Clinical trial \\
Vacina pertússis acelular & Clinical trial \\
Vacina contra raiva em células Vero & Clinical trial \\
Vacina BCG recombinante & Em desenvolvimento \\
Vacina DTP - Vitamina A & Em desenvolvimento \\
Vacina leptospira & Em desenvolvimento \\
Vacina dupla e tríplice viral & Negociação para desenvolvimento \\
Rotavírus & Negociação para desenvolvimento \\
Leishmânia & Negociação para desenvolvimento \\
S. Pneumoniae celular & Negociaçāo para desenvolvimento \\
HPV & Negociaçāo para desenvolvimento \\
Vacina contra meningite conjugada & Em desenvolvimento \\
\hline
\end{tabular}


Quadro 2 - Relaçáo de projetos e desenvolvimento com parcerias

\begin{tabular}{|c|c|c|c|c|c|c|}
\hline Projetos & Adolfo Lutz & Bio-Manguinhos & Butantan & Tecpar & At. de Paiva & Outros \\
\hline Vacinas contra meningite bacteriana $(B, C)$ & $x$ & $x$ & $x$ & & & \\
\hline Vacina contra esquistossomose & & $x$ & $x$ & & & \\
\hline Vacina pneumocócica & & $x$ & $x$ & & & \\
\hline Vacina quádrupla (DTP + Hib) & & $x$ & $x$ & & & \\
\hline Vacina quíntupla (DTP Hp + Hib) & & $x$ & $x$ & & & \\
\hline Vacina Hib & & $x$ & & $x$ & & \\
\hline Vacina BCG + hepatite B & & & $x$ & & & $x$ \\
\hline Vacina pertússis acelular & & & $x$ & & & \\
\hline Vacina contra raiva em células Vero & & & $x$ & & & $x$ \\
\hline Vacina $\mathrm{BCG}$ recombinante & & $x$ & $x$ & & & $x$ \\
\hline Vacina DTP - Vitamina A & & & $x$ & & & \\
\hline Vacina leptospira & & & $x$ & & & $x$ \\
\hline Vacina dupla e tríplice viral & & $x$ & & & & \\
\hline Rotavírus & & $x$ & $x$ & & & \\
\hline Leishmânia & & $x$ & $x$ & & & \\
\hline S. pneumoniae celular & & & $x$ & & & \\
\hline HPV & & & $x$ & & & \\
\hline Vacina contra meningite conjugada & & & $x$ & & & \\
\hline
\end{tabular}




\section{Desenvolvimento de Vacinas no Brasil: uma análise da potencialidade da P\&D e das estratégias de inovação}

José Vítor Bomtempo

Rosiceli Barreto G. Baetas

\section{INTRODUÇĀO}

Este trabalho tem como objetivo avaliar a capacitação para o desenvolvimento de vacinas no Brasil e identificar os obstáculos e deficiências que podem dificultar ou impedir a concretização das inovaçôes. Foram identificados mais de sessenta grupos de pesquisa e desenvolvimento (P\&D) em vacinas atuantes no país, 51 dos quais responderam a um questionário e forneceram dados para o estudo. Do total, $20 \%$ estão localizados nas unidades produtoras de vacinas e $80 \%$ em universidades e centros de pesquisa. 0 número de grupos voltados para as etapas básicas do desenvolvimento é consideravelmente superior ao daqueles atuando nas etapas finais; nestes, os grupos envolvidos são menos numerosos e os níveis médios de capacitação são mais baixos, em particular nas etapas de scale up e testes clínicos. Quarenta e três grupos declaram ter algum nível de capacitação em pesquisa básica. Essa capacitação é avaliada pelos próprios grupos como de nível elevado. Na etapa de pré-desenvolvimento, 41 grupos declaram possuir algum nível de competência. O nível médio de competência situa-se um pouco abaixo em relação ao da pesquisa básica. O número de grupos que reconhecem ter algum nível de expertise no desenvolvimento de vacinas candidatas e estudos pré-clínicos é de 37 entre os 51 respondentes. Apenas 25 grupos registram algum nível de competência na etapa de scale up, produção de lotes-piloto e aprovação para estudos clínicos. Somente cinco se 
consideram em nível alto e muito alto em todas as atividades dessa etapa. Em estudos clínicos, foram identificados 26 grupos que se declaram com algum nível de expertise. Poucos (entre 6 e 10) se consideram entre os níveis alto ou muito alto de competência.

No que se refere à atuação dos produtores de vacinas, são vistos como pontos positivos o reconhecimento da importância da inovação e a preocupação crescente com a capacitação tecnológica. Algumas limitações, porém, ainda entravam a capacidade efetiva de inovação dos produtores. O volume de recursos disponíveis para investimento em $P \& D$ parece muito pequeno se comparado com as cifras internacionais habitualmente mencionadas. Além disso, existem limitações de infra-estrutura dedicada para o desenvolvimento, em particular para a etapa de scale up e desenvolvimento dos processos de produção em escala-piloto e comercial. Deve ser mencionada, ainda, a necessidade de contar com uma formação multidisciplinar e em nível de doutorado nas equipes de $P \& D$, ressaltando-se, em particular, a importância de incorporar uma engenharia de alto nível nos processos de desenvolvimento. Apesar dos esforços e progressos dos produtores, este estudo constata que falta talvez, ainda, um passo para incorporar, de forma clara e explícita, uma estratégia de inovação bem-estruturada e difundida na gestão das unidades.

A capacitação em pesquisa básica identificada aqui corre o risco de se converter em um número pequeno de inovações, risco que parece real se considerarmos a falta de infra-estrutura para completar as demais etapas do desenvolvimento, em particular para as etapas de scale up e estudos clínicos. Em adição, parecem faltar condiçōes para canalizar esses desenvolvimentos para uma possível concretização no mercado. A falta de coordenação dos projetos, com ênfase na inovação como finalidade, é o principal problema a ser atacado para transformar a nossa 'potencialidade para inovar' em inovações efetivas. Com efeito, muitos projetos de pesquisa não parecem estar inseridos em redes de cooperação ou sob uma forma de coordenação que lhes dê rumo no que se refere à inovação final.

Esta análise da potencialidade para o desenvolvimento de vacinas no Brasil toma como ponto de partida a idéia de que o objetivo a ser alcançado pelos atores envolvidos é explicitamente a inovação em vacinas.

Esse objetivo inclui, sem dúvida, as inovaçōes de processo realizadas pelos produtores de vacinas para aprimoramento e atualização tecnológica de suas linhas de produçăo. O foco do estudo, entretanto, está nas inovações de produto, isto é, no desenvolvimento e comercialização de novas vacinas. Naturalmente, os conhecimentos acumulados e as competências adquiridas na busca de novas vacinas podem conduzir a inovações em outras áreas da biotecnologia. Nossa análise, porém, privilegiará as vacinas como produto-alvo.

Dentro dos objetivos amplos do Projeto Inovação em Saúde, as perguntas básicas a que este trabalho procura responder são: existe capacitação no país para o desenvolvimento de vacinas? Que obstáculos e deficiências podem dificultar ou impedir a concretização dessas inovações? 
Para orientar a busca dessas respostas, os objetivos são, especificamente, os seguintes: identificar grupos atuantes em $P \& D$ em vacinas no Brasil; avaliar o estágio das capacitações desses grupos, tendo em vista a inovação em vacinas; identificar e analisar os gargalos que deveriam ser considerados nas formulações de estratégias de inovação no Brasil.

O estudo está organizado em cinco seções. Além da introdução, apresenta-se a metodologia adotada na identificação dos grupos de $P \& D$ em vacinas e na coleta das informações. Descrevem-se as etapas do desenvolvimento de uma vacina, segundo o roteiro que serviu de referência para a análise. Apresentam-se os resultados das pesquisas e entrevistas feitas com os grupos de P\&D e com os produtores. São também apresentadas e discutidas as suas localizações; as relaçōes de parcerias e mecanismos de coordenação; os recursos aplicados e fontes de financiamento; o nível de competência nas etapas de desenvolvimento de uma vacina e as competências para inovar dos produtores. Com base em alguns casos de desenvolvimento em curso, são levantadas algumas dimensões críticas do processo de inovação em vacinas. Na penúltima seção, procuram-se extrair das análises feitas os fatores críticos de sucesso no desenvolvimento de vacinas no país. Finalmente, na última seção, são apresentadas as conclusões e recomenđações.

\section{METODOLOGIA}

A metodologia utilizada para realização da investigação proposta apoiou-se na identificação dos laboratórios e pesquisadores envolvidos de alguma forma com a P\&D em vacinas no Brasil. Foram enviados questionários a todos os atores identificados, e 51 grupos responderam. Alguns grupos selecionados foram entrevistados.

Utilizaram-se dois tipos de questionários. Para os grupos de P\&D, laboratórios e pesquisadores, foi enviado um questionário baseado numa caracterização das etapas de desenvolvimento de uma vacina. O objetivo foi conhecer os projetos desenvolvidos pelo grupo e, principalmente, o seu nível de capacitação em cada uma das atividades do desenvolvimento. Já os produtores de vacinas foram entrevistados e receberam um segundo tipo de questionário baseado no perfil ideal de uma organização inovadora. 0 objetivo foi a avaliação das competências para inovar dos produtores.

\section{Identificação dos grupos de P\&D}

A identificação dos grupos de P\&D partiu do Diretório Lattes de Pesquisadores e Grupos de Pesquisa, por meio de uma busca em áreas de atuaçâo de interesse do estudo: vacinas e/ ou doenças de interesse da saúde pública brasileira. A lista inicial obtida foi analisada, excluindo-se os grupos que foram julgados fora do escopo do estudo. Em adição, foram consultados sites e revistas da Fapesp, Faperj e da Fiocruz; sites dos produtores de vacinås (para informaçōes gerais) e sites das incubadoras de empresas de biotecnologia.

O objetivo foi identificar todos os grupos atuantes e seus contatos, independentemente de sua localização: universidades, centros produtores de vacinas, centros de pesquisa ou empresas de biotecnologia. A lista foi gerada de forma dinâmica. Cada entrevis- 
ta realizada ou questionário enviado continha sempre a pergunta sobre outros grupos ou laboratórios atuantes em desenvolvimento de vacinas no Brasil que os pesquisados julgavam relevantes.

\section{Questionário 1: caracterização das etapas de desenvolvimento de uma vacina}

Partiu-se de um roteiro de base, elaborado por meio de consultas a especialistas, em que foram listadas as principais etapas que compõem o desenvolvimento de uma vacina, desde as fases iniciais de pesquisa básica até o registro e comercialização da vacina.

o questionário teve como objetivo tanto conhecer os projetos em desenvolvimento quanto mapear, mediante uma auto-avaliação, o nível de competência dos grupos de $P \& D$ em cada uma das etapas do desenvolvimento de uma vacina. A idéia central foi caracterizar os diferenciais de expertise percebidos pelos próprios grupos nessas etapas, bem como identificar a capacitação do grupo em cada uma dessas fases e as principais pesquisas em curso.

Foi solicitado a cada grupo que identificasse as atividades em que atua e avaliasse a sua competência em cada uma delas, segundo cinco níveis: 1) incipiente, 2) baixa, 3) média, 4) alta e 5) muito alta.

Além da auto-avaliação dos níveis de competência, foram solicitadas aos grupos as seguintes informaçôes: principais resultados já alcançados, exceto publicaçōes; perspectivas de resultados para os próximos cinco anos, exceto publicações; parcerias com outros grupos de pesquisa e produtores de vacinas; fontes de financiamento e montante gasto nos últimos cinco anos.

Cada grupo listou ainda, conforme o seu entendimento: os fatores críticos de sucesso em $P \& D$ de vacinas; as principais dificuldades técnicas e não técnicas do grupo; outros grupos de referência no país.

Como já mencionado, as indicações de outros grupos de referência no Brasil permitiram que a lista de grupos fosse revista e complementada.

\section{Questionário 2: competências para inovar dos produtores de vacinas}

Partiu-se de um conjunto amplo de competências e habilidades que, de acordo com a literatura atual em gestão da inovação, as organizações inovadoras devem deter. Esse questionário, cuja elaboraçăo valeu-se dessa noção de competências para inovar, foi respondido pelos produtores e teve como objetivo avaliar as competências gerais do produtor, segundo também uma auto-avaliação. O questionário foi respondido pelos diretores ou gerentes da área de $P \& D$ das instituições emestudo.

Nas visitas aos produtores, foram levantadas informações quanto aos seguintes aspectos: histórico, produção e entregas/vendas de vacinas, vacinas em desenvolvimento, vacinas certificadas, vacinas em transferência de tecnologia, perspectivas de incorporação de novos produtos via acordos de tecnologia, principais parcerias, principais dificuldades. 


\section{Entrevistas}

Foram visitados e entrevistados os seguintes produtores de vacinas: Instituto BioManguinhos, Instituto Butantan, Fundação Ataulpho de Paiva (FAP) e Instituto Tecnológico do Paraná (Tecpar). As entrevistas foram realizadas com os diretores e/ou gerentes de $P \& D$ dessas instituições.

Entrevistaram-se, também, alguns grupos de $P \& D$ em vacinas localizados em universidades, centros de pesquisa e empresas. $O$ objetivo foi aprofundar a compreensão do processo de desenvolvimento e identificar os fatores críticos para o desenvolvimento de vacinas no país. Os grupos entrevistados foram escolhidos segundo três critérios principais: indicações dos próprios pesquisadores, experiência acumulada com o desenvolvimento e resultados já alcançados.

\section{ETAPAS DO DESENVOLVIMENTO DE UMA VACINA}

O desenvolvimento de uma vacina foi classificado como compreendendo cinco macroetapas principais:

- Etapa 1: pesquisa básica

- Etapa 2: pré-desenvolvimento

- Etapa 3: desenvolvimento da vacina candidata e estudos pré-clínicos

- Etapa 4: scale up, produção de lotes-piloto e aprovação para estudos clínicos

- Etapa 5: estudos clínicos - segurança, imunogenicidade e eficácia

Cada uma dessas etapas, por sua vez, é subdividida em subetapas, como descrito resumidamente, a seguir. Deve-se lembrar, contudo, que as fronteiras são fluidas e algumas atividades muitas vezes se sobrepõem. Ainda assim, as etapas consideradas permitem uma visualização do esforço científico e tecnológico que representa o desenvolvimento de uma nova vacina. Com base nesse roteiro, os pesquisadores puderam situar as suas áreas de atuação e o nível de competência que julgam deter.

\section{Etapa 1: pesquisa básica}

- entendimento da doença;

- entendimento do agente etiológico da doença;

- entendimento das interações complexas entre o patógeno e o homem;

- propagação do agente etiológico em quantidade e em condições apropriadas.

O entendimento das bases da imunidade depende tanto do entendimento dos agentes da doença, como também da resposta imune do homem. O entendimento da patogenicidade e do agente etiológico, bem como das interações do patógeno com o homem e os meios de sua propagação, são atividades definidas aqui como pesquisa básica. O conhecimento dessa interação é importante na seleção de antígenos com potencial vacinal. Nessa etapa, têm atualmente presença crescente os estudos sobre genoma. 


\section{Etapa 2: pré-desenvolvimento}

- identificação e análise do(s) gene(s) ou antígeno(s) protetor(es);

- atenuação, modificação genética, inativação ou obtenção de subunidade do agente etiológico;

- caracterização in vitro de organismos atenuados, modificados ou inativados e caracterização de subunidades;

- estabilidade e imunogenicidade de patógenos atenuados, modificados, inativados ou de subunidades do patógeno.

Denominamos pré-desenvolvimento as atividades relacionadas à identificação, análise dos genes ou antígenos protetores, sua caracterização e estabelecimento de condições para sua atenuação, modificação ou inativação, bem como análise de sua estabilidade e imunogenicidade.

A habilidade de seqüenciar o genoma de microorganismos é uma nova ferramenta para identificar quais proteínas ou subunidades de um patógeno podem ser utilizadas como antígenos. A atenuação molecular, a modificação genética, a utilização de subunidades, entre outras, são abordagens utilizadas atualmente em substituição às antigas técnicas de atenuação e inativação.

As atividades de pesquisa básica e pré-desenvolvimento são essenciais para o desenvolvimento de vacinas, mas não estão relacionadas ainda a uma vacina candidata específica.

\section{Etapa 3: desenvolvimento da vacina candidata e estudos pré-clínicos}

- produção de lotes experimentais vacinais para estudos pré-clínicos, avaliação de estabilidade e/ou critérios de pureza;

- seleção de adjuvantes;

- estudos de formulação;

- estudos de apresentação (líquida, liofilizada, monodose ou multidoses);

- estudos de inocuidade em animais;

- estudos de imunogenicidade em animais.

No desenvolvimento da vacina candidata são avaliadas as possibilidades de apresentação do produto e sua formulação, assim como a seleção de ađjuvantes. Estas atividades são conduzidas também em paralelo ao desenvolvimento e seleção de antígenos candidatos (etapa anterior).

Os estudos pré-clínicos são pesquisas laboratoriais de vacinas experimentais que têm como objetivo avaliar a inocuidade, a reatogenicidade, a toxicidade e a imunogenicidade da vacina candidata, para testes posteriores em seres humanos (testes clínicos). Para isso, utilizam-se cobaias. A disponibilidade de um modelo animal confiável é extremamente útil e a sua falta é um complicador nas pesquisas. Esses estudos com vacinas candidatas devem ser conduzidos segundo as Boas Práticas Laboratoriais (BPL). 


\section{Etapa 4: scale up, produção de lotes-piloto e aprovação para estudos clínicos}

- scale-up (demonstração de consistência);

- estabelecimento de lote-semente;

- produção de lotes-piloto e aprovação para estudos clínicos;

- estabelecimento de controles físico-químicos e biológicos para uso em seres humanos;

- estabelecimento de limites desses controles para o produto desenvolvido.

Nessa etapa, o desenvolvimento incorpora uma dimensão industrial que exige a atuação conjunta dos pesquisadores que conduziram as etapas anteriores e de engenheiros/doutores com capacitação em desenvolvimento de processos biotecnológicos. Na operação industrial, os biorreatores e a purificação são usualmente componentes centrais. Nas atividades de aumento de escala de produção (bancada para piloto e piloto para industrial), os processos biotecnológicos são analisados em termos de fatores de engenharia. Os processos de separação e purificação (downstream process) são também considerados nessa fase.

A pesquisa de processos e de métodos analíticos para a produção tem um papel relevante. Os procedimentos de controle estabelecidos ao longo do desenvolvimento-incluindo os limites de aprovação/reprovação definidos conforme os testes de toxicidade (inocuidade) e parâmetros de produção - são validados, documentados e aplicados ao produto desenvolvido.

Os estudos em escala-piloto vão permitir uma análise da viabilidade comercial do processo, tendo em vista a produção em escala industrial. A maioria dos processos envolve interações complexas de fatores biológicos, químicos e físicos, o que demanda uma visão sistêmica de desenvolvimento de produto. Além disso, as escolhas realizadas nessa etapa devem considerar as condiçōes futuras de produção em escala comercial, já que modificações posteriores de processo podem invalidar os testes clínicos realizados com a produção-piloto.

O estabelecimento do lote-semente garantirá a reprodutibilidade dos lotes vacinais. Os requisitos de Boas Práticas de Fabricação (BPF) correntes devem ser preenchidos na produção dos lotes que serão utilizados nos testes clínicos.

\section{Etapa 5: estudos clínicos - segurança, imunogenicidade e eficácia}

Os estudos clínicos contemplam quatro etapas:

- Fase 1 - segurança

Esta fase de pesquisa clínica tem como objetivo determinar a segurança da vacina. Usualmente, trabalha-se com pequeno número de voluntários e se expande à medida que os estudos văo apontando para a segurança da vacina. Nesta fase também se avalia preliminarmente a imunogenicidade.

- Fase 2 -segurança e imunogenicidade

São estudos mais extensos, em maior número de voluntários e às vezes em grupos mais diversificados. Nesta etapa, o objetivo é verificar se a vacina é segura e imunogêni$\mathrm{ca}$, sendo esta avaliada quanto à habilidade de suscitar resposta imune e por seu potencial de prevenir a doença. 
- Fase 3-segurança, imunogenicidade e eficácia

São estudos em larga escala, freqüentemente com milhares de voluntários, para confirmar que a vacina previne a doença. Em geral, os estudos de eficácia são realizados em uma população residente em uma determinada área endêmica.

- Fase 4-pós-comercialização

Nesta fase, os estudos, ou ensaios clínicos, visam ao acompanhamento não só da segurança, como também da imunogenicidade e eficácia da vacina já registrada e comercializada. São atividades complexas, pois trata-se de experimentações em seres humanos, envolvendo, conforme a fase, até milhares de pessoas que devem ser vacinadas e controladas de modo rigoroso.

\section{INOVAÇ̃̃O EM VACINAS NO BRASIL: GRUPOS DE P\&D E SUAS COMPETÊNCIAS}

Foram identificados cerca de sessenta grupos envolvidos em algum grau com a pesquisa e o desenvolvimento em vacinas no Brasil; entretanto, não são necessariamente sessenta projetos de novas vacinas. Incluem-se também grupos que detêm competências em fases específicas do desenvolvimento, como, por exemplo, scale up e estudos clínicos.

Os resultados da pesquisa junto a esses grupos refletem, portanto, o nível de competência existente. Esta é a base sobre a qual se apóiam os atuais desenvolvimentos, e corresponderia à potencialidade para o desenvolvimento de novas vacinas no Brasil.

Do total de grupos identificados, obtiveram-se 51 respostas, e é com base nestas que as análises que seguem se apóiam.

\section{Localização}

Do ponto de vista da instituição a que estão filiados e do local onde atuam, os 51 grupos respondentes se distribuem segundo a Tabela 1.

Tabela 1 - Localização dos grupos de P\&D em vacinas no Brasil

\begin{tabular}{l|c|c}
\hline Localização dos grupos & TOTAL & $\%$ \\
\hline Nos centros produtores de vacinas & 10 & 20 \\
\hline Butantan & 5 & \\
Bio-Manguinhos & 4 & \\
Tecpar (IBMP)* & 1 & \\
\hline Nas universidades e centros de pesquisa & 41 & 80 \\
\hline Fiocruz & 13 & \\
Instituto Evandro Chagas & 3 & \\
Universidades e outros centros de P\&D** & 25 & \\
\hline TOTAL & 51 & 100 \\
\hline
\end{tabular}

* Parceria Tecpar/Fiocruz

** Incluia ampresa BIOMM 
Vale notar que a Fiocruz concentra o maior número de grupos, totalizando 17 atuantes em vacinas, quando considerados conjuntamente os grupos localizados em BioManguinhos e nas demais unidades de pesquisa da instituição.

No que se refere aos produtores, o Instituto Butantan reúne, em todas as suas áreas de atuação, 18 doutores em $P \& D$ e o Instituto Bio-Manguinhos conta com 15. No Tecpar, não existem doutores em $P \& D$, a não ser os quatro que compõem os quadros do Instituto de Biologia Molecular do Paraná (IBMP), uma parceria Tecpar/Fiocruz, localizado no campus do Tecpar. A FAP não tem doutores atuando em grupos de $P \& D$ dentro da instituição.

O ponto principal que surge da localização dos grupos refere-se à participaçẫo expressiva daqueles que não estão sob a coordenação direta dos produtores de vacinas $(80 \%)$. Isso sugere que, do ponto de vista dos produtores públicos de vacinas, existe um trabalho importante de coordenação a ser feito, tendo em vista a possível incorporação desses desenvolvimentos em suas estratégias de inovação.

Quanto à inovação em vacinas, esse resultado sugere que os pesquisadores deveriam contar com outros caminhos para transformar suas pesquisas em inovações, além da produção pública já instalada. Essa concretização poderia não só conđuzir, em alguns casos, a inovações em vacinas, mas também, de modo mais amplo, poderia gerar oportunidades em biotecnologia. Nessa linha, do ponto de vista da capacidade de inovação tecnológica do país, além da busca de outros espaços, como empresas privadas, a via da criação de empresas de base tecnológica não pode ser esquecida como perspectiva.

\section{Relações de cooperação e mecanismos de coordenação}

\section{Parcerias e relações de cooperação}

A localização dos grupos de pesquisa e desenvolvimento conduz-nos naturalmente a examinar os laços de cooperação que esses grupos mantêm com os produtores e com outros grupos de pesquisa, no país ou no exterior.

Entre os 41 grupos localizados em universidades e centros de pesquisa, todos os grupos da Fundação Oswaldo Cruz, com exceção de um, mencionam parcerias com os produtores de vacinas. Todavia, o mesmo não se reflete nas universidades e demais centros de pesquisa, pois com exceção de quatro grupos, os demais (23) não informam a existência de parceria com os produtores de vacinas. Tal fato não sugere efetivamente a inexistência de alguma parceria, mas aponta que, mesmo havendo algum relacionamento com os produtores, as eventuais parcerias existentes não possuem relevância para esses grupos.

A integração dos 51 grupos com outros grupos de pesquisa no Brasil se mostra mais homogênea do que a integração com produtores: $65 \%$ dos grupos informam que possuem parcerias com outros grupos no país, conforme a Tabela 2. 
Tabela 2 - Parcerias dos grupos de P\&D

\begin{tabular}{c|c|c|c|c|c}
\hline \multicolumn{2}{c|}{ Com grupos de pesquisa } & \multicolumn{2}{c|}{ Com produtores de vacinas } & \multirow{2}{*}{$\begin{array}{c}\text { Sem } \\
\text { parceria }\end{array}$} & \multirow{2}{*}{ NR** } \\
\cline { 1 - 3 } No Brasil & Exterior & No Brasil & Exterior & 3 & 1 \\
\hline 33 & 13 & $6 *$ & 4 & $6 \%$ & $2 \%$ \\
\hline $65 \%$ & $25 \%$ & $21 \%$ & $8 \%$ & $6 \%$ \\
\hline
\end{tabular}

* Exclui os grupos localizados nos produtores e na Fiocruz

** NR (näo respondeu)

Quanto às parcerias com grupos de pesquisa no exterior, $25 \%$ dos respondentes informam que possuem - EUA, Reino Unido, França, Suíça, Argentina, Espanha, Cuba e Colômbia. Esse resultado sugere um nível de interação internacional pouco expressivo e que poderia ser mais desenvolvido. Outro dado que chama a atenção é que $8 \%$ informam possuir parceria com produtores de outros países (Corixa, Chiron e GlaxoSmithKline).

Registra-se ainda um pequeno número de parcerias com outros atores, tais como: BIOMM, Ministério da Saúde (MS)/Centro Nacional de Epidemiologia (Cenepi). Entre os respondentes, três grupos declaram não ter qualquer relação de cooperação.

\section{Mecanismos de coordenação}

No que se refere aos mecanismos e instrumentos de coordenação, o estudo pôde identificar algumas iniciativas que merecem ser analisadas.

Uma análise realizada diretamente na Fiocruz, independentemente das informaçōes fornecidas pelos grupos respondentes, mostra dois tipos de parcerias entre os grupos da própria instituição: as cartas-compromisso e o Programa de Desenvolvimento Tecnológico em Insumos para a Saúde (PDTIS).

As cartas-compromisso são estabelecidas entre Bio-Manguinhos e grupos da Fiocruz. A coordenação é feita por Bio-Manguinhos, com recursos próprios, o que confere a essa instituição uma oportunidade de indução das pesquisas em outros centros da Fiocruz. O mecanismo foi criado há cerca de três anos. Atualmente existe um acordo firmado e 11 encontram-se em renovação e/ou contratação.

O PDTIS é coordenado pela vice-presidência de pesquisa da Fiocruz e procura estabelecer redes entre projetos de modo a acompanhar e apoiar a evolução dos mesmos e explorar a sinergia entre eles. Duas redes são de interesse para este estudo: Rede de Vacinas Recombinantes e de DNA e Rede de Proteoma. Na primeira, foram estruturadas oito sub-redes, de acordo com os temas: malária, dengue, hepatite $\mathrm{C}$, leishmaniose, leptospirose, esquistossomose, tuberculose e adjuvantes.

No que se refere ao Instituto Butantan, a postura adotada é a de que cada grupo deve ter a iniciativa de submeter os seus projetos aos órgãos de fomento de forma independente. Defende-se esse mecanismo com base no argumento de que os projetos serão avaliados por consultores independentes, o que asseguraria tanto a independência da pesquisa quanto a qualidade das propostas de pesquisa. Essa validação dos projetos 
é por certo positiva, mas pode-se contra-argumentar que esse mecanismo propicia um nível de coordenação dos projetos baixo. Prevaleceria de certa forma a lógica dos financiadores, impedindo que o Instituto Butantan pratique uma estratégia de inovação explícita e fortemente inserida na organização.

Quanto aos grupos localizados em Bio-Manguinhos, são em geral financiados diretamente pela própria instituição, sem captação expressiva de recursos dos agentes financiadores por meio de projetos de iniciativa própria dos grupos. Bio-Manguinhos manifesta a necessidade de aumentar o grau de coordenação dos projetos em andamento com a criação recente de um grupo de gestão de projetos.

Fora do âmbito da Fiocruz e dos produtores de vacinas, deve ser mencionada a Rede Brasileira de Pesquisa em Tuberculose, formada por 47 institutos de pesquisa do Brasil, em torno da tuberculose. Registram-se ainda algumas redes voltadas para genomas e proteomas, como as da Fapesp, Faperj e do Ministério de Ciência e Tecnologia (MCT), que eventualmente podem envolver os grupos de $P Q D$ em vacinas.

A questão das parcerias e interaçōes dos grupos merece ser examinada no contexto da dinâmica das inovações em biotecnologia. Este tem sido o campo por excelência das relações đe cooperação, envolvendo grandes empresas, empresas pequenas e médias de base tecnológica, universidades e outros atores, numa lógica de rede que tem-se mostrado essencial para o aprendizado e o desenvolvimento das inovações. Alguns estudiosos dessa forma de organização em rede sugerem que o 'aprender a cooperar' está no centro do próprio processo de inovação em biotecnologia. Visto por essa ótica, o nível global das relaçōes estabelecidas pelos grupos envolvidos em $P \& D$ em vacinas no Brasil, segundo as respostas obtidas pela pesquisa, parece rudimentar.

\section{Fontes de financiamento e recursos aplicados}

\section{Fontes de financiamento}

Na identificação de suas fontes de financiamento, os grupos da Fiocruz, sejam aqueles localizados no produtor ou nos demais centros de $P \& D$ da instituição, apontam na maioria das vezes a própria Fiocruz, Bio-Manguinhos ou ainda o MS como financiadores das pesquisas, além de outras fontes. Os grupos do Butantan apontam em sua maioria a Fapesp como financiadora.

Um dado que chama a atenção é o número de citações de instituições internacionais, principalmente a Organização Mundial da Saúde (OMS) e o National Institute of Health (NIH), nos Estados Unidos da América. Dos treze grupos que informaram que têm parceria externa, cinco também possuem financiamento externo (NIH ou OMS). Pode-se perguntar, no caso dos financiamentos obtidos no exterior, principalmente no caso do NIH, se existiriam e quais seriam os mecanismos de indução dos projetos a serem financiados.

Na Tabela 3, são apresentadas as principais instituições financiadoras apontadas. $\mathrm{O}$ $\mathrm{MCT}$, principalmente por meio do $\mathrm{CNPq}$, foi citado por quase $50 \%$ dos grupos. 
Tabela 3 - Fontes de financiamento dos grupos de P\&D em vacinas

\begin{tabular}{l|c|c}
\hline Fonte de financiamento & N. de citaçöes da fonte & \% grupos que citou a fonte \\
\hline MCT/CNPqe Finep & 24 & $48 \%$ \\
MS e Fiocruz & 16 & $32 \%$ \\
Fapesp & 14 & $28 \%$ \\
Faperj & 8 & $16 \%$ \\
Fapemig & 4 & $8 \%$ \\
OMS & 8 & $16 \%$ \\
NIH & 6 & $12 \%$ \\
\hline
\end{tabular}

No que se refere ao volume de recursos obtidos nos últimos cinco anos, os valores informados estão fortemente concentrados em poucos grupos: cinco grupos informam ter recebido em torno de 1 milhão de dólares. Na Tabela 4, apresenta-se a distribuição dos recursos recebidos pelos grupos respondentes em termos das faixas de financiamento obtido.

Apesar de os gastos com a manutenção da equipe, como salários e infra-estrutura em geral, não estarem considerados na grande maioria das respostas, ainda assim os volumes informados são significativamente baixos ( $48 \%$ informam valores inferiores a 500 mil dólares em cinco anos).

Tabela 4 - Recursos recebidos - faixas de financiamento nos últimos cinco anos

\begin{tabular}{l|c|c}
\hline \multicolumn{1}{c|}{$\begin{array}{c}\text { Financiamento nos últimos } 5 \text { anos } \\
\text { US }\end{array}$} & N. de grupos & $\%$ \\
\hline Entre 1 e 1,4 milhão & 5 & $10 \%$ \\
Entre 500 mil e 1 milhāo & 2 & $4 \%$ \\
Entre 200 mil e 500 mil & 5 & $10 \%$ \\
Entre 100 mil e 200 mil & 4 & $8 \%$ \\
Entre 50 mil e 100 mil & 7 & $14 \%$ \\
Menos de 50 mil & 8 & $16 \%$ \\
Não responderam & 19 & $38 \%$ \\
\hline
\end{tabular}

\section{Recursos aplicados pelos produtores}

Uma idéia do volume de recursos que têm sido aplicados no desenvolvimento de vacinas pode ser obtida incluindo os gastos registrados pelos produtores de vacinas. As informações infelizmente estâo em bases diferentes, o que dificulta qualquer tentativa de totalização. Fica, de qualquer modo, estabelecida uma idéia do pequeno volume de recursos aplicados.

O Instituto Butantan estima em cerca de 5 milhões de reais anuais o volume de recursos aplicados em $P \& D$, em todas as suas áreas de atuação. Esse valor não inclui os salários. Os recursos são obtidos na forma de auxílios de agências financiadoras, principalmente Fapesp. 
Bio-Manguinhos gasta cerca de 3 milhões de reais anualmente, sem contar captações de agências financiadoras. Esses valores referem-se a gastos com insumos, pessoal, equipamentos e material permanente, principalmente.

Tecpar registra nos últimos cinco anos a aplicação de 11,5 milhões de reais em P\&D, principalmente em equipamentos $-8,3$ milhões $-e$ em insumos $-2,8$ milhões.

A FAP estima um gasto anual de cerca de 100 mil reais nos últimos cinco anos. Em adição, obteve cerca de 2 milhões de reais de agências internacionais (OMS, Medical Research Council, Wellcome Trust e Comunidade Econômica Européia), que foram aplicados em pesquisa com o BCG Moreau RJ no Brasil e no exterior. Essas pesquisas são realizadas por grupos localizados em universidades e centros de pesquisas, já que a FAP năo possui grupos internos de pesquisa.

\section{Nivel de competência no desenvolvimento de vacinas}

Esta seção dedica-se a explorar os principais resultados obtidos pela pesquisa realizada com os grupos envolvidos em $P \& D$ de interesse para a inovação em vacinas no Brasil. Analisamos a seguir o nível de competência desses grupos nas diversas atividades do processo de desenvolvimento de novas vacinas, tomando por base as notas que eles atribuíram a si próprios.

\section{Competência global}

A Tabela 5 apresenta as notas médias (1 a 5), atribuídas pelos próprios respondentes, quanto ao grau de expertise que julgam ter nas cinco etapas consideradas para o desenvolvimento de vacinas. Para facilitar a análise e interpretação dos resultados, as médias estâo também expressas na base 100.

Os resultados são claros. Em primeiro lugar, o número de grupos voltados para as etapas básicas do desenvolvimento (etapas 1 e 2) é consideravelmente superior ao número de grupos atuando nas etapas finais. Mais importante do que isso, não só são menos numerosos os grupos envolvidos com as etapas 3,4 e 5 , como os níveis médios de capacitação são mais baixos, em particular nas etapas de scale up e testes clínicos.

A Tabela 6 apresenta as notas médias, quanto ao grau de expertise nas cinco etapas do desenvolvimento, para os dez grupos de $P \& D$ localizados nos produtores de vacinas. As notas apresentam o mesmo perfil verificado na Tabela 5, que reúne todos os grupos identificados, independentemente da sua localização. Os pontos fortes continuam sendo a pesquisa básica e o pré-desenvolvimento. Entretanto, contrariamente ao que se verifica no caso geral, o nível em pré-desenvolvimento é superior ao da pesquisa básica. A nota média na etapa 'desenvolvimento da vacina candidata', mesmo ficando em $68 \%$, é superior em cinco pontos à do conjunto dos grupos. Os pontos fracos, porém, continuam sendo as etapas de scale up e ensaios clínicos.

Os resultados globais da capacitação dos grupos envolvidos com $P \& D$ em vacinas no Brasil sugerem que as possibilidades de concretizarmos as promessas de inovação geradas pelas etapas básicas dependem de uma evolução considerável desse nível de capacitação, em particular nas etapas scale up e testes clínicos. 
Tabela 5 - Competência nas etapas do desenvolvimento - notas médias dos 51 grupos

\begin{tabular}{l|c|c|c}
\hline Etapas do desenvolvimento & N. de grupos & $\begin{array}{c}\text { Nota média } \\
1-5\end{array}$ & $\begin{array}{c}\text { Nota média } \\
\%\end{array}$ \\
\hline Pesquisa básica & 43 & 4,1 & 82 \\
Pré-desenvolvimento & 41 & 3,8 & 76 \\
Desenvolvimento de vacinas candidatas & 37 & 3,2 & 63 \\
(estudos pré-clínicos) & 25 & 2,4 & 47 \\
Scale up & 26 & 2,7 & 54 \\
\hline Estudos clínicos & & & \\
\hline
\end{tabular}

Tabela 6 - Competências nas etapas do desenvolvimento - notas médias dos dez grupos localizados nos produtores

\begin{tabular}{l|c|c|c}
\hline Etapas do desenvolvimento & N. de grupos & $\begin{array}{c}\text { Nota média } \\
1-5\end{array}$ & $\begin{array}{c}\text { Nota média } \\
\%\end{array}$ \\
\hline Pesquisa básica & 7 & 3,8 & 76 \\
Pré-desenvolvimento & 9 & 4,1 & 82 \\
Desenvolvimento de vacinas candidatas & 7 & 3,4 & 68 \\
(estudos pré-clínicos) & 7 & 2,5 & 49 \\
Scale up & 7 & 2,2 & 44 \\
\hline Estudos clínicos & & & \\
\hline
\end{tabular}

Analisam-se em seguida as competências dos grupos em cada uma das etapas consideradas.

\section{Pesquisa básica}

A Tabela 7 detalha o nível de competência nas atividades relacionadas à pesquisa básica, na qual 43 grupos declaram ter algum nível de capacitação. Essa capacitação é avaliada pelos grupos como nitidamente acima da média em todos os itens considerados. Destacam-se, entre as atividades em pesquisa básica, o entendimento da doença, o entendimento do agente etiológico da doença e o entendimento das interações complexas entre o patógeno e o homem, com níveis de expertise bem acima de $80 \%$. A competência em propagação do agente etiológico em quantidade e em condiçōes apropriadas é tida como inferior às anteriores, situando-se em $74 \%$. 
Tabela 7 - Competências em pesquisa básica - notas médias dos 43 grupos

\begin{tabular}{|c|c|c|c|c|c|c|c|c|}
\hline \multirow{2}{*}{ Pesquisa básica } & \multicolumn{5}{|c|}{ Número de respostas } & \multirow{2}{*}{ NR } & \multirow{2}{*}{ MÉDIA } & \multirow{2}{*}{$\begin{array}{l}\text { MÉDIA } \\
(\%)\end{array}$} \\
\hline & incipiente & baixa & média & alta & muito alta & & & \\
\hline $\begin{array}{l}\text { Entendimento da } \\
\text { doença }\end{array}$ & 0 & 2 & 7 & 13 & 20 & 9 & 4,2 & 84 \\
\hline $\begin{array}{l}\text { Entendimento do agente } \\
\text { etiológico da doença }\end{array}$ & 1 & 1 & 3 & 12 & 26 & 8 & 4,4 & 88 \\
\hline $\begin{array}{l}\text { Entendimento das interaçōes } \\
\text { complexas entre o patógeno e o } \\
\text { homem }\end{array}$ & 1 & 2 & 9 & 8 & 22 & 9 & 4,1 & 83 \\
\hline $\begin{array}{l}\text { Propagação do agente etiológico } \\
\text { em quantidade e em condições } \\
\text { apropriadas }\end{array}$ & 4 & 4 & 10 & 5 & 17 & 11 & 3,7 & 74 \\
\hline \multicolumn{7}{|l|}{ MÉDIA } & 4,1 & 82 \\
\hline
\end{tabular}

\section{Pré-desenvolvimento}

Na etapa de pré-desenvolvimento, 41 grupos declaram possuir algum nível de competência. Os resultados estão na Tabela 8 . O nível médio de competência cai em relação à etapa anterior, situando-se em $76 \%$. As atividades listadas estão em níveis de competência muito próximos, não se observando diferenças significativas entre elas. Ressaltese, todavia, que é bem maior o número de grupos que se consideram competentes na atividade 'identificação e análise do(s) gene(s) ou antígeno(s) protetores' (41 grupos) do que nas demais atividades do pré-desenvolvimento ( 32 a 34 ).

Tabela 8 - Competências em pré-desenvolvimento - notas médias dos 41 grupos

\begin{tabular}{|c|c|c|c|c|c|c|c|c|}
\hline \multirow{2}{*}{ Pré-desenvolvimento } & \multicolumn{5}{|c|}{ Número de respostas } & \multirow{2}{*}{ NR } & \multirow{2}{*}{ MÉDIA } & \multirow{2}{*}{$\begin{array}{l}\text { MÉDIA } \\
(\%)\end{array}$} \\
\hline & incipiente & baixa & média & alta & muito alta & & & \\
\hline $\begin{array}{l}\text { Identificação e análise do(s) } \\
\text { gene(s) ou antígeno(s) protetor(es) }\end{array}$ & 3 & 3 & 9 & 11 & 15 & 10 & 3,8 & 76 \\
\hline $\begin{array}{l}\text { Atenuaçāo, modificaçãã genética, } \\
\text { inativação ou obtenção de } \\
\text { subunidade do agente etiológico }\end{array}$ & 4 & 3 & 6 & 8 & 13 & 17 & 3,7 & 74 \\
\hline $\begin{array}{l}\text { Caracterização in vitro de } \\
\text { organismos atenuados, } \\
\text { modificados ou inativados e } \\
\text { caracterização de subunidades }\end{array}$ & 2 & 4 & 6 & 9 & 13 & 17 & 3,8 & 76 \\
\hline $\begin{array}{l}\text { Estabilidade e imunogenicidade de } \\
\text { patógenos atenuados, } \\
\text { modificados, inativados ou de } \\
\text { subunidades do patógeno }\end{array}$ & 1 & 4 & 5 & 10 & 12 & 19 & 3,9 & 78 \\
\hline \multicolumn{7}{|l|}{ MÉDIA } & 3,8 & 76 \\
\hline
\end{tabular}




\section{Desenvolvimento da vacina candidata e estudos pré-clínicos}

A Tabela 9 apresenta os resultados obtidos na etapa de desenvolvimento da vacina candidata e estudos pré-clínicos. O número de grupos que reconhecem ter algum nível de competência nesta etapa é de 37 entre os 51 respondentes. Essa etapa é, de certa forma, um ponto de inflexão no nível brasileiro de capacitação no desenvolvimento de novas vacinas. O nível médio de competência cai para uma faixa próxima a $60 \%$.

Os 'estudos de imunogenicidade em animais' se destacam entre as atividades envolvidas nessa etapa, com nível de expertise em $74 \%$. Um pouco abaixo, com nota média $70 \%$, situa-se a atividade 'produção de lotes experimentais vacinais para estudos pré-clínicos, avaliação de estabilidade e/ou critérios de pureza'. As demais situam-se próximas a $60 \%$. Vale destacar o perfil de capacitação verificado nas atividades 'estudos de formulação' e 'seleção de adjuvantes', que se situa abaixo das demais, em $57 \%$ e $53 \%$, respectivamente. Nessas atividades, não só o número de respondentes que reconhecem alguma competência é pequeno, como também é expressivo o número daqueles que situam essa competência em níveis incipientes. Em 'seleção de adjuvantes', por exemplo, 11 se consideram com nível de competência alto ou muito alto, mas 13 reconhecem que possuem apenas um nível inicial. Esse resultado está de acordo com as respostas de alguns entrevistados, que identificaram os adjuvantes como um dos pontos que necessitam de maior desenvolvimento aplicado ao caso das vacinas, em particular no caso das vacinas de última geração.

Tabela 9 - Competências em desenvolvimento de vacina candidata e estudos pré-clínicos - notas médias dos 37 grupos

\begin{tabular}{|c|c|c|c|c|c|c|c|c|}
\hline \multirow{2}{*}{$\begin{array}{l}\text { Desenvolvimento da vacina } \\
\text { candidata (estudos pré- } \\
\text { clínicos) }\end{array}$} & \multicolumn{5}{|c|}{ Número de respostas } & \multirow{2}{*}{ NR } & \multirow{2}{*}{ MÉDIA } & \multirow{2}{*}{$\begin{array}{l}\text { MÉDIA } \\
(\%)\end{array}$} \\
\hline & incipiente & baixa & média & alta & muito alta & & & \\
\hline $\begin{array}{l}\text { Produção de lotes experimentais } \\
\text { vacinais para estudos pré-clínicos, } \\
\text { avaliação de estabilidade e/ou } \\
\text { critérios de pureza }\end{array}$ & 8 & 1 & 0 & 8 & 12 & 22 & 3,5 & 70 \\
\hline Estudos de formulaçāo & 10 & 3 & 6 & 3 & 8 & 21 & 2,9 & 57 \\
\hline $\begin{array}{l}\text { Estudos de apresentação (líquida, } \\
\text { liofilizada, monodose ou multidoses) }\end{array}$ & 8 & 1 & 5 & 3 & 9 & 25 & 3,2 & 63 \\
\hline Estudos de inocuidade em animais & 9 & 2 & 5 & 7 & 8 & 20 & 3,1 & 62 \\
\hline $\begin{array}{l}\text { Estudos de imunogenicidade em } \\
\text { animais }\end{array}$ & 5 & 1 & 7 & 7 & 14 & 17 & 3,7 & 74 \\
\hline \multicolumn{7}{|l|}{ MÉDIA } & 3,2 & 63 \\
\hline
\end{tabular}

\section{Scale up}

Vinte e cinco grupos registram algum nível de competência na etapa de scale up, produção đe lotes-piloto e aprovação para estudos clínicos. Mas mesmo esses grupos reconhecem que detêm um nível de competência baixo, da ordem de $47 \%$, apenas, conforme a Tabela 10. Em todas as atividades consideradas, o número de grupos com capacita- 
ção tida como incipiente é bem maior do que o total dos que classificam sua capacitação como alta ou muito alta. Trata-se, com efeito, da etapa com notas mais baixas, configurando-se como um claro gargalo no desenvolvimento das inovações em vacinas e, por extensão, em diversas outras áreas da biotecnologia.

Nesta etapa, as dificuldades são decorrentes, em primeiro lugar, da inexistência de instalações adequadas para a produção em condições de BPF correntes dos lotes para testes. Mesmo os grupos que declaram um bom nível de competência nesta etapa não têm acesso facilitado a essas instalações, o que, em termos práticos, restringe a possibilidade de conduzir efetivamente o desenvolvimento. A necessidade de prover instalações desse tipo parece ser um gargalo absoluto no desenvolvimento de vacinas e outros produtos biotecnológicos no Brasil. Destaque-se aqui o notável esforço do grupo liderado por Célio Silva (Faculdade de Medicina de Ribeirão Preto) que, em face dos obstáculos dessa etapa do desenvolvimento, decidiu montar uma unidade própria para produção de lotes-piloto.

Além das limitações de infra-estrutura, detectam-se também aqui problemas de qualificação adequada do pessoal, uma vez que o processo de desenvolvimento começa a ter características industriais que exigem competências em engenharia. Essa formação, apesar de essencial para o desenvolvimento dos processos, não é comum nas equipes de pesquisa e desenvolvimento, principalmente em nível de doutorado. Alguns poucos grupos que conseguiram chegar a esta etapa sublinham as enormes dificuldades que têm enfrentado para ultrapassá-la.

Tabela 10 - Competências em scale up - notas médias dos 25 grupos

\begin{tabular}{|c|c|c|c|c|c|c|c|c|}
\hline \multirow{2}{*}{ Scale up } & \multicolumn{5}{|c|}{ Número de respostas } & \multirow{2}{*}{ NR } & \multirow{2}{*}{ MÉdiA } & \multirow{2}{*}{$\begin{array}{l}\text { MÉDIA } \\
(\%)\end{array}$} \\
\hline & incipiente & baixa & média & alta & muito alta & & & \\
\hline $\begin{array}{l}\text { Scale up (demonstração de } \\
\text { consistência) }\end{array}$ & 11 & 4 & 3 & 2 & 5 & 26 & 2,4 & 49 \\
\hline Estabelecimento de lote semente & 11 & 4 & 3 & 1 & 5 & 27 & 2,4 & 48 \\
\hline $\begin{array}{l}\text { Produção de lotes-piloto e } \\
\text { aprovaçāo para estudos clínicos }\end{array}$ & 13 & 3 & 1 & 2 & 5 & 27 & 2,3 & 46 \\
\hline $\begin{array}{l}\text { Estabelecimento de controles } \\
\text { físico-químicos e biológicos para } \\
\text { uso em seres humanos }\end{array}$ & 12 & 4 & 0 & 2 & 5 & 28 & 2,3 & 46 \\
\hline $\begin{array}{l}\text { Estabelecimento de limites } \\
\text { destes controles para o produto } \\
\text { desenvolvido }\end{array}$ & 12 & 3 & 1 & 2 & 5 & 28 & 2,3 & 47 \\
\hline \multicolumn{7}{|l|}{ MÉDIA } & 2,4 & 47 \\
\hline
\end{tabular}

Entre os grupos que declaram expertise nesta etapa, cinco se consideraram em nível alto ou muito alto em todas as atividades. Encontram-se ainda grupos que se consideram especializados em algumas atividades. É o caso do recém-criado Laboratório de Engenharia de Cultivos Celulares (LECC), na Coppe/UFRI, em scale up, e também o caso do Grupo Microsferas e Lipossomos, do Instituto Butantan, em estabelecimento de controles físico-químicos e biológicos e estabelecimento de limites desses controles. Registre-se ainda aqui a identifica- 
ção de uma empresa de biotecnologia, a BIOMM, com interesses em vacinas humanas, que se apresenta como detentora de capacitação nas atividades de desenvolvimento de processos e scale up, embora sem atender integralmente as condiçőes de BPF correntes.

\section{Estudos clínicos}

Em estudos clínicos, 26 grupos se declaram com algum nível de competência. No entanto, o nível de capacitação que se atribuem chega apenas a 54\%, em média (Tabela 11). Poucos (entre 6e 10) se consideram em nível alto ou muito alto em estudos clínicos. Foram identificados cinco grupos que se consideram competentes nas quatro fases dos estudos clínicos. Alguns outros declaram níveis elevados de capacitação em uma ou duas das fases.

Deve ser assinalado que a competência de alguns grupos está sendo desenvolvida na condução de estudos clínicos para produtores estrangeiros de vacinas. A dificuldade central nesta etapa parece ser, além dos custos elevados para realização dos testes, o treinamento adequado de médicos para desenharem os testes dentro da sua complexidade atual.

Tabela 11 - Competências em estudos clínicos - notas médias dos 26 grupos

\begin{tabular}{l|c|c|c|c|c|c|c|c}
\hline \multirow{2}{*}{$\begin{array}{l}\text { Estudos clínicos } \\
\text { (segurança, } \\
\text { imunogenicidade e } \\
\text { eficácia) }\end{array}$} & \multicolumn{5}{|c|}{ Número de respostas } & \multirow{2}{*}{ NR } & MÉDIA & $\begin{array}{c}\text { MÉDIA } \\
(\%)\end{array}$ \\
\cline { 2 - 7 } & incipiente & baixa & média & alta & muito alta & & \\
\hline Fase 1 & 8 & 2 & 5 & 1 & 5 & 30 & 2,7 & 53 \\
Fase 2 & 10 & 0 & 2 & 3 & 7 & 29 & 2,9 & 57 \\
Fase 3 & 11 & 0 & 1 & 3 & 5 & 31 & 2,6 & 51 \\
Fase 4 & 10 & 0 & 2 & 5 & 4 & 30 & 2,7 & 53 \\
\hline MÉDIA & & & & & & 2,7 & 54 \\
\hline
\end{tabular}

Competências para inovar dos produtores de vacinas

A dinâmica da inovação requer um conjunto de competências que podemos chamar de complexas. Essa noção, ainda que imprecisa, é útil e traz à tona uma discussão de aspectos organizacionais, relacionais, técnicos, entre outros, que são a base para se pensar e trabalhar a inovação como uma finalidade.

Portanto, buscou-se avaliar como as instituições brasileiras produtoras de vacinas se apresentam quanto às competências que, no entendimento dos autores, favorecem o aprendizado contínuo e a inovação.

Foram avaliadas 12 dimensões consideradas fundamentais: 1) realização de inovação; 2) posicionamento tecnológico; 3) monitoramento das tecnologias; 4) capacidade de apropriação das tecnologias (externas principalmente); 5) conhecimento, previsão e 
ação sobre a evolução dos mercados; 6) recursos físicos e financeiros; 7) gerenciamento e defesa da propriedade intelectual; 8) inserção da inovação/aprendizado na estratégia de conjunto da organização (capacidade de se transformar); 9) organização e direção da produção/assimilação e difusão interna de conhecimento; 10) gestão de RH na perspectiva đe aprendizado e/ou inovação; 11) financiamento das inovações/assimilação de tecnologias; 12) cooperação.

Quadro 1 - Questões objetivas (ilustração para um aspecto)

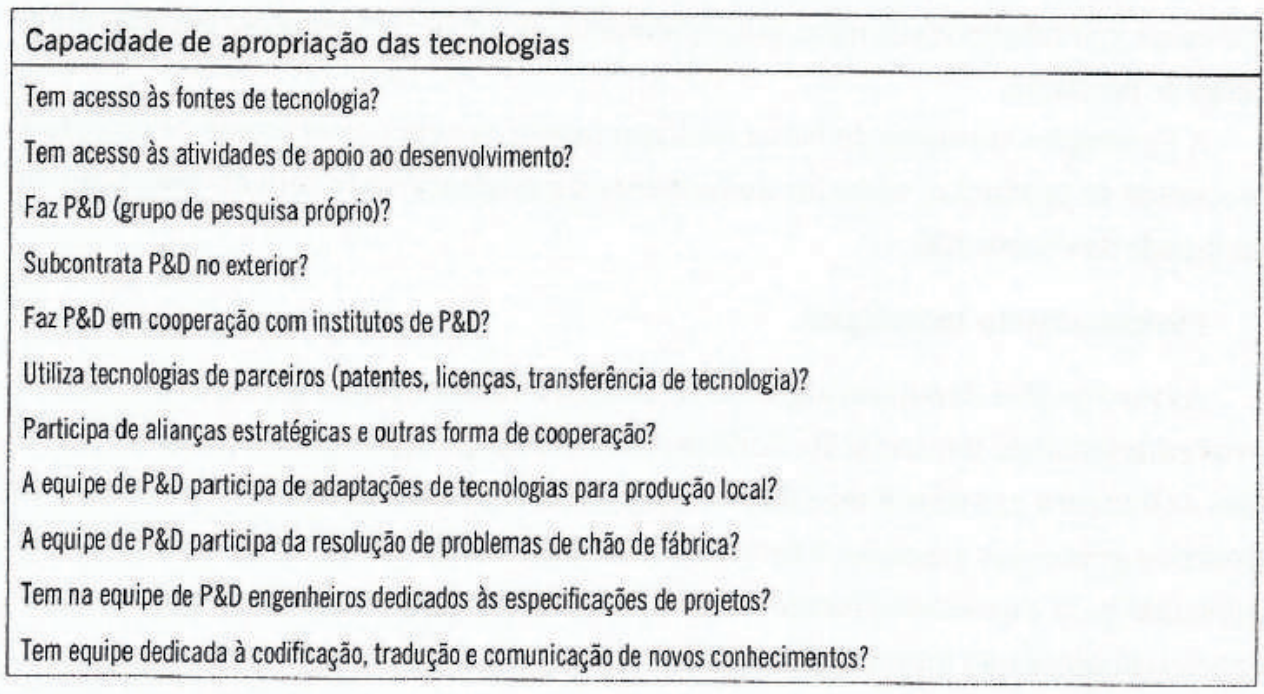

Para cada uma dessas dimensões, foi elaborado um conjunto de questões objetivas que visa a avaliar o nível de competência para inovar da instituição. O Quadro 1 ilustra o exposto para a dimensão 'capacidade de apropriação das tecnologias'.

Esta avaliação se deu com base nas respostas do dirigente ou responsável pela pesquisa e desenvolvimento de cada instituição produtora. Em cada caso, a instituição foi classificada como atuante ou não em cada questão e, se atuante, em nível baixo, médio, alto ou, ainda, alto com procedimentos formais.

As respostas obtidas nessa auto-análise dos produtores contiveram naturalmente um certo grau de subjetividade, agravado pelo fato de serem apenas quatro institutos. Por isso, a análise foi complementada com as entrevistas realizadas com diretores e gerentes.

O estudo das 12 dimensões, apresentado a seguir, indica que existem açōes a serem empreendidas pelas instituiçōes produtoras com vistas a estruturar cada instituição a fim de obter aprendizado e/ou inovação, conferindo-lhes, assim, um maior dinamismo. Vale notar que a preocupação em aprender e/ou inovar é um tema presente na diretoria de todas as instituições.

\section{Realização de inovação}

Foi analisado se as instituições inovaram nos últimos cinco anos na produção de vacinas, em produtos e/ou processos. Todas responderam que sim, mas, de fato, se considerarmos a realização de inovação apenas quando o novo produto chega ao merca- 
do, ou quando foram realizadas inovaçóes efetivas nos processos de produtos da linha, no mesmo período, o resultado é modesto.

Bio-Manguinhos lançou a vacina contra Hib, decorrente de acordo de transferência de tecnologia com a GlaxoSmithKline e posteriormente realizou uma inovação incremental com o lançamento da vacina combinada contra Hib/DTP (com DTP do Butantan). Também deve ser registrado o lançamento de nova apresentação da vacina contra febre amarela. O Butantan lançou a vacina contra hepatite B e possui acordo de transferência de tecnologia de produção da vacina contra influenza da Aventis. Vale ainda registrar que essas instituições realizaram, principalmente, inovações em processo em suas atividades de produçăo.

A Fundação Ataulpho de Paiva realizou inovaçōes em novos meios de cultura e processos de produçẫo, voltados ao aumento da produtividade com manutenção da qualidade da vacina BCG.

\section{Posicionamento tecnológico}

As instituições dominam algumas tecnologias fundamentais (cultura de vírus em ovos embrionados, fermentação, liofilização e conjugação química) e algumas tecnologias de fronteira nas suas linhas de produção (tecnologia recombinante). Tecnologias de fronteira (como, por exemplo, a tecnologia do BCG recombinante) também estão sendo utilizadas para o desenvolvimento de novas vacinas em alguns institutos onde as abordagens clássicas não foram suficientes.

\section{Monitoramento das tecnologias}

As instituições monitoram de forma mediana as tecnologias de futuro com uso de fontes externas e monitoram sem procedimentos formais as tecnologias de concorrentes. As publicações dos profissionais dos concorrentes são analisadas, mas as patentes dos concorrentes não o são, ou são pouco analisadas. Contudo, todos disseram que buscam sistematicamente novos desenvolvimentos e habilidades para imitar e copiar.

\section{Capacidade de apropriação de tecnologias}

Bio-Manguinhos e Butantan possuem grupos próprios de pesquisa em vacinas e um razoável acesso às fontes de tecnologia. Quanto à utilização de tecnologias de terceiros (patentes, licenças e transferência de tecnologia), as duas instituiçōes possuem acordos de transferência de tecnologia com empresas estrangeiras para produção das vacinas contra Hib e influenzae, respectivamente.

Observou-se, por outro lado, que a subcontratação de P\&D é limitada, sobretudo contratação no exterior. Butantan atua principalmente com grupos próprios e Bio-Manguinhos tem subcontratado pesquisas de outros grupos da Fiocruz e universidades em complemento às ações internas.

Nessas duas instituições, também as equipes de P\&D participam das adaptações de tecnologias tanto para produção local, quanto para resolver problemas de chão de fábrica, mas ainda há espaço para um fortalecimento dessas interações pesquisa-produção. 
Essas equipes ainda carecem de engenheiros dedicados às especificações de projetos. Também há uma deficiência na dedicação à codificação, tradução e comunicação de novos conhecimentos.

\section{Conhecimento, previsão e ação sobre a evolução dos mercados}

Nessa dimensão, as atividades de análise de epidemiologia, necessidades e segmentação dos clientes (internos e externos), necessidades perante os formadores de opinião, são realizadas de forma não sistematizada. Bio-Manguinhos foi certificado pela OMS para fornecer a vacina contra febre amarela para a OMS/Unicef e, com isso, abriu um importante segmento externo para atuação.

\section{Recursos físicos e financeiros}

A infra-estrutura existente para desenvolvimento tecnológico não atende às necessidades dos produtores. Repete-se aqui a mesma deficiência detectada entre os grupos de pesquisa, referente à infra-estrutura para scale up e produção de lotes para testes. Butantan e Bio-Manguinhos têm enfrentado o problema com o isolamento de uma área da produção para uso temporário em desenvolvimento. A ausência de uma infra-estrutura dedicada a desenvolvimento constitui uma limitação importante na capacidade atual de inovação dos produtores de vacinas. Estes, por sua vez, em sua totalidade, estão insatisfeitos com a falta de recursos assegurados para $P \& D$ e acham que têm pouco acesso a insumos tecnologicamente novos.

\section{Gerenciamento e defesa da propriedade intelectual}

Butantan e Bio-Manguinhos consideram que possuem poucas patentes; Tecpar e a Fundação Ataulpho de Paiva não têm patentes em vacinas. A avaliação global é de que essa dimensão deveria merecer maior atenção das instituições, pois não existem procedimentos formais para identificação dos conhecimentos e know-how estratégicos das instituições; incorporação de risco de cópia e imitação desde a concepção do produto; vigilância da existência e da difusão de cópias e imitações; controle da comunicação sobre os conhecimentos estratégicos; motivação especialmente às pessoas detentoras dos conhecimentos estratégicos (remuneração, carreiras); garantia, em caso de saída de um profissional, da conservação pelas instituições do máximo de conhecimento estratégico.

Apenas a FAP informou possuir procedimentos formais para identificação das pessoas da organização que detêm conhecimentos estratégicos e para sensibilização destas quanto ao caráter estratégico e confidencial de seus conhecimentos.

Inserção da inovação/aprendizado na estratégia de conjunto da organização

A capacidade de se transformar dessas instituições parece limitada. Em todas elas, situa-se entre pouca e média a avaliação e a experimentação de novos formatos organizacionais. Não há procedimentos formais para levantamento das competências do pessoal, e o favorecimento de uma visão global das instituições de cada funcionário situase entre baixo e médio. 
Organizaçăo e direção da produçăo/assimilação e difusão interna de conhecimento

Todas as instituições informaram que favorecem a canalização da criatividade e as ações de aprendizado, bem como avaliam os resultados da produção e assimilação de conhecimentos, mas em diferentes graus (pouco/médio/muito).

O incentivo à absorção e disseminação interna de conhecimento existe, mas observa-se que pode ser melhorado. Todas as instituições informaram que aceitam comportamentos criativos e de aprendizado não diretamente produtivos, em diferentes graus. Nelas existe um potencial para melhorar a avaliação da contribuição de cada um à produção e à absorção de conhecimento. Elas também informaram que valorizam, na avaliação individual, o desenvolvimento próprio (educação e treinamento).

\section{Gestão de RH na perspectiva de aprendizado e/ou inovação}

As instituições não se estruturam formalmente em torno de projetos, mas existem muitos em curso, sobretudo no Butantan e em Bio-Manguinhos; neste está em implantação uma área de gerenciamento de projetos. Tal iniciativa deve facilitar o envolvimento de todas as áreas/serviços desde o início do projeto e aumentar o grau de coordenaçăo na condução dos desenvolvimentos.

Ações de incentivo ao trabalho em equipe e identificação de especialistas, atuais e do futuro, no mercado existem, mas sem procedimentos formais. Na contratação, a avaliação da propensão a inovar e da capacidade de trabalhar em equipe é observada, segundo os respondentes; entretanto, se as instituiçōes deixam transparente a avaliação de cada um e a recompensa dos melhores, bem como as regras de mobilidade, não há consenso.

A avaliação da necessidade de formação de cada um é analisada segundo os respondentes.

Financiamento das inovações/assimilação de tecnologias

Observa-se que não há uma cultura de avaliar antecipadamente ou posteriormente o conjunto de custos ligados à inovação. Todos os produtores se declararam conhecedores dos modos de financiamento, tanto privados quanto públicos, e se comunicam habitualmente com financiadores potenciais da inovação.

\section{Cooperação}

Existem iniciativas por parte dos produtores de buscar parceiros para o desenvolvimento de vacinas, como, por exemplo, os acordos de cooperação liderados por BioManguinhos com outros grupos de pesquisa da Fiocruz e universidades. Butantan e BioMaguinhos possuem acordos de desenvolvimento conjunto de vacinas (N. meningitidis B e C, DTP/HBV + Hib).

O Tecpar vem utilizando principalmente o IBMP para o desenvolvimento da vacina anti-rábica em cultivo celular.

A Fundação Ataulpho de Paiva vem adotando a estratégia de atuar preferencialmente em cooperação com outros parceiros, pois não possui grupo próprio de pesquisa. 
Dentre as colaboraçōes em andamento, podem-se citar as pesquisas para o desenvolvimento e aplicação do BCG Moreau como recombinante para o uso como vacina polivalente infantil, via oral.

Vale registrar que a avaliação dessas 12 dimensōes se deu considerando-se a situação atual dessas instituições. Se as avaliarmos quanto a suas trajetórias, observa-se um esforço maior para inovar naquelas que possuem uma maior base de P\&D: Bio-Manguinhos e Butantan. Por outro lado, são inegáveis os movimentos recentes em busca de novas tecnologias no Tecpar e os esforços da FAP para participar de pesquisas sobre BCG por meio de outros centros de $P \& D$.

\section{Dimensões críticas da inovação em vacinas \\ Casos em inovação em vacinas}

Na realização das entrevistas com pesquisadores e diretores das unidades de produção, foi possível coletar um certo número de elementos que ilustram bem o que se poderia chamar de saga de uma inovação em vacinas. Na maior parte dos casos, tratase de experiências ainda em andamento que podem ou não vir a ser completamente bemsucedidas. Por isso, evitamos mencionar os nomes e personalizar os casos, mas retiramos deles alguns elementos que podem ser instrutivos na reflexão do que representa uma inovação, em particular em vacinas e no Brasil.

\section{- Motivação pessoal}

o papel do pesquisador que tem a iniciativa do projeto parece crítico. Com freqüência, a personalidade dos pesquisadores quase 'ofusca' o papel das instituições onde atuam. Nos casos dos desenvolvimentos realizados nos centros produtores de vacinas, o papel da instituição é mais relevante, mas a presença de pessoas fortemente motivadas pelo projeto continua sendo muito importante.

A motivação pessoal de obter uma vacina para uma doença específica é um fator determinante nos processos analisados. Os pesquisadores atuam com um foco, com uma meta, mesmo estando cientes de que há muito trabalho a ser realizado para obter a vacina. $O$ conhecimento gerado, os papers e os resultados acadêmicos em geral são importantes, podendo mesmo contribuir para ajudar a resolver os próprios problemas do desenvolvimento, mas o foco está claramente no produto final.

\section{- Persistência}

A persistência está, de certo modo, relacionada à motivação pessoal. Os casos identificados atestam um espírito empreendedor capaz de enfrentar cada obstáculo que surge. A trajetória é sempre uma sucessão de obstáculos que só se descortinam com clareza quando o obstáculo anterior é vencido. Apenas essa dimensão, em boa parte pessoal, explica a manutenção de projetos por vinte, trinta anos. 
- Empreendedorismo

O pesquisador/laboratório que se envolve com um efetivo projeto de inovação em vacinas tem que incorporar um elevado grau de empreendedorismo. Os obstáculos científicos e tecnológicos somam-se aos problemas de propriedade intelectual, de financiamento, de estruturação das diversas etapas do desenvolvimento, de montagem e manutenção de equipes com as competências adequadas e muitos outros que só podem ser resolvidos com a capacidade empreendedora. Esta capacidade não é menos exigida, sublinhe-se, nos projetos de desenvolvimento dos produtores de vacinas. Talvez, nesse caso, mereça até mais atenção, já que o processo de desenvolvimento corre o risco de ser diluído dentro da própria estrutura administrativa, se não existir uma base eficiente de gerenciamento de projetos.

- Obstáculos e oportunidades de mudanças de rumo

Sendo um processo longo por natureza, uma focalização no objetivo final - o produto - é fundamental. Mas isso não exclui oportunidades de mudanças de rumo e incorporação de novos conhecimentos e ferramentas que se tornam disponíveis durante o desenvolvimento. Em alguns casos estudados, os resultados hoje vislumbrados são muito mais ricos do que os que poderiam ser previstos no início do projeto.

Em mais de um caso, novos conhecimentos foram incorporados mudando a concepção inicial do produto ou gerando novos produtos. O processo não é linear em sua realização; não existe um caminho definido no qual as etapas se sucedem de forma seqüencial. No caso da biotecnologia, as possibilidades de redirecionamento e revisões de rota são muito importantes e devem ser criadas condiçốes para sua incorporação.

- Agregação de novas competências: a multidisciplinaridade em exercício

O processo de desenvolvimento de um novo produto biotecnológico nunca foi, e talvez seja menos ainda nas condiçōes atuais da tecnologia, um processo dominando pelas competências de poucos profissionais. Nos casos estudados, os pesquisadores líderes tiveram ao longo do caminho a necessidade de incorporar novos parceiros que trouxeram novas competências para o grupo. Com freqüência, as formações trazidas pelos novos parceiros eram decisivas, em virtude da multidisciplinaridade característica do processo de desenvolvimento de inovações em vacinas.

No Quadro 3, apresentamos a idéia da multidisciplinaridade no desenvolvimento das inovaçōes em vacinas de forma mais estruturada.

\section{- Os subprodutos da P\&D}

Os casos estudados são de vacinas ainda em desenvolvimento. Atingir a comercialização da vacina almejada ainda vai exigir algumas etapas a ultrapassar, alguns problemas a resolver. Mas quase todos os casos têm resultados interessantes que são subprodutos da acumulação tecnológica. Um desenvolvimento potencialmente resulta numa plataforma tecnológica que se constitui numa base de oportunidades a explorar. O foco foi fundamental na condução do desenvolvimento, mas os resultados foram diversificados. 


\section{Conceitos centrais em gestão da inovação e o desenvolvimento de vacinas}

Os pontos comentados anteriormente permitem realçar alguns conceitos centrais em gestão da inovação que, no nosso entender, não podem ser perdidos de vista nas estratégias de inovação que venham a ser formuladas em vacinas.

1) Inovação exige a obtenção de um resultado comercial, aplicado, utilizado pelos consumidores. No caso do desenvolvimento de novas vacinas, a concretização de uma inovação pressupõe a chegada do produto ao mercado.

2) A incerteza é inerente ao processo de inovação, e a gestão da inovação tem em mente a tentativa de reduzir o nível de incerteza.

3) A idéia inicial de uma inovação pođe partir de uma concepção de produto, inspirada numa analogia com um produto existente, com base numa possibilidade aberta pelos conhecimentos estabelecidos no assunto. $O$ novo produto não começa necessariamente com a 'nova ciência'. Isso não tira o peso da ciência, o que seria absurdo na fase atual da biotecnologia, mas estabelece uma relação dinâmica entre ciência e tecnologia ao longo do processo de desenvolvimento.

4) As diversas etapas do desenvolvimento apresentam uma sucessão de novos obstáculos que só se descortinam claramente à medida que cada problema é resolvido, numa sucessão de desafios que dá a impressão de ser, em muitos momentos, interminável.

5) O desenvolvimento, considerado da ciência básica até o produto final, exige a mobilização de novas competências que os iniciadores dificilmente terão. Fala-se de um processo que vai levar no mínimo dez anos. Os líderes devem ter claro que serão obrigados a incorporar novas competências

6) As inovações têm quase sempre o seu 'campeão' e costumam ser fortemente dependentes deles. Sem o 'campeão', os obstáculos se tornam intransponíveis. A ausência dessa capacidade empreendedora é igual à ausência de inovação.

7) Os resultados dos processos podem ser inesperados em relação aos objetivos iniciais. Um processo de desenvolvimento tão longo como o de uma vacina é por natureza uma fonte de resultados secundários que não podem ser desconsiderados. Esses resultados representam retornos adicionais e fazem com que o processo de desenvolvimento visando a uma nova vacina tenha com freqüência outros resultados relacionados. São novos produtos, como vacinas veterinárias, novas formas de administração, novos processos e técnicas etc. Por isso, embora o ponto de partida seja a busca de novas vacinas humanas, os resultados devem ser vistos de modo mais amplo, abrangendo, na verdade, a busca de aplicações em biotecnologia. 0 dinamismo do campo e sua potencialidade atual sugerem que essa perspectiva não deve ser perdida. 


\section{FATORES CRITIICOS DE SUCESSO NO DESENVOLVIMENTO DE VACINAS NO BRASIL}

Partindo da análise das respostas dos grupos de $P \& D$ e das entrevistas, pode-se tentar mapear os fatores críticos de sucesso para o desenvolvimento de vacinas e, em conseqüência, identificar as principais dificuldades encontradas.

Quadro 2 - Fatores críticos de sucesso

\begin{tabular}{|c|c|}
\hline $\begin{array}{l}\text { Recursos humanos/Competências } \\
\text { - Parcerias em cada etapa e no conjunto de etapas } \\
\text { - Multidisciplinaridade em cada etapa e no conjunto de } \\
\text { etapas } \\
\text { - Continuidade/preservação de grupos }\end{array}$ & $\begin{array}{l}\text { Coordenação/Gestăo } \\
\text { - Objetivos bem definidos/decisão política } \\
\text { - Coordenação para integrar pesquisa básica - } \\
\text { desenvolvimento tecnológico - ensaios clínicos - } \\
\text { produção - regulamentação - mercado } \\
\text { - Acompanhamento de metas } \\
\text { - Coordenação interinstitucional } \\
\text { - Estratégias de inovação }\end{array}$ \\
\hline $\begin{array}{l}\text { Financiamento } \\
\text { - Volume adequado e regularidade } \\
\text { - Recursos para investimento em P\&D dos produtores }\end{array}$ & $\begin{array}{l}\text { Infra-estrutura } \\
\text { - Planta-piloto em BPF } \\
\text { - Biotérios de experimentação }\end{array}$ \\
\hline $\begin{array}{l}\text { Aspectos operacionais } \\
\text { - Animais de alta qualidade } \\
\text { - Importação (equipamentos e insumos) } \\
\text { - Contratação de pessoas e serviços } \\
\text { - Manutenção de equipamentos }\end{array}$ & $\begin{array}{l}\text { Aspectos culturais } \\
\text { - Falta cultura de pesquisa aplicada, possivelmente por } \\
\text { falta de incentivo }\end{array}$ \\
\hline
\end{tabular}

A articulação dos fatores críticos identificados no Quadro 2, em particular no que se refere às dimensões de coordenação e gestão e de recursos humanos e competências, é explorada no Quadro 3. Neste quadro, relacionam-se as etapas de desenvolvimento de uma vacina com as áreas de conhecimento dominantes, os atores principais envolvidos, os perfis profissionais e as atividades integradoras em termos estratégicos. Resulta daí uma caracterização da multidisciplinaridade que se mencionou anteriormente como uma dimensão central da inovação em vacinas e das múltiplas interações organizacionais envolvidas no desenvolvimento. A dedução principal que pode ser extraída do Quadro 3 é a da absoluta importância da coordenação como fator crítico no desenvolvimento de inovaçōes em vacinas. 
Quadro 3 - Multidisciplinaridade, interações organizacionais e perfis no desenvolvimento de uma vacina

\begin{tabular}{|c|c|c|c|c|}
\hline & $\begin{array}{c}\text { Áreas de } \\
\text { conhecimento } \\
\text { dominantes }\end{array}$ & Atores principais & Perfil profissional & $\begin{array}{c}\text { Atividades } \\
\text { integradoras }\end{array}$ \\
\hline $\begin{array}{l}\text { Etapas } 1 \text { e } 2 \\
\text { Pesquisa básica e pré- } \\
\text { desenvolvimento }\end{array}$ & $\begin{array}{l}\text { Conhecimentos médicos da } \\
\text { doença } \\
\text { Infectologia } \\
\text { Epidemiologia } \\
\text { Biologia molecular } \\
\text { Microbiologia } \\
\text { Imunologia }\end{array}$ & Órgãos de saúde pública & $\begin{array}{l}\text { Médicos } \\
\text { Biólogos } \\
\text { Bioquímicos } \\
\text { Biologistas moleculares } \\
\text { Imunologistas } \\
\text { Epidemiologistas }\end{array}$ & $\begin{array}{l}\text { Política de saúde e C\&T } \\
\text { (planejamento político- } \\
\text { estratégico) } \\
\text { Gestāo da inovação } \\
\text { (plano estratégico) }\end{array}$ \\
\hline $\begin{array}{l}\text { Etapa } 3 \\
\text { Desenvolvimento da vacina } \\
\text { candidata - Estudos pré- } \\
\text { clínicos }\end{array}$ & $\begin{array}{l}\text { Modelos animais } \\
\text { Boas Práticas Laboratoriais } \\
\text { correntes } \\
\text { Biotecnologia de processos }\end{array}$ & $\begin{array}{l}\text { Centros de P\&D } \\
\text { Indústria } \\
\text { Biotério }\end{array}$ & $\begin{array}{l}\text { Biólogos } \\
\text { Bioquímicos } \\
\text { Biofísicos } \\
\text { Biologistas moleculares } \\
\text { Imunologistas } \\
\text { Veterinários }\end{array}$ & $\begin{array}{l}\text { Gestão de projetos } \\
\text { (plano tático) }\end{array}$ \\
\hline $\begin{array}{l}\text { Etapa } 5 \\
\text { Estudos clínicos: } \\
\text { segurança, } \\
\text { imunogenicidade e eficácia }\end{array}$ & $\begin{array}{l}\text { Engenharia econômica } \\
\text { Marketing } \\
\text { Engenharias } \\
\text { Boas Práticas de Fabricaçāo } \\
\text { correntes } \\
\text { Medicina } \\
\text { Imunologia } \\
\text { Epidemiologia } \\
\text { Ética }\end{array}$ & $\begin{array}{l}\text { Órgäos reguladores } \\
\text { Centro de desenvolvimento e } \\
\text { produção em escala-piloto } \\
\text { Comitê de ética } \\
\text { Indústria } \\
\text { Órgãos reguladores } \\
\text { Hospitais } \\
\text { Laboratórios } \\
\text { Centros de pesquisa }\end{array}$ & $\begin{array}{l}\text { Engenheiros (químicos, } \\
\text { bioquímicos, produçāo, } \\
\text { econômicos) } \\
\text { Administraçāo/Marketing } \\
\text { Pesquisadores * } \\
\text { Médicos } \\
\text { Agentes de saúde } \\
\text { Laboratoristas } \\
\text { Enfermeiros } \\
\text { Pesquisadores * }\end{array}$ & $\begin{array}{l}\text { Garantia da qualidade e } \\
\text { regulamentação } \\
\text { (plano tático) } \\
\text { Empreendedorismo } \\
\text { (formação de cultura) }\end{array}$ \\
\hline
\end{tabular}

* Pesquisadores com as formaçōes diversas descritas nas etapas 1 e 2.

\section{CONCLUSÕESE RECOMENDAÇÕES}

Como pontos positivos na potencialidade para o desenvolvimento de vacinas no Brasil destacam-se o reconhecimento e a preocupação crescente da parte dos produtores com a capacitação tecnológica, a inovação e a importância de incorporarem novos produtos e processos, bem como a existência de um número importante de grupos com capacitação em pesquisa básica.

Em termos de resultados, deve ser destacada inicialmente a capacitação adquiriđa pelos produtores em termos de melhoria dos processos de produção das vacinas tradicionais de suas linhas de produção, como a vacina contra febre amarela em Bio-Manguinhos. Além disso, o processo de transferência de tecnologia tem sido outra fonte citada como capacitadora do ponto de vista tecnológico. Citem-se, para ficar nos exemplos recentes, 
a Hib em Bio-Manguinhos e a influenza em Butantan. Caberia uma discussão importante, mas que foge ao escopo desse estudo, quanto às condiçōes em que devem ser feitas as transferências de tecnologia de modo a propiciar os melhores frutos em capacitação interna para futuras inovações. $O$ envolvimento do próprio pessoal de $P \& D$ no processo de transferência e absorção da tecnologia pode contribuir positivamente nessa direção.

Quanto à capacidade de desenvolvimento dos produtores, deve ser mencionado que Bio-Manguinhos e Butantan contam com pesquisadores com doutorado atuando em seus departamentos de $P \& D$. São 15 em Bio-Manguinhos e 18 no Instituto Butantan. Entretanto, pode-se questionar se a formação desses doutores inclui a multidisciplinaridade que exige o processo de desenvolvimento.

O Tecpar não conta diretamente com pessoal com doutorado atuando em P\&D em vacinas. A partir de 2000 , com a instalação do IBMP, uma parceria Fiocruz/Tecpar, localizado dentro do campus do Tecpar, o produtor paranaense começou a ter possibilidade de melhorar a formação do seu pessoal e de contar com um suporte científico para futuros esforços de desenvolvimento. Já a FAP não tem atividade interna de pesquisa estruturada, valendo-se de parcerias com grupos externos.

Todavia, algumas limitações ainda entravam a capacidade efetiva de inovação dos produtores. Em primeiro lugar, o volume de recursos disponíveis para investimento em $\mathrm{P} \& D$ parece muito pequeno e mesmo irrisório, se comparado com as cifras internacionais habitualmente mencionadas.

Ademais, existem limitações de infra-estrutura dedicada para o desenvolvimento, em particular para a etapa de scale up e desenvolvimento dos processos de produção em escala-piloto e comercial. Bio-Manguinhos tem um projeto de uma Planta de Protótipos que supriria essa necessidade. Além da limitação de infra-estrutura física de desenvolvimento, deve ser mencionada, ainda, a importância de contar com uma formação multidisciplinar e em nível de doutorado nas equipes de $P \& D$. Em particular, deve ser citada a importância de incorporar uma engenharia de alto nível nos processos de desenvolvimento.

Em síntese, apesar dos esforços e progressos dos produtores, falta talvez, ainda, um passo para incorporar de forma clara e explícita na gestão das unidades uma estratégia de inovação bem-estruturada e difundida em todos os departamentos. Isso traria para o primeiro plano a inovação como finalidade.

No que toca à capacitação em pesquisa básica identificada por este estudo, sem dúvida um ponto positivo, a preocupação é com o risco de que esses conhecimentos convertam-se em um número pequeno de inovações. Esse risco parece real, se considerarmos a falta de infra-estrutura para completar as demais etapas do desenvolvimento, em particular para as etapas de scale up e estudos clíniços. Em adição, parecem faltar condiçōes para canalizar esses desenvolvimentos para uma possível concretização no mercado. Os produtores de vacinas certamente podem e devem aprimorar sua capacidade de coordenação, identificando e completando o desenvolvimento dos projetos. Contudo, dificilmente terão condiçōes de absorver todas as iniciativas geradas pela pesquisa 
básica instalada. Do ponto de vista da inovação em biotecnologia no Brasil, outras formas deveriam ser consideradas e incentivadas, como transferências para empresas privadas e a própria criação de empresas de base tecnológica.

Como pôde ser constatado, existem algumas vacinas desenvolvidas no país que se encontram na etapa de estudos clínicos e algumas outras na etapa de produção de lotespiloto para estudos clínicos. Todas têm mais de 12 anos de desenvolvimento e existem casos de mais de trinta anos de esforços. Mas, entre os projetos citados pelos grupos de $P \& D$ identificados por este estudo, observa-se que predominam resultados iniciais, referentes às primeiras etapas de desenvolvimento.

Um ponto de destaque na tentativa de identificar os resultados dos esforços de desenvolvimento de vacinas no Brasil é a quase ausência de patentes. Entre os grupos identificados, apenas dois mencionaram que detinham patentes. Esse resultado pode subestimar o número real de patentes, já que a pergunta referente a resultados obtidos era aberta e não explicitava patentes. Mesmo assim, esse número baixo deixa transparecer, pelo menos, que a perspectiva dos grupos não está atualizada na lógica de proteção de resultados que darão origem às inovações.

Na tentativa de convergir estas conclusões para um ponto focal, apontaríamos a falta de coordenação dos projetos na forma de projetos de inovação como o principal problema a ser atacado no esforço de tornar a nossa 'potencialidade para inovar' em inovações efetivas. De fato, muitos projetos de pesquisa não parecem estar inseridos em redes de cooperação ou sob uma forma de coordenação que lhes dê rumo no que se refere à inovação final.

Em termos de recomendações, deixamos, para reflexão dos leitores e consideração dos pesquisadores, dirigentes das instituiçōes produtoras e responsáveis pelas políticas de ciência, tecnologia e inovação, algumas sugestōes que, em nosso entenđimento, poderiam contribuir para aumentar a capacidade de inovação em vacinas no Brasil.

- Intensificar as formas de coordenação dos projetos. Aprofundar os mecanismos de coordenação e de rede, tanto inter quanto intra-institucionais, para integrar as diversas etapas do processo de desenvolvimento dos projetos de vacinas.

- Direcionar a gestão de RH para a inovação e formação do 'empreendedor público'. Considerar em particular a multidisciplinaridade das equipes e a formação de recursos principalmente para as etapas finais de desenvolvimento de vacinas (scale up e ensaios clínicos). Buscar a inclusão de engenharia de alto nível para desenvolvimento de processos biotecnológicos, incluindo pessoal com doutorado em desenvolvimento tecnológico, com formação para tratar as etapas de engenharia dos processos.

- Buscar condições que favoreçam a criação e o desenvolvimento de empresas em biotecnologia como forma de concretizar o potencial de inovações contido na capacitação em pesquisa básica.

- Prover a instalação de infra-estrutura dedicada para desenvolvimento tecnológico, em particular para scale up e produção de lotes-piloto para testes. 
- Realizar um evento de integração de todos os pesquisadores de vacinas. Além de propiciar um espaço para fortalecimento das relações de cooperação e dos mecanismos de coordenação, o objetivo principal do evento seria uma oficina sobre a etapa de scale up e desenvolvimento de processos, enfatizando a natureza do problema envolvido, os tipos de infra-estrutura e de formaçāo necessários. A oficina deveria envolver tomadores de decisão (diretores das instituições produtoras, ministérios e agências relacionados), como forma de sensibilizá-los para o problema, além dos próprios pesquisadores, para dar-lhes dimensão do que se trata e prepará-los para eventualmente abordar o desenvolvimento dos seus processos. ${ }^{1}$

- Promover o desenvolvimento das etapas de seleção de adjuvantes e estudos de formulação nos estudos pré-clínicos.

- Criar mecanismos que garantam um investimento sustentado em P\&D pelos produtores de vacinas. ${ }^{2}$

\footnotetext{
'Esta recomendaçăo deriva de uma sugestão do Dr. Célio Silva a quem os autores do trabatho devem a idéia da oficina sobre scale up $\mathrm{e}$ desenvolvimento de processos em vacinas.

${ }^{2}$ Agradecemos a colaboração dos assistentes de pesquisa Gabriela Maria Amorim Padilha e Leonardo Gomes Cardoso.
} 


\section{Avaliação Gerencial dos Produtores de Vacinas no Brasil}

José Cezar Castanhar

Francisco Marcelo Barone

Paulo Roberto Motta

\section{INTRODUÇÃO}

A produção de vacinas é um setor marcado por desafios bastante peculiares. Tratase de um campo que requer uma base científica e tecnológica intensa, cuja produção implica um alto custo fixo, necessitando, portanto, operar numa escala significativa; além disso, tem um ciclo de produção longo (de 3 a 6 meses). A organização da produção tem se caracterizado por uma concentraçăo contínua dos produtores e tem sido submetida, crescentemente, a exigências regulatórias (no que toca ao processo produtivo, ao desenvolvimento, controle, registro e uso de produtos).

Do lado da demanda, a produção de vacinas apresenta como características a predominância do setor público como principal comprador, distribuindo os produtos conforme os objetivos de políticas de saúde pública. Tem-se observado, também, uma ampliação da variedade de produtos demandados, decorrente, de um lado, das inovaçōes científicas e tecnológicas obtidas nos últimos anos e, de outro, da constatação, por parte das autoridades públicas, do impacto das políticas preventivas de saúde pública, tanto na eficácia dos benefícios que propiciam, quanto no que diz respeito à sua eficiência, em termos de relaçầo benefício/custo, quando comparadas a outras alternativas de intervenção.

No Brasil, o setor apresenta peculiaridades adicionais. Entre elas está o fato de que o país conta com um dos maiores mercados mundiais internos, tendo em vista sua população. As estimativas são de que o mercado nacional de vacinas, soros, hemoderi- 
vados e reativos para diagnóstico seja da ordem de 600 milhões de dólares (Homma, 2003). Uma outra particularidade é que o país tem uma significativa capacidade de produção de vacinas, a qual está, hoje, sob responsabilidade de produtores públicos ou filantrópicos, tendo em vista a decisão dos produtores privados internacionais de se retirarem do setor há cerca de duas décadas. Um outro aspecto crucial das características da produção de vacinas no Brasil é o fato de o governo federal, por intermédio da Fundação Nacional da Saúde (Funasa), vinculada ao Ministério da Saúde (MS), ser o único comprador de vacinas de todos os produtores nacionais.

Essas características resultam em marcantes fragilidades, impõem complexos desafios, mas oferecem importantes oportunidades. Dentre as fragilidades existentes pode-se mencionar a alta dependência do governo como comprador; o reduzido investimento em desenvolvimento, tecnologia e inovação, e a limitação da capacidade de inovação que daí resulta; a falta de flexibilidade administrativa decorrente das características institucionais da maioria dos produtores (instituiçōes submetidas às regras da administração pública). No que se refere às oportunidades, cabe destacar o próprio mercado em crescimento; as perspectivas de cooperação entre os produtores nacionais; a possibilidade de expansão das exportações; projetos em andamento de modernização e ampliação das plantas existentes; as possibilidades de parcerias com empresas multinacionais e o fato de que as políticas públicas de saúde parecem estar inseridas com prioridade na agenda política.

O subprojeto Vacinas, do Projeto Inovação em Saúde, procura estudar, discutir e propor alternativas para os vários desafios e oportunidades mencionados anteriormente. 0 projeto abrange várias dimensōes, tais como: perspectivas estratégicas de longo prazo, capacidade tecnológica, potencialidades em pesquisa e desenvolvimento (P\&D) e capacitação gerencial.

o presente trabalho trata da dimensão capacitação gerencial e está organizado da seguinte maneira: na próxima seção são feitas a descrição e a análise da situação atual; na seguinte são apresentadas recomendações de ações gerenciais, institucionais é políticas. $O$ Anexo 1 compõe-se do roteiro da entrevista utilizado na pesquisa e o Anexo 2, de alguns quadros que auxiliam a análise.

\section{ANÁLISE DA SITUAC̣̃̃O ATUAL}

Parece haver um consenso entre os especialistas do setor de produção de vacinas de que os seus desafios gerenciais estão relacionados aos seguintes aspectos: falta de flexibilidade administrativa decorrente de modelos institucionais adotados; limitação do montante de recursos financeiros e irregularidade do fluxo destes; limitações na gestão dos recursos humanos; restrições nos processos de aquisições e manutenção de insumos e equipamentos; fragilidade estratégica em virtude da dependência do setor público como único comprador (Homma, 2003).

Assim, a análise dos desafios de capacitação gerencial dos produtores de vacinas no Brasil foi dividida em duas dimensōes: institucional e funções gerenciais. Na dimensão institucional, examinaram-se as características jurídicas dos produtores e como isso afeta não só seu processo decisório, mas também as tarefas gerenciais. Na dimensão 
gerencial propriamente dita, identificaram-se as similaridades ou peculiaridades dos diferentes produtores no que toca às seguintes funções: gestão de Recursos Humanos; produção; comercialização e finanças. Nesta última foram destacados os aspectos relacionados à natureza dos controles financeiros existentes, especialmente no que diz respeito à apuração de custos, à composição da receita, à gestão de fluxo de caixa e rentabilidade.

Para o levantamento desses aspectos, foi desenvolvido um roteiro de entrevista semi-estruturada, o qual é apresentado no Anexo 1. Foram objeto da pesquisa, os quatro principais produtores de vacinas nacionais, a saber: a Fundação Ataulpho de Paiva (FAP), o Instituto Butantan, o Instituto de Tecnologia em Imunobiológicos (Bio-Manguinhos) e o Instituto de Tecnologia do Paraná (Tecpar). Além disso, foi pesquisado material bibliográfico relevante e relatórios de pesquisas relacionadas ao setor, dentre eles o relatório das oficinas que precederam este estudo.

$\mathrm{Na}$ análise apresentada a seguir, optou-se por discutir segundo cada dimensão, comparando-se características das instituiçōes analisadas em conjunto, em vez de descrever a situação de cada uma separadamente. Cabe destacar que, além da descrição e análise da situação existente, apresentam-se sugestões e recomendações com vistas a enfrentar as limitaçōes identificadas e aproveitar as oportunidades existentes.

\section{Dimensão institucional}

As quatro instituições pesquisadas apresentam situações bastante đistintas quanto ao seu status jurídico e modelo gerencial, como pode ser observado no Quadro 1 (Anexo 2). Existe uma fundação de direito privado, sem fins lucrativos e de utilidade pública, a FAP; uma empresa pública, pertencente integralmente ao Governo do Estado do Paraná, o Tecpar; um instituto, sem personalidade jurídica própria, vinculado a uma fundação pública (Fundação Oswaldo Cruz - Fiocruz), o Instituto de Tecnologia em Imunobiológi$\cos$ (Bio-Manguinhos); um centro de pesquisa vinculado à Secretaria de Saúde do Governo do Estado de São Paulo, o Instituto Butantan.

Em adição, como também indicado no Quadro 1, algumas dessas instituições contam com unidades independentes de apoio à gestão, denominadas fundaçōes de apoio, porém com características e finalidades bem distintas.

Assim, o Instituto Butantan conta com a Fundação Butantan, instituição privada, criada em 1984 para dar apoio gerencial ao primeiro, permitindo maior flexibilidade na gestão de recursos financeiros, de pessoal, processos de compra, entre outros. A Fundação Butantan tem sua vinculação ao Instituto assegurada por duas vias: uma por meio do seu processo de governança, já que a indicação de seus conselhos e de sua diretoria executiva resulta de um processo que está sob supervisão e controle do próprio Instituto Butantan e do governo estadual, a outra mediante instrumentos operacionais que distribuem responsabilidades entre o Instituto e a Fundação.

Já Bio-Manguinhos, que também conta com uma fundação de apoio - a Fiotec-, não a utiliza com a abrangência que se observa no Insituto Butantan, embora ela tenha sido criada com finalidade semelhante à de São Paulo. Existem, aparentemente, várias 
razões para isso. Uma delas é o fato de que a Fiotec não é exclusiva de Bio-Manguinhos, mas sim da Fiocruz como um todo, o que tornaria mais complexa a separação e transferência de funçōes gerenciais do Instituto para a Fundação. Outra razão é o posicionamento mais crítico e restritivo dos órgãos de controle interno da Fiocruz quanto ao uso desse mecanismo para aumentar a flexibilidade gerencial de Bio-Manguinhos, tendo em vista uma interpretação mais formal e rigorosa das normas administrativas do setor público.

o Tecpar, por seu turno, utiliza também uma fundação de apoio para a contratação de mão-de-obra, a Citipar. Entretanto, esta é uma entidade vinculada à Federação das Indústrias do Estado do Paraná e não tem nenhum vínculo institucional com o Tecpar, ao contrário dos dois casos anteriores.

A quarta instituição pesquisada, a Fundação Ataulpho de Paiva, é a única regulada pelo direito privado. Nesse sentido, não é afetada pelas restrições administrativas que atingem as demais, especialmente no que tange à gestão de pessoal, de compras e financeira. Dessa forma, a utilização de veículos institucionais para buscar a flexibilidade gerencial em qualquer dos seus aspectos é, naturalmente, dispensável.

o formato institucional (status jurídico, autonomia administrativa, designação de direção, características do processo decisório) e os mecanismos auxiliares discutidos anteriormente são um aspecto crucial na definição do grau de flexibilidade administrativa de que dispõe a organização. Essa flexibilidade - é bom lembrar - é especialmente importante para o desempenho das funções gerenciais fundamentais: gestão de recursos humanos, financeira (investimentos e gestão de caixa), compras e manutenção. A dimensão de marketing e comercialização é secundária, neste caso, tendo em vista o papel de único comprador representado pelo governo, o qual define a quantidade e o leque de produtos demandados.

De maneira geral, no que toca a todos os aspectos mencionados, o formato de instituição pública (fundação, instituto ou empresa) reduz de forma considerável essa flexibilidade e explica a busca de mecanismos, como as fundações de apoio, para recuperá-la. Como se observará nos itens seguintes, a eficácia dessas soluçōes depende de aspectos específicos do contexto em que estão sendo utilizadas. Essas iniciativas quase sempre colocam em lados opostos os dirigentes das organizaçōes - que têm a responsabilidade de produzir com eficiência e qualidade, no volume e no tempo exigidos pelo cliente, gerar excedentes para investir em pesquisa e equipamentos, inovar em produtos tecnologias e processos, contratar e qualificar pessoal-e os responsáveis pelo controle administrativo (auditores, procuradores). Esses últimos têm como tarefa assegurar que as regras do direito administrativo sejam cumpridas e, não raro, tendem a colocar o cumprimento ritualístico dos 'processos' antes do alcance de objetivos organizacionais substantivos (produção, eficiência, qualidade, inovação). Não se trata aqui de decidir quem tem razão. Provavelmente, ambos tenham, considerando os seus respectivos pontos de vista. O problema resulta de uma questão preliminar, ou seja, o desafio de realizar uma atividade de natureza empresarial (no caso, uma atividade altamente sofisticada, do ponto de vista tecnológico, e complexa, 
do ponto de vista gerencial) sendo um órgão público, cuja lógica de funcionamento não contempla as características de uma atividade empresarial.

Sendo assim, a busca de uma solução deve contemplar, como se argumentará mais à frente, diferentes alternativas, que vão desde a busca de formatos jurídicos mais apropriados, passando por soluções intermediárias (como o próprio uso de fundaçōes de apoio), e chegando a identificar açōes gerenciais mais tópicas e pragmáticas, que podem ser utilizadas no âmbito decisório das próprias organizações, sem necessariamente ferir regras de controle administrativo externo.

Note-se que a obtenção de flexibilidade administrativa pode ser uma condição necessária para a melhoria dos resultados da organização, mas certamente não será suficiente, nem pode ser vista como panacéia para os desafios dela. Um exemplo contundente e convincente desse argumento é a própria situaçăo da única das instituiçōes analisadas que não sofre das restrições impostas às organizações públicas, a FAP. Esse produtor, a despeito de dispor da flexibilidade administrativa típica das instituições privadas, enfrenta inúmeras dificuldades que estão associadas a outras dimensões gerenciais: as restriçôes financeiras decorrentes de um mercado controlado por um único comprador governamental atrasam a conclusão de investimentos para ampliação e melhoria da capacidade produtiva, limitam os investimentos em pesquisa e desenvolvimento e obriga a uma gestão de recursos humanos focada na restrição de custos.

Mais uma vez, a comparação deixa claro que a busca de soluções para o setor deve necessariamente considerar ações que contemplem tanto o modelo institucional dos produtores - na medida em que este limite a tarefa gerencial - quanto as práticas gerenciais internas de cada organização. Deve-se levar em conta, todavia, que soluções mais duradouras e eficazes exigiriam uma discussão do modelo de relacionamento dos produtores com o seu grande comprador, o governo.

\section{Dimensão gerencial}

Discutem-se a seguir as váriaș funções gerenciais analisadas, comparando-se a situação observada nas instituiçōes pesquisadas.

\section{Gestão de recursos humanos}

Nesta função, a análise pode ser dividida nos seguintes itens: modalidades e mecanismos de contratação, políticas de remuneração e qualificação. No que se refere à contratação, encontramos situações bastante distintas, mesmo entre as instituições de natureza pública pesquisadas.

Assim, em Bio-Manguinhos, como pode ser visto no Quadro 2 (Anexo 2), de um total de 745 funcionários, apenas 150 são do quadro permanente (no caso regidos pelo Regime Jurídico Único dos Servidores Civis da União), sendo os 595 restantes terceirizados. 0 pessoal terceirizado é alocado em atividades ligadas à produção (técnicos, administrativos e de apoio), ou em atividades de apoio, como manutenção e limpeza; para essas contratações, utilizam-se empresas de intermediação de mão-de-obra. Essa é uma situ- 
ação que decorre diretamente da característica jurídica do Instituto, uma vez que, sendo um órgão público, só pode recrutar pessoal mediante concurso público. Essa exigência acarreta pelo menos dois problemas gerenciais. De um lado, a autorização para concursos públicos é um processo demorado e quase sempre submetido às restriçōes orçamentárias gerais do governo. O processo de produção, contudo, não pode esperar o tempo demandado para a realização do concurso público, mesmo que ele fosse autorizado; portanto, a contratação de mão-de-obra por meio de mecanismos mais flexíveis e práticos torna-se, assim, inevitável. De outro lado, a convivência com dois regimes distintos de contratação, com políticas salariais distintas, acarreta novo problema gerencial, o de convivência de pessoas em funçōes equivalentes, porém com remunerações diferentes, além de uma instabilidade maior no quadro de pessoal, ocorrendo maior rotatividade, o que pode trazer transtornos para o processo produtivo. Note-se que, mesmo que houvesse a possibilidade de contratar todos os empregados na condição de funcionários públicos, poderia não ser uma solução adequada, já que, para as funções de apoio, poderia ocorrer uma elevação significativa de salários e, conseqüentemente de custos, criando aí um problema financeiro.

A situação do Tecpar é semelhante à de Bio-Manguinhos no tipo de solução adotada, embora diferente em termos de escala. O Tecpar utiliza também uma instituição externa, a Citipar, para a contratação de funcionários terceirizados que irão compor seu quadro de pessoal. Todavia, do quadro total de pessoal (420 pessoas), 280 são funcionários do Tecpar (regime CLT, já que se trata de uma empresa) e 140 são contratados através da Citipar, $90 \%$ dos quais trabalham na produção (lotados nos dois biotérios do Instituto) e $10 \%$, em funções administrativas, em diferentes setores.

Cabe destacar que, nos dois casos, existe uma pressão grande dos órgãos de controle (procuradores), questionando a legalidade e manutenção desse arranjo. No caso do Paraná, por exemplo, existe a perspectiva de se realizar concurso público para preenchimento das funções que hoje são realizadas pelo pessoal terceirizado. Ressalte-se que tal medida, se resolve um problema (o legal), cria outro (de natureza gerencial), já que o pessoal hoje contratado indiretamente realiza atividades importantes para o processo produtivo e, mais ainda, acumulam uma importante experiência nessas funções. Logo, a substituição abrupta de um terço do pessoal da organização poderia provocar um grave problema de descontinuidade.

No Instituto Butantan, a situação tem características próprias, tanto pelo número de empregados do quadro total, quanto pela distribuição destes segundo a forma da contratação. Como pode ser observado no Quadro 2 , quase $80 \%$ dos funcionários são servidores públicos estaduais, contratados diretamente pelo Instituto. Os cerca de $20 \%$ restantes são contratados pela Fundação Butantan, que funciona como um braço gerencial do Instituto. A Fundação adota, inclusive, a mesma estrutura salarial dos servidores públicos, assegurando que não haja diferenças de remuneração entre pessoas trabalhando em funções equivalentes. 
Já na Ataulpho de Paiva, apenas os prestadores de serviços auxiliares (manutenção e limpeza) não são do quadro, sendo terceirizados. Curiosamente, no caso dessa instituição que não tem restrições para contratar funcionários e que tem autonomia para definir sua política salarial, o problema se revela pelo lado financeiro. Ou seja, quando a situação financeira se agrava não resta alternativa a não ser reduzir a folha salarial, o que se faz ou com a demissão de funcionários, ou com a contratação de funcionários menos experientes, com menor salário.

O tópico políticas de remuneração encontra pouco ou nenhum espaço de discrição no caso das instituições públicas. De maneira geral, tem-se uma política salarial definida externamente para os funcionários do quadro permanente, a qual servirá de balizamento para os salários dos demais funcionários (indiretos), podendo-se adotar a equivalência, no caso de Butantan, ou políticas diferenciadas, no caso de Bio-Manguinhos. o Tecpar tem uma situação diferente já que pode adotar sua própria estrutura salarial. Em face das restrições financeiras existentes, a empresa tem se limitado a conceder os reajustes definidos em acordos coletivos de trabalho, tanto para os funcionários do quadro, como para os terceirizados. A Fundação Ataulpho de Paiva, por sua vez, estabelece política de remuneração atrelada às restrições financeiras, limitando-se a conceder os aumentos legais aplicáveis.

Em nenhum dos casos se adota algum mecanismo de remuneração variável, aplicável com base na avaliação de desempenho dos funcionários e associado ao cumprimento de metas. Nas instituições onde existem complementações ou gratificaçōes, elas são generalizadas e decorrentes de atributos do funcionário (tempo de serviço, cargo).

Quanto à qualificação do pessoal, como já foi evidenciado nos estudos sobre avaliação tecnológica e potencialidades em $P \& D$, existe um déficit de qualificação, que ocorre também nas funções gerenciais. Neste item podem ser identificados dois tipos de restriçôes. Um de natureza legal, que se aplica principalmente a funcionários públicos, os quais são regidos por regras mais rígidas no que se refere a dispensas para treinamentos, afastamentos do país; podendo haver, inclusive, dificuldades em termos da estrutura orçamentária e da disponibilidade de recursos para financiar o treinamento desses funcionários. Trata-se de um tipo de restrição que poderia ser contornado com a utilização de fundações de apoio. O outro tipo de restrição é de natureza financeira. Lidando permanentemente com severa escassez de recursos, e com prioridades muitas vezes inadiáveis para investimentos em produção, não raro os recursos destinados à qualificação de pessoal são vistos como 'despesas' e não como 'investimentos', numa avaliação de curto prazo que pode comprometer objetivos estratégicos de longo prazo (como desenvolvimento tecnológico e inovação, melhoria de eficiência gerencial).

\section{Produção e comercialização}

A escala e a variedade de produtos de cada um dos laboratórios pesquisados variam significativamente, formando, de fato, dois grupos distintos, conforme pode ser verificado no Quadro 3 (Anexo 2). Num grupo, com escala de produção superior a 100 milhões de 
doses anuais e com um portfolio de vacinas bastante variado, situam-se Bio-Manguinhos e o Instituto Butantan. Essas duas instituições apresentam receita da ordem de $150 \mathrm{mi}$ lhões de reais anuais e poderiam ser classificadas como empresas de médio para grande porte. $O$ outro grupo, constituído pelo Tecpar e a FAP, produz uma única vacina: o primeiro produz a vacina anti-rábica canina, com produção anual da ordem de 30 milhōes de doses, e o segundo a vacina BCG, com produção anual da ordem de 16 milhões.

o Tecpar, na realidade, tem ainda uma singularidade, já que, além do desenvolvimento dos produtos biológicos, também presta serviços variados de apoio à indústria do estado do Paraná, tais como certificação de sistemas de qualidade, informação, tecnologia de materiais, saúde e meio ambiente (apoio ao controle de qualidade da indústria), metrologia (calibração elétrica e mecânica) e educação e treinamento (Gadelha \& Temporão, 1999). Ademais, produz ainda antígenos para diagnóstico de doenças em animais, como a brucelose.

A receita operacional (oriunda da venda de produtos e serviços) do Tecpar é da ordem de 20 milhões de reais anuais e a da FAP situa-se na casa dos 5 milhões, deixando clara a diferença de escala entre os dois grupos pesquisados, bem como dentro desse segundo grupo.

Ėm relação à comercialização, as quatro instituições dependem, em mais de $90 \%$, das vendas realizadas para o MS, por intermédio da Funasa, para atender aos programas públicos de vacinação. Isso, naturalmente, traz vantagens e desvantagens. A vantagem óbvia é a garantia de um comprador para toda a produção, dispensando as instituições de estratégias de comercialização mais agressivas e competitivas e reduzindo a incerteza no que diz respeito ao escoamento da produção. A desvantagem, também óbvia, é a dependência de um único comprador com os riscos que daí decorrem: a possibilidade de imposição de preços que obrigam os produtores a trabalhar com margens reduzidas - ou mesmo negativas - em alguns produtos e a incerteza quanto ao fluxo financeiro, na ocorrência de atrasos no pagamento, o que não é incomum. Esses dois últimos aspectos voltarão a ser discutidos no item Gestão Financeira.

Das quatro instituições, cabe mencionar uma peculiaridade do Tecpar, que vende os antígenos para veterinários particulares e adota uma política de comercialização bastante desvantajosa do ponto de vista financeiro, que é a venda em consignação. Dessa forma, só há receita quando (e se) ocorrer a venda, o que significa, na prática, que a empresa está financiando o capital de giro dos profissionais privados. Existe, ainda, um outro problema decorrente do fato de que os produtos têm prazo de validade e, se não consumidos nesse prazo, têm de ser inutilizados. Quando a devolução se dá após o prazo de validade, o que também não é incomum, a empresa arca com os custos, o que impacta negativamente na sua rentabilidade. A solução para esse problema requereria uma melhoria significativa nos sistemas de distribuição e monitoramento de estoques.

As outras três instituições estão iniciando diversificação de suas estratégias de comercializaçăo, procurando direcionar excedentes de produção para o mercado externo. Bio-Manguinhos já iniciou a exportação da vácina contra a febre amarela e Butantan 
prevê exportar, além dos soros, outras vacinas, conforme negociações com o Unicef. A FAP também tem possibilidade de exportar sua vacina $\mathrm{BCG}$, dependendo, para isso, da certificação da Anvisa.

Deve-se enfatizar que essa estratégia deveria ser vista como prioridade por todas as instituições, já que traz benefícios em todos os sentidos. Aumenta a receita, pode produzir um fluxo mais regular do que com o comprador nacional, permite ocupar capacidade ociosa, cujos custos fixos já são incorridos, aumentando, portanto, a eficiência e, eventualmente, permite vender a preços mais vantajosos do que o obtido com o comprador nacional. Para tanto, o grande esforço e investimento que todos devem fazer é melhorar a qualidade dos processos produtivos e obter gradualmente certificaçōes internacionais.

Ainda um outro ponto que representa uma séria dificuldade na gestão das instituiçōes pesquisadas diz respeito às regras existentes para realização de compras e contratação de serviços. As instituições públicas estāo sujeitas à Lei 8.666, que estabelece um rígido procedimento para essas duas atividades, o qual, com freqüência, revela-se incompatível com a dinâmica exigida por uma atividade industrial, com a escala e a sofisticação apresentada nessas instituições para a produção de vacinas. Para Bio-Manguinhos e Tecpar, esse tem sido um ponto crítico no processo de gestão, que geralmente acarreta conseqüências negativas para o processo produtivo.

Por exemplo, uma estratégia moderna de gestão é a parceria e a certificação de fornecedores, o que, para o setor de vacinas, no qual a qualidade é crucial, é particularmente importante. Essa possibilidade, entretanto, tende a ser vetada pelos auditores, sob a alegação de que fere a lógica da concorrência estimulada pela lei.

É interessante observar que a FAP, por ser uma instituição privada, não sofre conseqüências nesse aspecto e que no Instituto Butantan esse problema é minimizado pela parceria e vínculo institucional com a Fundação Butantan, também de natureza privada.

Tendo em vista a análise do volume e da variedade de produtos das quatro instituiçóes, mostrados no Quadro 3, é importante observar, ainda, que, a despeito das dificuldades e restriçōes e incerteza com que operam, os produtores nacionais têm realizado progressos significativos tanto no aumento da produção quanto no aumento da variedade de produtos oferecidos Dessa forma, contribuem grandemente para a redução da dependência do país de produtos importados e, ao mesmo tempo, permitem que o governo possa, a um custo baixo, melhorar as condiçōes de saúde da população, o que pode ser confirmado pelo exame do Quadro 4 (Anexo 2).

Uma outra mudança considerável observada nos últimos três anos é a ampliaçâo e consolidação de estratégias de parcerias entre as várias instituiçōes. Essa parceria vem. se dando no plano de estratégias de produção conjuntas, no de utilização de insumos e na realização de pesquisas conjuntas. Assim, por exemplo, vacinas produzidas pelo Butantan estăo sendo conjugadas com vacinas produzidas por Bio-Manguinhos, como é o caso da DTP + Hib, e insumos produzidos pelo Tecpar, como anatoxina tetânica, serão utilizados por Bio-Manguinhos para a produção da vacina Hib. Vale ressaltar esse aspecto porque, do ponto de vista estratégico, no que tange tanto à escala de produção, 
quanto a estratégias de pesquisa e comercialização, cada vez mais a integração, associação e parcerias serão vitais no setor, como já foi enfatizado por vários autores (Homma, 2003; Temporão, 2003). Além do mais, também do ponto de vista gerencial, existem importantes possibilidades de melhorar a eficiência por meio de estratégias de cooperação e parcerias.

\section{Gestão financeira}

Neste tópico, três aspectos distintos foram examinados: o preço praticado pelo comprador, a regularidade do fluxo financeiro e os controles de custos adotados pelas instituiçōes pesquisadas.

Com relação ao preço praticado, os produtores lidam com uma política do governo que, se por um lado, pode parecer eficiente quando analisada isoladamente e a curto prazo, por outro, pode trazer graves conseqüências quando olhada numa perspectiva estratégica do país como um todo, e em particular para a área de pesquisa científica, desenvolvimento, tecnologia e inovação. Trata-se do critério estabelecido pelo MS de estabelecer o preço de referência do Fundo Rotatório da Organização Pan-Americana da Saúde como preço máximo para a aquisição das vacinas. De fato, esse critério pode trazer economia para o governo a curto prazo e impõe aos laboratórios o desafio gigantesco de se tornarem eficientes segundo padrōes internacionais. Existem argumentos e evidências, no entanto, de que os preços cotados para o Fundo Rotatório por empresas internacionais podem embutir uma estratégia de dumping, visto que, como estas já têm os seus custos fixos amortizados pelos mercados domésticos, poderiam exportar o produto por um valor pouco acima do custo marginal.

Se verdadeira, essa manobra imporia aos laboratórios brasileiros uma concorrência desleal. Pode-se argumentar que, para o governo (e em conseqüência para a população), sempre haveria uma vantagem, pois estaria comprando o produto pelo preço mais baixo possível, porém essa visão desconsidera dois aspectos. Se essa estratégia de compras inviabilizar a existência dos produtores nacionais, a médio prazo o país aumentaria a sua dependência do fornecimento externo com desvantagens tanto em termos de gasto de divisas como em termos de preço, uma vez que, sem o anteparo de uma competição local, os fornecedores externos poderiam praticar preços abusivos. Um segundo aspecto que não é levado em conta nessa visão contábil de curto prazo é o fato de que, em outros setores da economia, o governo questiona os competidores internacionais quando suspeita que estes estejam praticando dumping, abrindo inclusive processos contra os mesmos (quando encontra evidências respeitáveis) na Organizaçăo Mundial do Comércio (OMC). Um exemplo disso foi a demanda recente do governo brasileiro na OMC envolvendo a disputa pelo mercado internacional de aviōes entre a Embraer e a canadense Bombardier. Ora, o setor de produção de vacinas é, no mínimo, tăo importante para o país quanto o de aviação, seja em termos de geração de tecnologia, seja em termos de economia de divisas, e, além disso, traz um incomparável benefício social. 
Em face da política vigente, são comuns as reclamações entre os produtores de que algumas vacinas são vendidas por preços que deixam margens mínimas de lucro e, em casos extremos, até com margem negativa. Um estudo recente realizado pelo Tecpar-e encaminhado ao MS - sobre o custo efetivo da vacina contra a raiva canina aponta para uma defasagem de mais $20 \%$ entre o preço pago pelo MS e o custo efetivo (incluindo custos indiretos e sem considerar qualquer valor para investimento ou superavit). Com isso, na prática, a empresa está subsidiando, através dos recursos orçamentários que recebe do governo do estado, o governo federal.

Um outro caso em que essa política tem trazido prejuízos estratégicos para o país como um todo é a situação da FAP, que tem um importante projeto de modernização paralisado pela falta de um valor relativamente pequeno para concluí-lo. Essa situação é injustificável por dois motivos. Primeiro, porque um volume de investimentos significativo já foi realizado e está sendo depreciado sem ser utilizado, impondo à sociedade um enorme custo de oportunidade. Segundo, porque, concluído o projeto, a instituição poderá melhorar suas práticas de fabricação, aumentar sua escala de produção e passar a exportar seu produto, gerando divisas para o país.

A conseqüência mais visível e negativa dessa visão de curto prazo, entretanto, tem sido o comprometimento da capacidade de investimento na produção e, principalmente, na pesquisa e desenvolvimento científico. Como já ressaltado na discussão dos outros estudos que fazem parte deste capítulo, ampliar essa capacidade de investimento é crucial para que o país não aprofunde a defasagem tecnológica que hoje apresenta em relação aos países desenvolvidos e para alavancar a sua, já importante, base de pesquisa estabelecida.

Dessa forma, deve-se fazer um esforço, a curto prazo, por uma discussão ampla das consequeências dessa política e por uma revisão da mesma.

No que toca aos controles de custos, essa é uma ferramenta gerencial essencial, tanto para a busca de maior eficiência, como para o próprio municiamento do setor para a discussão com as autoridades governamentais sobre mudanças na política de preços em vigor. Neste tópico observam-se, mais uma vez, situações distintas. Em Bio-Manguinhos e no Instituto Butantan, a informação obtida é que, embora se adotem e se utilizem procedimentos para a apuração de custos, estes são parciais e não muito precisos, senđo essa uma área em que as duas instituiçōes considerem prioritário investir e aprimorar.

No caso da FAP, a situação é mais simples e a a puração de custos praticamente redundante, já que a instituição desenvolve um único produto. Assim, o custo final é o custo total da instituição dividido pela produção.

Das instituições pesquisadas, aquela que apresenta uma condição mais sofisticada nesse aspecto é o Tecpar. A empresa paranaense dispõe de uma metodologia bem-estruturada de apuração de custos de todos os seus produtos, incluindo todos os custos diretos e, através de rateio, todos os indiretos. Esse cálculo ainda é feito por meio de sistemas específicos pela área financeira. Contudo, a empresa já adquiriu um sistema de automação gerencial integrado (Enterprise Resources Planning ou ERP), que permite a 
automação e integraçăo das informaçōes sobre produçăo, estoques e vendas, obtendose, em tempo real, a apuração de custos, produção, estoques. Esse sistema ainda está em fase de implantação, mas revela que a empresa está tratando de forma estratégica e prioritária a melhoria gerencial.

Com relação à regularidade do fluxo de recursos financeiros, esse tem sido, segundo os representantes dos institutos, o principal problema de gestão financeira enfrentado nos últimos anos. Em face das restrições orçamentárias em vigor há, pelo menos, quatro anos e da busca de superavits fiscais, os produtores têm de enfrentar o "contingenciamento' de recursos, o que acarreta enorme incerteza em relação ao recebimento destes e, não raro, atrasos significativos, provocando óbvias conseqüências negativas em toda a cadeia produtiva. A seqüela mais visível é a necessidade de ter de atrasar o pagamento a fornecedores, podendo acarretar o desinteresse da empresa em continuar fornecendo ou levando os fornecedores a embutir nos preços o custo de atraso, havendo, assim, um aumento de custos no setor.

Na FAP, esse problema é dramático porque, sendo uma instituição privada, acaba tendo de recorrer a empréstimos no mercado financeiro, fragilizando ainda mais sua situação financeira.

Das instituições pesquisadas, a única que não considerou esse problema como comprometedor de sua programação financeira foi o Tecpar, que informou receber com regularidade os valores resultantes das vendas feitas ao governo.

\section{RECOMENDAÇÕES}

Apresentam-se a seguir algumas recomendações de ações por parte do conjunto de instituições produtoras de vacinas, a fim de aprimorar seu modelo de gestão e contribuir para enfrentar com sucesso os desafios gerenciais apresentados no item anterior. Essas ações compreendem três níveis distintos: ações imediatas que não exigem mudanças institucionais ou mobilizações políticas mais complexas e que demandam apenas iniciativas no nível de direção e gerencial de cada instituição; ações com vistas a mudanças no modelo institucional, que exigem uma mobilização política maior, porém mais focada em cada instituição isoladamente; açōes de natureza estratégica e política, que requerem maior mobilização política e que envolvem o setor como um todo.

\section{Ações gerenciais}

A pesquisa mostrou que, apesar de tamanhos, culturas, trajetórias e estruturas diferentes, cada instituição se destaca em algum aspecto. Trata-se aqui, portanto, de aprofundar o exame dessas 'melhores práticas gerenciais' ou 'alavancas institucionais' de que cada organização dispõe, em benefício de todas ąs outras.

O Instituto Butantan, por intermédio da Fundação Butantan, por exemplo, dispõe de maior flexibilidade para compras. Sugere-se examinar a constituição de algum mecanismo de cooperativa ou consórcio para compras, centralizado na Fundação. O repasse para as demais instituições poderia ser feito mediante troca de serviços, de produtos, ou 
mesmo por meio de um fundo de compensação que fosse criado entre as quatro instituições. É importante ressaltar que o resultado final dessa iniciativa será a compra de produtos e serviços mais baratos, com mais agilidade, beneficiando, conseqüentemente, a sociedade como um todo, que é exatamente o que o direito administrativo busca.

o Tecpar está num estágio mais avançado, no que se refere ao controle de custos e à aquisição de um sistema de gestão integrada, o que, provavelmente, será inđispensável, a médio prazo, para aumentar a melhoria gerencial e a eficiência, principalmente, dos grandes produtores. Uma outra ação seria estabelecer uma parceria com o Tecpar, inicialmente para treinamento dos funcionários das demais instituições e transferência dos modelos de apuração de custos que o Instituto já adota, e, num segundo momento, para a própria transferência, se isso se revelar apropriado, do Sistema Integrado de Gestão que está sendo implantado naquela empresa.

Bio-Manguinhos conseguiu recentemente certificação internacional para a vacina da febre amarela. Esse processo é complexo, demorado e requer um treinamento muito específico das pessoas envolvidas. Uma outra ação sugerida, na linha da anterior, é que Bio-Manguinhos seja a 'âncora' de um programa de capacitação dos profissionais de cada instituto para o processo de certificação, disseminando o conhecimento adquirido.

O uso comum de infra-estrutura, de logística (caminhões) e outros recursos gerenciais juntamente com a criação de um grupo de trabalho que vise a identificar na Lei 8.666 pontos críticos para o setor de vacinas são outros exemplos de linhas de ação que podem ser institucionalizadas e praticadas com freqüência, ampliando as áreas e as possibilidades de cooperação gerencial, à semelhança do que se vem fazendo no plano de pesquisa e de produção. A idéia geral dessas recomendaçōes é identificar instituiçõesâncora, à semelhança do proposto por Gadelha (2003), para identificar e disseminar melhorias gerenciais.

\section{Mudanças institucionais}

Foi mencionado anteriormente que vários dos problemas gerenciais e estratégicos que o setor enfrenta resultam do formato institucional de organização pública que algumas delas ostentam. Os resultados dessa pesquisa indicam que não é necessariamente o formato institucional, e sim o contexto em que ele é praticado que pode levar, ou ao surgimento de maiores restrições, ou a um ambiente de maior flexibilidade e cooperação.

O risco aqui é de investir muito tempo e esforço em mudanças institucionais mais radicais para finalmente chegar à conclusão de que a melhoria não foi tão grande. Todavia, para orientar essa discussão, apresenta-se, nos Quadros 5 a 9 (Anexo 2), um exame detalhado dos formatos jurídicos possíveis para o setor público, para o setor privado e para o terceiro setor. Examinam-se, em particular, os modelos de organização social (OS), serviço social autônomo (SSA), organização da sociedade civil de interesse público (Oscip) e empresa pública (EP).

Nesses quadros, apresentam-se as características de cada formato, os procedimentos para sua implantação, vantagens e desvantagens de cađa modelo, enfatizando-se na última tabela o modelo de os. 
Apenas para ilustrar, cabe mencionar que a rede de Hospital Sarah Kubitschek apresenta of formato de SSA e que o Instituto de Biologia Molecular do Paraná se organiza sob a forma de OS. Cabe notar, ademais, que o Incor, vinculado ao Hospital Universitário da USP, tem o formato de fundação privada, semelhante à Fiotec e à Fundação Butantan. Esses três exemplos, embora organizados de forma diferente, são conhecidos por terem atendido amplamente e com sucesso o objetivo para o qual foram criados: dar maior autonomia e flexibilidade para um serviço de natureza pública, prestado com recursos predominantemente públicos. Mais uma vez, a razão do sucesso parece estar menos vinculada à natureza jurídica da organização e mais ao contexto político, social, cultural e científico que cercaram e inspiraram sua criação.

\section{Mudanças estratégicas}

Trata-se aqui de desafiar as lideranças científicas e políticas da área para lutarem por mudanças significativas no contexto em que o setor opera. O combustível dessa mudança é, indiscutivelmente, mobilização e influência política.

Sugerem-se, em princípio, quatro tipos de ações:

1) Insistir na mudança dos preços praticados atualmente pelo governo, de forma a assegurar que os valores pagos incluam margem de lucro suficiente para permitir a boa gestão das empresas e a geração de um excedente para investimentos. A analogia e a inspiração para essa ação é a Petrobras. Uma política de governo permitiu que esta empresa praticasse internamente um preço para o combustível muito superior aos seus custos. Com isso, ela foi capaz de gerar uma quantia gigantesca de lucro, os quais estão sendo investidos integralmente no setor e estão permitindo à Petrobras alcançar a autosuficiência, objetivo estratégico do país.

2) Criar um fundo de capital de giro, capitalizado pelo governo e que será gerido de forma paritária pelos produtores de vacinas e por representantes do governo. Tem como objetivo suprir os produtores com capital de giro na eventualidade de irregularidade no fluxo de recursos, impedindo prejuízos na produção, custos extras e ineficiências.

3) Buscar mercados alternativos, mediante a exportação de vacinas. Essa estratégia, associada a uma política pública de abertura de novos mercados, aproveitando a posição de liderança regional do Brasil, além de diminuir os custos fixos com a ampliação da escala de produção, captaria recursos fora do MS, reduzindo a dependência dos produtores, e geraria divisas para o país.

4) Insistir na regularidade do fluxo de recursos para o setor, o que complementa as ações anteriores. Deve-se insistir à exaustão e usar toda a capacidade de mobilização política das lideranças do setor para argumentar e comprovar os enormes benefícios que este traz para a sociedade, em termos sociais (melhoria das condições de saúde), econômicos (produção e geração de empregos) e de balança de pagamentos (economizando importações a curto prazo e gerando exportações a longo prazo). 0 exemplo inspirador aqui é a Embrapa, que, respondendo ao apoio e à prioridade que obteve do governo, deu uma 
contribuição decisiva para que o setor agrícola desse um salto espetacular nos últimos cinco anos, gerando benefícios sociais (abastecimento), econômicos (combate à inflação e geração de empregos) e para a balança de pagamentos.

Para finalizar, e se essas sugestões parecem exageradas ou irrealistas, vale lembrar o seguinte pensamento: "para realizar um sonho, antes é preciso sonhar".

\section{REFERÊNCIAS BIBLIOGRÁFICAS}

BRASIL. Ministério da Saúde. Avaliação tecnológica da produção de imunobiológicos no Brasil e definiçāo de nichos de atuação. Projeto Inovação em Saúde. Rio de Janeiro: Fiocruz/MS, 2003.

GADELHA, C. A. Estruturas, dinâmica e articulação da política inđústria e tecnológica com a política de saúde. In: SEMINÁRIO NACIONAL SOBRE O COMPLEXO INDUSTRIAL DA SAÚDE. Rio de Janeiro: BNDES, 2003.

GADELHA, C. A. \& TEMPORĀO, J. G. A Indústria de Vacinas no Brasil: desafios e perspectivas. Rio de Janeiro: BNDES, 1999. (Mimeo.)

HOMMA, A. A inđústria de vacinas no Brasil: aspectos gerenciais dos produtores. In: SEMINÁRIO NACIONAL SOBRE O COMPLEXO INDUSTRIAL DA SAÚDE. Rio de Janeiro: BNDES, 2003.

MARTINS, H. F. Modelos Jurídico-Organizacionais no Setor Público. Palestra proferida na Fundação Getúlio Vargas, em agosto de 2002.

TEMPORÃO, J. G. A indústria de vacinas: o Brasil no contexto mundial. In: SEMINÁRIO NACIONAL SOBRE O COMPLEXO INDUSTRIAL DA SAÚDE. Rio de Janeiro: BNDES, 2003. 


\section{ANEXO 1 - Roteiro da Entrevista}

\section{Questionário}

I-Perfil Institucional:

1) Definir a estrutura organizacional do produtor de vacinas. Levar em consideração e explicitar os níveis institucional, intermediário e operacional.

2) Definir, de acordo com as práticas organizacionais vigentes, as seguintes dimensões e sua utilização e importância no dia-a-dia do produtor de vacinas:

2.1) Planejamento (explicitar os objetivos a atingir e os meios para alcançá-los).

2.2) Controle (explicitar os padrões de desempenho e a avaliação de desempenho (se existirem).

2.3) Direção (levar em consideração: alcance dos objetivos da organização, preenchimento dos cargos, comunicação, liderança, motivação).

2.4) Organização (levar em consideração: definição e alocação dos recursos, estruturação dos órgãos, autoridade e responsabilidade).

3) Definir, caso exista, a relação do produtor de vacinas com o governo, levando em consideração os seguintes pontos:

3.1) Subordinação política.

3.2) Implicaçōes legais desta subordinação, tais como: legislação, estatutos, Lei 8.666, pessoal (barreiras à contratação versus terceirização), questões financeiras (orçamento 'público', orçamento 'privado' - fundação de apoio -, captação de recursos), Ministério da Saúde, Agência Reguladora, entre outros.

II - Práticas Gerenciais:

1) Definir, através das seguintes variáveis, a relação do produtor de vacinas com o mercado.

1.1) Fornecedores de insumos.

1.2) Concorrentes (nacionais e internacionais).

1.3) Clientes (nacionais e internacionais).

1.4) Possibilidade de novos entrantes.

2) Gestão financeira e orçamentária do produtor de vacinas.

2.1) Descrever o processo de gestão financeira da instituição.

2.2) Informar se existe um sistema de informações gerenciais ou de contabilidade gerencial.

2.3) Descrever o processo de gestão do caixa (com ênfase em contas a receber e contas a pagar).

2.4) Informar se existe planejamento financeiro de curto, médio e longo prazo. Quais são os parâmetros/critérios norteadores das projeções?

3) Definir o modus operandi da produção, levando em consideração:

3.1) Tipos de produtos e suas principais características. 
3.2) Organização da produção (variáveis a serem detalhadas por produto: custos, preço final, produtividade, competitividade, capacidade produtiva e ociosa, Boas Práticas de Fabricação-BPF).

3.3) Processo produtivo e sua logística interna.

4) Definir a política de recursos humanos através das seguintes variáveis:

4.1) Força de trabalho (quadro permanente e terceirizados).

4.2) Política de cargos e salários.

4.3) Política de desenvolvimento pessoal.

5) Descrever a tecnologia de produção utilizada no processo produtivo, sob o ponto de vista gerencial, levando em consideração os produtos, recursos humanos, mercado, planejamento e finanças.

5.1) Com relação a cada produto, levar em consideração, entre outras, as seguintes variáveis: grau de atualização; se o processo é o mais adequado em termos de layout, procedimentos (por exemplo, manipulação), seqüências de transformação (matéria-prima > processo produtivo > vacina), tendo como pano de fundo a questão das BPF.

5.2) Recursos Humanos: a qualificação e a qualidade da força de trabalho vis-a-vis à tecnologia utilizada (e desejada, se for o caso) no processo produtivo.

5.3) Mercado: a tecnologia utilizada no processo produtivo habilita o produtor de vacinas a atuar no mercado local em nichos, segmentos e/ou massa? Com relação ao mercado internacional, como esta tecnologia está relaciona com as questôes de preço e BPF?

5.4) Planejamento: Como a tecnologia atualmente utilizada se relaciona com os planos e estratégias de ação de médio e longo prazo? É sustentável no tempo?

5.5) Finanças: Quais os resultados da tecnologia utilizada em termos de margem (custo, volume e receitas)?

6) Qual a relação entre a ação gerencial e a gestão estratégica (estratégia/planejamento), nos níveis estratégico, tático e operacional?

6.1) A gestão da organização está harmonizada com o planejamento? De que forma?

6.2) A organização está apta a executar uma gestão estratégica? Por quê?

6.3) Até que ponto, e de que forma, a relação com o governo afeta o planejamento da organização?

6.4) Definir, se existir, a missão, visão, objetivos e hierarquia dos objetivos organizacionais.

6.5) Como se dá o desdobramento das ações (passagem do plano estratégico para o operacional)?

6.6) Existe benchmarking em alguma área da organização? 
ANEXO 2-Quadros

Quadro 1 - Perfil institucional dos produtores

\begin{tabular}{|c|c|c|}
\hline Produtor & Natureza jurídica & Fundação de apoio \\
\hline Bio-Manguinhos & $\begin{array}{l}\text { Instituto vinculado à Fundação } \\
\text { Oswaldo Cruz (Fiocruz), uma } \\
\text { fundação pública }\end{array}$ & $\begin{array}{l}\text { Fiotec: } \\
\text { - fundação de apoio privada sem fins } \\
\text { lucrativos; } \\
\text { - não é espeć́fica de Bio- } \\
\text { Manguinhos, serve toda a Fiocruz; } \\
\text { - utilizada para a exportação da } \\
\text { vacina de febre amarela; } \\
\text { - utilizada para o treinamento dos } \\
\text { terceirizados; } \\
\text { - supre algumas das deficiências } \\
\text { orçamentárias, realizando pequenas } \\
\text { compras necessárias para as } \\
\text { atividades produtivas. }\end{array}$ \\
\hline Instituto Butantan & $\begin{array}{l}\text { Órgão da administraçāo direta do } \\
\text { estado de São Paulo, vinculado à } \\
\text { Secretaria de Saúde }\end{array}$ & $\begin{array}{l}\text { Fundação Butantan: } \\
\text { - fundação de apoio privada sem fins } \\
\text { lucrativos; } \\
\text { - comercializa toda a produção do } \\
\text { Instituto; } \\
\text { - agente que firma os contratos com o } \\
\text { MS; } \\
\text { - supre as deficiências } \\
\text { orçamentárias, realizando as } \\
\text { compras necessárias para as } \\
\text { atividades produtivas; } \\
\text { - possui uma política de apoio às } \\
\text { atividades de pesquisa básica do } \\
\text { Instituto. }\end{array}$ \\
\hline Fundaçāo Ataulpho de Paiva & $\begin{array}{l}\text { Instituição de direito privado, sem } \\
\text { fins lucrativos, de utilidade pública }\end{array}$ & Não possui fundação de apoio. \\
\hline $\begin{array}{l}\text { Instituto de Tecnologia do Paraná - . } \\
\text { Tecpar }\end{array}$ & $\begin{array}{l}\text { Empresa pública de direito privado do } \\
\text { governo do estado do Paraná }\end{array}$ & $\begin{array}{l}\text { - Não possui fundação de apoio. } \\
\text { - Utiliza uma entidade ligada à . } \\
\text { Federaçãa das Indústrias do Estado } \\
\text { do Paraná (Citipar) para a } \\
\text { contratação de funcionários } \\
\text { terceirizados. }\end{array}$ \\
\hline
\end{tabular}

Fonte: Pesquisa de campo. 
Quadro 2 - Recursos humanos

\begin{tabular}{|c|c|c|c|}
\hline Produtor & Total & Diretos & Terceirizados \\
\hline Bio-Manguinhos & 745 & 150 & $\begin{array}{l}595 \text { (através de empresas } \\
\text { de intermediação de mão- } \\
\text { de-obra) }\end{array}$ \\
\hline Instituto Butantan & $\begin{array}{c}1.020 \\
\text { (aproximado) }\end{array}$ & $\begin{array}{c}800 \\
\text { (do Instituto) }\end{array}$ & 220 (da Fundação) \\
\hline $\begin{array}{l}\text { Fundação Ataulpho de } \\
\text { Paiva }\end{array}$ & 155 & 140 & $\begin{array}{l}15 \text { (prestadores de } \\
\text { serviço) }\end{array}$ \\
\hline $\begin{array}{l}\text { Instituto de Tecnologia do } \\
\text { Paraná - Tecpar }\end{array}$ & 420 & 280 & $\begin{array}{l}140 \text { (por intermédio da } \\
\text { Citipar - empresa de } \\
\text { intermediação de mão-de- } \\
\text { obra) }\end{array}$ \\
\hline
\end{tabular}

Fonte: Pesquisa de campo.

Quadro 3 - Evolução da produção nacional - 1999-2002

\begin{tabular}{|c|c|c|c|c|c|c|}
\hline \multirow{2}{*}{ Produtor } & \multirow{2}{*}{ Vacina } & \multicolumn{5}{|c|}{ Produção } \\
\hline & & 1998 & 1999 & 2000 & 2001 & 2002 \\
\hline \multirow[t]{9}{*}{ Instituto Butantan } & BCG & 1.227 .580 & 2.015 .400 & 2.964 .120 & 5.745 .200 & 2.120 .000 \\
\hline & $\begin{array}{l}\text { DT } \\
\text { Dupla adulto }\end{array}$ & 27.115 .970 & 40.034 .546 & 34.878 .160 & 26.727 .060 & 23.332 .140 \\
\hline & $\begin{array}{l}\text { DT } \\
\text { Dupla infantil }\end{array}$ & 720.000 & 542.431 & 354.285 & 380.000 & 60.000 \\
\hline & DTP & 17.520 .300 & 24.317 .955 & 29.003 .130 & 21.078 .380 & 19.000 .000 \\
\hline & Tríplice & \multicolumn{3}{|c|}{ DTP para quádrupla } & 8.216 .950 & 17.855 .076 \\
\hline & $\begin{array}{l}\text { Recombinante } \\
\text { contra hepatite B }\end{array}$ & 961.860 & 5.100 .000 & 2.291 .500 & 2.850 .740 & 12.000 .000 \\
\hline & Contra gripe & - & - & 15.400 .000 & 15.620 .000 & 16.418 .028 \\
\hline & $\begin{array}{l}\text { Tा } \\
\text { Toxóide } \\
\text { Tetânico }\end{array}$ & 772.400 & - & - & - & - \\
\hline & $\begin{array}{l}\text { Contra raiva } \\
\text { Célula Vero }\end{array}$ & - & 3.746 & 13.652 & - & 7.240 \\
\hline Ataulpho de Paiva & BCG & 16.910 .320 & 18.943 .190 & 7.969 .670 & 16.060 .890 & 17.681 .900 \\
\hline Tecpar & Contra raiva canina & 24.000 .000 & 25.500 .000 & 26.670 .925 & 26.000 .000 & 29.000 .000 \\
\hline \multirow[t]{3}{*}{ Bio-Manguinhos } & Contra sarampo & 5.009 .000 & 12.432 .000 & 10.788 .000 & 7.480 .000 & 2.866 .000 \\
\hline & $\begin{array}{l}\text { Contra febre } \\
\text { amarela }\end{array}$ & 54.308 .000 & 109.934 .000 & 32.311 .000 & 10.823 .000 & 32.168 .000 \\
\hline & $\begin{array}{l}\text { Contra meningite } \\
\text { meningocócica } \\
\mathrm{A}+\mathrm{C}\end{array}$ & - & - & 505.000 & - & 519.000 \\
\hline
\end{tabular}


VACINAS, SOROS E IMUNIZAÇÕES NO BRASIL

Quadro 3 - Evolução da produção nacional - 1999-2002 (continuação)

\begin{tabular}{|l|l|c|c|c|c|c|}
\hline \multirow{2}{*}{ Produtor } & \multirow{2}{*}{ Vacina } & \multicolumn{5}{|c|}{ Produção } \\
\cline { 2 - 6 } & Bio-Manguinhos & 1998 & 1999 & 2000 & 2001 & 2002 \\
\hline & $\begin{array}{l}\text { Oral trivalente } \\
\text { Contra poliomielite }\end{array}$ & 44.976 .000 & 30.656 .000 & 19.545 .000 & 36.638 .000 & 65.854 .000 \\
\cline { 2 - 7 } & $\begin{array}{l}\text { Contra Haemophilus } \\
\text { influenziae tipo B } \\
\text { (Hib) }\end{array}$ & - & 7.778 .000 & 15.530 .000 & 9.822 .000 & - \\
\cline { 2 - 7 } & $\begin{array}{l}\text { Tetravalente } \\
\text { (DTP + HIB) }\end{array}$ & - & - & - & 8.644 .000 & 14.965 .000 \\
\hline
\end{tabular}

Fonte: Brasil (2003).

Quadro 4 - Necessidade versus produção nacional de vacinas

\begin{tabular}{|c|c|c|c|}
\hline $\begin{array}{c}\text { Imunobiológicos } \\
1998-2002\end{array}$ & Demanda nacional & Produçăo nacional & $\begin{array}{c}\text { Importaçāo } \\
\text { (produto acabado) }\end{array}$ \\
\hline Vacina pólio oral & 352.064 .360 & - & 157.831 .000 \\
\hline Vacina sarampo & 46.172 .285 & 46.290 .000 & - \\
\hline Vacina BCG & 81.576 .700 & 91.608 .270 & - \\
\hline Vacina tríplice & 91.833 .350 & 87.000 .000 & - \\
\hline Vacina dupla adulto (DT) & 132.161.208 & 120.196 .170 & - \\
\hline Toxóide tetânico & 500.000 & 772.400 & - \\
\hline Vacina dupla infantil (DT) & 1.368 .150 & 1.450 .000 & - \\
\hline Vacina meningite $\mathrm{A} / \mathrm{C}$ & 2.988 .150 & 1.536 .000 & - \\
\hline Vacina meningite $B / C$ & 413.636 & - & - \\
\hline Vacina dupla viral & 70.840 .000 & - & 65.000 .000 \\
\hline Vacina hepatite B & 100.136 .465 & 17.324 .555 & 78.000 .000 \\
\hline Vacina tríplice viral & 72.998 .000 & - & 73.000 .000 \\
\hline Vacina febre amarela & 189.758 .485 & 239.544 .000 & - \\
\hline Vacina raiva humana & 9.862 .845 & 9.740 .000 & - \\
\hline Vacina raiva canina & 130.176 .040 & 130.000 .000 & - \\
\hline Vacina H. influenziae B (Hib) & 42.537 .606 & - & 9.022 .680 \\
\hline Vacina pneumococo & 3.086 .200 & - & 1.000 .000 \\
\hline Vacina raiva (cel. dipl. humana) & 622.220 & - & 43.720 \\
\hline Vacina tríplice acelular & 64.000 & - & 49.000 \\
\hline Vacina varicela & 388.040 & . & 14.500 \\
\hline Vacina hepatite A & 54.400 & - & 4.000 \\
\hline Vacina influenzae & 52.126 .380 & - & 7.626 .380 \\
\hline Vacina quádrupla (DTP/Hib) & 22.173 .948 & 23.300 .000 & - \\
\hline TOTAL & 1.403.902.468 & 768.761 .395 & 391.591 .280 \\
\hline
\end{tabular}

Fonte: Brasil (2003). 


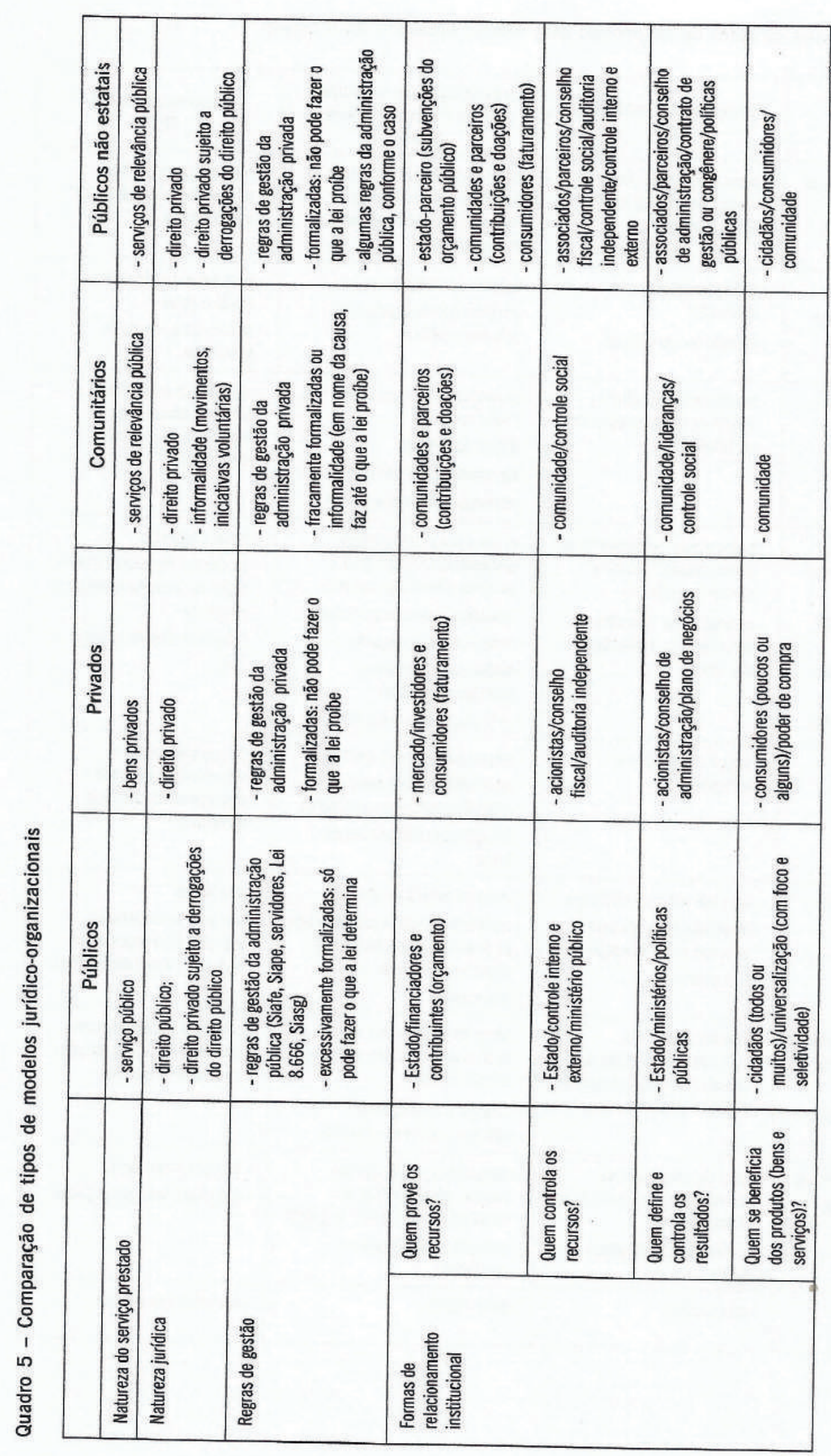

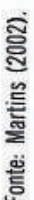


Quadro 6 - Modelos jurídico-institucionais de entes de cooperaçāo com relação especial com o Estado

\begin{tabular}{|c|c|c|c|c|}
\hline & $\begin{array}{l}\text { Organização social } \\
\text { (OS) }\end{array}$ & $\begin{array}{c}\text { Serviço social autônomo } \\
\text { (SSA) }\end{array}$ & $\begin{array}{l}\text { Organizaçāo da sociedade } \\
\text { civil de interesse público } \\
\text { (Oscip) }\end{array}$ & $\begin{array}{l}\text { Empresa pública } \\
\text { (EP) }\end{array}$ \\
\hline $\begin{array}{l}\text { Definição } \\
\text { jurídica }\end{array}$ & $\begin{array}{l}\text { - qualificação de pessoa jurídica de } \\
\text { direito privado (associação ou } \\
\text { fundação), com derrogaçōes de } \\
\text { direito público }\end{array}$ & $\begin{array}{l}\text { - pessoa jurídica de direito } \\
\text { privado, com derrogaçōes de } \\
\text { direito público }\end{array}$ & $\begin{array}{l}\text { - qualificação de pessoa jurídica de } \\
\text { direito privado (associação ou } \\
\text { fundação), com derrogações de } \\
\text { direito público }\end{array}$ & $\begin{array}{l}\text { - pessoa jurídica de direito } \\
\text { privado, com derrogaçōes de } \\
\text { direito público }\end{array}$ \\
\hline $\begin{array}{l}\text { Forma de } \\
\text { criação }\end{array}$ & $\begin{array}{l}\text { - estatuto por particulares } \\
\text { - decreto de qualificação do Poder } \\
\text { Público (ato discricionário) }\end{array}$ & $\begin{array}{l}\text { - lei cria ou autoriza a } \\
\text { instituição } \\
\text { - estatuto por particulares }\end{array}$ & $\begin{array}{l}\text { - estatuto por particulares } \\
\text { - ato vinculado de qualificação } \\
\text { pelo poder público }\end{array}$ & $\begin{array}{l}\text { - lei autoriza a instituiç̧ão, } \\
\text { ato de registro } \\
\text { - lei autoriza a criaçāo de } \\
\text { subsidiária }\end{array}$ \\
\hline Objetivo & $\begin{array}{l}\text { - atividades não exclusivas do } \\
\text { Estado (saúde, educação, } \\
\text { pesquisa, meio-ambiente e } \\
\text { cultura) }\end{array}$ & $\begin{array}{l}\text { - prestação de assistência e } \\
\text { ensino de interesse específico } \\
\text { de beneficiários }\end{array}$ & $\begin{array}{l}\text { - prestaçăo de serviços sociais não } \\
\text { exclusivos } \\
\text { - defesa de direitos } \\
\text { - representação de interesses } \\
\text { - promoção do interesse público }\end{array}$ & $\begin{array}{l}\text { - atividade de prestação de } \\
\text { serviço público ou de } \\
\text { exploração de atividade } \\
\text { econômica }\end{array}$ \\
\hline $\begin{array}{l}\text { Controle e } \\
\text { avaliaçã̃o }\end{array}$ & $\begin{array}{l}\text { - meios e processo (conselho de } \\
\text { administração e auditoria interna } \\
\text { e/ou externa) } \\
\text { - resultados (contrato de gestāo) } \\
\text { - controle social (conselho de } \\
\text { administração, publicidade dos } \\
\text { atos) } \\
\text { - se fundação (Ministério Público) }\end{array}$ & $\begin{array}{l}\text { - meios e processo (conselho de } \\
\text { administração e auditoria } \\
\text { interna e/ou externa) } \\
\text { - controle social (conselho de } \\
\text { administração, publicidade } \\
\text { dos atos) }\end{array}$ & $\begin{array}{l}\text { - meios e processo (colegiado } \\
\text { deliberativo, conselho fiscal e } \\
\text { auditoria interna e/ou externa) } \\
\text { - resultados (termo de parceria) } \\
\text { - controle social (colegiado } \\
\text { deliberativo e consultivo, } \\
\text { publicidade dos atos) } \\
\text { - se fundação (Ministério Público) }\end{array}$ & $\begin{array}{l}\text { - meios e processo } \\
\text { - secretarias de controle interno, } \\
\text { órgãos de auditoria interna dos } \\
\text { ministérios } \\
\text { - Tribunal de Contas da União - } \\
\text { TCU }\end{array}$ \\
\hline Patrimônio & $\begin{array}{l}\text { - da União (impenhorável e } \\
\text { inexecutável) e próprio } \\
\text { (penhorável e executável) }\end{array}$ & $\begin{array}{l}\text { - próprio (penhorável e } \\
\text { executável) }\end{array}$ & $\begin{array}{l}\text { - próprio (penhorável e executável) } \\
\text { - inalienabilidade dos bens } \\
\text { adquiridos com recursos públicos } \\
\text { - licitação para utilizar bens da } \\
\text { União }\end{array}$ & $\begin{array}{l}\text { - próprio (penhorável e } \\
\text { executável) se dedicada a } \\
\text { desempenho de atividade } \\
\text { econômica }\end{array}$ \\
\hline $\begin{array}{l}\text { Aspectos } \\
\text { jurídicose } \\
\text { tributários }\end{array}$ & $\begin{array}{l}\text { - utilidade pública e filantropia; } \\
\text { - imunidade tributária para } \\
\text { impostos se de educação } \\
\text { - foro estadual }\end{array}$ & $\begin{array}{l}\text { - utilidade pública e filantropia } \\
\text { - imunidade tributária para } \\
\text { impostos se de educação } \\
\text { - foro estadual }\end{array}$ & $\begin{array}{l}\text { - utilidade pública e filantropia } \\
\text { - imunidade tributária para impostos } \\
\text { se de educação, de assistência } \\
\text { social e microcrédito } \\
\text { - foro estadual }\end{array}$ & $\begin{array}{l}\text { - foro federal } \\
\text { - não goza de imunidade } \\
\text { tributária para impostos se } \\
\text { dedicada à atividade econômica }\end{array}$ \\
\hline Parcerias & $\begin{array}{l}\text { - contrato de gestāo com o poder } \\
\text { público (escolha discricionária) } \\
\text { - acordos e contratos com } \\
\text { entidades públicas e privadas } \\
\text { com ou sem repasses }\end{array}$ & $\begin{array}{l}\text { - acordos e contratos } \\
\text { com entidades públicas e } \\
\text { privadas com ou sem repasses, } \\
\text { inclusive consórcio }\end{array}$ & $\begin{array}{l}\text { - termo de parceria com o poder } \\
\text { público (processo de escolha ou } \\
\text { escolha direta) } \\
\text { - acordos e contratos com } \\
\text { entidades públicas e privadas }\end{array}$ & $\begin{array}{l}\text { - convênios e contratos com } \\
\text { entidades públicas e privadas } \\
\text { com ou sem repasses }\end{array}$ \\
\hline Extinção & $\begin{array}{l}\text { - desqualificação mediante decreto } \\
\text { - patrimônio volta para a união } \\
\text { - extinção mediante quorum } \\
\text { qualificado }\end{array}$ & $\begin{array}{l}\text { - extinção dificultada por } \\
\text { quorum exigido no conselho de } \\
\text { administração } \\
\text { - patrimônio cedido volta à } \\
\text { União }\end{array}$ & $\begin{array}{l}\text { - desqualificação por decisão } \\
\text { judicial, administrativa, de } \\
\text { iniciativa popular, do MP ou própria } \\
\text { - extinção mediante quorum } \\
\text { qualificado }\end{array}$ & $\begin{array}{l}\text { - extinção mediante lei } \\
\text { - patrimônio volta para a União }\end{array}$ \\
\hline $\begin{array}{l}\text { Modelo } \\
\text { jurídico }\end{array}$ & - Lei $9.637 / 98$ & - lei específica & - Lei $9.790 / 99$ & - administraçāo indireta \\
\hline
\end{tabular}

Fonte: Martins (2002). 
Quadro 7 - Implementação de modelos jurídico-institucionais de entes de cooperação

\begin{tabular}{|c|c|c|c|}
\hline Fase & OS & Oscip & SSA \\
\hline $\begin{array}{l}\text { Constituiçãa da } \\
\text { associação }\end{array}$ & $\begin{array}{l}\text { Sócios fundadores aprovam } \\
\text { um estatuto que contempla } \\
\text { os requisitos da legislação e } \\
\text { registram em cartório. }\end{array}$ & $\begin{array}{l}\text { Sócios fundadores aprovam } \\
\text { um estatuto que contempla } \\
\text { os requisitos da legislaçäo e } \\
\text { registram em cartório. }\end{array}$ & $\begin{array}{l}\text { A lei autoriza o poder público } \\
\text { a criar uma associação. }\end{array}$ \\
\hline $\begin{array}{l}\text { Solicitação de } \\
\text { qualificação }\end{array}$ & $\begin{array}{l}\text { A entidade requer } \\
\text { qualificação de OS ao } \\
\text { Ministério; a qualificação se } \\
\text { dá via decreto após a } \\
\text { manifestação do respectivo } \\
\text { ministro e do Ministério do } \\
\text { Planejamento quanto à } \\
\text { oportunidade e a } \\
\text { conveniência. }\end{array}$ & $\begin{array}{l}\text { A entidade requer ao } \\
\text { Ministério da Justiça e, uma } \\
\text { vez cumpridas as exigências } \\
\text { documentais e estatutárias, } \\
\text { a qualificação é automática } \\
\text { via portaria do ministro. }\end{array}$ & $\begin{array}{l}\text { Não há qualificação. As } \\
\text { prerrogativas equivalentes } \\
\text { às das entidades } \\
\text { qualificadas são } \\
\text { estabelecidas em lei } \\
\text { específica. }\end{array}$ \\
\hline $\begin{array}{l}\text { Firmatura de } \\
\text { contrato de } \\
\text { gestão ou termo } \\
\text { de parceria }\end{array}$ & $\begin{array}{l}0 \text { contrato de gestão é } \\
\text { elaborado conjuntamente, } \\
\text { negociado entre as partes e } \\
\text { sua assinatura tramita pelos } \\
\text { Ministérios do Planejamento } \\
\text { e Fazenda. }\end{array}$ & $\begin{array}{l}0 \text { termo de compromisso é } \\
\text { elaborado conjuntamente, } \\
\text { negociado entre as partes e } \\
\text { sua assinatura requer } \\
\text { aprovação do conselho da } \\
\text { política pública em questão. }\end{array}$ & $\begin{array}{l}0 \text { instrumento contratual é } \\
\text { definido em lei específica. }\end{array}$ \\
\hline
\end{tabular}

Fonte: Martins (2002).

Quadro 8 - OS, Oscip e SSA: vantagens e desvantagens

\begin{tabular}{|l|l|l|}
\hline & \multicolumn{1}{|c|}{ Vantagens } & \multicolumn{1}{c|}{ Desvantagens } \\
\hline OS & - cessão de servidores e de patrimônio & $\begin{array}{l}\text { - processo de qualificação é ato discricionário } \\
\text { que parte do ministério interessado, tramita } \\
\text { pelo Ministério do Planejamento e requer } \\
\text { decreto }\end{array}$ \\
\hline SSA & -transferência de quadros e patrimônio & $\begin{array}{l}\text { - criação da entidade e estabelecimento da } \\
\text { relação contratual requer lei específica }\end{array}$ \\
\hline Oscip & $\begin{array}{l}\text { - simplicidade da qualificação (ato vinculado } \\
\text { mediante portaria do Ministério da Justiça) e } \\
\text { do termo de parceria }\end{array}$ & $\begin{array}{l}\text { - impossibilidade de cessão de servidores e } \\
\text { restriçōes (licitação) para cessão de } \\
\text { patrimônio }\end{array}$ \\
\hline
\end{tabular}

Fonte: Martins (2002). 
Quadro 9 - Argumentos contra e a favor das OS

\begin{tabular}{|c|c|}
\hline Argumentos contra & Argumentos a favor \\
\hline $\begin{array}{l}\text { Trata-se nāo apenas de ato discricionário, mas personalístico, } \\
\text { arbitrário e não isonômico, porque a autoridade escolhe qualificar } \\
\text { uma determinada associação criada por determinadas pessoas. } \\
\text { Deveria haver licitação. }\end{array}$ & $\begin{array}{l}\text { Ato discricionário não se confunde com ato arbitrário. } 0 \text { melhor exemplo está nos convênios, } \\
\text { cujas partes são escolhidas pelo poder público conforme avaliaçăo. }\end{array}$ \\
\hline Trata-se de 'intervenção do Estado no terceiro setor'. & $\begin{array}{l}\text { A participação do Estado no conselho é minoritária (entre } 20 \% \text { e } 40 \% \text { ), mas preponderante, } \\
\text { porque tem mais condiçōes de formar coalizões. Isto é muito usual em várias experiências } \\
\text { congêneres, em diversos países, nos quais o terceiro setor é muito mais forte. Por outro lado, a } \\
\text { participação no conselho năo é a principal forma de controle do Estado: o poder contratante, que } \\
\text { prevê os meios para o alcance das metas pactuadas em contrato de gestão, é usualmente } \\
\text { preponderante. }\end{array}$ \\
\hline $\begin{array}{l}\text { O fomento do Estado às OS desestimula o mercado e promove um } \\
\text { 'dumping social'. Proporciona vantagens competitivas para o } \\
\text { desenvolvimento de produtos comerciais (o Estado paga o pessoal e } \\
\text { outras despesas). }\end{array}$ & $\begin{array}{l}\text { Desenvolver e vender produtos comerciais nāo deve ser a finalidade precípua de nenhuma OS, } \\
\text { mas esta possibilidade não deve ser coibida, porque poderá haver brechas (nichos e } \\
\text { oportunidades de mercado) que auxiliem na auto-sustentabilidade, embora a OS deva, em } \\
\text { alguma extensāo, depender de recursos do Estado. Por outro lado, em alguns casos, o efeito } \\
\text { regulador de preços pode ser desejável. }\end{array}$ \\
\hline Grupo de pessoas físicas cria a entidade. Há personalismo. & $\begin{array}{l}0 \text { grupo de pessoas que cria não tem poder sobre a entidade, delega-o integralmente a um } \\
\text { conselho de administração que detém controle total sobre a organização (isto é um requisito legal } \\
\text { para a qualificação), com participação estatal preponderante, embora minoritária. }\end{array}$ \\
\hline A dita 'publicização' é uma 'privatização branca'. & $\begin{array}{l}\text { Não é privatização porque não há venda de patrimônio público (que continua sendo público e } \\
\text { inclui até o patrimônio que a OS adquirir), tampouco a entidade que detém o uso deste tem } \\
\text { autonomia para usá-lo em favor de terceiros (o uso está vinculado aos objetivos da política } \\
\text { pública do contrato de gestāo). } \\
\text { A publicização não implica a desoneração do Estado em relação à atividade publicizada, mas } \\
\text { consiste em uma forma descentralizada de implementação de política social, sob o fomento e } \\
\text { supervisão do Estado. }\end{array}$ \\
\hline $\begin{array}{l}\text { Trata-se de uma 'estatal disfarçada': o poder público induz sua } \\
\text { criação, por meio dos dirigentes das atividades a serem } \\
\text { publicizadas, para escapar dos controles estatais. Isto é uma porta } \\
\text { aberta às práticas patrimonialistas. As OS deveriam estar no Siafi e } \\
\text { se submeter à Lei } 8.666 \text {. }\end{array}$ & $\begin{array}{l}\text { Certamente não se trata de um terceiro setor genuíno, senão uma zona intermediária entre } \\
\text { Estado e terceiro setor. A criação pode até ser induzida pelo Estado, mas não visa a escapar dos } \\
\text { controles estatais, e sim da padronização das regras operacionais. } \\
\text { Os controles de uma OS são mais abrangentes que os controles à auditoria independente do } \\
\text { conselho de administraçăo e ao controle social (via conselho, publicidade e transparência dos } \\
\text { atos e fatos de gestão). } \\
\text { A fim de estar no Siafi e atender à Lei } 8.666 \text {, não promove o controle, mas um engessamento que } \\
\text { se choca com a idéia do modelo. }\end{array}$ \\
\hline
\end{tabular}

Fonte: Martins (2002). 


\section{Programa Nacional de Competitividade em Vacinas (Inovacina)}

José da Rocha Carvalheiro

José Gomes Temporão

Akira Homma

Hisako Gondo Higashi

Este artigo apresenta uma versão do Programa Inovacina que resume as conclusões de amplo processo de discussão em Oficinas de Trabalho, envolvendo os diversos setores, que se desenvolveu a partir da apresentação de textos produzidos por especialistas. Expressa, portanto, a síntese das discussōes, e as opiniōes devem ser creditadas ao coletivo de gestores, produtores e acadêmicos que participaram do processo. Foram quase duzentos participantes providos de interesse (stakeholders), compondo o que se tem internacionalmente chamado a hélice tripla (triple helix).

A proposta completa, foi encaminhada ao Ministério da Saúde para concretizar a criação do Inovacina, e um resumo semelhante a este foi submetido à discussão no Grupo de Biotecnologia em Saúde Humana, do Fórum de Competitividade em Biotecnologia (MDIC).

Numa etapa preliminar, a equipe do Projeto Inovação em Saúde desenvolveu um trabalho de síntese do pensamento do coletivo reunido nas sucessivas Oficinas de Trabalho, empregando metodologia qualitativa. Neste esforço, inicialmente agrupou as idéias geradas nas discussões mediante uma leitura crítica da transcrição dos debates, que haviam sido gravados. ' Construiu-se uma matriz em que as idéias ("Desdobramentos iniciais") foram classificadas em seis grupos e quatorze subgrupos (Quadro 1).

Em seguida, foi reagrupado o conteúdo dessa matriz para concretizar as idéias em quatro componentes do Inovacina: a) definição de políticas e organização da produção; b) modernização do parque produtivo; c) avaliação e regulação; d) desenvolvimento e inovação.

${ }^{1}$ Este material empíico encontra-se disponivel na Coordenação do Projeto Inovação em Saúde e sua organizaçāo contou com a colaboração de Flávia Neves Rocha Alves. 
Quadro 1 - Grupos e subgrupos componentes do Programa Nacional de Competitividade em Vacinas (Inovacina)

\begin{tabular}{|l|l|}
\hline Grupos & Subgrupos \\
\hline Política & $\begin{array}{l}\text { Implementação de políticas } \\
\text { Redesenho setorial para a cooperação }\end{array}$ \\
\hline Estrutura física & $\begin{array}{l}\text { Modernização do parque produtor } \\
\text { Certificação das plantas de produção }\end{array}$ \\
\hline Organizacional & $\begin{array}{l}\text { Modelo organizacional e gerencial } \\
\text { Recursos humanos }\end{array}$ \\
\hline Atividades relacionadas à avaliação e regulação & $\begin{array}{l}\text { Ensaios clínicos } \\
\text { Propriedade intelectual } \\
\text { Regulação }\end{array}$ \\
\hline Produção e comercialização & Produção \\
& $\begin{array}{l}\text { Política de preços } \\
\text { Qualidade }\end{array}$ \\
\hline Inovação e desenvolvimento & Inovação e desenvolvimento de produtos e processos \\
& Vacinas prioritárias \\
\hline
\end{tabular}

Em cada componente são indicados "Propósitos", "Objetivos" e "Instrumentos". Na versão encaminhada ao Ministério da Saúde, em "Instrumentos", são detalhadas as propostas de ação concreta em cada componente. Aqui, excluíram-se os prazos previstos e suprimiu-se a indicação dos órgãos que devem executar essas ações. Um componente essencial, relacionado com a indicação das "Vacinas Prioritárias" para desenvolvimento a curto e médio prazos, foi complementado por um trabalho adicional de responsabilidade de dois dos autores deste artigo. Representa, assim, o 'estado da arte' das perspectivas imediatas dos dois principais produtores públicos de vacinas no país (Quadros 2 e 3).

\section{COMPONENTE A: DEFINIC̣ÃO DE POLÍTICAS E ORGANIZAC̣ÃO DA PRODUC̣ÃO}

\section{Propósitos}

- Estabelecer o Programa Nacional de Competitividade em Vacinas (Inovacina), coordenado pelo Ministério da Saúde;

- Estabelecer um espaço estratégico e permanente de discussão e definição de políticas, indicando nichos para cada instituição produtora, no âmbito do Programa;

- Investir nos mecanismos de coordenação e de formação de rede interinstitucional, propiciando a formação de consórcio para integração dos produtores e incentivando-os a adotar estrutura jurídica que garanta uma maior flexibilidade e autonomia, facilitando a integração e a cooperação; 
- Fortalecer a capacidade produtiva nacional, para atender a demanda de vacinas essenciais para o Programa Nacional de Imunizações (PNI);

- Promover mudanças na atual modalidade de financiamento da produção de imunobiológicos, empregando o poder de compra do Ministério da Saúde como instrumento de regulação de preços.

\section{Objetivos}

- Contribuir na definição das políticas científica, tecnológica, industrial e sanitária na área de vacinas e imunizaçōes;

- Dinamizar o crescimento do segmento, aumentando a sua capacidade tecnológica e o sinergismo entre os produtores públicos, garantindo competitividade e autosustentabilidade tecnológica e econômica do Programa;

- Garantir a integração entre os atores do processo, coordenando as diversas etapas do desenvolvimento dos projetos específicos de vacinas e propiciando a utilização da plena capacidade instalada e de pessoal, visando à redução dos custos fixos de produção para suprir as necessidades nacionais e favorecer a exportação;

- Garantir o aproveitamento das potencialidades de cada produtor, o aumento das possibilidades de negócio e a eliminação das restrições legais para exportação, propiciando ainda a internalização de vacinas que incorporem tecnologia avançada;

- Fortalecer o entendimento, pelos técnicos do Ministério da Saúde, das peculiaridades do setor de vacinas, propiciando a melhoria do fluxo de recursos financeiros, assim como propor mudanças no mecanismo de preços praticado pelo governo, pleiteando a obtenção de um excedente para investimentos que permitam atingir a auto- suficiência;

- Estreitar o relacionamento dos produtores com o Ministério da Saúde no processo de formulação orçamentária, garantindo a prioridade da área e a regularidade nos desembolsos;

- Melhorar a capacitação de pesquisadores e tecnologistas na pesquisa básica, desenvolvimento tecnológico, ensaios clínicos, propriedade intelectual, produção e gestão de projetos na perspectiva da inovação, incluindo a formação e capacitação de pessoal estratégico (multidisciplinar) em vacinas, particularmente na engenharia de processos e nas funções de regulação;

- Atuar no sentido de garantir a melhoria do regime de contratação de pessoal para continuidade e preservação dos grupos.

Instrumentos

- Formalizar o Programa contendo as estratégias e as proposições resultantes das Oficinas de Trabalho realizadas pelo Projeto Inovação/Fiocruz, estabelecendo mecanismos regulares de consulta dos ministérios entre si, com a Câmara Técnica e os produtores; 
- Propor o financiamento da Finep e do BNDES para produtores públicos e modelos alternativos de financiamento que permitam a garantia de transferência de recursos financeiros;

- Providenciar instrumentos legais (decreto e/ou portarias) criando o Inovacina, o Grupo Executivo e a Câmara Técnica de Imunobiológicos e nomeando os seus componentes;

- Lançamento formal do Programa, pelo presidente da República e ministros;

- Comunicar o Programa ao Colegiado de Gestão do Ministério da Saúde, ao Conselho Nacional de Saúde, à CIT e ao Congresso Nacional, além de divulgar amplamente à sociedade pela mídia;

- Publicar livro com todas as contribuições e conclusôes;

- Incluir o Programa nas discussões da XII CNS e da II Conferência de CT\&I em Saúde;

- Incluir o Programa na agenda do Mercosul;

- Definir o modelo jurídico institucional que formalize a integração em redes de cooperação e propiciar a utilização pelos participantes de Modelo Integrado de Gestão e de controle dos custos;

- Solicitar a utilização de bolsas RHAE em instituições públicas produtoras e propor mecanismos especiais para fixação de doutores na área, além de incentivar a formação de programas de pós-graduação incluindo a temática do desenvolvimento e produção de imunobiológicos;

- Propor uma série de medidas que garantam a consolidação đo Programa, entre elas: a) buscar orientação legal para utilizar o poder de compra do Ministério da Saúde em área de interesse público estratégico; b) pleitear a alocação na área de vacinas de recursos dos Fundos Setoriais de Saúde, de Biotecnologia e de outras fontes como Qualisus, fundações estaduais etc.; c) propor a criação de Fundo de Capital de Giro, capitalizado pelo governo para caso de falta de regularidade no fluxo de recursos;

d) buscar a utilização de fundaçōes pela maior flexibilidade nas compras.

\section{COMPONENTE B: MODERNIZAC̣ÃO E CERTIFICAC̣ÃO DO PARQUE PRODUTIVO}

\section{Propósitos}

- Avaliar as necessidades de modernização em cada nicho;

- Viabilizar a modernização das instalaçōes de cada nicho;

- Fortalecer o sistema nacional de controle de qualidade em vacinas e implantar sistema de garantia de qualidade.

\section{Objetivos}

- Garantir a qualidade da produção local para atender às necessidades internas (qualitativas e quantitativas), substituindo importações e propiciando ingresso no mercado mundial; 
- Aumentar a competitividade externa dos produtores nacionais, visando à superação das barreiras sanitárias para exportação;

- Garantir a certificação das plantas industriais no âmbito do Inovacina, com medidas que fortaleçam o sistema de controle e garantia de qualidade das vacinas produzidas.

\section{Instrumentos}

- Implementar infra-estrutura para cumprimento das BPF (GMP) adequadas ao padrão internacional e propícias ao desenvolvimento de novas vacinas;

- Garantir a aquisição para substituir equipamentos obsoletos e atingir porte tecnológico;

- Definir fontes de financiamento e garantir o planejamento para a alocação dos recursos;

- Viabilizar a articulação dos produtores com o BNDES, a Finep e os programas de investimento do Ministério da Saúde e dos estados;

- Pleitear a eliminação das restrições impostas ao financiamento das instituições públicas produtoras de bens e serviços pelos órgãos públicos de fomento;

- Elaborar plano de certificação, pela Anvisa e OMS, de cada produto e de cada planta no âmbito do Programa, detalhando etapas e custos;

- Utilizar produtor âncora para capacitação dos profissionais de outras instituiçōes no processo de certificação;

- Garantir compras compartilhadas ou centralizadas, no âmbito do Programa, de produtos e serviços a um custo menor;

- Integrar-se no esforço de constituição de um Sistema de Controle e Garantia de Qualidade para os produtos incluídos no Programa.

\section{COMPONENTE C: AVALIAC̣ÃO E REGULAÇÃO}

\section{Propósitos}

- Estabelecer infra-estrutura nacional para ensaios (clínicos e não clínicos) de imunobiológicos (Rede Brasileira de Ensaios);

- Buscar a incorporação da propriedade intelectual nas estratégias de desenvolvimento, gestão e produção;

- Desencadear processo de discussão visando à adaptação da legislação regulatória de imunobiológicos à realidade brasileira.

\section{Objetivos}

- Fortalecer as atividades de ensaios (pré-clínicos, clínicos e epidemiológicos) em instituições públicas;

- Difundir a discussão da importância da propriedade intelectual entre pesquisadores e produtores; 
- Desencadear ações visando à construção de conceitos que possam vir a mudar a legislação sobre ensaios clínicos e pré-clínicos e as exigências para registro de imunobiológicos.

\section{Instrumentos}

- Promover seminários de âmbito nacional para discutir proposta de um programa para o desenvolvimento de ensaios (pré-clínicos, clínicos e epidemiológicos) dos imunobiológicos desenvolvidos no âmbito do Programa;

- Retomar e formalizar os contactos já existentes entre instituições públicas que têm participado em ensaios de vacinas produzidas pelos produtores públicos nacionais;

- Propor e desenvolver um projeto completo para a Rede Brasileira de Ensaios de Vacinas, no âmbito do Programa;

- Estabelecer contacto com centros do exterior envolvidos no esforço de realização de ensaios clínicos independentes, com financiamento exclusivamente público ou de instituições filantrópicas, à semelhança da European Science Foundation com seu Pan-European Clinical Trials;

- Estabelecer relacionamento com as instâncias nacionais quem têm se preocupado com a questão da propriedade intelectual para orientar os produtores a trabalhar com vacinas patenteadas a partir de acordo comercial ou licença, compatíveis com o TRIPS;

- Estabelecer mecanismo permanente de consulta aos bancos de patentes de produtos que possam ser incluídos no Programa;

- Desenvolver mecanismos para fortalecer as áreas de gestão de tecnologia das instituições participantes, incluindo a propriedade intelectual, com vistas a patentear os resultados do desenvolvimento de produtos e processos no âmbito do Programa;

- Promover estudos visando a uma consulta pública para revisão da legislação de registro dos produtos gerados pelo Programa.

\section{COMPONENTE D: DESENVOLVIMENTO E INOVACCÃO}

\section{Propósitos}

- Incorporar a inovação na estratégia das organizações, visando ao desenvolvimento autônomo (e/ou a internalização) de tecnologias mais avançadas com alto valor agregado;

- Definir um conjunto de vacinas prioritárias, incluindo adjuvantes e plataformas de aplicação de cada vacina;

- Selecionar nichos tecnológicos prioritários, formação de redes e fortalecimento das instituições âncora. 


\section{Objetivos}

- Articular as ações de saúde com ações de competitividade, elaborando uma agenda de pesquisa em vacinas com base nas prioridades públicas explícitas da política nacional de saúde;

- Garantir a coordenação das atividades no âmbito do Programa, integrando pesquisa básica, desenvolvimento tecnológico, ensaios clínico-epidemiológicos, produção, regulamentação e mercado, levando em conta que as parcerias mudam em cada etapa;

- Definir as rotas tecnológicas e coordenação das atividades do ciclo de desenvolvimento dos produtos;

- Estimular a criação de empresas autônomas de biotecnologia e o desenvolvimento desse setor nas organizações envolvidas no programa especialmente, mas não apenas, nas âncoras.

\section{Instrumentos}

- Capacitar os produtores para o estabelecimento de estratégias competitivas de inovação e de penetração no mercado internacional;

- Realizar estudos (custo-benefício, carga de doença, epidemiológicos pós-licenciamento) para orientar a definição das prioridades;

- Identificar os principais gargalos para o desenvolvimento de cada vacina;

- Contemplar sempre a transferência de tecnologia (internalização) como alternativa possível de desenvolvimento dos produtos;

- Definir os cronogramas e as responsabilidades, para cada produto proposto no âmbito do Programa;

- Propor a adoção de incentivos financeiros para os produtores como garantia para o esforço de desenvolvimento de novas vacinas: incentivos fiscais; cartas-compromisso garantindo a aquisição do produto; financiamento para os grupos de gestão de projetos e das redes; criação de uma 'alíquota de inovação' (o preço do produto vendido para Ministério da Saúde acrescido de um percentual de inovação); inclusão nos orçamentos dos produtores de elemento capaz de assegurar o esforço de $P \& D$ etc.

Quadro 2 - Critérios para a seleção de vacinas prioritárias (ordenados por relevância)

$\left.1^{9}\right)$ Impacto epidemiológico (considerar a existência ou não, de tecnologia alternativa para prevenção e controle).

$\left.2^{\circ}\right)$ Necessidade para o Programa Nacional de Imunizaçāo (se importado, avaliar o respectivo custo).

$3^{2}$ ) Existência de base tecnológica e domínio tecnológico do processo no país e no exterior.

$\left.4^{9}\right)$ Estágio de desenvolvimento do produto no país.

$5^{2}$ ) Existência de grupos de PD\&l no país.

$\left.6^{0}\right)$ Estudo da viabilidade técnica e econômica.

79) Existência de tecnologia alternativa para controle e prevenção da doença (p. ex., controle de vetores, uso de preservativo, saneamento básico etc.).

$8^{0}$ ) No caso de vacinas requeridas para o PNI, e não havendo ainda no país grupos envolvidos, deve-se levar em consideração: premência da necessidade de inclusão do produto no PNI; custo-benefício da vacina; avaliação econômica, além da definição das bases para transferência tecnológica. 


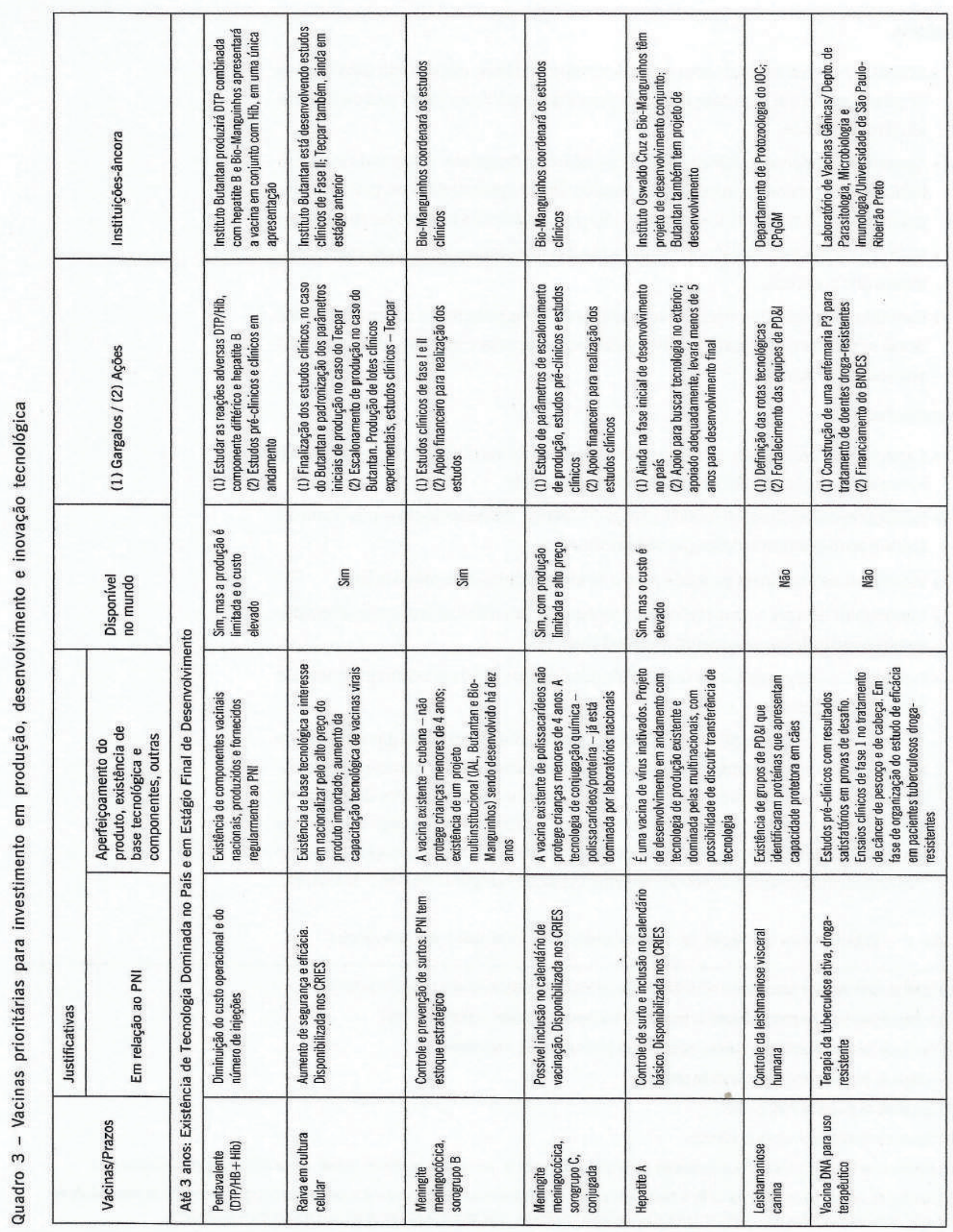




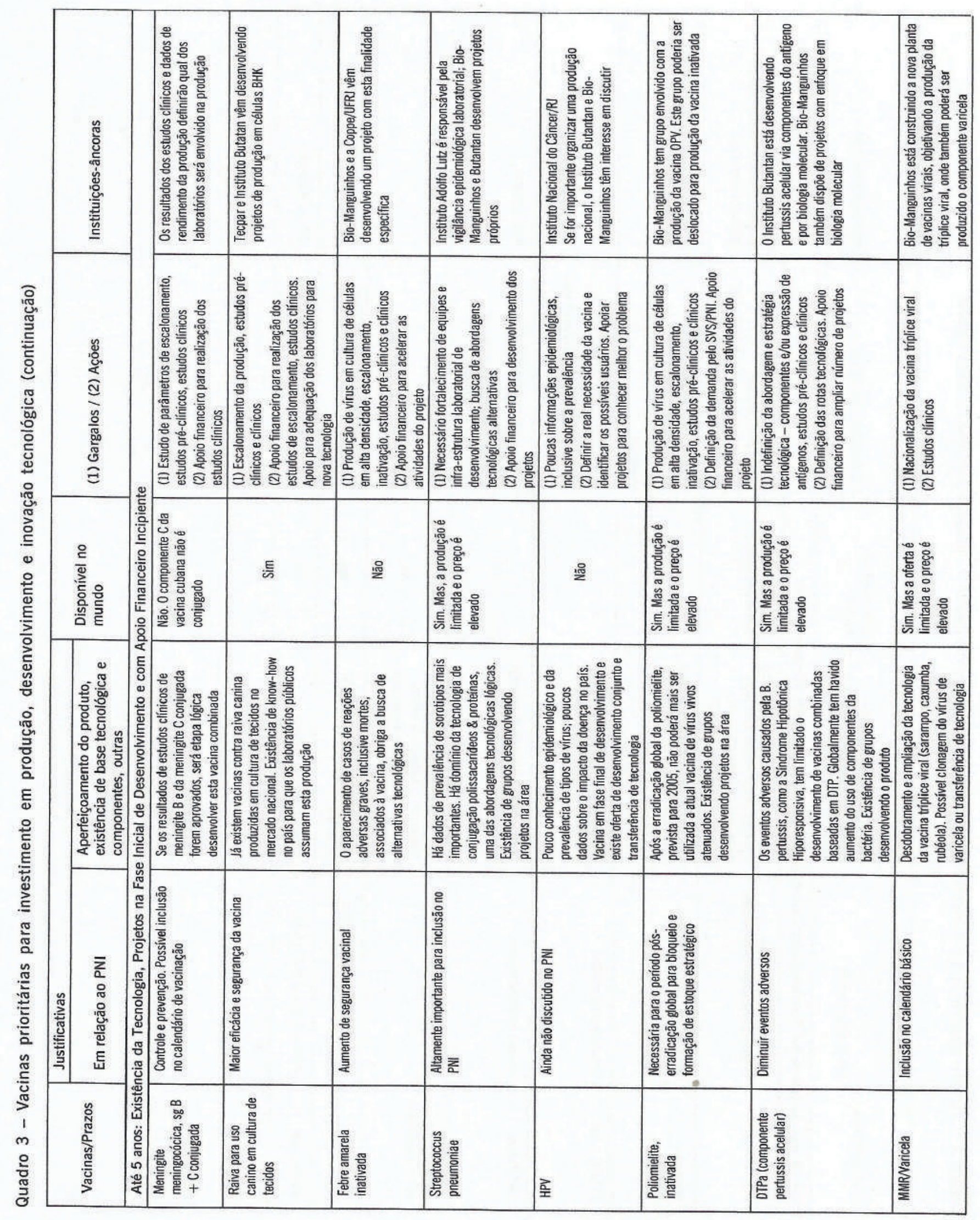


VACINAS, SOROS E IMUNIZAÇOEES NO BRASIL

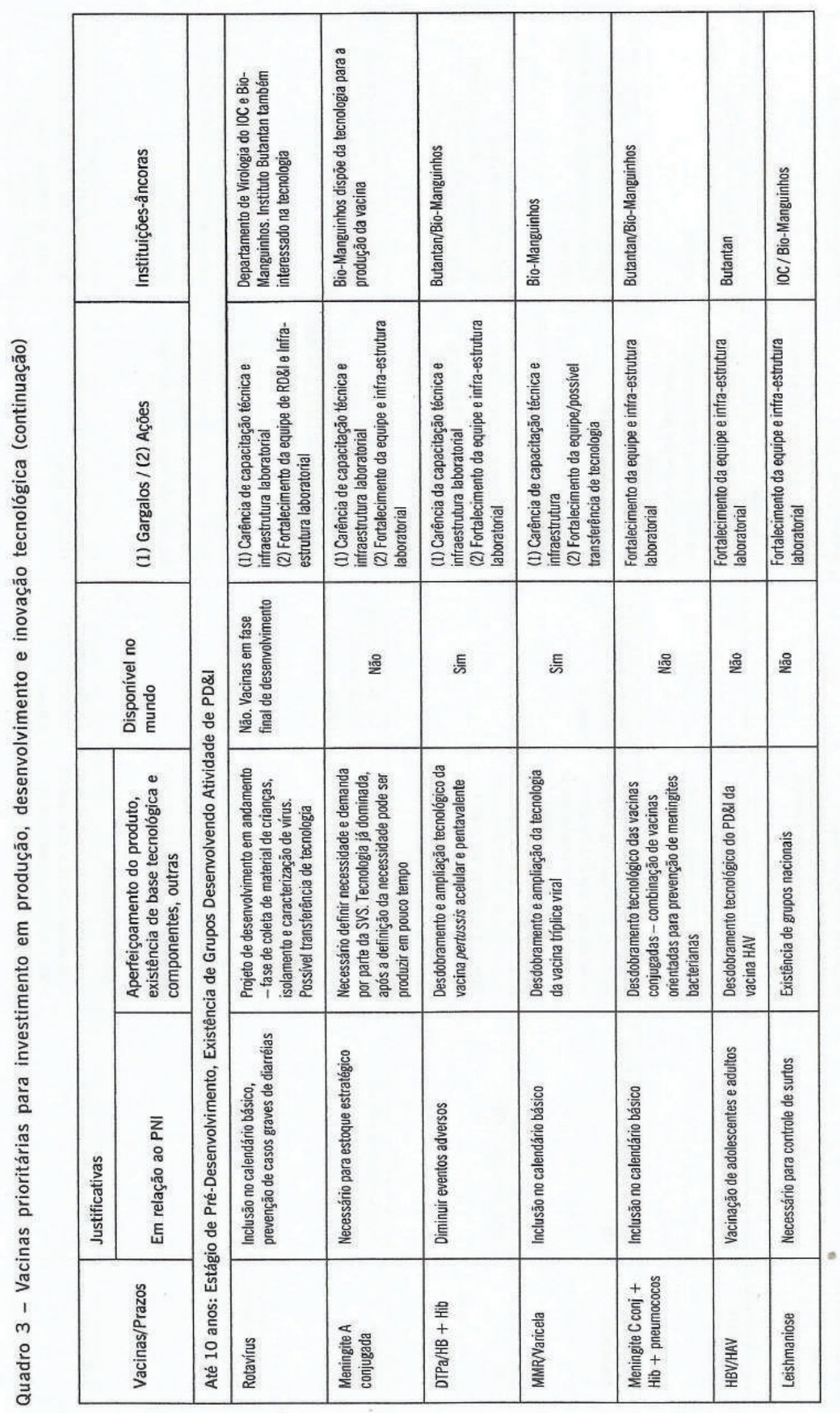




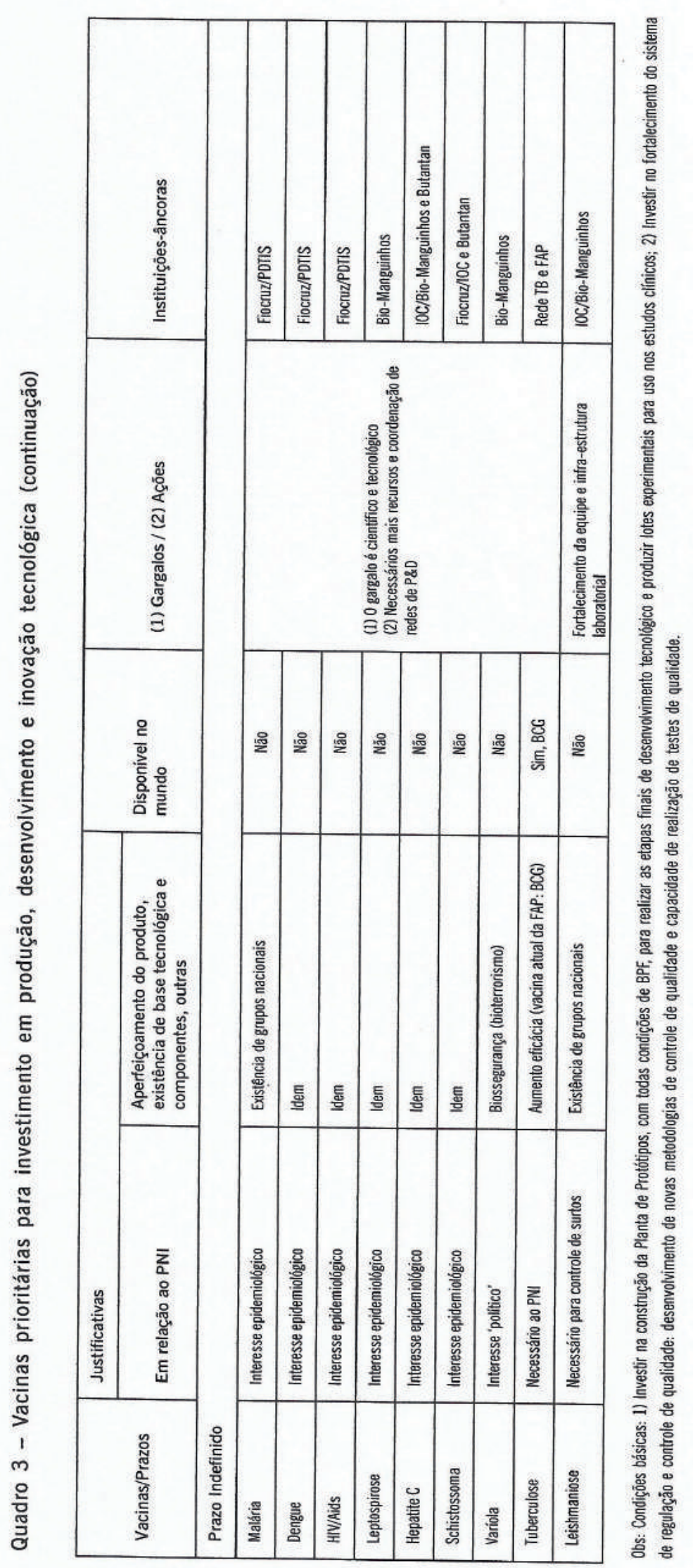




\section{Parte IV}

PESQUISA, DESENVOLVIMENTO E INOVAÇÁO EM VACINAS NO BRASIL 


\section{Fomento à Pesquisa e Desenvolvimento em Vacinas e Soros no CNPq}

Manoel Barral Netto

Erney Plessmann Camargo

Vacinas são armas poderosíssimas na prevenção de doenças, e sua relação custobenefício, bastante favorável, justifica amplamente o seu desenvolvimento e produção. Após um longo período com pouco avanço em vacinas, recentemente ocorreu um novo período de crescimento na área. Isto se deve, entre outros fatores, a uma combinação de desenvolvimento tecnológico e aumento do conhecimento sobre a etiologia e patogênese de muitas doenças. Todavia, tal avanço não está sendo igualmente sentido por todos. Em 1985, os países ricos utilizavam, de forma rotineira, sete vacinas nos seus esquemas de imunização, enquanto os países pobres usavam seis. No ano 2000 , os pobres passaram a usar sete vacinas e os ricos doze, evidenciando que aumenta o fosso, também neste aspecto, entre países ricos e pobres.

O Institute of Medicine, nos Estados Unidos, em estudo recente sobre a prioridade de vacinas no século XXI, indicou como um dos critérios a importância primariamente doméstica da doença a ser prevenida. A Global Alliance for Vaccines and Immunization (GAVI), uma iniciativa que visa a garantir o uso amplo das vacinas existentes e estimular o seu desenvolvimento, dirige seus esforços contra as doenças responsáveis por maior mortalidade nos países mais pobres, o que não necessariamente atende as necessidades do Brasil. $O$ estabelecimento das prioridades de pesquisa em novas vacinas no país deve, pois, levar em conta estes fatores. Dirigir os esforços para áreas não cobertas por outras iniciativas contribuirá para o sucesso do nosso empreendimento e resultará em maior benefício para todos. 
Os dados de ciência e tecnologia (C\&T) do Brasil demonstram um aumento expressivo do número de doutores, acompanhado de um aumento do volume e da qualidade da produção científica brasileira de forma constante nos últimos anos. Adicionalmente, tal crescimento atingiu praticamente todas as áreas científicas, com marcante presença da área biológica e da saúde. Apesar disso, esse desenvolvimento não resultou em avanços evidentes na forma de produtos ou conhecimentos de aplicação direta no campo da saúde. O Brasil ocupa a nona posição nos Gastos em Saúde, mas ocupa apenas a $108^{\text {" }}$ posição na classificação de Igualdade em Saúde, estimado pela Organização Mundial da Saúde (OMS) para os 150 países-membros com base na taxa de sobrevida infantil.

Por tudo isso, um dos grandes desafios na área científica é incrementar a capacidade tecnológica e transformar conhecimento básico em benefício da sociedade brasileira. Muitos são os obstáculos nesse terreno, como, por exemplo, a inexistência de uma política industrial orgânica e prioritária e a incipiente inserção de atividades de C\&T na cultura empresarial, como já reconhecido na I Conferência Nacional de C\&T em Saúde em 1994 e reafirmado na II Conferência de Ciência, Tecnologia e Inovação em Saúde em 2004.

Além da definição de prioridades, vários outros aspectos devem ser considerados para o efetivo avanço na obtenção de vacinas. O desenvolvimento destas necessita de avanços nos conhecimentos da patogenia de doenças de interesse, de estudos de novas tecnologias em vacinologia, estudos de antígenos potenciais candidatos para vacina, estudos de adjuvantes, estudos pré-clínicos padronizados e realizados em condições de boas práticas de laboratório, que permitam uma posterior pesquisa clínica segura. Há necessidade, também, de grupos capazes e interessados em realizar todas as fases de teste de uma nova vacina ou formulação vacinal.

Ao levantar o panorama recente de apoio a vacinas e soros no CNPq, pretendemos contribuir para identificar as áreas pouco ou năo atendidas, permitindo o planejamento de ações que contribuam para um esforço nacional de desenvolvimento e produção de vacinas. A busca de dados de financiamento em vacinas e soros localiza os projetos já diretamente relacionados com este tema. Não são incluídos estudos que, embora importantes para a compreensão de mecanismos de doença e do agente patogênico e, assim, capazes de contribuir para a obtenção de vacinas, năo visem diretamente a este fim.

A pesquisa básica desempenha importante papel para o desenvolvimento de novas vacinas. Realizada há várias décadas, sobretudo em universidades e institutos públicos, ela é responsável por extraordinários avanços técnico-científicos na área da parasitologia, imunologia, microbiologia e correlatas, proporcionando maior compreensão do sistema imune e das complexas interações patógeno-hospedeiro; utilização da tecnologia de DNA recombinante; seqüenciamento de genomas; síntese de peptídeos; identificação de novas toxinas microbianas etc. Nesse sentido, devemos avaliar brevemente o suporte geral do CNPq para a área de saúde, o que necessariamente extrapola o apoio às áreas que são o foco deste texto.

Em 2002, o apoio do CNPq à área da saúde, incluindo o fomento à pesquisa e à formação de recursos humanos, totalizou 43 milhōes de reais. Somados aos 82 milhōes 
dedicados à área das ciências biológicas, temos um valor máximo deste campo de 125 milhões. Quando analisado esse montante em relação ao número de doutores de cada uma das áreas do conhecimento (Gráfico 1), observamos mais claramente a insuficiência do suporte à área da saúde. Mesmo considerando todo o suporte à pesquisa básica em ciências biológicas e da saúde, vemos que o esforço não é suficiente para um progresso considerável no desenvolvimento de novas vacinas. Para uma melhor análise, buscamos os dados de financiamento em projetos e bolsas com identificação de compromisso com a obtenção de vacinas ou soros voltados para a saúde humana (excluindo aqueles voltados para a área veterinária), nos anos de 2001 e 2002, na base de dados do CNPq.

Gráfico 1 - Relação entre os investimentos do CNPq no fomento à pesquisa e na formação de RH e o número de doutores,* segundo as grandes áreas do conhecimento - 2002

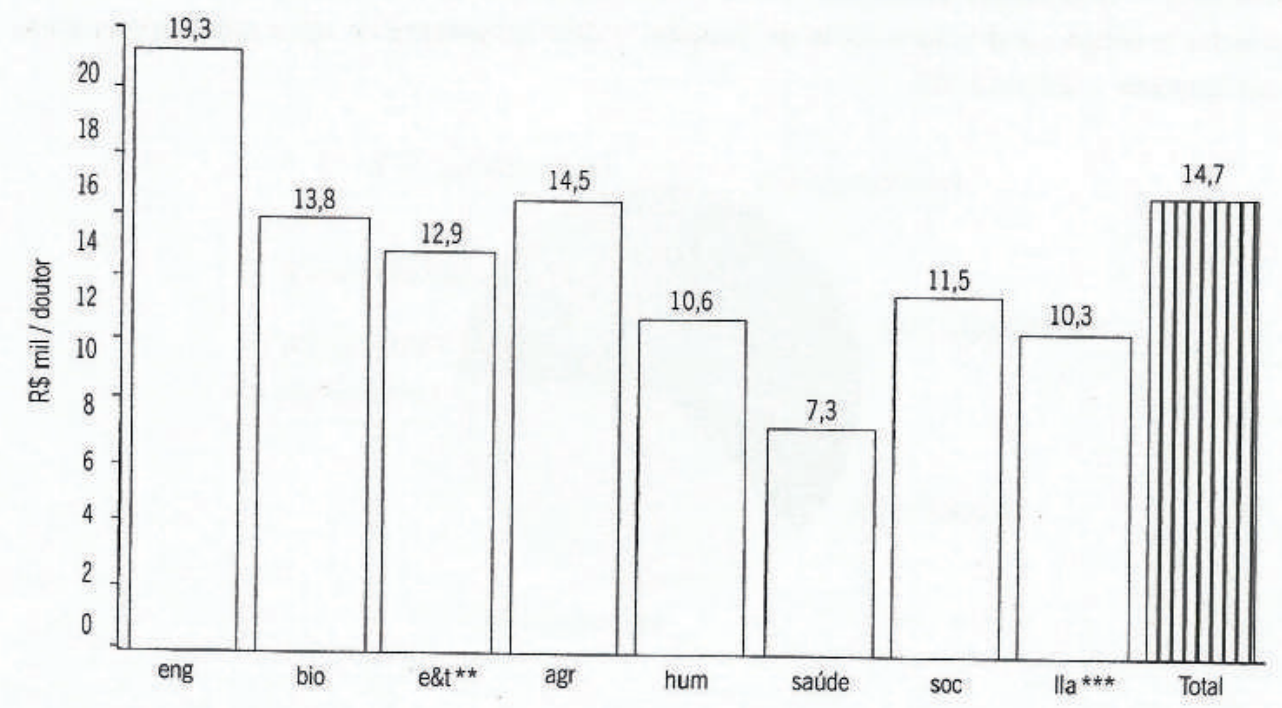

* $n^{0}$ de doutores cadastrados, segundo a grande área predominante nas atividades do grupo, no Censo 2002 do Dietório dos Grupos de Pesquisa no Brasil.

** exatas e da terra $\quad * \star *$ lingüistica, letras $\mathrm{e}$ artes

Fonte: CNPQ/AEI.

Os dados foram obtidos com a ferramenta Data Warehouse, banco de dados de projetos efetivamente pagos pelo CNPq. Para maior abrangência, foram utilizados os radicais 'soro' $\mathrm{e}$ 'vacin' no campo de busca 'Título de Projeto', nos exercícios 2001 e 2002. Na análise de dados, foram considerados apenas aqueles projetos diretamente correlatos ao tema deste trabalho.

A busca foi dirigida às etapas de pré-desenvolvimento (identificação e análise de genes ou antígenos protetores; atenuação, modificação genética, inativação ou obtenção de subunidade do agente etiológico; caracterização in vitro e avaliação da imunogenicidade de organismos atenuados, modificados ou inativados e caracterização de subunidades; estudos de novos adjuvantes), estudos pré-clínicos (produção de lotes experimentais vacinais para estudos pré-clínicos; avaliação de estabilidade e/ou critérios de pureza; seleção de adjuvantes; estudos de inocuidade ou de imunogenicidade em animais) e estudos clínicos nas suas diversas fases. 
O investimento do $\mathrm{CNPq}$, no apoio a projetos e pagamento de bolsas, na área de vacinas e soros, em 2001 e 2002, somou $R \$ 1.597 .924,67$, ou uma média de quase 800 mil reais por ano, aproximadamente 270 mil dólares (taxa de câmbio: $R \$ 2,96$ ). Desse total, $76 \%$ dos recursos foram aplicados no campo de vacinas.

O Gráfico 2 mostra a distribuição dos recursos de projetos e bolsas nas áreas de soro e vacinas por campo do conhecimento, indicando que as áreas de imunologia (37\%), microbiologia (19\%) e saúde coletiva (17\%) recebem a maior parte dos recursos, o que não surpreende, por serem áreas mundialmente relacionadas com a temática. Chama a atenção, por outro lado, a pequena participação da parasitologia (6\%), por se tratar de área tradicional no país e ser campo com grande carência de vacinas.

Gráfico 2 - Distribuição percentual, por área de conhecimento, do investimento do CNPq em projetos e bolsas identificados como de pesquisa e desenvolvimento de soros e/ou vacinas para uso humano - 2001-2002

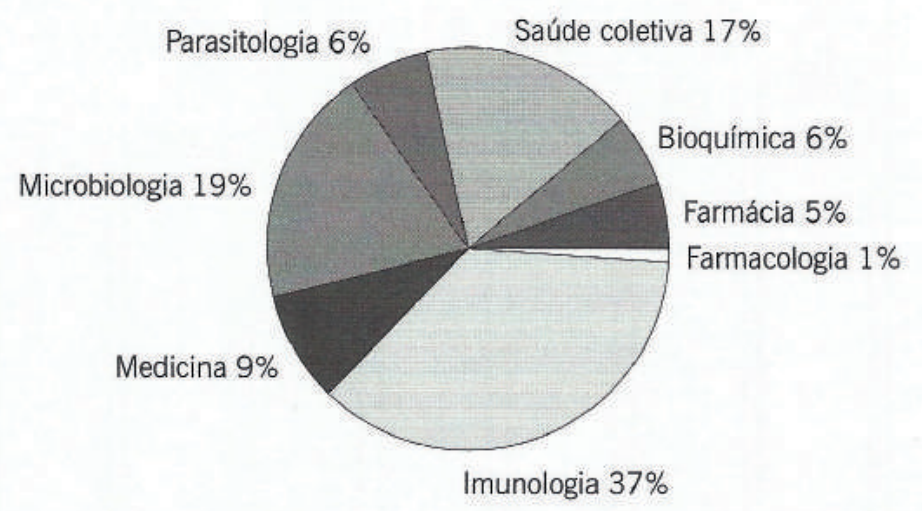

Uma outra indicação da insuficiência de recursos para o apoio aos estudos de soros e vacinas é o dado de que apenas $22 \%$ dos recursos são investidos em capital e custeio (Gráfico 3), o equivalente a aproximadamente 45 mil dólares anuais para todos os projetos de vacina.

Gráfico 3 - Distribuição percentual, por instrumento de fomento, do investimento do CNPq em projetos e bolsas identificados como de pesquisa e desenvolvimento de soros e/ou vacinas para uso humano - 2001-2002

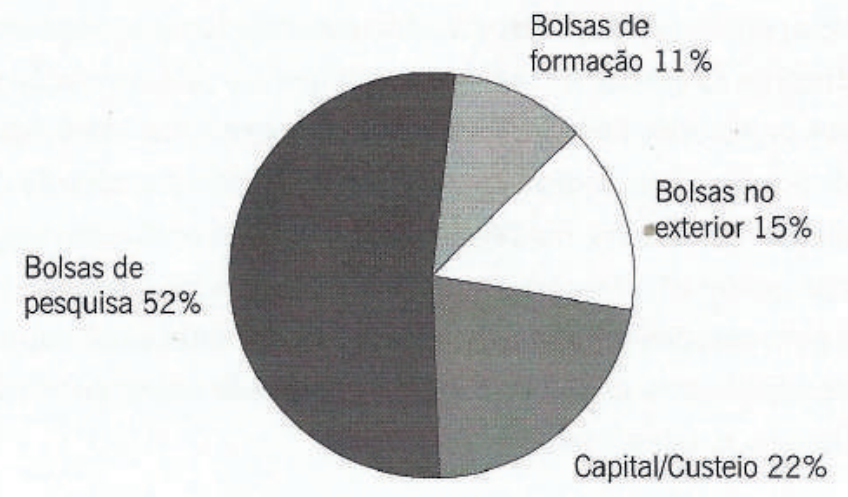


$\mathrm{Na}$ área de soros, quase metade dos investimentos se dirigiu para os aspectos de diagnóstico com os alvos tradicionais (38\%) ou com novos alvos (11\%), seguido de estudos epidemiológicos de seu uso. O suporte tecnológico ao desenvolvimento desta área utilizou $20 \%$ dos recursos do setor de soros e na forma de bolsas, enquanto a investigação de mecanismos de ação dos produtos foi o setor com menor suporte (Gráfico 4).

Gráfico 4 - Distribuição percentual, por tipo de ação, do investimento do CNPq em projetos e bolsas identificados como de pesquisa e desenvolvimento de soros para uso humano - 2001-2002

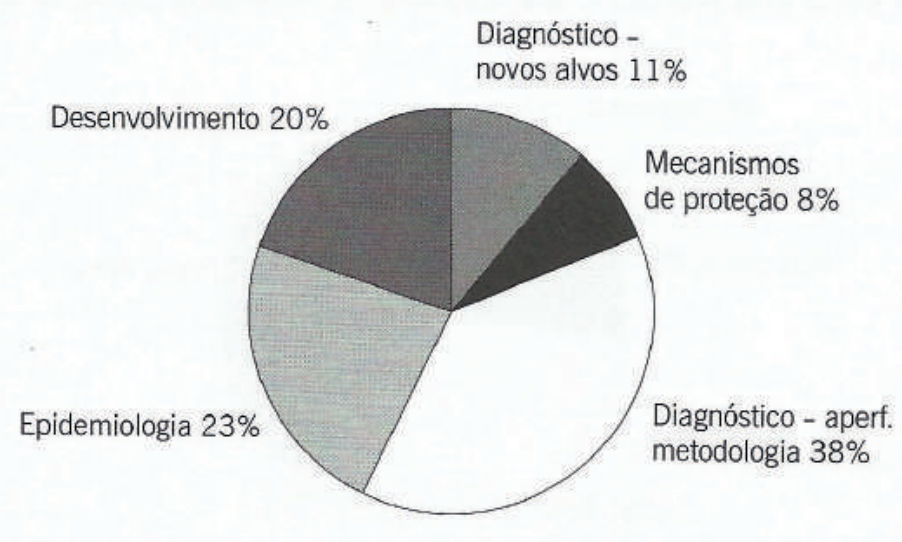

O campo de vacinas apresentou perfil distinto na sua forma de ação. A pesquisa de novas abordagens e de novos alvos vacinais representa mais de $50 \%$ do investimento, 0 que, somado à investigação dos mecanismos de proteção, consumiu $75 \%$ dos recursos no período de 2001 e 2002 (Gráfico 5).

Gráfico 5 - Distribuição percentual, por tipo de ação, do investimento do CNPq em projetos e bolsas identificados como de pesquisa e desenvolvimento de vacinas para uso humano - 2001-2002

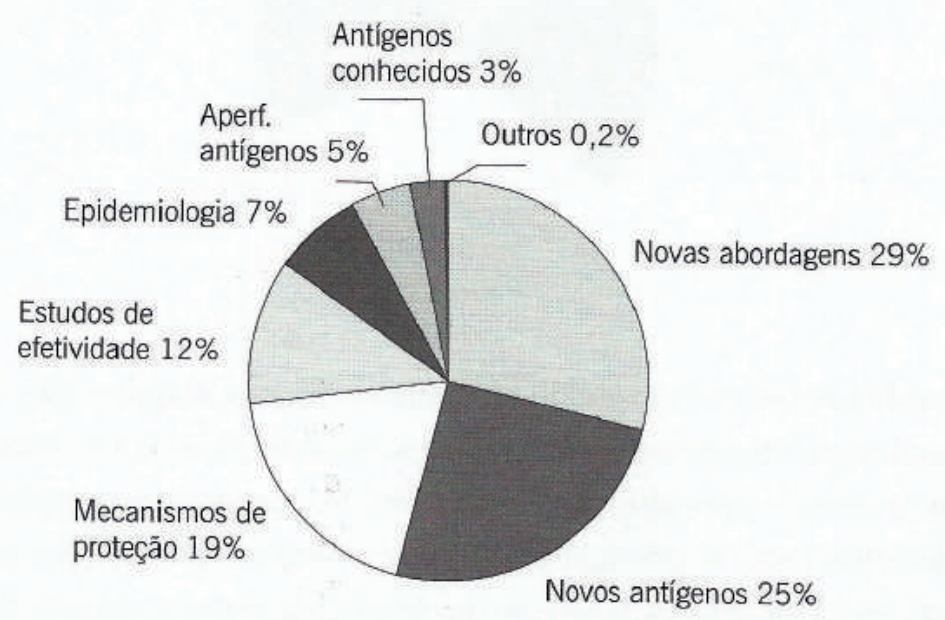


Os estudos com ênfase em vírus consumiram $40 \%$ dos recursos na pesquisa ou desenvolvimento em soros e $32 \%$ na área de vacinas (Gráficos 6 e 7), sendo a mais representada em ambas. Os parasitas foram o foco de $31 \%$ dos estudos em vacinas e de apenas $12 \%$ em soros. Considerando que no campo do soro estão incluídos, nesta análise, a pesquisa e o desenvolvimento de alvos para diagnóstico, vemos uma subrepresentação da área da parasitologia, considerado o desenvolvimento da pesquisa básica no campo (Gráficos 6 e 7).

Gráfico 6 - Distribuição percentual, por grupo de microrganismo alvo, do investimento do CNPq em projetos e bolsas para pesquisa e desenvolvimento de soros para uso humano - 2001-2002

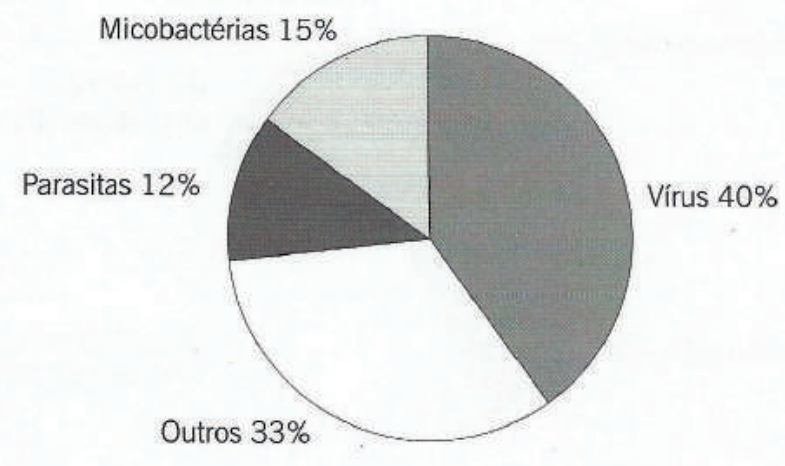

Gráfico 7 - Distribuição percentual, por grupo de microrganismo alvo, do investimento do CNPq em projetos e bolsas para pesquisa e desenvolvimento de vacinas para uso humano - 2001-2002

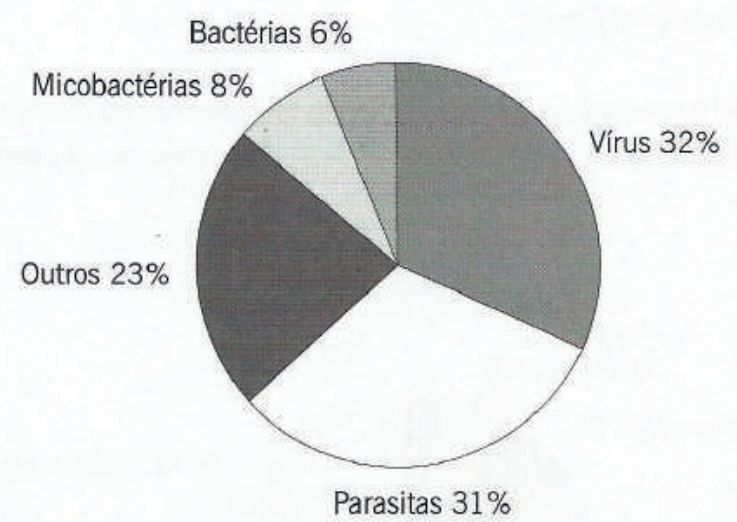

Analisando por doença individual, vemos que os recursos dirigidos à área de vacinas foram utilizados prioritariamente para leishmaniose, malária, Aids e tuberculose (Gráfico 8). Chama a atenção o pequeno investimento em doenças de grande impacto na saúde pública brasileira, como as doenças diarréicas e a dengue, por exemplo. Estes dados também refletem a escassa participação da ciência brasileira no campo das doenças crônico-degenerativas, a qual tem sido uma das áreas de grande atividade na busca de vacinas internacionalmente. 
Gráfico 8 - Volume de recursos do CNPq aplicados em apoio a projetos e bolsas para estudos de vacinas de uso humano. Identificação das principais doenças apoiadas - 2001-2002

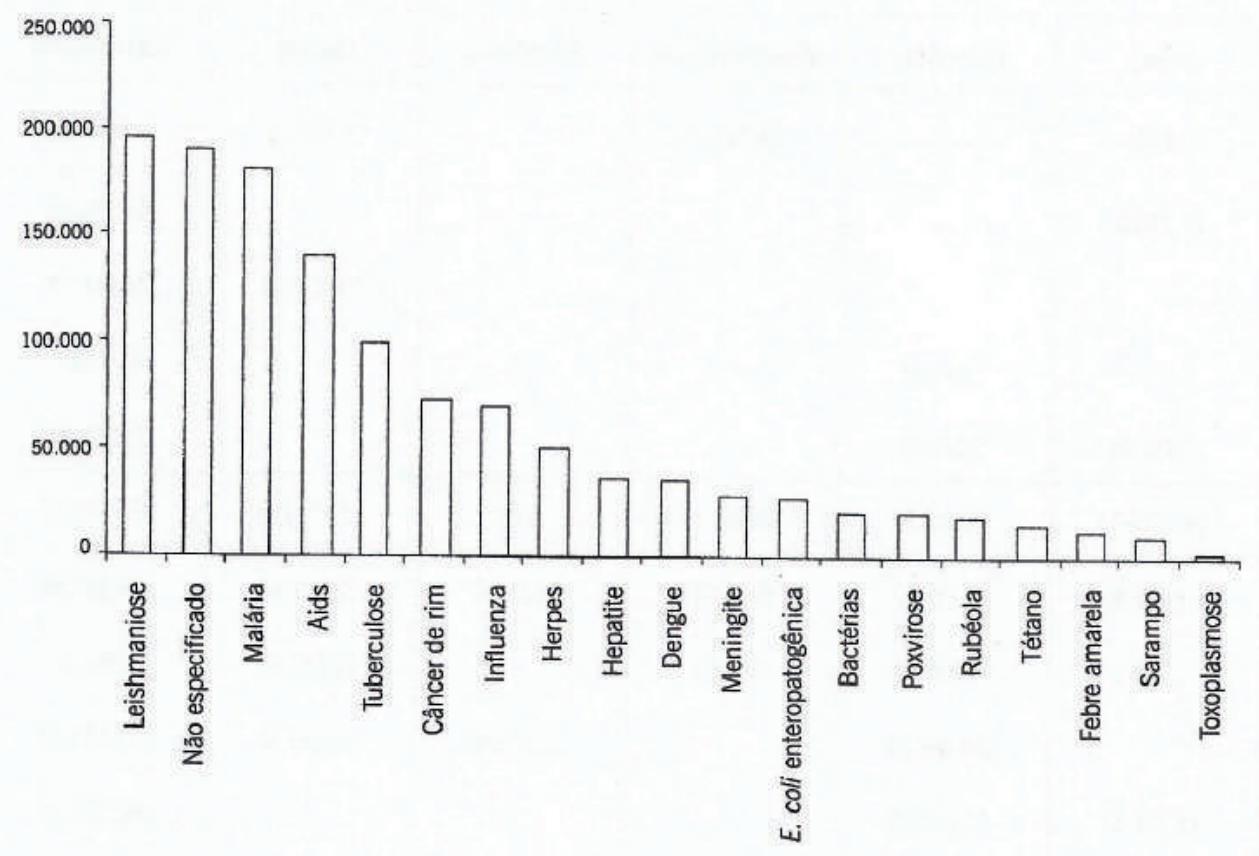

A Tabela 1, a seguir, demonstra que nenhum grupo de agentes patogênicos foi objeto de financiamento em todos os tipos de ação necessários para a obtenção de uma vacina ou de soros. Há sempre algum tipo de ação não contemplado nesse período. Além da existência dessas grandes lacunas de financiamento, a tabela ilustra, ainda, a notável dispersão de recursos. Atendidos os diversos alvos e as diversas modalidades, e considerando-se que esse suporte se estende por um período de dois anos para bolsas e apoio ao projeto na forma de custeio e capital, é inegável a insuficiência de recursos em praticamente todas as áreas.

Um plano de desenvolvimento de vacinas no Brasil é possível e necessário. A ausência de suporte ao conhecimento básico nas doenças de interesse e ao desenvolvimento de tecnologia em vacinologia é uma das limitações à sua concretização. Será essencial cuidar da proteção da propriedade intelectual e industrial, da formação de equipes multidisciplinares, bem como do aparelhamento adequado de unidades de teste-em modelos experimentais e para a realização de ensaios clínicos. Porém, mais importante do que iniciativas isoladas para a correção das falhas, é necessária a integração de todas as instituições e medidas num plano global, com clara definição de prioridades para emprego dos recursos disponíveis. ${ }^{1}$

\footnotetext{
${ }^{1}$ Agradecemos a Alerino Filho, pela ajuda no levantamento dos dados e na elaboraçẫo dos gráficos, e a Gilberto Souza e Flavio Neves, pelas sugestões.
} 
VACINAS, SOROS E IMUNIZAÇÕES NO BRASIL

Tabela 1 - Investimento do CNPq, em reais, na área de pesquisa e desenvolvimento de soros e vacinas para uso humano, por grupo de agentes patogênicos identificados como alvo e tipo de ação pesquisada - 2001 e 2002

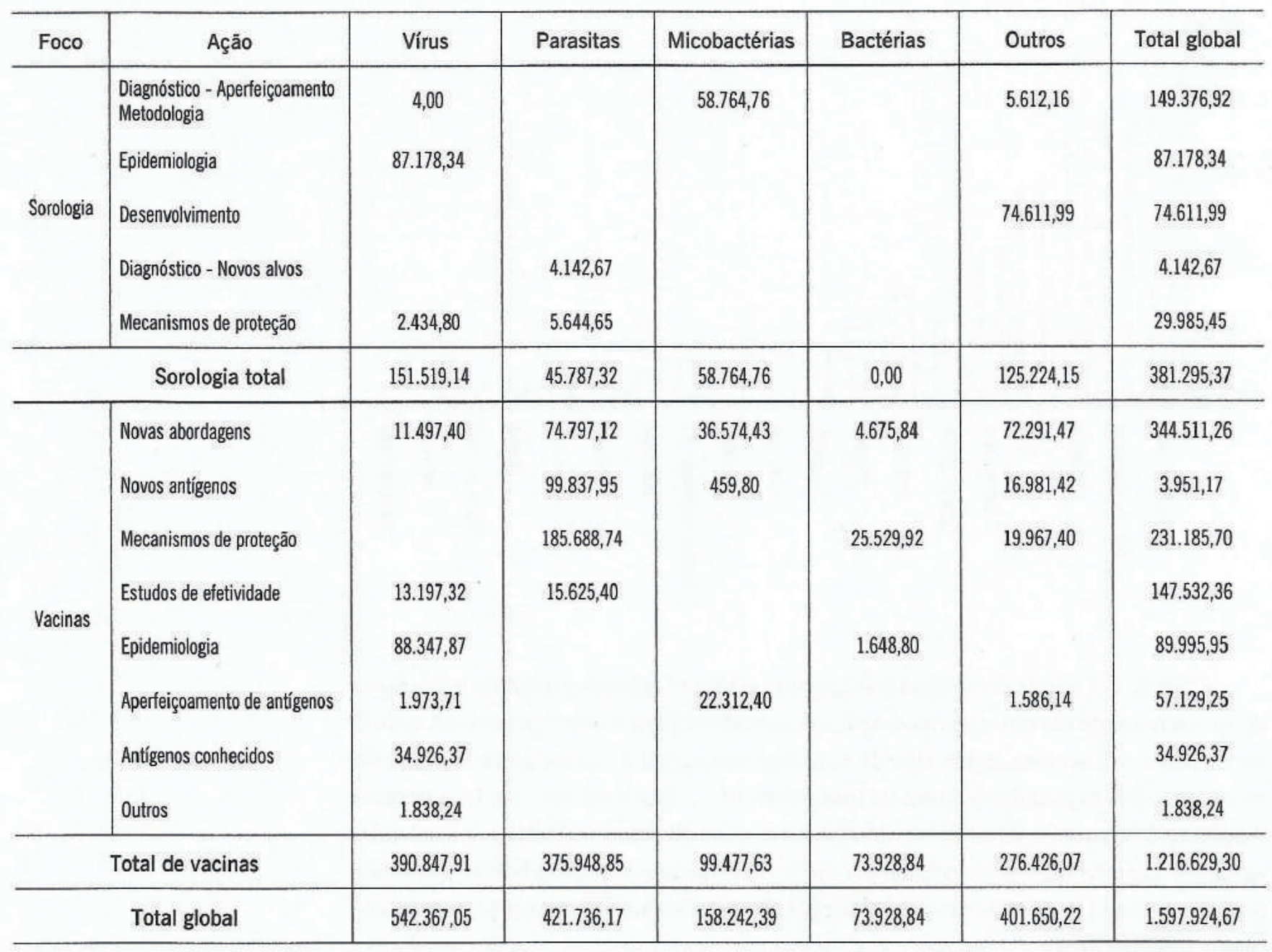

Obs.: Os valores (R\$) compreendem 0 apoio a bolsas, capital e custeio de projetos. 


\section{Desenvolvimento Tecnológico em Vacinas e outros Insumos para a Saúde na Fiocruz}

Euzenir Nunes Sarno Jussara Nascimento Wim Maurits Sylvain Degrave Paulo Marchiori Buss

\section{INTRODUÇÃO}

A Fundação Oswaldo Cruz (Fiocruz) é uma instituição centenária, cuja tradição e principal atividade, desde sua criação, é a pesquisa e o desenvolvimento de tecnologias (P\&D) na área da saúde.

Com o risco das simplificações, mas procurando ser didático, entendemos que as atividades de P\&D na Fiocruz distribuem-se em três grandes áreas: pesquisa biológica e biomédica, pesquisa clínica e pesquisa em saúde pública. Esta última, por sua vez, inclui as áreas de políticas, sistemas e serviços de saúde; epidemiologia e das vigilâncias em saúde. Evidentemente, quando se examina determinado projeto desenvolvido na instituição, este pode ser classificado em mais de uma dessas vertentes, nele envolvendo-se profissionais diversos, utilizando referências de diferentes disciplinas.

Cerca de 1.500 pesquisadores e tecnólogos, entre os quais cerca de 500 doutores e 700 mestres, das mais diferentes profissões - incluindo médicos, biólogos, químicos, cientistas sociais, engenheiros, matemáticos, historiadores -, trabalhando com base na vertente de dezenas de disciplinas e campos disciplinares - como saúde pública, biotecnologias, imunologia, biologia celular e molecular, epidemiologia, economia, administração e planejamento, métodos quantitativos aplicados à saúde, entre outros-, constroem o acervo científico e tecnológico da Fiocruz, fazendo desta uma das mais importantes instituições no campo da ciência e tecnologia em saúde da América Latina. 
Como em muitas instituições no país, a Fiocruz tem sua força maior na pesquisa e, só mais recentemente, a preocupação com a inovação e a geração de tecnologias para a saúde passou a ocupar de forma mais persistente e prioritária seus cientistas e a alta direção da Fundação.

Em abril de 2001, a Presidência da Fiocruz apresentou ao Conselho Deliberativo (CD) o documento Diretrizes para o Plano Quadrienal 2001-2005, no qual revisava as atividades de $P \& D$ na instituição e propunha a priorização das suas atividades de $P \& D$, com ênfase na inovação e no desenvolvimento de tecnologias para a saúde, além de sedimentar a pesquisa científica. Para dar materialidade a essas diretrizes, propôs a implementação do Programa de Desenvolvimento Tecnológico em Insumos em Saúde (PDTIS) e do Programa de Desenvolvimento Tecnológico em Saúde Pública (PDTSP), além da manutenção do já existente Programa de Apoio à Pesquisa em Saúde (Papes).

Com o Papes, pretende-se reforçar a chamada 'gestão da diversidade', isto é, apoiar projetos de pesquisa de alta qualidade científica, nas mais diversas áreas de domínio dos institutos, departamentos, laboratórios e dos cientistas da Fundação. Em 2003 estavam financiados 122 projetos, com um gasto anual de cerca de 2 milhões de reais, oriundos do orçamento regular e de receitas próprias, para financiar essas pesquisas, além, obviamente, de recursos de fontes externas à Fiocruz. A seleção dos projetos é feita por um comitê de alto nível, composto de cientistas da casa e externos à Fundação. $\mathrm{O}$ apoio aos projetos constitui-se de recursos para custeio e bolsas de pesquisadores visitantes e de iniciação científica, além de estímulo à inserção, nas atividades dos projetos financiados pelo Papes, de mestrandos e doutorandos dos programas de pós-graduação da Fundação.

Com o PDTSP pretende-se fomentar a inovação em saúde pública, nas suas dimensões populacional (políticas e sistemas e serviços de saúde; vigilâncias em saúde) e individual (pesquisa clínica). Este aspecto não será apresentado neste texto, que se destina a examinar exclusivamente $P \& D$ em vacinas na Fiocruz.

O PDTIS, que tem no desenvolvimento de vacinas um de seus principais objetivos, será analisado a seguir.

\section{PROGRAMA DE DESENVOLVIMENTO TECNOLÓGICO DE INSUMOS PARA A SAÚDE (PDTIS)}

O Programa de Desenvolvimento Tecnológico de Insumos para a Saúde (PDTIS) tem como objetivos induzir (ou identificar) e apoiar projetos de desenvolvimento tecnológico em imunobiológicos (vacinas, kits e reativos para diagnóstico), produtos para controle de vetores, fármacos e medicamentos da Fiocruz, que apresentem perspectivas de resultados imediatos ou a curto prazo. São prioridades deste programa as doenças infectoparasitárias prevalentes no Brasil.

Para atingir esse objetivo, foram elaboradas açôes procurando diagnosticar e direcionar o potencial tecnológico das pesquisas já em andamento na Fundação. O PDTIS procura promover maior interação entre as unidades de pesquisa e de produção; capacitar 
recursos humanos direcionados para $P \& D$; otimizar, fortalecer e modernizar a infra-estrutura laboratorial; atuar como facilitador na implementação das Boas Práticas de Laboratório (BPL); agilizar a aquisição de equipamentos e materiais de consumo; otimizar a utilização de recursos institucionais e externos; interagir com outras instituições nacionais e internacionais. Na Figura 1, apresenta-se o organograma do Programa. ${ }^{1}$

Figura 1 - Estruturaçăo do PDTIS

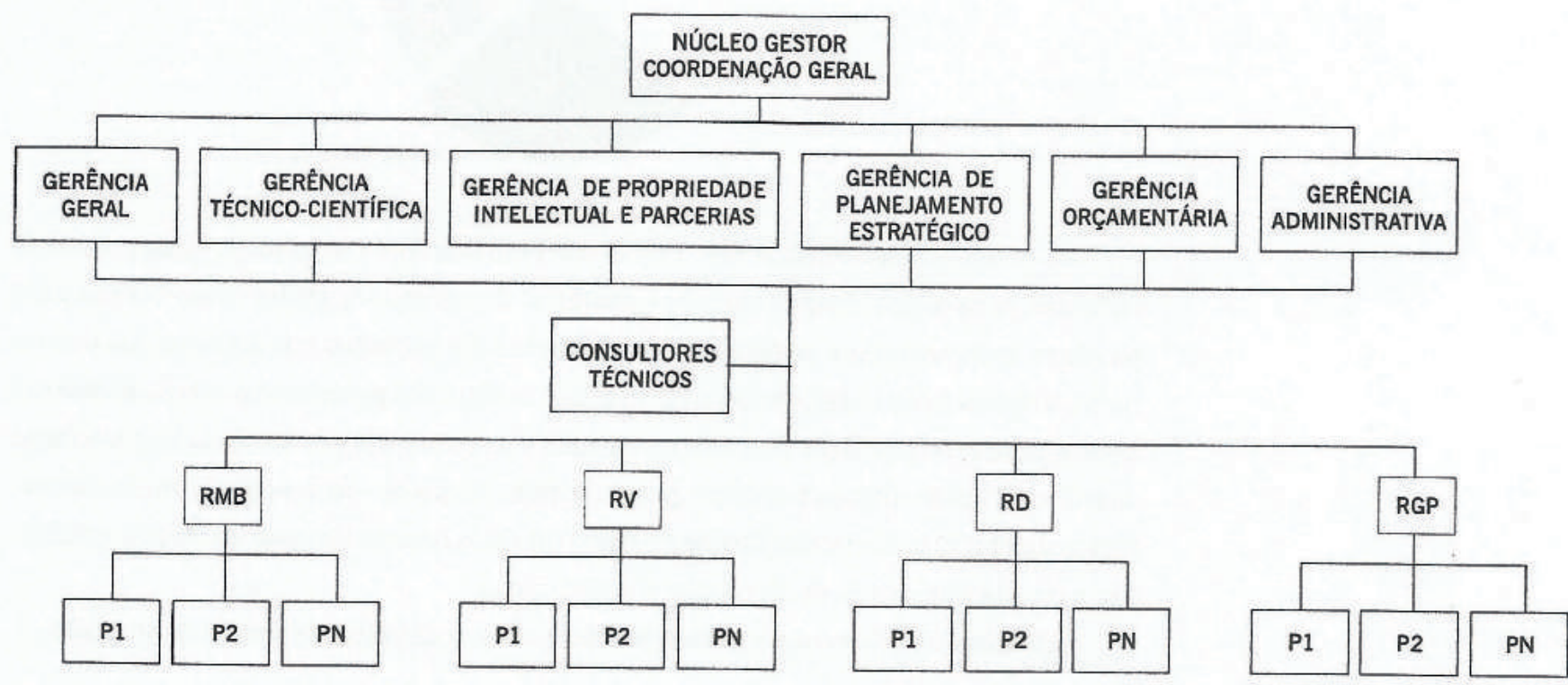

RMB - Rede de Medicamentos e Bioinseticidas

RV - Rede Vacina

RD - Rede Diagnóstico

RGD - Rede Genoma e Proteoma

A implantação do PDTIS, aprovado em 2001, após estudos preliminares e cuidadoso planejamento, foi iniciada em 2002 e o Programa será continuamente implementado sempre que novas ações e projetos forem necessários. O núcleo gestor do PDTIS realizou cerca de cinqüenta reuniōes em 2002 e 2003 para alcançar os resultados atuais. Duas oficinas de trabalho foram organizadas em 2003, uma com pesquisadores já incluídos nas três redes do Programa para padronização das medidas de garantia de qualidade, biossegurança e propriedade intelectual; outra, com participantes dos novos projetos selecionados, para a organização da rede de reativos e kits para diagnóstico.

O PDTIS é financiado por um fundo competitivo específico, criado e gerenciado pela Presidência, que recebe recursos oriundos do resultado financeiro da produção de insumos na Fiocruz (Fundo Pró-Insumo). Os mecanismos de seleção de projetos incluídos no Programa são baseados na qualidade científica e na aplicação potencial do resultado (produto ou processo) para o sistema de saúde. Em 2003, os gastos totais realizados no PDTIS foram de cerca de 9,5 milhōes de reais, que foram distribuídos pelas quatro redes, conforme o Gráfico 1.

'Aequipe permanente do PDIIS está composta dos seguintes profissionais: Coordenaçăo Geral, Euzenir Sarno; Gerência Geral, Cassia D. Pereira, Wim Degrave e Ana Paula Brum Pizarro (ad-hoc); Gerência Técnico-Científica, Jussara Nascimento, Tereza Cristina dos Santos, Norma Labarte e Wim Degrave; Gerência de Propriedade Intelectual e Parcerias, Celeste Emerick; Gerênciade Planejamento Estratégico, Cristiane Quental; Gerência Orçamentária, Charles da Silva Bezerra e Débora Cristina Silva; Apoio Administrativo, Elizabeth Machado; e Coordenadores Técnicos/ Executores de Projetos. 
Gráfico 1 - Distribuiçăo de recursos por redes - 2003

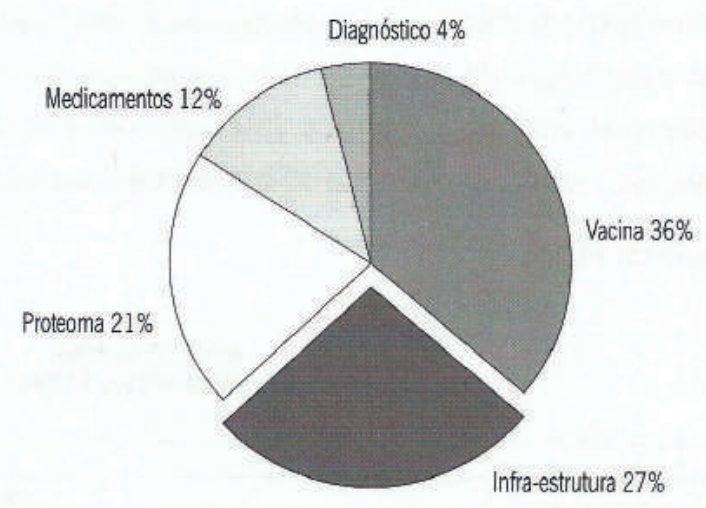

Os projetos selecionados pelo PDTIS recebem auxílios integrados, constituídos de recursos para obras, equipamentos e material de consumo, assim como bolsas para técnicos, tecnologistas e pesquisadores visitantes, financiados nos âmbitos dos Convênios CNPq/Fiocruz e Faperj/Fiocruz. Além disso, muitos dos pesquisadores envolvidos são bolsistas de produtividade do CNPq e possuem estudantes de pós-graduação e iniciação científica trabalhando nos seus projetos. Ou seja, busca-se, no desenvolvimento tecnológico da Fiocruz, a articulação dos projetos também com os programas de pós-graduação e outras iniciativas de formação da instituição.

A distribuição dos recursos globais por elementos de dispêndio encontra-se no Gráfico 2.

Gráfico 2 - Orçamento PDTIS - 2003

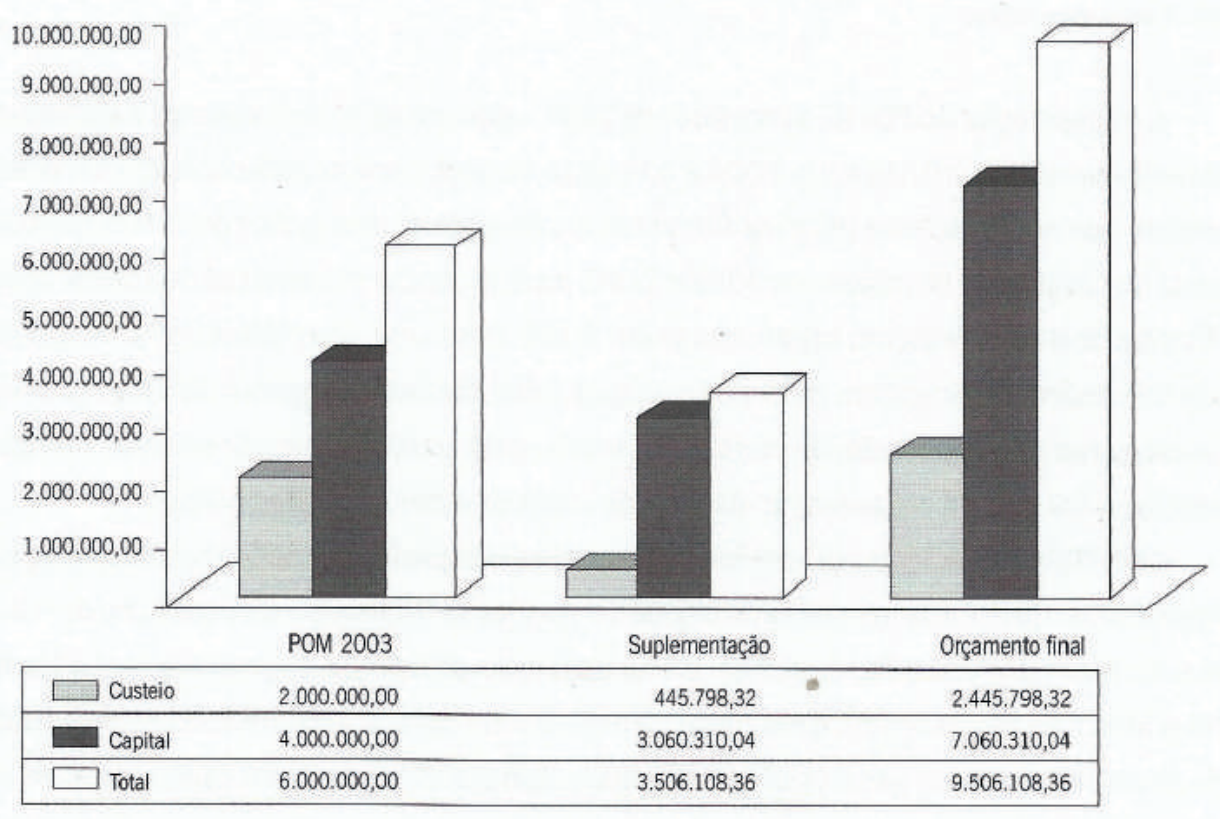


As atividades de pesquisa e desenvolvimento tecnológico em saúde na Fiocruz são tratadas sob diversas óticas, abrangendo desde o campo da biologia básica até a pesquisa clínica. Têm como objetivo fornecer respostas às questões apresentadas pelo quadro sanitário nacional, a partir da geração de novos conhecimentos para a promoção da saúde e a prevenção, diagnóstico e terapêutica de doenças prevalentes no país; do desenvolvimento de processos e produtos e de tratamentos clínicos específicos. A convivência das atividades de pesquisa pura e aplicada e de produção confere à Fundação um potencial singular para o desenvolvimento tecnológico.

As diferentes unidades que compõem a Fiocruz participam do PDTIS cooperando por meio das seguintes atividades, segundo sua missão institucional (Figura 2):

- Produção e desenvolvimento tecnológico de medicamentos: Far-Manguinhos

- Produção e desenvolvimento tecnológico de vacinas e reativos para diagnóstico: Bio-Manguinhos

- Suporte ao controle de qualidade de vacinas, medicamentos e reativos para diagnóstico: Centro de Criação de Animais de Laboratório (Cecal)

- Controle de qualidade: Instituto Nacional de Controle e Qualidade em Saúde (INCQS)

- Pesquisa clínica - Ensaios fases 1, 2 e 3: Instituto de Pesquisa Clínica Evandro Chagas (Ipec) e Instituto Fernandes Figueira (IFF)

- Pesquisas em fase de pré-desenvolvimento: Instituto Oswaldo Cruz (IOC), Centro de Pesquisas René Rachou (CPqRR), Centro de Pesquisas Gonçalo Muniz (CPqGM) e Centro de Pesquisa Aggeu Magalhães (CpqAM)

Figura 2 - Área de aplicação dos resultados (PDTIS)

Desenvolvimento tecnológico

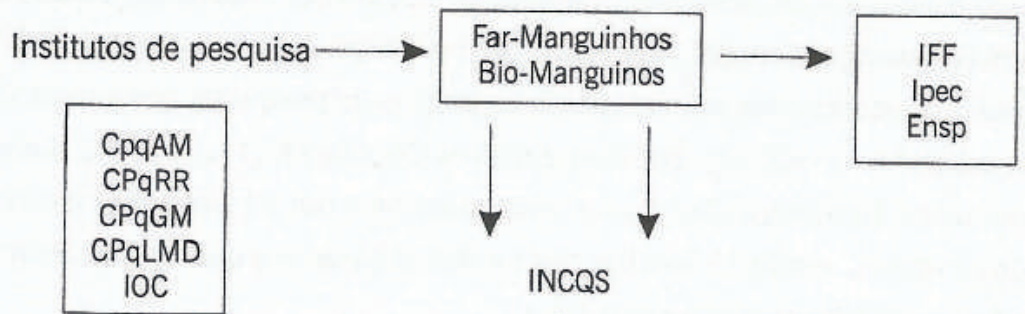

Pesquisa básica

Pré-desenvolvimento Controle de qualidade Pesquisa clínica

O PDTIS foi elaborado contanđo com a ativa participação dos setores com experiência em desenvolvimento tecnológico da Fiocruz, principalmente Bio-Manguinhos e FarManguinhos. A seleção dos projetos que participam das redes do Programa teve principalmente o enfoque de desenvolver produtos de interesse do SUS, produtos voltados para doenças negligenciadas (malária, leishmaniose e outras), ou para doenças prevalentes na população (dengue, HIV e outras). A aplicação dos resultados (produtos) obtidos no PDTIS é compromisso assumido por Far-Manguinhos e Bio-Manguinhos, desde a elaboração do programa, definição das redes e prioridades dos projetos selecionados. 
O PDTIS foi idealizado e estruturado em discussōes amplas com a comunidade de gestores da Fiocruz e do $\mathrm{CD} /$ Fiocruz, sendo divulgado através de edital único. A comunidade técnico-científica da Fundação foi convocada para participar de oficinas, em número de três, a fim de constituir as três redes iniciais do PDTIS: Medicamentos e Bioinseticidas; Vacinas Recombinantes e de DNA; Proteoma. Após as oficinas, foram lançados os editais para envio das cartas de intenção por parte da comunidade científica da Fiocruz. A aprovação das cartas de intenção contou com a participação de consultores internos e externos, além do núcleo gestor do PDTIS. Uma quarta rede de pesquisa em kits e reativos para diagnóstico foi implementada a partir de 2003.

As quatro redes que compõem atualmente o programa foram organizadas ao longo de várias reuniões com os grupos de pesquisa selecionados, e os projetos foram elaborados dentro de um padrão passível de acompanhamento sistemático, visando à detecção precoce de problemas e rápida solução dos mesmos. Os 58 projetos que compõem as quatro redes, assim como os respectivos coordenadores, estão discriminados a seguir.

\section{Rede de Medicamentos e Bioinseticidas (RMB)}

Coordenação: Teresa Cristina dos Santos - 11 projetos

A Rede de Medicamentos e Bioinseticidas foi a primeira rede do PDTIS. Formou-se mediante convite aos pesquisadores, que se apresentaram em 11 cartas de intenção, selecionadas entre as 23 recebidas em resposta ao edital de chamada lançado em abril de 2002. Esses pesquisadores foram convocados para uma reuniăo organizada em junho do mesmo ano, quando foram definidas as normas para elaboração dos projetos em cooperação e estabelecidas as parcerias que proporcionassem agilização dos experimentos e obtenção de resultados. Os pesquisadores se organizaram em 11 projetos, centralizados no IOC (3), em Far-Manguinhos (3), no CPqGM (2), no INCQS (1), na Ensp (1) e no CPqRR (1). A esses pesquisadores com seus respectivos grupos de pesquisa, somam-se mais oito grupos localizados no IOC (3), Far-Manguinhos (3), CPqRR (1) e Ipec (1). Atualmente, Medicamentos e Bioinseticidas é uma rede composta por 11 projetos envolvendo 19 grupos de pesquisa, sendo 15 localizados no Rio de Janeiro e quatro nos centros regionais, conforme discriminação no Quadro 1.

Nesta rede temos um total de 110 profissionais envolvidos. Todos os pesquisadores (gerentes de projeto e responsáveis técnicos) assinaram cartas-compromisso com o PDTIS, tendo o aval da direção das unidades onde os projetos são desenvolvidos. A classificação desses projetos se deu segundo as fases de desenvolvimento tecnológico em que se encontram, e, neste caso, todos foram classificados como projetos em pré-desenvolvimento, desde o nível básico (3), inicial (7), médio (4) até o nível avançado (1). Alguns projetos vêm sendo desenvolvidos há mais tempo, tendơ gerado publicações, teses de estudantes de pós-graduação, recebido financiamentos anteriores de diferentes órgãos de fomento nacionais e internacionais e gerado patentes. Outros grupos são praticamente iniciantes nesta área, embora muito experientes em pesquisa básica e aplicada a outras áreas de ciências biológicas e da saúde. 
Quadro 1 - Projetos da Rede de Medicamentos e Bioinseticidas (RMB)

\begin{tabular}{|c|c|}
\hline Título do projeto & Coordenação \\
\hline Implementação de infra-estrutura para avaliação toxicopatológica de fármacos & $\begin{array}{l}\text { Ricardo Ribeiro dos Santos (CPqGM) e Therezinha Coelho Barbosa Tomassini } \\
\text { (Far-Manguinhos) }\end{array}$ \\
\hline $\begin{array}{l}\text { Avaliação da atividade imunomoduladora in vivo e dos mecanismos de açāo de } \\
\text { fisalinas purificadas de Physalis angulata }\end{array}$ & $\begin{array}{l}\text { Milena Botelho Pereira Soares (CPqGM) e Therezinha Coelho Barbosa Tomassini } \\
\text { (Far-Manguinhos) }\end{array}$ \\
\hline Rede cooperativa para bioprospecção de plantas e fungos & Carlos Eleomar Zani (CPqRR) \\
\hline $\begin{array}{l}\text { Avaliação de compostos sintéticos, semi-sintéticos e naturais como potenciais } \\
\text { agentes leishmanicidas. Aspectos biológicos, bioquímicos e imunológicos }\end{array}$ & Leonor Leon $(10 \mathrm{C})$ \\
\hline $\begin{array}{l}\text { Avaliaçāo farmacológica de extratos, fraçōes e princípios ativos purificados de } \\
\text { plantas da flora brasileira }\end{array}$ & Válber da Silva Frutuoso (IOC) e Maria Raquel Figueiredo (Far-Manguinhos) \\
\hline $\begin{array}{l}\text { Busca de moléculas bioativas para o tratamento dos sintomas da infecção com o } \\
\text { vírus da dengue }\end{array}$ & André Luiz Franco Sampaio (Far-Manguinhos) \\
\hline Avaliação não clínica de segurança de fármacos e bioinseticidas & Francisco José Roma Paumgartten (Ensp) \\
\hline $\begin{array}{l}\text { Desenvolvimento de fitoterápico com atividade anti-hipertensiva de extratos da } \\
\text { espécie Echinodorus grandiflorus (Chamisso \& Schlechtendal) Micheli }\end{array}$ & Maria Raquel Figueiredo (Far-Manguinhos) e Eduardo Tibiriçá (IOC) \\
\hline $\begin{array}{l}\text { Avaliação de extratos de plantas previamente estabelecidos como referência } \\
\text { (atuaçăo de contra-referência) }\end{array}$ & André L. Gemal (INCQS) \\
\hline Identificação de novos princípios ativos com atividade antimicrobiana & $\begin{array}{l}\text { Maria das Graças Muller de Oliveira Henriques (Far-Manguinhos), Maria Inez } \\
\text { Sarquis (IOC) e Maria Cristina Lourenço (Ipec) }\end{array}$ \\
\hline $\begin{array}{l}\text { Avaliação do ácido guinardico, derivados e de frações do extrato produzido pelo } \\
\text { fungo Guinardia mangiferae e outros microfungos como antibiótico, antiprotozoário } \\
\text { e antitumoral }\end{array}$ & Kátia F. Rodrigues Heerklotz (IOC) \\
\hline
\end{tabular}

O PDTIS Medicamentos mobilizou, em 2003, recursos da ordem de 1,1 milhão de reais para contemplar esses 11 projetos; em adição, muitos deles recebem recursos de outras fontes, inclusive do Plano de Objetivos e Metas (POM) das unidades. Complementarmente, eles tiveram suas equipes ampliadas, com a inclusão de sete bolsistas (técnicos, tecnologistas e pesquisadores) dos convênios Fiocruz/Faperj e Fiocruz/CNPq.

É ainda de interesse ressaltar as interligações entre os diferentes projetos, através das quais a avaliação toxicopatológica, a avaliação não clínica đe segurança e a atuação em contra-referência serão utilizadas por distintos grupos de pesquisa, possibilitando múltiplas cooperações. 0 grupo que mais foi beneficiado pelas cooperações inter-redes foi o de candidatos a fitomedicamentos para o tratamento das infecções causadas pelo vírus da dengue, já que existe uma rede de pesquisa em dengue no PDTSP/Fiocruz que mobilizou recursos da ordem de 1,6 milhão de reais, assim como 11 bolsistas dos convênios Fiocruz/Faperj e Fiocruz/CNPq, nos seus projetos que servem de apoio aos de vacinas e medicamentos contra a dengue. Ainda em 2003, foram lançados o Instituto Virtual de Dengue, da Faperj, e editais específicos para pesquisas na doença por agências de fomento nacionais e internacionais. A busca por recursos fora da Fiocruz ampliou as possibilidades de cooperações científicas, que foram traduzidas em avanço na qualidade e na quantidade de metas alcançadas pelo projeto do PDTIS Medicamentos. 


\title{
Rede de Vacinas Recombinantes e de DNA (RV)
}

\author{
Coordenação: Jussara Nascimento - 15 projetos
}

A Rede de Vacinas Recombinantes e de DNA foi formada por meio de convite aos pesquisadores, que se apresentaram em 16 cartas de intenção, selecionadas entre as 23 recebidas em resposta ao edital de chamada lançado em abril de 2002 . Esses pesquisadores foram convocados para oito reuniões distintas, organizadas entre agosto e novembro do mesmo ano, quando foram definidas as normas para elaboração dos projetos em cooperação e estabelecidas as parcerias que proporcionassem agilização dos experimentos e obtenção de resultados. Os pesquisadores se organizaram em 15 projetos, centralizados no $I O C$ ( 9 ), em Bio-Manguinhos (1), no INCQS (1), no Ipec (1), no CPqGM (1) no CPqRR (1) e no CpqAM (1). A estes pesquisadores com seus respectivos grupos de pesquisa somam-se mais 21 grupos localizados no IOC (7), Bio-Manguinhos (6), CPRR (2), CPGM (2), CPAM (1), Ipec (1), INCQS (1) e Cecal (1). No momento atual, esta rede é composta por 15 projetos (Quadro 2), envolvendo 36 grupos de pesquisa e abrangendo 172 profissionais. Vinte e oito grupos estão localizados no Rio de Janeiro e oito, nos centros regionais e apresentam-se discriminados por doenças-alvo das vacinas (7) ou por estudos em adjuvantes (1).

Todos os pesquisadores (gerentes de projeto e responsáveis técnicos) assinaram cartas-compromisso com o PDTIS, tendo o aval da direção das unidades onde os projetos são desenvolvidos. A classificação desses projetos se deu segundo as fases de desenvolvimento tecnológico em que se encontram, e, neste caso, todos foram classificados como projetos em pré-desenvolvimento, desde o nível básico (3), inicial (7), médio (4) até o nível avançado (1). Alguns representam projetos de carreira do pesquisador líder, sendo desenvolvidos desde 1979, tendo gerado várias publicaçōes, teses de estudantes de pósgraduação, recebido financiamentos anteriores de diferentes órgãos de fomento nacionais e internacionais e gerado patentes. Outros grupos são praticamente iniciantes na área de vacinas, embora muito experientes em pesquisa básica e aplicada a outras áreas de ciências biológicas e da saúde.

O PDTIS Vacinas mobilizou, em 2003, recursos da ordem de 3,3 milhōes de reais para contemplar esses 15 projetos, e muitos deles recebem recursos de outras fontes, inclusive do POM das unidades. Os projetos tiveram, ainda, suas equipes ampliadas, com a inclusão de 24 bolsistas (técnicos, tecnologistas e pesquisadores) dos convênios Fiocruz/ Faperj e Fiocruz/CNPq. É interessante ressaltar, também, as interligações entre os diferentes projetos, nos quais vetores vacinais como BCGr, formas de imunização (vacina DNA) e os modelos experimentais em animais são utilizados por distintos grupos de pesquisa possibilitando múltiplas cooperações.

Os grupos que mais se beneficiaram pelas cooperações inter-redes foram aqueles que trabalharam em vacinas para dengue, já que existe uma rede de pesquisa nessa doença no PDTSP/Fiocruz, que mobilizou recursos da ordem de 1,6 milhão de reais, assim como 11 bolsistas dos convênios Fiocruz/Faperje Fiocruz/CNPq, nos seus projetos que servem de apoio aos projetos de vacinas e medicamentos contra a enfermidade. Ainda em 
2003, foram lançados o Instituto Virtual de Dengue, da Faperj, e editais específicos para pesquisas em dengue por agências de fomento nacionais e internacionais. A busca por recursos fora da Fiocruz ampliou as possibilidades de cooperações científicas, que foram traduzidas por avanço na qualidade e na quantidade de metas alcançadas por alguns destes projetos do PDTIS vacinas.

Quadro 2 - Projetos da Rede de Vacinas Recombinantes e de DNA (RV)

\begin{tabular}{|c|c|}
\hline Título do projeto & Coordenaçăo \\
\hline \multicolumn{2}{|l|}{ Dengue } \\
\hline $\begin{array}{l}\text { Desenvolvimento do vírus da febre amarela vacinal } 170 \text { como vetor de expressäo } \\
\text { para antígenos de dengue }\end{array}$ & Ricardo Galler (IOC) Elena Caride (Bio-Manguinhos) \\
\hline Desenvolvimento de vacinas de DNA contra o vírus da dengue & Ada Maria de Barcelos Alves (IOC) e Marcos da Silva Freire (Bio-Manguinhos) \\
\hline Desenvolvimento de vacinas de DNA contra o vírus da dengue & Norma Lucena C. Licinio da Silva e Ernesto Marques (CpqAM) \\
\hline $\begin{array}{l}\text { Desenvolvimento, implantação e validação de metodologias analíticas para o } \\
\text { controle da qualidade de vacinas de DNA }\end{array}$ & Humberto Pinheiro de Araújo e Maria Aparecida Boller (INCQS) \\
\hline \multicolumn{2}{|l|}{ Malária } \\
\hline $\begin{array}{l}\text { Vacina contra malária: protocolos prime-boost com adenovirus recombinantes e } \\
\text { DNA plasmidiano }\end{array}$ & Ricardo Gazinelli e Oscar Bruna Romero (CPqRR) \\
\hline $\begin{array}{l}\text { Malária: avaliação pré-clínica de antígenos de Plasmodium falciparum candidatos } \\
\text { à vacina em primatas neotropicais Saimiri sciureus e Aotus infulatus }\end{array}$ & Cláudio Tadeu Daniel Ribeiro (IOC) e Antonio Mota (Cecal) \\
\hline $\begin{array}{l}\text { Desenvolvimento do vírus da febre amarela vacinal } 170 \text { como vetor de expressão } \\
\text { para antígenos de malária }\end{array}$ & Myrna C. Bonaldo (IOC) Marcos da Silva Freire (Bio-Manguinhos) \\
\hline \multicolumn{2}{|l|}{ Leishmaniose } \\
\hline $\begin{array}{l}\text { Desenvolvimento de vacinas candidatas contra leishmaniose a partir de genes de } \\
\text { Leishmania amazonensis }\end{array}$ & Sergio Mendonça Coutinho (IOC) e Geraldo Armoa (Bio-Manguinhos) \\
\hline \multicolumn{2}{|l|}{ Esquistossomose } \\
\hline $\begin{array}{l}\text { Vacina anti-helmíntica bivalente contra a esquistossomose e a fasciolose, a partir } \\
\text { do antígeno recombinante Sm14 }\end{array}$ & Mirian Tendler e Mônica Vilar (IOC) e Geraldo Armoa (Bio-Manguinhos) \\
\hline \multicolumn{2}{|l|}{ Tuberculose } \\
\hline $\begin{array}{l}\text { Avaliação de novos antígenos para a vacina BCG e otimizaçāo desta através da } \\
\text { inserçẫo de genes específicos de } M \text {. bovis } \Theta M \text {. tuberculosis }\end{array}$ & Elizabeth Sampaio (IOC) \\
\hline $\begin{array}{l}\text { Imunogenicidade de novas construçōes vacinais e caracterização de novos } \\
\text { antígenos para imunização ou terapia gênica contra tuberculose }\end{array}$ & Maria da Glória Bonecini (lpec) \\
\hline $\begin{array}{l}\text { Desenvolvimento da tecnologia recombinante BCGr visando à utilização do BCG } \\
\text { (subcepa Moreau) como vetor de expressão de proteínas associadas com proteção } \\
\text { contra doenças }\end{array}$ & Geraldo Armoa (Bio-Manguinhos) \\
\hline \multicolumn{2}{|l|}{ Hepatites virais } \\
\hline Vacinas recombinantes e quimeras dos vírus da hepatite $B$ e da hepatite $C$ & Elisabeth Lampe (IOC) e Mitermayer G. Reis (CPqGM) \\
\hline \multicolumn{2}{|l|}{ Leptospirose } \\
\hline Desenvolvimento de vacina recombinante para leptospirose & $\begin{array}{l}\text { Albert Ko (CPqGM), Marco Alberto Medeiros (Bio-Manguinhos) e Marcelo Alves } \\
\text { (IOC) }\end{array}$ \\
\hline \multicolumn{2}{|l|}{ Adjuvantes } \\
\hline Avaliação moléculas candidatas e adjuvantes para vacinas antiinfecciosas & $\begin{array}{l}\text { Alda Maria da Cruz, Mariza Gonçalves Morgado e Joselli Lanes (IOC), Ricardo } \\
\text { Tostes Gazzinelli (CPaRR) e Lain Carlos Pontes de Carvalho (CPqGM) }\end{array}$ \\
\hline
\end{tabular}




\section{Rede de Genoma e Proteoma (RGP)}

Coordenação: Wim Degrave - 13 projetos

A rede de Genoma e Proteoma foi formada por meio de convite aos pesquisadores, que se apresentaram em 15 cartas de intenção, selecionadas entre as 23 recebidas em resposta ao edital de chamada lançado em abril de 2002. Estes pesquisadores foram convocados para uma reunião organizada em setembro do mesmo ano, quando foram definidas as normas para elaboração dos projetos em cooperação e estabelecidas as parcerias que proporcionassem agilização dos experimentos e obtenção de resultados. Os pesquisadores se organizaram em 13 projetos centralizados no IOC (11), em Bio-Manguinhos (1) e no CPqRR (1). A esses pesquisadores com seus respectivos grupos de pesquisa somam-se mais dois grupos, localizados em Bio-Manguinhos. No momento atual, a Rede de Genoma e Proteoma é composta por 13 projetos envolvendo 15 grupos de pesquisa (abrangendo 107 profissionais), sendo 14 no Rio de Janeiro e 1 no CPqRR, conforme discriminados no Quadro 3.

Quadro 3 - Projetos da Rede de Genoma e Proteoma (RGP)

\begin{tabular}{|c|c|}
\hline Título do projeto & Coordenaçăo \\
\hline Bioinformática: suporte aos projetos PDTIS & Antonio Basílio de Miranda (IOC) \\
\hline Implementação de uma plataforma proteômica na Fiocruz & Jonas Enrique Aguilar Perales (10C) \\
\hline $\begin{array}{l}\text { Plataforma técnica de caracterização estrutural (eletroforese } 2 \mathrm{D} \text {, fragmentação-purificação, } \\
\text { seqüenciamento, modelagem, cristalografia e síntese de peptídeos) }\end{array}$ & Salvatore Giovanni De Simone (IOC) \\
\hline $\begin{array}{l}\text { Obtenção e caracterização de anticorpos espećficcos e de proteínas imunogênicas virais ou bacterianas: } \\
\text { aplicação da tecnologia proteômica no diagnóstico ou geração de novas vacinas em Bio-Manguinhos }\end{array}$ & $\begin{array}{l}\text { Márcia Terezinha Baroni de Moraes e Souza (Bio- } \\
\text { Manguinhos) }\end{array}$ \\
\hline $\begin{array}{l}\text { Proteoma de Trypanosoma cruzi: análise de diferenças fenotípicas entre as cepas com distintos perfis } \\
\text { patogênicos }\end{array}$ & Octavio Fernandes (IOC) \\
\hline Proteoma de Paracoccidioides brasilliensis & Cíntia de Moraes Borba (IOC) \\
\hline $\begin{array}{l}\text { Definição do proteoma do Mycobacterium leprae e aplicação de proteômica na identificação de moléculas } \\
\text { relevantes na interaçăo de micobactérias com o ser humano }\end{array}$ & Maria Cristina Vidal Pessolani (10C) \\
\hline $\begin{array}{l}\text { Abordagem proteômica para identificação de antígenos de } P \text {. falciparum e } P \text {. vivax com potencial uso em } \\
\text { vacinas }\end{array}$ & Maria de Fátima Ferreira da Cruz (IOC) \\
\hline $\begin{array}{l}\text { Plataforma de eletroforese } 2 D \text { para proteoma e análise do perfil protéico do sobrenadante e superfície de } \\
\text { cepas de micobactérias }\end{array}$ & Leila de Mendonça Lima (IOC) \\
\hline $\begin{array}{l}\text { Proteoma de leishmânia do novo mundo: caracterização do perfil protéico de cepas de referência e análise } \\
\text { de diferenças fenotípicas entre as cepas de acometimento cutâneo e mucoso }\end{array}$ & Elisa Cupolillo (IOC) \\
\hline $\begin{array}{l}\text { Busca de novos alvos moleculares para o controle das leishmanioses: } 1 \text { - estudos do endereçamento } \\
\text { celular em leishmânia; 2- estudos moleculares de flebotomíneos vetores }\end{array}$ & Yara Maria Traub-Cseko (IOC) \\
\hline $\begin{array}{l}\text { Caracterização de proteínas de membrana de Leptospira interrogans, expressas in vitro e in vivo utilizando } \\
\text { técnicas proteômicas }\end{array}$ & Martha Maria Pereira (10C) \\
\hline Estudos proteômicos de parasitas e vetores de importância médica & Álvaro Romanha (CPRR) \\
\hline
\end{tabular}


Todos os pesquisadores (gerentes de projeto e responsáveis técnicos) assinaram cartas-compromisso com o PDTIS, tendo o aval da direção das unidades onde os projetos são desenvolvidos; estes foram classificados como projetos em pré-desenvolvimento, no nível básico. Os três primeiros representam a infra-estrutura da Rede Proteoma e são pontos de convergência para todos os demais integrantes da rede. Alguns projetos já geraram várias publicaçōes, teses de estudantes de pós-graduação, tendo recebido financiamentos anteriores de diferentes órgãos de fomento nacionais e internacionais. Outros grupos são praticamente iniciantes na área de proteomas, embora muito experientes em pesquisa básica e aplicada a outras áreas de ciências biológicas e da saúde.

O PDTIS Proteoma mobilizou, em 2003, recursos da ordem de 2,2 milhōes de reais para contemplar os 13 projetos, e muitos deles recebem recursos de outras fontes, inclusive do POM das unidades. Além disso, esses projetos tiveram suas equipes ampliadas com a inclusão de dez bolsistas (técnicos, tecnologistas e pesquisadores) dos convênios Fiocruz/Faperj e Fiocruz/CNPq.

O grupo que mais foi beneficiado pelas cooperaçōes inter-redes foi aquele trabalhando em proteoma de dengue, já que existe uma rede de pesquisa nessa doença no PDTSP/ Fiocruz, mobilizando recursos da ordem de 1,6 milhão de reais, assim como 11 bolsistas dos convênios Fiocruz/Faperj e Fiocruz/CNPq, nos seus projetos. Ainda em 2003 foram lançados o Instituto Virtual de Dengue, da Faperj, e editais específicos para pesquisas nessa enfermidade por agências de fomento nacionais e internacionais. A busca por recursos fora da Fiocruz ampliou as possibilidades de cooperaçōes científicas, que foram traduzidas por avanço na qualidade e na quantidade de metas alcançadas por este projeto do PDTIS Proteoma.

\section{Rede de Diagnóstico (RD)}

Coordenação: Norma Labarthe -19 projetos

A Rede de Diagnóstico foi formada em 2003 mediante convite aos pesquisadores que se apresentaram em 19 cartas de intenção, selecionadas entre as 45 recebidas em resposta ao edital de chamada lançado em abril de 2003. Estes pesquisadores foram convocados para cinco reuniōes organizadas entre junho e novembro de 2003, quando as normas para elaboração dos projetos em cooperação foram definidas e se estabeleceram as parcerias que proporcionassem agilização dos experimentos e obtenção de resultados. Os pesquisadores se organizaram em 19 projetos centralizados no $\operatorname{IOC}(7)$, em Bio-Manguinhos (1), no IBMP (1), no Instituto de Pesquisas em Patologias Tropicais - Ipepatro (1), no CPqGM (3), no CPqRR (3) e no CpqAM (3). Esses grupos de pesquisa contam com 117 profissionais, distribuídos nos 19 projetos, sendo oito localizados no Rio de Janeiro e 11 nos centros regionais, conforme a discriminação no Quadro 4.

A classificação dos projetos se deu segundo as fases de desenvolvimento tecnológico em que se encontram, e, neste caso, todos foram classificados como projetos em prédesenvolvimento, desde o nível médio (16) até o nível avançado (3). Muitos deles já geraram publicações, teses de estudantes de pós-graduação, tendo recebido financiamentos anteriores de diferentes órgãos de fomento nacionais e internacionais e gerado patentes. 
Quadro 4 - Projetos da Rede de Diagnóstico (RD)

\begin{tabular}{|c|c|}
\hline Título do projeto & Coordenação \\
\hline $\begin{array}{l}\text { Estabelecimento de ensaio imunoenzimático-ElA para detecçāo de rotavírus, adenovírus e astrovírus em } \\
\text { amostras fecais }\end{array}$ & José Paulo Gagliardi Leite (IOC) \\
\hline $\begin{array}{l}\text { Desenvolvimento de insumos (conjugados) para imunofenotipagem e quantificaçāo de } \mathrm{CD} 3 / \mathrm{CD} 4 / \mathrm{CD} 8 \text { por } \\
\text { citometria de fluxo, em amostras de indivíduos infectados pelo HIV }\end{array}$ & Marli Sidoni (Bio-Manguinhos) \\
\hline $\begin{array}{l}\text { Desenvolvimento de conjuntos (kits) diagnósticos para leishmaniose visceral utilizando antígenos } \\
\text { recombinantes }\end{array}$ & Lain Carlos Pontes de Carvalho (CPqGM) \\
\hline Padronização e avaliação da técnica de aglutinação direta para o diagnóstico da leishmaniose visceral & Ana Rabello (CPqRR) \\
\hline $\begin{array}{l}\text { Desenvolvimento de método de diagnóstico para infecçāo pelo Toxoplasma gondï utilizando } 0 \text { antígeno } \\
\text { SAG1/P30 }\end{array}$ & Joseli Lannes-Vieira (10C) \\
\hline Desenvolvimento e validação de kit para diagnóstico rápido para leptospirose & Albert Ko (CPqGM) \\
\hline Produção de antígeno recombinante de vírus dengue tipo 2 para utilização no diagnóstico de dengue & Flávia Barreto dos Santos (10C) \\
\hline $\begin{array}{l}\text { Preparação de insumos imunológicos e moleculares para diagnóstico da dengue, visando à precocidade e à } \\
\text { identificação de serotipo }\end{array}$ & Luiz Hildebrando Pereira da Silva (IPEPATRO) \\
\hline $\begin{array}{l}\text { Desenvolvimento e validação de um método diagnóstico novo, baseado em PCR Nested, em um único tubo } \\
\text { para o diagnóstico de doenças infecciosas, parasitárias e genéticas }\end{array}$ & Frederico G. C. Abath (CpqAM) \\
\hline $\begin{array}{l}\text { Desenvolvimento de antígenos recombinantes, anticorpos recombinantes e PCR quantitativo em tempo real } \\
\text { para utilizaçăo em testes diagnósticos }\end{array}$ & Marco Aurélio Krieger (IBMP) \\
\hline Validação de abordagens moleculares e imunológicas para o diagnóstico de tuberculose infantil & Haiana Charifker Schingler (CPqAM) \\
\hline Desenvolvimento de um kit diagnóstico para o vírus da hepatite $C$ por meio de RT-PCR & Guilherme Corrêa de Oliveira (CPqRR) \\
\hline $\begin{array}{l}\text { Validação de teste molecular para tubérculos em pacientes com diagnóstico de TB pulmonar e baciloscopia } \\
\text { negativa (subprojetol) e TB extrapulmonar }\end{array}$ & Norma Lucena Cavalcanti Licínio da Silva (CPqAM) \\
\hline $\begin{array}{l}\text { Desenvolvimento de método e kit para diagnóstico da esquistossomose pela reação em cadeia da } \\
\text { polimerase }\end{array}$ & Ana Rabello (CPqRR) \\
\hline Desenvolvimento e validação de kit para o diagnóstico molecular da leishmaniose & Otávio Fernandes $(10 \mathrm{C})$ \\
\hline $\begin{array}{l}\text { Diagnóstico sorológico e molecular da infecção pelo vírus da hepatite C (HCV): desenvolvimento de kits } \\
\text { para detenção de anticorpos anti-HCV por ensaio imunoenzimático e genotipagem do HCV por hibridização } \\
\text { reversa }\end{array}$ & Clara Fumiko Tachibana Yoshida (IOC) \\
\hline $\begin{array}{l}\text { Detecção simultânea de Neisseia meningitidis, Haemophilus influenzae e Streptococcus pneumoniae em } \\
\text { amostras de líquido cérebro-espinhal ou sangue, por meio da reaçāo de polimerase em cadeia (PCR) }\end{array}$ & David Eduardo Barroso (IOC) \\
\hline $\begin{array}{l}\text { Desenvolvimento de uma PCR gênero-específica para o diagnóstico da malária em indivíduos } \\
\text { pauciparasitados }\end{array}$ & Maria de Fátima Ferreira da Cruz (10C) \\
\hline $\begin{array}{l}\text { Desenvolvimento, produção de protótipo e validação de um kit de PCR para o diagnóstico de leishmaniose } \\
\text { tegumentar americana. }\end{array}$ & Aldina Barral (CPqGM) \\
\hline
\end{tabular}

O PDTIS Diagnóstico mobilizou, em 2003, recursos da ordem de 400 mil reais para contemplar alguns destes projetos, e muitos recebem recursos de outras fontes inclusive do POM das unidades. Por serem mais recentes, estes projetos ainda não receberam bolsistas dos convênios Fiocruz/Faperj e Fiocruz/CNPq. Também na Rede de Diagnóstico os grupos que mais foram beneficiados pelas cooperações inter-redes foram aqueles dois (IOC e Ipepatro) que trabalham no diagnóstico de dengue, já que existe uma rede de pesquisa nessa doença no PDTSP/Fiocruz que mobilizou recursos da ordem de 1,6 milhão de reais. Ainda em 2003 foram lançados o Instituto Virtual de Dengue, da Faperj, e editais específicos para pesquisas na enfermidade por agências de fomento nacionais e internacionais. 
Além dos recursos alocados para cada uma das quatro redes que compõem o PDTIS, foram ainda implementadas ações que visam a modernizar a infra-estrutura comum a todas as redes, principalmente por meio da aquisição de equipamentos de grande porte $\mathrm{e}$ uso comum. Para tanto foram mobilizados recursos da ordem de 2,8 milhões de reais.

\section{CONCLUSÕES}

O PDTIS vem apoiando esses 58 projetos com o objetivo principal de otimizar as pesquisas caracterizadas como pré-desenvolvimento. Vem fortalecendo as equipes com a injeção de recursos humanos e novas tecnologias, a fim de obter produtos a curto, médio e longo prazo. Os projetos voltados para detecção de moléculas candidatas a antígenos para diagnóstico laboratorial ou imunógenos para vacinas são considerados de curto prazo, enquanto aqueles voltados para o desenvolvimento tecnológico de kits de diagnóstico e de vacinas são considerados de médio e longo prazo, respectivamente.

Com a certificação da vacina contra febre amarela pela OMS, surgiram novas perspectivas para exportação de produtos da Fiocruz. De acordo com essa realidade estão as metas institucionais de certificação de outros produtos, para o que se torna necessário a expansão do sistema de garantia de qualidade, o saneamento e organização de cadastro de materiais, além do aprimoramento das medidas de biossegurança e segurança do trabalho. Da mesma forma, torna-se prioritária a aquisição de conhecimentos teóricos e práticos de atendimento, técnicas de negociação e marketing, para uma abordagem mais eficiente e eficaz com os clientes internacionais. Dentro dessa filosofia, as ações que visam ao melhoramento do controle de produtos, à implantação de práticas que garantam a qualidade destes e os tornem competitivos em nível nacional e internacional são também implementadas pelo PDTIS. 


\title{
Centro de Desenvolvimento Tecnológico em Saúde (CDTS):
}

\author{
um instrumento da Fiocruz para \\ avanço tecnológico do Brasil
}

Eduardo de Azeredo Costa Carlos Médicis Morel

Paulo Marchiori Buss

\section{INTRODUÇÃO}

Estudos recentes conduzidos sob a égide da Organização Mundial da Saúde (OMS) demonstraram que a saúde é um dos requisitos fundamentais para o desenvolvimento econômico e social, e não apenas sua conseqüência. As conexões entre saúde, redução da pobreza e crescimento econômico a longo prazo são muito mais fortes e poderosas do que geralmente apreciado. Ainda segundo a OMS, melhorar a saúde e a longevidade das populaçóes carentes, um fim em si mesmo, é um objetivo fundamental do desenvolvimento econômico e também uma maneira de alcançar os objetivos de desenvolvimento do milênio relacionados com a redução da pobreza (WHO, 2001; Morel, 2004).

Ainda assim, é fundamental entender que a prestação de serviços de saúde pode significar, para países tecnologicamente dependentes, maior dependência econômica, mais dívida, mais juros e menor aporte de recursos para investimentos críticos na infraestrutura social e econômica.

Essas observações indicam a necessidade de mudanças profundas nas políticas de governos e de organismos internacionais, para que a aplicação de recursos em saúde nã̃o seja vista só como despesa e que contenha um componente de investimento tecnológico. Isto é particularmente verdadeiro para os países menos desenvolvidos e em desenvolvimento, onde coexistem todos os três tipos de doenças segundo distribuição geográfica ${ }^{1}$ (WHO, 2001; Berman \& Moon, 2001; Yamey \& Torreele, 2002; Trouiller et al., 2002). 
Essa visão implica ênfase redobrada nas atividades de pesquisa estratégica, desenvolvimento tecnológico e inovação em saúde (Stokes, 1997; Gibbons et al, 1994), priorizando-se os projetos de pesquisa com base em critérios objetivos, gestão pautada em resultados (Willcox, 2004) e maior integração com as políticas sanitárias.

Espera-se para as duas primeiras décadas do século XXI um avanço acelerado nos recursos diagnósticos, terapêuticos e de prevenção, maior do que em qualquer outro período da história. De fato, as descobertas recentes no campo do genoma humano e de parasitas e seus vetores indicam que está em curso veloz no mundo uma revolução biotecnológica que substituirá, com grandes vantagens - pela maior precisão nos alvos - muitos dos recursos hoje utilizados na promoção da saúde humana.

Desde os primórdios da terapêutica química até hoje, foram identificados cerca de quinhentos alvos (nas células humanas ou nos microorganismos - bactérias, vírus e fungos) para resolver doenças que acometem os seres humanos. Com os avanços da genômica e da pós-genômica, estima-se que esses alvos ultrapassem dez mil. Portanto, as possibilidades de diagnóstico e tratamento dos cânceres, das doenças crônico-degenerativas (como Alzheimer e outras) e das doenças infecto-parasitárias estarão sendo multiplicadas pelo menos por vinte.

Os produtos resultantes desse novo ciclo do conhecimento na área de saúde terão altos valores, científico e econômico, agregados. Sem dúvida, custarão substancialmente mais do que os produzidos com as tecnologias hoje disponíveis, podendo representar a exclusão da maioria dos países em desenvolvimento no acesso a tais produtos.

o Brasil é um dos poucos países em desenvolvimento - ao lado de alguns outros como Índia, China, Cuba e África do Sul - que tem potencialidades para ingressar neste seleto mundo da revolução biotecnológica. De fato, as políticas públicas de saúde e ciência e tecnologia (C\&T) das últimas décadas - aceleradas nos últimos anos-propiciaram ao país as condiçōes mínimas: acúmulo científico e tecnológico em algumas instituições maduras; doutores, tecnólogos e técnicos experientes na área; expressivos mercados interno (extensa população e um sistema público de saúde organizado) e externo (particularmente na América Latina e África).

Ficar de fora ou atrasar o desenvolvimento científico e o domínio de tecnologias nessas áreas certamente representará substanciais perdas de competitividade e enormes gastos no futuro.

1 Tipo 1 (doenças de distribuição global como sarampo, diabetes); Tipo 2 (doenças negligenciadas que, apesar de existirem globalmente, atingem particularmente os países menos desenvolvidos, como a tuberculose $e$ a Aids) e Tipo 3 (doenças mais negligenciadas, existentes quase que exclusivamente nos países em desenvolvimento, como a doença de Chagas, a úicera de Buruli, a doença do sono, a esquistossomose) (WHO, 2001).

\section{CONTEXTOS SANITÁRIO E CIENTÍFICO-TECNOLÓGICO NO BRASIL}

\section{Contexto sanitário}

Mesmo que nos últimos anos vários indicadores de saúde tenham melhoradocomo a mortalidade infantil, em virtude do controle das doenças imunopreveníveis, por exemplo - ainda persistem no cenário epidemiológico importantes enfermidades infecto-parasitárias, como diarréias, infecçōes respiratórias agudas, malária, leishma- 
niose, determinando altas taxas de morbidade e mortalidade. É preocupante o aumento das chamadas doenças emergentes e reemergentes, como HIV/Aids, dengue, tuberculose, hepatites virais, hantavírus, arenavírus e outras arboviroses, como também a crescente resistência bacteriana a antibióticos. Além disso, várias doenças crônicodegenerativas, tanto cardiovasculares como neoplásicas, de alta incidência e prevalência, têm gênese associada a infecções. De resto, as possibilidades de intervenção sobre as principais causas de sofrimento e morte não se restringirão àquelas infecto-parasitárias. Na verdade, o campo que se abre inclui também as demais crônico-degenerativas e mesmo as genéticas.

É claro que uma gama variada de problemas sociais que afetam o acesso da população brasileira aos bens e serviços de saúde, em princípio, continuará a existir, pois dependem também de outras políticas públicas. Porém, os benefícios indiretos de dominarmos tais tecnologias, se passarmos à etapa de produção de bens e insumos de saúde, não serão pequenos. Os benefícios econômicos, desde emprego, redução de leitos hospitalares, diminuição de importaçōes, podem liberar investimentos para outros programas sociais.

É nesse contexto que os desafios para a ciência e tecnologia na área da saúde se tornam centralmente estratégicos para o país. A diversidade e a complexidade dos problemas existentes, todavia, tornam crítica a definição de estratégias adequadas de C\&T para o encaminhamento de soluçōes para os diferentes problemas de saúde existentes.

\section{Contexto científico-tecnológico}

Com a acelerada ampliação dos conhecimentos na área das ciências da vida e, particularmente, nos campos da biologia molecular e da genética, abriu-se um novo e formidável campo de atuação industrial, o da biotecnologia em saúde. ${ }^{2}$

o Livro Verde, do Ministério da Ciência e Tecnologia (MCT), ao identificar os desafios estratégicos para a ciência, tecnologia e inovação no país, dedicou atenção especial às áreas de fármacos e medicamentos e à área da biotecnologia em saúde (Brasil, 2001).

Quando aborda "as grandes vulnerabilidades e oportunidades", aponta tais objetos como "áreas do conhecimento e setor econômico nas quais o país não pode correr riscos associados à falta de domínio científico e tecnológico" (Brasil, 2001: 185). O documento cita, ainda, alguns pontos de suma importância: o setor de fármacos (incluindo os imunobiológicos) e outras especialidades da química fina cobrem uma ampla variedade de produtos, com elevado conteúdo tecnológico e alto valor agregado. Possuem importante aplicação nas áreas de saúde e alimentação e têm implicação estratégica para o desenvolvimento econômico por causa da inter-relação com grande número de outros setores industriais (p. 186 a 188).

As áreas industriais relacionadas à produçăo de medicamentos e imunobiológicos, como também a de equipamentos médico-odontológicos, revestem-se de crescente importância estratégica, pelo seu peso econômico no mercado interno (elevada participação no PIB e efeitos dinâmicos sobre outros setores produtivos) e no déficit da balança comercial (o país importa a maior parte dos produtos biotecnológicos em saúde que

\footnotetext{
20 termo biotecnologia refere-se a "um conjunto amplo de tecnologias habilitadoras e potencializadoras, envolvendo a utilizaçāo, a alteraçāo controlada e a otimização de organismos vivos ou suas partes, células e moléculas para a geraçăo de produtos, processos e serviços. A biotecnologia e suas novas ferramentas de manipulaçăo e transferência gênica abrem novas perspectivas de potencializaçäo dos métodos tradicionais de melhoramento genético e exploraçāo da biodiversidade e variabilidade genética (...) com rápido e preciso desenvolvimento (...) de medicamentos" (Brasil 2001: 203).
} 
consome): A produção nacional nessas áreas está concentrada ( $80 \%$ do total) em empresas de grande porte, diversificadas, com produtos de alta tecnologia, normalmente subsidiárias de empresas internacionais. Apenas $20 \%$ do faturamento total do setor é gerado por empresas brasileiras, percentual que se reduziu nos últimos anos. De especial relevo para o avanço da utilização científica e industrial da biotecnologia é o patrimônio genético natural, em que o Brasil é particularmente rico.

Segundo o Livro Verde, as empresas brasileiras têm demonstrado enorme fragilidade em relação às demais, representada pela dificuldade de acesso à tecnologia, quer via transferência, quer via geração própria.

De outro lado, positivamente, identificam-se importantes decisōes tomadas no âmbito do governo federal, implementadas pelo Ministério da Saúde (MS) nessas áreas, desde a década de 70: o Programa de Auto-Suficiência Nacional em Imunobiológicos (Pasni) - para prover, com produção nacional e pública, ainda que com tecnologias importadas, as vacinas requeridas pelo Programa Nacional de Imunizações (PNI) - e a Central de Medicamentos (Ceme), a fim de suprir a rede pública de serviços de saúde, com uma lista de medicamentos básicos (Rename), contando com o reforço da rede de laboratórios oficiais e do uso do poder de compra do Estado para regular os preços praticados pela indústria privada.

Com essas iniciativas, foram feitos investimentos importantes em instituições públicas brasileiras, como o Instituto de Tecnologia em Imunobiológicos (Bio-Manguinhos), da Fundação Oswaldo Cruz (Ministério da Saúde, no Rio de Janeiro), o Instituto Butantan e a Fundação do Remédio Popular (Furp), ambas do governo de São Paulo. O resultado dos últimos 25 anos foi muito animador, pelo menos em algumas áreas. Hoje, por intermédio de Bio-Manguinhos e do Instituto Butantan, o Brasil produz cerca de $80 \%$ de toda a vacina que consome no seu programa nacional de imunizaçōes e continua internalizando tecnologias para a produção de vacinas sofisticadas, como a Hib (contra o Haemophilus influenzae tipo b) (1996), a vacina da gripe (1999), a vacina contra a hepatite B (2000), a vacina tetravalente (DTP+Hib) (2001) e, mais recentemente, a perspectiva da pentavalente (DTP+Hib+hepatite $B)$.

$\mathrm{Na}$ área dos fármacos, a produção nacional de anti-retrovirais, por exemplo, foi capaz de reduzir drasticamente a dependência externa e os custos do programa de controle da Aids, considerado pelas Nações Unidas um dos melhores do mundo e modelo para os países em desenvolvimento, passando a ter importante papel de regulação do mercado.

No entanto, a demanda do país por novos produtos, insumos e serviços especializados na área da saúde é muito grande. O próprio dinamismo das descobertas recentes, propiciadas pelos avanços da biologia molecular e da biotecnologia, impõe tais demandas ao Brasil, que quer ter sua população sadia e produtiva, o que significa a adoção de recursos diagnósticos, preventivos e terapêuticos sempre mais sofisticados e precisos.

No caso de medicamentos, ainda que o mercado brasileiro seja expressivo (chegou a 10 bilhōes de dólares anuais de faturamento em 1998), as indústrias farmacêuticas mais im- 
portantes existentes no país são multinacionais e desenvolvem a maioria das atividades de pesquisa e desenvolvimento (P\&D) nos seus países de origem (Queiroz \& Velazquez, 2001).

OMS, em conjuntura recente, implementou políticas muito claras de retomada dos princípios do Pasni, com investimentos substantivos em Bio-Manguinhos e no Instituto Butantan, assim como na rede de laboratórios oficiais produtores de medicamentos básicos, entre os quais se destacam a Far-Manguinhos, da Fiocruz, e a Furp, entre outros.

Da mesma forma, baseado na experiência nacional, o MS liderou e venceu, no plano mundial, uma luta importante para assegurar o suprimento de medicamentos essenciais, mesmo vindo a acarretar quebra de patentes, para situações epidêmicas ou que representassem, a juízo das autoridades nacionais, ameaças à saúde pública e à segurança nacional. Tal firmeza, e justeza de propósitos, geraram, na última reunião da Organização Mundial do Comércio (OMC), em Qatar, uma resolução apoiando a proposta do Brasil e recomendando-a aos demais países em desenvolvimento. ${ }^{3}$

\section{A DEMANDA DE INOVACCÃO TECNOLÓGICA PARA INSUMOS EM SAÚDE}

A partir da década passada, aconteceram mudanças substantivas no arcabouço jurídico nacional e internacional relacionado com a regulamentação dos direitos de propriedade intelectual. No Brasil, o Congresso Nacional aprovou, em 31 de dezembro de 1994, o tratado internacional TRIPS (abreviatura do inglês Trade-Related Aspects of Intellectual Property Rights), que entrou em vigor no dia $1^{\circ}$ de janeiro de 1995. Em 1996 , o Congresso aprovou a Lei 9.279, que trata da proteção da propriedade inđustrial (Lei de Patentes) e que entrou em vigor no dia 15 de maio de 1997, exatamente um ano após sua publicação no Diário Oficial da União, endossando imediata e integralmente todo o acordo TRIPs, sem nenhum período de transiçāo.

Essa adesão brasileira precoce e imediata ao TRIPs, pela promulgação da nova Lei de Patentes, provocou mudanças radicais no rumo do nosso desenvolvimento na área farmacêutica e de nutrição. Essas mudanças, absorvidas com sucesso no âmbito da agricultura brasileira; trouxeram graves conseqüências para a área da saúde, em particular por não ter o Brasil estipulado um período de adaptação, nem ter adotado novas políticas científico-tecnológicas e industrial, adequadas e necessárias em face desse novo quadro legal (Basu, 2005). Segundo o autor:

Enquanto a Índia e o Egito aproveitaram os períodos de transição aceitos pelo TRIPS e os utilizaram para estimular a pesquisa doméstica e os negócios [até 2005], o Brasil decidiu avançar a todo vapor e fez com que a Lei de Patentes seguisse integralmente o TRIPS já desde 1997. (...) Todas as análises mostram, contudo, que as indústrias farmacêuticas e biotecnológicas estavam completamente despreparadas para estas mudanças. A situação ficou ainda mais complicada devido ao débil suporte das agências governamentais, à confusão em relação às novas regras, à desvalorização cambial, ao controle de preços de
${ }^{3} \mathrm{~A}$ Declaraçāo define que "each Member has the right to grant compulsory licences and the freedom to determine the grounds upon which such licences are granted" bem como "has the right to determine what constitutes a national emergency or other circumstances of extreme urgency, it being understood that public health crises, including those relating to HIVIAids, tuberculosis, malaria and other epidemics, can represent a national emergency or other circumstances of extreme urgency". E conclui, reafirmando "the commitment of developed-country members to provide incentives to their enterprises and institutions to promote and encourage technology transfer to least-developed country". 
medicamentos e à ansiedade da opinião pública, temerosa quanto ao impacto que o TRIPs poderia acarretar nos preços dos remédios. O resultado disso foi enfraquecer o mercado farmacêutico brasileiro, antes o mais forte da América Latina, agora atrás do México (...). (Basu, 2005: 13-15)

Várias empresas farmacêuticas nacionais privadas fecharam e acumulamos um déficit no balanço de pagamentos de insumos de saúde (fármacos, medicamentos, imunobiológicos, hemoterápicos e equipamentos médico-odontológicos) de cerca de 3,5 biThōes de dólares anuais. Medidas isoladas para restabelecer um processo de substituiçăo de importações foram pouco efetivas. E, de fato, não estão dirigidas para os fármacos princípios ativos -, mas para as formulaçōes dos medicamentos.

A inovação nesse campo encontra dificuldades não só pela presença de grandes conglomerados que investem em pesquisa e desenvolvimento fora do Brasil, mas também porque, pela própria natureza do SUS, alguns poucos medicamentos têm compras centralizadas, sendo os demais adquiridos pulverizadamente por estados, municípios e hospitais públicos e privados, exigindo estruturas de comercialização e distribuição dispendiosas para pequenas e médias empresas, ou para as que comercializam poucos produtos. Assim, as demandas por inovação por parte das empresas brasileiras são pequenas ou nulas.

Nessa situação, três tipos de estímulo à inovação se fazem necessários: 1) o primeiro dirigido ao setor público produtor de medicamentos; 2) o segundo voltado à formação de pequenas empresas de base tecnológica para produtos isolados ou mercados restritos, nos quais seria necessário apoio por meio de estruturas ou vias especiais de comercialização, e/ou investimentos elevados para risco também elevado; 3) finalmente, apoio a parcerias público-privadas, tendo em vista a promulgação da Lei 10.973 (Lei de Inovação) pelo Congresso Nacional em 3 de dezembro de 2004.

Como o setor farmacêutico público objetiva atender demandas governamentais, e essas são logicamente de produtos essenciais e na quase totalidade com patentes vencidas, não sofre uma marcada indução inovativa. Mais ainda, pelo fato de não serem as entidades públicas produtoras de matéria-prima - fármacos-, mas sim de medicamentos, pouco contribuem para a redução da dependência econômica, embora contribuam para a diminuição dos gastos orçamentários da saúde.

Essa questão está sendo examinada dentro do Projeto Inovação Tecnológica da Fundação Oswaldo Cruz (Fiocruz), ao mesmo tempo em que foi agregado novo parque produtivo de medicamentos, a fábrica Rio 2000, em Jacarepaguá. Esta foi incorporada à Fiocruz como um Complexo Tecnológico de Medicamentos (CTM) e passará a operar com a perspectiva de estimular a formação nacional de toda a cadeia produtiva de fármacos de maior consumo, como também de desenvolver inovação na área farmoquímica.

De maneira peculiar, no entanto, insere-se a área biotecnológica, não só por serem diversas as características dos produtores privados, como também pela marcada presença do setor público produtivo na área de vacinas, como vimos anteriormente. 
Por isso mesmo, as potencialidades para o desenvolvimento e a produção que os avanços biotecnológicos permitirão na área de biofármacos abrem oportunidades excepcionais para o Brasil e a Fiocruz, em particular.

\section{O CENÁRIO DA FIOCRUZ ${ }^{4}$}

A Fiocruz vem atuando de forma ativa no encaminhamento de vários problemas do Sistema Único de Saúde (SUS), especialmente na formação de recursos humanos especializados, pesquisa biomédica, oferta de serviços de referência, desenvolvimento tecnológico e produção de insumos básicos (vacinas, medicamentos, kits diagnósticos e produtos para controle de vetores) requeridos pelos programas governamentais. Também tem contribuído de forma importante na formulação das políticas de saúde e de C\&T em saúde do país.

Em adição, há alguns anos a Fiocruz vem se adaptando à nova realidade científica e tecnológica da área de saúde, resultante da adesão do país ao tratado de patentes na área farmacêutica e biotecnológica e às políticas de inserção na economia mundial com incorporação de conceitos de qualidade e preceitos gerenciais em c\&T e na produção de medicamentos e vacinas. Esse caminho pavimentou-se na instituição com ampla discussão interna, dando condições de introduzir novos processos de organização do trabalho e da produção com solidez.

De fato, a revisão crítica de sua atuação para as novas necessidades mostra que as atividades integradoras entre unidades de pesquisa e de produção são tênues, ainda que estas estejam locadas, na maior parte, no mesmo espaço geográfico e ainda que haja amplo intercâmbio científico e discussōes administrativas comuns. Desse modo, muitos produtos potenciais da pesquisa acabam sem incorporação ao arsenal diagnóstico e terapêutico, e não se transformam em vantagens econômicas para a instituição e o país. Finalmente, a falta de possibilidade de comercialização leva à livre circulação do conhecimento e sua eventual utilização alhures em economias desenvolvidas (Costa, 1992).

Por isso, a Fiocruz estabelece no seu Plano Quadrienal 2001-2005 (Fiocruz, 2001b) a orientação estratégica de buscar uma maior participação institucional, no encaminhamento dos problemas de saúde, oferecendo mais e melhores serviços especializados, insumos e produtos imprescindíveis para a prevenção de doenças e a promoção da saúde. Para cumprir essa orientação estratégica, o Programa Institucional de Desenvolvimento Tecnológico de Insumos em Saúde (PDTIS) ${ }^{5}$ foi recentemente estabelecido pela Presidência da Fiocruz e aprovado pelo Conselho Deliberativo.

A existência de uma experiência tecnológica real na Instituição - com pessoal treinado e operando volumes industriais em modernos equipamentos de fermentação, separação e purificação, ultracentrifugação, filtração tangencial, cultura de células em volumes industriais, formulação, envase e liofilização, farmacotécnica, síntese química e produtos naturais - é um elemento facilitador para o entendimento dos requisitos técni-

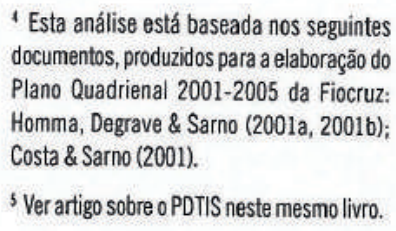

- Esta análise está baseada nos seguintes documentos, produzidos para a elaboração do Plano Quadrienal 2001-2005 da Fiocruz: Homma, Degrave \& Sarno (2001a, 2001b); Costa \& Sarno (2001).

${ }^{5}$ Ver artigo sobre o PDTIS neste mesmo livro. 
cos e diferentes parâmetros envolvidos no desenvolvimento tecnológico de produtos e insumos, que está se realizando com o PDTIS.

É muito importante ressaltar o papel desse Programa e de suas redes cooperativas no desenvolvimento das capacidades tecnológicas nacionais para além da Fiocruz-RJ, o que confere a ele uma abrangência efetivamente nacional, mesmo quando consideramos apenas as unidades da instituição localizadas em diversas partes do território nacional. (Dessas redes participam as unidades técnicas, tecnológicas e de pesquisa da Fundação situadas no Sudeste, Nordeste, Amazônia e Sul do país).

Ademais, a Fiocruz mantém inúmeras parcerias çom instituiçōes científicas nacionais, que necessariamente serão aprofundadas e expandidas com a nova política proposta. Tais parcerias foram estabelecidas em torno de projetos de desenvolvimento tecnológico. Um bom exemplo é a rede instituída, com a participação da Fiocruz, sob a égide do MCT, pelo Instituto do Milênio para o Controle da Tuberculose, que se valerá, assim como os demais projetos, dos recursos do PDTIS e também de grande infra-estrutura.

Por outro lado, por meio de acordo assinado com o National Institutes of Health, dos EUA, e de outras cooperações internacionais já em curso, garante-se um fluxo permanente de cooperação técnica, particularmente nas áreas de ponta da genômica e da proteômica aplicadas às doenças infectoparasitárias.

Todo esse esforço cooperativo e organizativo não prescinde, todavia, de um lócus de acumulação e transformação dos projetos em realidade, ou seja, um espaço de apropriação do valor potencial da pesquisa para o benefício da saúde e do país.

\section{PROPOSTA INSTITUCIONAL}

A Fiocruz é uma das poucas instituições nacionais capazes de responder às necessidades do país na área da biotecnologia em saúde (diagnóstico, prevenção e tratamento), vinculadas aos grandes problemas nacionais: malária, tuberculose, dengue, febre amarela, HIV/Aids, hepatites, leishmanioses, esquistossomose, viroses oncogênicas (como HPV e HTLV) e as arboviroses hemorrágicas, por exemplo.

Além da implementação do PDTIS, a Fundação realizou recentemente concurso público para cerca de 220 novos pesquisadores e tecnologistas, muitos deles para $P \& D$ em biotecnologia. A manutenção da infra-estrutura básica e do custeio das atividades de $P \& D$ encontra-se razoavelmente equacionada pelo esquema financeiro propiciado pelo Ministério da Saúde. Desta sorte, o que se desenvolve no momento é um novo 'salto tecnológico', representado por investimentos não previstos no esquema orçamentário-financeiro básico, que se traduz por importantes investimentos na infraestrutura institucional.

Essa infra-estrutura organiza-se no Centro de Desenvolvimento Tecnológico para a Saúde (CDTS), capaz de transformar idéias, processos e produtos em bens de saúde comercializáveis, isto é, prontos para seu processamento industrial ou outro tipo de 
exploração econômica. ${ }^{6}$ Articulada ao CDTS, uma planta de protótipos permitirá avaliar, em escala adequada, os novos produtos, particularmente imunobiológicos, dando-lhes padrōes de qualidade industrial.

Esquematicamente, mostramos na Figura 1 a articulação do Centro com seus principais 'parceiros' internos e externos.

Figura 1 - Diagrama das interfaces de trocas ativas do CDTS

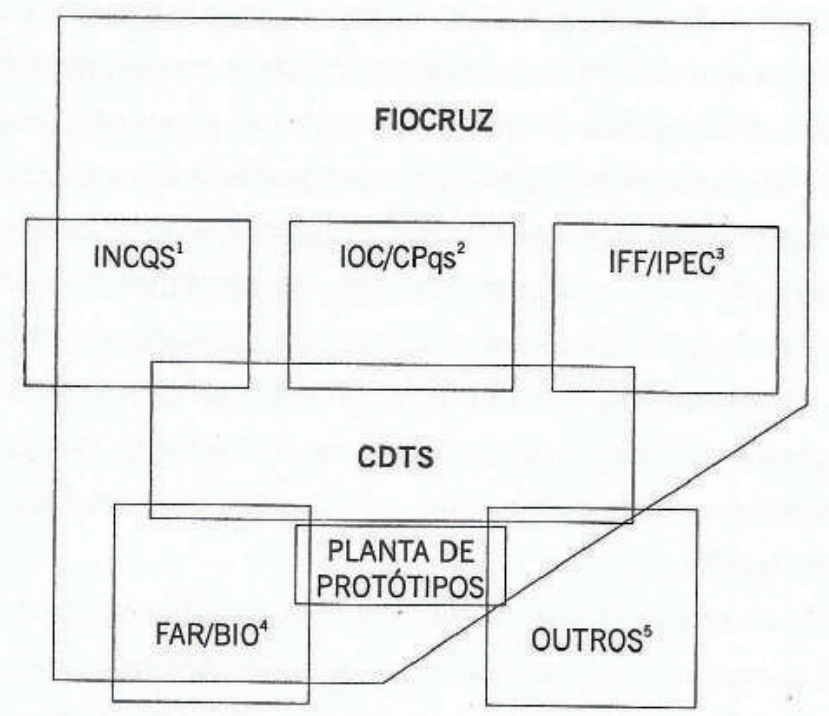

1 - Área de controle de qualidade e regulaçăo da Fiocruz/MS

2 - Área de pesquisa biológica da Fiocruz e suas redes cooperativas internas e externas

3 - Área de pesquisas clinicas pré-licenciamento

4 - Áreas de produção da Fiocruz

5 - Áreas externas públicas ou privadas

Obs: Outras unidades e setores da Fiocruz, tais como Ensp, EPSJV, CICT, Cecal, Dirad, Dirac, daräo suporte técnico-administrativo e fornecerão insumos ao CDTS, além de fazer a capacitação de recursos humanos.

Do ponto de vista tecnológico, o CDTS deverá levar a Fiocruz a um novo patamar na infra-estrutura científica e tecnológica, propiciando a instalação de plataformas para estudos de genoma e proteoma (Gene-Manguinhos), com vistas à identificação e caracterização das diferentes proteínas expressas por células ou tecidos nas condiçōes fisiológicas e sua modificação em estados patológicos (a utilização đe um esquema terapêutico poderá ser avaliada do mesmo modo). A bioinformática será instrumento essencial para esses estudos.

Ainda neste contexto, pretende-se implementar novos procedimentos tecnológicos, como a espectrometria de massa aplicada a proteínas, microarranjos de DNA (DNA microarrays), mutagênese dirigida e modelagem molecular.

Nessa mesma linha de inovação, o CDTS deverá se preparar para a manipulação gênica em animais de experimentação (transgênicos e knock-outs), buscando estabelecer procedimentos de futura terapia gênica de interesse para a saúde humana.
'Entende-senesse texto 'exploração econômica' como atividades capazes de captar recursos näo orçamentários, como vendas, cessão ou alienaçẵo de direitos, transferências tecnológicas. 
Essa tecnologia transgênica permitirá: 1) desenvolvimento de modelos animais de doenças humanas e busca de novas estratégias de cura por meio da terapia gênica; 2) produção de proteínas de interesse médico, através de animais transgênicos que expressem genes humanos; 3) introdução de transgenes em tecidos e órgãos humanos para tratamento de doenças genéticas; 4 ) desenvolvimento de animais transgênicos para doação de tecidos ou órgãos a serem usados para transplantes em seres humanos; 5) delineamento e monitoração de ensaios clínicos de terapia gênica.

o desenvolvimento de insumos e testes diagnósticos para diversas doenças infectoparasitárias deverá contar com técnicas moleculares. Os testes poderão ter aplicações em diagnóstico clínico, como também em tipagem fenotípica e genotípica de agentes infecciosos, na definição de marcadores diagnósticos e prognósticos, em análises populacionais e no rastreamento epidemiológico de microorganismos e seus vetores. Insumos como peptídeos sintéticos, enzimas e sondas moleculares poderão também ser desenvolvidos.

Serăo ainda instalados no CDTS outros laboratórios requeridos, como, por exemplo, o de toxicologia, sendo também reunidos equipamentos preexistentes, assim como alguns recursos humanos dispersos. Para o Centro, especificamente, está prevista a absorção de 150 pessoas no quadro permanente e outras 150 com contratos temporários ligados a projetos específicos.

Farão parte dessa estrutura, além de laboratórios microbiológicos de segurança nível 3 (P3) (isto é, que permitem manipular microorganismos agressivos causadores das principais doenças infecto-parasitárias do país), um infectório (com as instalações de tipo $\mathrm{P} 3+$ ) para pequenos animais de laboratório; bem como equipamentos de alto custo e complexidade, para uso comum dos projetos, entre outras facilidades.

Para todas essas instalações, estão previstas condições de Boas Práticas de Laboratório (BPL) e incorporação das necessidades de Boas Práticas Industriais (BPI), imprescindíveis para o desenvolvimento dos antígenos e moléculas candidatos nos estudos pré-clínicos e para a aceitação industrial dos produtos.

\section{ABSORVENDO EXPERIÊNCIAS COM FOCO NA INOVACC̄ÃO}

Visitas de observação voltadas para a inovação tecnológica em Cuba, Inglaterra e França ajudaram a absorver conceitos e a iniciar a definição de parâmetros para o detalhamento do Projeto CDTS.

A abordagem cubana de construir centros produtivos estatais com base em desafios concretos para atender a necessidades sanitárias e econômicas é semelhante ao que foi feito no início do século passado no Brasil, do que resultou a Fiocruz. Ainda que a demanda por parte do mercado interno (público) seja de produtos essenciais, a necessidade econômica de exportação levou ao desenvolvimento de estruturas comerciais que passaram a ter necessidades competitivas. Assim, o setor produtivo público se dispôs a inovar. Uma política de não-reconhecimento de patentes não registradas no país favoreceu o desenvolvimento de novos processos para produtos já conhecidos. 
O modelo inglês, pautado na produção privada de bens e insumos, mas com serviços de saúde essencialmente públicos, tem procurado, diante da adesão ao mercado comum europeu, induzir inovação competitiva. Incubadoras de empresas, à semelhança do que foi iniciado há quase 15 anos no Rio (BIO-RIO), estão articulando a academia à capacidade empreendedora de professores e pesquisadores. Esse modelo voltado para a criação de pequenas empresas de base tecnológica se iniciou há algumas décadas nos Estados Unidos da América, mas a estratégia inglesa incorporou também a idéia de cessão de espaços laboratoriais e técnicos da área acadêmica, sob contrato, a empresas já existentes, de qualquer porte, para o desenvolvimento de novos produtos - o que podemos chamar de incubadoras de produtos simplesmente.

O modelo de inovação francês para a formação de empresas de base tecnológica é semelhante, porém inova com o financiamento público de plataformas tecnológicas, o que também é claramente imperativo no caso brasileiro, para dar suporte aos pequenos empreendedores e, em particular, à Fiocruz, que precisa ingressar plenamente na era genômica e proteômica.

Nesse caminho, o Instituto Pasteur, com tantas semelhanças com a Fiocruz, estabeleceu suas plataformas tecnológicas, inauguradas em abril de 2003, na área de genoma e proteoma-ogenopole-, e criou a incubadora de empresas-o BioTop.

Digno de registro é que o genopole não integra e não é integrado por nenhum dos 12 departamentos preexistentes no Instituto Pasteur.

o Genopole do Instituto Pasteur, integrado à rede de genopolos nacionais, abriga cinco laboratórios high tech, que funcionam como plataformas tecnológicas: genômica, microarranjos de DNA, proteômica, anotação e genômica estrutural. Além desses, há outros laboratórios de suporte: bioinformática, imagem dinâmica, microseqüenciamento de proteínas, citometria de fluxo, microscopia eletrônica e informática científica. As cinco plataformas e, pelo menos, os três primeiros laboratórios de suporte deverão integrar o core do CDTS.

\section{O ARGUMENTO CDTS}

A Fiocruz de hoje tem potencialidade institucional para procurar novos rumos aproveitando essas observações internacionais. De um lado, as já estabelecidas unidades produtivas - apesar de necessariamente focadas nas atividades de produção, não tendo, portanto, como missão primordial promover um desenvolvimento inovativo de pesotêm conseguido absorver tecnologias para a produção de alguns itens de consumo do MS. Os modelos praticados de absorção de tecnologias, no entanto, deverão ser revisados, para assegurar pleno licenciamento para exportar para o Mercosul, por exemplo, ou para atender programas de solidariedade com países da África.

Inexistiam, contudo, mecanismos institucionais estimuladores de uma ampla utilizaçăo, por estas unidades, da pesquisa realizada na própria Fiocruz, voltada para o desenvolvimento de novos produtos e daí para a produção. O PDTIS foi o primeiro passo 
concreto nesse sentido, ajudando a diminuir a dispersão de recursos e esforços colocados na área de pesquisa.

A diversidade de produtos e atividades necessários para os programas do MS na área de imunobiológicos e fármacos, de outro lado, mostra que não teríamos, mesmo com a articulação com outros produtores estatais, capacidade de atender a todas as necessidades atuais e futuras com nossa estrutura produtiva. Ou seja, a geração de inovação, a partir das unidades de pesquisa, mesmo mais focalizada pelo PDTIS, extrapola a capacidade física e organizativa industrial de nossas unidades de produção.

Assim, parcerias com instituições públicas e privadas devem representar novos mecanismos de atuação da Fiocruz na pesquisa e inovação tecnológicas. A recente competência dada pelo governo federal para que a Fundação possa tornar seus produtos disponíveis também para exportação poderá vir a ser importante elemento de indução inovativa e de construção de tais parcerias.

Colocar foco na área de reagentes diagnósticos, por exemplo, poderia ser particularmente promissor, já que, de modo geral, há intensa articulação entre pesquisadores e a área de desenvolvimento de Bio-Manguinhos. Na verdade, essa atividade anda lentamente por sua pouca ou nenhuma agressividade comercial. As demandas centralizadas do MS se restringem a diagnósticos para atividades de vigilância epidemiológica e, mesmo assim, acaba comprando-os de outros produtores não públicos. As grandes necessidades nacionais, especialmente na área de vigilância sanitária e assistência médica, que tanto oneram o SUS e os usuários de modo geral, são em grande parte supridas por importaçăo. Nesse campo, o estímulo a pequenas empresas de base tecnológica, pela própria diversidade de produtos, precisa da articulação com estruturas estatais tecnologicamente avançadas, que o CDTS poderia oferecer.

Essas iniciativas vão precisar de um processo inovativo também na área gerencial, particularmente a elaboração de código de Boas Práticas de Negócios, em que o interesse público e a transparência sejam mandatários nas articulações público-privadas.

Em resumo, veríamos quatro razões para uma área de desenvolvimento nova na Fiocruz, fora dos espaços de nossas unidades técnicas (de pesquisa ou produção) e que se articulasse à comercialização de produtos ou direitos ou transferência de tecnologias para outros países ou empresas:

1) capacidade de pesquisa da Fiocruz mais diversa do que a de produção;

2) pouca capacidade competitiva do parque industrial, quer por seus custos reais elevados, quer por depender de matéria-prima ou tıcnologias importadas, quer por estar desaparelhado para comercializar urodutos fora das encomendas públicas;

3) laboratórios próprios de desenvolvimento das unidades prodøltivas subordinadas a resolver situações específicas para a produção, determinando a busca, corretamente, de caminhos de baixo custo e zero risco, sem poder romper a adequação ao seu programa industrial planejado;

4) inadequação gerencial de laboratórios de pesquisa e das unidades técnicas, para atividades comerciais. 


\section{OBJETIVOS, FUNC̣ÕES E PERFIL DO CDTS}

O CDTS tem como meta, essencialmente, dar ao país capacidade de desenvolver e produzir bens e insumos de saúde de natureza biotecnológica, atendendo a necessidades de saúde da população, viabilizando os programas sanitários nacionais e diminuindo a dependência externa nesse campo. Diante disso, o Centro localiza-se estrategicamente numa instituição - a Fiocruz - com significativa tradição na área de ciência e tecnologia em saúde nacional, alta qualificação científica de seus quadros e importante capacidade instalada, porém com nível baixo de integração funcional para o objetivo proposto, em virtude da diversidade de funções de suas unidades técnicas. Assim, o CDTS precisará cumprir uma função integradora na instituição, atraindo todo o seu potencial para o desenvolvimento tecnológico de bens, produtos, insumos e direitos comercializáveis, com o pressuposto de diminuir o valor de novos investimentos e dar competitividade aos seus produtos, justificando, portanto, a escolha da Fiocruz para receber novos recursos.

A existência de unidades de produção de imunobiológicos e fármacos na Fundação exige que seja dada alta prioridade no CDTS aos projetos aplicáveis a essas unidades ou por elas demandados, mas o espaço estará também aberto para outras iniciativas de unidades ou quadros técnicos da instituição que não tenham possibilidades de aproveitamento em Far-Manguinhos ou Bio-Manguinhos, mas que apresentem proposta de utilização econômica, dentro ou fora da Fiocruz. O CDTS poderá processar também demandas externas, associando assim a Fiocruz à comercialização, privada ou não, posterior.

Para viabilizar o desenvolvimento laboratorial desses projetos com gerenciamento compartilhado pelo CDTS, este Centro terá incorporados à sua estrutura física laboratórios flexíveis para o desenvolvimento e apuro de qualidades de produtos e processos, com a perspectiva de sua aplicação sanitária e exploração econômica. As unidades técnicas descentralizadas da Fiocruz serão estimuladas a também criarem tais laboratórios de projetos. Os avanços e as exigências reguladoras no campo biotecnológico determinam que o perfil do CDTS seja marcado por instalações modernas, equipamentos de última geração, infra-estrutura pertinente e capacidade gerencial que se estenda às áreas de proteção de direitos, avaliação econômica e negócios.

Para cumprir seu papel, a gestão dos projetos de inovação incluirá o planejamento, acompanhamento e avaliação de estudos pré-clínicos e clínicos. Para estes últimos, serão parceiros o Instituto de Pesquisa Evandro Chagas (Ipec), o Instituto Fernandes Figueira (IFF) e o Departamento de Epidemiologia e Métodos Quantitativos em Saúde da Escola Nacional de Saúde Pública (Ensp). O tratamento econômico a ser dado ao CDTS o qualificará para ser, também, instrumento de desenvolvimento institucional em áreas fora do objetivo de comercialização, pelo financiamento, com seus rendimentos, de programas e projetos da Fiocruz. 
Ademais o CDTS proporcionará oportunidade de observaçōes científicas e tecnológicas, graças às suas modernas instalaçōes e equipamentos - as plataformas tecnológicas e os laboratórios de apoio-, que levarão a Fiocruz a ingressar ativamente na era genômica e proteômica, na transgênese e terapia gênica. Logo, suas instalações deverão ser também utilizadas para projetos da área de pesquisa básica e na cooperação científica e tecnológica com outras instituições nacionais e do exterior, sem qualquer objetivo de aplicação comercial. Por sua vez, as áreas do Instituto Oswaldo Cruz (IOC) de apoio ao CDTS, assim como ele próprio, precisarão de estrutura de biotério diferenciada pela inclusão de infectório, devendo, pois, constituir-se numa estrutura compartilhada pelo IOC/CDTS.

Finalmente, o CDTS se integrará à Rede de Laboratórios para Desenvolvimento Tecnológico em Saúde (RELDTS), ${ }^{7}$ que incluirá, em particular, os centros regionais de pesquisa da Fiocruz (CPqAM em Recife, CPqGM em Salvador, CPqLMD em Manaus e CPqRR em Belo Horizonte), assim como os laboratórios associados localizados em Curitiba (Instituto de Biologia Molecular do Paraná - IBPM) e Porto Velho (Instituto de Pesquisa em Patologia Tropical-Ipepatro).

\section{SUMÁRIO ORGANIZACIONAL}

Podemos conceber a conformação funcional do CDTS como um centro de integração de atividades gerenciais, técnicas e experimentais voltadas para o desenvolvimento de produtos, processos e estudos. Nele, serão estruturados os elos que ligam a bancada do laboratório de pesquisa até a produção, passando pelo licenciamento, registro ou patentes, no menor prazo possível (Figura 2).

Para tanto, atividades de suporte administrativo, técnico-científico e legal serão adequadamente organizadas. $O$ processo decisório será fortemente articulado ao conhecimento científico mundial (comitê científico) e às necessidades e interesses sanitários e econômicos nacionais (comitê gerencial). Cuidado particular será dado à área de informação, pela coexistência no mesmo espaço institucional de projetos com estratégia competitiva e outros de estratégia colaborativa (Oliveira, Magarão \& Mota, 2003).

A estrutura física central, localizada no campus de Manguinhos mas dotada de amplas facilidades de comunicação e interação com as demais Unidades da Fiocruz e outras entidades nacionais ou estrangeiras (Figura 3), resumidamente, contará com:

1) Escritórios e infra-estrutura gerencial de apoio e manutenção, incluindo: informática; regulação interna, monitoração e qualidade; aquisição e estoque de insumos críticos; automaçăo e controle; manutenção predial e de equipamentos; centro de negócios tecnológicos; gerência tecnológica e rede de bancos de dados tecnológicos; avaliação e supervisão de projetos; administração; treinamento.

2) Plataformas tecnológicas analíticas, a saber: genômiça; proteômica; nanotecnologias e microarranjos; bioinformática; análises de polissacarídeos e lipídios.

3) Plataformas tecnológicas de produção de reagentes: proteínas recombinantes; crista-

7 Proposta para criação, no âmbito da Fiocruz, de uma Rede de Laboratórios para Desenvolvimento Tecnológico em Saúde-RELDTS. (Em colaboraçäo comL. P. Carvalho, 2004) (Mimeo.). lização de proteínas para estudos analíticos; anticorpos monoclonais; oligonucleotídeos. 4) Laboratórios de apoio: análises físico-químicas; certificação e coleção de amostras; citometria de fluxo; microscopia; PCR em tempo real; toxicologia. 
5) Área de experimentação animal: testes toxicológicos; atividades transgênicas; inoculaçōes experimentais (inclui infectório BSL 3+).

6) Laboratórios flexíveis: abrigarão projetos ou etapas destes para desenvolver processos ou produtos 'fênix'. Serăo cedidos temporariamente sob contrato ou convênio e equipados de acordo com cada projeto aprovado.

o projeto arquitetônico já contratado permite prever seu pleno funcionamento para o final de 2007. No entanto, as atividades gerenciais destinadas a promover o desenvolvimento de novos processos e produtos estão já iniciadas e devem ter impulso maior em $2005 .{ }^{8}$

Figura 2 - Fases e atividades relacionadas ao CDTS

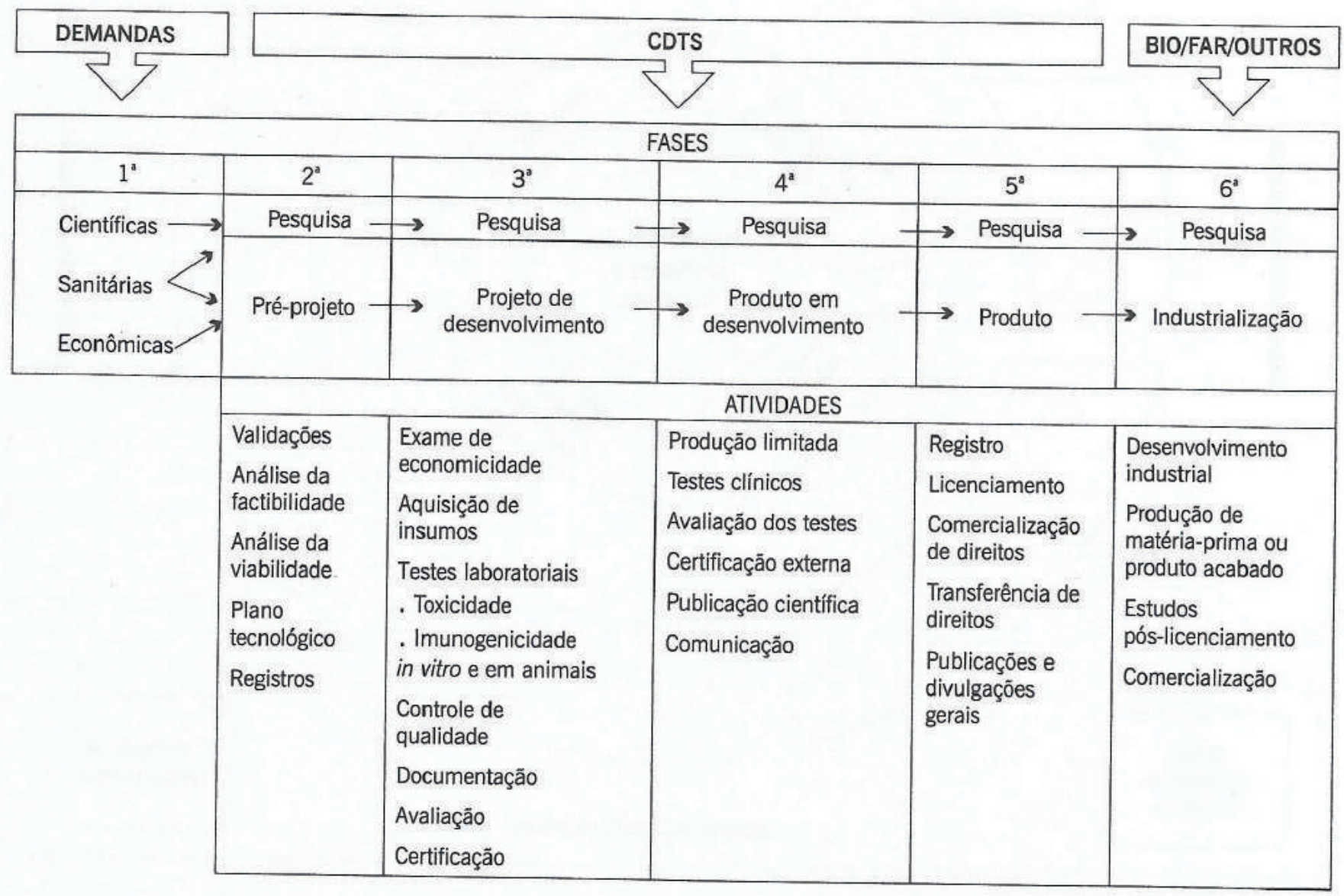

${ }^{8}$ Entre muitos cientistas, técnicos e auxiliares que participaram da elaboração do projeto CDTS, destacamos: Wim Degrave, Jorge Castro, Licia de Oliveira, Luiz Mendes, Antonio Werneck de Castro, Carlos Mauricio Andrade, Silvio Valle, Carlos Muller, Joel Majerowics, Graça Henriques, Sérgo Goes de Paula, Fernanda Garcia, Eliane Azevedoe Elaine Neves (Fiocruz-Brasil); Lúcia Previato (UFRJ-Brasil); Oswaldo Magalhães Junior e Laura Walker (PAAL - Brasil); além de Manoel Limonta (Instituto de Hematologia Cuba); John Horton (OMS - Reino Unido); Jay McAuliffe e Jonathan Richmond (CDC-EUA); Paola Minoprio (Instituto Pasteur - França). 
Figura 3 - Diagrama da estrutura central do CDTS

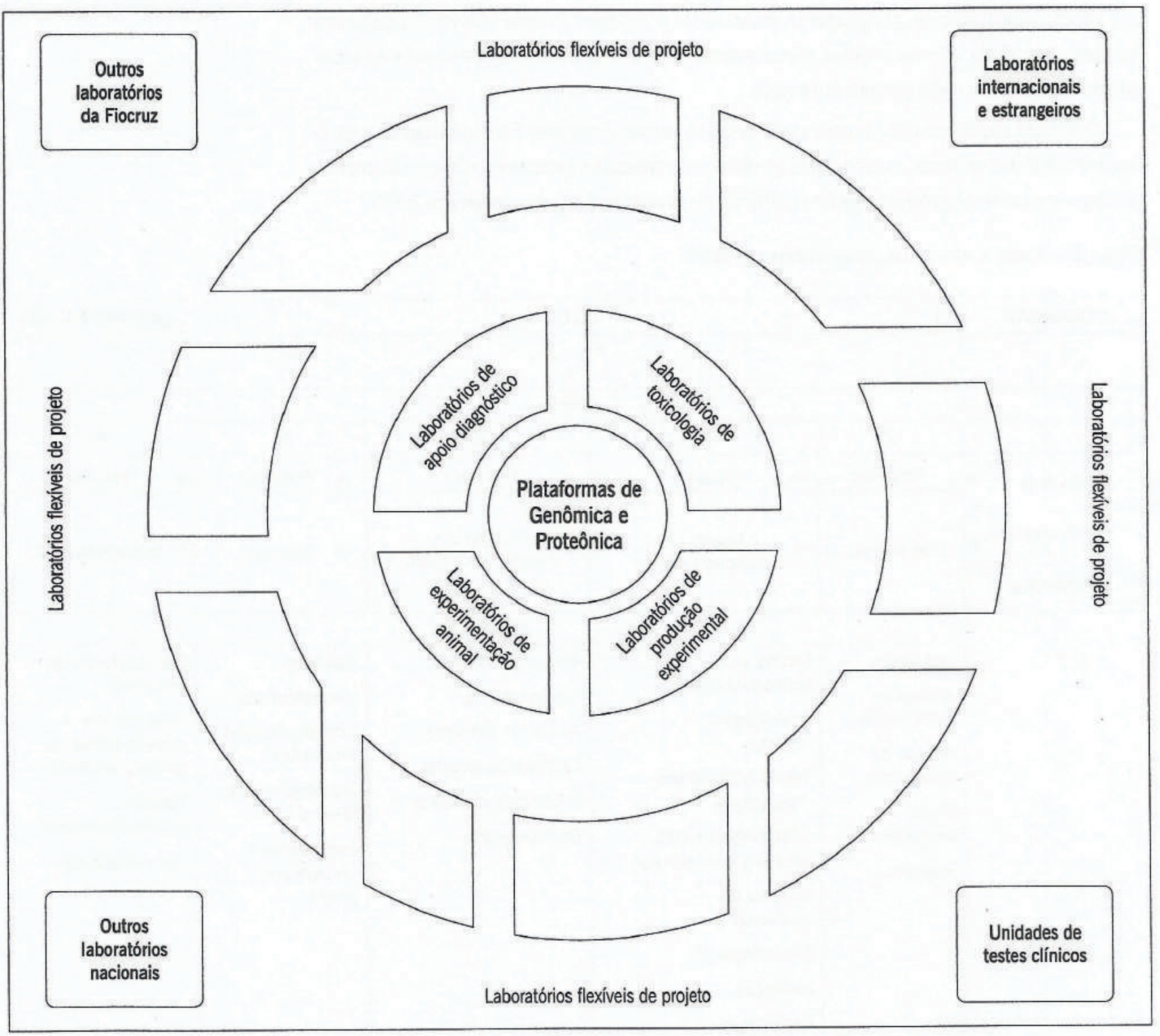

Obs.: Delineamento Inicial Projeto CDTS - versão 5 - 11/09/03. 


\section{REFERÊNCIAS BIBLIOGRÁFICAS}

BASU, P. International patent law: boon or bane of biotech? Nature Biotechnology, 23:13-15, 2005.

BERMAN, D. \& MOON, S. Fatal Imbalance: the crisis in research and development for drugs for neglected diseases. Médecins Sans Frontières Access to Essential Medicines Campaign. Bruxelas: MSF, 2001.

BRASIL. Ministério da Ciência e Tecnologia. Livro Verde: o debate necessário: ciência, tecnologia e inovaçāo - desafio para a sociedade brasileira. Brasília: MCT, 2001.

COSTA, E. A. A política estadual de Ciência e Tecnologia. Revista da Fundação CIDE (ERJ), 1992.

COSTA, N. R. \& SARNO, E. N. Governança Organizacional e Inovaçāo: a perspectiva estratégica da Fundação Oswaldo Cruz. Rio de Janeiro: Fiocruz, 2001.

FIOCRUZ. Documento Institucional. Rio de Janeiro: Fiocruz, 2001a.

FIOCRUZ. Plano Quadrienal 2001-2005. Rio de Janeiro: Fiocruz, 2001b.

FIOCRUZ. Plano de Investimentos 2001-2005. Rio de Janeiro: Fiocruz, 2001c.

FIOCRUZ. Portaria da Presidência XX/O2, que institui o Programa de Desenvolvimento Tecnológico de Insumos em Saúde - PDTIS. Rio de Janeiro: Fiocruz, 2002a.

FIOCRUZ. Programa de Desenvolvimento Tecnológico de Insumos em Saúde (PDTIS) Redes cooperativas. Rio de Janeiro: Fiocruz, 2002b.

GIBBONS, M. et al. The New Production of Knowledge: the dynamics of science and research in contemporary societies. Londres/Nova Déli: Thousand Oaks/SAGE Publications, 1994.

HOMMA, A.; DEGRAVE, W. M. \& SARNO, E. N. A Fundaçāo Oswaldo Cruz e os Desafios Estratégicos. Rio de Janeiro: Fiocruz, 2001a.

HOMMA, A.; DEGRAVE, W. M. \& SARNO, E. N. Programa de Desenvolvimento Tecnológico em Vacinas: um desafio estratégico nacional em biotecnologia. Rio de Janeiro: Fiocruz, 2001b.

MOREL, C. M. A pesquisa em saúde e os objetivos do milênio: desafios e oportunidades globais, soluções e políticas nacionais. Ciência e Saúde Coletiva, 9:261-276, 2004.

OLIVEIRA, L.; MAGARĀO, M. \& MOTA, P. R. Relatório da Consultoria para a Área Organizacional do CDTS, 2003.

QUEIROZ, S. \& VELAZQUEZ, A. G. Mudanças recentes na estrutura produtiva da indústria farmacêutica. In: NEGRI, B. \& GIOVANNI, G. D. (Eds.). Radiografia da Saúde. Campinas: Instituto de Economia, 2001.

STOKES, D. E. Pasteur's Quadrant: basic science and technological innovation. Washington: The Brookings Institution, 1997.

TROUILLER, P. et al. Drug development for neglected diseases: a deficient market and a public-health policy failure. Lancet, 359:2.188-2.194, 2002. 
WORLD HEALTH ORGANIZATION (WHO). Macroeconomics and Health: investing in health for economic development. Report of the Commission on Macroeconomics and Health. Genebra: WHO, 2001.

WILLCOX, L. C. B. Avaliação do desenvolvimento tecnológico e transferência de tecnologia: o caso Instituto Oswaldo Cruz - Fundação Oswaldo Cruz. Ciência e Saúde Coletiva, 9:389-398, 2004.

YAMEY, G. \& TORREELE, E. The world's most neglected diseases. British Medical Journal, 325:176-177, 2002. 


\section{Pesquisa e Desenvolvimento em Vacinas e Soros no Instituto Butantan}

Isaías Raw

Hisako Gondo Higashi

Otávio Azevedo Mercadante

\section{O CENTRO DE BIOTECNOLOGIA}

Em 1984, o Instituto Butantan, reconhecendo a redução no volume e qualidade da sua produção científica devido ao envelhecimento de seus quadros, saiu do isolamento, abrindo suas portas para contratar uma dezena de pesquisadores experientes, na maioria aposentados pelas universidades paulistas. Estes pesquisadores, credenciados pelas universidades, atraíram estudantes de pós-graduação, arejanđo o ambiente de pesquisa com jovens com sua natural energia e criatividade. Com seus currículos e liberdade para escolher os projetos, trouxeram para o Instituto dezenas de auxílios de pesquisa da Fundação de Amparo à Pesquisa do Estado de São Paulo (Fapesp), do Conselho Nacional de Desenvolvimento Científico e Tecnológico (CNPq) e da Financiadora de Estudos e Projetos (Finep). Iniciou-se uma revolução na pesquisa básica, que muitos imaginavam e continuam a imaginar fosse a função principal do Instituto.

Foi então reconhecido o papel fundamental da instituição como órgão da Secretaria da Saúde, sendo priorizados o desenvolvimento e a produção de insumos biológicos para saúde humana. Tal concepção foi introduzida por Louis Pasteur em Paris, ao atender a demanda da sociedade por soros e vacinas, exigindo recursos adicionais para a manutenção da pesquisa. Esse foi o modelo para a criação do Instituto Butantan por Vital Brazil, em 1901, que o diferenciou da pesquisa/ensino formal que caracteriza as univer- 
sidades. O modelo teve que ser corrigido para atrair estudantes de pós-graduação, essencial à continua renovação da instituição.

A concepção de um instituto que pesquisa e produz levou, em 1985, à criação do Centro de Biotecnologia, que atraiu um grupo de jovens doutores que aceitavam o repto de ter metas de pesquisa relevantes e do domínio da tecnologia de escalonamento.

Nessa época foi lançado o Programa de Apoio ao Desenvolvimento Científico e Tecnológico (PADCT), programa que contava, pela primeira vez, com um financiamento à altura das metas de desenvolvimento científico-tecnológico e que, como todos os programas até então, incluindo este, colocava a biotecnologia como uma das prioridades nacionais. $O$ Centro foi escolhido para vários projetos, contando, em paralelo, com importantes recursos que permitiram a instalação real dos laboratórios, com equipamentos sofisticados.

Entre os vários projetos, estava o desenvolvimento de processos de purificação, cromatografia em larga escala (projeto de hemoderivados) e a utilização de biorreatores de última geração no cultivo de células animais, acoplados a processos cromatográficos automatizados, usando novas resinas para produção de anticorpos monoclonais.

Hoje, o Centro de Biotecnologia (Laboratório de Produtos e Processos), ocupa um conjunto de edifícios, que sofreram reformas internas (os edifícios são tombados), numa área de cerca de $3.000 \mathrm{~m}^{2}$. Com duas dezenas de doutores, doutorandos, mestres, mestrandos e jovens estudantes, forma um grupo de quarenta pesquisadores. Em contraste com pesquisadores da divisão científica, que tem total liberdade na escolha de seus projetos, desde que submetidos e financiados por auxílio à pesquisa, os pesquisadores do Centro têm o compromisso de dar prioridade aos projetos de interesse imediato para a saúde humana.

Os projetos, inicialmente, eram sempre submetidos em bloco para agências de financiamento que, com seu porte, permitiram equipar o Centro de Biotecnologia. Atualmente, com a maturidade e experiência dos pesquisadores mais credenciados, os projetos tendem a ser específicos, com um grupo de pesquisa responsável. Alguns desses projetos encontram-se listados no Quadro 1.

Quadro 1 - Vacinas e biofármacos em desenvolvimento no Centro de Biotecnologia

\begin{tabular}{|l|l|}
\hline Meningite B-C conjugadas & Ensaios em 2004 \\
\hline Haemophilus b & Conjugação em desenvolvimento \\
BCG-pertússis, BCG-tétano, BCG & Cepas construídas para pesquisa \\
Pneumococos: proteínas recombinantes & Expressadas, em testes animais \\
Pneumococos: 23F & Produçäo de polissacarídeo em escalonamento \\
Esquistossomose & Novas vacinas candidatas baseadas no seqüenciamento genômico \\
Leptospirose & Novas vacinas candidatas baseadas no seqüenciamento genômico \\
HPV & Em desenvolvimento \\
Eritropoetina & Em escalonamento \\
Interferon alfa e beta & Em desenvolvimento \\
Glucocerebrosidase & Em desenvolvimento \\
\hline
\end{tabular}


Na euforia do desenvolvimento nacional, as agências de financiamento e programas, como o PADCT e o Programa de apoio a Núcleos de Excelência (Pronex), estimularam projetos que tinham como meta potencial o desenvolvimento de tecnologia e produtos. Os pesquisadores, na disputa de recursos, passaram a orientar seus projetos acenando com o desenvolvimento de vacinas e medicamentos. Outro programa extremamente útil foi o Programa de Desenvolvimento de Recursos Humanos para Atividades Estratégicas (RHAE), que ofereceu bolsas para treinamento de pessoal em tecnologia de produção e que foi usado para o treinamento durante o desenvolvimento de processos.

Contudo, os financiadores e os tomadores de decisão não se conscientizaram plenamente de que este é um longo processo, que exige a participação dos vários atores que intervêm na pesquisa básica, no desenvolvimento e otimização de tecnologia real, na produção de lotes-piloto e seu ensaio clínico controlado e na produção em grande escala. Estas várias etapas requerem investimentos, que a cada passo aumentam por um fator de 5 a 50 , ultrapassando os orçamentos para incentivo. Mais ainda, desconhecem que, na área de saúde humana, o processo da pós-bancada à disponibilidade do produto, único critério que permite considerar como sucesso o investimento, tarda uma década ou mais nos países do Primeiro Mundo, que contam com recursos muitas vezes maiores do que o Brasil, pois não basta comparar a porcentagem do PIB de dois países, já que este é totalmente diferente uma década antes. Esse longo prazo contribuiu para que o Brasil perdesse a primeira batalha contra as patentes e que novamente perderá se não acelerar a competição pela produção de insumos essenciais à saúde, agora que muitas patentes começam a caducar.

No esforço de acelerar o desenvolvimento de novas vacinas e bioprodutos, conseguiu-se trazer, por um período de vários anos, alguns pesquisadores estrangeiros. Um deles desenvolvia a vacina recombinante contra hepatite B, usando uma levedura que expressa $o$ antígeno recombinante em quantidade muito maior do que a levedura de cerveja. Com a estrutura, equipamentos e pessoal competente disponível do Centro de Biotecnologia e na divisão de produção, foi possível desenvolver o escalonamento da produção da vacina contra hepatite $B$.

O projeto foi traduzido numa planta especial, que já atingiu a produção de 36 milhões de doses em 2003. Essa etapa, que deveria ser a mais difícil, passou a ser secundária em face dos 'fantasmas' que tentaram por anos evitar que a vacina do Butantan fosse testada e registrada, eliminando um dos maiores mercados representado pela vacinação pública e gratuita e reduzindo o mercado de clínicas privadas. Tal batalha, que ressurge encampada por interesses privados, principalmente estrangeiros, está praticamente vencida. A vacina que custaria US $\$ 8$ por dose, quando o projeto se iniciou, é hoje fornecida ao Ministério da Saúde (MS) por R\$0,80. Resultado de uma tecnologia eficaz e de baixo custo, tornou viável vacinar não apenas recém-nascidos, mas recuperar a vacinação de todos os que não o foram na infância, cobrindo os jovens que atingem a maturidade sexual ou acabam prisioneiros de drogas, engros- 
sando os mais de três milhões de portadores do vírus da hepatite $B$, que, além de transmitir ao resto da população jovem, terão que ser socorridos pelo SUS com cirrose ou câncer hepático no futuro.

A alta capacidade de produção instalada está permitindo atender a demanda para vacinar todos os menores de vinte anos que não foram imunizados na infância.

\section{DESENVOLVIMENTO DE NOVA GERACุÃO DE VACINAS BACTERIANAS}

O principal critério para a seleção dos projetos tem sido a demanda do Programa Nacional de Imunizações (PNI). Com uma meta de médio prazo, para tornar o Brasil auto-suficiente, optamos pelo desenvolvimento de tecnologia de vacinas semelhantes às que o Brasil adquiria ou pretendia adquirir no mercado internacional. Como não basta auscultar o interesse do MS, pudemos, nestes anos e no futuro próximo, antecipar-nos à decisão do Ministério, oferecendo vacinas eficazes a preços compatíveis com o orçamento público e, portanto, possíveis de ser introduzidas. Uma análise responsável que as comissões de vacinação, levando em conta interesses e modismos, não faziam. Com esses parâmetros, os projetos eram mais seguros e viáveis em prazo mais curto.

Nessa seleção, tomamos a iniciativa de evitar a competição com Bio-Manguinhos e nos esforçarmos por criar projetos de cooperação. Um destes, iniciados pelo Instituto Adolfo Lutz, com assessoria do Dr. C. Frasch do National Institutes of Health (NIH) e da Organização Pan-Americana da Saúde (Opas), foi a seleção de cepas prevalentes para uma vacina contra a meningite B. O projeto ganhou momento para desenvolver uma vacina financiada com auxílios do PADCT e da Fapesp ao Butantan e vem sendo desenvolvido em paralelo pelo Centro de Biotecnologia e por Bio-Manguinhos, com a colaboração essencial da equipe de meningite do Instituto Adolfo Lutz. Os dois laboratórios desenvolveram métodos alternativos para a produção dos proteossomos (membranas externas liberadas durante o cultivo da bactéria), em que a expressão de proteínas específicas é induzida pela restrição de ferro. A equipe do Centro concentrou-se em metodologia escalonável, que substitui operações discretas com ultracentrífugas por ultrafiltração molecular e cromatografia. Para esse projeto, foi montando temporariamente um laboratório de Boas Práticas de Fabricação (BPF) para a produção de lotes da vacina que possam ser testados.

Um projeto simultâneo foi o desenvolvimento da produção do polissacarídeo do meningoco $\mathrm{C}$, uma vez que a vacina final será uma vacina combinada contra meningites $\mathrm{B}$ e C. Como o uso de polissacarídeos pode induzir anergia, a vacina contra meningite $\mathrm{C}$ deverá ser conjugada com o toxóide tetânico de alta pureza, produzido pelo Butantan. Uma nova perspectiva que foi abordada com sucesso, em nível de teste em animais, é a conjugação do polissacarídeo com a vacina contra meningite $\mathrm{B}$. As duas vacinas, meningite $B+C$ e meningite $B=C$, serão suplementadas com lipopolissacarídeo do meningococo, detoxificado pela hidrólise (LOS). As várias formulações, $\mathrm{B}+\mathrm{C}, \mathrm{B}=\mathrm{C}$, com e sem LOS, estão prontas para ensaio clínico, o grande gargalo para o desenvolvimento de vacinas no país. 
Uma segunda linha é baseada na DTP. Quando o Butantan iniciava a produção de DTP, ainda sem condições de atender à demanda nacional, esta foi comparada, quanto à toxicidade e proteção, com vacinas importadas. Ficou clara a superioridade da vacina produzida pelo Butantan. Como todas as que utilizam hidróxido de alumínio como adjuvante, a vacina pode até produzir um pequeno nódulo no local da injeção, mas é efeito local, insignificante e sem importância, quando se compara com a cicatriz produzida pela vacina contra varíola. A vacina DTP causa, também, efeitos colaterais na proporção de cerca de 1:2000 vacinados, que variam desde o choro prolongado até convulsōes; contudo, embora esses efeitos sejam reais, epidemiologicamente não são importantes quando comparados com a mortalidade causada pela coqueluche (trágica para os ingleses, que suspenderam a vacinação para reinstituí-la três anos depois).

o Centro de Biotecnologia investiu longamente no desenvolvimento de uma vacina acelular para pertússis, que poderia ser produzida a um preço viável para o programa brasileiro de vacinação. As três doses da vacina contra DTP custam hoje US\$ 0,09 contra cerca de US $\$ 9,00$ da vacina chamada de acelular. Optamos por desenvolver uma vacina a partir do sobrenadante da cultura de pertússis, subproduto da vacina celular, contendo os principais antígenos, purificados por um sistema simples que remove LPS e reduz a concentração de pertussigênio, presente em excesso. Este processo resulta numa vacina que protege contra o desafio intracerebral e poderia ser produzida a um preço viável, se a vacina for usada apenas em crianças que apresentam uma história clínica de problemas neurológicos, ou como segunda e terceira doses em crianças que tiveram efeitos colaterais sérios. Uma vez que do sobrenadante só é possível produzir uma dose para cada dez doses de vacina celular, a substituição da vacina celular pela acelular desprezaria a primeira e teria um custo muito maior, além de exigir um investimento grande para o aumento do volume de biorreatores, que hoje é de 1.500 litros. A antiga Comissão Assessora de Imunizações e a direção da Sociedade Brasileira de Pediatria, nas quais estão representados pediatras que mantêm clinicas privadas de vacinação ou que têm projetos com os produtores privados, podem imaginar que é legitimo exigir a vacina acelular, sem, entretanto, levar em conta que o aumento de custo inviabilizaria a vacinação universal e gratuita.

A utilizaçāo universal do hidróxido de alumínio, apesar da ampla gama de novos adjuvantes que têm sido desenvolvidos, alguns sendo utilizados para vacinas veterinárias, inibiu o seu uso em vacinas humanas. Pesquisas realizadas em colaboração com o Instituto de Biociências da Universidade de São Paulo (USP) e de Microbiologia da Unifesp levaram ao desenvolvimento de um novo adjuvante, produzido das células da Bordetella. Este importante processo (patente depositada) permitirá produzir um adjuvante para várias vacinas, que é eficaz e isento dos efeitos locais produzidos pelo hidróxido de alumínio. Essa produção utilizaria parte da vacina celular. Por outro lađo, o uso deste novo adjuvante cria uma vacina acelular de custo mais baixo e eficaz. A nova vacina acelular deverá entrar proximamente em teste clínico, processo longo para detectar efeitos colaterais pouco freqüentes como os da vacina celular. 
A impressão superficial é que uma parte importante de vacinas é perđida pela exposição a temperaturas elevadas em virtude das deficiências da rede de frio, e o custo delas tende a duplicar pela introdução, diretamente no rótulo, de um indicador térmico. Todavia, o maior descarte resulta do congelamento de vacinas, durante o transporte, ou dentro de refrigeradores sem circulação de ar. A solução aventada pela World Health Organization (WHO) e pelo Unicef é a introdução de outro monitor que, para vacinas de baixo custo como o DTP, novamente dobra seu preço. Uma pesquisa desenvolvida no Centro de Biotecnologia, que poderá ter resultados interessantes, é o uso do DTP e DTPHep B em emulsão oleosa, protegendo a vacina de hepatite B contra congelamento. $O$ uso dessa emulsão tem inconvenientes, em particular pela necessidade de utilização de uma agulha de diâmetro maior. Não obstante, apresenta uma vantagem em áreas onde a deficiência da vitamina A é endêmica. óleo contendo vitamina A substitui o hidróxido de alumínio e poderá oferecer no primeiro ano de vida, simultâneo à vacinação, a dose mínima necessária da vitamina.

\section{AQUISIC̣ÃO DE VACINAS A GRANEL E TECNOLOGIA}

Não aceitamos como legítimo que o Programa de Auto-Suficiência Nacional em Imunobiológicos (Pasni) se transforme na imagem especular da indústria de fármacos, pública ou privada, limitada à importação de princípios ativos de outros países, dominando apenas a manipulação.

O Butantan negociou com a Aventis a completa transferência da tecnologia da produção da vacina contra influenza, embutindo na aquisição de vacinas a granel, limitada a quatro anos, o pagamento dessa tecnologia. Na negociação, o produto a granel foi adquirido a US $\$ 1,60$-US\$ 1,80 por dose, contra US $\$ 3,50$, mais $3 \%$ pelo custo da intermediação oferecida pela Opas. Definitivamente, a Fundação Butantan foi muito mais eficaz na negociação do que a Opas, e o impacto nestes quatro anos foi uma economia da ordem de 100 milhões de dólares para o programa brasileiro de vacinação. Não se trata apenas de economia, mas de viabilizar a introdução da vacina que hoje cobre mais de $90 \%$ dos maiores de sessenta anos, associada à revacinação contra difteria e tétano.

A incorporação da tecnologia da influenza foi recentemente garantida pelo acordo de cooperação, segundo o qual a Secretaria da Saúde do Estado de São Paulo construirá a nova planta com sua infra-estrutura e o MS financiará os equipamentos. Este acordo foi selado na presença do Presidente da República, em cerimônia realizada no Instituto Butantan em 2003. Um pacto similar foi realizado entre BioMaguinhos e GlaxoSmithKline (GSKB).

Acordos como o da influenza aceleram a absorçăo de tecnologia e a auto-suficiência, porém dependem de uma definição muito clara de pontos essenciais. Um deles é que só podem realizar acordos institutos que dominam grande parte da tecnologia, não apenas garantindo sua implementação, mas sendo capazes de analisar a tecnologia 
oferecida. É fácil para grandes empresas, prestes a mudar de tecnologia, transferir aquela que será abandonada. Instituições que não dominam tecnologias não têm capacidade de analisar a tecnologia oferecida, nem podem garantir que a absorverão. Sem a assimilação da tecnologia e implantação das plantas de produção, os acordos passam a ser uma cobertura para eterna aquisição de vacina a granel, que se torna monopólio de um fornecedor, ao arrepio do processo licitatório.

No caso da influenza, trata-se de uma vacina de produção complexa, por ser composta de três cepas, anunciadas pela WHO no limite de tempo para sua produção antes da entrada do inverno. Ao optar pelo acordo, que representou milhōes de dólares de economia, o Butantan está consciente de que essa tecnologia será a plataforma para o desenvolvimento da nova geração da vacina, eliminando o cultivo em ovos embrionados e pesquisando, pela adição de adjuvantes e veículo apropriado, uma vacina de administração nasal.

O Instituto também já vem investindo no desenvolvimento da vacina contra raiva, produzida em células Vero. Enquanto aguardamos o final do ensaio clínico, este já demonstrou que duas ou três doses da vacina desenvolvem uma resposta imune que exigia até dez doses da antiga vacina Fuenzalida-Palacios. Esse projeto, que suprirá a demanda nacional de vacina contra a raiva, serve de plataforma para a produção de outras vacinas em cultura celular. Com tecnologia própria, o Butantan apenas negociou uma assistência tecnológica pontual (ensaio e processo de liofilização) acoplada à aquisição de vacina a granel até o termino do projeto de ensaio clínico. o domínio de produção viral em cultura celular, em suspensão ou em microcarregadores, é fundamental para uma nova família de vacinas. No momento, o Instituto Butantan está concentrado na produção de vírus da raiva para imunização de cavalos na produção do soro anti-rábico.

\section{VACINAS CONJUGADAS}

Além da vacina conjugada contra meningites $(\mathrm{C}=$ tétano e $\mathrm{B}=\mathrm{C})$, o Centro de Biotecnologia iniciou esforços para desenvolver o isolamento de polissacarídeos vacinais, investigando condições de cultivo e cepas para obter alta produtividade. A idéia original da Opas seria um esforço compartilhado de pesquisadores de vários países, que levaria em paralelo ao desenvolvimento da produção dos polissacarídeos de S. pneumoniae, para uma vacina com cobertura suficientemente ampla. Depois de um estudo epidemiológico (que infelizmente não mais reflete a realidade atual), ficou estabelecido que a meta seria produzir uma vacina com cerca de sete serotipos. Como o objetivo era a vacinação infantil, e sabia-se que polissacarídeos não eram bons imunogênicos em crianças menores de dois anos, podendo até criar anergia, imaginava-se produzir uma combinação de vacinas, cada uma conjugada. Tratava-se de uma tarefa complexa que não tinha qualquer chance de ser completada, mas o projeto prosseguiu com o subtipo $23 \mathrm{~F}$, que usualmente determina uma infecção resistente aos antibióticos habituais.

Entretanto, uma vacina múltipla, além da simples đificuldade de sua fabricação (era romântica a idéia de que cada uma delas seria produzida num laboratório ou país 
diferente), teria, como já tem no mercado internacional, um preço extraordinariamente alto para ser introduzido universalmente para crianças e idosos. Esperamos, como alternativa, a produção đe uma vacina conjugada com apenas os serotipos antibiótico-resistentes que, com um custo muito menor, reduzirá a internação e/ou uso de antibióticos especiais de alto custo.

o Centro também investiu na tecnologia de produção do polissacarídeo do hemófilo b. Esse projeto foi temporariamente interrompido, quando Bio-Manguinhos negociou a tecnologia com GSKB, porém a estamos retomando para exportação e, eventualmente, produção suplementar.

Uma tecnologia a ser dominada é a da conjugação. A tecnologia tradicional tem um rendimento inferior a 30\%, que impede a recuperação do polissacarídeo ou do toxóide, gerando, portanto, um custo alto. Não fomos informados da tecnologia que a GSKB estaria transferindo a Bio-Manguinhos, mas sabemos que existem métodos de conjugação (pelo menos para meningite A - tétano) que chegam a menos de $80 \%$. O Centro está iniciando um setor destinado a pesquisar tecnologias de conjugação, que seriam empregadas tanto para produção da vacina contra meningite $\mathrm{B}=\mathrm{C}$ e para o Hib conjugado, como para S. pneumoniae conjugada. A reação de conjugação depende da estrutura do polissacarídeo e se precisa dominar mais de um processo.

\section{BIOLOGIA MOLECULAR E O DESENVOLVIMENTO DE NOVAS VACINAS}

A concepção de equilibrar uma linha de desenvolvimento mais rápido e menos sofisticado com o estímulo à iniciativa dos pesquisadores de enveredar por novas linhas de investigação é, provavelmente, um bom exemplo do sucesso da dualidade, que leva a resultados sem amputar o futuro.

Uma iniciativa que partiu de um grupo de investigadores colocou o Centro de Biotecnologia na era do genoma. O grupo participou ativamente do seqüenciamento do genoma da Xylella fastidiosa, primeiro patógeno vegetal que teve sua seqüência completada. Esse primeiro projeto abriu caminho para outros de interesse médico. Os investigadores participaram do seqüenciamento do genoma do câncer humano de cabeça e pescoço, engajaram-se no seqüenciamento da Leptospira fastridiosa e do Schistosoma mansoni. Existe um racional para identificar no genoma proteínas que podem potencialmente ser antígenos vacinais, como as proteínas transmembrana expostas ao exterior e, portanto, a anticorpos. Nos próximos anos, os antígenos da Leptospira e do Schistosoma devem ser investigados.

A Fiocruz (Salvador) participou no projeto do genoma da Leptospira. Na instituição foi desenvolvido um caminho alternativo, em que a presença de anticorpos em indivíduos infectados com Schistosoma levou ao isolamento do antígeno e seu seqüenciamento, que, por sua vez, permitiu o seqüenciamento genético e a clonagem. O Centro de Biotecnologia ofereceu-se para expressar esta proteína para ensaio em animais susceptíveis ao verme, e durante a expressão e refolding ficou evidente que seria necessário alterar a seqüência da proteína. $O$ antígeno está sendo fornecido a Bio-Manguinhos para testes em grandes animais. 
A produção de clones para expressão de antígenos vacinais vem sendo intensamente estudada pela equipe do Centro. Foram expressos os fragmentos $C$ do tétano, que é imunogênico e protetor; da subunidade B da toxina colérica (CTB), igualmente imunogênica e que atua como adjuvante para vacinas nasais e orais. Igualmente temos clones da E.coli que expressam as proteínas PspA e PsaA da membrana do $S$. pneumoniae, que podem ser componentes de uma vacina contra o $S$. pneumoniae. Uma proteína de fusão CTB-PsaA está sendo investigada como vacina nasal. A vacinação com DNA para PsaA juntamente com a sua expressão em Lactobacillus foram testadas em animais.

o Centro de Biotecnologia também investiu na idéia de introduzir no BCG genes para antígenos de outros microorganismos patogênicos, criando uma vacina viva e que persiste anos no organismo. Recombinantes com pertussigênio, toxinas diftérica e tetânica ou SM-14 do Schistosoma foram construídos e estudados em animais, como vacinas, com bons resultados.

\section{BUTANTAN COMO PARCEIRO INTERNACIONAL}

O Butantan vem se firmando internacionalmente como centro de desenvolvimento e como produtor de imunobiológicos, ao que se soma a política social do Brasil, firmemente estabelecida, segundo a qual vacinas são oferecidas gratuitamente à população de recémnascidos, jovens e maiores de sessenta anos, criando um importante mercado cativo. Hoje ocupamos a presidência do Developing Country Vaccine Manufacture Network. Essa conjuntura vem atraindo o interesse de pesquisadores no exterior que desenvolvem vacinas dirigidas às populações de menos recursos, que buscam um parceiro capaz de escalonar a vacina candidata para ensaios clínicos.

Nem sempre a vacina mais sofisticada é a mais eficaz do ponto de vista epidemiológico, pois depende da disponibilidade e custo da vacinação em massa. Uma vacina celular, não encapsulada contra S. pneumoniae, poderia permitir a proteção com recursos modestos, quando comparada a uma vacina com múltiplos polissacarídeos conjugados. Em um projeto de colaboração internacional, estamos investigando a sua produção e, em seguida, sua eficácia contra os vários serotipos. O mesmo vem ocorrendo com a leishmaniose: um grupo da Universidade de Seatle está considerando a transferência de clones vacinais para o Butantan. Além disso, o Butantan negocia com o National Institutes of Health (NIH) a produção da vacina contra rotavírus.

\section{HEMODERIVADOSE IMUNOGLOBULINAS}

Há cerca de uma década o Centro de Biotecnologia vem investindo na produção de hemoderivados, uma prioridade nacional que é óbvia para evitar o descarte de cerca de 300 mil litros de plasma colhidos a cada ano e a aquisiçấo de cerca de 100 milhões de dólares ao ano de hemoderivados. Mais uma vez a associação de importadores com responsáveis pelo programa de hemoderivados bloqueou a implantação de uma planta de fracionamento. 
Sem acesso ao plasma, o Centro tomou como base o projeto do Laboratório Merieux, que por muito tempo foi um dos grandes produtores de albumina a partir do sangue contido em placentas. Com o congelamento das placentas colhidas em muitos países, $o$ sangue sofre hemólise e o processo de isolamento da albumina exige um complexo processo cromatográfico. A produção da Merieux foi vendida a numerosos países, sem qualquer problema com a transmissão viral, pois incluía etapas viricidas e de remoção viral. A exigência descabida de que as placentas fossem identificadas, ao invés de se basear, como fazia a Merieux, na premissa de que os métodos de purificação eliminariam totalmente os vírus, criou problemas intransponíveis. O perigo da transmissão da enfermidade de Creutzfeldt-Jacob (príons) é real, mas numa proporção insignificante. A identificaçăo da mãe ou do doador de plasma para fracionamento geraria uma informação pouco útil, uma vez que seria pouco provável que, uma década depois, se o doador desenvolvesse a doença, fosse identificado, assim como quais os pacientes que receberam os hemoderivados. Mesmo que o fossem, a informação não permite qualquer prevenção, retardo da doença ou tratamento.

o Centro de Biotecnologia levou o projeto à frente, permitindo o isolamento simultâneo do sangue placentário hemolizado de albumina, imunoglobulina, catalase, superóxido dismutase e transferrina. $\mathrm{O}$ uso da placenta como fonte de hemoderivados tornou-se impossível.

Recentemente, retomamos o projeto visando a uma planta de processamento totalmente por cromatografia, que opere à temperatura ambiente, sem operações manuais, sem baixas temperaturas e sem precipitar as frações, o que cria condições para polimerização de proteínas com atividade pirogênica.

A produção de albumina e imunoglobulinas por cromatografia pura foi desenvolvida pela Pharmacia e basicamente implementada na mais moderna planta existente, na Austrália. Todavia, ainda utiliza a crioprecipitação para separar o fator VIII. A crioprecipitação resulta da separação cuidadosa do plasma que foi congelado e degelado, deixando o fator VIII parcialmente insolúvel. o Centro, por sua vez, desenvolveu uma técnica de cromatografia direta do plasma, que permite separar o fator VIII e outros fatores da coagulação, da albumina e da imunoglobulina. 0 rendimento em fator VIII aumenta, pois não depende de um degelo cuidadoso, com separaçăo do precipitado por centrifugação, que em parte re-suspende o fator VIII no resto do plasma. A Pharmacia investiu na mesma idéia e hoje existem duas etapas alternativas para a separação de fatores de coagulação sem uso do crioprecipitado, eliminando totalmente da planta o processo de degelo e a centrifugação.

Um estudo pormenorizado deu origem a um projeto para uma planta de processamento de 150 mil a 250 mil litros de plasma por ano, com um custo de apenas 30 milhōes de đólares, dos quais metade seria destinada à aquisição de equipamentos no mercado brasileiro. A estimativa de uma planta com a tecnologia de Cohn, introduzida na década de 40 , que usa precipitação alcoólica a baixas temperaturas e é complemen- 
tada por tratamentos antivirais que exigem separação cromatográfica, foi orçada em 60 milhões de dólares. O governo do estado de São Paulo pretende construir e equipar a planta em 2004-2005.

Um processo mais simplificado vem sendo desenvolvido para a purificação de imunoglobulinas do plasma de doadores imunizados contra tétano, raiva, vírus sincicial respiratório e hepatite B e que substituirāo o uso de soros hiperimunes em cavalo. A sua importação para pacientes que tomaram soros antipeçonhentos ou outros, com imunidade contra IgG de cavalo, custa, para o MS, mais de um milhão de dólares por ano. Esses doadores devem ser mobilizados (como, por exemplo, veterinários, auxiliares e estudantes de veterinária que manejam cães e que receberiam vacinas contra raiva produzida pelo Butantan), testados para presença de vírus HIV e hepatites B ou C (por PCR) e o processo de purificação validado para eliminação viral atingindo $<10^{8} / \mathrm{ml}$.

Mais complexo é o uso de doadores com alto nível de anticorpos decorrentes de uma infecção prévia ou ainda persistente de forma crônica, caso em que o aproveitamento do processo deve garantir a eliminação viral. O soro antivírus sincicial é produzido, nos Estados Unidos, a partir de plasma de doadores que foram infectados.

\section{NOVOS SOROS, MONOCLONAIS E BIOFÁRMACOS}

O Centro de Biotecnologia iniciou a produção de anticorpos monoclonais em biorreatores em 1990. Investigou o uso de vários tipos de bioreatores, mantendo hibridomas em suspensão, aderidas a rollers ou a microcarregadores, ou no interior de fibras ocas. Logrou-se a produção de gramas de anticorpos monoclonais em culturas que continuavam a produzir, mantidas por vários meses. Os processos de purificação foram desenvolvidos. O monoclonal anti-CD3 utilizado para controle de rejeição de alguns transplantes foi produzido e utilizado pelo Instituto do Coração. Uma produção mais industrial está prevista.

Temos hoje tecnologias que estão em implantação para a produção de surfactante pulmonar e toxinas botulínicas. O primeiro deve diminuir a mortalidade perinatal de prematuros, a um custo várias vezes menor do que os produtos existentes no mercado. o que está atualmente em fase de teste clínico contém, como os similares comercializados, fosfolipídios naturais do pulmão e duas proteínas hidrofóbicas. Uma segunda geração do surfactante pulmonar deverá conter proteínas hidrofílicas, que atuam na defesa contra infecções e podem ser de valia para o seu uso em adultos com doenças pulmonares, hoje não tratados com esse produto por causa do seu altíssimo custo. A adição de enzimas antioxidantes ao surfactante usado no prematuro, recuperando tecnologia desenvolvida para isolamento a partir de placentas humanas, pode tornar o produto mais eficaz em prematuros graves.

A produção de aprotinina, usada em cirurgia cardíaca, poderá ser o próximo subproduto do isolamento do surfactante. 


\section{APRESENTACุÃO DE VACINAS}

Voltado para o futuro, o Centro de Biotecnologia mantém um laboratório que vem investigando o uso de microcarregadores e lipossomos para apresentação de vacinas. O próprio surfactante pulmonar, que é um lipossomo polilamelar, parece ser um bom adjuvante. 


\section{Parte V}

COMPLEXO PRODUIIVO DA SAÚDE NO BRASIL: A EXPERIÊNGIA DAS INSTITUIÇÕES 


\section{Desenvolvimento e Produção de Vacinas e Soros no Instituto Butantan}

Hisako Gondo Higashi

Isaías Raw

Otávio Azevedo Mercadante

No período entre o final do século XIX e início do século XX, o Brasil enfrentava graves problemas sanitários, com surtos de febre amarela, cólera e outras doenças infecciosas. A origem do Instituto Butantan está ligada a um grave surto de peste bubônica que tomou conta da cidade de Santos de 1898 a 1899. Na época, o tratamento das vítimas da doença baseava-se na administração de um soro contendo anticorpos que reconheciam e combatiam a bactéria causadora. Em virtude da dificuldade para se obter o soro, o governo de São Paulo decidiu instalar um laboratório e prepará-lo com urgência, na área de uma fazenda nas cercanias da capital paulista - Fazenda Butantan. 0 laboratório começou a funcionar em dezembro de 1899 , sob a direção de Vital Brazil Mineiro da Campanha. A produção nacional foi decisiva para o controle da peste trazida pelos navios que chegavam de países onde grassava a infecção.

Em fevereiro de 1901, o laboratório, desvinculado do Instituto Bacteriológico, passou a se chamar Instituto Serumtherápico do Estado de São Paulo.

Vital Brazil, percebendo a necessidade de combater também os sintomas de envenenamento por animais peçonhentos, envidou estudos nesse sentido e, em agosto de 1901 , foram entregues as primeiras partidas de soros antipestosos e antipeçonhentos. Nos anos seguintes, o Instituto passou a estender suas pesquisas sobre problemas ligados ao preparo de produtos para a defesa da saúde da população paulista e brasileira. 
Vital Brazil retirou-se da direção do órgão em 1919, retornando em 1924. Neste ano, intensificou o trabalho no campo da microbiologia e imunologia, desenvolveu novos estudos e produziu a vacina para prevenção da febre tifóide que atingiu São Paulo na época. Com a reorganização do Serviço Sanitário do Estado, em 1925, o Instituto Serumtherápico passou a chamar-se Instituto Butantan.

Ao longo de sua história, além de estudos sobre diferentes doenças causadas por agentes patogênicos e da produção de soros e vacinas para o controle e a prevenção de diversos males, o Instituto Butantan sempre manteve, entre suas atribuições, a pesquisa sobre os venenos de animais peçonhentos e a produção de soros para neutralizá-los, que era um dos principais interesses de Vital Brazil.

Em 1930, foi iniciada a produção de vacinas, destacando-se na época a antivariólica.

o desenvolvimento científico, particularmente em áreas que servem de suporte para a solução de problemas de saúde pública, é hoje um dos princípios fundamentais de atuação do Instituto Butantan. Em face dos avanços tecnológicos, a pesquisa e a produção nesse setor exigem equipes multidisciplinares, que colaborem em diferentes áreas e níveis de conhecimentos.

\section{TECNOLOGIA PARA A PRODUÇÃO DE SOROS: SISTEMAS FECHADOS E BOAS PRÁTICAS DE FABRICAÇÃO (BPF)}

Em 1985, o governo federal constatou que os soros antipeçonhentos produzidos por laboratórios públicos e algumas empresas particulares no Brasil não possuíam a qualidade necessária para os produtos injetáveis. A fim de enfrentar o problema, já que não podia ocorrer a importação, o Ministério da Saúde (MS) decidiu tomar uma série de medidas; entre elas, determinou que os imunobiológicos só poderiam ser liberados depois de uma análise independente pelo Instituto Nacional de Controle de Qualidade em Saúde (INCQS), trazendo, dessa maneira, uma garantia de qualidade.

Em sua visão simplista, o MS decidiu investir num número limitado de institutos públicos de porte maior para aquisição de equipamentos novos. 0 problema não residia só na aquisição desses equipamentos, mas na tecnologia empregada, tecnologia esta que definiria as instalações necessárias. Obviamente, a prioridade seria desenvolver a tecnologia e reinstalar a planta de produção de soros hiperimunes.

\section{Obtenção do antígeno}

Com procedimentos rudimentares, as serpentes eram mantidas em ambiente único e seu veneno, após extração, era seco em dessecador. Dentro do programa de reestruturação, foi construído um laboratório especial, onde as serpentes, depois de uma quarentena, eram transferidas para as caixas plásticas (as gaiolas anteriores eram de madeira, de difícil higienização); em seguida, estas eram colocadas em ambiente com ar filtrado, com temperatura e umidade controladas. As serpentes selecionadas se reproduzem em cativeiro; logo, o Butantan, que por décadas dependeu de serpentes capturadas ou doadas, tornou-se independente. Neste particular, os antígenos ofídicos, escorpiônicos e aracní- 
dicos eram colhidos e dessecados; hoje, após sofrerem uma filtração, são liofilizados, tornando o produto mais estável.

A composição da mistura atual do veneno utilizado na imunização dos cavalos para as diferentes espécies de serpentes, escorpióes e aranhas é decorrente de um estudo desenvolvido pela área de produção e pelos laboratórios de herpetologia e artrópodes, cujo objetivo era obter um soro antipeçonhento que atendesse a acidentes em nível nacional. Os esquemas de imunização com adjuvantes adequados também foram objeto de longos estudos. $O$ conjunto dessas ações nos possibilitou melhorar a eficiência dos antígenos empregados na imunização de cavalos soro-produtores, resultando no aumento da quantidade e qualidade do plasma obtido.

Um importante desenvolvimento que deve ser destacado foi a descoberta, no veneno laquético, de uma fração imunossupressora (patente depositada) que dificultava a produção de soro laquético, mas que poderia dar origem a um novo imunossupressor para uso clínico.

\section{Obtenção de plasmas hiperimunes}

Até 1985 , o sangue era coletado em latōes de leite, um sistema totalmente aberto, sujeito a contaminações ambientais; depois de separado, o plasma era depositado em recipientes plásticos e transportado para a área de processamento. Desenvolveu-se, então, uma bolsa plástica dupla onde, em um dos compartimentos, é coletado o sangue e, após uma noite em câmara fria, separam-se os elementos figurados do plasma, que é recolhido no segundo compartimento, em um sistema totalmente fechado e esterilizado. Esse procedimento possibilita, ainda, devolver as hemácias ao cavalo, num processo denominado de plasmaferese, o que permite uma recuperação mais rápida do animal.

Com as inovações introduzidas tanto no antígeno, como nos esquemas de imunização e na obtenção de plasma, hoje temos na Fazenda cerca de 380 cavalos que produzem maior volume de plasmas hiperimunes do que os 2.000 que tínhamos em 1985.

\section{Produção de soros hiperimunes}

A urgência da solução para um grave problema de fornecimento de soro à população não permitiu que a experiência que começava a ser adquirida no isolamento-por cromatografia para obtenção de hemoderivados a partir da placenta humana-pudesse ser empregada na produção de soros hiperimunes. A estratégia foi adaptar a tecnologia tradicional a um sistema totalmente autocontido, evitando a contaminação do plasma e a manipulação dos produtos nas fases intermediárias, em que as operações se sucedem usando equipamentos adequados.

O sistema foi desenvolvido na Divisão de Produção do Instituto Butantan e conśstruído por empresas nacionais especializadas em tanques de aço inoxidável. O único equipamento importado desse sistema foi a ultracentrífuga de pratos, que permite a centrifugação contínua de grandes volumes separando simultaneamente precipitados e sobrenadante. 
O processo converte as imunoglobulinas (IgT do cavalo que tem um domínio a mais do que os IgG) em Fab2, removendo, assim, o Fc, que, ligado ao antígeno, desencadearia a reação de complemento. A utilização da pepsina em pH ácido apropriado e o uso de ácido caprílico são, por si, tratamentos que eliminam possível presença de vírus. Esta foi a primeira planta industrial construída no Butantan, usando empresas especializadas para fornecer os tanques e outros equipamentos em aço inoxidável de qualidade para fins farmacêuticos; o processo foi definido pela equipe de produção, sem necessidade de contratação externa. Essa experiência bem-sucedida permitiu ao Instituto produzir sua cota de soros. Hoje, a purificação de alguns soros é completada por cromatografia, sendo o Butantan o segundo produtor a utilizar o processo cromatográfico no mundo.

\section{Soros antitóxicos, anti-rábico, terapêutico e monoclonais}

Os soros antitetânico e antidiftérico são produzidos pelo mesmo processo, com pequenas alterações mais adequadas para as imunoglobulinas neutralizantes. Recentemente, o Butantan retomou a produção de toxinas botulínicas, em ambientes de biossegurança, o que permitiu a produção do soro antibotulínico A e B e, a partir de 2004, do anti-E (cuja toxina está presente em pescados).

A produção de soro anti-rábico dependeu da produção de vírus para imunização, resultando numa planta especial em que os vírus são cultivados em células BHK. Esse processo produz uma vacina eficaz não apenas para imunizaçăo de cavalos, mas também para uso veterinário, e a sua tecnologia está sendo transferida para uma empresa privada. A raiva é a única infecção para a qual o tempo de incubação permite (como foi descoberto por Louis Pasteur) a imunização protetora com a vacina. Para neutralizar a maior parte dos vírus decorrentes do acidente provocado por cães ou morcegos, a vacina é administrada simultaneamente com o soro anti-rábico.

A produção de soro anti-rábico é fundamental, principalmente para países menos desenvolvidos onde a vacinação de cães não tem cobertura suficiente ou quando a raiva é transmitida por morcegos. Como a produção desse soro em cavalos, fornecido por empresas européias, foi descontinuada, o Butantan tem recebido um grande volume de pedidos de outros países, os quais começará a atender tão logo seu soro seja registrado nos países solicitantes.

O Butantan iniciará também a produção de soro antidigitálico, empregado para o tratamento de intoxicações causadas por medicamentos específicos, o que é comum, em virtude da diferença pequena entre a dose terapêutica e tóxica destes medicamentos.

o Butantan, em colaboração com o Incor, vem produzindo uma pequena quantidade de soro antitimocitário humano, usando timócitos isolados de cirurgias neonatais praticadas para corrigir defeitos congênitos. O soro antitimocitário (e alguns outros) são purificados por cromatografia em coluna. Um substituto para o soro antitimocitário são anticorpos monoclonais. O Instituto tem a única planta de produção de anticorpos monoclonais em escala média, que utiliza vários tipos de biorreatores. Cultivos em reatores 
perfundidos e de fibra oca permitem a produção contínua por muitos meses. O anti-CD3 vem sendo suprido para uso no Hospital das Clínicas e no Incor e tem aplicações definidas, não substituindo totalmente o soro antitimocitário humano. Proximamente estaremos ampliando a produção, bem como investigando sua imobilização para remover linfócitos $\mathrm{CD} 3$ de amostras para transplante medular.

O uso de monoclonais é indicado quando se pretende remover um determinado tipo de célula do organismo pela ação do monoclonal ou de uma toxina a ele ligado, ou ainda pela ligação de um complexo anticorpo monoclonal com um marcador para detectar a presença de metástases. Este é um investimento tecnológico para o futuro, que, entretanto, jamais substituirá o anticorpo policlonal, como os antivenenos (proposta ingênua sempre repetida), que tem uma atividade contra vários antígenos tóxicos, nos quais anticorpos diferentes atuam adequadamente para componentes antigênicos. Obviamente, o custo de um coquetel de monoclonais seria milhares de vezes mais alto e menos eficaz do que o tradicional soro hiperimune.

A produção de anticorpos humanos é obviamente uma meta importante e depende da implantação do programa de hemoderivados no Butantan. Atualmente, o Instituto está desenvolvendo um processo e uma pequena planta para a separação de IgG de doadores de sangue que foram imunizados (contra tétano, raiva ou hepatite B) pelo uso de vacinas ou que sofreram infecção e têm alto nível de anticorpos (vírus sincicial respiratório). Este programa, desenvolvido em cooperação com alguns centros de coleta de plasma humano, deverá ser implementado em 2005.

\section{BUTANTANE APRODUCุÃO DE SOROS}

Hoje o Butantan produz 50\% dos soros que a Fundação Nacional de Saúde (Funasa/ MS) tem distribuído no território nacional (Gráfico 1). A capacidade seria de atender toda a demanda nacional, e em condiçōes BPF, a cujas normas as presentes instalaçōes dos outros produtores ainda não obedecem (Quadro 1). Em adição, esses soros incluem outros que os demais produtores também ainda não fornecem: antilonomia, antidiftérico, antiaracnídico, além dos soros especiais como o soro antitimocitário, usado no controle de rejeição de transplante.

Para maior elasticidade produtiva, o Butantan tomou duas decisões: 1) terceirizar parte da produção de plasmas hiperimunes para o Instituto de Biologia do Exército e o Instituto de Química do Estado de Goiás (Iquego); 2) suprir a falta de soros que outros produtores não fornecem e utilizar o excedente de capacidade de produção para exportação. Alguns países do continente latino-americano já adquirem soros antipeçonhentos e outros; o mesmo ocorre com o soro anti-rábico no norte da África. A exportaçăo de soros deve duplicar a produção nos próximos dois anos e apenas aguarda o longo processo de registro em vários países.

o Butantan, por sua planta e experiência na produção de soros, foi escolhido pela Organização Mundial de Saúde (OMS) para validação do processo de purificação de soros hiperimunes e verificação de que estes processos eliminam o risco de contaminação por vírus que eventualmente infectam os cavalos. 
Gráfico 1 - Produção de soros - 1986-2002

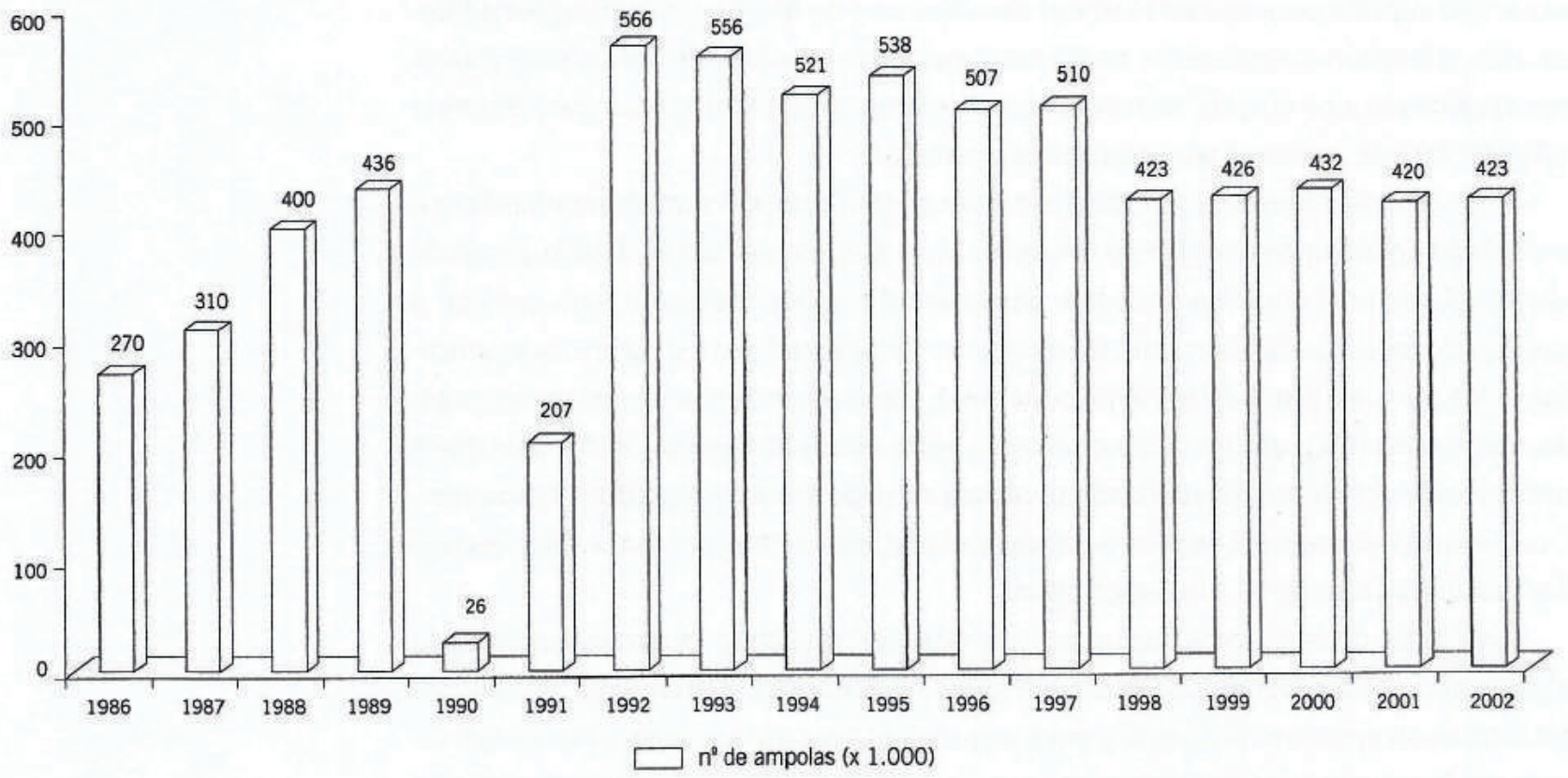

Quadro 1 - Produção de soros hiperimunes no Butantan

\begin{tabular}{|l|l|}
\hline Produtos & Produção \\
\hline Soros antiofídicos & Atende a demanda nacional e exportação \\
Soros antitoxinas de artrópodes - 2 tipos & Atende a demanda nacional \\
Soros antitoxinas bacterianas - 3 tipos & Atende a demanda nacional e exportação \\
Soro anti-rábico & Atende mercado nacional e exportação \\
Soro antitimocitário & Em ensaio clínico ampliado \\
Soro monoclonal anti-CD3 & Em ensaio clínico ampliado \\
Soro antidigitálico & Em imunização \\
\hline
\end{tabular}

\section{BUTANTAN E APRODUC̄̃̃O DE VACINAS}

As plantas de produção das vacinas e soros foram otimizadas, sofreram modificaçōes para melhorar a produção e adequar-se às BPF, somando ao sistema autocontido, com automatização e o mínimo de manipulação, áreas biolimpas e outros critérios internacionais necessários para a certificação (Gráfico 2 e Quadro 2). As plantas de vacinas foram inspecionadas pela primeira vez em 1990 por um grupo de especialistas estrangeiros escolhidos pela Organização Pan-Americana da Saúde (Opas), os quais atestaram o cumprimento das exigências do Canadá e dos Estados Unidos. Ainda em 2004 teremos uma nova inspeção, sob a égide da OMS, que deve atestar se as plantas e processos atendem às suas exigências. 
Gráfico 2 - Produção de vacinas - 1986-2002

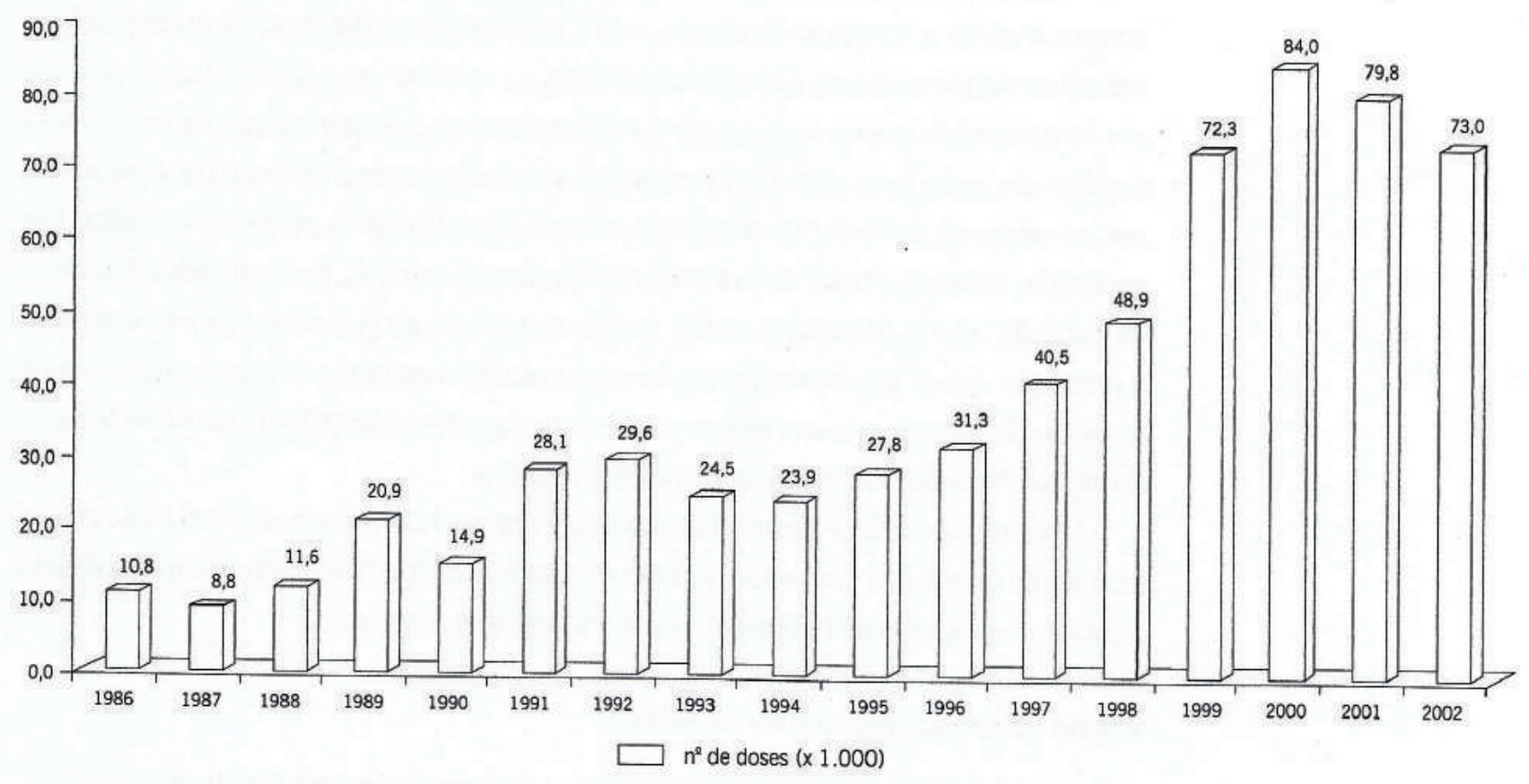

Quadro 2 - Produção de vacinas no Butantan

\begin{tabular}{|l|l|}
\hline Produtos & Produção \\
\hline Pertussis & Capacidade instalada 60,8 milhões \\
Toxóide e toxina tetânica & Capacidade instalada 156 milhōes \\
Toxóide e toxina diftérica & Capacidade instalada 222,5 milhões \\
BCG - vacina e intravesical & Capacidade instalada 8 milhöes \\
Hepatite B & Capacidade instalada 72 milhões \\
Raiva & Capacidade instalada 1,2 milhōes \\
Influenza & Planta em construção para 20 milhões \\
\hline
\end{tabular}

\section{Vacinas DTP e DT}

A partir de 1986, foram construídas três plantas para, respectivamente, produção da vacina pertussis (celular inativada), da anatoxina tetânica e da anatoxina diftérica.

A produção das toxinas é feita em biorreatores de 600 e 500 litros em sistema autocontido. A otimização do processo durante estes últimos anos permitiu produzir muito mais do que seria a demanda nacional de 156 milhões a 222 milhöes de doses. A definição de que todos os idosos acima de sessenta anos seriam revacinados contra difteria e tétano foi atendida pela entrega de 22 milhões de doses em prazo curto, sem maiores dificuldades. As anatoxinas produzidas são purificadas por cromatografia e atingem um altíssimo grau de pureza, o que permite o seu uso na conjugação de polissacarídeos para a produção de vacinas contra Haemophilus tipo b e pneumococo. 
A capacidade hoje instalada para produzir pertussis, em biorreatores de mil litros, levou em conta a demanda nacional, mas o processo de otimização permite produzir uma quantidade acima do necessário. A produção anual de pertussis celular é estimada em 40 milhões de doses, mas novos desenvolvimentos devem permitir até dobrar essa capacidade, usando os mesmos biorreatores. O sistema autocontido separa as bactérias por um processo de filtração tangencial controlado, que evita a perda dos antígenos de superfície. O sobrenadante deverá permitir a produção, por ano, de 4 milhões a 8 milhões de doses da vacina pertussis acelular, acoplada à produção da vacina celular, bem como a produçăo de um adjuvante para a vacina pertussis acelular e outras vacinas. Com a implantação desse processo, espera-se produzir não só vacina DTP, da qual grande parte do efeito tóxico foi removido, como também o DTPa.

A vacina tríplice DTP é fornecida ao MS por apenas $\mathrm{R} \$ 0,18$ a dose. Uma parte dela já está sendo convertida em vacina quádrupla, isto é, a vacina DTP do Butantan é utilizada para diluir a vacina Hib importada por Bio-Manguinhos/Fiocruz.

\section{Vacina recombinante contra hepatite $B$}

A partir de 1997, o Butantan desenvolveu a tecnologia de produção da vacina recombinante contra hepatite $B$, produto que sofreu uma campanha longa para ser finalmente aprovado depois de um megaensaio patrocinado pela Funasa. Esse ensaio clínico revelou que a dose infantil da vacina ( 10 microgramas) é suficiente para pessoas até vinte anos. A fábrica instalada permite a produção de 72 milhões de doses por ano, o que vem atendendo a demanda nacional, que inclui 10 milhões referentes às três doses para recém-nascidos e 16 milhões para proporcionar, em poucos anos, a vacinação de jovens que atingem a maturidade sexual e estão sujeitos à infecção (por atividade sexual ou múltiplo uso de seringas). Está previsto o ensaio clínico da vacina quádrupla DTP-hepatite B - que, combinada à Hib de Bio-Manguinhos, será convertida na vacina pêntupla brasileira.

Vacinas virais: influenza e raiva

Em 2000, o Butantan fez um acordo de transferência de tecnologia de influenza, da Aventis, acoplada à importação da vacina a granel. A vacina, contendo três cepas, foi definida pela OMS no fim do ano, poucos meses antes do prazo para a sua administração, que no Brasil ocorreu em abril. Numa primeira etapa, dominamos o envase e ensaio da vacina, envasando inicialmente 14 milhões de doses; em 2003 foram 16,6 milhões, num verdadeiro recorde.

Nesse intermédio, a equipe de produção, controle e engenharia recebeu da Aventis toda a informação detalhada que permitiu projetar a planta de produção, cuja construção está sendo iniciada (com recursos do governo estadual) junto com a encomenda de equipamentos importados e nacionais para esse processo (com recursos federais). A montagem dessa fábrica não é trivial e, além da tecnologia de produção, que utiliza um 
ovo fecundado por vacina, implica a utilização de cerca de 17 milhões de ovos em cerca de noventa dias, que devem ser produzidos por empresas privadas, assim como o descarte com inativação viral.

A vacina contra raiva produzida em células Vero foi desenvolvida pela divisão de produção. Lotes iniciais da vacina já foram produzidos e usados em ensaio clínico, demonstrando ser esta muito mais eficaz do que a vacina produzida em cérebro de camundongo (três doses contra dez, respectivamente). Enquanto estendemos o ensaio clínico, estamos já instalando o laboratório de produção da vacina que deverá iniciar a produção no segundo semestre de 2004. Neste intervalo, estamos adquirindo vacina a granel, testando e envasando. Simultaneamente, devemos iniciar a liofilização, com a instalação da central de liofilização.

\section{VACINAS COMBINADAS}

Um importante avanço foi a produção de vacinas combinadas baseadas em DTP. Esta vacina tríplice, adotada décadas atrás, tem sido base para produção de novas vacinas múltiplas (Quadro 3). Em cooperação com Bio-Manguinhos, a vacina DTP do Butantan está sendo utilizada como diluente da vacina conjugada contra Haemophilus b (Hib). A vacina tríplice do Butantan será convertida na vacina quádrupla, pela combinação com a vacina recombinante contra hepatite $B$. Os ensaios em animais estão completos $\mathrm{e}$ aguardam apenas o ensaio clínico, que será feito tanto para a vacina DTP-HpB, como DTP-HpB + Hib (Butantan - Bio-Manguinhos). Com isso, o Brasil deverá produzir a sua vacina pêntupla e validar para exportação a vacina quádrupla, mais freqüentemente adotada pela maioria dos países.

Novos antígenos devem ser testados para ampliar ainda mais a vacina multivalente, que diminui o trabalho de imunização, reduzindo o número de picadas e visitas aos postos de vacinação, assim como o número de seringas, cujo custo é significativo e exige descarte apropriado.

Uma combinação totalmente nova, que já se encontra em teste clínico, é a BCGhepatite B intradérmica, substituindo as duas vacinas separadas que devem ser administradas ainda na maternidade. A BCG, além de ser uma vacina, é um poderoso adjuvante e substituirá o hidróxido de alumínio para a vacina contra hepatite B. Essa combinação também poderá ser útil para a vacinação de pessoas acima de cinqüenta anos (que não respondem adequadamente à vacina contra hepatite $\mathrm{B} \mathrm{e}$ que por razões profissionais são expostos à contaminação por sangue) e estará entrando em ensaio clínico ao mesmo tempo em que a vacina contra hepatite B com adjuvante extraído de Bordetella.

Estão começando a ser produzidas as toxinas botulínicas A, B e E, essenciais para a produção do soro antibotulínico (Quadro 4). As toxinas, além do seu uso estético, têm um amplo uso clínico em doenças neurológicas. 
Quadro 3 - Produção de vacinas combinadas no Butantan

\begin{tabular}{|l|l|}
\hline Produtos & Produção \\
\hline DTP & Em produção \\
DTP acelular & Ensaio clínico (2004) \\
DTP+hepatite B & Ensaio clínico (2004) \\
DTP+hepatite B+Hib & Com Hib Bio-Manguinhos para uso nacional: em produção \\
Hib & Escalonamento, para produção da pentavalente para \\
BCG +hepatite B neonatal & exportação \\
BCG + pertussis & Ensaio clínico \\
Hepatite B novo adjuvante & Produção prevista para 2005 \\
BCG +pertussis neonatal & Para > 50 anoS, prevista para 2005 \\
DTP + vitamina A e DTP congelável & Prevista para 2005 \\
Meningite B conjugada com C & Prevista para 2005 \\
Pneumococo multivalente & Prevista para 2005 \\
Pneumococo conjugado para cepas resistentes a & Prevista para 2005 \\
antibióticos (BB) & Prevista para 2005 \\
Esquistossomose Sm-14 (BB)* & \\
\hline
\end{tabular}

* BB: Butantan - Bio-Manguinhos

Quadro 4 - Produção de biofármacos no Butantan

\begin{tabular}{|l|l|}
\hline Produtos & Produção \\
\hline Toxinas botulínicas para uso clínico (A, B) & Produção em 2004 \\
Eritropoetina & Em escalonamento final \\
Surfactante pulmonar padräo & Ensaio clínico, produção em 2004 \\
\hline
\end{tabular}

\section{ECONONOMIA DE DIVISAS, CRIACุÃO DE EMPREGOS DIRETOS}

Essa produção representa domínio tecnológico e economia de importação da ordem de milhões de đólares, além da criação de 220 empregos diretos. Não está incluído, nesses dados, o custo da importação de vacinas a granel, que é de US\$35.578.000. Só na importação do granel da vacina contra influenza, o preço pago pelo Butantan é menos de $50 \%$ do preço oferecido através da Opas, representando uma economia anual da ordem de 30 milhões de dólares somados ao valor da tecnologia, que na época foi orçado em US\$18.400.000. Com o início da produção das vacinas de influenza e raiva, a economia em divisas poderá subir para cerca de 40 milhões de dólares.

Imaginamos que, dependendo da inspeção programada pela OMS, o Butantan deverá exportar cerca de 8 milhōes de dólares em vacinas e soros. 


\section{ESTRANGULAMENTO DA INOVAÇÃO: DESENVOLVIMENTO, ENSAIO CLÍNICO E CAPITAL}

A combinação de um instituto público com uma fundação sem fins lucrativos, bem gerenciada, demonstrou a capacidade de inovação e resposta à demanda oficial de imunobiológicos. Partindo da produção zero, em 1985, já somos uma empresa média, de alta tecnologia, que produz e entrega cerca de 50 milhões de reais em produtos, a preços irrisórios estabelecidos pelas multinacionais, para os fundos do Unicef, Opas e The Global Alliance for Vaccines and Immunization (GAVI) para os países subdesenvolvidos. O valor desse fornecimento representa menos de $10 \%$ do faturamento dessas multinacionais, que é decorrente de vacinas vendidas cerca de cem vezes mais caras para os usuários dos países ricos, onde essas empresas auferem seus lucros.

Nós temos de produzir, entregar e aguardar o pagamento ao preço que o MS determina, em torno de um ano após o início da produçâo. Mais ainda, temos de ser responsáveis iniciando a produção, com significativos investimentos, muitos meses antes que o próprio MS torne oficial seu pedido. $O$ aumento de produção demanda um capital de giro que é inexistente e cujo custo financeiro criaria um déficit sem solução para um produtor sem fins lucrativos.

Neste contexto, năo temos recursos de giro para produção, tampouco inexistem os recursos para manutenção dos atuais parques produtivos, que representam um investimento realizado há cerca de seis anos, com uma perspectiva de produção muito menor. o Butantan espera absorver recursos para estabelecer a planta para produzir a vacina de raiva em cultura celular. Obviamente não temos recursos para novas plantas; o auxílio para a aquisição do equipamento para a planta de influenza ainda não foi liberado e já planejamos a produção da vacinas contra o vírus do papiloma do colo do útero, cuja vacinação deve ser iniciada nos próximos anos.

Novas vacinas exigem outro investimento, que é o ensaio clínico. No Brasil, o ensaio clínico foi 'profissionalizado' por empresas que cobram grandes somas. Sem um sistema público, que mobilize voluntários em hospitais universitários e postos de saúde, utilizando médicos e enfermeiros dos quadros, realizando os ensaios para medir resposta e toxicidade em laboratórios oficiais, não lograremos os resultados que o estágio atual prevê.

\section{PAPEL CENTRAL DO BUTANTAN NO PROGRAMA NACIONAL DE AUTO-SUFICIÊNCIA}

o Butantan é o único laboratório que produz todos os tipos de soros hiperimunes, atendendo pelo menos a $50 \%$ da demanda nacional.

Dos sete antígenos vacinais para uso humano produzidos no país, o Butantan produz seis. O Instituto só não é o produtor principal de apenas um deles, o BCG, devendo manter o compromisso de dar à Funđação Ataulpho de Paiva o espaço para que esta continue suprindo a maior parte da demanda nacional, porém utilizando sua capacidade de produção da vacina combinada hepatite B com BCG. Implantará a produção da vacina conjugada contra Haemophilus b, criando sua vacina pentavalente reservada apenas 
para exportação, respeitando o investimento que vem sendo feito por Bio-Manguinhos. Em 2003 a produção de antígenos vacinais pelo Butantan dobrou, e, com a certificação pela OMS, o Instituto deverá exportar para o Unicef e para vários outros países o produto a granel, o que provavelmente dobrará a produção de 2004-5.

\section{Domínio tecnológico}

O que se desenvolveu até agora e o que está em andamento incluem o domínio de um número de rotas tecnológicas, que fizeram progredir a competência dos profissionais da produção e desenvolvimento, permitindo prever um ritmo cada vez maior de novas tecnologias para os atuais e para os novos produtos, que mantêm viável o Instituto no futuro. As novas tecnologias incluem:

- fermentação aeróbica e anaeróbica em larga escala;

- ultrafiltração molecular e tangencial;

- centrifugação e ultracentrifugação contínua e em gradiente;

- cromatografia em larga escala;

- cultura em células animais em larga escala;

- produção e purificação em larga escala de vírus;

- produção e purificação em larga escala de toxinas bacterianas;

- produção em escala de membrana externa de bactérias;

- produção e purificação de proteínas recombinantes em leveduras;

- produção de proteínas recombinantes em células animais;

- controle biológico, microbiológico e físico-químico de vacinas e outros produtos para uso médico;

- planificação, lay-out e projetos de plantas de produções farmacêuticas e veterinárias; - planificação e instalação de sistemas de água de qualidade injetável e outras utilidades para produtos farmacêuticos e veterinários. 


\title{
Desenvolvimento e Produção de Vacinas no Instituto de Tecnologia em Imunobiológicos (Bio-Manguinhos) da Fiocruz
}

\author{
Akira Homma \\ Maria da Luz Fernandes Leal \\ Mario Santos Moreira \\ Fernando de Oliveira Pina \\ Rosiceli Barreto G. Baetas \\ Ana Paula Brum Pizarro \\ Artur Roberto Couto
}

\section{INTRODUÇÃO}

Este trabalho tem por objetivo apresentar o Instituto de Tecnologia em Imunobiológicos (Bio-Manguinhos) da Fundação Oswaldo Cruz, desde sua criação até o presente. São discutidas as motivações para sua criação, as estratégias adotadas no fortalecimento de sua capacitação tecnológica para atender às novas demandas de saúde pública dentro de um contexto de mudanças epidemiológicas e tecnológicas nacionais e internacionais, a trajetória de sua inserção no Sistema Único de Saúde (SUS), os desafios mais complexos enfrentados e os principais resultados alcançados.

A primeira seção apresenta um breve histórico da criação de Bio-Manguinhos. A seguir são considerados os marcos da capacidade de aperfeiçoamento e de incorporação de novas vacinas de Bio-Manguinhos à sua linha de produtos. A terceira seção traz as bases da concepção do atual Complexo Tecnológico de Vacinas. A quarta mostra como Bio-Manguinhos vem enfrentando os desafios decorrentes das novas bases paradigmáticas no campo das vacinas. As duas últimas seções apresentam os principais resultados alcançados, expressos em vacinas entregues, desde 1987 , ao Programa Nacional de Imunização, e em diversos outros indicadores relativos aos últimos sete anos. 


\section{BREVE HISTÓRICO}

A origem de Bio-Manguinhos se confunde com a história de combate a epidemias de grande impacto para a saúde pública brasileira e com o reconhecimento, por parte das instâncias governamentais, da necessidade de criar e fortalecer a produção de vacinas no país.

Em julho de 1900, foi criado o Instituto Soroterápico Federal, como instituição do governo federal, com funções de desenvolver e produzir soros e vacinas requeridas para combater e controlar as epidemias, como a peste bubônica, febre amarela, varíola e outras que grassavam na cidade do Rio de Janeiro. Em março de 1908, foi transformado em Instituto Oswaldo Cruz e em 22 de maio de 1970 recebeu a denominação atual de Fundação Oswaldo Cruz (Fiocruz), incorporando na sua estrutura o Instituto Oswaldo Cruz e outras instituições, como o Instituto Nacional de Endemias Rurais, o Instituto de Leprologia, o Instituto Fernandes Figueira e a Escola Nacional de Saúde Pública (Azevedo, 2000).

Até a década de 50, o Instituto Oswaldo Cruz produzia dezenas de diferentes vacinas e soros, inclusive para uso veterinário. Os recursos obtidos da venda desses produtos eram investidos em novos laboratórios, no financiamento de pesquisas de novos imunobiológicos, na modernização de laboratórios, na aquisição de novos equipamentos, em pagamento de pessoal e em outras atividades relacionadas. Nas décadas seguintes, por razões de ordem política interna e governamental, diminuiu o foco dessas atividades, resultando em gradativa obsolescência tecnológica (Benchimol, 2001a).

Nos anos iniciais da década de 70, ainda teve importante papel na produção da vacina contra a varíola, mas, com a erradicação desta virose, tal atividade também deixou de existir e a produção ficou reduzida a apenas um produto importante: a vacina contra a febre amarela. Mesmo esta vacina tinha grandes limitantes tecnológicos, de produção em escala e apresentação; sua produção continuou apenas porque recebia o apoio logístico da Organização Pan-Americana da Saúde (Opas), que financiava a aquisição de pequenos equipamentos e complementava os salários dos pesquisadores envolvidos na produção da vacina.

A grande epidemia de meningite meningocócica de sorogrupos A e C, na década de 70 , causou centenas de mortes e encontrou o país completamente despreparado para enfrentar essa dramática situação. Para o suprimento da vacina contra a doença, o governo brasileiro buscou o Instituto Mérieux na França, que produziu, em operação emergencial, 80 milhões de doses, utilizadas para vacinação em massa da população brasileira.

Ocorre, então, a decisão do governo federal de fortalecer a capacitação tecnológica nacional de produção de imunobiológicos essenciais e estratégicos para a saúde pública, com instalações apropriadas e incorporação de tecnologias contemporâneas. Nesse contexto, cria-se, em 4 de maio de 1976, pela Norma Regulamentar 02/76 do presidente da Fundação Oswaldo Cruz, o Instituto de Tecnologia em Imunobiológicos (Bio-Manguinhos), que incorpora as atividades tecnológicas desenvolvidas até então pelo Insti- 
tuto Oswaldo Cruz, herdando, portanto, as funções e atividades do antigo Instituto Soroterápico Federal.

As atividades assumidas por Bio-Manguinhos não estavam estruturadas como unidade de produção; eram executadas por pesquisadores que, com tecnologias obsoletas, sem condições adequadas de trabalho, sem apoio institucional e de forma artesanal, davam o melhor de si para produzirem as vacinas contra febre tifóide, cólera, antígeno pertussis e toxóides diftérico e tetânico. A prođução da vacina contra a febre amarela era a única a dispor de uma planta planejada e dedicada para a finalidade. No entanto, as instalações não atendiam às normas internacionais que já norteavam as atividades nessa área, as metodologias de prođução eram ultrapassadas, a apresentaçâo da vacina era incompatível com a necessidade do campo e a capacidade de produção, limitada.

\section{A EVOLUÇÃO DA CAPACITAC̣ÃO TECNOLÓGICA: MARCOS PRINCIPAIS}

Nesta seção são apresentados os principais marcos do processo de capacitação tecnológica de Bio-Manguinhos, as decisōes estratégicas tomadas, os acordos de transferência de tecnologia firmados e os desenvolvimentos endógenos realizados.

Alguns princípios básicos nortearam o processo de capacitação tecnológica de BioManguinhos na nova fase:

- adoção de tecnologia de ponta em todas as atividades produtivas; em decorrência, Bio-Manguinhos deixou de produzir os toxóides diftérico e tetânico, antígeno pertussis e as vacinas contra cólera, febre tifóide e gripe;

- busca da qualidade e consistência de produção, objetivando conquistar o usuário e as autoridades competentes pela garantia da qualidade de vacinas produzidas e oferecidas à população;

- busca de escala de produção, com a finalidade de diminuir seus custos, atender a demanda nacional e aumentar a competitividade de seus produtos quando comparados com os importados;

- estabelecimento da confiabilidade, produzindo e disponibilizando as vacinas compromissadas de forma oportuna e cumprindo com a programação previamente estabelecida com o Ministério da Saúde (MS);

- organização de atividades de desenvolvimento tecnológico com vistas à melhoria de qualidade das vacinas existentes e ao desenvolvimento de novos imunobiológicos.

As primeiras vacinas de nova geração: contra meningite meningocócica, sorogrupos A e C; sarampo e poliomielite

Demarcado pelos princípios supracitados, Bio-Manguinhos foi se estruturando e se organizando para atender de forma conseqüente os seus compromissos com o Programa Nacional de Imunizaçōes (PNI) (Temporão, 2003).

Em 1976, foi instalada a planta-piloto da vacina contra meningite meningocócica, sorogrupos A e C, graças a um acordo de cooperação técnica firmado com o Instituto Mérieux. Pela primeira vez no Brasil, uma subunidade de cápsula bacteriana (polissa- 
carídeos) para uso humano era produzida em biorreatores, o que ocorreu como resultado da negociação envolvendo o fornecimento de 80 milhões de doses dessa vacina ao Brasil por ocasiāo da epidemia de meningite.

Em 1980, o Instituto absorveu as tecnologias de produção das vacinas contra o sarampo e poliomielite, transferidas pelo Laboratório Biken, da Universidade de Osaka, e pelo Japan Institute of Polyomielites Research, no âmbito do Acordo de Cooperação Técnica Brasil-Japão. Este acordo permitiu que Bio-Manguinhos realizasse treinamento especializado de seus profissionais nesses laboratórios, elevando substantivamente o nível de conhecimento tecnológico e de produção. Pela primeira vez no país, uma vacina viral para uso humano - a vacina contra o sarampo - era produzida em cultura de tecidos, em escala industrial.

Em relação à vacina contra poliomielite oral de vírus vivos atenuados, sustentado em estudos de custo-benefício, foi decidido, ainda em meados da década de 80 , que não seria implementado todo o ciclo de produção, limitando-se as atividades à formulação, envase e controle de qualidade do produto final, a partir de concentrado viral importado.

A existência dessa atividade em Bio-Manguinhos possibilitou importantes resultados para o país, com o desenvolvimento de uma nova formulaçâo da vacina contra poliomielite. Por solicitação do MS, em virtude da ocorrência de vários casos da doença no Nordeste brasileiro numa população com alta cobertura vacinal, foi desenvolvida uma nova formulação, contendo o componente tipo 3 da vacina, com potência viral aumentada. A nova formulação mostrou ser altamente eficaz e possibilitou o controle da virose, seguido da sua erradicação, no país: o último caso de poliomielite determinado por vírus selvagem ocorreu em 19 de março de 1989, no município de Sousa, na Paraíba (Schtzmayr et al., 2002). A Opas adotou essa nova formulação para todos os países das Américas e, com a estratégia de vacinação em massa, conseguiu erradicar a virose da região. $O$ último caso de poliomielite ocorreu no Peru em 22 de agosto de 1991 (Schtzmayr et al., 2002; Patriarca et al., 1988). Mais recentemente, a Organização Mundial da Saúde (OMS) recomendou o uso dessa formulação para todos os países tropicais, contribuindo para erradicação global dessa virose, inicialmente programada para o ano 2005. No entanto, a OMS vem encontrando grandes dificuldades na implementação e manutenção de altas coberturas em alguns países da África (sobretudo Nigéria), o que ainda determina centenas de casos de poliomielite. Essas dificuldades, por sua vez, permitem a exportação de vírus selvagem para países vizinhos e até para Ásia, como é o caso da epidemia de poliomielite que está ocorrendo na Indonésia. Este fato determinou a postergação da erradicaçăo global da poliomielite pela OMS para 2007.

Além disso, a existência dessa atividade permitiu quie Bio-Manguinhos atendesse as necessidades do PNI nos anos 2001 e 2002, quando houve um grande déficit dessa vacina no mercado internacional, causado pela entrada da Iniciativa Global de Vacinas e Imunização (GAVI) no mercado internacional, comprando vacinas para os países considerados mais pobres do mundo. 
As novas vacinas: contra Haemophilus influenzae tipo b (Hib), tetravalente bacteriana combinada e tríplice viral

Em 1998, foi estabelecido um acordo de transferência tecnológica de ponta com o laboratório GlaxoSmithKline (GSK) para a produção nacional da vacina contra Haemophilus influenzae tipo $\mathrm{b}(\mathrm{Hib})$. A nacionalização de todo o ciclo de produção dessa vacina deverá ocorrer em 2005, quando também serão realizados estudos clínicos de campo para verificar a qualidade da vacina produzida em Bio-Manguinhos, em comparação com a vacina produzida a partir de concentrado importado da GSK. A tecnologia utilizada é considerada a mais contemporânea para vacinas desse tipo e inclui operaçôes complexas, envolvendo reaçōes químicas de conjugação do polissacarídeo do Hib com uma proteína, no caso o toxóide tetânico altamente purificado, resultando em um aumento da capacidade imunogênica da vacina. De 1999 a 2001, o PNI utilizou essa vacina de forma monovalente e, em 2002, passou a adquirir a vacina combinada tetravalente (DTP+Hib) desenvolvida por Bio-Manguinhos em conjunto com o Instituto Butantan, representando um marco no esforço cooperativo entre os dois laboratórios públicos brasileiros na busca de vacinas mais avançadas e requeridas pelo PNI. Em uma única operação, a criança é protegida contra quatro doenças imunopreveníveis.

Em novembro de 2003, foi negociado e assinado um novo acordo de transferência de tecnologia com a GSK para incorporação da tecnologia de produção da vacina tríplice viral (sarampo, caxumba e rubéola), a única do calendário básico de imunização ainda importada. Deve ser acrescentado que, por solicitaçăo do MS, a cepa de caxumba é uma derivada da cepa Jeryl Lynn, considerada a melhor cepa vacinal de caxumba por apresentar a menor taxa de reação adversa e alta imunogenicidade.

Aperfeiçoamento e desenvolvimento de vacinas: vacina contra febre amarela e as vacinas contra meningite meningocócica

As atividades de desenvolvimento tecnológico também vêm sendo fortalecidas ao longo dos anos. No Anexo 1, estáo relacionados os vários projetos de inovação incremental realizados em Bio-Manguinhos, responsáveis pelos diversos aperfeiçoamentos tecnológicos em produtos e processos de produção de vacinas produzidas no Instituto. A vacina contra a febre amarela, por exemplo, sofreu inovação incremental nos seguintes aspectos: 1) aperfeiçoamento da termoestabilidade; 2) utilização de melhores insumos, como ovos specific pathogenic free (SPF); 3) melhoria de processos e de rendimento de produção; 4) modificação da apresentação existente - de ampolas de 200 doses para apresentação de 50 doses e, finalmente, apresentação atual de cinco doses; 5) aumento da capacidade de produção de produto intermediário e do produto final - de 8-10 milhões em apresentação de 200 doses, para 100 milhões de doses do produto intermediário e 40 50 milhões de doses em cinco doses.

A quinta apresentação passou a ser produzida nos últimos três anos, o que permitiu a redução significativa do desperdício de vacinas no campo. Além disso, melhorou a qualidade da vacina, pois, com menor número de doses, esta, depois de reconstituída, é 
utilizada em tempo mais curto e há menor número de perfuraçōes na rolha do frasco do produto, diminuindo a possibilidade de contaminação bacteriana.

Novas iniciativas em inovação tecnológica de vacinas

Vários projetos de desenvolvimento de vacinas estăo sendo implementados em Bio-Manguinhos:

- Vacina contra meningite meningocócica, sorogrupo B, em conjunto com o Instituto Adolfo Lutz e o Instituto Butantan; encontra-se em fase final de desenvolvimento.

- Nova vacina contra meningite meningocócica sorogrupo C, conjugada, também estará pronta para os estudos clínicos de Fase 1 em 2005; a expectativa é de apresentar essas vacinas de forma combinada, com os dois sorogrupos B e C.

- Nova vacina combinada, a vacina DTP, em parceria com o Instituto Butantan. Formulada com a vacina contra hepatite $\mathrm{B}$, essa vacina tetravalente será utilizada para diluir a vacina contra Haemophilus influenzae tipo $\mathrm{b}$ (Hib), derivando a vacina pentavalente, ou seja, com uma injeção a criança receberá cinco antígenos protetores. A vacina tetravalente DTP/HBV será produzida pelo Instituto Butantan e a vacina conjugada Hib por Bio-Manguinhos, que terá também a responsabilidade de prepará-las em apresentação única.

No início do mandato da atual presidência da Fundação Oswaldo Cruz (2002), foi criado o Programa de Desenvolvimento Tecnológico de Insumos para Saúde (PDTIS), definindo a área de vacinas como a primeira a ser desenvolvida. Tendo como plataforma tecnologias recombinantes, o PDTIS vem apoiando financeiramente mais de quatro dezenas de importantes projetos que poderăo resultar em novas tecnologias e produtos para Bio-Manguinhos produzir. Além disso, está em fase final de concepção o Centro de Desenvolvimento Tecnológico em Saúde (CDTS), que deverá incorporar as tecnologias mais avançadas para desenvolver novos produtos para a área de saúde.

A multiplicidade e a complexidade envolvendo as atividades de inovação tecnológica de vacinas foram objetos de uma publicação específica (Homma et al., 2003), que chama atenção para a necessidade de o governo federal estabelecer um programa específico para essas ações.

Bio-Manguinhos está também envolvido nas atividades de desenvolvimento e produção de reativos para diagnóstico laboratorial de doenças importantes em saúde pública.

\section{O COMPLEXO TECNOLÓGICO DE VACINAS DE BIO-MANGUINHOS}

Nesta seção, são enfocados aspectos relacionados à înfra-estrutura laboratorial e de apoio, que atendem às normas de Boas Práticas de Fabricação (BPF) (WHO, 1992; Brasil, 2003), economia de escala, racionalidade operacional e de manutenção técnica, entre outros, que compõem o atual Complexo Tecnológico de Vacinas (CTV) de Bio-Manguinhos. 
Em meados da década de 80 , com a crise de suprimento de soros antiofídicos e antitóxicos e de vacinas, gerada pela saída abrupta de uma multinacional do mercado brasileiro, o MS decidiu investir na modernização dos laboratórios públicos produtores de imunobiológicos. Criou, assim, em 1985, o Programa de Auto-Suficiência Nacional de Imunobiológicos (PASNI) (Benchimol, 2001b), o que permitiu dotar o país de um parque produtor moderno e capacitado para atender às demandas de imunobiológicos essenciais aos programas de saúde pública.

Nessa oportunidade, Bio-Manguinhos desenvolveu um Plano Diretor de Desenvolvimento Institucional, integrando os laboratórios de produção com a infra-estrutura de produção industrial, como energia, água gelada e do tipo injetável, vapor comum e limpo, ar comprimido, ar condicionado, de tal forma a racionalizar as operações produtivas e facilitar as atividades operacionais e de manutenção técnica, formando então o Complexo Tecnológico de Vacinas (CTV). Os investimentos iniciais do PASNI foram direcionados para a modernização do atual Centro de Criação de Animais de Laboratório (Cecal) e, em seguida, para a construção de uma parte do CTV, o Centro de Processamento Final (CPFI) e do Centro de Produção de Antígenos Bacterianos (CPAB). Com construção iniciada em 1991, o CPFI teve suas atividades operacionais iniciadas em 1996.

No CPFI $\left(5.250 \mathrm{~m}^{2}\right)$ são realizadas as atividades de formulação, envase e liofilização, produção de diluentes, envase de vacinas líquidas, rotulagem, empacotamento e controle visual do produto final. A central de liofilização é dotada de três liofilizadores industriais (350 kg de gelo cada), capaz de liofilizar em cada operação 77 mil frascos de apresentação de cinco ou 50 doses (por exemplo, febre amarela). Para atividades de formulação, envase e liofilizaçăo, dispõe de salas biolimpas, cumprindo com as normas de BPF. Com isso, o CPFI se constitui no maior centro de liofilização de vacinas para uso humano da América Latina.

O CPAB $\left(2.400 \mathrm{~m}^{2}\right)$ teve alterado o seu escopo inicial e foi adaptado às novas finalidades. O início de operação ocorreu no segundo semestre de 2004 , com a nacionalização de todo o ciclo de produção da vacina conjugada contra Haemophillus influenzae tipo B (Hib).

o Centro de Produção de Antígenos Virais (CPAV) está em construção, com previsão de conclusão das obras e instalações até o final de 2005 , seguida do processo de validaçăo, que deverá ser concluído em meados de 2006. O CPAV (2.500 m2) foi planejado para atender às normas de BPF e de biossegurança. As vacinas virais produzidas em cultura de tecidos (sarampo, caxumba, rubéola, varicela, hepatite $A$ e outras) serão produzidas neste centro, que tem capacidade nominal para 100 milhões de doses.

Uma outra novidade denominada Centro de Controle e Garantia da Qualidade (CCGQ), completamente independente da área de produção, abrigará essas atividades essenciais, incluindo o laboratório de experimentação animal. Atualmente, tais atividades são dêsenvolvidas em laboratórios dispersos, sem condições adequadas, sendo difícil melhorar a infra-estrutura ou modernizar as instalações existentes.

Para complementar o CTV, Bio-Manguinhos está desenvolvendo o projeto da planta de protótipos $\left(6.500 \mathrm{~m}^{2}\right)$, que apoiará as atividades de desenvolvimento tecnológico 
- produção de lotes experimentais de vacina para uso clínico -, as quais exigem instalaçōes laboratoriais que cumpram as normas de BPF. Integrando esta planta, serão organizados os laboratórios de produção de reativos para diagnóstico laboratorial e de biofármacos. Estas duas últimas atividades terăo apoio dos laboratórios da planta de protótipos para produção de biomassas, que serão utilizadas para etapas subseqüentes de downstream, direcionadas para produção de reativos de diagnóstico laboratorial ou para biofármacos.

É importante ressaltar que um dos grandes entraves existentes na cadeia da inovação tecnológica de vacinas é a inexistência de uma planta-piloto no país, cumprindo com as normas de BPF, para estudar parâmetros de escalonamento de produção, formulação e produção de lotes experimentais de vacinas para uso clínico.

\section{MUDANCุASESTRUTURAIS NA INDÚSTRIA E POSICIONAMENTOESTRATÉGICO ATUAL}

A necessidade de mudanças dos paradigmas dos laboratórios públicos produtores de vacinas existentes na América Latina já tinha sido apontada anteriormente (Homma, Di Fabio \& De Quadros, 1998). Nesta seção, as novas bases do paradigma da indústria de vacinas são analisadas, assim como seu impacto sobre Bio-Manguinhos. São apresentadas as principais ações empreendidas pelo Instituto para enfrentar esses desafios. A fim de facilitar o entendimento e visualização da complexidade dessas atividades, esses itens estão estruturados de modo a representar as principais áreas organizacionais atuais de Bio-Manguinhos.

Globalmente, os anos recentes são marcados pelo advento de novas bases paradigmáticas da indústria de vacinas, que inclui novas abordagens organizacionais e estruturais, como as fusões e aquisições de empresas e tecnologias, aumentando o oligopólio do setor. Além disso, são enormes os desafios representados pelas inovações tecnológicas contínuas e rápidas, resultantes de grandes investimentos em tecnologia que vêm sendo realizados pelos países desenvolvidos e pelos grandes laboratórios multinacionais. $O$ poder dessas multinacionais é medido mundialmente pelo domínio tecnológico, lançamento anual de produtos de alto valor agregado e a conquista de novos mercados.

Os laboratórios públicos brasileiros produtores de vacinas, diante dessas inovações, também buscam outros caminhos para enfrentar o novo cenário mundial e têm nessa empreitada a parceria do governo federal, que considera estratégico dotar o país com capacitação tecnológica para atender as necessidades básicas no campo da saúde pública. Todavia, o panorama atual é muito mais competitivo: as grandes multinacionais oferecem produtos tecnologicamente mais avançados e de maior qualidade; a sociedade exerce pressão mercadológica, demandando novos produtos. Assim, torna-se cada vez mais difícil o desafio de dar continuidade às atividades produtivas desenvolvidas pelos laboratórios brasileiros nas bases atuais.

A busca pelo equilíbrio econômico da produção depara muitas vezes com contradições, pois, de um lado, para conseguir preços competitivos é necessário ter produção em 
escala, o que diminui os altos custos fixos da atividade; de outro lado, a busca incessante pela confiabilidade do produto aumenta os investimentos em garantia de qualidade, incluindo o cumprimento das normas de BPF, o que aumenta o custo de produção.

Portanto, como os paradigmas institucionais vêm se tornando mais exigentes, é necessário profissionalizar as atividades de planejamento estratégico e de gestão de todos os recursos e funçōes relacionados: recursos humanos, produção, qualidade de produtos, administração, desenvolvimento tecnológico, engenharia e manutenção.

Bio-Manguinhos, nos últimos dez anos, vem dedicando um espaço específico para atualizar, de forma permanente e contínua, a estratégia institucional, a fim de enfrentar os novos desafios tecnológicos, econômicos e mercadológicos gerados globalmente. Limitado pelas legislaçōes específicas do setor público (como a Lei 8.666) e desenvolvendo atividades de produção industrial em um setor fortemente pressionado pela competitividade tecnológica e econômica, tornou-se uma necessidade imperiosa fortalecer não somente a capacidade tecnológica, mas também o planejamento estratégico e as formas de gestāo institucional.

Após busca e discussão, novos instrumentos de planejamento estratégico e đe gestão adaptados e aplicáveis ao Bio-Manguinhos foram introduzidos, os quais visam a racionalizar as diferentes atividades, focalizar e dar prioridade aos temas centrais, fortalecer as atividades mais vulneráveis, aumentar a produtividade e confiabilidade das atividades desenvolvidas pela instituição.

Com base nesta abordagem, nos últimos anos Bio-Manguinhos vem implementando alguns instrumentos contemporâneos de gestão estratégica e operacional, descritos a seguir:

\section{Planejamento estratégico institucional}

A Assessoria de Planejamento, criada em 1994, vinculada diretamente ao diretor do Instituto, tinha como propósito, a curto prazo, lançar as bases do pensamento estratégico como ferramenta de gestão. Foi dada ênfase à articulação entre as atividades orçamentárias, execução, avaliação e planejamento de médio e longo prazo. O modelo clássico de planejamento implantado inicialmente era difícil de ser executado, pois BioManguinhos dependia totalmente de repasses de recursos do orçamento federal, compartilhando do orçamento de toda Fiocruz; além disso, no processo de gestão participativa tinha que lutar pela fatia correspondente com outras unidades técnicas da Fiocruz. Acrescentam-se outras dificuldades de ordem administrativa, pois, sendo a administração centralizada, havia prioridades de demanda que nem sempre contemplavam as necessidades de Bio-Manguinhos. A arrecadação própria como resultado da disponibilização de vacinas ao MS era direcionada pela Fiocruz ao financiamento de programas institucionais de todas as unidades da instituição.

Uma análise da evolução na gestão estratégica em Bio-Manguinhos apontou para a necessidade de implementação de um Planejamento Estratégico Institucional. Vale notar que, apesar de, na prática, as açōes estratégicas possuírem aspectos não somente já deliberados, mas também emergentes, um planejamento formal, amplamente discutido, 
com a participaçăo de todos os atores, vem trazendo benefícios diversos para a instituição, aliás, procedimento adotado nas grandes corporações industriais e tecnológicas.

Bio-Manguinhos apoiou-se em metodologias consagradas para a institucionalização do pensamento estratégico, como o SWOT, ferramenta de análise do contexto interno e externo; o modelo das cinco forças de Porter (Porter, 1985), para se perceber melhor a inserção do Instituto no setor, e, mais recentemente, um modelo que privilegia a implementação, avaliação e acompanhamento de estratégias, o Balanced Scorecard, de Kaplan (Kaplan, 1996).

o planejamento de Bio-Manguinhos é, então, construído coletivamente por todos os departamentos e, antes de ser encaminhado à presidência da Fiocruz, é chancelado pelo Conselho Superior de Administração (CSA). As atividades desenvolvem-se em várias instâncias, que permitem a participação ativa de todos os gerentes na discussão e definição de prioridades e estratégias institucionais para o atendimento dos compromissos assumidos com o MS, bem como a execução dos projetos de desenvolvimento tecnológico e institucional.

O estatuto da Fiocruz contempla o Congresso Interno como órgão máximo de deliberação e tem a participação de representantes eleitos de todas unidades técnicas da Fundação. Neste fórum, as suas principais linhas estratégicas e políticas são discutidas e traçadas de forma coletiva e participativa, o que vem permitindo amalgamar as várias tendências institucionais, fortalecendo o órgão em torno de alguns princípios básicos, cujo norte é o sistema público fortalecido.

Outros referenciais utilizados, não menos relevantes, são o Programa Plurianual da Fiocruz, proposto pela presidência da instituição e aprovado pelo conselho deliberativo, além dos planos formais de ação do governo federal para a área de saúde, como o Plano Plurianual.

A visão de futuro de Bio-Manguinhos é, portanto, "ter certificações nacionais e internacionais de todos os produtos, desenvolvidos de forma autóctone e por meio de parcerias, um corpo de pessoal permanentemente qualificado, comprometido e motivado"; e está relacionada com a sua missão, definida como "contribuir para a melhoria dos padrôes de saúde pública brasileira, através da pesquisa tecnológica e da produção de imunobiológicos capazes de atender à demanda gerada pelo quadro epidemiológico do país" (Brasil, 2001). Essas duas referências foram estabelecidas junto com a comunidade de Bio-Manguinhos e mantêm o norte institucional.

As linhas gerais da metodologia Balanced Scorecard são utilizadas como base para garantir que as estratégias sejam traduzidas em metas que direcionem o comportamento e o desempenho. Os objetivos estratégicos de Bio-Manguinhos são classificados à luz de quatro perspectivas, a saber: cliente; responsabilidade financeira; processos internos; aprendizado, conhecimento e inovação.

O mapa estratégico (Figura 1), que apresenta as macroestratégias institucionais, é o referencial para o alinhamento de toda a instituiçáo. Para cada perspectiva foram defini- 
dos temas ou palavras-chave, totalizando 12 , que reúnem as questōes estratégicas centrais; também em cada perspectiva, foram desenvolvidos indicadores específicos, que são utilizados como instrumentos de avaliação, medição do desempenho e medição dos progressos das estratégias da Instituição.

- cliente - os temas se referem à garantia da oferta de produtos adequados às necessidades da população, com qualidade, regularidade e melhor relação preço/benefício para o cliente; contempla 11 indicadores;

- responsabilidade financeira - está relacionada à produtividade e às estratégias de ampliação de receita para garantir a auto-sustentabilidade institucional; contempla cinco indicadores;

- processos internos - aponta as estratégias para alcançar a excelência operacional e indica a infra-estrutura e tecnologias estratégicas necessárias; contempla 21 indicadores;

- aprendizado, crescimento e inovação - relaciona-se à motivação dos funcionários, à utilização das habilidades e conhecimentos estratégicos de cađa um, necessários para o alcance da visão; contempla nove indicadores.

A freqüência - trimestral, semestral ou anualmente - com que ocorre a avaliação de cada indicador varia de acordo com a natureza do trabalho desenvolvido. No Anexo 2 , são apresentados os indicadores para cada perspectiva, a periodicidade e a fórmula adotada para avaliação.

O trabalho de desdobramento das estratégias foi complementado com um outro instrumento gerencial, organizado e implementado em 2003, para manter alta a motivação dos funcionários: o Programa de Produtividade e Qualidade (Proqual). Este programa preconiza que se alcancem as metas institucionais, compostas de metas estratégicas, globais e departamentais, as quais são desenvolvidas tendo sempre em vista a superação das perspectivas e inđicadores estabelecidos no mapa estratégico. como a meta global e as metas departamentais do Proqual são interdependentes, o interesse para que elas sejam superadas é geral, contando com a contribuição de todos.

Dessa forma, o Proqual é uma ferramenta motivacional, que norteia a premiação dos funcionários para atingir a superação das metas. Em 2003, foram acompanhados 28 indicadores estratégicos, 30 iniciativas globais e 78 departamentais. Os resultados foram considerados altamente satisfatórios para a instituição, que alcançou todas as metas institucionais e departamentais e um clima de motivação dos funcionários altamente positivo.

Bio-Manguinhos também busca se inserir no contexto das políticas governamentais na área de gestăo pública e vem participando do Programa de Qualidade de Serviço Público (PQSP), desde o ano de 2003, quando obteve a classificação C, status ainda inicial. Esse programa de gestão pública tem foco em resultados e é orientado para o cidadão. Procura acompanhar o estado da arte da gestão com o pensamento contemporâneo sobre excelência em gestão, composto por sete critérios: liderança; estratégias e planos; clientes; informação; pessoas; processos; resultados. 
Figura1 - Mapa estratégico de Bio-Manguinhos
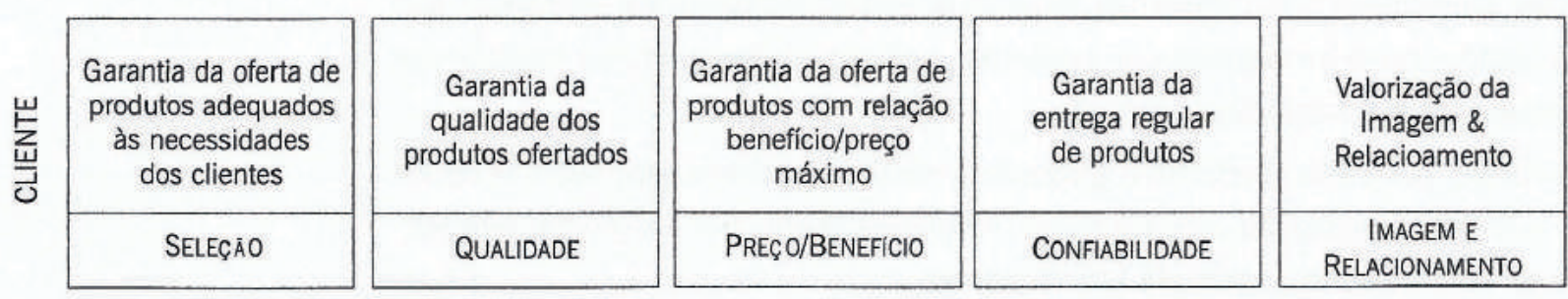

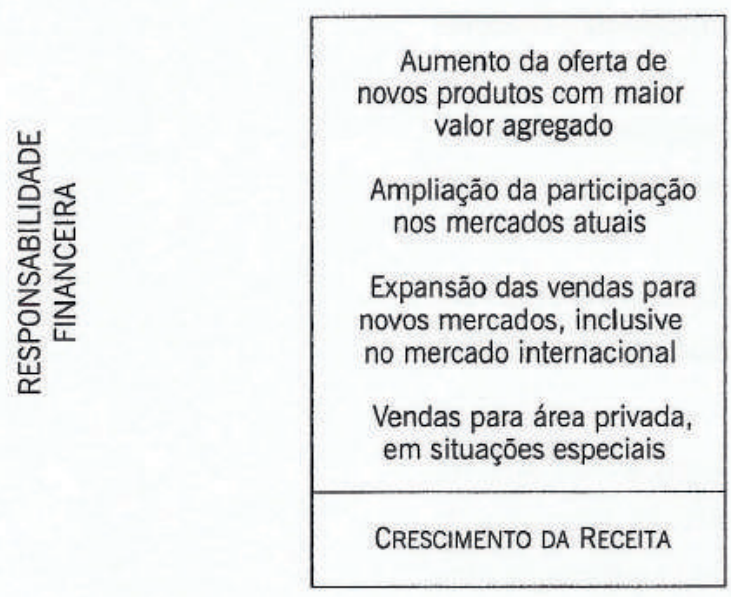

\begin{tabular}{|c|}
\hline $\begin{array}{c}\text { Otimização da utilização } \\
\text { dos ativos }\end{array}$ \\
$\begin{array}{c}\text { Melhoria da estrutura } \\
\text { de custos }\end{array}$ \\
Diminuição de erdícios \\
\hline PRODUTIVIDADE \\
\hline
\end{tabular}

\begin{tabular}{|c|c|}
\hline $\begin{array}{l}\text { Garantia da } \\
\text { qualidade e } \\
\text { eficácia das } \\
\text { operaçōes }\end{array}$ & $\begin{array}{c}\text { Excelência } \\
\text { na gestão } \\
\text { da demanda }\end{array}$ \\
\hline $\begin{array}{c}\text { Garantia da } \\
\text { segurança e } \\
\text { saúde (pessoal e } \\
\text { meio ambiente) }\end{array}$ & $\begin{array}{c}\text { Gestão da } \\
\text { cadeia de } \\
\text { fornecimento }\end{array}$ \\
\hline \multicolumn{2}{|c|}{ EXCELEENCIA OPERACIONAL } \\
\hline
\end{tabular}

Ampliação e otimização
da capacidade de produção
existente
Ampliação das etapa
de produção
Melhoria da
instalaçōes existentes
Expansão da produção
(novos produtos)

\begin{tabular}{|c|}
\hline Desenvolvimento tecnológico \\
Transferência de tecnologia \\
Alianças estratégicas \\
Infra-estrutura tecnológica \\
Tecnologia proprietária \\
\hline TECNOLOGIA ESTRATÉGICA \\
\hline
\end{tabular}

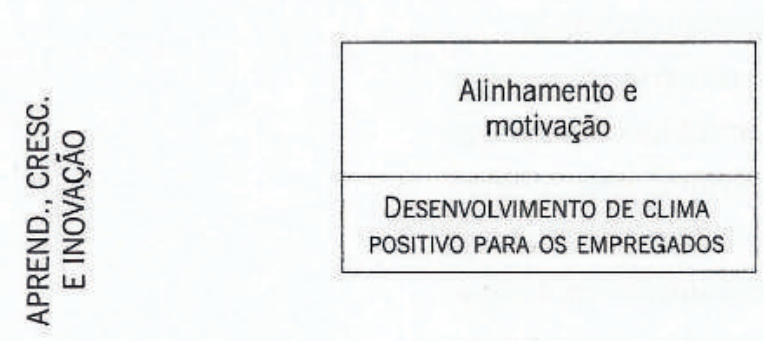

\begin{tabular}{c} 
Habilidades e \\
conhecimentos estratégicos \\
Liderança \\
\hline COMPETÊNCIAS ESTRATÉGICAS \\
\hline
\end{tabular}


Por ser importante para a imagem da instituição, foi definido como meta o reconhecimento de excelência de gestão pública até 2006 , e, para a consecução desse objetivo, é necessário buscar a integração e motivação institucional de alto nível.

\section{Gestão administrativa}

Dinâmica dos modelos de gestão administrativa adotados em Bio-Manguinhos, com especial ênfase na perspectivas de responsabilidade financeira e processos internos

Os objetivos institucionais e especialmente a natureza dos trabalhos voltados para atividades de desenvolvimento tecnológico e produção industrial vêm determinando uma preocupação contínua de se estruturar e conferir às funções administrativas um espaço próprio especializado que realize uma gestão adequada das atividades finalísticas. BioManguinhos, ao final dos anos 80 , já se apresentava como a unidade técnica mais descentralizada da Fiocruz, autônoma nas atividades de compras, finanças e administração de pessoal. Este avanço rumo à autonomia das atividades administrativas, no entanto, ocorreu marcado por rígidos limites, por um lado, em virtude do contexto político-institucional da Fiocruz, que privilegiava a homogeneidade dos arranjos estruturais e administrativos de suas unidades técnico-científicas, independentemente das suas peculiaridades e requerimentos; por outro, fortemente regulamentado pelas regras gerais do serviço público quanto a compras, finanças e pessoal. Mesmo premido entre esses dois marcos, o Instituto consolidou sua estrutura administrativa, base de sustentação que se verificou mais tarde como fundamental ao crescimento que apresentaria no futuro.

Em meados da década de 90 , por causa de uma grave crise institucional, motivada pela queda abrupta de seus indicadores de qualidade e produtividade, e diante do desafio de implementar as operações industriais do Centro de Processamento Final de Imunobiológicos (CPFI), Bio-Manguinhos deu partida a um projeto de desenvolvimento institucional, focalizando questões estruturais, organizativas e de gestăo administrativa. Buscou analisar experiências bem-sucedidas na produção pública de vacinas no contexto mundial e, a partir de um projeto aprovado pelo CNPq e com apoio de consultores da Opas/OMS, profissionais de Bio-Manguinhos visitaram laboratórios públicos produtores de vacinas, localizados na Indonésia, África do Sul, México e EUA. Esses laboratórios foram selecionados por serem considerados de referência na produção pública de vacinas e, nessa pesquisa, foram coletados importantes subsídios para o desenho de um modelo organizacional adequado às atividades de Bio-Manguinhos.

O projeto foi levado adiante alguns anos depois, tendo importantes apoios políticos e técnicos de outros setores da Fundação, que permitiram o aprofundamento e justificação do modelo, culminando, em 1997, com a aprovação, pelo Conselho Deliberativo đa Fiocruz, de um novo modelo de gestão para Bio-Manguinhos. O modelo estava baseado em quatro pilares:

- Bio-Manguinhos deveria atingir a situaçăo de auto-sustentabilidade econômica em cinco anos; a partir de 1998, as atividades de produção não seriam financiadas 
por intermédio dos recursos do tesouro, retendo, em contrapartida, a totalidade dos recursos provenientes da entrega de vacinas e reativos para diagnóstico ao MS e outros programas de saúde.

- As relações entre a Fiocruz e Bio-Manguinhos seriam reguladas por compromissos anuais de gestão, baseados no estabelecimento de responsabilidades mútuas, indicadores estratégicos e operacionais que permitissem à Fiocruz acompanhar o desempenho e as atividades centrais do Instituto.

- O diretor de Bio-Manguinhos não seria mais eleito pelos funcionários, conforme regra geral para as unidades técnicas da Fiocruz, mas sim recrutado no mercado e selecionado pelo presidente da Fiocruz segundo critérios estabelecidos pelo conselho Superior de Administração da Unidade.

- Seria criado o Conselho Superior de Administração (CSA), órgão responsável pelas deliberações estratégicas e políticas do Instituto.

Embora esse novo modelo tenha sido desenhado para ser implantado a médio prazo, todos os pontos previstos foram implementados, assim como as metas qualitativas e quantitativas, que foram alcançadas antes do prazo previsto. Hoje, as atividades de produção são auto-sustentáveis e Bio-Manguinhos ainda retorna recursos à Fiocruz em patamares definidos no Termo Anual de Compromisso de Gestáo.

O Instituto apresentou, na última década, um impressionante crescimento, sejam quais forem os critérios adotados. As atividades laboratoriais, predominantes nos primórdios do Instituto, não se comparam às complexas atividades industriais de BioManguinhos. Essas atividades, inseridas em contexto de intensa e rápida evolução tecnológica, requerem outro patamar e mecanismos de gestão administrativa.

Em 2002, dando curso ao processo de reconversão institucional iniciado com a implantação do novo modelo de gestão e que ainda hoje faz parte da sua agenda, BioManguinhos reformou a sua estrutura organizacional, buscando maior funcionalidade e distribuição de responsabilidades, num esforço de adequação aos novos requisitos e desafios de manter-se como instituição pública, com finalidades igualmente públicas, cujas atividades, no entanto, devem se dar em níveis de produtividade, excelência econômica e operativa próprios do setor privado. Além disso, o orçamento da instituição é estruturado em projetos e atividades, em nível de departamento e setorial, correlacionados aos temas e objetivos estratégicos institucionais.

A nova estrutura organizacional da unidade contempla quatro áreas: produção; desenvolvimento tecnológico; qualidade e gestão.

A formulação política, administrativa e tecnológica da unidade é realizada pelo Diretor, executivo principal do Instituto, que é auxiliado em suas funções pelas assessorias de Planejamento, Gerência de Projetos, Clínica e Esstudos Clínicos, Acompanhamento e Avaliação. Sob sua subordinação, opera a vice-diretoria de gestão e mercado, responsável pelas áreas de recursos humanos, finanças, compras, engenharia, manutenção e mercado, e a vice-diretoria de produção, responsável pelas atividades de produção da unidade. 


\section{Gestão de recursos humanos com ênfase na perspectiva aprendizado, crescimento e inovação}

A gestão dos recursos humanos é, nesta nova fase, fator crítico das atividades de Bio-Manguinhos. Essa necessidade, pela excelência na administração de seus recursos, amplia a já existente tensão entre os requerimentos de uma indústria, premida pela necessidade constante de inovação e desenvolvimento de novos produtos, e os marcos regulatórios da administração pública. Para contornar esse obstáculo, o Instituto vem, proativamente, buscando alternativas, algumas heterodoxas, como terceirização de pessoal, para operar o maior complexo industrial de vacinas da América Latina dentro dos parâmetros de qualidade e produtividade colocados pelo setor.

Bio-Manguinhos tem hoje em seu quadro muito menos funcionários do sistema Regime Jurídico Único (RJU) do que possuía há dez anos, embora tenha aumentado sua produção e faturamento mais de dez vezes nesse mesmo período. Essa lacuna de profissionais e funcionários foi preenchida à medida das necessidades de crescimento e, atualmente, somente um terço de seu efetivo é composto por funcionários públicos; os demais são funcionários terceirizados ou por contratos de serviços.

A complexidade tecnológica e de gestão de Bio-Manguinhos vem aumentando a necessidade de se buscarem recursos humanos especializados, mas, nesta área específica, são inexistentes, pois apenas o Instituto Butantan e Bio-Manguinhos têm produção de vacinas para uso humano em escala industrial. Por esse motivo, vêm-se investindo crescentes volumes de recursos na formação e atualização dos recursos humanos, sem diferenciação ou discriminação de vínculos, reconhecendo-se que uma melhor qualificação de pessoal é de fundamental importância para o futuro institucional.

Foi estruturado e organizado em 2002 , dentro da própria unidade, um curso de Mestrado Profissional em Tecnologia de Imunobiológicos, em colaboração com o Instituto Oswaldo Cruz; curso este já aprovado pela Capes. Além disso, vários profissionais estão cursando especialização, mestrado e doutorado em suas áreas de atuação. No Gráfico 1, é apresentada a situação atual de qualificação dos funcionários de Bio-Manguinhos, e pode-se observar a presença de um significativo número de profissionais com cursos de mestrado ( $64-11 \%$ da força de trabalho, entre concluídos e por concluir), doutorado ( $22-4 \%$ da força de trabalho, entre os concluídos e por concluir) e pósdoutorado (4 profissionais). Em se tratando de uma instituição majoritariamente voltada para atividade fabril, a presença de um contingente enorme de profissionais com pósgraduação confere maior segurança e confiabilidade nas atividades desenvolvidas atualmente e no futuro institucional.

A política de renovação de pessoal é atendida por um programa de sucessão gerencial que alcança todos os níveis de supervisão e gerência e tem o objetivo principal đe evitar descontinuidade das atividades causada por saída de profissionais experimentados. Outro programa destinado à formaçăo de técnicos e profissionais multifuncionais tem como objetivo desenvolver o potencial existente em cada funcionário em áreas distintas, permitindo fortalecer a base de conhecimentos de todo o quadro de pessoal. 
Gráfico 1 - Perfil educacional dos funcionários de Bio-Manguinhos*

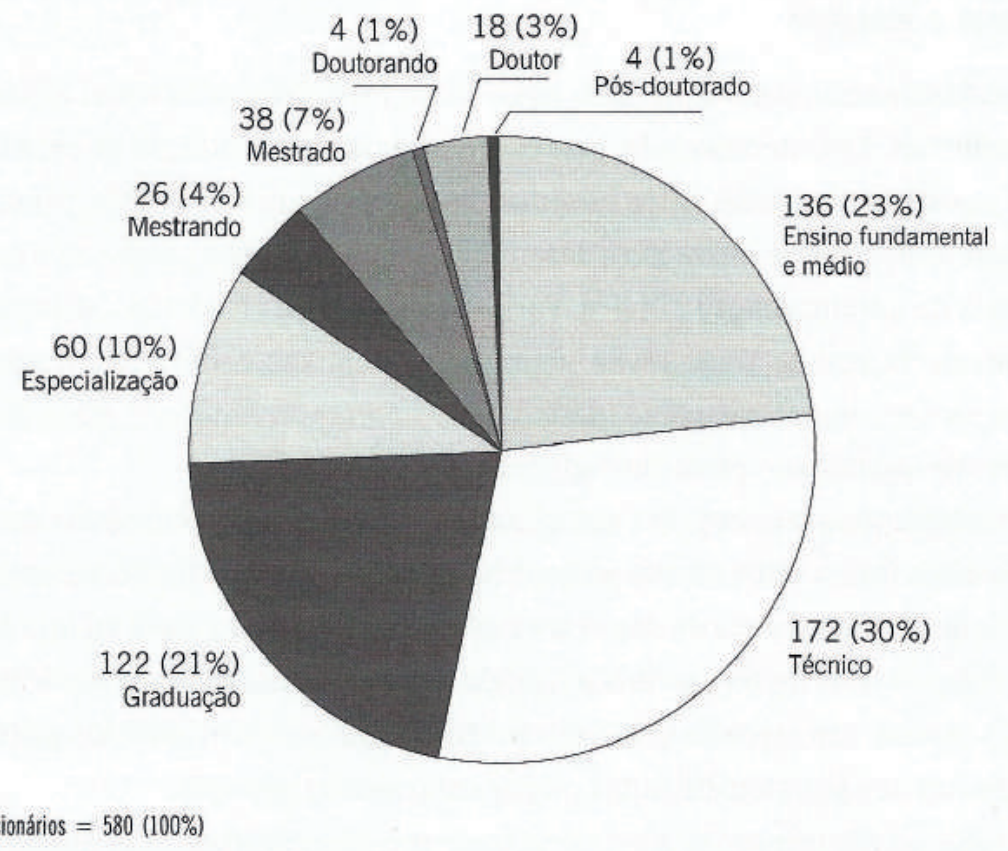

* Total de funcionários $=580(100 \%)$

Gestão de compras, engenharia e manutenção, com ênfase na perspectiva processos internos

Nas atividades de compras, nacionais e internacionais, não são poucas as dificuldades e inflexibilidades impostas pela Lei 8.666. De toda a sorte, muito tem sido feito no desenvolvimento de novos fornecedores e, mais recentemente, têm-se dirigido recursos e prioridade para a certificação de fornecedores. A redução de itens de estoque e mudança na concepção de almoxarifado, de área de estocagem para área de distribuição, são prioridades atuais e vêm sendo gradativamente implementadas, realizando-se a sintonia fina entre as atividades de Planejamento e Controle da Produção (PCP) e suprimentos. Essa estratégia, no entanto, precisa ser sustentada por um fluxo de caixa firme que permita boas negociações, de preços, qualidade e prazos, baseadas na relação de confiança entre cliente e fornecedor.

Um dos mais agudos problemas enfrentados por Bio-Manguinhos se deu na passagem da condição de laboratório para indústria. Estruturar um departamento de engenharia e manutenção industrial se colocava como uma exigência. Com apenas três engenheiros em seus quadros, o Instituto fomentou e apoiou a formação de uma cooperativa de engenheiros, muitos deles prestadores de serviços, envolvidos com o projeto industrial de Bio-Manguinhos desde a sua concepçăo. Hoje, a cooperativa é a principal fornecedora de serviços nesse campo para a unidade.

Gestão de mercado com ênfase na perspectiva clientes

Em 1997 foi criada uma área de comercialização, incumbida de restabelecer boas relações com os principais clientes, maculadas, principalmente, pela crise de confiabilidade provocada pelos problemas que se sucederam nos inícios dos anos 90 . Com a 
certificação de Bio-Manguinhos, em 1999, pela OMS, como produtor e fornecedor internacional da vacina contra a febre amarela, essa unidade comercial foi ampliada e, a partir de então, vem cumprindo importante papel na consolidação da posição de BioManguinhos como principal fornecedor dessa vacina para a Opas/OMS, Unicef e OMS.

\section{Gestão de projetos biotecnológicos com ênfase na perspectiva processos internos}

As atividades de desenvolvimento tecnológico sempre ocuparam espaço importante em Bio-Manguinhos, e essa é uma das razões da alta qualidade das vacinas produzidas no Instituto. Inúmeros projetos de inovação incremental forneceram informações e dados para melhoria dos processos de produção, termoestabilidade das vacinas, metodologias de controle de qualidade, cuja lista é apresentada no Anexo 1.

Três desses projetos incrementais resultaram em grande impacto e extrapolaram a instituição:

- a nova formulação potenciada do tipo 3, da vacina contra a poliomielite, que foi adotada pelo PNI e serviu para conseguir a erradicação dessa virose do país em 1987; posteriormente foi adotada pela Opas/OMS para toda a América e pela OMS para todos os países do mundo;

- melhoria da termoestabilidade da vacina contra o sarampo (cepa Biken 70), que foi utilizada largamente no país, contribuindo para erradicar a virose;

- melhoria dos processos de produção e desenvolvimento de apresentação em menor dose da vacina contra a febre amarela, atividade que recebeu a certificação de BPF da Agência Nacional de Vigilância Sanitária (Anvisa) e da OMS, em 2001; desde então, Bio-Manguinhos forneceu essa vacina para mais de quarenta países.

Com a finalidade de conseguir maior efetividade e melhores resultados dos investimentos realizados em projetos de inovação tecnológica, Bio-Manguinhos decidiu aperfeiçoar os processos internos de inovação tecnológica e organizou um grupo de gestão de projetos biotecnológicos. Atualmente, todas as atividades de inovação tecnológica de produtos, desenvolvimento de novas metodologias de produçăo e controle de qualidade, os estudos préclínicos e de campo, são organizadas em forma de projetos, com detalhamento de todas as atividades, cronogramas e orçamentos, e que deve estar contemplado no Planejamento Estratégico. Desta forma, a expectativa é permitir um melhor acompanhamento, monitoração, avaliação de diferentes projetos em desenvolvimento em Bio-Manguinhos.

Para que Bio-Manguinhos atinja um padrão de competitividade tecnológica e econômica internacional, faz-se necessária a superação da expectativa dos clientes, dentro dos prazos definidos, dos padrōes de qualidade e usando os recursos de forma otimizada. Principalmente por estar inserido em uma área eminentemente tecnológica, a sobrevivência de Bio-Manguinhos depende de sua agilidade e competência para alcançar melhores resultados. Nessa área, a garantia do sucesso não está apenas em seguir à risca as modernas teorias de administração, mas também na habilidade e versatilidade para gerenciar temas pouco difundidos.

O gerenciamento de projetos pode identificar e controlar as limitações inerentes a cada atividade com vistas a proporcionar um foco em prioridades e objetivos para que a 
comunicação, a coordenação e o controle sejam eficientes. Pode, ainda, fortalecer a atividade de planejamento, promover uma melhor administração de mudanças e atuar nos processos decisórios. Garante, portanto, um maior número de projetos bem-sucedidos em virtude da melhoria no desempenho, do aumento da eficiência e da eficácia.

Em Bio-Manguinhos, os projetos estão institucionalizados de acordo com os objetivos estratégicos e os temas definidos em cada perspectiva do mapa estratégico (Figura 1) da unidade, destacando-se o tema tecnologia estratégica, que enfoca desenvolvimento tecnológico, transferência de tecnologia, alianças estratégicas, infra-estrutura tecnológica e tecnologia proprietária. Além disso, os projetos são selecionados conforme os seguintes critérios: existência de demanda por parte do MS; estágio do desenvolvimento tecnológico; existência da capacidade e projeção tecnológica para chegar ao produto; estudo da viabilidade tecnológica (inclusive para utilização) e econômica; capacidade de gerenciamento e financiamento.

Esses projetos estão estruturados de maneira a atender prioritariamente o desenvolvimento de vacinas, reativos para diagnóstico e biofármacos, alinhados com as demandas e programas do MS, referentes a doenças de alto impacto em saúde pública como malária, leishmaniose, dengue, Aids e biofármacos de interesse.

Os projetos de inovação tecnológica são organizados levando-se em conta o respectivo estágio de desenvolvimento, possibilidade de alcance das metas estabelecidas, sendo, nessa perspectiva, considerada fundamental a busca de resultados de produtos. Os projetos organizam-se em quatro fases - preparação, estruturação, desenvolvimento e encerramento-, determinadas a partir da cadeia de definições de atividades que originam a pesquisa, e a finalizam em um produto para o mercado. As fases exigem um gerenciamento específico, dentro de um controle institucional, que objetiva a conclusão pragmática do projeto.

Essa administração é feita pela Gerência de Projetos, constituída por uma equipe que utiliza os conceitos básicos de gerenciamento do Project Management Institute (PMBOK Guide, 2004), com o objetivo de planejar, acompanhar, apoiar e avaliar os projetos, com ampla participação de todos os envolvidos, de acordo com as seguintes atividades principais: a) seleção dos projetos prioritários a partir de critérios pré-definidos; b) registro institucional dos projetos; c) elaboração do planejamento dos projetos, incluindo cronograma físico-financeiro; d) acompanhamento dos projetos mediante análises periódicas de viabilidade técnico-econômica, identificando os pontos críticos e garantindo o desenvolvimento dentro da regulamentação específica para cada produto; e) elaboração de dossiês tecnológicos padronizados visando ao registro dos produtos; f) gestão de parcerias institucionais e empresariais; g) captação de recursos externos para financiamento de projetos prioritários.

No Anexo 3, estão listados os principais projetos de inovação tecnológica, na área de vacinas, conduzidos e coordenados pelo grupo de Gestão de Projetos.

\section{ENTREGA DE VACINAS AO PNI}

A entrega de vacinas expressa o resultado numérico final da atividade produtiva. Do início de uma produção até a entrega ao cliente final, que no caso de Bio-Manguinhos éo PNI, leva até seis meses. A série histórica de entrega de vacinas dos últimos 17 anos - 1987 
a 2003 - aponta as variações dos quantitativos de entrega de vacinas por Bio-Manguinhos ao MS ocorridas nesse período e explicita as causas dessas variações (Tabela 1):

- As produções das vacinas contra cólera e febre tifóide foram interrompidas respectivamente em 1992 e 1993, por solicitação do PNI.

- As vacinas contra a meningite meningocócica, sorogrupos A e C. A produção destas vacinas, com os dois sorogrupos, teve início em 1976 e se estendeu até 1990. A partir de 1990 até 1996, foi produzido apenas o sorogrupo C, pela ausência de sorogrupo A no país. Em 1991, foram observadas algumas reações adversas compatíveis com a vacinação na região de Campinas e a produção dessa vacina foi temporariamente suspensa em 1997, sendo retomada em 2000 , com produção da vacina com sorogrupos A e C.

- A análise dos números totais anuais mostra que, em alguns anos $(1988,1992,1996)$, houve menor entrega de vacinas, devido a quebras de produção.

- A vacina contra o sarampo em apresentação de 20 doses foi substituída pela apresentação de cinco doses em 1991. Houve problemas de produção em 1992 e quase nenhuma produção em 1993, também decorrente de quebras de produção.

- O laboratório da vacina contra poliomielite teve que interromper suas atividades de 1990 a 1993, por causa de um incêndio que destruiu as suas instalações. Retomou suas atividades em 1997, normalizando suas operações, atingindo um recorde de produção em 2002, com mais de 64 milhões de doses, representando mais do que o dobro da sua capacidade nominal de produção.

- A vacina contra a febre amarela em apresentação de 50 doses foi, a partir de 2000 , gradativamente substituída pela de cinco doses. É importante registrar que, em virtude da infestação da maioria das regiões geográficas do país pelo vetor urbano da febre amarela, o Aedes aegypti, o PNI solicitou, em 1999, a produção de 100 milhões de doses da vacina contra a febre amarela. Bio-Manguinhos dobrou a linha de produção de concentrado viral, implantou regime excepcional de trabalho, sem feriados e finais de semana, e conseguiu produzir o concentrado em quantidade suficiente para 100 milhões de doses. Contudo, no terceiro trimestre daquele ano, o PNI solicitou que o quantitativo de doses fosse diminuído, pois o estoque de vacinas já era suficiente para fazer frente a qualquer ameaça de reurbanização da virose; ainda em 1999, foram entregues $65 \mathrm{mi}$ lhöes de doses, um número recorde de vacinas.

- Os quantitativos em doses produzidos em 1996 foram significativamente baixos, em decorrência de várias dificuldades operacionais de grande magnitude que culminaram em uma crise institucional, no bojo da qual foram iniciadas discussões para mudança de formas de gestão que ocorreram em 1997. Desde então, com a introdução de novas sistemáticas de trabalho, houve gradativa melhora de desempenho das atividades produtivas. Os números ainda variam para menos, como em 2001, mas os motivos são a existência de grande estoque de vacinas e a mudança gradativa da apresentação da vacina contra a febre amarela de 50 doses para cinco - em menor apresentação, menor desperdício no campo e menor solicitação do produto pelo MS. 


\begin{tabular}{|c|c|c|c|c|c|c|c|c|c|c|c|c|}
\hline ટ્స & 0 & 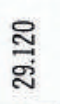 & 0 & 0 & . & . & ஜֶ. & & 0 & - & ఫ్రి & 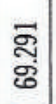 \\
\hline స్ & $\underset{\text { జ్ }}{\text { జ్ }}$ & $\underset{\Xi}{\Xi}$ & $\mathscr{8}$ & 0 & . & . & $\frac{\overrightarrow{7}}{4}$ & 嵒 & 0 & 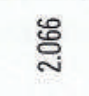 & 志 & $\underset{\mathrm{g}}{\mathrm{g}}$ \\
\hline ठ્స & ఫ్ & $\stackrel{\cong}{\Xi}$ & 0 & 0 & . & ' & 忐 & 응 & 0 & $\stackrel{\bar{\Xi}}{\sim}$ & . & 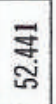 \\
\hline ర్లి & $\begin{array}{l}\text { ळ్లి } \\
\text { ల్ }\end{array}$ & 芯 & 용 & 0 & . & . & $\begin{array}{l}\infty \\
\stackrel{\$}{\circ} \\
\infty\end{array}$ & 怘 & 0 & $\underset{\mathbb{Z}}{\mathbb{5}}$ & , & $\begin{array}{l}\mathscr{心} \\
\stackrel{\circ}{\sigma} \\
\end{array}$ \\
\hline Дે & $\begin{array}{l}8 \\
\text { ठ․ } \\
\text { แ. }\end{array}$ & . & 0 & 0 & , & , & $\underset{\vec{\rightleftarrows}}{\vec{\rightleftarrows}}$ & ষ্ণ & 0 & 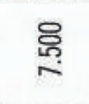 & . & $\begin{array}{l}\overrightarrow{\widetilde{S}} \\
\stackrel{g}{\Xi}\end{array}$ \\
\hline$\stackrel{\text { § }}{\stackrel{-}{-1}}$ & 疍 & . & 0 & 0 & . & , & 总 & 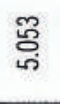 & 0 & . & . & $\begin{array}{l}\approx \\
\tilde{\Xi} \\
\stackrel{\varrho}{\varrho}\end{array}$ \\
\hline ภે & 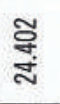 & . & 0 & 0 & . & . & $\begin{array}{l}\text { : } \\
\text { ָิ }\end{array}$ & $\begin{array}{l}\text { 莒 } \\
\text { co }\end{array}$ & 0 & . & . & $\underset{\Xi}{\Xi}$ \\
\hline Дั & $\begin{array}{l}\text { 。్ } \\
\text { ఏ }\end{array}$ & . & 0 & 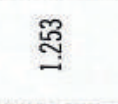 & . & . & 0 & 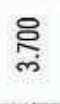 & 0 & . & . & 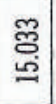 \\
\hline ભू & 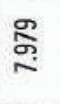 & , & 0 & $\underset{\sim}{\stackrel{\infty}{*}}$ & , & . & $\underset{\infty}{\stackrel{\leftrightarrow}{\circ}}$ & ఫ్ర్ర్ర & 0 & , & . & 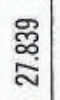 \\
\hline รั & ్ㅗㅁ & . & 0 & $\underset{乛}{\stackrel{్}{*}}$ & 0 & 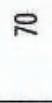 & $\underset{-\infty}{\stackrel{\infty}{-~}}$ & 胥 & 0 & , & . & 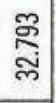 \\
\hline ஜू & 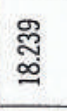 & . & 0 & 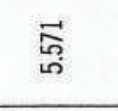 & 0 & ஜ & 0 & 로 & 0 & . & , & $\begin{array}{l}\mathscr{0} \\
\stackrel{0}{\Delta} \\
\end{array}$ \\
\hline รั & 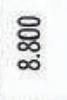 & . & 0 & 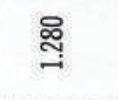 & 0 & க & 0 & జ్ & 0 & . & ' & $\underset{\mathbb{I}}{\stackrel{\widetilde{I}}{\mathbf{I}}}$ \\
\hline Бี & 怘 & . & 0 & 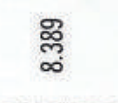 & ఇ & $\Sigma$ & 0 & :్ & 0 & . & , & $\underset{\stackrel{\leftrightarrow}{\circ}}{\stackrel{\circ}{\circ}}$ \\
\hline ஜి & ఫ్ర్రి & ' & 0 & চ্ণ্ণী & 요 & స్తి & 0 & 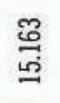 & $\stackrel{\circledast}{=}$ & . & . & 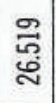 \\
\hline $\begin{array}{l}\text { ळ } \\
\stackrel{-}{-1}\end{array}$ & 응 & , & 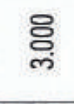 & & 유 & 음 & 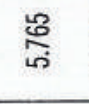 & $\begin{array}{l}\text { \&్ } \\
\stackrel{్}{=}\end{array}$ & ర్ & . & . & 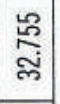 \\
\hline 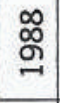 & 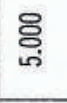 & , & 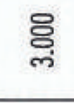 & & 요 & 음 & 总 & $\begin{array}{l}\mathscr{\varpi} \\
\stackrel{\varpi}{\sigma}\end{array}$ & 0 & . & . & 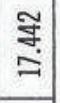 \\
\hline $\begin{array}{l}\hat{\infty} \\
\stackrel{-}{2}\end{array}$ & 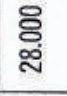 & . & స్తి & & దำ & คి & 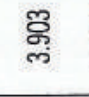 & 宊 & 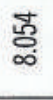 & . & . & 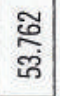 \\
\hline 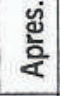 & : & : & 옹 & 몽 & 웅 & $\ddot{q}$ & ¿ & : & 모 & $\ddot{8}$ & $\ddot{8}$ & \\
\hline $\begin{array}{l}\frac{\pi}{\pi} \\
\frac{5}{u} \\
\stackrel{0}{>}\end{array}$ & 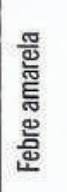 & 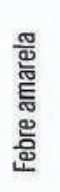 & 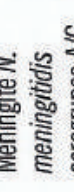 & 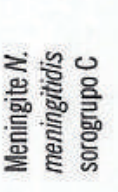 & 荧 & 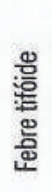 & 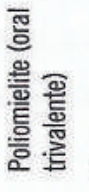 & 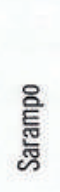 & $\begin{array}{l}\text { 을 } \\
\text { 롱 }\end{array}$ & 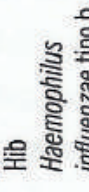 & 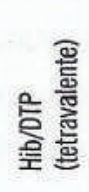 & $\begin{array}{l}\vec{\sigma} \\
\stackrel{5}{\circ}\end{array}$ \\
\hline
\end{tabular}


- Em 1999, Bio-Manguinhos iniciou o fornecimento da vacina contra Haemophilus influenzae, tipo $b(\mathrm{Hib})$, resultante do acordo de transferência de tecnologia estabelecido com o laboratório GlaxoSmithKline (GSK), e, a partir de 2002, ela passou a compor a vacina tetravalente - DTP+Hib. A DTP, que é líquida, é utilizada para reconstituir a vacina Hib, que é liofilizada; dessa forma, a criança recebe quatro antígenos protetores em uma só aplicação. A DTP é fornecida pelo Instituto Butantan em forma concentrada e Bio-Manguinhos realiza a formulação, envase e empacota com a Hib.

No ano de 2003, Bio-Manguinhos produziu toda a quantidade da vacina Hib de que se precisava para compor a vacina tetravalente (DTP + Hib), porém, como houve quebra de produção da vacina DTP pelo Instituto Butantan, a entrega ficou abaixo da necessidade.

Os números da série histórica apresentada na Tabela 1 devem ser analisados no contexto do quadro epidemiológico e tecnológico do país. Indicam a evolução qualitativa e quantitativa da produção de vacinas em Bio-Manguinhos. As vacinas, como febre tifóide e cólera, que eram utilizadas depois das inundaçōes, mas que não eram eficazes, deixaram de ser produzidas. Os números indicam a busca pela escala de produção - essencial para diminuir os altos custos fixos - e as apresentações das vacinas buscam contemplar as necessidades do campo. Foram incorporadas novas vacinas de tecnologia mais complexa, com valor agregado maior, significando expressiva economia em divisas para o país.

Nos anos recentes, as respostas adequadas à demanda do PNI, com entregas oportunas dos compromissos assumidos, vêm possibilitando melhorar e aumentar a confiabilidade das atividades e produto final de Bio-Manguinhos.

\section{INDICADORES DAS ATIVIDADES DE BIO-MANGUINHOS - 1997-2003}

A análise do quadro de indicadores (Anexo 2) de Bio-Manguinhos permite concluir que houve melhorias de desempenho quando medido por diferentes indicadores, que virão expostos a seguir.

Além da variação de números de doses de vacinas entregues para o PNI, já comentada e explicada anteriormente, o indicador percentual de custo de pessoal em relação à receita líquida mostra uma evolução excepcional: em 1997, o percentual foi de $77 \%$, no ano seguinte baixou para $43 \%$ e nos anos subseqüentes ficaram abaixo de $15 \%$, o que é altamente satisfatório. A melhoria desse indicador se deveu ao início do fornecimento da vacina Hib, um produto de alto valor agregado.

O indicador faturamento líquido por empregado também mostra uma evolução altamente positiva, a partir de 1998, quando se iniciou a entrega da vacina Hib. Os resultados crescentes a partir do ano 2000 significam que está havendo maior efetividade das operações, menores perdas operacionais e que, proporcionalmente aos anos anteriores, um menor número de funcionários vem obtendo os mesmos resultados.

O índice de desenvolvimento de recursos humanos, medido pelo número de cursos de treinamento pelo universo de funcionários, mostra tendência de crescimento-em 2003 foi muito maior do que a soma dos dois anos anteriores -, demonstrando a preocupação institucional com a qualificação dos seus funcionários. 
O índice de P\&D tem tendência de crescimento; nos últimos sete anos, foram lançados 16 novos produtos, sendo 13 reativos para diagnóstico laboratorial e três novas vacinas (contra febre amarela em apresentação de cinco doses; Hib e a vacina tetravalente), que são números muito positivos.

A taxa de acidentes de trabalho, medida a partir de 1999, ainda se mantém estável. Existe um trabalho sistemático e ativo do grupo de segurança de trabalho, que deve apresentar resultados positivos, devendo diminuir a taxa de acidentes nos anos vindouros.

\section{CONCLUSÕES}

A evolução de Bio-Manguinhos vem se procedendo de tal modo que possa enfrentar os desafios para atender as novas demandas geradas pelo quadro epidemiológico nacional e os avanços científicos e tecnológicos da área. Os investimentos necessários para dotar o Instituto de adequada infra-estrutura laboratorial e de apoio vêm sendo realizados pelo governo federal. Internamente, as avaliaçōes e indicadores diversos indicam que o modelo de gestão implementado desde 1997, com fortalecimento da gestão em todos os níveis, melhoria do perfil de qualificaçẫo do pessoal, desenvolvimento do plano estratégico, tem propiciado impacto positivo para Bio-Manguinhos.

Assim, pode-se afirmar que:

- existe confiança dos setores do governo federal na capacidade de resposta de BioManguinhos, pelos resultados já demonstrados;

- a credibilidade da população foi, igualmente, conquistada, havendo a percepção de que a qualidade dos produtos produzidos por Bio-Manguinhos é similar à daqueles produzidos pelas multinacionais;

- as premissas básicas de auto-sustentabilidade econômica das atividades produtivas foram alcançadas;

- as incorporações de novas tecnologias de produção via transferência de tecnologia de novos produtos de alto valor agregado têm contribuído para melhorar o desempenho institucional;

- a criação do grupo de gestão de projetos biotecnológicos está fortalecendo as atividades de desenvolvimento tecnológico e permite vislumbrar o desenvolvimento autóctone de importantes vacinas e de novos reativos para diagnóstico laboratorial em futuro próximo;

- a inovação tecnológica tem necessidade de um laboratório de protótipos, cujas instalações devem cumprir as normas de BPF;

- os importantes investimentos que estão sendo realizados nas novas instalações laboratoriais, cumprindo as normas de BPF, permitirão consolidar as atividades de produção de novas vacinas, como a tríplice viral; "

- os recursos humanos estão sendo qualificados para os desafios das próximas décadas.

O novo programa de desenvolvimento de vacinas organizado pela presidência da Fiocruz, o Programa de Desenvolvimento Tecnológico de Insumos para Saúde (PDTIS), deverá aportar importantes tecnologias para Bio-Manguinhos. Além disso, parece muito 
mais clara a intenção do governo federal de investir na inovação tecnológica de vacinas, em virtude, especialmente, das discussões sobre Inovação Tecnológica de Insumos para a Saúde, organizadas pela presidência da Fundação.

Finalmente, mas não menos importante: as atividades desenvolvidas por Bio-Manguinhos são estratégicas para o país, e é necessário dotar o Instituto de instrumentos legais que flexibilizem a administração de suas atividades, hoje uma importante indústria de produção de vacinas para uso humano e reativos para diagnóstico laboratorial.

\section{REFERÊNCIAS BIBLIOGRÁFICAS} de Doutorado, Rio de Janeiro: Instituto Universitário de Pesquisas do Rio de Janeiro.

BENCHIMOL, J. L. Manguinhos. In: BENCHIMOL, J. L. (Org.) Febre Amarela: a doença e a vacina, uma história inacabada. Rio de Janeiro: Bio-Manguinhos-Editora Fiocruz, $2001 \mathrm{a}$.

BENCHIMOL, J. L. O Programa Nacional de Auto-Suficiência em Imunobiológicos. In: BENCHIMOL, J. L. (Org.). Febre Amarela: a doença e a vacina, uma história inacabada. Rio de Janeiro: Bio-Manguinhos-Editora Fiocruz, $2001 \mathrm{~b}$.

BRASIL. Ministério da Saúde. Relatório Anual de Atividades, Bio-Manguinhos-Instituto de Tecnologia em Imunobiológicos. Rio de Janeiro: Fundação Oswaldo Cruz/MS, 2001.

BRASIL. Agência Nacional de Vigilância Sanitária (Anvisa). Boas práticas de fabricação medicamentos. RDC210. Brasília, DOU 14/08/2003.

HOMMA, A.; DI FABIO, J. L. \& DE QUADROS, C. Los laboratorios públicos productores de vacunas: el nuevo paradigma. Revista Panamericana de Salud Pública, 4:223-232, 1998.

WHO (WORLD HEALTH ORGANIZATION). Good manufacturing practices for pharmaceutical products. Technical Report Series, n. 823, annex 1. Genebra: WHO, 1992.

HOMMA, A. et al. Desenvolvimento tecnológico: o elo deficiente na inovação tecnológica de vacinas no Brasil. História, Ciências, Saúde-Manguinhos, 10:671-696, 2003.

KAPLAN, R. The Balanced Scorecard. Boston: Harvard Business School Press, 1996.

PATRIARCA, P. A. et al. Randomised trial of alternative formulations of oral poliovaccine in Brazil. Lancet, 27(1): 429-433, 1988.

PMBOK GUIDE. A Guide to the Project Managment Body of Knowledge. 3.ed. International Institute of learning, Inc., 2004.

PORTER, M. E. Vantagem Competitiva. Tradução de Elizabeth M. P. Braga. Rio de Janeiro: Campus, 1989.

SCHTZMAYR, H. G. et al. Erradicação da poliomielite no Brasil: a contribuição da Fundäção Oswaldo Cruz. História, Ciências, Saúde-Manguinhos, 9:11-24, 2002.

TEMPORÃo, J. G. O Programa Nacional de Imunização (PNI): origens e desenvolvimento. História, Ciências, Saúde-Manguinhos, 10:601-617, 2003. 


\section{ANEXO 1 - INOVAC̣ÃO INCREMENTAL DE VACINAS}

1. Estudo de imunogenicidade da vacina contra o sarampo, cepa CAM 70, produzida no Brasil. Concluído em 1981.

2. Desenvolvimento da metodologia de controle de qualidade da vacina contra a febre amarela em cultura de células. Concluído em 1982.

3. Desenvolvimento de um novo termoestabilizador da vacina contra a poliomielite, de vírus vivos atenuados. Concluído em 1984.

4. Desenvolvimento de um novo termoestabilizador da vacina contra a febre amarela. Concluído em 1985.

5. Desenvolvimento da metodologia de controle de qualidade da vacina contra a febre amarela em cultura de células. Concluído em 1985.

6. Desenvolvimento de uma nova formulação da vacina contra a poliomielite, com o componente tipo 3, potenciada. Concluído em 1986.

7. Desenvolvimento de um novo termoestabilizador da vacina contra o sarampo. Concluído em 1994.

8. Desenvolvimento de um novo ciclo de liofilização da vacina contra o sarampo. Concluído em 1994.

9. Desenvolvimento de tecnologias de produção da vacina contra a febre amarela em Cultura de Células Fibroblásticas de Pinto. Concluído em 1995.

10. Desenvolvimento de tecnologias de produção da vacina contra o sarampo em garrafas roller. Concluído em 1997.

11. Estudo de campo da vacina contra o sarampo, cepa CAM 70, para definição de dosagem da vacina. Concluído 1997.

12. Aperfeiçoamento do processo de produçăo da vacina contra a febre amarela, etapa de obtenção da suspensão viral. Concluído em 1998.

13. Desenvolvimento de tecnologias de formulação e liofilização para apresentação da vacina contra a febre amarela em cinco doses. Concluído em 1999.

14. Padronização de técnicas de controle de qualidade de endotoxina e ovoalbumina da vacina contra a febre amarela. Concluído em 1999.

15. Padronização de técnicas de identificação e determinação de polissacarídeo livre por método Elisa. Concluído em 1999.

16. Padronização de técnicas de controle de qualidade de leucose aviária em Elisa. Concluído em 2000.

17. Padronização de técnicas de determinação de polissacarídeos por cromatografia líquida da vacina contra Haemophilus influezae, tipo B. Concluído em 1999.

18. Padronização de técnicas de determinação de peso molecular de polissacarídeos de Haemophilus influenzae, tipo b. Concluído em 1999.

19. Padronização de metodologias de controle de qualidade in vitro da vacina DTP. Concluído em 2000. 
20. Desenvolvimento da vacina tetravalente DTP+Hib: estudos clínicos de imunogenicidade. Concluído em 2000.

21. Padronização de técnicas de TOC para controle de qualidade de águas purificadas. Concluído em 2001.

22. Estudo de imunogenicidade da cepa Matsuura, vacina contra a rubéola. Concluído em 2001.

23. Estabelecimento de um novo lote-semente para produção da vacina contra a febre amarela. Concluído em 2001.

24. Padronização de técnicas de TOC para controle de qualidade de águas purificadas. Concluído em 2001. 


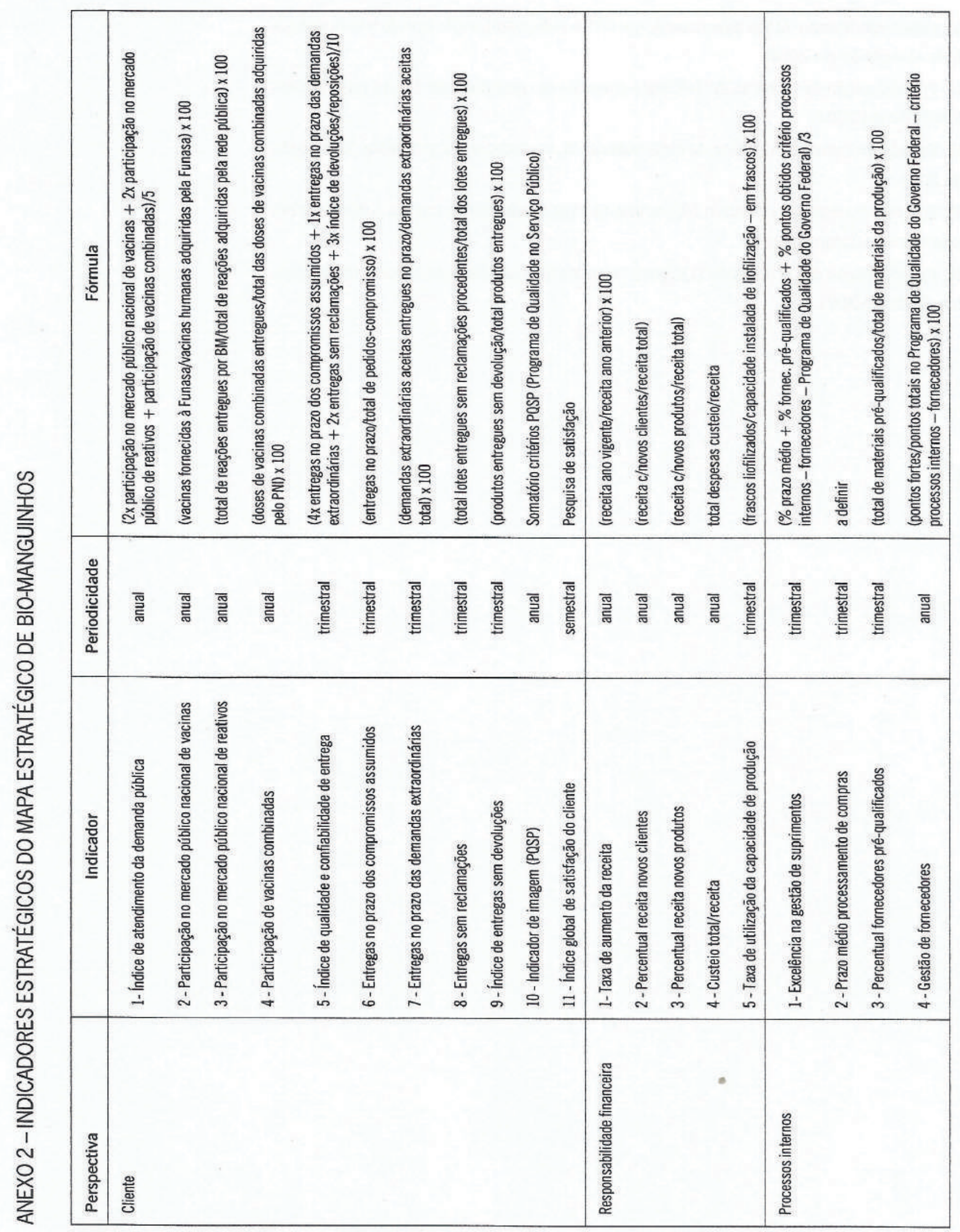


Desenvolvimento e PRoduçāo de Vacinas no instituto de tecnOLOgia em imunobiológicos...

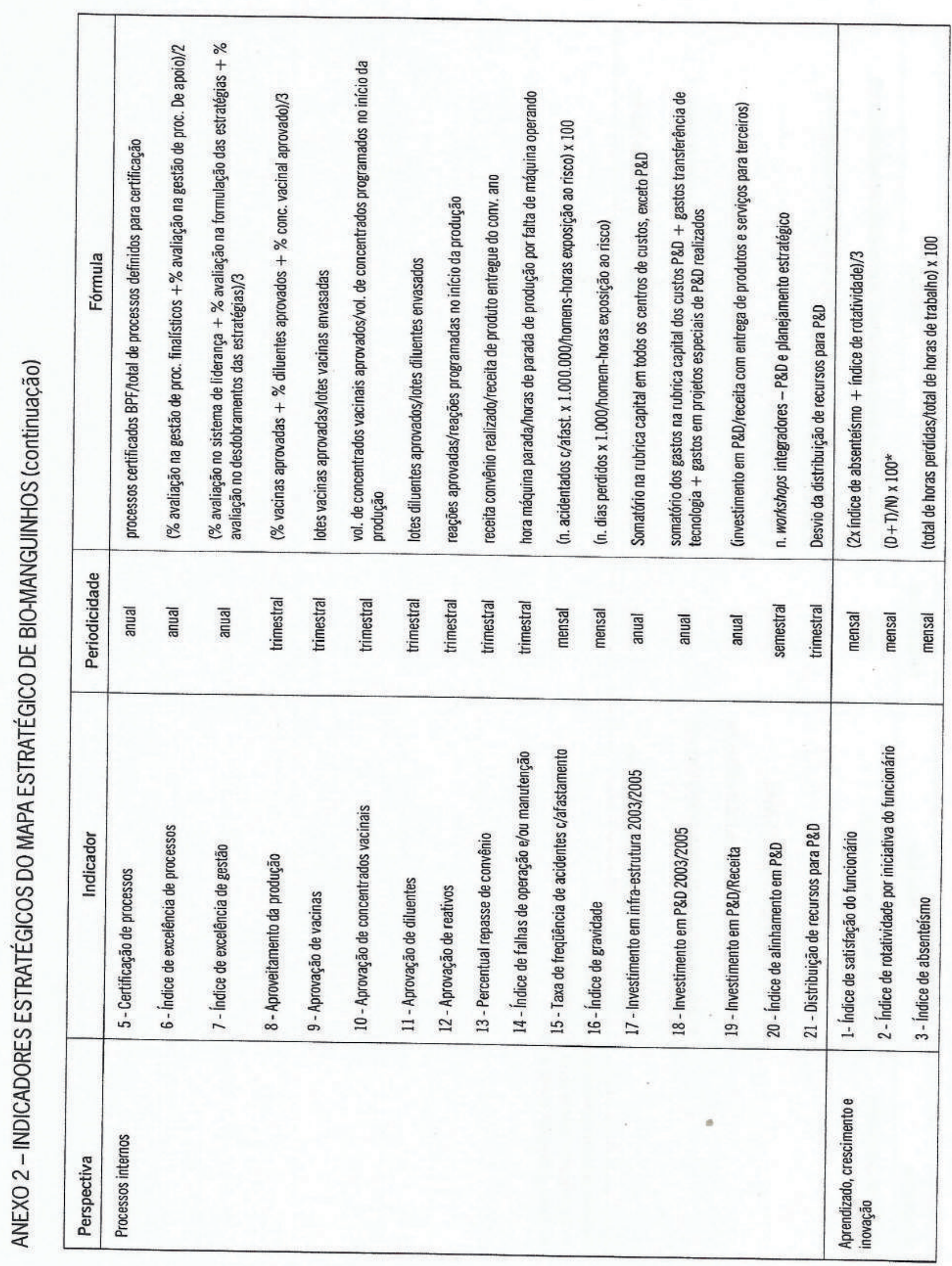




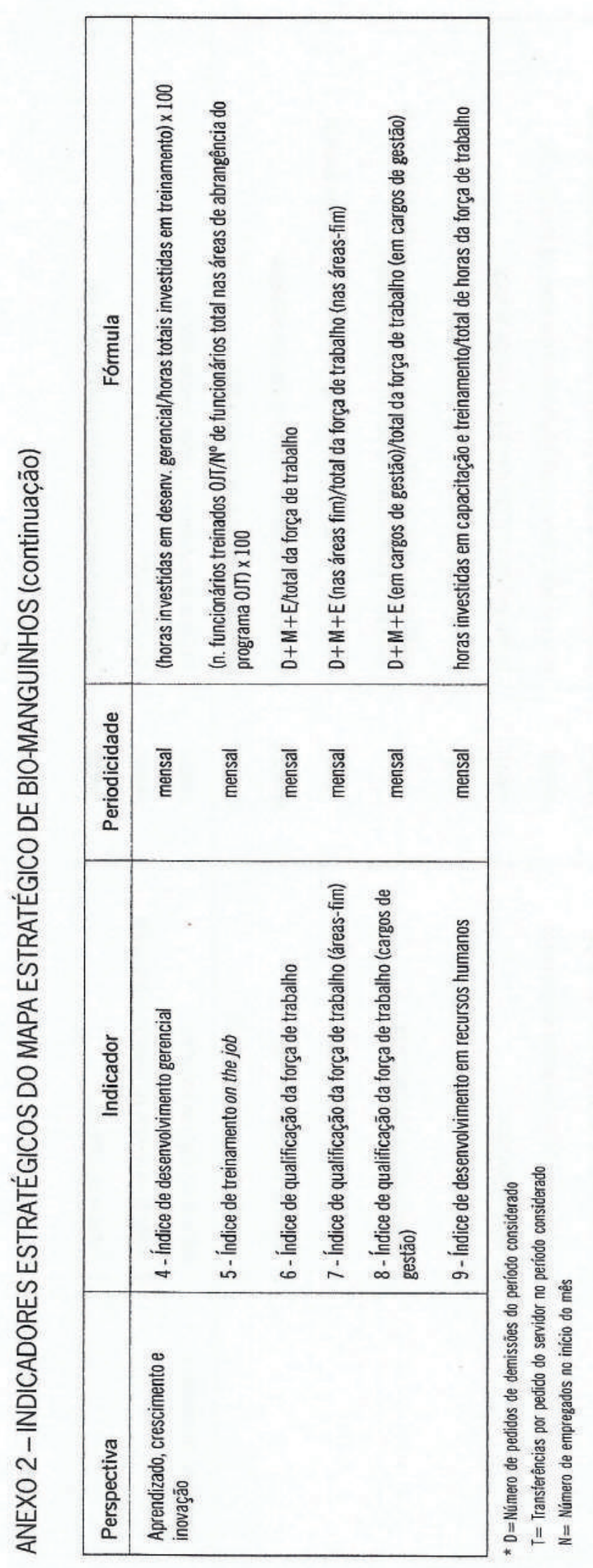




\section{ANEXO 3 - PROJETOS DE DESENVOLVIMENTO TECNOLÓGICO DE VACINAS}

- Bacterianas:

- vacina aprimorada contra $N$. meningitidis, sorogrupo B;

- vacina C, N. meningitidis, sorogrupo C, conjugada;

- vacina combinada de $N$. meningitidis, sorogrupo B e C conjugada;

- otimização de processos de cultivo de N. meningitidis sorogrupos A, C, Y, W135 em biorreatores;

- otimização de processos fermentativos para obtenção de polissacarídeos pneumocócicos;

- vacina heptavalente conjugada contra pneumococos.

- Virais:

- vacinas inativadas contra a febre amarela e poliomielite;

- vacina quimera: vírus amarílico vacinal 17D e dengue;

- vacina quimera: vírus amarílico vacinal 17D e Plasmodium;

- vacina contra febre amarela, apresentação 1 e 10 doses;

- avaliação do vírus da caxumba, cepa Jeryl Lynn para a produção de um lote somente visando à tríplice viral;

- vacina contra a febre amarela em CEF (cultura de fibroblasto de embrião de galinha); - expressão e purificação de proteínas do rotavírus, astrovírus e adenovírus: aplicação no desenvolvimento de um Elisa para detecção em amostras fecais;

- caracterização de anticorpos monoclonais contra o vírus da hepatite B (anti-HBs): utilização no diagnóstico e no estabelecimento de metodologias de humanização;

- caracterização genômica e biológica do vírus do sarampo cepa vacinal CAM-70 e padronização de metodologias de expressão e purificação de proteínas do sarampo.

- Tecnologia recombinante:

- melhoramento da vacina BCG subcepa Moreau;

- subprojeto 1: avaliação das ORFs da região RD16 e RD1 e reintrodução seletiva de genes no BCG;

- subprojeto 2: desenvolvimento e avaliação preliminar do BCG recombinante expressando listeriolisina como uma alternativa para a vacina contra a tuberculose;

- avaliação do potencial protetor do BCG recombinante (BCGr) expressando o fragmento $\mathrm{B}$ da toxina diftérica;

- vacina recombinante contra leptospirose humana;

- protótipo vacinal BCG recombinante pertussis;

- produção e purificação em grande escala das proteínas recombinantes nâo estruturais NS1 e NS3 do vírus da dengue em Pichia pastoris;

- produção e purificação em grande escala do fragmento B da toxina diftérica (DTB) expressos em E. coli;

- vacina recombinante contra leishmaniose.

- Tecnologia imunológica:

- indução de óxido nítrico, proliferação linfocitária e produção de anticorpos no controle de qualidade da imunogenicidade da fração pertussis da vacina DTP; 
- estudo colaborativo entre Bio-Manguinhos e Instituto Butantan para a padronização e validação de testes alternativos na determinação da imunogenicidade no controle de qualidade da vacina tríplice difteria-tétano-pertussis (DTP);

- cinética das respostas imunes inespecíficas e específicas na vacinação contra a febre amarela. 


\section{Desenvolvimento da Produção de Vacinas e Soros no Instituto de Tecnologia do Paraná (Tecpar)}

Júlio Salomão

Mariano de Matos Macedo

Renato Rau

\section{INTRODUÇÃO}

O Instituto de Tecnologia do Paraná (Tecpar) é uma empresa pública de direito privado - com autonomia administrativa e financeira - ligada à Secretaria de Estado da Ciência, Tecnologia e Ensino Superior do Paraná (Seti). Além de iniciativas no estado, atua também na área da ciência, tecnologia e inovação do país.

Conta atualmente com cerca de quinhentos trabalhadores entre técnicos de suas atividades-fins e pessoal de apoio administrativo. Cerca de $75 \%$ a $80 \%$ de seu orçamento é gerado internamente pela produção de imunobiológicos, antígenos e prestação de serviços tecnológicos (certificação, metrologia, informações tecnológicas e ensaios laboratoriais). $\mathrm{O}$ aporte direto de recursos do Tesouro Estadual responde pelos $25 \%$ a $20 \%$ restantes, na qualidade de contrapartida pelas atividades típicas de fomento à produção e de apoio aos processos de formulação e operacionalização de projetos específicos, voltados ao desenvolvimento do Estado, que o Instituto realiza no Paraná.

O Tecpar já foi credenciado pela ISO 9000/2000 e atualmente encontra-se em fase de adaptação às normas de conformidade previstas pela ISO 9001/2000. Essas normas implicam um novo sistema de gestão do órgão, de forma que cada atividade tenha suas metas definidas e indicadores que permitam o monitoramento sistemático. Além disso, encontrase em fase final de implantação um sistema ERP de gestão integrada, o que permite a 
definição de custos por atividade e a integração de processos de compras, suprimentos, produção de bens e serviços, estoques, vendas e gestão contábil e financeira.

O objetivo deste artigo é o de indicar a trajetória do Tecpar na produção de imunobiológicos no contexto histórico do seu desenvolvimento como uma instituição que atua não só nessa área, mas também na de prestação de serviços tecnológicos de variada natureza.

\section{O TECPAR: A IMPORTÂNCIA DE SUA HISTÓRIA}

O início do Tecpar foi em 1940, por meio da criação do Laboratório de Análises e Pesquisas (LAP) do Departamento de Agricultura da Secretaria de Obras Públicas, Viação e Agricultura do Estado.

Marca a economia paranaense dessa época uma intensa expansão da fronteira agropecuária estadual, principalmente com a cafeicultura associada à agricultura de subsistência, no norte do estado, e com o início do processo de ocupação do oeste e sudoeste do Paraná.

Se no estado đe São Paulo, até a década de 40 , a agricultura e pecuária já contavam com o apoio do Instituto Agronômico, do Instituto Biológico e da Escola Superior de Agricultura Luiz de Queiroz, no Paraná, onde essas atividades encontravam-se em forte expansão, não existiam ainda institutos de pesquisa dedicados a este fim. Havia o Departamento de Agricultura, vinculado à Secretaria de Obras Públicas, Viação e Agricultura, duas escolas superiores - veterinária e agronomia - e o Instituto de Química, que se ocupavam das atividades de pesquisa e ensino na área agropecuária e industrial.

Nesse contexto, mediante o Decreto 9.452 de 02/02/1940, o interventor Manoel Ribas reorganizou os quadros funcionais do Departamento de Agricultura da Secretaria de Obras Públicas, Viação e Agricultura do Estado, designando, entre outros, o químico industrial Dulcídio Lacerda para chefiar o laboratório de química e o veterinário e agrônomo Marcos Augusto Enrietti para o laboratório de bacteriologia. A partir de então, passou-se à modernizaçăo desses laboratórios, incluindo desde a compra de equipamentos até a construção de um prédio apropriado para o futuro LAP.

Com o LAP em operação, começavam a ser trilhados os primeiros passos em direção à produção local de imunobiológicos veterinários, atenuando a dependência que o estado tinha do Ministério da Agricultura e todos os problemas de logística de abastecimento que, na época, isso implicava.

Em virtude da contínua e intensa expansão das atividades agropecuárias no Paraná e atendendo às necessidades da criação de um órgão especializado, o interventor, por meio do Decreto-Lei 13.121941 e sob a orientação do Professor Doutor Marcos Augusto Enrietti, transformou o LAP em Instituto de Biologia Agrícola e Animal (IBAA).

O decreto estabeleceu que o IBAA, além de realizar análises diversas e preparar vacinas e quimioterápicos de uso animal, tinha também que desenvolver as seguintes atividades, conforme a estrutura organizacional delineada na Figura 1: a) estudar os solos do estado e determinar as suas possibilidades para as diversas culturas; b) realizar estudos de bacteriologia agrícola e animal; c) analisar produtos vegetais e seu aproveitamento industrial; d) estudar e orientar o combate às epifitias, epizootias e organizar 
campanhas contra as pragas agrícolas; e) estudar os produtos destinados à alimentação animal; f) proteger os agricultores e criadores contra as fraudes e adulteraçōes de produtos destinados à agricultura e pecuária; $g$ ) estudar e pesquisar alternativas de industrialização, transformação e aproveitamento dos produtos de origem animal; h) estudar a flora e as plantas cultivadas no estado; i) estudar e determinar as plantas tóxicas e medicamentosas relacionadas à agricultura e pecuária; j) formar e capacitar recursos humanos especializados.

Figura 1 - Estrutura organizacional do IBBA - 1941

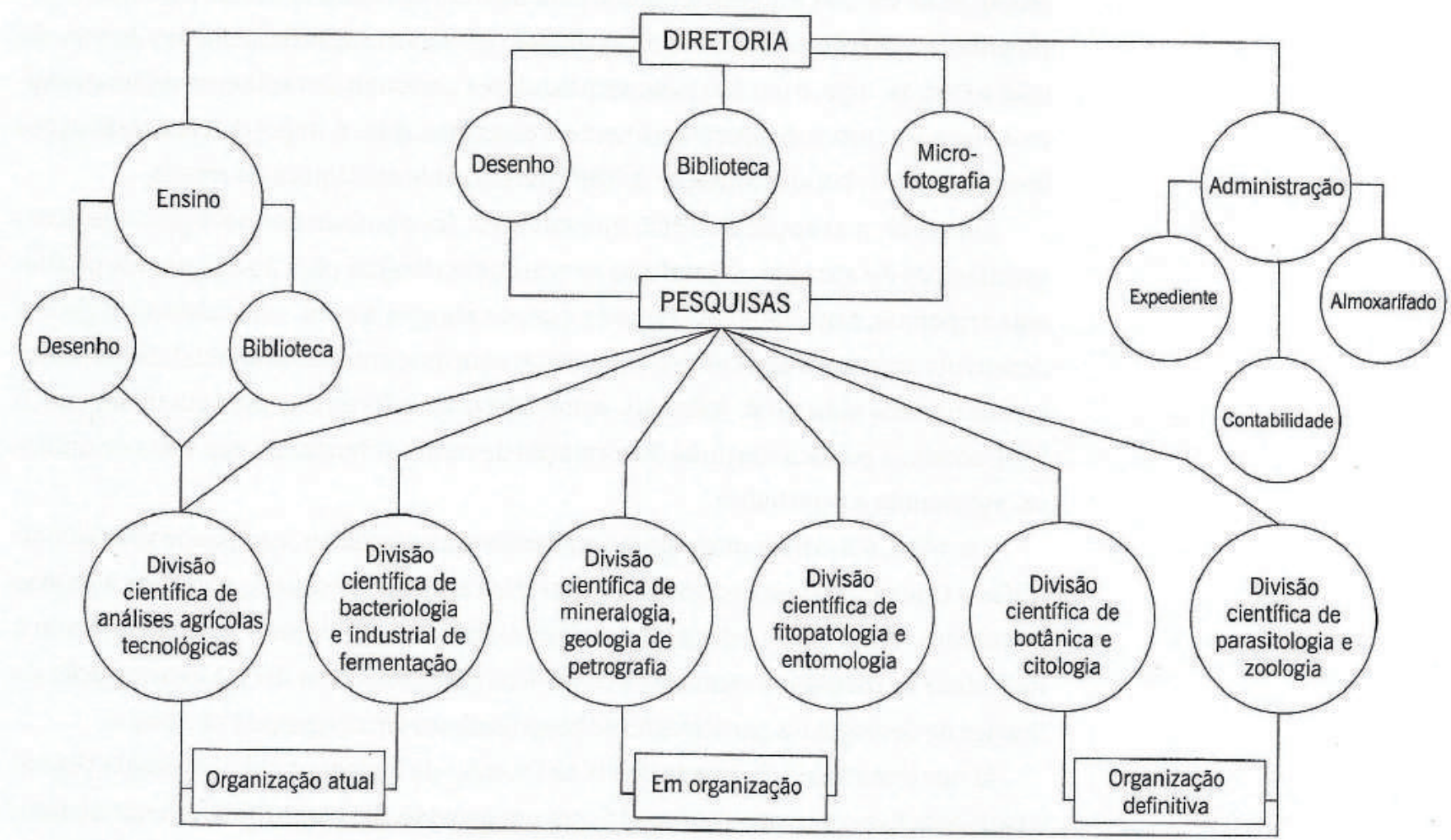

Há que se ressaltar que, nessa época, ao contrário do que ocorria com a agropecuária, o governo do Paraná não possuía diretrizes claras quanto ao fomento da indústria, tampouco uma pasta destinada à coordenação dos assuntos referentes à indústria e ao comércio no estado. Numa ação antecipatória, Enrietti propôs a criação de um órgão público que atendesse - com base em princípios técnicos e científicos - a todos os problemas tecnológicos dos segmentos produtivos da economia estadual, a fim de poder condensar no seu âmbito ações destinadas à prestação de serviços de fomento tecnológico no período da Segunda Guerra Mundial (1940-1945) e muito especialmente após o seu término.

Com essa perspectiva, em 1942, através do Decreto-Lei 110 de 30/12/1942, Manoel Ribas, sob a orientação do Professor Marcos Augusto Enrietti, transformou o IBAA no Instituto de Biologia e Pesquisas Tecnológicas (IBPT), mantendo a estrutura anterior, mas dotando-a de melhores condições físicas e materiais. 
'Essa publicação vem percorrendo a história do Tecpar até os dias atuais. A publicação Brazilian Archives of Biology and Technology, atualmente ainda editada pelo Instituto, é considerada uma das mais relevantes revistas cientfficas de sua área de atuaçãa.
O IBPT nasceu como uma instituição única que passava a aglutinar os estudos e pesquisas nas áreas agropecuária e industrial, sob o mesmo teto e direção. Essa característica o diferenciava de seus congêneres nacionais, pois a sua organização e linhas de pesquisa foram estabelecidas de tal forma que o IBPT atuava como se fosse uma filial híbrida do Instituto de Pesquisas Tecnológicas e do Instituto Agronômico de Campinas, em São Paulo. Com esse foco ampliado, em 1944, o IBPT passou a integrar a recém-criada Secretaria de Agricultura, Indústria e Comércio, desenvolvendo atividades principalmente nas seguintes áreas: elaboração de mapas geológicos; serviços de prospecção de solos; produção de vacinas e quimioterápicos para uso animal; laboratórios de patologia experimental; cultivo do Rhizobacter e sua difusão para inoculação de sementes de soja, da qual o Paraná, hoje, é um dos maiores produtores nacionais; levantamento climatológico do estado; cursos de aperfeiçoamento e especialização. A importância dessas ações levou, em 1951, à transformação do IBPT em entidade autárquica do estado.

Em geral, a atuação do IBPT, nos anos 40 , foi pautada por dois grandes eixos estratégicos de atuação. O Instituto se voltou totalmente para a solução dos problemas regionais, especialmente aqueles que, de alguma forma, colocassem em risco o desenvolvimento da agricultura e pecuária, sem descurar das potencialidades emergentes na área industrial. Ademais, como a base científica no estado era incipiente, o IBPT adotou a política contínua de formação de recursos humanos nas áreas de química, agronomia e veterinária.

Em 1946, o Instituto prosseguia ampliando suas atividades, equipando seus laboratórios e contratando novos pesquisadores. No campo da pesquisa, surgiram algumas novidades, entre elas a criação da revista Arquivos de Biologia e Tecnologia, ${ }^{1}$ com a finalidade de divulgar os trabalhos científicos realizados pelo IBPT; a estruturaçăo do Serviço de Geologia e a participação de pesquisadores em congressos nacionais.

Já nos anos finais da década de 40, as Divisōes de Biologia Animal, Biologia Vegetal e Patologia Experimental - contando com um corpo técnico capacitado e tendo acumulado experiências em anos de pesquisas de campo-começaram a definir mais claramente suas linhas de pesquisa.

A Divisão de Biologia Animal, responsável pela elaboração de diagnósticos e pela produção de vacinas (17.275 ampolas) e quimioterápicos, passou a dedicar-se ao estudo e identificação de doenças animais. Em 1949, com auxílio do Dr. Vitor Carneiro, do Instituto Biológico de São Paulo, os técnicos dessa Divisão conseguiram identificar o surto de encefalomielite que vinha atacando o rebanho eqüino do estado. Durante trinta dias, Carneiro e os técnicos do IBPT percorreram o interior coletando material, que, mais tarde, foi testado no Instituto Biológico de São Paulo, visto que o IBPT não possuía em seu biotério cobaias para realizar os seus experimentos. Prosseguia o levantamento estatístico das helmintoses, trabalho que subsidiava as ações do serviço sanitário animal, na época coordenado pela Secretaria de Agricultura. 
A Divisão de Patologia Experimental, recém-criada, surgiu da fusão dos serviços de anatomia patológica e de química biológica a fim de realizar estudos nas seguintes áreas: fisiologia e funções dos órgãos de animais e plantas; hormônios, vitaminas, antibióticos, enzimas, alcalóides e outras substâncias com ação fisiológica ou farmacológica de origem animal ou vegetal, especialmente nos campos da biologia, microbiologia, farmacologia, toxicologia, histologia etc.; patologia das doenças de origem desconhecida. Cabia-lhe ainda realizar estudos na área de química fisiológica e análises de substâncias orgânicas e inorgânicas do sangue, urina e órgãos animais para fins científicos e de diagnóstico.

Nessa época, ocorreu a incorporação da produção de vacinas de uso humano. Foram mantidos entendimentos com a Secretaria de Saúde para a transferência do setor encarregado da produção de vacina anti-rábica humana para o IBPT.

Em linhas gerais, até a década de 60 , o IBPT seguiu uma trajetória com duas vertentes. De um lado, a consolidação de algumas áreas de atuação, principalmente aquelas de assessoramento técnico ao setor industrial e agropecuário, corporificado nas Divisões de Química, Solos, Combustíveis, Mineralogia e Geologia e Divisão de Biologia Animal. De outro, o fortalecimento de duas Divisões - Patologia Experimental e, em menor escala, Biologia Vegetal - que, pela própria característica das áreas em que atuavam, acabaram formando um núcleo de pesquisa básica dentro do IBPT.

A Divisão de Biologia Animal, chefiada por Astolpho de Macedo, consolidava-se no estudo e diagnóstico das doenças causadas por vírus e na fabricação de vacinas e quimioterápicos, inclusive algumas de uso humano. Este foi o caso da vacina contra a gripe asiática, surto ocorrido no Paraná em 1957. A competência técnico-científica adquirida pela equipe possibilitou, num tempo relativamente curto, produzir vacinas contra a gripe. Após o processo de isolamento do vírus e decorridos trinta dias do início da produção, a Divisāo de Biologia Animal colocou à đisposição da Secretaria de Saúde do Estado, cerca de 31 mil doses de vacinas.

Em virtude do aumento gradativo da produção de vacinas e produtos veterinários, a Divisāo estudava a possibilidade de começar a produzir em escala industrial, pois, na época, o IBPT já oferecia cerca de dez tipos de vacinas, destacando-se as do tifo aviário, carbúnculo, garrotilho, curso branco, peste suína e raiva. Mas esse projeto não foi concretizado de imediato e essa situação continuaria até o início dos anos 70. Por sua vez, as pesquisas básicas sobre a febre aftosa, raiva e brucelose prosseguiram, inclusive com a instalação de uma seção de cultura de tecidos.

A Divisão de Patologia Experimental passou a constituir quase um órgão autônomo dentro do IBPT. Com exceção do pagamento de pessoal, os equipamentos, materiais de pesquisa, treinamento de pesquisadores eram viabilizados com recursos oriundos do CNPq, Capes e Fundação Rockfeller.

Em 1959, diante do desenvolvimento científico e do grau de capacitação técnica dos pesquisadores do Instituto, a Fundação Rockfeller concedeu um auxílio no valor de 72 mil dólares para serem gastos num período de três anos na montagem e aparelhamento 
dos laboratórios, principalmente os da Divisão de Patologia Experimental. A concessão desses recursos foi condicionada à construção, pelo IBPT, de um prédio específico para os laboratórios de bioquímica. Isso foi feito e o Instituto passou a contar com instalações especializadas de cerca de $2.000 \mathrm{~m}^{2}$.

Em fevereiro de 1961, mês em que o IBPT comemorava o seu vigésimo aniversário, Marcos Enrietti deixava a direção do centro de pesquisa que havia idealizado e dirigido desde a sua criação. Os depoimentos são unânimes em afirmar que uma das primeiras providências do novo governo, empossado em 31 de janeiro de 1961, foi a de retirar a direção do IBPT de Enrietti. Em 15 de fevereiro de 1961, o governador Ney Braga colocou o diretor à disposição da Escola Superior de Agricultura e Veterinária.

Com a saída de Enrietti, seguem-se, nos dez anos seguintes, várias e breves administraçōes, que pouca força tiveram para assegurar recursos em volume suficiente à expansão das linhas de pesquisa ou sequer manter os níveis anteriores. Menos força ainda tiveram para resistir à crescente subalternação do Instituto e sua redução a simples órgão acessório da política de fomento à agropecuária.

Em 1971, assume a direção do IBPT o engenheiro químico Dinor Olegário Voss, pesquisador com extensa folha de serviços já prestados ao Instituto e que permaneceu à frente da instituição por 12 anos consecutivos (1971-1983). Dinor administrou o IBPT aos moldes do seu mestre antecessor, o Dr. Marcos Augusto Enrietti.

Foi durante essa gestão que o Instituto implantou, a partir de 1971, a produção em grande escala da vacina anti-rábica canina com base no método desenvolvido pelos pesquisadores chilenos Fuenzalida e Palacios (multiplicação viral em cérebro de camundongo lactante), em razão de convênio com o Ministério da Saúde (MS) e tendo em vista a Campanha Nacional de Profilaxia da Raiva.

A Organização Pan-Americana da Saúde (Opas) teve um decisivo papel na capacitação de técnicos do IBPT, enviando consultores ao Paraná e propiciando oportunidades de aperfeiçoamento nos centros nacionais e estrangeiros de produção da vacina. Os biotérios foram reformados e redimensionados para a criação em escala de camundongos em condições de excelência técnica.

Nesse contexto, o IBPT passou a assumir gradativamente a condição de fornecedor exclusivo de vacina para as campanhas federais de erradicação da raiva, em quantitativos anualmente crescentes (Gráfico 1), prestando uma relevante e crucial contribuição ao controle da raiva animal no Brasil (Gráfico 2). A produção de cérebro infectado de camundongos acompanhou a evolução e a demanda da produção de vacinas, chegando atualmente a atingir 1 tonelada/ano, a partir de uma criação anual de cerca de 6,5 milhões animais.

O crescimento do IBPT, as dificuldades administrativas de uma estrutura autárquica, as mudanças na concepção dos institutos de pesquisa e o avanço do processo de industrialização da economia estadual - no bojo do 'milagre econômico' (1968-1974) e do II Plano Nacional de Desenvolvimento Econômico (1974-1979) - sinalizaram para a necessidade de uma reestruturação do velho Instituto no fim da década de 70. Assim, em 1978, o IBPT se transformou no Instituto de Tecnologia do Paraná (Tecpar). As Figuras 2 e 3 indicam as mudanças verificadas na estrutura organizacional do Instituto. 
Gráfico 1 - Produçăo de vacina anti-rábica canina. Brasil - 1971-2003

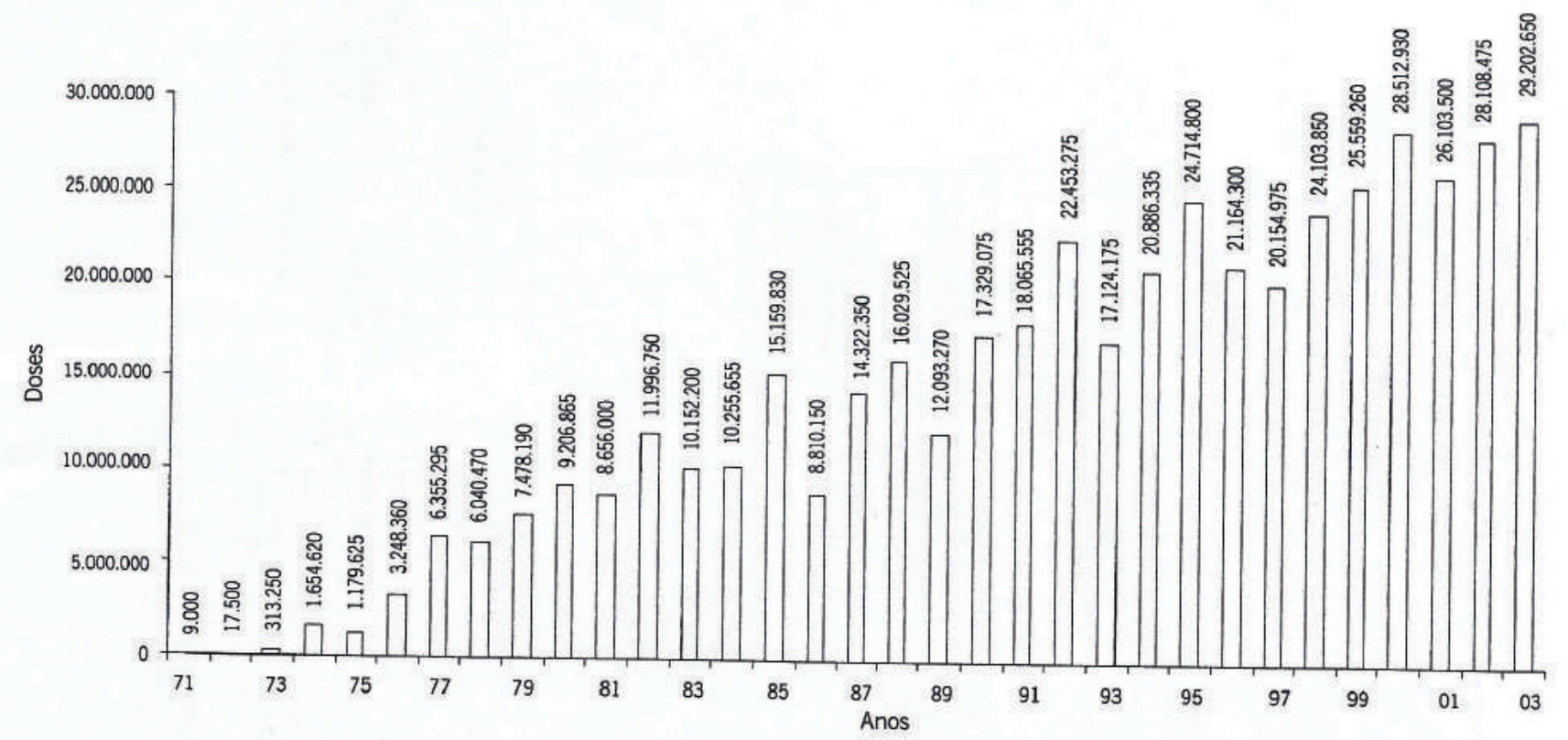

Gráfico 2 - Número de casos de raiva canina. Brasil - 1980-1997

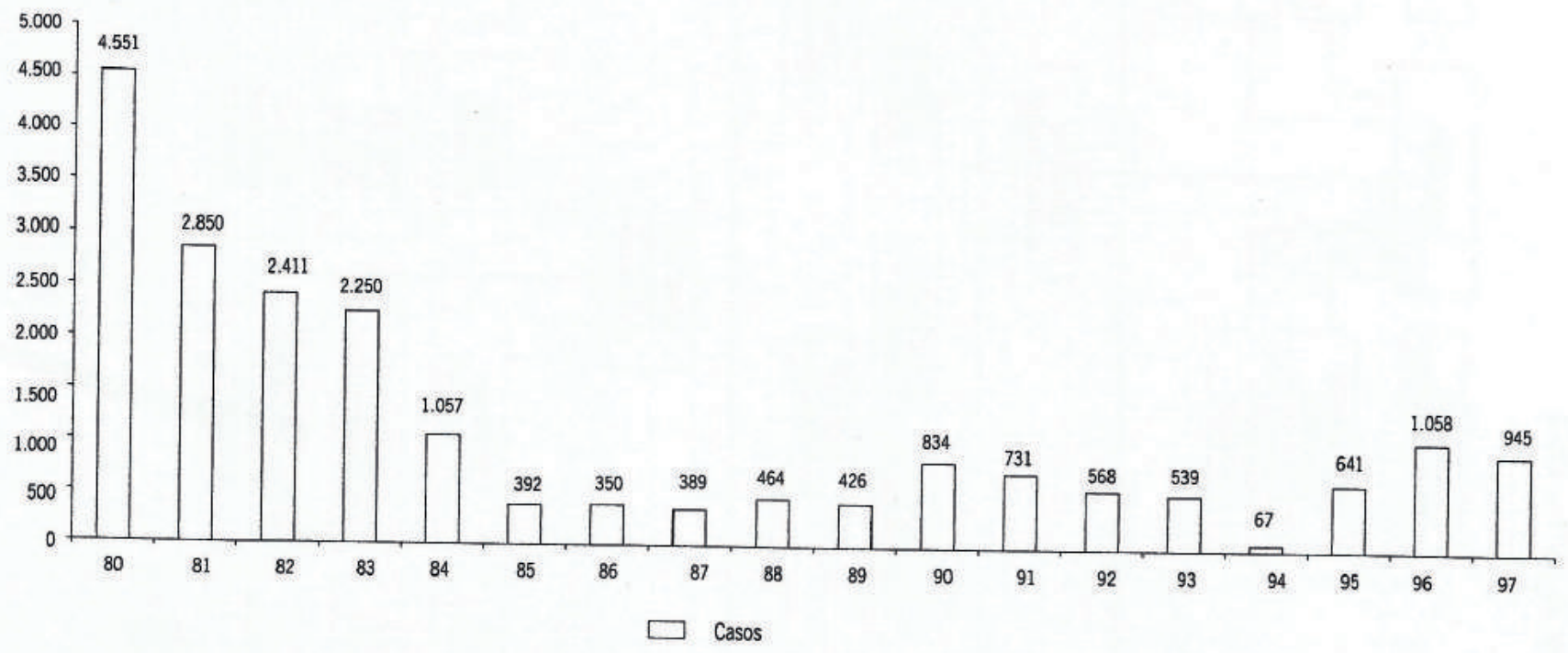




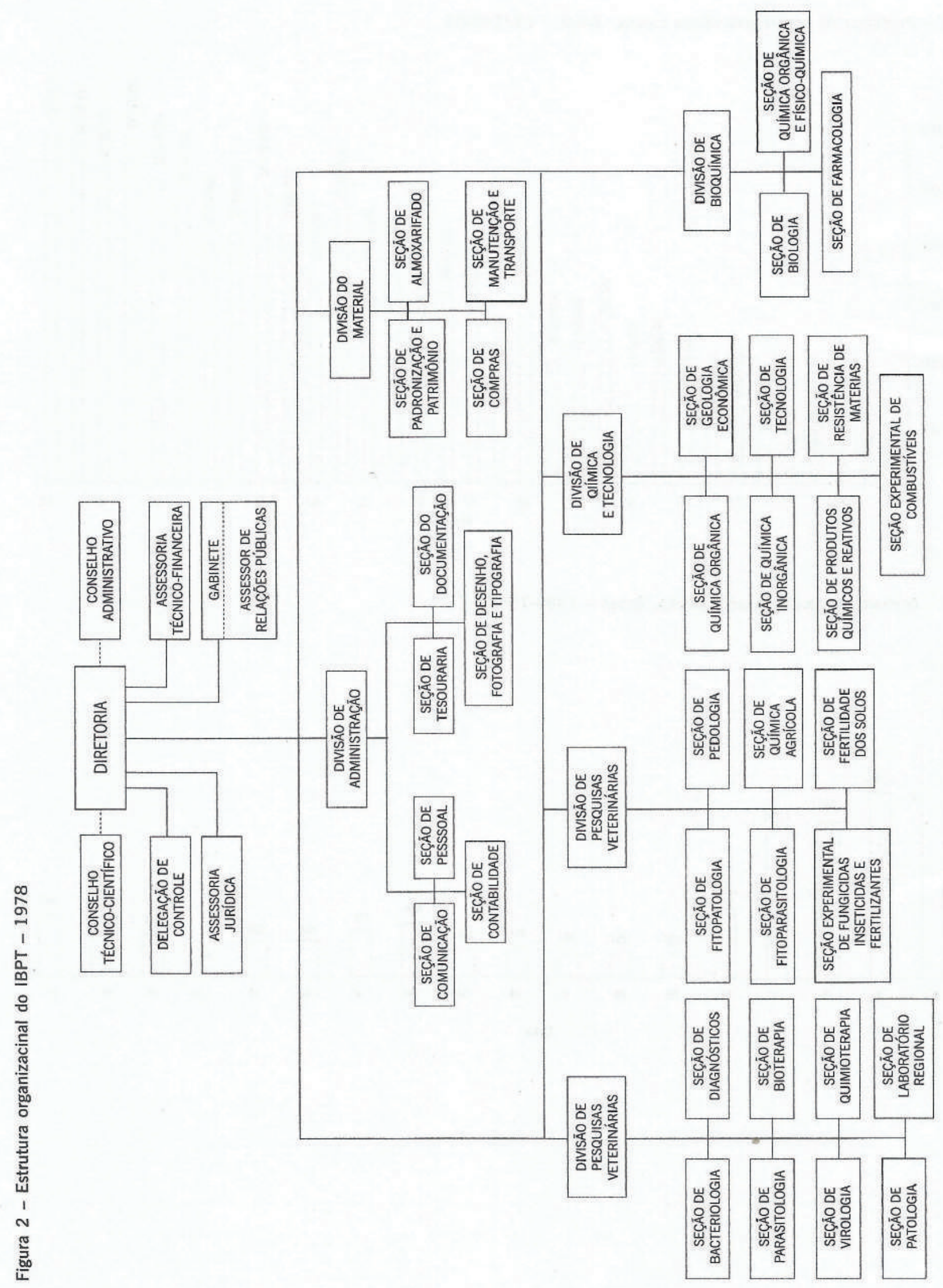


Figura 3 - Estrutura organizacinal do Tecpar - 1979

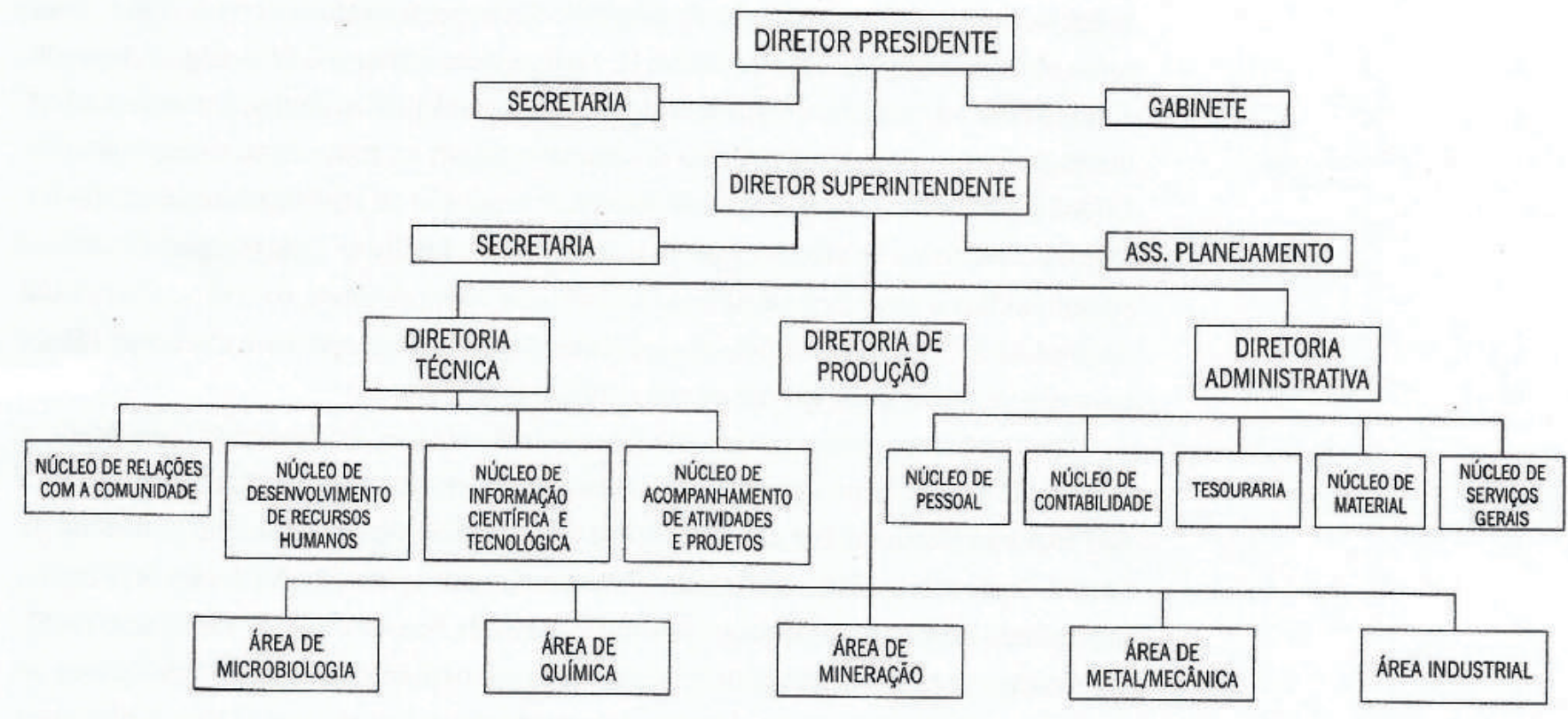

As principais características da nova estrutura organizacional se fundamentaram nos seguintes parâmetros:

- As atividades do Tecpar foram organizadas em uma estrutura de áreas e programas. Definiram-se como áreas prioritárias de atuação do Instituto a agroindústria, a mineração, a química e farmacêutica, a metal-mecânica e a eletroeletrônica. Foram estabelecidos os seguintes programas: Programa de Certificação e Controle da Qualidade; Programa de Desenvolvimento de Recursos Humanos; Programa de Assistência Técnica à Indústria; Programa de Implantação de Novas Bases Físicas; Programa de Pesquisa de Novas Tecnologias; Programa de Tecnologias Consagradas.

- Adoção de um modelo jurídico para o Tecpar que possibilitasse a indispensável flexibilidade operacional; esta, conjugada a novas posturas de sensibilidade e comportamento empresarial, deveria permitir ao Instituto gerar novas fontes de recursos, além de atrair e reter recursos humanos especializados mediante estímulos salariais. Nesse contexto, o Tecpar substituiu a sua forma autárquica; transformou-se em uma empresa pública, com personalidade jurídica de Direito Privado, patrimônio próprio, autonomia administrativa e financeira, tendo o governo do estado como único acionista, passando a ser vinculado à Secretaria de Estado da Indústria e do Comércio.

- Estrutura da diretoria, com uma diretoria executiva, constituída pelo diretorpresidente, pelo diretor-superintendente e por três diretores (de produção, técnîco e administrativo).

- Nítida orientação para o mercado consumidor de produtos e serviços e para a autosustentabilidade financeira da Instituição, visando à redução da dependência de recursos do Tesouro Estadual. 
Durante o período de gestão de Dinor Olegário Voss (1971-1983), foram iniciadas as negociações para a concretização do convênio de cooperação técnica com o Japão, tendo como objetivo a implantação do Centro de Treinamento e Pesquisa Tecnológica Aplicada, voltado para as áreas de metal-mecânica e eletro-eletrônica. Atribui-se também à administração Voss a decisão estratégica de colocar o Tecpar no rumo da sua auto-sustentabilidade, mediante a implantação de setores de produção de medicamentos e imunobiológicos como fonte de arrecadação de receitas para o Instituto. Dentre essas iniciativas podemos citar o setor de produção de anestésicos odontológicos, com venda garantida do produto à Central de Medicamentos (Ceme/MS), e a produção de vacina anti-rábica para uso veterinário em grande escala (Gráfico 1).

Em 1983, teve início a gestão de Edmundo Reichman, que procurou consolidar a posição do Tecpar como importante produtor de imunobiológicos do Brasil, inserindo-o no Programa Nacional de Auto-Suficiência em Imunobiológicos (Pasni) do Ministério da Saúde. Como conseqüência, diversas obras e reformas de instalações foram realizadas, procurando enquadrar os laboratórios nas normas de Boas Práticas de Fabricação (BPF). Verificaram-se também elevados investimentos em treinamento dos técnicos da área de produção, principalmente na tecnologia de produção da vacina anti-rábica. A produção de antígenos de uso veterinário foi implantada, e o Instituto foi credenciado pelo MS a receber significativos recursos financeiros para a implantação do setor de produção de vacina tríplice.

Na gestão Reichman, iniciou-se a busca incessante de uma política interna da qualidade. Organizou-se o Departamento de Controle da Qualidade, e todos os produtos e processos, a partir de então, passaram a ser submetidos a rigorosos testes de qualidade. A melhoria da qualidade dos produtos paranaenses sempre foi uma das orientaçōes do Instituto de Tecnologia do Paraná, desde a sua criação. Porém, a visão que se tinha, em conformidade com as tendências correntes da época, era direcionada mais para o controle da qualidade do produto do que para a gestão da qualidade de todo o processo.

Esse enfoque mais moderno começou a ser discutido pelo Tecpar em 1978, ano em que se esboçou um projeto de cooperação com o Japão, concretizado mais tarde através da Japan International Cooperation Agency (JICA). O projeto, proposto pela Secretaria da Indústria e Comércio, tinha o objetivo de desenvolver no Instituto um Centro de Tecnologia Industrial para dar suporte à melhoria da qualidade e ao desenvolvimento tecnológico das pequenas e médias empresas paranaenses, principalmente as dos setores metal-mecânico e eletroeletrônico. A JICA enviou equipamentos e peritos japoneses ao Paraná e, em julho de 1983, foi inaugurado o prédio que atualmente abriga o Tecpar, na Cidade Industrial de Curitiba (CIC), onde passou a funcionar o Centro de Tecnologia Industrial Brasil-Japão do Paraná. Para o Tecpar, como principal instituição de tecnologia do estado, esse esforço empreendido na área da qualidade possibilitou o aumento da oferta de serviços laboratoriais voltados para a promoção da melhoria da qualidade dos produtos paranaenses.

Em 1988, ocorreu um fato marcante para o Tecpar: deixou de pertencer à Secretaria de Estado da Indústria e Comércio e passou a ser vinculado à recém-criada Secretaria de 
Estado do Ensino Superior, Ciência e Tecnologia. Abriu-se, dessa forma, o horizonte de atuação do Instituto, que, além da produção de vacinas e correlatos, voltou a realizar pesquisa básica e desenvolvimento de serviços tecnológicos visando à sua auto-sustentabilidade financeira, não deixando, no entanto, de realizar ações de fomento junto às empresas industriais do Paraná.

\section{A DÉCADA DE $90 \mathrm{E}$ OS ANOS ATUAIS}

No quadriênio 1991-1994, houve uma preocupação dos dirigentes quanto à inserção do Tecpar nas rápidas mudanças do ambiente externo mundial, com a realização de um grande esforço de adaptação às novas condições verificadas no contexto da ciência e tecnologia brasileiras, incluindo aí o processo de transição para o Mercosul.

Objetivando clarificar e simplificar a visão estratégica, decidiu-se englobar as 'idéias-força' e, assim, compor, na sua totalidade, o que o Tecpar desejava tornar-se no futuro: centro de referência na disseminação de técnicas e conceitos de qualidade e produtividade no Brasil e no Mercosul; centro de excelência em vírus da raiva para a América Latina e Caribe; o principal centro de referência no país em pesquisa e desenvolvimento $(\mathrm{P} \& D)$ de sistemas de informática, produtos, processos químicos e biológicos; laboratório de referência para o Sistema Nacional de Vigilância Sanitária e, finalmente, tornar-se auto-sustentável financeiramente.

Contudo, uma das maiores marcas deixada pela gestão 1991-1994 foi, sem dúvida alguma, o programa de obras e reformas. Foram construídos novos blocos na sede do Tecpar/CIC, incorporando ao seu patrimônio $19.000 \mathrm{~m}^{2}$, o que possibilitou a mudança da sede e dos laboratórios de química e biologia, anteriormente instalados no bairro do Juvevê (regiāo central de Curitiba), para essas novas instalações. Em 1991, foi criada a Incubadora Tecnológica de Curitiba (Intec), atualmente uma das referências de excelência em sua área de atuação.

Operando sob o enfoque da norma ISO 9000, o Programa Qualidade Tecpar passou a abranger todas as atividades da empresa: a produção de vacinas; o conjunto de laboratórios que prestam serviços tecnológicos; o controle da qualidade, testes, ensaios para as empresas e, ainda, o desenvolvimento de projetos específicos, voltados ao crescimento tecnológico-industrial do estado.

Em 1990, a Divisão de Produção de Antígenos havia reiniciado a produção de reativos para o diagnóstico de brucelose e tuberculose bovina (Gráfico 3), interrompido de 1980-1989, quando o Ministério da Agricultura assumiu a responsabilidade por sua produção. O Tecpar montou uma linha semi-industrial e, com o decorrer dos anos, essa produção foi substancialmente sendo elevada e hoje atende ao Programa Nacional de Controle e Erradicação da Brucelose e Tuberculose, coordenado pelo Ministério da Agricultura, Pecuária e do Abastecimento. A previsão de produção para os próximos anos alcança os 18 milhões de doses/ano desses reativos. 
Gráfico 3 - Produção de antígenos para diagnóstico de brucelose e tuberculose - 1990-2003

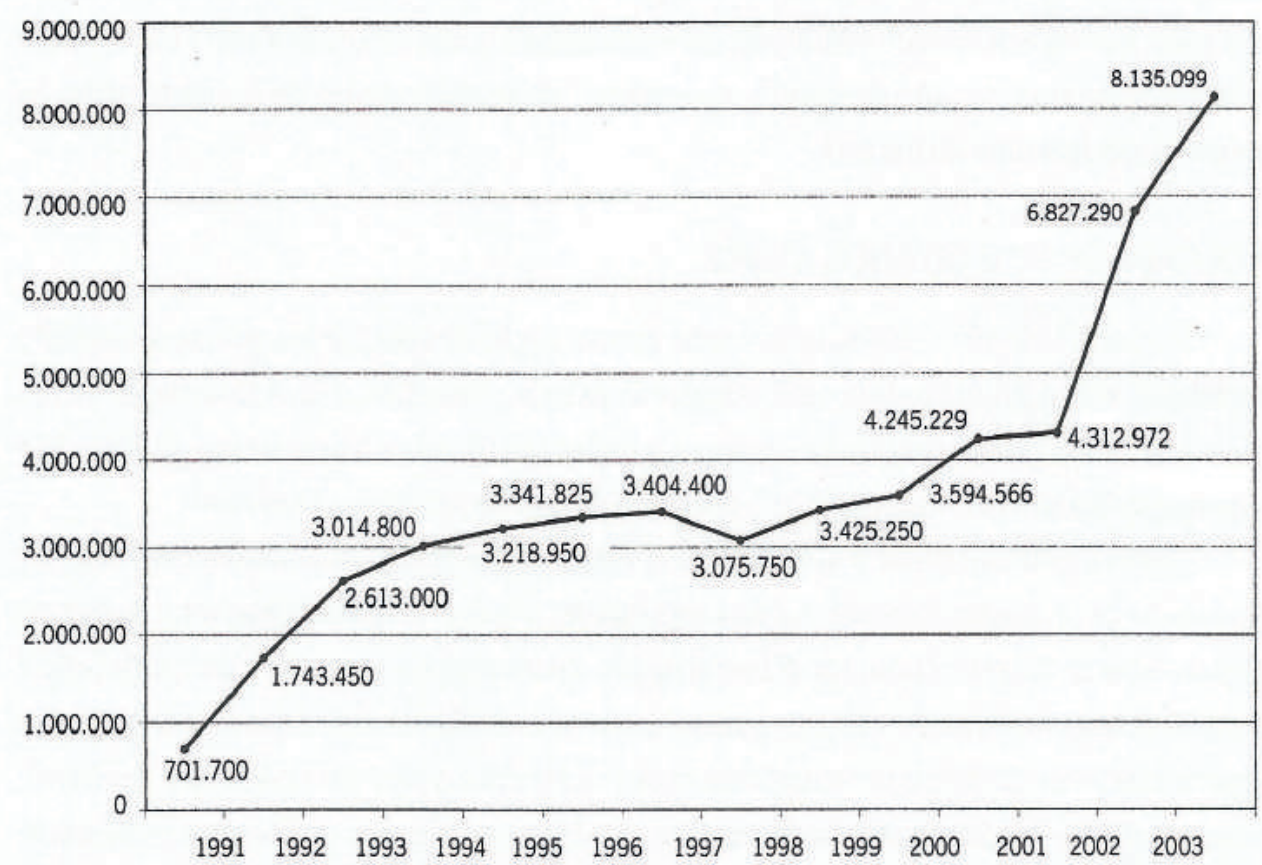

No quadriênio seguinte (1995-1998), estava fortalecido o papel do Tecpar como Centro de Inovação e Geração de Soluções Tecnológicas, em decorrência da atuação de seus diversos núcleos de serviços tecnológicos: Certificação de Sistemas da Qualidade; Informação e Extensão Tecnológica; Tecnologia de Materiais; Saúde e Meio Ambiente; Educação e Treinamento.

O Núcleo de Certificação foi criado em 1997 para atender as empresas que buscam a conquista de novos mercados e para fazer frente à concorrência externa. Esse núcleo é credenciado no Sistema Brasileiro de Certificação (SBC) através do Inmetro, de forma que - Tecpar foi o primeiro órgão público da Região Sul do país a ser definido como Organismo de Certificação Credenciado (OCC) para sistemas da qualidade. Entre os programas de certificação consagrados oferecidos pelo Tecpar estão: certificação de sistemas de gestão da qualidade (NBR ISO 9001); certificação de sistemas de gestão ambiental (NBR ISO 14001); qualificação de empresas construtoras (PBQP-H/SIQ-Construtoras); certificação de produtos industriais (fios e cabos elétricos, pneus remoldados, telecomunicação); gestão de pesquisa, desenvolvimento e inovação tecnológica; emissor de cupom fiscal. $\mathrm{Na}$ área de avaliação de conformidade de agronegócios, os seguintes programas vêm sendo desenvolvidos: soja e farelo de soja, não geneticamente modificados; certificação de frutas (maçã); avaliação da conformidade de cestas de alimentos e similares; carne bovina; manejo florestal (plantações florestais e cadeia da custódia); sistema de gestāo de Análise de Perigos e Pontos Críticos de Controle (APPCC)/Segurança de Alimentos; produtos orgânicos e Mećanismo de Desenvolvimento Limpo. 
Um dos principais avanços da política estadual de ciência e tecnologia no quadriênio 1995-1998 foi a regulamentação da Lei 12.020 de 9 de janeiro de 1998. Com base nessa lei, foram criados o Conselho Científico e Tecnológico - organismo presidido pelo governador do Paraná, com a função de formular as políticas de ciência e tecnologia (C\&T) para o estado - e o Fundo Paraná. Até 30\% dos recursos desse Fundo, constituídos pelo repasse de no mínimo $2 \%$ da receita tributária do estado, financiam a formação de recursos humanos, por intermédio da Fundação Araucária; até $50 \%$ são destinados à viabilização de programas e projetos estratégicos de interesse do governo na área de C\&T e até $20 \%$ são destinados ao Tecpar, para a modernização de suas atividades.

Em 2000, foi criado o Instituto de Biologia Molecular do Paraná (IBMP). Localizado nas instalações do Tecpar, originou-se de uma associação entre a Funđação Oswaldo Cruz (Fiocruz), a Secretaria de Estado da Saúde do Paraná e a Secretaria de Estado da Ciência, Tecnologia e Ensino Superior do Paraná, tendo como principal parceiro o Tecpar. A finalidade do IBMP é desenvolver pesquisa e prestar assessoria na área de biologia molecular voltada para o estudo da saúde humana e animal, tendo como objetivo apoiar os esforços de adequação dos produtores de imunobiológicos (Tecpar e Fiocruz) a novas tecnologias de produção.

O IBMP surgiu de parceria inédita em nosso país decorrente do interesse mútuo das entidades convenentes. Assim, o estado do Paraná implantou rapidamente competência altamente qualificada em biologia molecular aplicada à saúde, enquanto $a$ Fiocruz difundiu e ampliou suas atividades para o Sul do Brasil. Dentre os projetos de pesquisa e desenvolvimento tecnológico que se encontram em pleno funcionamento, podem-se relacionar:

- Bases moleculares da diferenciação do Trypanosoma cruzi.

- Enzimas-alvo para a quimioterapia da doença de Chagas e da dengue.

- Desenvolvimento de antígenos recombinantes como reagentes para diagnóstico.

- Desenvolvimento e padronização do uso de anticorpos recombinantes como insumos em testes diagnósticos.

- Estudos de genomas funcionais.

- Ferramentas de bioinformática para a análise de microarranjos de DNA (chips de DNA).

- Desenvolvimento e aprimoramento de vacinas com base em cultivo celular e DNA recombinante.

- Criação de um Centro de Certificação de Produtos Biológicos.

Historicamente, a diversificação das atividades do Tecpar acompanhou o desenvolvimento e as demandas decorrentes das mudanças estruturais da economia e da sociedade do Estado.

Atualmente, o Instituto atua em várias frentes, tais como a saúde (vacinas antirábicas canina e humana, anatoxina tetânica e de antígenos para o điagnóstico de brucelose e tuberculose em animais), biologia molecular, química fina, metrologia, ensaios laboratoriais, certificação de conformidades, educação tecnológica, informações tecnológicas, incubadora tecnológica e serviços de extensão tecnológica. O organograma atual do Tecpar pode ser observado no Figura 4. 
Figura 4 - Estrutura organizacional do Tecpar - 1998

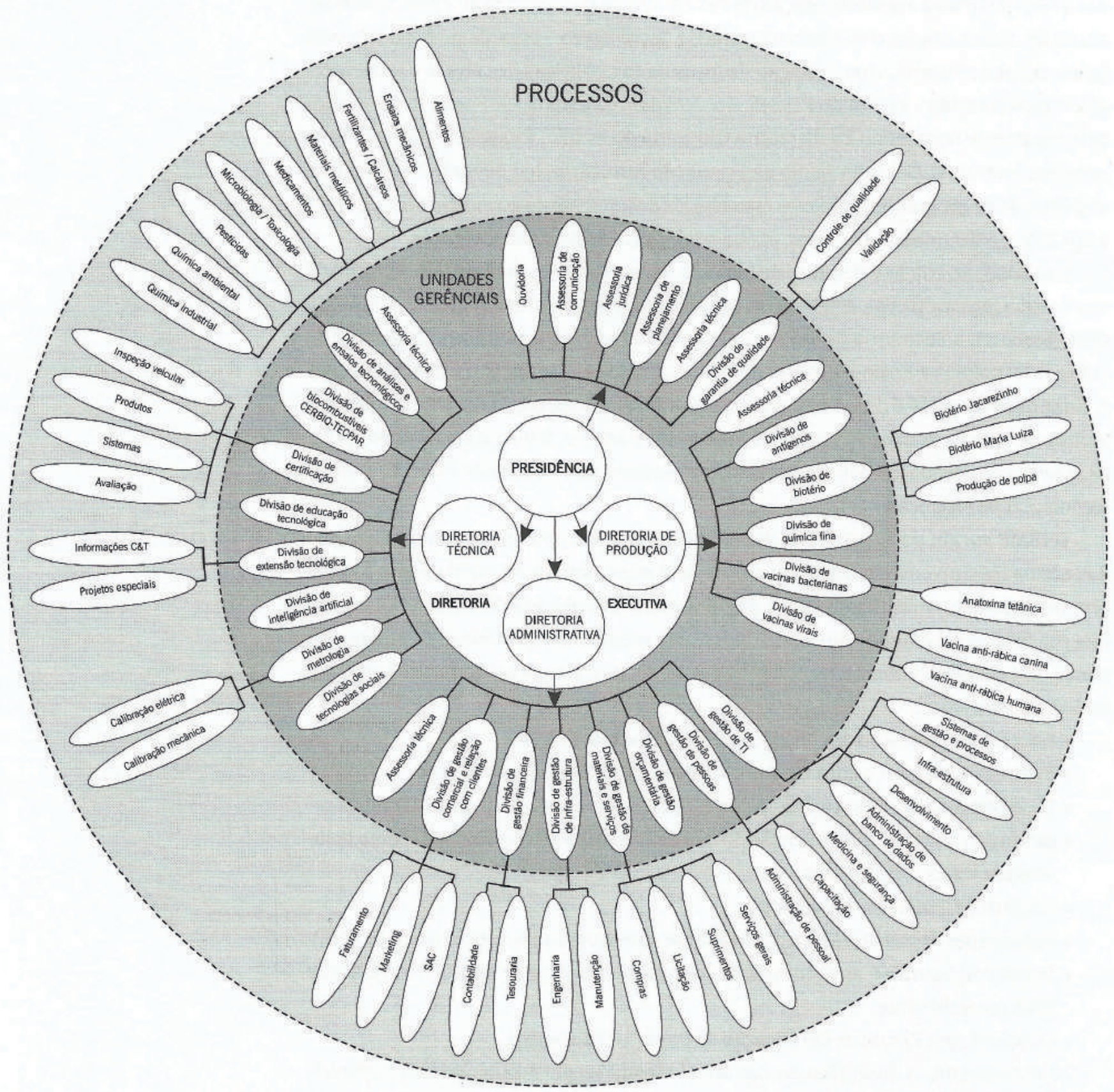

Em virtude da constante evolução tecnológica dos produtos imunobiológicos, a vacina anti-rábica começou a ser produzida pelos grandes laboratórios multinacionais seguindo a tecnologia de cultivo celular em alta densidade. Desde 1990, o Tecpar vem desenvolvendo essa tecnologia em pesquisas internas, fazendo uso da competência técnica instalada, gerada pelos conhecimentos adquiridos nos seguidos anos de experiência na produção e controle da qualidade dessa vacina. Esse esforço resultou, já em 1995, no 
domínio da tecnologia em escala piloto (padrão BHK), e a sua transposição para a escala industrial está sendo realizada, com a aplicação de significativos investimentos financeiros para a construçāo da planta laboratorial, obedecendo às normas preconizadas pelas BPF, num quantitativo de trinta milhões de doses anuais, capaz de atender as necessidades do MS.

A vacina anti-rábica para uso humano, elaborada valendo-se de células vero, foi igualmente desenvolvida a partir de 1990 pelo grupo de pesquisadores do Departamento de Pesquisa e Desenvolvimento de Imunobiológicos do Tecpar, obtendo-se resultados satisfatórios de eficácia já a partir de 1997. Por causa dos rigorosos requisitos exigidos na etapa de purificação, juntamente com o fato de que somente em 2003 adquiriu-se um sistema de robótica (CELLMATE) que fornece a segurança na elaboração e reprodutibilidade dos resultados, o tempo de desenvolvimento da vacina em escala piloto foi afetado, vindo a ocorrer somente em 2004. O Tecpar está também edificando a planta laboratorial dessa vacina em escala industrial com capacidade instalada para a produçăo de $5 \mathrm{mi}$ lhões de doses/ano, a ser voltada não só para o mercado interno, mas também para o externo. Dessa forma, o Tecpar se coloca perante o MS como um grande fornecedor de vacina anti-rábica para uso veterinário e humano, podendo também se credenciar futuramente na Organização Mundial da Saúde (OMS) como exportador dessas vacinas.

Além disso, o Tecpar instalou, em 2003, uma planta industrial de produção de anatoxina tetânica. A produção desse insumo, a partir de 2004, vai ser destinada à Fiocruz, que vai utilizá-lo para produzir a vacina quádrupla no Brasil (tríplice + meningite B), a ser difundida nos programas públicos de imunização já no ano de 2005. Com essa planta industrial e a competência técnica que vem sendo desenvolvida na área, o Tecpar está se credenciando para ser um dos grandes produtores mundiais desse insumo.

A Divisão de Produção de Antígenos estará recebendo investimentos para a modernização dos kits para diagnóstico de doenças infecciosas para uso pecuário (rinotraqueíte infecciosa bovina, leptospirose, artrite e encefalite caprina, brucelose e tuberculose). 0 objetivo é reduzir a dependência tecnológica do Brasil no que se refere à importação de produtos para diagnóstico de doenças infecciosas, o que tanto produz perdas econômicas significativas quanto restringe a colocação de produtos e animais brasileiros no comércio internacional. Esse avanço poderá proporcionar o monitoramento constante de rebanhos e a redução das taxas de prevalência de doenças infecciosas, além de tornar disponível aos produtores brasileiros um produto elaborado com tecnologia brasileira adaptada às condições locais e de menor custo. As pesquisas para o desenvolvimento desses produtos estão sendo realizadas pelo corpo técnico do Tecpar em parceria com o IBMP, resultando na conjunção da pesquisa básica e da aplicada. Com isso, formam-se novos profissionais nessa área, que produzem teses de pós-graduação, participando ativamente no desenvolvimento da tecnologia propriamente dita e na aplicação prática do resultado de seus trabalhos.

A Divisão de Biotérios também deverá receber significativos investimentos nos próximos anos, visando à produção de animais (cobaias, ratos e camundongos) em condições 
de sanidade que permitam a sua utilização por laboratórios de pesquisa de medicamentos e para controle da qualidade de insumos farmacêuticos, de acordo com as exigências da Agência Nacional de Vigilância Sanitária (Anvisa) e as BPF. No Brasil, são bastante raras as instituições que têm capacidade para a produção de animais de laboratório livres de germes contaminantes. Pela experiência adquirida nos cinqüenta anos de funcionamento do biotério do Tecpar e com os seguidos treinamentos efetuados pelos profissionais atuantes nessa área, o Instituto se candidata a produzir animais com qualidade sanitária e geneticamente apropriados, tão necessários no atual momento do país.

Em 2003, o Tecpar montou, com apoio da Financiadora de Estudos e Projetos (Finep), um dos mais sofisticados laboratórios de química fina do Brasil. Além de outros usos, esse laboratório vai permitir avanços expressivos no controle de qualidade dos imuniobiológicos produzidos pelo Instituto.

Em torno dessas principais linhas de produção, o Tecpar vem estruturando os seus núcleos internos de pesquisa e desenvolvimento. A estratégia tem sido a de articulação com instituições com competência técnica nessa área, em particular universidades. No geral, a política de estruturação desses núcleos tem sido a de 'interiorizar' no Instituto recursos de excelência técnica dessas instituições. O IBMP, associado à intensificação de qualificação dos pesquisadores que atuam diretamente na produção de vacinas antirábica do Tecpar, constitui um desses núcleos. Na área de testes de novos produtos, a instituição vem se associando à Universidade Estadual de Londrina (UEL); no que se refere à produção de antígenos, o núcleo de $P \& D$ tem por base a qualificação de recursos humanos e a associação com a Universidade Federal do Paraná (UFPR) e a Fiocruz, através do IBMP. A área de química fina vem incorporando pesquisadores da UFPR de forma a se tornar o principal centro de referência de pesquisa, desenvolvimento e inovação de produtos correlatos, inclusive de forma articulada a núcleos de $P \& D$ do setor privado, a exemplo da Cooperativa Agroindustrial (Cocamar). 


\section{Desenvolvimento e Produção de Imunobiológicos no Centro de Produção e Pesquisa de Imunobiológicos (CPPI)}

\section{HISTÓRICO}

o Centro de Produção e Pesquisa de Imunobiológicos (CPPI) nasceu de uma nova necessidade na área de saúde pública percebida por um grupo de técnicos que enxergavam além dos exames tradicionais feitos pelos laboratórios. Situado no estado do Paraná, ocupava área de exíguos $180 \mathrm{~m}^{2}$ junto ao Laboratório de Pesquisas Biológicas, atual Laboratório Central de Saúde Pública do Paraná (Lacen), e contava com um quadro de 17 funcionários.

Em 1989, após a conclusão parcial das reformas e ampliação de áreas desocupadas do Hospital de Dermatologia, foi transferido para sua nova sede, em Piraquara, município da região metropolitana de Curitiba.

A criação do CPPI, em 22 de abril de 1987, por intermédio da Deliberação 11/87 da então Fundação de Saúde Caetano Munhoz da Rocha, foi motivada pela alta incidência de óbitos por acidentes ofídicos, decorrentes da pouca disponibilidade de soros antiofídicos, conseqüência da obsolescência do parque produtor nacional e da má qualidade dôs produtos ofertados pela iniciativa privada, o que levou à interdição e desativação dos laboratórios particulares. Na época, os investimentos realizados pelo Ministério da Saúde (MS) não contemplaram a produção de soros no estado do Paraná. No início, a produção se limitou ao consumo do Estado. 
Nos laboratórios de saúde pública e de hospitais universitários, a ausência de oferta, por parte da iniciativa privada, de alguns produtos usados para diagnóstico de doenças infecciosas e parasitárias levou à implantação da produção de antígenos e anti-soros, iniciada com o antígeno de Montenegro, antígeno de Mitsuda e soro antibotrópico.

o Decreto 1.421, de 30 de junho de 1992, regulamenta o CPPI como uma unidade da Diretoria de Vigilância e Pesquisa, regendo-se pelo regulamento do Instituto de Saúde do Paraná (Isep) e define as competências institucionais.

O Isep é uma autarquia estadual dotada de personalidade jurídica de direito público, com autonomia administrativa, técnica e financeira, vinculada à Secretaria de Estado da Saúde nos termos do artigo 12 da Lei 8.485, de 5 de junho de 1987 , tendo como principal fonte de receita $o$ orçamento do Estado.

Ao CPPI compete: a) o planejamento, a programação, a coordenação, a execuçã́o e a supervisão da produção e pesquisa de imunobiológicos; b) a promoção, a realização e a divulgação de estudos e de pesquisas em biotecnologia aplicada à área de saúde pública; c) o estímulo à capacitação de recursos humanos de sua área de atuação, em consonância com as normas de recursos humanos; d) o desenvolvimento de intercâmbio e cooperação técnico-científica com instituições congêneres nacionais e internacionais; e) a elaboração de normas de funcionamento e controle das atividades de sua área.

\section{EVOLUCุÃO}

O CPPI teve, no transcorrer de sua existência, mudança de rumos para se adaptar aos novos tempos da administração pública, em que os recursos são escassos e os resultados têm que ser multiplicados, nunca perdendo de vista $o$ atendimento à realidade epidemiológica.

Em 1995, o CPPI deu seus primeiros passos no mercado nacional, participando de convênios para o fornecimento do antígeno de Montenegro e de venenos, iniciando, na época, a implantação de um sistema de qualidade em conformidade com as Boas Práticas de Fabricação (BPF). Nessa etapa, foram elaborados e padronizados os procedimentos técnicos, definidos pontos de controle de processo, iniciada a inspeção e ensaio de matéria-prima e o controle de equipamentos, entre outras atividades.

Em 1997, a implantação da norma ISO 9000 foi escolhida como estratégia para dar início a um processo de gestão da qualidade, pois este processo resulta em alteração na cultura institucional. A característica mais marcante, no gerenciamento, não é apenas fornecer controles para assegurar a qualidade do produto final, mas também reduzir o desperdício de tempo, o 'retrabalho' e a ineficiência, tendo como conseqüência a maior produtividade.

Foram definidas uma nova missão e novas diretrizes para o órgão; optou-se por uma estratégia de médio prazo, investindo na formação de pessoal, otimizando os poucos recursos disponíveis, implementando a pesquisa e desenvolvendo novos produtos epi- 
demiologicamente necessários para o Estado e para a nação. Inseria-se, assim, o CPPI dentro de uma cadeia produtiva, na qual pudesse ser necessário e eficiente, e, para atender os objetivos de maior eficiência na gestão pública, efetivou-se a adesão ao Programa Nacional de Qualidade no Serviço Público.

Tudo isso fez crescer não só o órgăo, mas também seus funcionários, pois é impossível separar o trabalhađor. É nesse contexto que os resultados não programados também trazem satisfação, porque muitos melhoraram sua formação profissional, sua autoestima e sua qualidade de vida, aplicando no meio familiar e social os conhecimentos aprendidos nas mais diversas atividades e treinamentos ofertados.

\section{ESTRUTURA}

Para o desenvolvimento de suas atividades, o CPPI atualmente conta com uma área de 30 hectares e uma extensão construída de $2.500 \mathrm{~m}^{2}$, assim distribuída: Laboratórios de Produção (soros, antígenos e anti-soros, insumos); Biotério de Grandes Animais (eqüinos e ovinos); Biotério de Pequenos Animais; Infectório; Seção de Biologia Médica e Animais Peçonhentos (serpentário e artrópodes); Laboratórios de Controle de Qualidade (biológico, físico-químico e microbiológico).

Conta com 48 funcionários (18 graduados em medicina, farmácia/bioquímica, biologia, medicina veterinária e administração) e 30 de nível médio e elementar.

Dos funcionários graduados, seis são especialistas em saúde pública; três em microbiologia; dois em qualidade; dois em análises clínicas; um em imunologia; um em biologia geral; um mestre em saúde pública, dois mestres em ciências veterinárias; um mestre em patologia animal e dois mestres em microbiologia, parasitologia e patologia básica e um doutor em biotecnologia.

\section{POLITICA INSTITUCIONAL}

O CPPI tem como missão planejar, coordenar e executar a produção e a pesquisa de imunobiológicos e insumos para auxílio diagnóstico/prognóstico, atendendo a toda a rede de serviços de saúde pública.

\section{Principais atividades}

As principais atividades do CPPI são: produção de imunobiológicos (soros hiperimunes antiveneno); produção de antígenos, anti-soros e insumos para auxílio diagnóstico/prognóstico para doenças de interesse de saúde pública; produção de animais de laboratório; educação em saúde; pesquisa e desenvolvimento na área de biotecnologia; assessoramento laboratorial para vigilância entomológica.

\section{Produtos}

- Antígenos para reação intradérmica: antígeno de Montenegro, para auxílio diagnóstico da leishmaniose (úlcera de Bauru); antígeno de Mitsuda, para auxílio prognóstico da hanseníase. 
- Antígeno para reação de imunofluorescência: antígeno para pesquisa de anticorpos anti-Cysticercus cellulosae, para diagnóstico da cisticercose e neurocisticercose humana; antígeno para pesquisa de anticorpos anti-Leishmania $(V)$ brasiliensis, para diagnóstico da leishmaniose.

- Antígeno para reação de Elisa: antígeno para pesquisa de anticorpos - anti-Cysticercus cellulosae para diagnóstico da cisticercose e neurocisticercose humana.

- Antígenos para imunodifusão: exoantígeno de Paracoccidioides brasiliensis, para aplicação na técnica de imunodifusão dupla (CPPI/Universidade Estadual de Maringá e UFPR).

- Anti-soros: anti-soro Estreptococo b hemolitico sorogrupos A, B, Ce G, para pesquisa e diagnóstico de estreptococcias, como parte do Programa de Prevenção da Febre Reumática. O CPPI é o único produtor nacional destes anti-soros em nível institucional.

- Insumos: sangue desfibrinado de carneiro para ser incorporado a meios de cultivo bacteriológicos; plasma de coelho liofilizado para identificação de Staphylococus aureus; soro eqüino.

- Soros hiperimunes antivenenos: soro antiloxoscélico.

- Animais de laboratório: camundongos Swiss, usados para diagnóstico da raiva e para testes de controle de qualidade biológico.

\section{Soro antiloxoscélico}

O loxoscelismo ou envenenamento pela aranha marrom é, atualmente, um importante problema de saúde pública. Notificações e investigações epidemiológicas apontam um aumento no número de acidentes por aranhas de gênero Loxosceles nos centros urbanos, com a presença de alta taxa de infestação intradomiciliar (Ribeiro et al., 1993; Fischer, 2002), demonstrando, assim, a relevância desse problema. O Paraná tem sido o estado que mais notifica acidentes loxoscélicos, que correspondem a aproximadamente $52 \%$ dos provocados por aracnídeos (Brasil, 1999).

\section{Principais pesquisas}

De acordo com suas diretrizes, o CPPI vem estimulando e priorizando o desenvolvimento de projetos de pesquisa, tendo como objetivo, principalmente, a melhoria de processos e o desenvolvimento de produtos, em atendimento às necessidades epidemiológicas, por meio de uma política de parceria interinstitucional.

- Produção de anti-soro Estreptococo b hemolítico sorotipo M (CPPI/Lacen). Produto comercial não disponível no mercado nacional. Projeto financiado pela Fundação Araucária.

- Produção de exoantígeno de Paracoccidiodes brasiliensis para aplicação na técnica de imunodifusão dupla (CPPI/Universidade Estadual de Maringá e Laboratório do 
Hospital de Clínicas da UFPR). Produto comercial não disponível no mercado. Projeto financiado pela Fundação Araucária.

- Diagnóstico da cisticercose humana por Elisa e Western blotting, utilizando fraçōes do fluído vesicular da larva da Taenia crassiceps como antígeno. Tese de Doutorado em Biotecnologia pela UFPR.

- Produção do antígeno de E/S do Toxocara canis (CPPI/Universidade Estadual de Ponta Grossa).

- Produção do fosfato de histamina para auxílio diagnóstico da hanseníase (CPPI/Fiocruz).

- Avaliação do teste de Elisa no controle de qualidade biológico do soro antiloxoscélico.

\section{PARCERIAS INSTITUCIONAIS}

- Convênio com a Fundação Nacional de Saúde/MS para fornecimento, em todo território nacional, dos seguintes produtos: antígeno de Montenegro (desde 1997), antígeno de Mitsuda, fosfato de histamina e soro antiloxoscélico.

- Convênio com o Centro Diagnóstico Marcos Enrieti/Secretaria de Estado da Agricultura e Abastecimento e Universidade Tuiuti do Paraná, para o fornecimento de animais de laboratório.

- Convênio com as Universidades Estaduais de Londrina, Maringá, Ponta Grossa e Unioeste; com o serviço de análises clínicas do Hospital de Clínicas/UFPR e com a Pontifícia Universidade Católica, para fornecimento de antígenos, anti-soros e insumos, bem como para o desenvolvimento conjunto de pesquisas e novos produtos.

- Convênios com o CNPq/Ministério da Ciência e Tecnologia e a Fundação Araucária, para financiamento de pesquisas.

- Parceria com o Incor/Universidade de São Paulo no projeto de desenvolvimento da vacina contra a febre reumática.

- Criação do comitê técnico-assessor a fim de implementar o relacionamento entre o CPPI/Isep/Secretaria de Estado da Saúde e outras instituiçōes como forma de atender, de forma ágil, as demandas epidemiológicas.

- Convênio com a Secretaria de Estado da Educação, para servidores de primeiro e segundo graus.

\section{DIRETRIZES}

Para tornar-se um órgão auto-sustentável, de reconhecimento público e científico em nível nacional e internacional, atendendo a demanda epidemiológica da América Latina, o CPPI tem como diretrizes básicas: a) adequação às necessidades e exigênciảs internacionais de produção (estruturais, físicas e organizacionais); b) planejamento estratégico (visão do presente e do futuro, trabalhando as oportunidades); c) gestão da qualidade; d) consolidação da área de pesquisa com estímulo à formação efetiva đe pesquisadores, a fim de acompanhar o desenvolvimento técnico-científico e o autode- 
senvolvimento; d) desenvolvimento de 'talentos humanos' (quadro de pessoal definido, com treinamento contínuo e remuneração compatível, formação e manutenção de um 'time' comprometido com os resultados da instituição); e) modelo estrutural mais flexível, com maior autonomia (gerenciamento de orçamento e de custos); f) intercâmbio técnico-científico interinstitucional; g) busca da excelência técnica e ética.

o elevado índice de morbidade e o custo social relacionado ao afastamento do trabalho, tratamento ambulatorial, hospitalar e até mesmo cirúrgico fazem com que o controle do loxoscelismo seja considerado uma das prioridades de atuação das políticas de saúde.

Uma terapia definitiva para o tratamento do loxoscelismo não está estabelecida (White, Cardoso \& Fan, 1995). O tratamento mais utilizado continua sendo a soroterapia, que até 1996 era realizada exclusivamente com o soro polivalente antiaracnídico (Loxosceles gaucho, Phoneutria negriventer e Tityus serrulatus), produzido pelo Instituto Butantan. Em 1997, o CPPI tornou disponível o soro antiloxoscélico (Loxosceles intermedia).

Estudo realizado em 1999 pela Secretaria de Saúde do Estado do Paraná, objetivando mapear o estado em relação às espécies de loxosceles existentes, demonstrou a presença das espécies de interesse médico: L. intermedia, L. laeta e L. gaucho, com predominância das primeiras em Curitiba e região metropolitana (Marques da Silva \& Fischer, 2000).

Em relação ao estado de Santa Catarina, Sezerino et al. (1998) citam a predominância de $L$. laeta, presença nas áreas sul e central, e $L$. intermedia por todo o estado.

o quadro epidemiológico no Paraná vem se modificando nos últimos anos. Curitiba e região metropolitana não mais se apresentam como área de maior incidência em acidentes loxoscélicos; por outro lado, tem ocorrido aumento significativo destes acidentes no sul do estado.

Estudos ecológicos e comportamentais da loxosceles (Fisher, 2002) mostram que a L. laeta, originária da América do Sul, foi dispersa para várias partes do mundo por intermédio do transporte passivo. Tem preferência por ambiente antrópico, assim como a $L$. intermedia, porém apresenta menor atividade de locomoção fora da teia, estando associada a um hábito mais especialista. Contribuem também para uma menor dispersão a restrição a certos tipos de ambiente e a sua maior agressividade. Já a L. intermedia, por apresentar atividade de locomoção freqüente fora da teia, somada a um hábito mais generalista, tem uma distribuição mais ampla, o que possibilita que esta espécie estabeleça, com sucesso, grandes populações em outros locais, podendo agravar o quadro do loxoscelismo em nosso país.

0 aumento do número de acidentes por Loxosceles intermedia (aranha marrom), concentrados em Curitiba e região metropolitana, aliado à ausência de um soro específico para o tratamento das conseqüências clínicas da picada estimularam o desenvolvimento e produção do soro antiloxoscélico, proporcionando uma alternativa terapêutica com maior disponibilidade e especificidade. O produto é desenvolvido a partir do veneno das três espécies de aranha marrom: Loxosceles intermedia, Loxosceles laeta e Loxosceles gaucho.

Dados epidemiológicos, estudos ecológicos e resultados de pesquisas indicaram que epítopos diferentes podem estar presentes nas principais proteínas responsáveis pela 
atividade tóxica dos venenos loxoscélicos (Guilherme, Fernandes \& Barbaro, 2001) e enfatizaram as diferenças na composição e toxicidade dos venenos loxoscélicos. Isso indica que a soroterapia efetiva deve conter anticorpos contra todas as espécies de importância médica (Guilherme, Fernandes \& Barbaro, 2001). A partir de 1999 foram adicionadas ao soro antiloxoscélico as frações anti L. gaucho e L. laeta.

Estudos realizados no CPPI (Abreu et al., 2000) demonstram uma maior reatividade antigênica do soro antiloxoscélico poliespecífico (L. gaucho, $L$. laeta e $L$. intermedia) em face dos três venenos, mostrando ser este mais efetivo do que o soro antiloxoscélico (L. intermedia) e antiaracnídico, pelos métodos de soroneutralização em orelha de coelho (Furlanetto, 1961), soroneutralização em dorso de coelho (Barbaro, 1996) e reatividade antigênica pelo método de Elisa modificado (Braz et al., 1999).

\section{PERSPECTIVAS FUTURAS}

A produção de imunobiológicos está regulamentada por legislação federal, e esta, por causa da importância e do risco desses produtos, exige de empresas privadas e públicas competência comprovada para a execução dessa atividade. Tal competência traduz-se em estrutura técnica (recursos humanos capacitados, equipamentos adequados, processos validados, procedimentos operacionais que garantam qualidade assegurada e a rastreabilidade dos produtos) e estrutura física (área de produção em consonância com as exigências das BPF).

As crescentes pressões por melhor desempenho das instituições públicas obrigam-nas a tornarem-se inovadoras e flexíveis, visando ao atendimento das necessidades dos clientes, gerando receitas em vez de despesas, financiando resultados e não recursos, possibilitando a captação de recursos necessários e sua aplicação de forma racional e competente.

Em atendimento a essas exigências, o CPPI tem como objetivos:

- operacionalizar ações com foco em resultados e impacto na sociedade, obtendo retorno social dos investimentos propostos por meio da implantação e desenvolvimento de novos serviços e produtos;

- ampliar beneficiados e clientes, por meio da exploração de oportunidades de fornecimento de produtos e serviços a outras instituições, reduzindo os custos de produção, otimizando a capacidade instalada e propiciando o acesso a esses produtos e serviços, que na sua maioria não são ofertados pela iniciativa privada;

- implementar o relacionamento entre o CPPI/Isep/Sesa e outras instituições de modo a atender, de forma ágil, as demandas epidemiológicas;

- estimular a área de pesquisas e tornar viável o financiamento para o desenvolvimento de novos produtos e tecnologias de produção, as quais poderão ser repassadas para outras instituições e empresas com retorno do investimento ao Estadô e propiciando o seu acesso à comunidade;

- atender a todas as exigências legais que permeiam a produção de imunobiológicos, de forma a capacitar-se para a ampliação do fornecimento nacional e para o mercado internacional. 


\section{REFERÊNCIAS BIBLIOGRÁFICAS}

ABREU, J. C. et al. Produção do soro antiloxoscélico poliespecífico e comparação de sua eficácia com outros soros antiloxoscélicos. Relatório Técnico. CPPI/Sesa-PR, 2000.

BARBARO, K. C. et al. Identification and neutralizatiodn of biological activities in the venoms of Loxosceles spiders. Brazilian Journal of Medical and Biological Research, 29:1.491-1.497, 1996.

BRASIL. Ministério da Saúde. Manual de diagnóstico e tratamento de acidentes por animais peçonhentos. Fundação Nacional de Saúde/Coordenação de Controle de Zoonoses e Animais Peçonhentos. Brasília: Cenepi, 1999.

BRAZ, A. et al. Development and evaluation of the neutralizing capacity of horse antivenom against the Brazilian spider Loxosceles intermedia. Toxicon, 37:1.323-1.328, 1999.

CPPI. Centro de Produção e Pesquisa de Imunobiológicos. Proposta de consolidação do CPPI como instituição de produção e pesquisa. Piraquara-Pr, jun. 2002a.

CPPI. Centro de Produção e Pesquisa de Imunobiológicos. Relatório anual de avaliação2002. Piraquara-PR, dez. 2002b.

CPPI. Centro de Prođução e Pesquisa de Imunobiológicos. Relatório de Gestão-2002. Piraquara-Pr, abr. 2003.

FISCHER, M. L. Utilização do habitat por Loxosceles intermedia Mello-Leitão, 1934 e Loxosceles laeta (NICOLET, 1849) no município de Curitiba, PR: uma abordagem experimental sobre aspectos ecológicos e comportamentais. Tese de Doutorado, Curitiba: Universidade Federal do Paraná, 2002.

FURLANETTO, R. S. Estudos sobre a preparação do soro antiloxoscélico. Tese de livredocência, São Paulo: Faculdade de Farmácia e Odontologia, Universidade de São Paulo, 1961.

GUILHERME, P.; FERNANDES, I. \& BARBARO, K. Neutralization of dermonecrotic and lethal activities and differences among $32-35 \mathrm{kDa}$ toxins of medically important Loxosceles spider venoms in Brazil revealed by monoclonal antibodies. Toxicon, 39:1.333-1.342, 2001.

MARQUES DA SILVA, E. \& FISCHER, M. L. Occurence of species of the genus Loxosceles in Paraná State. In: REUNIÃO CIENTÍFICA ANUAL DO INSTITUTO BUTANTAN, 2000, São Paulo. Anais... São Paulo, 2000. p. 51.

RIBEIRO, L. A. et al. Epidemiologia do acidente por aranhas do gênero Loxosceles Heinecken e Lowe (Loxoscelidae) no Estado do Paraná (Brasil). Memórias do Instituto Butantan, 55(1):19-26, 1993.

SEZERINO, M. L. et al. A clinical and epidemiological study of Loxosceles spider envenoming in Santa Catarina, Brazil. Transaction of the Royal Society of Tropical Medicine and Hygiene, 92:546-548, 1998.

WHITE, J.; CARDOSO, J. L. \& FAN, H. W. Clinical toxicology of spider bites. In: MEIER, J. \& WHITE, J. (Eds.) Handbook of Clinical Toxicology of Animal Venoms and Poisons. Boca Raton: CRC Press, 1995. 


\section{Parte VI}

VAGINAS E IMUNIZZACÕES: A EXPERIÊNCIA INTERNAGIONAL 


\section{Fundo Rotatório de Imunização da Opas:}

\section{sustentabilidade de programas de imunização na América Latina e Caribe ${ }^{1}$}

\author{
Jon Kim Andrus \\ John Fitzsimmons \\ Peter Carrasco \\ Jose Luis Di Fabio \\ Gina Tambini \\ Mirta Roses Periago
}

Na década de 90 , sob a égide do Programa Ampliado de Imunização (PAI) da Organização Mundial da Saúde (OMS), foi lançado o desafio de acelerar e expandir os programas de imunização dos países das Américas (Homma, Di Fabio \& Quadros, 1998). Naquela época, apenas seis doenças faziam parte da estratégia de proteção da infância contra doenças preveníveis por vacinação, a saber, sarampo, coqueluche, tétano, difteria, pólio e tuberculose. Entre essas enfermidades, as que mais matavam eram sarampo, coqueluche e tétano, e a que causava maior incapacidade era a pólio.

Hoje, o Programa prevê mais quatro vacinas: contra rubéola, hepatite B, Haemophilus influenzae tipo b e caxumba, doenças causadoras de incapacitação e óbito em crianças. $O$ PAI alcançou várias metas no controle de doenças, tais como a erradicaçāo da pólio e a eliminação do sarampo nativo no hemisfério ocidental. Entretanto, a eliminação do sarampo revelou a 'ponta do iceberg' do ônus causado pelo vírus da rubéola, enfermidade que mutila crianças, causando defeitos inatos a bebês nascidos de mães infectadas. Esses defeitos incluem perda auditiva, catarata, anomalias cardíacas e deficiência mental. Em 2003, novamente os países das Américas uniram esforços com o objetivo de tomar a iniciativa de eliminar a rubéola e a síndrome da rubéola congênita (PAHO, 2003).

Tais realizações, porém, ainda deixam muito a desejar. As vacinações contra doenças 'antigas', como coqueluche e tétano, precisam ser realizadas de modo mais eficaz.

\footnotetext{
1 Tradução do original em inglês: Emily Catafano e Flávia Romano.
} 
Por ano, a coqueluche continua matando aproximadamente 12 mil crianças nas Américas e mais de 34 morrem de tétano neonatal. Os programas regionais de imunização desenvolvidos ao longo dos últimos 25 anos precisam continuar seus esforços para abordar as questōes de desigualdade e garantir sustentabilidade. Vacinas seguras, eficazes e baratas devem ser oferecidas àqueles que mais precisam delas.

Apesar da rápida introdução de quatro vacinas subutilizadas (hepatite B, Haemophilus influenzae tipo $\mathrm{b}$, rubéola e caxumba) no final da década de 90 , os países da América Latina e do Caribe ainda estão muito atrasados no fornecimento das tecnologias e serviços quando comparados com o que o Canadá, Estados Unidos, Reino Unido e vários países da Europa são capazes de oferecer. Por exemplo, nos Estados Unidos, vacinas contra gripe, varicela e doença pneumocócica estão amplamente implantadas na rede de serviços.

Os maiores desafios para os programas de imunização nos países em desenvolvimento são reduzir as desigualdades e, ao mesmo tempo, garantir que a expansão do atendimento se sustente. $O$ melhor modo de garantir que esses programas se sustentem é o financiamento público, especialmente na compra de vacinas. A configuração das estratégias de compras dos programas de imunização deveria ser desenvolvida tendo como pressuposto-chave a sustentabilidade.

Os mecanismos de compra deveriam também funcionar como uma ferramenta prática para promover e implementar um amplo programa de assistência técnica, cobrindo sustentabilidade epidemiológica, financeira e logística, sem se limitar apenas à compra de vacinas. Em última instância, isso garantiria que todos pagassem, principalmente os governos que compram as vacinas. Os estados membros da Organização Pan-Americana de Saúde (Opas) desenvolveram o Fundo Rotatório exatamente com essa função, que é proporcionar aos países um mecanismo de compra e financiamento para vacinas, seringas e agulhas, componentes básicos de seus programas de imunização. Depois, os países usam seus próprios recursos para pagar ao Fundo (Figura 1). Este fator os diferencia dos países de outras regiões onde há uma dependência cada vez maior de recursos de doadores para a compra de vacinas, geralmente por intermédio de mecanismos do Fundo para Infância das Nações Unidas (Unicef).

O Fundo foi inaugurado em 1979. Inicialmente, foi capitalizado com, aproximadamente, um milhão de dólares, oriundo de contribuiçōes dos países-membros, organizaçōes parceiras e países doadores. 0 objetivo era garantir um planejamento nacional melhor e mais eficiente para evitar interrupções no fornecimento de vacinas ou dos recursos para sua aquisição; permitir a compra de vacinas em moeda local para evitar atrasos e perdas cambiais; consolidar os pedidos de vacina por economia de escala, resultando, assim, em preços menores para os países; gafantir a qualidade das vacinas e desenvolver contratos com fornecedores que permitissem que pedidos urgentes fossem entregues em prazos curtos.

O conceito do Fundo Rotatório interessa aos países-membros da Opas por vários motivos. Ele proporciona uma fonte pronta e contínua de recursos que, uma vez com- 
prometidos com a compra, tornam-se disponíveis para novo compromisso assim que reembolsados (WHO, 1983). Além disso, tem garantido a boa qualidade das vacinas, tem mantido baixo o preço destas nos últimos 24 anos e tem possibilitado cooperação técnica para o programa e cadeia de frio.

\section{Figura 1 - Operação do Fundo Rotatório da Opas}

Países desenvolvem planos de ação nacionais com a Opas e enviam as necessidades anuais de vacina em uma 'autorização de compra' para a Organização.

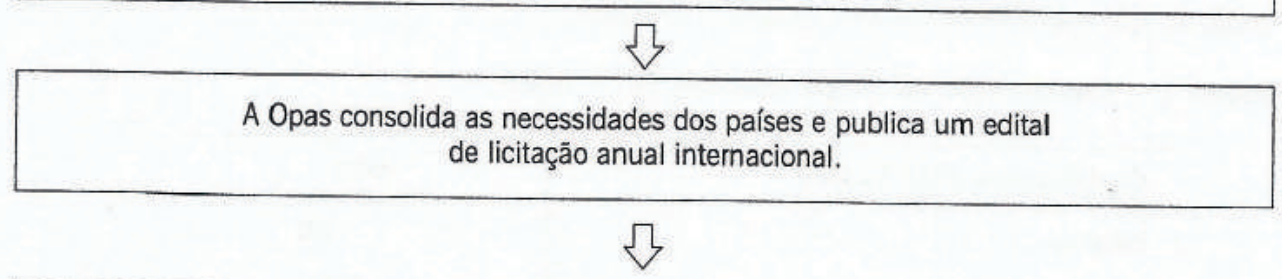

O Comitê de Revisão da Opas abre e avalia os lances e seleciona dois fabricantes por vacina. Uma notificação é enviada aos ganhadores.

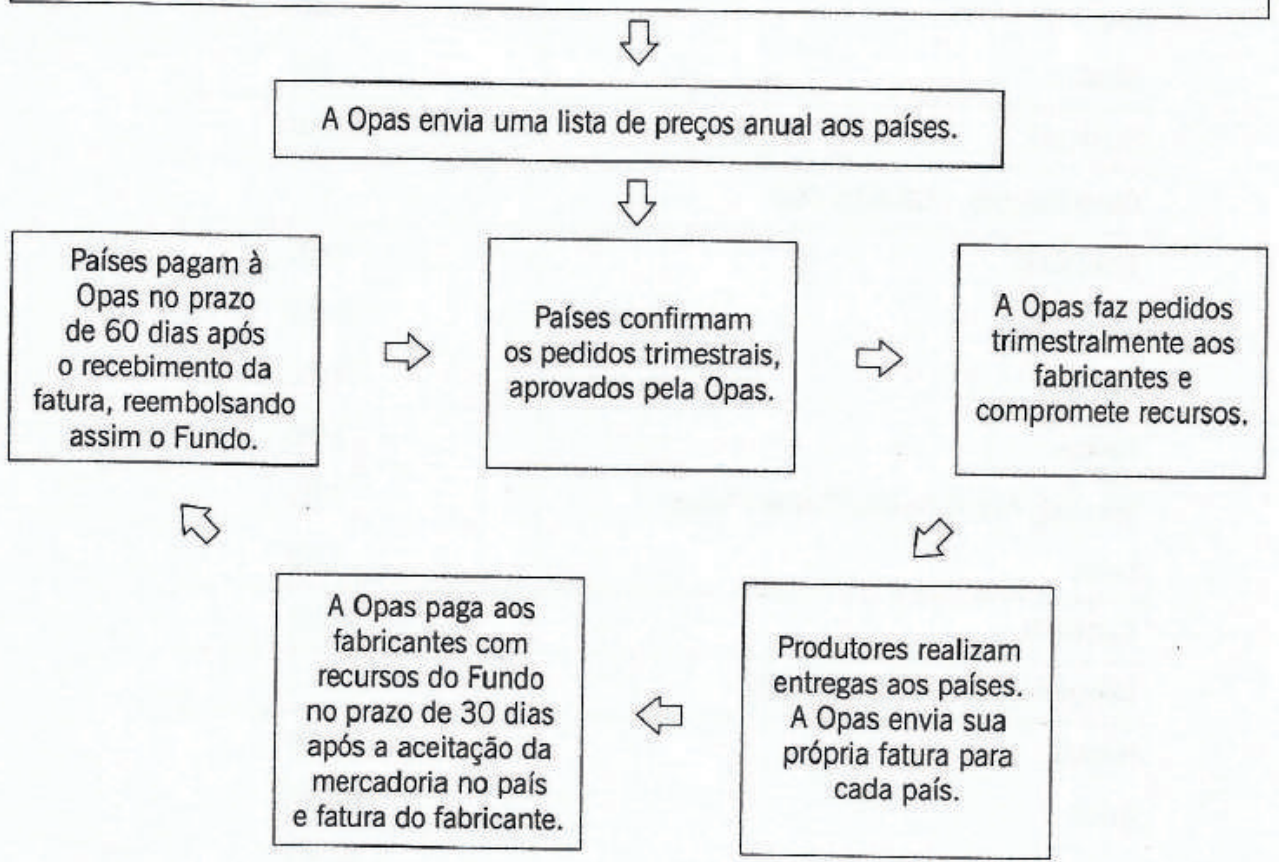

Antes da inauguração do Fundo, a Opas e seus países-membros encontravam enormes dificuldades para coordenar a compra de vacinas. Sempre que pedidos urgentes eram feitos, não se levava em conta o preço; em geral, negociava-se exclusivamente com base na capacidade de os fornecedores atenderem o pedido. Ademais, os fabricantes achavam difícil planejar sua produção com antecedência. Conseqüentemente, os países enfrentavam o esgotamento de estoques com freqüência porque a oferta não conseguia acompanhar a demanda. Em alguns casos, a confiança do público nos programas de vacinação ficava seriamente comprometida. 
Desde a criação do Fundo Rotatório, a Opas abre anualmente licitaçōes para fabricantes. Os critérios de seleção que a Organização utiliza para fornecedores de vacinas abordam questốes como preço, histórico de qualidade, capacidade de entrega dentro dos prazos e uma estimativa de se a compra irá estimular a competição. A Opas não vende vacinas, mas as compra em nome dos países membros, cobrando destes $3 \%$ sobre os custos. Esta taxa de serviço permitiu que a capitalização do Fundo crescesse de um milhão de dólares originais para mais de 23 milhões de dólares até 2003 (Tabela 1). O número de países que participam também aumentou de 19, em 1977, para 35, em 2002, e os gastos reais cresceram para mais de 120 milhões de dólares em 2003 (Gráfico 1).

Tabela 1 - Capitalização do Fundo Rotatório PAI - 2003

\begin{tabular}{l|c}
\hline Contribuições $\leq$ US $\$ 1.000$ & Valor \\
\hline Bahamas & 500 \\
Barbados & 1.000 \\
Belize & 500 \\
Cuba & 1.000 \\
Dominica & 500 \\
\hline SUBTOTAL & 3.500 \\
\hline Contribuições $\leq$ US $\$ 15.000$ & 1.500 \\
\hline Ilhas Caiman & 11.253 \\
Chile & 4.000 \\
México & 5.000 \\
Panamá & 1.400 \\
Lions Club, Porto de Espanha (Trinidad e Tobago) & 1.308 \\
Outros & 24.461 \\
\hline SUBTOTAL & \\
\hline Contribuições $\geq$ US $\$ 500.000$ & 500.000 \\
\hline Holanda & 500.000 \\
Unicef & 1.686 .000 \\
Estados Unidos & 21.272 .086 \\
\hline Opas e taxa de serviço (3\%) & 23.958 .086 \\
\hline SUBTOTAL & 23.986 .047 \\
\hline ToTAL & \\
\hline & \\
\hline
\end{tabular}

Fonte: Opas. 
Gráfico 1 - Custos para obtenção de vacinas - 1991-2003

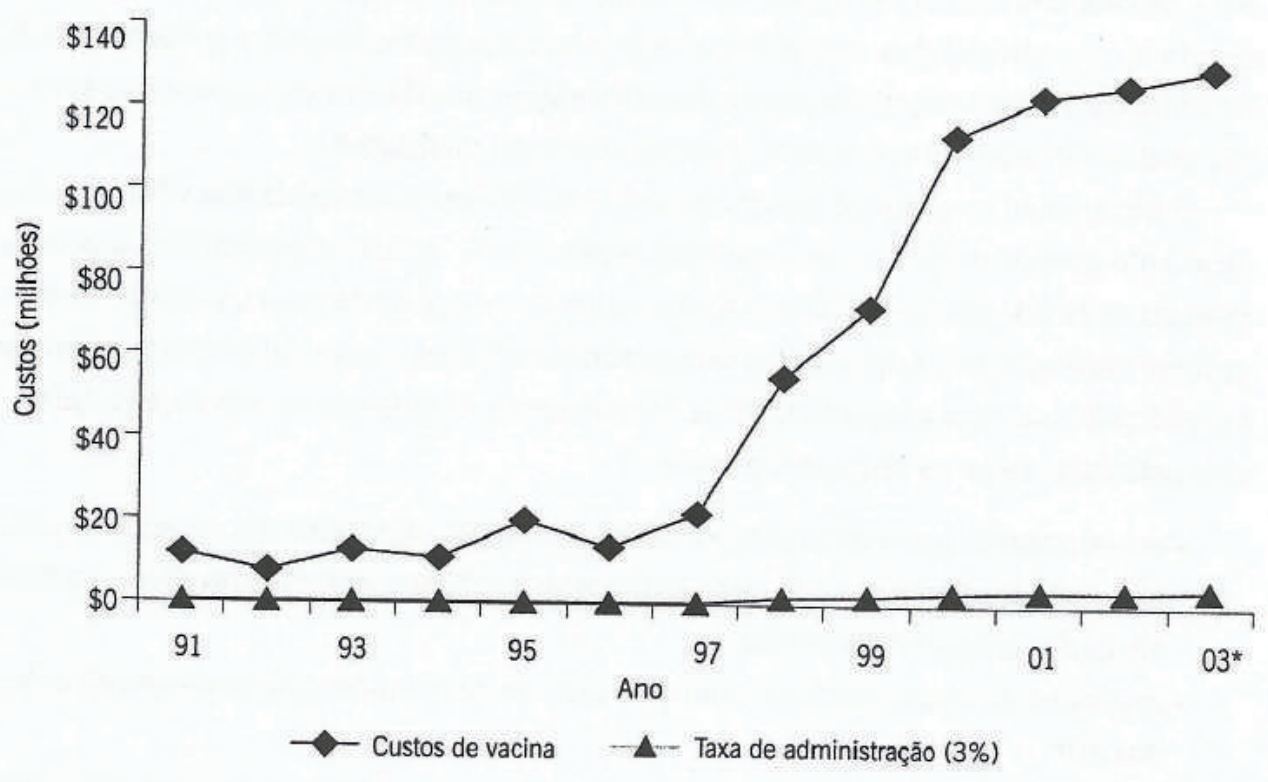

*Projeção.

Fonte: Opas.

Ao fazer pedidos aos fornecedores, a Opas cobra dos países-membros um preço médio com base nas licitações realizadas. Esse mecanismo de preço médio ajuda a diminuir os custos para os países-membros, que são beneficiados com preços mais baixos de vacina. O preço médio tem permitido que a Opas evite estratégias de preços escalonados que comprometeriam os esforços para manter a eqüidade como o principal objetivo de suporte ao país. Se os países deixam de reembolsar o Fundo, nenhum outro pedido é atendido, pois a falta de pagamento se soma à dívida geral do Fundo Rotatório. A Opas manteve esse princípio de gerenciamento nos últimos 24 anos, o que resultou nos baixos preços atuais para todos os países, contribuindo, dessa forma, para uma cultura de disciplina entre os países que assegura recursos adequados para vacinas. Todavia, os países devem mostrar seu compromisso com seus programas nacionais de imunização, obedecendo a um conjunto de critérios.

Uma vez consolidados os pedidos de vacina para os países da região, os diferentes fabricantes do mercado mundial são comunicados e convidados a participar de uma licitação para compra de vacinas. Os contatos são realizados somente com os laboratórios que foram avaliados pelo Departamento de Vacinas e Biológicos (V\&B) da OMS, que estabeleceu um mecanismo de suporte ao Unicef e a outras agências das Nações Unidas com a aceitação, em princípio, das vacinas que planejam comprar. Os procedimentos seguidos pela OMS foram publicados pela primeira vez no $39^{\circ}$ Relatório do Comitê de Especialistas da OMS (WHO, 1989), sendo posteriormente modificados e substituídos em 1996 (WHO, 1997) e recentemente atualizados em 2002. Maiores informações podem ser encontradas na página da OMS na internet. 
O sistema começou com a avaliação das vacinas do programa de imunização básica: BCG, toxóide tetânico, DT, DPT, pólio e sarampo. A lista de vacinas cresceu e outras foram recentemente adicionadas: contra hepatite $\mathrm{B}$, o conjugado Haemophilus influenza tipo $\mathrm{b}$, febre amarela, vacinas em complexos de combinações multivalentes, assim como produtos usados em epidemias e surtos, como de cólera ou meningite.

O objetivo da avaliação é assegurar que as vacinas sejam produzidas e controladas de acordo com os princípios recomendados pela OMS, inclusive os contidos nas Boas Práticas de Fabricação (BPF). Dessa forma, garante-se que as vacinas usadas pelos programas nacionais de imunização sejam seguras e eficazes, como também obedeçam às especificações técnicas de embalagem e apresentação. 0 processo de avaliação estabelecido pela OMS inclui os seguintes passos:

- conhecimento geral do produto e da apresentação oferecidos, processo de produção, métodos de controle de qualidade e relevância para a população-alvo com base em dados clínicos disponíveis;

- avaliação da consistência de produção através de cumprimento das especificaçōes das BPF;

- teste randomizado de vacinas para monitorar o cumprimento das especificações propostas, de forma continuada;

- monitoramento de reclamações vindas do setor.

Um dos elementos-chave no processo de avaliação da OMS é a verificação de que o órgão regulamentador do país fabricante obedece estritamente às seis funções regulamentadoras básicas estabelecidas pela Organização com relação a vacinas. Essas funçôes incluem: sistema de registro, capacidade de conduzir inspeções de BPF, capacidade de avaliar estudos clínicos, acesso a laboratório para realizar testes apropriados, liberação lote a lote e sistema de farmacovigilância.

É essencial nesse sistema que a OMS tenha confiança na capacidade do órgão regulamentador de garantir a qualidade, de forma eficiente e independente. Nesse sentido, a OMS recomenda que os fabricantes: a) informem o órgão regulamentador do seu pedido de submissão ao processo de avaliação pela OMS; b) solicitem, ao mesmo tempo, que este órgão participe desse processo; c) forneçam ao órgão regulamentador um consentimento para que informações pertinentes possam ser compartilhadas com os representantes da OMS.

A Opas identificou questôes que permitem aos países tornar seus programas nacionais de imunização sustentáveis. Os países devem alocar no orçamento nacional uma linha específica para financiar os custos de vacinas e seringas; elaborar um plano de ação abrangente e realista para o programa nacional, cobrindo vários anos de operações, de forma consistente com a política da Opas; indicar um gerente do programa nacional com autoridade para desenvolver o plano de ação nacional.

Essas questões ajudam a garantir que as vacinas não só sejam compradas, mas que também cheguem às comunidades que mais precisam delas. As vantagens para os países que participam do Fundo são: o método de coordenação, preços reduzidos das vacinas, 
introduçāo precoce de vacinação, estabilidade de preço, possibilidade de os países comprarem vacinas em moeda local, melhor projeção das estimativas de demanda para os fabricantes, processo de planejamento mais ordenado para os países, qualidade aprimorada das vacinas, existência de mecanismos para cobrir emergências no caso de surtos e sustentabilidade na compra de vacinas pelos países decorrente da incorporação da linhaitem em seus orçamentos.

A experiência acumulada pelo gerenciamento do Fundo pela Opas deve beneficiar outras regiōes do mundo. A questão crítica é se um fundo semelhante funcionaria em áreas fora das Américas. Se afirmativo, seria um catalisador para assegurar a sustentabilidade no suprimento mundial de vacinas. Claramente, mecanismos adicionais para garantir a sustentabilidade na produção e suprimento globais de vacinas são uma necessidade crítica. Logo, os esforços de países maiores, como Brasil, México e Cuba, no desenvolvimento de laboratórios de saúde pública para produzir vacinas devem ser apoiados. Esses laboratórios ajudarão muito a assegurar a disponibilidade das vacinas básicas necessárias aos programas nacionais de imunização.

\section{REFERÊNCIAS BIBLIOGRÁFICAS}

HOMMA, A.; DI FABIO, J. L. \& QUADROS, C. A. Los laboratorios públicos productores de vacunas: nuevo paradigma. Revista Panamericana de Salud Pública, 4(4):223-232, 1998.

PAHO (PAN AMERICAN HEALTH ORGANIZATION). Sustaining immunization programs: elimination of rubella and congenital rubella syndrome. In: $44^{\text {th }}$ DIRECTING COUNCIL RESOLUTION (CD44.R1), September, 2003, Washington. Washington, DC: PAHO, 2003.

WHO (WORLD HEALTH ORGANIZATION). EPI in the Americas, benefits from the Revolving Fund. WHO Chronicle, 37(3):81-85, 1983.

WHO (WORLD HEALTH ORGANIZATION). Biological standards. Technical Report Series 786, annex 1. Genebra: WHO, 1989.

WHO (WORLD HEALTH ORGANIZATION). Procedure for assessing the acceptability, in principle, of vaccines for purchases by United Nations Agencies - OMS/BSO/97.06. Genebra: WHO, 1997. 


\section{Financiamento Internacional para a Pesquisa e Desenvolvimento de Vacinas e Imunização'}

Marie Paule Kieny

O mundo em desenvolvimento é vítima de mortes prematuras e incapacitações causadas por várias doenças infecciosas para as quais ainda não existem vacinas, ou existem, mas precisam ser aprimoradas (Widdus, 2001). Globalmente, as doenças infecciosas são responsáveis por um terço dos óbitos e matam pelo menos 15 milhões de indivíduos por ano. Dessas mortes, 63\% (WHO, 1999) ocorrem em crianças abaixo de cinco anos de idade. ${ }^{2}$ Além dessa alta mortalidade, milhões de crianças adoecem ou ficam incapacitadas por não terem sido imunizadas. Existem, entretanto, motivos para otimismo. De fato, o sucesso da campanha de erradicação da pólio reduziu a incidência mundial da doença em mais de $99 \%$ e há novas e bem-sucedidas vacinas conjugadas contra o Haemophilus influenzae tipo b (Hib) e Neisseria meningitidis sorogrupo C. Nunca houve tantas vacinas candidatas em tantos estágios de desenvolvimento. A revolução biotecnológica, junto com o maior conhecimento de respostas imunes, está permitindo o desenvolvimento racional de vacinas recombinantes contra doenças 'difíceis', como a Aids, malária e tuberculose.

\section{O PROCESSO DE PESQUISAE DESENVOLVIMENTO (P\&D) DE VACINAS}

O processo de Pesquisa e Desenvolvimento (P\&D) preenche a lacuna entre a descoberta científica e os produtos disponíveis para intervenções em saúde. O processo se inicia com a elaboração de um método eficaz de produção de uma vacina candidata

\footnotetext{
1 Traduçāo do original em inglês: Emily Catafano e Flávia Romano.

${ }^{2}$ Estimativa da OMS, 2001.
} 
potencial; ela então é testada com relação à sua segurança e eficácia, primeiro, em experimentaçôes animais e, depois, em voluntários humanos, usando as abordagens científicas mais pertinentes.

A decisão de registrar um produto potencial e gerar um dossiê que permita aprovação dos órgãos regulamentadores e comercialização da vacina se baseará nesses elementos.

Como a $P Q D$ é um processo caro e de alto risco, o registro de uma vacina como produto final pode levar mais de dez anos (Struck, 1996) e exige não só excelência em pesquisa e desenvolvimento, mas também compromisso administrativo e de financiamento permanentes. Os riscos para inovação de vacinas podem ser divididos de forma ampla em duas categorias: em primeiro lugar, riscos de que o desenvolvimento do produto fracasse por questões de segurança ou eficácia; em segundo lugar, riscos de implementação ou de comercialização, isto é, o risco de que o produto, mesmo que complete a fase de desenvolvimento com sucesso, não consiga alcançar o impacto sobre a população em que é empregado. Do ponto de vista estatístico, muitos projetos em estágio inicial de desenvolvimento são exigidos para que apenas um seja bem-sucedido, já que a probabilidade de entrada no mercado de vacinas candidatas pré-clínicas foi estimada em 0,22. Além disso, estima-se que o registro de uma nova vacina tenha um custo agregado próximo de 200-500 milhões de dólares (André, 2002).

Avalia-se o mercado mundial de vacinas em aproximadamente 6,5 bilhões de dólares, o que representa somente cerca de $2 \%$ do mercado de produtos farmacêuticos no mundo (Greco, 2001), tornando a P\&D de vacinas menos atraente para o setor privado do que o desenvolvimento de drogas. Além disso, vacinas geralmente são produtos de pequena margem de lucratividade e de uso não repetido, o que o mercado associa a altos riscos de comercialização. Finalmente, a falta de correspondência entre a necessidade que a sociedade tem de vacinas e a decisão de pagar por elas tem sido objeto de ampla discussão (Rappuoli, Miller \& Falkow, 2002). Essa disjuntiva se deve principalmente à relutância dos indivíduos em investir em vacinas caras para doenças que nunca enfrentarão individualmente, o que, conseqüentemente, desestimula o investimento da iniciativa privada em $P Q D$.

Nesse contexto, o conceito de compartilhamento de riscos de P\&D entre o público e o privado tem sido avaliado nos últimos anos para promover a pesquisa pelo setor privado. Para conseguir maior interesse, um novo paradigma precisa ser desenvolvido, incluindo todos os envolvidos, tais como a Organização Mundial da Saúde (OMS), a indústria farmacêutica, fabricantes emergentes em países em desenvolvimento, investidores a longo prazo em $P \& D$, como órgãos de financiamento nacionais e internacionais, e novos personagens de saúde global, a Fundação Bill e Melinda Gates, entre outros. Mais importante, países do mundo em desenvolvimento terão um papel cada vez maior na decisão sobre quais são os produtos de que precisam e como gostariam que fossem aplicados, cabendo à OMS o papel fundamental de tornar isso possível. 


\section{FORC̣AS PROPULSORAS (PUSHE PULL) PARA PESQUISA DE VACINAS}

Várias forças propulsoras têm um impacto sobre o processo de P\&D de vacinas cujo alvo é o bem comum. Podem ser agrupadas em duas categorias gerais, denominadas a seguir como força de empuxo (push) e força de tração (pull). Assim, em termos abstratos, uma nova vacina é desenvolvida em virtude de uma demanda clara do mercado (pull) ou porque sua viabilidade técnica (push) foi comprovada. Em termos práticos, a chegada do produto ao mercado depende, em geral, de uma ação de ambos os conjuntos de forças.

No contexto de desenvolvimento de vacinas, as forças de empuxo (push) são compostas principalmente de avanços científicos e tecnológicos, aprimoramento em estruturas de apoio de coordenação e administração e disponibilidade de recursos para investimentos em inovaçōes e desenvolvimento de produtos.

Por outro lado, tração (pull) reflete a resultante das forças que emanam de um mercado potencial ainda não atingido. São pedidos de programas nacionais de imunizações ou compromisso de compra de vacinas por várias organizações, geralmente internacionais. Ou, ainda, compras por doadores aos países pobres e também pela ação da militância efetiva ( $a d v o c a c y$ ), que destaca o benefício de destinar fundos para áreas com necessidades médicas ainda não atendidas.

Em adição, várias tendências com um potente efeito tração (pull) têm ocorrido recentemente. Em primeiro lugar, há uma conscientização crescente de que saúde é um pré-requisito para o desenvolvimento econômico, assim como um impacto aumentado da defesa de idéias de justiça e eqüidade para a população mundial.

Como resultado de um aumento nos financiamentos públicos e privados para programas de $P \& D$ dirigidos a áreas de doenças relevantes para países em desenvolvimento, várias novas iniciativas públicas e privadas foram lançadas.

\section{INICIATIVAS E PROGRAMAS DE SAÚDE PÚBLICA PARA P\&D DE VACINAS}

Pesquisa e desenvolvimento efetivos de vacinas dependem de estruturas administrativas eficientes com acesso a recursos comprometidos a médio e longo prazo. Apesar de um número crescente de atores, como delineado anteriormente, o processo global de desenvolvimento de vacinas ainda não abrange todos os aspectos essenciais de uma ação contínua, que incluem descoberta, pesquisa pré-clínica, pesquisa clínica/regulamentação e pós-registro, assim como acesso a todas as doenças infecciosas de importância em saúde pública. Portanto, atores do setor público em $P \& D$ de vacinas devem idealmente tentar preencher as lacunas reconhecidas.

A seguir, são analisados os objetivos, intenção estratégica e modelos operacionais de várias das principais iniciativas internacionais, orientadas para descoberta, desenvolvimento, registro e disponibilização de produtos de vacina cujo alvo são doenças negligenciadas.

Além dessas iniciativas, a Iniciativa para Pesquisa em Vacinas (IVR), da OMS, pretende desenvolver e promover um processo de P\&D global e sustentável, produzindo 
vacinas de ótima qualidade para as doenças consideradas prioritárias. Portanto, a IVR se concentra em passos críticos do processo de $\mathrm{P} \& \mathrm{D}$, com alavancagem nos desenvolvimentos existentes, para facilitar a descoberta e desenvolvimento de vacinas eficazes contra doenças infecciosas de importância em saúde pública, especialmente em países em desenvolvimento.

As atividades de $P \& D$ da IVR são transversais, abrangendo todo o processo, das questões pré-clínicas às de pós-registro. $O$ enfoque na doença também é amplo, incluindo plataformas tecnológicas (tais como novos sistemas de đisponibilização); alvos globais (HIV, malária, tuberculose) e doenças tratadas como de baixa prioridade em outros locais (encefalite japonesa, dengue, entre outras). Por fim, mas também importante, muitos programas bem estabelecidos, além de instituições nacionais e internacionais específicas, são responsáveis pela advocacy, fundos e apoio ad hoc extremamente valiosos para pesquisa e desenvolvimento (Davey, 2002).

\section{Programa Especial do PNUD, Banco Mundial e OMS para Pesquisa e Treinamento em Doenças Tropicais (TDR)}

Criado oficialmente em 1975, o TDR concentra suas atividades em duas áreas principais: P\&D de novas ferramentas (vacina, drogas, diagnóstico, questionários de vigilância) e estratégias e treinamento de pesquisadores, por meio de capacitação/fortalecimento em pesquisa. O conjunto de doenças-alvo do TDR abrange: malária, tuberculose, esquistossomose, filariose linfática, oncocercose, leshmaniose, tripanossomíase americana, dengue e hanseníase. Até o momento, embora o TDR tenha desenvolvido várias drogas, ainda não registrou nenhuma vacina; por outro lado, tem promovido várias vacinas candidatas contra malária, desde a descoberta até os estudos pré-clínicos avançados e tem dado apoio a pesquisas para a descoberta de vacinas para outras doenças do seu grupo-alvo.

\section{Programa para Tecnologia Apropriada em Saúde (PATH)}

O PATH foi fundado em 1977, com a missão de melhorar a saúde, particularmente, de mulheres e crianças em ambientes com poucos recursos. Em 1998, o PATH criou o Programa de Vacina de Crianças (CVP), com apoio da Fundação Bill e Melinda Gates. Em seguida, mais programas de vacina foram criados pelo $\mathrm{PATH}$, incluindo a iniciativa para a vacina da malária e os projetos de iniciativa para a vacina do rotavírus, financiados pela Aliança Global para Vacinas e Imunização (GAVI).

O PATH está no painel de operações de tecnologia, que reúne ainda a OMS, o Unicef, a Usaid, para planejar a introdução de novas tecnologias de imunizações.

Iniciativa Internacional da Vacina contra a Aids (IAVI)

Fundada em 1996 para garantir o desenvolvimento de vacinas preventivas, seguras, eficazes e acessíveis contra o HIV para uso em todo o mundo, a IAVI é uma organização virtual que desenvolve vacinas criando várias parcerias, com a obrigação de incluir 
pesquisadores dos países em desenvolvimento. A IAVI concentra-se nas cepas de HIV prevalentes nesses países e apóia ações que garantam a disponibilidade de futuras vacinas para todas as populaçốes que necessitem delas.

\section{O Programa de Vacina de Crianças do PATH (CVP)}

O CVP foi fundado em 1998 com uma doação inicial da Fundação Bill e Melinda Gates. O programa investe em projetos que preparam países para a introdução de novas vacinas através da coleta de informações científicas sobre carga de doença, custo-benefício da vacina e realização de imunização. Os esforços de P\&D do programa concentramse atualmente em vacinas contra o pneumococo e encefalite japonesa.

\section{Iniciativa para a Vacina contra Malária (MVI)}

Este programa global começou em 1999 com uma doação inicial ao PATH da Fundação Bill e Melinda Gates. Tem como missão acelerar o desenvolvimento de vacinas promissoras contra a malária e garantir sua disponibilidade e acesso para o mundo em desenvolvimento. O programa técnico da MVI apóia vacinas candidatas desde a produção avançada em escala laboratorial até sua implementação.

A principal prioridade da iniciativa é uma vacina para prevenção de óbitos e doenças graves em crianças. Como parte essencial de seu programa, também realiza a advocacy.

\section{Fundação Aeras Global da Vacina contra Tuberculose}

A Fundação Aeras Global da Vacina contra Tuberculose foi criada como uma resposta à necessidade crítica de coordenação e financiamento para facilitar o desenvolvimento de ferramentas para o controle da tuberculose. Trabalhando com pesquisadores do mundo todo, a fundação pretende ser a catalisadora de novos diagnósticos, drogas e vacinas que possam inibir a crescente onda de óbitos pela doença. Concentra-se particularmente na pesquisa translacional - a arena científica carente đe recursos, porém essencial, entre a pesquisa básica e o desenvolvimento de produtos reais.

Em 1999, a Fundação Bill e Melinda Gates premiou a Aeras Global com uma doação de US $\$ 25$ milhões ao longo de cinco anos, para apoiar a P\&D de uma vacina para a tuberculose.

\section{Aliança Global para Vacinas e Imunização (GAVI)}

Fundada em 2000, o objetivo da GAVI é garantir o direito de todas as crianças à proteção contra doenças preveníveis por vacina que representam preocupação para a saúde pública. A maior parte de seus esforços concentra-se no fornecimento de vacinâs existentes a milhões de crianças em países pobres e na construção de programas nacionais de imunização nesses países.

A fundação da GAVI e a disponibilidade de recursos, novos ou redirecionados, já mudaram o panorama de desenvolvimento de vacinas. A aliança trouxe credibilidade ao 
conceito de que novas vacinas podem ser compradas quando fornecidas a preços acessíveis. Além disso, um dos objetivos declarados da GAVI é acelerar os esforços de pesquisa e desenvolvimento em vacinas de necessidade primária em países em desenvolvimento.

A IVR foi parceira da GAVI na força-tarefa que, entre 2000 e 2003, estimulou o aumento de investimentos em projetos centrados em P\&D que pudessem desempenhar um papel-chave na abordagem de lacunas óbvias no acesso igualitário a vacinas prioritárias necessárias para imunizar crianças do mundo todo contra infecções preveníveis por vacinas. Atualmente as prioridades de $P \& D$ da GAVI são o desenvolvimento de vacinas candidatas contra a meningite meningocócica, rotavírus e pneumococo na África. Como um grande esforço já foi feito em 2002 para o desenvolvimento de uma nova vacina conjugada contra meningite do subgrupo A (veja adiante o Projeto para Vacina da Meningite-MVP), o objetivo atual da GAVI é acelerar o desenvolvimento e introdução de duas vacinas prioritárias contra o Streptococccus pneumoniae e o rotavírus, que, juntos, matam quase dois milhões de crianças todos os anos.

Em nome da GAVI, a Fundação Gates e o Banco Mundial encomendaram um estudo a Mckinsey \& Company explorando as estratégias para acelerar a introdução de vacinas para pneumococo e rotavírus em países em desenvolvimento. Foram propostos dois Planos para Desenvolvimento Acelerado e Introdução (ADIPS) dessas vacinas, descritos a seguir.

- ADIP Pneumococo: foi concedido à Escola de Saúde Pública Johns' Hopkins, em janeiro de 2003, pelo conselho da GAVI. Em parceria estratégica com a OMS, o ADIP Pneumococo estuda a epidemiologia da pneumonia pneumocócica e a prevalência dos sorogrupos de Streptococcus pneumoniae nos países em desenvolvimento, avaliando a eficácia das vacinas conjugadas candidatas para pneumococo mais avançadas nesses países. Espera-se que os resultados desses estudos permitam a países e agências financiadoras tomarem decisōes baseadas em evidências acerca da introdução de vacinas pneumocócicas em programas de vacinação infantil.

- ADIP Rotavírus: foi concedido pelo Conselho da GAVI ao PATH em janeiro de 2003. Em parceria com a OMS e centros de controle e prevenção de doenças nos Estados Unidos, o Programa da Vacina Rotavírus (RVP) está realizando um plano de desenvolvimento e introdução acelerados de uma vacina contra o rotavírus para fornecer a países em desenvolvimento. Os elementos essenciais deste programa são semelhantes aos do ADIP Pneumococo.

\section{O Projeto da Vacina da Meningite (MVP)}

Este projeto é uma parceria entre a OMS e o PATH com o objetivo de controlar a meningite epidêmica na África subsaariana através do desenvolvimento, testes, introdução e uso disseminado de vacinas meningocócicas conjugadas. A Fundação Bill e Melinda Gates concedeu ao MVP, fundado em 2001, uma doação de US $\$ 70$ milhões para o desenvolvimento de uma vacina conjugada para meningite. Estima-se que $o$ 
primeiro ensaio clínico de Fase 1 para um vacina monovalente A, feita especialmente para a África, ocorra em 2005 . O produto, quando registrado, terá o preço-alvo de menos de 50 dólares por dose.

\section{Iniciativa da Vacina Pediátrica da Dengue (PDVI)}

Um novo esforço para acelerar o desenvolvimento de uma vacina contra dengue iniciou-se em 2002, com a fundação da PDVI. O trabalho de base para a iniciativa, que é financiada por uma doação da Fundação Rockfeller, incluía o desenvolvimento de projetos de pesquisa para calcular a carga causada pela dengue em determinados países do sudoeste asiático, América e Caribe. A sede desse programa se encontra no Instituto Internacional da Vacina, em Seul, Coréia. A Fundação Bill e Melinda Gates concedeu à PDVI uma doação de US\$ 56 milhões em 2003.

\section{O Projeto da Encefalite Japonesa}

Este projeto iniciou-se em 2003, graças a uma doação de 27 milhōes de dólares concedida ao PATH pela Fundação Bill e Melinda Gates, para acelerar o desenvolvimento de vacinas seguras e eficazes contra a encefalite japonesa.

\section{CONCLUSÃO}

O universo atual de instituições e iniciativas com intenção estratégica de operar dentro da esfera do desenvolvimento e fornecimento de vacinas possui responsabilidades, modos de operação e prioridades em doença-alvo muito diversas. É fundamental desenvolver novas vacinas continuamente, ou aperfeiçoar as já existentes, gerando maior segurança, eficácia e método de đistribuição com menor custo de produção e transporte, a fim de assegurar cobertura e acesso efetivos.

A maior parte das iniciativas recentes, até o momento, compreensivelmente, ainda não possui um histórico de realizações, sendo freqüentemente financiadas por compromissos de curto prazo e sem vínculo. Apesar de trabalhar em direção à meta comum de preparar vacinas mundiais para o bem público, os atores atuais e seus papéis declarados são fragmentados, e o processo global de desenvolvimento de vacinas reflete tal fato.

Por isso, é necessário um investimento público maior, sustentado na P\&D de vacinas para doenças-alvo específicas, que prejudicam principalmente as populações 'negligenciadas', cujos mercados não possuem as características necessárias para atrair o capital privado. Sem isso, o rápido progresso tecnológico resultante da $P \& D$, centrado principalmente em doenças com apelo comercial, não será eficazmente canalizado e integrado a programas abordando patologias e populaçōes que representam pouca lucratividade. 


\section{REFERÊNCIAS BIBLIOGRÁFICAS}

ANDRÉ, F. E. How the research-based industry approaches vaccine development and establishes priorities. Joumal of Development Biology, 110:25-29, 2002.

DAVEY, S. The 10/90 Report on Health Research 2001-2002. Genebra: Global Forum for Health Research, 2002.

GRECO, M. The future of vaccines: an industrial perspective. Vaccine, Suppl. 1:S101103, 2001.

RAPPUOLI, R.; MILLER, H. I. \& FALKOW, S. Medicine. The intangible value of vaccination. Science, 297:937-939, 2002.

STRUCK, M. M. Vaccine R\&D sucess rates and development times. Nature Biotechnology, 14:591-593, 1996.

WHO (WORLD HEALTH ORGANIZATION). Removing Obstacles to Healthy Development. Genebra: WHO, 1999.

WIDDUS, R. Public-private partnerships for health: their main targets, their diversity, and their future directions. Bulletin of the World Health Organization, 79:713-720, 2001. Rio de Janeiro, outubro de 2005.

Não encontrando nossos títulos em livrarias, contactar a Editora Fiocruz: Av. Brasil, $4036-1^{\circ}$ andar-sala 112 - Manguinhos 21040-361 - Rio de Janeiro - RJ Tel.: (21) 3882-9039 e 3882-9041 - Telefax: (21) 3882-9006 